Universidade de São Paulo

Faculdade de Filosofia, Letras e Ciências Humanas

Departamento de História

Programa de Pós-Graduação em História Social

\title{
Bahia: de capitania a província, 1808-1823
}

Maria Aparecida Silva de Sousa

Orientador: Prof. Dr. István Jancsó

São Paulo

2008 
Universidade de São Paulo

Faculdade de Filosofia, Letras e Ciências Humanas

Departamento de História

Programa de Pós-Graduação em História Social

\title{
Bahia: de capitania a província, 1808-1823
}

\author{
Maria Aparecida Silva de Sousa
}

Tese apresentada ao programa de pós-graduação do Departamento de História da Faculdade de Filosofia, Letras e Ciências Humanas da Universidade de São

Paulo, para obtenção do título de Doutor em História

Orientador: Prof. Dr. István Jancsó

São Paulo

2008 


\title{
Resumo
}

O reordenamento do Império português materializado na instalação da Corte na América (1808) e na elevação do Brasil à categoria de Reino Unido (1815) revigorou a capacidade de mediação com os residentes da Bahia que perceberam a dilatação das oportunidades e, de diversas maneiras, buscaram usufruir os benefícios propiciados pelas mudanças conjunturais. No entanto, a despeito dos vínculos estabelecidos com o regente e da censura imposta pelo governo absolutista, a província não ficou imune à difusão do ideário liberal e às experiências políticas em curso na América espanhola, evidenciados em sua adesão ao constitucionalismo em princípios dos anos 1820. O estudo discute como as alterações políticas no período de 1808-1823 influíram no processo de aprendizado individual e coletivo na Bahia, esgarçando os mecanismos que até então haviam possibilitado a sustentação do Estado português ao mesmo tempo em que demandaram novas articulações entre as classes dirigentes para o encaminhamento da instabilidade política e a conformação de uma nova estrutura de poder político.

Palavras-chave: Aprendizado político; Bahia, século XIX; Brasil Reino; Crise política; Período Joanino.

\begin{abstract}
The rearrangement of the Portuguese Empire materialized in instalation of the Court in America (1808) an the elevation of Brazil the United Kingdom (1815) reanimated the capacity of the mediation with the residents of Bahia conscious the dilatation of oportunities and, in many ways, sough enjoy the benefits gained by conjucture. However, in spite of the bond with the regent and the censorship imposed by absolutism, the province absorbed the liberal ideas and experiences in the hispanic America, as evidenced by its adherence to constitucionalism in the early 1820 . The study analyses how the political changes in the years of 1808 and 1823 influenced the the private and collective learning process in Bahia, tearing the mechanisms which until then allowed the support of the Portuguese State at the same time that required news articulations between the ruling classes for the conduct of the political instability and conformation of a new strucuture of political power.
\end{abstract}

Key-words: Political Apprendice; Bahia, Nineteenth Century; Brazil Kingdom; Political Crisis; Period Joanino. 
Para Caio, minha alegria, meu amor. 


\section{Agradecimentos}

Possuo muitas razões para me sentir gratificada por este doutorado. Uma delas, sem dúvida, é ter tido a possibilidade de retornar a São Paulo, cidade que tem um enorme significado em minha vida. Sem a bolsa de estudos concedida pela Universidade Estadual do Sudoeste da Bahia (UESB), no entanto, a realização do curso não teria sido possível. Ter contado com a orientação do prof. dr. István Jancsó foi fundamental para que a pesquisa tivesse o direcionamento teórico-metodológico apresentado aqui. Devo a ele momentos de intenso aprendizado e guardo uma profunda admiração por seu compromisso e entusiasmo pela pesquisa histórica, a busca pelo rigor da análise e por sua crença nos resultados positivos do trabalho coletivo. Sinto-me privilegiada por ter tido a oportunidade de tê-lo como orientador e sou muito grata por isso. Em função do Projeto Temático que coordena, A fundação do Estado e da nação brasileiros, tive a oportunidade de contatar pessoas cujas contribuições a esse trabalho são absolutamente inegáveis. As discussões ocorridas no âmbito do temático foram fundamentais para que eu refizesse muitas das perguntas sobre o tema e contribuíram imensamente para meu amadurecimento enquanto pesquisadora. Da mesma maneira, os cursos oferecidos pelos professores doutores Cecília Helena de Salles Oliveira, Fernando Antônio Novais, Márcia Regina Berbel e Rafael de Bívar Marquese esclareceram dúvidas e semearam outras tantas. Os professores doutores João Paulo Garrido Pimenta e Wilma Peres Costa, integrantes da banca de qualificação, foram essenciais para que eu esclarecesse a problematização da pesquisa. $O$ meu agradecimento especial a Andréa Slemian e João Paulo que acompanharam-me desde o início. Tive o prazer de tê-los como leitores cuidadosos, amigos e grandes incentivadores. André Machado, Claus Rodarte e Daniel Afonso fizeram observações importantes ao tema da pesquisa. Com eles, juntamente com Ana Rosa Cloclet da Silva e Fernanda Spósito, compartilhei conversas estimulantes. Valdei Lopes e Flávia Varella chegaram depois mas a tempo de emprestarem material e de desfrutarmos de uma boa vizinhança.

No decorrer do curso fui auxiliada por servidores extremamente competentes e dispostos a ajudar. No Instituto de Estudos Brasileiros (IEB), agradeço a atenção de Cleide Marques, Daniela Pires, Denis Rossi, Inês Bento, Renato Munhoz e a equipe da biblioteca. No Arquivo Público do Estado da Bahia (APEB), a dedicação de Marlene Oliveira e sua equipe do setor de microfilmes, bem como o empenho e a simpatia de Paulo Roberto Meirelles. Lara Marques e Jacira Primo auxiliaram-me, respectivamente, na digitalização e 
na transcrição de documentos. Tive agradáveis conversas sobre os nossos vários projetos de vida com colegas da UESB e também pós-graduandos: Cristina Pina, Francisco Carlos, Gildásio Júnior, Jânio Diniz, João Diógenes, Rubens Mascarenhas, Suzane Tosta, junto com Rosângela, a amiga campineira Creuza e Dulce. Nessas ocasiões sempre nos lembrávamos da nossa querida Bete (Albertina Vasconcelos), ainda mais quando ela desapareceu de repente nos fazendo sentir um pouco órfãos. Edmilson Carvalho, Ricardo, Ivo, Priscila, Ana e Jomar ajudaram-me a dimensionar a riqueza do processo histórico sob outras perspectivas. Além disso, o Baixo (Edmilson) fez uma leitura atenta de partes do trabalho fornecendo valorosas contribuições.

O curso propiciou-me também estar mais próxima de pessoas pelas quais tenho grande estima. A Rita Duca, minha amiga-irmã paulistana, não tenho como expressar a minha gratidão por sua imensa generosidade e pela importância que tem em minha vida. Ao lado dela, de Loreto, de Lúcia e de Regina, vivenciei momentos singulares. Ainda em São Paulo tive muita sorte em contar com a amizade e a solidariedade de Maraísa Bonilha e a família Simonetti: Sr. João Batista, d. Lílian, Paula e Antenor. Não poderia deixar de mencionar a satisfação por ter conhecido Mário Maccarone.

Kátia Lorena (de Salvador) enviou material, fez sugestões, esteve por perto mesmo distante comprovando que uma velha e boa amizade pode resistir ao tempo. Em Vitória da Conquista, Weslei Piau se manteve sempre a postos mesmo envolvido com o seu doutoramento; Margozinha, minha amiga de longa data, uma companhia indispensável apesar de os nossos encontros terem ficado cada vez mais raros. Agradeço ainda aos colegas do Departamento de História da UESB pela liberação das minhas atividades acadêmicas nesse período.

Por fim, um reconhecimento expressivo aos meus queridos pais, Cerillinha e Preto, pelo incomensurável carinho e confiança, meus irmãos e irmãs, em especial Tânia (tia Teca) pela imensa disposição em colaborar, e meus adorados sobrinhos, porque, entre outras coisas, me fazem sentir saudades de casa e da singular família Sousa. A meu companheiro Argemiro, pelos momentos de cumplicidade e porque há muito aprendemos juntos, e ao nosso amado filho, Caio, que com a sua alegria infantil me permite sentir a plenitude da vida. 


\section{Sumário}

Página

Introdução 6

Capítulo 1: A Bahia na crise do Antigo Regime na América portuguesa 20

1.1 Conjunturas e crise política $\quad 21$

1.2 A construção do espaço da política 46

1.3 Experiências políticas em situação colonial 68

Capítulo 2: Administração política no tempo do $8^{\circ}$. conde dos Arcos, 1810-1818 82

2.1 A política de Acomodação: A Bahia e a Corte 83

2.2 Brasil Reino: crise e reordenamento político 111

2.3 A política da desagregação: a Bahia e a revolução pernambucana 129

Capítulo 3: Crise e crescimento na Bahia nos anos 1810

3.1 Conjuntura econômica em tempos de crise 157

3.2 Idéias de reforma e de conservação 181

3.3 A conjuntura política nas páginas da Gazeta Idade d’Ouro do Brazil 195

Capítulo 4: $O$ aprofundamento da crise e as tentativas de superação, 1820-1823 206

4.1 O constitucionalismo na Bahia: experiência política e expectativas de mudança 207

4.2 O aprofundamento da crise e a refundação das alianças 232

4.3 De capitania a província 265

Conclusões 283

Fontes Documentais e Bibliografia 288 


\section{Introdução}

No dia 10 de fevereiro de 1824, os membros do Senado da Câmara de Salvador, o recém-empossado presidente da província da Bahia, Francisco Vicente Vianna, as autoridades civis, militares, eclesiásticas e demais cidadãos, reuniram-se na casa do Conselho

para o fim de se conhecer a opinião geral daquela parte dos Habitantes desta Província, por quem a Câmara representa, sobre o Projeto de Constituição, apresentado por S.M. o Imperador, e coordenado pelo Conselho de Estado em data de onze de Dezembro de 1823, aí formando todas as referidas pessoas um Conselho com esta Câmara, cujo Presidente fez uma fala análoga ao objeto, foi unanimemente decidido, que o resultado deste Conselho era sem dúvida o que se devia ter por opinião geral, pela maneira ampla, com que foi convocado e por se terem reunido tantos Cidadãos, e passando-se a tratar do referido Projeto de Constituição, unanimemente se concordou e assentou pelo Conselho que logo, e logo se pedisse mui respeitosamente a S.M. Imperial que Se Digne de fazer publicar, jurar e Mandar jurar, observar como Constituição do Império o mesmo Projeto, pois são bem óbvias as vantagens que resultam a esta Província, e a todo o Império de termos desde já uma Constituição [.... ${ }^{1}{ }^{1}$

A reunião ocorria três anos depois de a Bahia ter manifestado adesão às Cortes

Gerais e Extraordinárias, instaladas em 26 de janeiro de 1821 em Lisboa, com o objetivo de deliberar sobre as leis que passariam a regular a nação portuguesa. A partir dessa decisão, os habitantes da província vivenciaram intensas experiências políticas, sobretudo, depois que as dificuldades para a manutenção dos Reinos europeu e americano manifestaram-se com muito mais vigor. Internamente a situação também era complexa. A despeito de o documento destacar a unidade dos presentes com relação à adoção do projeto de constituição proposto pelo imperante, um dos elementos mais significativos da conturbada conjuntura nesse período foi justamente a expressão de distintos posicionamentos políticos resultantes da profunda instabilidade e de incertezas que marcaram o período. Ao concretizarem uma articulação entre os diferentes segmentos da província com o Rio de Janeiro, as autoridades locais buscavam uma saída possível para o controle da situação política aprovando a proposta de constituição apresentada por d. Pedro

\footnotetext{
1 Termo de vereação extraordinária, em 10 de fevereiro de 1824. Documentos da municipalidade de Salvador relacionados com a Independência do Brasil, 1821-1823. Salvador: Prefeitura Municipal/Departamento de Cultura da SMEC, 1972, p. 145.
} 
I. Anunciava-se um tempo novo, o Império do Brasil erguia-se assentado em certo consenso de variados grupos da província. Mas os caminhos percorridos até a consolidação desse projeto haviam sido bastante tortuosos.

A perspectiva de adoção de uma carta constitucional como mecanismo de regulação das relações políticas no Império do Brasil, ainda que outorgada, era uma grande novidade para os contemporâneos. Afinal, até a difusão dos ideais constitucionalistas intensificada com a Revolução do Porto, o projeto de estabelecimento de uma monarquia constitucional permanecia restrito, principalmente, ao universo de alguns liberais ilustrados sem muito espaço para divulgarem suas proposições. No entanto, não obstante as restrições impostas pelo governo absoluto ao movimento de idéias consideradas perniciosas aos interesses do Estado, na prática, elas encontraram canais de circulação. Nesse aspecto, algumas questões adquirem especial relevância.

De fato, os anos que antecederam o constitucionalismo no Brasil Reino evidenciam um processo de fortalecimento dos vínculos entre a Coroa portuguesa, personificada na figura do príncipe regente e posterior rei d. João VI, e os residentes da parte americana do Império português, em particular, da Bahia. As táticas e as estratégias utilizadas pela corte do Rio de Janeiro para concretizar essa aliança indicam que se, por um lado, as alterações daí resultantes reforçaram a submissão dos súditos ao poder real, por outro, contraditoriamente, potencializaram a sua capacidade de exigir a ampliação de benefícios políticos e econômicos. Essa situação não era definida somente pelas circunstâncias internas. Afinal, os primeiros decênios do século XIX foram tempos de grande instabilidade política para os governos absolutistas do mundo Ocidental. A instalação da família real portuguesa na América, em 1808, deu-se em decorrência das profundas transformações de fins do Setecentos impulsionadas pelos acontecimentos revolucionários que sacudiram os alicerces de sustentação das monarquias absolutistas em grande parte da Europa, atingindo o velho e o novo mundo. O impacto desses acontecimentos na Península Ibérica e, em particular, no reino português, demandou intervenções políticas de amplas dimensões, expondo os elementos centrais de um processo de corrosão das estruturas do absolutismo monárquico. No entanto, a materialização dessa crise nas distintas partes da América revela as singularidades de uma realidade complexa sob a qual estava assentada o poder da Coroa portuguesa que, a despeito da aparente integração do conjunto, guardava profundas diferenças não apenas entre as partes como também em seu interior. 
As relações entre a metrópole portuguesa e seus domínios na América produziram um complexo de formações sociais decorrente da natureza do sistema colonial, entendido aqui como parte integrante do Antigo Regime e estruturalmente vinculado às formas antigas de organização política e de exploração econômica características da Época Moderna. ${ }^{2}$ A rigor, pelo menos até meados do Setecentos a organização políticaadministrativa montada pelo Estado português garantiu a convivência dos vassalos do rei que, de alguma maneira, encontravam-se atados a Lisboa, então sede da corte, como membros de uma mesma nação portuguesa. Para as autoridades régias situadas no reino europeu ou na América, as diferenças no âmbito de uma nação não eram desconhecidas, porém, poderiam ser manejadas a partir de um plano racionalmente definido que conferisse a grandeza necessária à monarquia. Internamente, a referência à nação portuguesa combinava, de maneira tensa ou não dependendo de situações específicas, as identidades locais “correspondentes às muitas pátrias criadas pela colonização”. 3

As contradições de ordem mais geral, entretanto, calcadas na crise do Antigo Regime e, no seu interior, do sistema colonial, abriram graves tensões que exigiram reajustes no todo e em suas partes. Para os Impérios ibéricos era preciso encaminhar soluções de maneira a garantir a preservação de um bem extremamente valioso às suas respectivas monarquias: as possessões das colônias na América. Nesse sentido, a implementação de medidas de caráter administrativo, econômico, militar, visava recompor as condições de exploração colonial e desvencilhar-se da subversão que a tudo transformava. ${ }^{4}$

É nesse quadro político que Portugal, por sua posição peculiar e diante do agravamento das tensões na Europa, encaminhará proposições políticas como tentativas de superação da crise, cujas relações específicas mantidas com a colônia americana resultarão

\footnotetext{
${ }^{2}$ De acordo a formulação de Fernando A. Novais. Portugal e Brasil na crise do Antigo Sistema Colonial (1777-1808). São Paulo: Hucitec, 1983. Ver também do autor: "Colonização e Sistema Colonial: discussão de conceitos e perspectiva histórica”. In: _. . Aproximações: estudos de História e Historiografia. São Paulo: Cosacnaify, 2005. A compreensão aqui do conceito de Antigo Regime considera as observações apontadas por Laura de Mello e Souza: "A especificidade da América portuguesa não residiu na assimilação pura e simples do mundo do Antigo Regime, mas na sua recriação perversa, alimentada pelo tráfico, pelo trabalho escravo de negros africanos, pela introdução, na velha sociedade, de um novo elemento, estrutural e não institucional: o escravismo. Subordinadas à monarquia portuguesa, que entre a Restauração e o período pombalino tornou-se crescentemente centralizadora, tendo assim que recriar suas relações com os domínios ultramarinos, as terras brasílicas integraram o mundo do Antigo Regime por meio do antigo sistema colonial”. O sol e a sombra. Política e administração na América portuguesa do século XVIII. São Paulo: Companhia das Letras, 2006, p. 68-69.

${ }^{3}$ István Jancsó. "Independência, Independências". _ _ (Org.). Independência: história e historiografia. São Paulo: Hucitec/Fapesp, 2005, p. 21. Para uma discussão recente sobre o papel da administração política colonial na América portuguesa. Laura de Mello e Souza, op. cit.

${ }^{4}$ Fernando A. Novais, op cit., 1983; Andréa Slemian; João Paulo G. Pimenta. O "nascimento político do Brasil”. As origens do Estado e da nação (1808-1825). Rio de Janeiro: DP\&A, 2003.
} 
em conseqüências importantes para ambos os lados, principalmente, após os projetos reformistas terem se mostrado incapazes de solucionar os problemas postos pela instabilidade. A transferência da família real portuguesa para a América inaugura, assim, um período de grandes transformações decorrentes de uma situação crítica abrangente mais com efetivas repercussões no âmbito local que, vistas no conjunto, inserem-se numa mesma conjuntura de desestruturação do sistema colonial. Com efeito, se anteriormente os colonos americanos relacionavam-se com Lisboa e para lá dirigiam-se obedecendo aos trâmites formais estabelecidos pelo Estado, a fixação da corte no Rio de Janeiro redefiniu o centro de peregrinação fixando novos parâmetros de articulação política e econômica para os antigos coloniais. ${ }^{5}$ Para o caso da Bahia, as intensas articulações que se estabeleceram entre a corte, as autoridades locais e parte dos residentes evidenciam um jogo de concessões e beneficiamentos que funcionaram como um mecanismo de resposta às demandas não somente internas como também do Império português. Nesses termos, embora o estudo enfoque as alterações verificadas na capitania/província nos primeiros decênios do século XIX, busca-se associá-lo a um contexto de crise mais geral indicando o caráter contraditório de determinação e ambigüidade desse movimento e, como resultante, a sua complexidade. Desse modo, parte-se do pressuposto que os elementos específicos identificados se articulam a um processo mais amplo do qual o movimento particular é parte integrante, e da compreensão desse todo articulado é que se pode apreender a lógica interna dos acontecimentos. ${ }^{6}$

Ocupando um lugar de grande importância entre os domínios da Coroa portuguesa, não somente por sua posição econômica assentada na produção agroexportadora impulsionada pelo trabalho cativo, como também por sua localização geográfica estratégica, a Bahia desempenhava um papel essencial no projeto político de reordenamento da monarquia bragantina. Se para as autoridades régias esses elementos seriam levados em consideração nos projetos de intervenção do Estado, para as classes proprietárias locais, a presença do príncipe na América não tinha um significado menor. Afinal de contas, a capitania ocupara a primeira sede de Vice-Reino na colônia e a mudança da capital para o Rio de Janeiro, ocorrida em 1763, não havia sido assimilada

\footnotetext{
${ }^{5}$ Cf. István Jancsó e João Paulo G. Pimenta discutem em profundidade o alcance da fixação da corte no Rio de Janeiro e a sua importância no processo de constituição das identidades políticas na América portuguesa. "Peças de um mosaico (ou apontamentos para o estudo da emergência da identidade nacional brasileira)". In: Carlos Guilherme Mota (Org.). Viagem Incompleta. A experiência brasileira (1500-2000). Formação: histórias. São Paulo: Senac, 2000. p. 127-175.

${ }^{6}$ Karel Kosik. A dialética do concreto. Rio de Janeiro: Paz e Terra, 1976; Edmilson Carvalho. A produção dialética do conhecimento. São Paulo: Xamã, 2008.
} 
sem consternação. As mudanças conjunturais de princípios do Oitocentos traziam consigo a possibilidade de recuperação de uma situação política que, certamente, na prática, tinha outras implicações. Não à toa, na passagem do regente por Salvador, o corpo do comércio local e os membros do Senado da Câmara intercederam junto a d. João para que se instalasse definitivamente na cidade. Os argumentos reiteravam as vantagens econômicas e estratégicas da capitania, superiores ao do Rio de Janeiro, assim como a lealdade de seus residentes, condições importantes para a conformação de um projeto de Império na América acalentado pelos conselheiros régios e com plena ressonância entre os colonos. As expectativas por mudanças positivas eram patentes e permaneceriam mesmo com a partida do regente para a nova sede da corte.

Nessa direção, parece sintomático que algum tipo de relação mediadora foi estabelecida com a capitania visando assegurar certo equilíbrio político em meio a uma conjuntura que demandava extrema cautela por parte dos dirigentes do Estado português. De algum modo, isso dizia respeito não somente à valorização das potencialidades econômicas da Bahia, como também ao reconhecimento da capacidade de articulação dos seus segmentos proprietários que, a despeito de diferenças quanto ao volume de riqueza material, já tinham dado significativas mostras de que tentariam influir no encaminhamento de determinados problemas práticos de interesse da classe tomados por interesse também do Estado. ${ }^{7}$ Esse comportamento ficara evidenciado logo após a chegada do regente a Salvador em uma outra representação encaminhada pelos negociantes na qual expressavam preocupação com o decreto de abertura dos portos em virtude da presença de produtos estrangeiros. Posteriormente, por ocasião das deliberações entre a Coroa portuguesa e o governo britânico acerca da proibição do tráfico de escravos ao Norte do Equador, os indivíduos envolvidos com esse tipo de comércio internacional demonstraram uma grande articulação para evitar os prejuízos financeiros que poderiam resultar da decisão. Não à toa, d. Fernando José de Sousa Portugal, ministro para os Negócios do Reino, recomendava ao governador da Bahia que ao "ouvir as Pessoas mais inteligentes e práticas nos Negócios dessa Capitania” conviria que o fizesse de maneira particular "sem maior aparato, e fazendo as suas reflexões e interpondo o seu parecer”. ${ }^{8}$ Em outras palavras, é possível apontar para uma mobilização interna de frações das classes proprietárias desejosas de preservarem vantagens pessoais e coletivas constituindo, desse

\footnotetext{
${ }^{7}$ István Jancsó discute os termos dessa experiência de classe a partir de uma representação dos senhores de engenho e lavradores de cana e tabaco da Bahia em 1752. Op. cit., 2005, p. 26 e passim.

${ }^{8}$ Citado por Pierre Verger. Fluxo e refluxo do tráfico de escravos entre o Golfo de Benin e a Bahia de Todos os Santos. Dos séculos XVII a XIX. São Paulo: Corrupio, 1987, p. 309.
} 
modo, um elemento de grande relevância para apreender o significado do seu comportamento político anos depois. Essa constatação nos remete para um outro aspecto da dinâmica interna da capitania nos primeiros decênios de 1800.

Embora a proximidade da Coroa portuguesa tenha reforçado os vínculos entre o príncipe e futuro monarca d. João VI e os seus súditos propiciando a dilatação de oportunidades no campo econômico e na ocupação de cargos burocráticos, as condições precárias de existência de muitos residentes permanecia um dado incontornável para as autoridades locais. Além das contradições econômicas internas que impunham uma profunda distinção entre as classes proprietárias, de um lado, e os destituídos dessa condição, de outro, cujo lugar ocupado pelos escravos demarcava a diferença, as capitanias do Norte amargavam a cobrança de pesadas taxações que incidiam, sobretudo, sob a parcela dos residentes onerados por outras tantas dificuldades. Certamente isso ajuda a entender a mobilização desses segmentos no momento em que novas perspectivas de mudança política foram anunciadas em 10 de fevereiro de 1821.

Ademais, não se pode menosprezar que os acontecimentos políticos na Europa e, mais precisamente, nas partes hispano-americanos não eram de todo desconhecidas por muitos dos principais protagonistas do constitucionalismo na Bahia. A despeito do controle e dos métodos repressivos utilizados pelo Estado português, as informações circulavam e com elas todo um arsenal de expectativa de mudanças que encontraria na conjuntura daqueles anos as condições ideais para sua manifestação de maneira mais intensa. Nesse aspecto, a experiência do ensaio de sedição de 1798 aparece como um marco inegável das possibilidades de formação e de movimentação de uma parcela dos residentes mesmo considerando as limitadas condições para exercitar suas práticas políticas. Ao lado desse movimento, as ocorrências registradas em Minas (1789) e em Pernambuco (1801) servem como exemplos de que algo novo se processava na vida política dos habitantes da América portuguesa. Perspectiva reforçada também pelos indícios quanto a existência de alguns canais de socialização da informação já nesse período. ${ }^{9}$

Embora esses movimentos não possam ser explicados, de maneira anacrônica, como o início dos preparativos para a Independência do Brasil, como já se apontou, ${ }^{10}$ servem para indicar sobre as particularidades de um ambiente gerador de algum tipo de

\footnotetext{
${ }^{9}$ István Jancsó. "A sedução da liberdade”. In: Laura de Mello e Souza (Org.). História da vida privada no Brasil. Cotidiano e vida privada na América portuguesa. (Coleção dirigida por Fernando A. Novais). São Paulo: Companhia das Letras, 1997, p. 388-437; Luis Carlos Villalta. "O que se fala, o que se lê: língua, instrução e leitura”. In: Laura de Mello e Souza (Org.)., op. cit., p. 332-385.

${ }^{10}$ Fernando A. Novais; Carlos Guilherme Mota. A independência política do Brasil. 2. ed. São Paulo: Hucitec, 1996, p. 12 Andréa Slemian; João Paulo G. Pimenta, op. cit., p. 8.
} 
aprendizado político. O elemento novo e de fundamental importância nos anos seguintes seria dado pelo agravamento da crise na Europa e seus desdobramentos na América espanhola, propiciando o acompanhamento das notícias sobre as colônias hispânicas, principalmente, pelas autoridades régias preocupadas com a própria situação do Império português. A conformação da crise nesses territórios se apresentava não somente por meio das semelhantes dificuldades enfrentadas pelos Impérios espanhol e português, mas também pelas possibilidades abertas de construção de novas alternativas políticas de exercício do poder. ${ }^{11}$ É nesse sentido que podem ser compreendidas a criação das Juntas de Governo independentes nas colônias hispânicas em 1810 e a Revolução pernambucana de 1817 no Brasil. Nesse último caso, rompia-se com o pretenso equilíbrio no interior do Reino Unido de Portugal, Brasil e Algarves, cuja constituição se dera dois anos antes no contexto de restauração das monarquias absolutas após o fim das guerras napoleônicas, além de evidenciar a possibilidade de articulação política entre capitanias denotando que a existência de perspectivas políticas contrárias à ordem monárquica absolutista tinha uma disseminação mais ampla do que possivelmente as autoridades régias acreditavam. A rigor, a elevação do Brasil a Reino Unido havia sido uma tática importante utilizada pela Coroa portuguesa tanto no processo de encaminhamento do equilíbrio europeu definido pelo Congresso de Viena, quanto no contexto de potencialização dos movimentos nas colônias hispânicas. No plano interno, era o reconhecimento oficial do fim da distinção hierárquica entre metrópole e colônia, assim como a valorização da antiga colônia no conjunto dos domínios do Império português adquirindo, em razão disso, um significado político muito mais amplo do que aquele atribuído pela historiografia e, inclusive, pelos coevos. ${ }^{12}$

De qualquer modo, a partir de então, a referência a um corpo político comum forneceu maior precisão, ainda que simbólica, a uma idéia de nação luso-brasílica que, se por um lado acalentava os desejos de realização do Império português na América, por outro, ampliava os descontentamentos dos habitantes do Reino europeu contra os projetos políticos e econômicos da Coroa no Rio de Janeiro, conforme ficou evidenciado em um

\footnotetext{
${ }^{11}$ Andréa Slemian; João Paulo G. Pimenta, op. cit., p. 22 e seq. Sobre os acontecimentos no Império espanhol nesse período e sua repercussão nos projetos políticos elaborados na América portuguesa, ver também João Paulo G. Pimenta. Estado e nação no fim dos impérios ibéricos no Prata (1808-1828). São Paulo: Hucitec; Fapesp, 2002 e Brasil e América Espanhola. São Paulo. Universidade de São Paulo, 2003 (Tese de Doutorado). A concepção sobre a leitura de uma história passada como "espaço de experiência" a projetar um "horizonte de expectativas" no tempo presente é tratada por Reinhart Kosseleck. "Espaço de experiência” e "horizonte de expectativa": duas categorias históricas. In: __. Futuro Passado. Contribuição à semântica dos tempos históricos. Rio de Janeiro: Contraponto; Editora Puc-Rio, 2006, p. 305-327.

${ }^{12}$ Maria de Lourdes Viana Lyra. A utopia do poderoso Império. Portugal e Brasil: Bastidores da política, 1798-1822. Rio de Janeiro: Sette Letras, 1994. Ver também István Jancsó, op.cit., 2005.
} 
movimento em Lisboa, no mesmo ano de 1817, contra a regência de Portugal que foi rapidamente sufocado. Em meio a uma crise abrangente, as intervenções promovidas pela corte do Rio de Janeiro davam mostras de que eram insuficientes para assegurar a estabilidade política da monarquia bragantina. A eclosão do movimento constitucionalista no Porto, em princípios dos anos 1820, e a repercussão que obteve entre os portugueses americanos expôs, de maneira mais visível, a fermentação política existente nas províncias do Brasil Reino e, em particular, na Bahia.

Com efeito, a intensidade da atividade política exercida por uma ampla parcela dos residentes da província propiciaria a manifestação de distintas perspectivas de intervenção, apesar de num primeiro momento os interesses gerais das lideranças do movimento aparecessem conciliados em um projeto de construção de uma monarquia constitucional. Nesse cenário, um dos sinais significativos não apenas da recusa da ordem política do absolutismo como também do compartilhamento das experiências ocorridas na América hispânica fora a criação da Juntas Provisionais de Governo, em toda parte, que passariam a responder pelo governo local. No caso da Bahia, a sua composição revela, logo de início, a preocupação em estabelecer uma ampla aliança com os indivíduos de condição de maneira a evitar a ocupação do espaço público pelos segmentos populares assegurando a manutenção da ordem política diante de uma conjuntura extraordinária e, portanto, imprevisível. ${ }^{13}$

Entretanto, a impossibilidade de conter as divergências internas nos marcos pretendidos pelas Cortes constituintes e pelas lideranças locais resultou na eclosão de uma guerra civil aprofundando a situação de instabilidade e de ampliação das tensões políticas.

\footnotetext{
${ }^{13}$ István Jancsó, op. cit., 2005, p. 46. A bibliografia sobre os desdobramentos políticos do constitucionalismo na Bahia é vasta, destaca-se: Ignácio Accioli de Cerqueira e Silva. Memórias históricas e políticas da província da Bahia (anotadas por Braz do Amaral). Bahia: Imprensa Oficial do Estado, 1931, v. III; Braz do Amaral. História da Independência na Bahia. Salvador: Progresso, 1957; Zélia Cavalcanti. O processo de Independência na Bahia. In: Carlos Guilherme Mota (Org.). 1822, dimensões. São Paulo: Perspectiva, 1972, p. 231-250; Ubiratan Castro de Araújo. A guerra da Bahia. Salvador: Centro de Estudos Afro-Orientais, 2001; Luis Henrique Dias Tavares. Luis Henrique Dias Tavares. Independência do Brasil na Bahia. Salvador: EDUFBA, 2005; Lina Maria Brandão de Aras. A Santa Federação Imperial: Bahia, 1831-1833. São Paulo, Universidade de São Paulo, 1995 (Tese de Doutorado); Thomas Wisiak. A 'Nação partida ao meio': tendências políticas na Bahia na crise do Império luso-brasileiro. São Paulo, Universidade de São Paulo, 2001 (Dissertação de Mestrado); Argemiro Ribeiro de Souza Filho. A guerra de Independência na Bahia: manifestações políticas e violência na formação do Estado Nacional (Rio de Contas e Caetité). Salvador, Universidade Federal da Bahia, 2003 (Dissertação de Mestrado); Hilton Barros Coelho. "Authoridades" e "Anarchistas" no "Império da desordem": conflitos e reconfigurações do poder dominante na Bahia da guerra à consolidação da Independência. Salvador: UFBa, 2003 (Dissertação de Mestrado); Sérgio Armando Diniz Guerra Filho. O povo e a guerra. Participação das camadas populares nas lutas pela Independência da Bahia. Dissertação (Mestrado em História) - Universidade Federal da Bahia, Salvador, 2004.
} 
Por pouco mais de um ano, a província viu-se mergulhada em um conflito militar e político cuja significância situa-se além da disputa entre portugueses europeus e americanos, evidenciando uma complexidade interna que recusa uma distinção bipolar. Ademais, o recurso à violência para garantir a adesão a um projeto de unidade reitera mais um elemento de aproximação entre as experiências das colônias da América espanhola. Um aspecto importante tanto no que se refere a já combatida idéia de uma Independência pacífica no Brasil, se comparada ao violento processo da América hispânica, quanto à relevância de pensar-se nessa conjuntura luso-americana em um contexto mais ampliado, particularmente no que se refere a um mundo ibérico. ${ }^{14}$

A configuração do quadro político da Bahia entre os anos de 1821, momento de adesão das Cortes, e 1823, com o fim da guerra civil apresenta uma intensificação do exercício político - não apenas centrada na capital e no Recôncavo -, motivada pelas particularidades internas que, por sua vez, ganhavam evidência a partir dos acontecimentos verificados no Rio de Janeiro e nas Cortes de Lisboa. Esse movimento mais amplo com ressonância no interior da província resultou na polarização das forças políticas fornecendo maior complexidade às tensões locais, sobretudo quando a esfera da política passou a ser cada vez mais ocupada por outros segmentos da população de um modo imprevisível. É, portanto, um período de grande aprendizado individual e coletivo, de resto em todo o Brasil Reino, confirmando a observação feita por Caio Prado Júnior de que o processo de Independência do Brasil não pode ser resolvido por uma explicação "simplista e esquemática” reduzida a uma oposição entre Brasil/colônia e Portugal/Metrópole “sem levar em conta o sem-número de ações e reações que se processam no seio e interior de cada qual” e, dessa forma, "esquecendo o que houve de luta social dentro de ambos". ${ }^{15}$ De fato, estudos recentes têm, inclusive, dimensionado esse equacionamento ao discutirem o potencial de inserção dos escravos no período, segmento ausente em suas considerações. ${ }^{16}$

Além disso, na esteira de um debate mais amplo sobre a questão nacional, revigorado pelos acontecimentos mundiais das últimas décadas do século $\mathrm{XX}$, novas

\footnotetext{
${ }^{14}$ Conforme propõe os estudos de João Paulo Garrido Pimenta mencionados acima.

15 Caio Prado Jr. “O Tamoio e a política dos Andradas na Independência do Brasil”. In: __. Evolução política do Brasil e outros estudos. 6. ed. São Paulo: Brasiliense, 1969, p. 181 (O texto foi publicado pela primeira vez em 1944).

${ }^{16}$ Para a Bahia: João José Reis. “O jogo duro do dois de julho: O 'Partido Negro' na Independência da Bahia”. In__.; Eduardo Silva. Negociação e conflito. A resistência negra no Brasil escravista. São Paulo: Companhia das Letras, 1989; Hendrik Kraay. "Muralhas da independência e liberdade do Brasil: a participação popular nas lutas políticas (Bahia, 1820-1825)”. In: Jurandir Malerba (Org.). A Independência brasileira: novas dimensões. Rio de Janeiro: Editora FGV, 2006, p. 303-341 e do mesmo autor "Em outra coisa não falavam os pardos, cabras e crioulos: o 'recrutamento' de escravos na guerra de independência no Brasil, 1822-1823”, Revista Brasileira de História, v. 22, 2002, p. 109-126.
} 
investigações têm possibilitado a reflexão acerca dos intricados nexos de diferentes projetos políticos que envolveram a emergência do Estado e da nação brasileiros, ampliando abordagens clássicas da historiografia sobre o tema. ${ }^{17}$ No entanto, a despeito disso, ainda persiste uma visão sobre a Independência do Brasil que ignora a dinâmica desse processo e, em decorrência, reproduz equívocos sobre um passado histórico complexo e ainda mal interpretado.

Certamente uma questão importante nessa perspectiva diz respeito ao lugar ocupado pelas províncias, cujos processos políticos apenas reiteram que a construção do Império do Brasil não se efetivou de maneira simples e sem conflitos de vária natureza. Pelo contrário, os anos de aprofundamento da crise política foram também o da expressão de distintas alternativas políticas evidenciando que não havia uma homogeneidade entre os governos provinciais em sua relação com Lisboa ou com o Rio de Janeiro, do mesmo modo que não se verificou entre os habitantes de uma mesma província. Essa percepção requer não somente que se rediscuta o projeto político de uma unidade nacional formulado e direcionado pelos principais protagonistas situados no Rio de Janeiro e em São Paulo e, portanto, possuidores de ampla visão sobre as perspectivas futuras de um governo monárquico constitucional, mas também que apreenda a dinâmica interna das províncias, com as suas contradições e desarticulações aparentes, como partes recíprocas de uma mesma totalidade histórica. Dessa apreensão é que se pode estabelecer as questões centrais do movimento como um todo.

No caso da Bahia, pesquisas recentes que tratam da história política do período da Independência, de diferentes modos, mencionadas acima, têm discutido aspectos importantes desse processo, inclusive, incorporando outras realidades para além da capital e do Recôncavo. O mérito desses trabalhos reside justamente no fato de realçar as particularidades da província num momento de extrema fluidez e incertezas quanto às perspectivas de consolidação de uma nova ordem política, avançando nas perspectivas analíticas da historiografia clássica sobre o tema ao mesmo tempo em que dilatam os caminhos para futuras investigações.

Não restam dúvidas, pelas razões mencionadas acima, que os intensos acontecimentos políticos na Bahia em princípios dos anos 1820 demandam a reabertura da discussão sobre os violentos encaminhamentos da crise na província. Essa questão torna-se

\footnotetext{
${ }^{17}$ Um exemplo de estudos sobre o tema podem ser vistos em: István Jancsó (Org.). Brasil: Formação do Estado e da Nação. São Paulo: Hucitec/Fapesp; Ijuí: ed. Unijuí, 2003 e Independência: História e Historiografia. São Paulo: Hucitec; Fapesp, 2005.
} 
ainda mais motivadora quando confrontada com alguns registros anteriores ao constitucionalismo que afirmavam as significativas transformações para as capitanias após a vinda da família real e, particularmente, para a Bahia, ao mesmo tempo em que apontavam perspectivas ainda mais promissoras. No panfleto que anunciava o lançamento da gazeta Idade d'Ouro do Brazil, em 13 de maio de 1811, por exemplo, o redator observava que

atentando para a face atual das nações civilizadas do universo inteiro, vendo guerras intermináveis deturpar o risonho semblante da polida Europa, não podemos deixar de sentir uma doce emoção, se conferimos o convulsivo estado de uma política devastadora com a tranqüilidade pacífica de que se goza neste vasto império do Brasil [...]. Paralelizemos o dourado século de Augusto com a presente idade do Brasil e não temos susto de que se taxe de lisonjeira a alusiva comparação, principalmente na Bahia”. ${ }^{18}$

Era uma época de grandes alterações e não à toa o nome escolhido para o periódico foi Idade de Ouro. Mesmo que se considere o caráter oficioso da gazeta, os anos que se seguiram ao estabelecimento da monarquia bragantina no Rio de Janeiro propiciaram, de fato, mudanças importantes para parte dos residentes da Bahia. A despeito disso, a capitania fora uma das primeiras a manifestar sua adesão às Cortes de Lisboa se recusando a acatar as ordens vindas do governo do Rio de Janeiro. A proposta desse estudo, centrado nos marcos temporais de 1808-1823, é examinar o significado das transformações no território da Bahia a partir da presença da Coroa portuguesa na América partindo do pressuposto que, a partir de então, novas condições foram inauguradas e, se por um lado, visavam atender as necessidades do Estado português de dar respostas imediatas à crise, por outro, criaram as condições propícias para que outras formas de superação dessa mesma crise pudessem ser elaboradas naquele contexto. Nessa direção, compreende que o alargamento do aprendizado político resultante do movimento vintista dos anos 1820 não se deu de maneira inesperada ou como simples reprodução dos acontecimentos externos, mas decorreu de um processo de maturação no interior da situação concreta de crise do absolutismo vivenciada pelos homens no período, na linha de discussão proposta por Denis Bernardes. ${ }^{19}$ Crise, aprendizado político e formas de mediação constituem, assim, os elementos pelos quais nos conduzimos para a observação

\footnotetext{
${ }^{18}$ Prospecto da Gazeta da Bahia. Bahia, na Tipografia de Manoel Antonio da Silva Serva, ano de 1811. Biblioteca Pública do Estado da Bahia. Setor de Periódicos Raros.

${ }^{19}$ Denis Antônio de Mendonça Bernardes. O patriotismo constitucional: Pernambuco, 1820-1822. São Paulo: Hucitec/Fapesp; Pernambuco: UFPE, 2006.
} 
de uma agitada conjuntura que impunha o reordenamento da monarquia portuguesa e, contraditoriamente, abria outras possibilidades para os contemporâneos.

Quase dez anos depois de propalar sobre a fase próspera e a estabilidade do Império do Brasil, em março de 1821, o redator do Idade d'Ouro utilizava as páginas do periódico para, dessa vez, atacar os ministros de d. João VI. A sua fala sintetiza a dimensão dos acontecimentos apenas um mês depois de a Bahia aderir ao movimento vintista:

Eles [os ministros] tiveram a habilidade de iludir alguns pixotes, dizendo-lhes que o Brasil não era país de Constituição e que só era país para injustiças e roubos. Qual é o país do mundo que não seja próprio de um governo sábio e justo! Muito má idéia fazem eles da palavra Constituição, que a julgam planta exótica do Brasil. Dizem que a raça africana torna perigosa a Constituição. E os deputados das Cortes são, por ventura, néscios para não terem em vista as providências que tal artigo exige? [...] De quem eles devem ter medo não é dessa gente infeliz e esfaimada; é sim das luzes do século que destecem as trevas da sua maliciosa ignorância. E por isso bom seria que mandassem queimar todos os livros e que só ficasse a Ordenação podre do reino, com alguns ligeiros retoques para se saber pedir vista, apelar, agravar, enforcar, etc., que é quanto basta para que o Brasil floresça. ${ }^{20}$

Embora produzidos em circunstâncias distintas, a fala do periódico e a ata do Senado da Câmara de Salvador, mencionada no início dessa introdução, enfatizam a importância de uma ordem constitucional para afirmar o começo de um tempo novo. Certamente o elemento significativo nesse período não se encontra na sobreposição do novo sobre o antigo, como assinala Andréa Slemian, mas na rapidez com que proposições alternativas de superação da crise foram formuladas e nos caminhos percorridos até que adquirissem concretude. ${ }^{21}$

O trabalho está estruturado em quatro capítulos que buscam dar conta da problemática anunciada acima. O primeiro discute as circunstâncias que propiciaram a transferência da Coroa portuguesa para a América. Buscou-se vincular o movimento de reordenação da monarquia bragantina à conjuntura de crise do sistema colonial como desdobramento da desagregação do Antigo Regime. No plano interno, isso significou o aumento das expectativas para os portugueses americanos residentes na Bahia manifestas

\footnotetext{
${ }^{20}$ Citado por Maria Beatriz Nizza da Silva. A primeira gazeta da Bahia: Idade d'Ouro do Brazil. 2. ed. revista e ampliada. Salvador: Edufba, 2005, p. 307-308.

${ }^{21}$ Andréa Slemian. Vida política em tempo de crise: Rio de Janeiro (1808-1824). São Paulo: Hucitec, 2006, p. 22-23.
} 
desde a passagem do regente por Salvador, cidade que por sua situação econômica e geopolítica, mas também por reunir uma das maiores populações escravas da América, ocupava um lugar de destaque nos projetos de intervenção elaborados pelas autoridades régias. Para além da capital, outros territórios revelavam a diversidade e a integração da capitania, elementos importantes na apreensão da sua dinâmica interna.

As estratégias utilizadas pela Coroa ficarão ainda mais evidentes no decorrer do segundo decênio de 1800 com a nomeação do conde dos Arcos, d. Marcos de Noronha e Brito, como governador da Bahia, portador de alguns atributos políticos que lhe permitiriam administrar a província em um período de agravamento da desestabilização política, assunto tratado no segundo capítulo. A despeito da vitória das potências aliadas sobre o exército francês e o início da política reformista das monarquias absolutas, a situação das colônias hispânicas punha em alerta não somente o governo espanhol como também o Estado português. Era preciso reforçar as medidas de contenção da possível contaminação de idéias revolucionárias e, ao mesmo tempo, reconhecer a importância das partes americanas dos domínios portugueses. É nesse contexto que, em 1815, o Brasil foi elevado à categoria de Reino Unido resultando em reações distintas nos dois lados do Atlântico. Dois anos depois os habitantes de Pernambuco lideraram um movimento contra a centralização do Rio de Janeiro, denotando que a relação da corte mantida com as províncias era bastante desigual e a possibilidade de articulação entre as capitanias do Norte um dado irrefutável, inclusive a Bahia, cujas evidências apontam-na como uma aliada em potencial.

O terceiro capítulo procurou traçar um quadro das alterações econômicas da Bahia nos anos de 1810. Um de seus objetivos foi demarcar a atuação de uma fração das classes proprietárias - de engenhos e escravos - frente a adoção dos tratados de 1810 e as negociações impostas por força da abolição do tráfico ao Norte do Equador. A capacidade de articulação e de elaboração de algumas figuras proeminentes na capitania fica evidenciada a partir da análise de algumas de suas concepções sobre o Estado e a questão econômica. É possível perceber o potencial de movimentação desses indivíduos sobretudo quando os seus interesses econômicos estavam em jogo. A configuração desse quadro encerra-se com a posição assumida pela gazeta Idade d'Ouro do Brasil, criada em 1811, e que durante anos será o único canal de informação oficioso dos residentes sobre a conjuntura política do período.

O aprofundamento da crise política com a eclosão da Revolução constitucionalista do Porto é o tema do quarto e último capítulo. Nele discute-se a maneira 
pela qual essas alterações foram absorvidas pelos habitantes enfatizando a riqueza do período para o alargamento do aprendizado político de amplos segmentos sociais e não apenas para as lideranças políticas. A eclosão de uma guerra civil evidenciou as profundas divergências existentes no interior da província ao mesmo tempo em que os protagonistas inovavam em suas formas de organização políticas distintas daquelas que até então haviam conhecido, embora os Senados das Câmaras tenham também se constituído em espaço de discussão e mobilização. Essa intensa atividade política permitiu a manifestação de distintas alternativas de superação da crise exigindo uma articulação entre os setores das classes proprietárias para conter o movimento nos marcos reformistas que então defendiam. Quando o conflito militar encerrou-se, as classes vitoriosas buscaram assentar as condições para a aceitação do projeto de Império proposto pelo governo do Rio de Janeiro.

Por fim, as fontes documentais primárias buscaram conferir consistência à investigação. Em boa parte proveniente do acervo do Arquivo Público do Estado da Bahia, atualizando-se a ortografia nas citações, mantendo-se a pontuação e as iniciais maiúsculas. Foi também utilizado documentos da Biblioteca Nacional do Rio de Janeiro, entre outros disponíveis no site dessa e de outras instituições. A pesquisa se valeu também de muitos documentos transcritos na íntegra em obras clássicas, a exemplo de, Ignácio Accioli de Cerqueira e Silva (Memórias históricas e políticas da província da Bahia, v. III e IV), Braz do Amaral (História da Independência da Bahia) e Alexandre de Mello Moraes (História do Brasil Reino, tomos 1 e 2). 


\section{Capítulo 1}

\section{A Bahia na crise do Antigo Regime na América portuguesa}

Em 22 de janeiro de 1808 atracaram nos portos de Salvador as embarcações que conduziriam o príncipe regente d. João e parte da família real ao Rio de Janeiro, nova sede do Império português, depois de uma turbulenta viagem que durou quase dois meses. Alertado sobre a possibilidade de a frota real desembarcar na cidade, o então governador e capitão-general, d. João de Saldanha da Gama Mello e Torres Guedes de Brito (18051809), $6^{\circ}$. conde da Ponte, intensificou as determinações para as autoridades locais visando atender as necessidades que a ocasião exigia: iluminação da cidade, procissões, Te-Deum, beija-mão, além das acomodações e alimentação necessárias para tão ilustres visitantes. ${ }^{1}$ Era a primeira vez que um membro da monarquia portuguesa pisava em terras americanas após mais de três séculos de domínio colonial e a sua permanência durante os treze anos que se seguiram resultou em amplas alterações para os habitantes dos seus domínios nos dois lados do Atlântico.

Embora as manifestações dos residentes de Salvador possam revelar aspectos típicos da relação entre os súditos e o seu príncipe, é possível examinar a dimensão que a transferência da Coroa bragantina provocou no reordenamento das relações estabelecidas com a capitania, procurando articulá-la às transformações políticas mais gerais de crise do Antigo Regime na Europa e na América em particular. ${ }^{2}$ Pretende-se apontar os elementos de fundo desse contexto realçando, desse modo, o seu significado histórico.

\footnotetext{
${ }^{1} \mathrm{O}$ conde da Ponte teria sido avisado que a família real partira de Lisboa, em 27 de novembro de 1807, pela tripulação de um navio mercante da praça da Bahia e após ter recebido a cópia do decreto, datado do dia anterior, no qual o regente justificava a resolução de transferir-se para a colônia americana. Essa informação deve ter chegado logo nos primeiros dias de janeiro de 1808, pois, no dia 8 desse mês expediu ordens ao coronel do Regimento de Milícias da Torre alertando que o mesmo ordenasse "aos portos do mar de seu distrito, no sentido de os pescadores, jangadeiros e soldados dos referidos postos manterem toda vigilância para que o governo fosse com antecedência avisado da aproximação da frota, no caso de vir aqui arribar”. Citado por Wanderley Pinho. A abertura dos portos. Cairu. Os Ingleses. A Independência. Salvador: Publicações da Universidade da Bahia, 1961, p. 49. As condições climáticas desfavoráveis ocasionaram a divisão da frota portuguesa obrigando o príncipe a aportar em Salvador, fato que preocupou os ministros de d. João no Rio de Janeiro. No começo de fevereiro, João Rodrigues de Sá de Meneses, o visconde (e depois conde) de Anadia, ministro e secretário de Estado dos Negócios da Marinha e Domínios Ultramarinos, enviou ofício ao conde da Ponte alertando que "por causa da falta de munições ou de outro qualquer motivo" as embarcações poderiam ancorar na Bahia, solicitando informações sobre o assunto "a fim de sossegar o justo cuidado que causa a demora de S.A.R. à Real Família e aos fiéis vassalos do Mesmo Senhor que se acham já aqui fundeados”. Correspondência do visconde de Anadia ao conde da Ponte, de 5 de fevereiro de 1808. Arquivo Público do Estado da Bahia (APEB). Seção de Arquivo Colonial e Provincial. Ordens Régias. Maço: 108 (1807-1810).

${ }^{2}$ Para uma ampla análise das transformações no período, ver Eric J. Hobsbawm. A era das revoluções. 9 ed. Rio de Janeiro: Paz e Terra, 1994; René Rémond. O século XIX (1815-1914). São Paulo: Cultrix, 1976;
} 


\subsection{Conjunturas e crise política}

A historiografia sobre as independências das Américas hispânica e portuguesa já destacou a importância do contexto mais amplo de fins do século XVIII, sobretudo após 1789, para a compreensão dos movimentos nas áreas coloniais que alteraram os pilares das monarquias absolutas ibéricas. As múltiplas mediações e experiências políticas vivenciadas pelas populações lusa e hispano-americana fornecem um dos traços marcantes dos acontecimentos no período, evidenciando uma dinâmica político-social que reitera a complexidade das circunstâncias de emergência dos Estados independentes e do sentimento nacional no Oitocentos. A extensão dessas alterações resultou de um mesmo processo de desestrutura do conjunto político do Antigo Regime possibilitando, no entanto, reações diversas entre as populações americanas resultantes das suas próprias experiências políticas e em função das alternativas possíveis de superação da crise. ${ }^{3}$

De fato, as pressões exercidas por Napoleão Bonaparte para ampliar o seu domínio no continente europeu atingiram frontalmente a estabilidade política das monarquias ibéricas. Se é possível estabelecer alguma semelhança com os acontecimentos daí advindos seria o fato de as monarquias ibéricas encontrarem-se submetidas aos mesmos infortúnios em virtude das conseqüências das guerras napoleônicas ainda que, em linhas gerais, seja possível apontar características similares no processo de sustentação dos respectivos impérios ancorados nos grupos de poder situados na península ou nas áreas coloniais até a eclosão do movimento revolucionário na Europa. ${ }^{4}$

A turbulência característica da segunda metade do Setecentos resultou no isolamento dos países ibéricos no quadro dos arranjos políticos e econômicos da Europa. Nas áreas coloniais, apesar da subordinação dos grupos vinculados ao poder do Estado,

Jaques Godechot. Europa e América no tempo de Napoleão (1800-1815). São Paulo: Pioneira; Edusp, 1984. A sucessão dos acontecimentos pode ser acompanhada em: István Jancsó (Orient.). Cronologia de História do Brasil Monárquico, 1808-1889. São Paulo: Humanitas; FFLCH/USP, 2000.

${ }^{3}$ As conexões do movimento de Independência do Brasil ao processo mais amplo da crise do Antigo Sistema Colonial são discutidas por Fernando A. Novais. “As dimensões da independência”. In: Carlos Guilherme Mota (Org.). 1822, dimensões, op. cit., 1972, p. 15-26 e Portugal e Brasil na crise do Antigo Sistema Colonial (1777-1808). São Paulo: Hucitec, 1983. O impacto da crise do Antigo Regime nas sociedades hispano e luso-americana pode ser vista em: Josep Fontana. La crisis del Antiguo Régimen, 1808-1833. 2.ed. Barcelona: Editorial Crítica, 1982; T. Halperin Donghi. História da América Latina. 3. ed. Rio de Janeiro: Paz e Terra, 1975; István Jancsó. “A construção dos Estados nacionais na América Latina. Apontamentos para o estudo do Império como projeto”. In: Tamás Szmrecsányi; José Roberto do Amaral Lapa (Orgs.). História econômica da Independência e do Império. 2. ed. São Paulo: Hucitec; Edusp; Imprensa Oficial, 2002; João Paulo Garrido Pimenta, 2002 e 2003; Osvaldo Coggiola (Org.). A Revolução Francesa e seu impacto na América Latina. São Paulo: Nova Stella/Editora da USP; Brasília: CNPq, 1990; Miguel Artola. Antiguo Régimen y Revolucion liberal. Madrid, 1979, entre outros.

${ }^{4}$ Cf. István Jancsó, op. cit., 2002. 
não se pode afirmar que se encontravam permanentemente no campo da oposição ao absolutismo. Para o caso da América hispânica, François-Xavier Guerra afirma que as “elites”, ainda pouco numerosa e inseguras quanto à sua força política, optaram, durante boa parte do século XVIII, por apoiarem-se na autoridade do rei para assegurar a concretização de seus projetos reformistas. Mesmo que essa aliança tenha se enfraquecido aos poucos com a difusão das "luzes”, a figura do monarca permanecia para a maior parte dos seus súditos como o "senhor natural do Reino, situado no pico de uma pirâmide de dignidades e honras”. ${ }^{5}$ Todavia, o aprofundamento da crise e a sua percepção pelos homens do período propiciaram diferentes possibilidades de intervenção conduzindo a movimentos de natureza diversa e soluções variadas.

Nas áreas coloniais hispano-americanas, a transferência da Coroa espanhola dos Bourbons para José Bonaparte, irmão de Napoleão, em virtude das abdicações de Fernando VII e Carlos IV, em maio de 1808, resultou no rompimento do princípio da legitimidade dinástica ante o fortalecimento dos poderes regionais, se diferenciando do processo ocorrido na América portuguesa. Em outras palavras, se no espaço lusoamericano a presença da monarquia revigorou os vínculos mantidos com os seus súditos, nas áreas submetidas a Espanha, os antigos colonos, protagonistas de uma situação sui generis, viram-se na condição de súditos sem rei. ${ }^{6}$ Ou seja, não havia soberano a obedecer e isso remetia naturalmente à discussão sobre a estrutura do poder local e sobre a natureza

\footnotetext{
${ }^{5}$ François-Xavier Guerra. Modernidad y Independências: Ensayos sobre las revoluciones hispânicas. 2. ed. México: Editorial Mapfre; FCE, 1993, p. 27. Analisando as condições que propiciaram o desmoronamento do edifício colonial, em particular da América espanhola, Halperin Donghi relativiza as causas apontadas pela historiografia - as reformas econômicas e político-administrativas introduzidas pela Coroa espanhola, a renovação ideológica da cultura hispano-americana proporcionada pelo iluminismo, os movimentos insurrecionais característicos da segunda metade do século XVIII - ressaltando que se anunciavam um estado de alerta, não indicavam a possibilidade do rompimento em curto prazo. Para ele, o progresso das novas idéias políticas que permite o uso de um novo vocabulário nas distantes localidades deve ser visto como conseqüência de um contexto mais amplo, sobretudo depois de 1789, com a "existência de uma América republicana, de uma França revolucionária”. Os acontecimentos advindos desse contexto não deixariam a Península Ibérica imune. "Portugal está fechado numa difícil neutralidade, ao passo que a Espanha [...] demonstra uma fraqueza cada vez maior entre as gigantescas lutas iniciadas com o ciclo revolucionário. Nessas condições, nem mesmo os mais fiéis servidores do rei podem deixar de levar em conta a possibilidade de que também essa Coroa, como ocorreu com outras, venha a desaparecer. Na América espanhola, a crise da independência é a conseqüência da desagregação do poder espanhol, iniciada por volta de 1795 e que assume um ritmo cada vez mais intenso". Cf. T. Halperin Donghi, op. cit., p. 50; Guerra, da mesma maneira, ressalta a importância da filiação entre as revoluções hispânicas e a Revolução Francesa na compreensão dos fenômenos das independências americanas. Op. cit. (especialmente o capítulo I).

${ }^{6}$ Conforme a análise empreendida por István Jancsó, op. cit., 2002. Sobre a crise política instalada na Espanha com a invasão napoleônica e a quebra da legitimidade, ver ainda: T. Halperin Donghi op. cit.; João Paulo G. Pimenta, op. cit., 2002; Juan Carlos Garavaglia. "Os primórdios do processo de Independência hispano-americano”. In: István Jancsó (Org.)., op. cit., 2005, p. 207-234. Para uma discussão sobre o lento processo de construção da cidadania em Buenos Aires, ver: Oreste Carlos Cansanello. "De súbditos a ciudadanos. Los pobladores rurales bonaerenses entre el Antiguo Régimen y la modernidad". Boletin del Instituto de Historia Argentina y americana Dr. Emilio Ravignani. Buenos Aires, Fondo de Cultura Económica, n. 11, 3ª Serie, 1995, p. 113-139.
} 
da soberania; acirrando os conflitos internos, que forneceram caráter diverso às guerras de independência nessas localidades. ${ }^{7}$

Em Portugal, meses antes do afastamento dos soberanos espanhóis, d. João, ocupando a regência, desde 1792, em substituição a rainha-mãe, d. Maria - considerada incapacitada mentalmente para governar - diante das ameaças de invasão do Reino pelo exército napoleônico viu-se obrigado a quebrar a política de neutralidade que mantivera no conflito europeu e transferiu-se para a colônia americana. A situação do Reino português era, realmente, calamitosa e, apesar dos esforços do governo para se manter fora do redemoinho dos conflitos na Europa, a sucessão dos acontecimentos evidenciava a impossibilidade de escapar de uma crise política que subvertia as estruturas consideradas até então duradouras.

A expansão da França napoleônica era acompanhada com atenção pelos funcionários régios da Coroa portuguesa. Afinal de contas, mesmo não se envolvendo diretamente nas guerras napoleônicas, o destino político e econômico de Portugal dependeria do desfecho dos conflitos entre a França e a Grã-Bretanha em disputa pelo controle do comércio europeu e das colônias. ${ }^{8}$ Para o caso da capitania da Bahia, a documentação sinaliza a preocupação constante com a possibilidade de uma invasão das potências beligerantes. Na correspondência mantida entre os ministros da Coroa e o governador, à época d. Fernando José de Portugal (1788-1801), transparece uma

\footnotetext{
${ }^{7}$ As tentativas de resistência ao invasor na Espanha mobilizaram a população local resultando na formação de juntas provinciais e de uma Junta Central Suprema e Governativa do Reino, em 25 de setembro de 1808, que passou a articular as estratégias, inclusive militares, para a sobrevivência da monarquia espanhola, preservando, desse modo, a sua lealdade à dinastia deposta. Reunida inicialmente em Aranjuez, a junta transferiu-se para Sevilha e posteriormente, em novembro de 1809, para Cádiz em virtude do avanço das tropas francesas. É nesse contexto que as Cortes espanholas irão debater e aplicar um conjunto de reformas, além de elaborar uma constituição, convocando para isso representantes da população americana que, por meio do decreto lançado em 22 de janeiro de 1809, passou a ser considerada como integrante da monarquia espanhola. Era, de fato, um acontecimento notável, pois até então os hispano-americanos não haviam sido considerados membros de um corpo político homogêneo, numa relação de pretensa igualdade que os credenciava a discutir, lado a lado, com os peninsulares, os destinos da monarquia espanhola. Pela proposta da Junta, cada Vice-Reino - Rio da Prata, Nova Granada, Nova Espanha e Peru -, bem como as Capitanias Gerais do Chile - Venezuela, Cuba, Porto Rico e Guatemala -, teriam direito a um representante frente aos 36 peninsulares. Evidente que esta visível desproporcionalidade na representação gerou enormes protestos americanos denunciando que a idéia de equivalência entre os habitantes do Reino espanhol possuía fissuras. Cf. Manuel Chust. La cuestión nacional americana en las Cortes de Cádiz (1810-1814). Fundación Instituto Historia Social/Universidad Nacional Autónoma de México, 1999, p. 32 (nota 5). Para Guerra, a publicação do decreto em 22 de Janeiro faz dessa data uma das principais de todo o período revolucionário. Observa também que o texto do decreto, apesar de falar em igualdade, trata os americanos de maneira desigual e sua participação na representação nacional aparece como uma concessão e não como um direito. Op. cit., p. 134135.

${ }^{8}$ Por essa época, Portugal possuía um grande império colonial em diferentes continentes: África (ilhas de São Tomé e Príncipe, ilhas do Cabo Verde, Guiné e Bissau, Angola e Moçambique), Índia (Goa, Damão e Diu), China (Macau), Indonésia (Timor) e Atlântico Sul (Brasil). Cf. Charles R. Boxer. O império marítimo português, 1415-1825. São Paulo: Companhia das Letras, 2002; Jacques Godechot, op. cit.
} 
inquietação patente não apenas com a presença de navios franceses na costa da capitania, que ocupava uma posição altamente estratégica, mas, sobretudo, com a falta de recursos disponíveis para a sua defesa. Em 29 de agosto de 1796, o governador relatava as precárias condições para manter a segurança diante das suspeitas de embarcações inimigas:

Sem embargo de me achar bastantemente falto de munições de guerra, como constantes vezes tenho representado por essa Secretaria de Estado, mandei aquele socorro, que me foi possível, de pólvora, bala e armamento para a capitania do Espírito Santo, para Porto Seguro, para os Ilhéus e para outras partes, [...] mas me não é possível dar a providência mais própria e oportuna para afugentar estes inimigos da Costa do Brasil [...], e por em mais algum sossego o comércio desta Capitania que está bastantemente perturbado com estes fatos bem notórios por não haver nestes portos embarcações de guerra que saíssem de guarda-costas quando a ocasião assim o pedisse. [...] Quem é responsável pela defesa de uma capitania tão importante como esta deve expor continuamente o estado em que se acha de defesa [...]. ${ }^{9}$

Adiante reiterava a penúria dos armazéns reais pela falta de pólvora e de outras peças de artilharia, arrematando: "porém, como ninguém conhece melhor que V.Exa. o estado atual da Europa e as circunstâncias em que nos achamos com a França, não devo fazer mais ponderação alguma sobre esta matéria”. ${ }^{10}$ Dois anos depois, o governo era comunicado que a rainha, "sempre pronta a beneficiar e premiar os seus vassalos quando neles reconhece merecimento e virtudes”, pretendia condecorar todos que se empenhassem na expulsão dos invasores, recomendando “a mais exata e escrupulosa vigilância” a um possível desembarque de uma fragata francesa. ${ }^{11}$ Em novembro de 1805, foi a vez de uma poderosa esquadra inglesa, a caminho do Cabo da Boa Esperança, aportar na Baía de Todos os Santos, tendo seus pedidos atendidos pelo então governador Francisco da Cunha Menezes (1802-1805). ${ }^{12}$

Curioso é que pouco tempo antes dos conflitos entre a França e Portugal se acirrarem, atracou no porto de Salvador, em 2 de abril do ano seguinte, uma esquadra francesa que tinha entre seus comandantes Jerônimo Bonaparte, irmão de Napoleão. Retornando de uma tentativa frustrada de ocupação da ilha de Santa Helena, os tripulantes necessitavam de reparos nas embarcações, víveres e tratamento para os doentes. Após a

\footnotetext{
${ }^{9}$ Correspondência de d. Fernando José de Portugal para Luiz Pinto de Sousa, em 29 de agosto de 1796. Ignácio Accioli, op. cit., v. III, p. 194.

${ }^{10}$ Idem, ibidem. Loc. cit.

${ }^{11}$ Idem, ibidem, p. 190-191.

${ }^{12}$ Cf. Luiz Henrique Dias Tavares. História da Bahia. 10. ed.. São Paulo: Editora Unesp; Salvador: Edufba, 2001, p. 207.
} 
sua partida, quase um mês depois, o governador da Bahia encaminhou ao ministro e secretário de Estado dos Negócios da Marinha e Domínios Ultramarinos, d. João Rodrigues de Sá de Meneses, um relatório circunstanciado do seu contato com os comandantes da esquadra. Nele, esclarece sobre a maneira hospitaleira como os recebeu, intermediando, inclusive, um empréstimo com alguns negociantes para a aquisição dos gêneros de que necessitavam, sabendo “o quanto era conveniente aos interesses desta praça e ao sossego desta colônia, e, igualmente seria do agrado do Príncipe, Nosso Senhor, o pronto provimento desta esquadra, abreviando a sua saída deste porto". ${ }^{13}$ Procurava demonstrar, assim, que havia agido com certa habilidade.

Em 12 de agosto de 1807, Napoleão Bonaparte, depois de ter estabelecido um tratado com a Espanha (Fointanebleau), exigiu uma tomada de posição de Portugal frente aos conflitos na Europa. No ano anterior já havia decretado o bloqueio continental que, em linhas gerais, proibia qualquer intercâmbio comercial com a Grã-Bretanha numa tentativa de debilitar a resistência inglesa. Entre ficar e enfrentar o poderoso exército napoleônico ou seguir para a América, o príncipe regente decidiu pela segunda alternativa abandonando o Reino sob a proteção de uma escolta naval inglesa. Antes dessa decisão, porém, e ignorando a reação da Coroa britânica, o conde da Ponte havia sido avisado, em 7 de outubro, para impedir a saída de navios portugueses da capitania, tendo em vista que “apesar dos esforços e dos sacrifícios que o Príncipe Regente” havia feito para manter uma política de neutralidade,

[...] as circunstâncias políticas atuais da Europa são tais que é muito para recear que Portugal se ache muito brevemente obrigado a fechar os seus Portos do Continente desta parte do Mundo aos Ingleses, para evitar uma invasão de Tropas Francesas superiores neste Reino. O que suposto, e ignorando-se por ora o partido que tomará a Grã-Bretanha: É S. A. R. servido que V.Ex. impeça até nova ordem a partida dos Navios Portugueses que se acham nos postos desta Capitania, e se ponha em estado de defesa, mais respeitável, para poder com vantagem, e confiança de sucesso, repelir gloriosamente qualquer ataque hostil contra o território cujo governo lhe foi confiado pelo Nosso Augusto Soberano. ${ }^{14}$

\footnotetext{
${ }^{13}$ Correspondência do conde da Ponte ao visconde de Anadia, em 22 de abril de 1806. Ignácio Accioli, op. cit., v. III, p. 40. Os negociantes Manoel José de Mello, Antônio da Silva Lisboa, Francisco Dias Coelho, José Domingues e José da Silva Ribeiro teriam fornecido uma quantia de 24:000\$000 para os comandantes a juros de 20\%, passando-se letras sobre o tesouro do Império. Op. cit., p. 37 . O ofício encontra-se transcrito também, na íntegra, em Alexandre José de Mello Moraes. História do Brasil-Reino e do Brasil Império. Belo Horizonte: Itatiaia; São Paulo: Edusp, 1982, t. I, p.421-425.

${ }^{14}$ Correspondência do visconde de Anadia ao conde da Ponte, em 7 de outubro de 1807. Wanderley Pinho, op. cit., p. 48.
} 
Poucos dias depois desse aviso, uma convenção secreta entre a Grã-Bretanha e Portugal estabelecia, em seu artigo $2^{\circ}$, que a Coroa britânica estaria pronta a ajudar e proteger o embarque do príncipe para a América caso esse resolvesse partir ou enviar algum membro da família real. Estudos recentes afirmam a existência de um projeto secreto elaborado pelos ingleses que previa o envio de uma esquadra armada ao Brasil, na hipótese de Portugal cair sob o domínio do Império napoleônico, “quer a Corte de Lisboa aceite a nossa oferta ou não”. ${ }^{15}$ Se a corte portuguesa aceitasse a transferência para seus domínios americanos, as forças britânicas seguiriam para o Rio de Janeiro, do contrário, o objetivo seria conquistar o porto de Salvador de onde se poderia atacar "simultaneamente os portos de Buenos Aires, Lima e Caracas, considerados estratégicos para o escoamento das mercadorias inglesas na América do Sul”. ${ }^{16}$ Sabedor ou não dessas articulações, o fato é que ao decidir pela aliança com a Grã-Bretanha e se refugiar em sua colônia mais proeminente, o príncipe tentava evitar um destino semelhante ao do soberano espanhol.

Embora a preparação para a travessia do Atlântico em direção ao Rio de Janeiro pareça ter sido feita de maneira atabalhoada, o projeto de o monarca residir na América não era recente e a sua saída, naquelas circunstâncias, não se dera de maneira irrefletida. Não se pode esquecer que a possibilidade desse deslocamento já havia sido cogitada anteriormente em caso de situações críticas que pusessem a estabilidade da monarquia em risco. Em fins do século XVI, por exemplo, na época da invasão de Portugal pela Espanha; no governo de d. João IV (1640-1656); no reinado de d. João V (1706-1750) a conselho do ministro d. Luis da Cunha e, posteriormente, em 1762, quando, inclusive, uma esquadra havia sido preparada para transportar o rei d. José I ao Brasil diante da ameaça de invasão do Reino por exércitos franceses e espanhóis. Perspectiva que seria recuperada posteriormente por agentes ilustrados, em fins do século XVIII e princípios do seguinte, cuja imagem de grandeza do Novo Mundo como uma alternativa nas circunstâncias de crise extrema vivenciada pela monarquia portuguesa aparece de maneira recorrente. $^{17}$

\footnotetext{
${ }^{15}$ Citado por José Jobson de Andrade Arruda. Uma colônia entre dois impérios. A abertura dos portos brasileiros, 1800-1808. Bauru: EDUSC, 2008, p. 33. O autor discute os termos da Convenção Secreta de Londres, realizada em 22 de outubro de 1807, pouco mais de um mês antes da partida da família real, assim como as articulações promovidas pelas autoridades inglesas nesse contexto.

${ }^{16}$ Idem, p. 34.

${ }^{17}$ Maria de Lourdes Viana Lyra, op. cit. Segundo a autora, a fala dos agentes ilustrados retoma a concepção do “Quinto Império”, elaborada pelo Padre Antônio Vieira no século XVII no contexto do domínio espanhol, no sentido de reforçar a potencialidade do Brasil para o fortalecimento do Reino de Portugal. A conjuntura política do período que determinou a saída da família, bem como os resultados imediatos dessa decisão, constam da análise de Alan Manchester. "A transferência da Corte portuguesa para o Rio de Janeiro”. In:
} 
O que importa destacar, na linha argumentativa sugerida por Viana Lyra, é que as estratégias sobre o fortalecimento do Império português, com ênfase no papel a ser desempenhado pelo Brasil, foi um tema recorrente da história política colonial sofrendo alterações à medida que as transformações do quadro conjuntural assim o exigiam. A historiadora analisa com vagar as principais proposições que visavam ao fortalecimento do Império português em diferentes conjunturas em que a monarquia se viu pressionada. Essas orientações sugerem, por um lado, que os ideólogos da política colonialista da metrópole portuguesa estavam atentos aos problemas que decorriam da exploração das áreas coloniais no ultramar, possuindo ampla visão sobre os seus limites e as suas potencialidades e, por outro, que o movimento histórico geral impunha a adoção de reajustamentos importantes somente apreendidos na percepção mais ampla desse processo. ${ }^{18}$ É nesse sentido que se deve situar a vinda da família real para o Brasil e os desdobramentos políticos daí resultantes nas primeiras décadas do século XIX. Conforme assinala Ana Cristina Araújo, “a dinastia de Bragança atravessou vários momentos de crise interna na metrópole com os olhos postos no Brasil, como espaço de riqueza e poder, ou seja, como parcela determinante de unidade e fortalecimento econômico da monarquia”. 19

As evidências de agravamento da crise e as alternativas possíveis para a sua superação expunham também as diferentes posições dos ministros de Estado. Na defesa de um amplo plano de reformas cuja centralidade recaía sobre o Brasil estava d. Rodrigo de Sousa Coutinho, provavelmente o que possuía uma visão mais abrangente sobre a importância da colônia americana em seus aspectos geopolítico e econômico em situação de crise e para quem: "Portugal, reduzido a si só, seria dentro de um breve período uma província da Espanha”. ${ }^{20}$ Afastado do governo em função das divergências no ministério, o futuro conde de Linhares retornaria tão logo a conjuntura revolucionária apresentasse sinais de aprofundamento. Uma carta dirigida ao príncipe por outro partidário das reformas, o marquês de Alorna, d. Pedro de Almeida e Portugal, em 30 de maio de 1801,

Henry H. Keith; S. F. Edwards (Orgs.). Conflito e continuidade na sociedade brasileira. Rio de Janeiro: Civilização Brasileira, 1970, p. 177-217.

${ }^{18}$ Maria de Lourdes Viana Lyra cita trechos de uma carta enviada por Silvestre Pinheiro Ferreira ao príncipe regente, em 1801, se referindo à mudança conjuntural por ocasião do fracasso das potências aliadas contra a França: “os cálculos de há dez anos saem todos errados na era presente”, sendo necessária uma medida urgente para que "não suceda à sua Coroa, o que sucedeu à de Sardenha, à de Nápoles [...] a todas as Coroas de segunda ordem na Europa”. Op. cit., p. 109.

${ }^{19}$ Ana Cristina Bartolomeu de Araújo. “O Reino Unido de Portugal, Brasil e Algarves, 1815-1822”. Revista de História das Idéias. Faculdade de Letras/Instituto de História e Teoria das Idéias, Coimbra, 1992, p. 235.

${ }^{20}$ Idem, ibidem, p. 237. 
alertando-o sobre o agravamento da situação política da Europa, exemplifica a retomada da possibilidade de mudança da corte para a colônia americana:

V.A.R. tem um grande império no Brasil, e o mesmo inimigo que ataca agora com tanta vantagem, talvez que trema, e mude de projeto, se V.A.R. o ameaçar de que se dispõe a ser imperador naquele vasto território adonde pode facilmente conquistar as colônias espanholas e aterrar em pouco tempo as de todas as potências da Europa. Portanto é preciso que V.A.R. mande armar com toda a pressa os seus navios de guerra, e todos os de transporte, que se acharem na praça de Lisboa - que meta neles a princesa, os seus filhos, e os seus tesouros, e que ponha tudo isso pronto a partir sobre a barra de Lisboa, e que a pessoa de V.A.R. venha a esta fronteira da Beira, aparecer aos seus povos, e acender o seu entusiasmo $[\ldots] .{ }^{21}$

Alguns anos depois, as turbulências políticas propiciaram a execução de um projeto que, naquela conjuntura, se apresentou como a alternativa mais apropriada para a sobrevivência da Coroa portuguesa tornando inadiável a proposição de retirada da família real da Europa. ${ }^{22}$ Em ofício de 29 de novembro de 1807, o ministro da Grã-Bretanha em Portugal, Lord Strangford, comunicou ao seu governo a partida da família real:

Tenho a honra de anunciar-vos que o Príncipe Regente de Portugal efetuou a sua sábia e magnânima resolução de se retirar de um Reino, que não podia conservar por mais tempo, senão reduzindo-se a vassalo da França; e que S. A. R. e família, acompanhado pela maior parte de suas naus de guerra, e por grande multidão de seus fiéis vassalos, partiu hoje de Lisboa e se acha em viagem para o Brasil, debaixo da escolta de uma esquadra inglesa. Este grande e memorável acontecimento foi o resultado do sistema constante de confiança e moderação, adotado por S. M. a respeito deste país e porque me tinha feito responsável, em observância das vossas instruções. ${ }^{23}$

Ainda que a medida fosse considerada provisória diante das circunstâncias, inclusive para alguns dos ministros já que o projeto de construção de um império no novo mundo não era consensual, o enorme contingente de pessoas que incluía membros da família real, nobres e funcionários régios e o arsenal de objetos que deixaram o porto de

\footnotetext{
${ }^{21}$ Correspondência de d. Pedro, marquês de Alorna, ao príncipe regente, em 30 de maio de 1801. José Jobson de Andrade Arruda, op. cit., p. 147-148. O documento encontra-se também transcrito, na íntegra, em Luís Norton. A corte de Portugal no Brasil. 2. ed. São Paulo: Companhia Editora Nacional; Brasília: INL, 1979, p. 1. Ana Rosa Cloclet da Silva discute as formulações dos principais estadistas sobre os encaminhamentos da crise do Antigo Regime português na América. Inventando a nação. Intelectuais ilustrados e estadistas luso-brasileiros na Crise do Antigo Regime português (1750-1822). São Paulo: Hucitec; Fapesp, 2006.

${ }^{22}$ Para Oliveira Lima (D. João VI no Brasil. 3. ed. Rio de Janeiro: Topbooks, 1996, p. 43), longe de ser vista como uma deserção covarde, a trasladação da corte para o Rio de Janeiro deve ser considerada "uma inteligente e feliz manobra política”.

${ }^{23}$ Correspondência enviada pelo Lord Strangford ao governo britânico, em 29 de novembro de 1808. Ignácio Accioli, op. cit., v. III, p. 46.
} 
Lisboa naquele dia para a instalação da nova sede do Império sugeria que o retorno não seria imediato. A partir de então, portugueses europeus e americanos vivenciariam intensas mudanças cuja previsibilidade política não estava dada. ${ }^{24}$

A entrada da esquadra real no porto de Salvador mudou o cotidiano da cidade. Além do número expressivo dos membros da comitiva, cerca de cem pessoas, a presença da família real era um acontecimento de grande magnitude para boa parte dos seus habitantes. ${ }^{25}$ Não à toa, após ter ocupado a sede da maior autoridade política na América portuguesa, desde 1549, ano da sua fundação, até 1763, a cidade era também a primeira a receber o príncipe e seu séqüito. Fatos, aliás, freqüentemente lembrados em documentos posteriores com o intuito de demarcar os vínculos entre a Bahia e a Coroa e, mais do que isso, reafirmar a sua importância no interior do Império português.

Muitas foram as providências tomadas pelo conde da Ponte nos dias que antecederam a chegada de d. João e no decorrer de pouco mais de um mês em que permaneceu na capital. Ao Senado da Câmara coube exigir dos habitantes a iluminação da cidade por três noites consecutivas, assim como a apresentação de seus membros "na praça à entrada do mesmo palácio, para que com o corpo de Relação, e mais nobreza da cidade, façam ajuntamento de corte para o recebimento do mesmo Senhor”, ${ }^{26}$ Ao ouvidor

\footnotetext{
${ }^{24}$ Alguns estudos recentes têm aprofundado a discussão sobre o impacto da presença da família real na América: Andréa Slemian; João Paulo G. Pimenta. A corte e o mundo. Uma história do ano em que a família real portuguesa chegou ao Brasil. São Paulo: Alameda, 2008; Andréa Slemian, op. cit.; Denis Antônio de Mendonça Bernardes, op. cit.; Kirsten Schultz. "A era das revoluções e a transferência da Corte portuguesa para o Rio de Janeiro". In: Jurandir Malerba. A Independência brasileira: novas dimensões. Rio de Janeiro: Editora FGV, 2006, p. 125-151; Maria de Fátima Silva Gouveia. "As bases institucionais da construção da unidade dos poderes do Rio de Janeiro: administração e governabilidade no Império luso-brasileiro". In: István Jancsó (Org.), op. cit., 2005, p. 707-752. István Jancsó; João Paulo G. Pimenta, “Peças de mosaico...”, op. cit.; Andréa Slemian; João Paulo G. Pimenta, op. cit., 2003; Jurandir Malerba. A Corte no exílio. Civilização e poder no Brasil às vésperas da Independência (1808-1821). São Paulo: Companhia das Letras, 2000; Cecília Helena L. de Salles Oliveira. A astúcia liberal. Relações de mercado e projetos políticos no Rio de Janeiro (1820-1824). Bragança Paulista: Edusf; Ícone, 1999. Parte dessa historiografia dialoga diretamente com os estudos clássicos de Oliveira Lima, op cit; Sérgio Buarque de Holanda. "A herança colonial - sua desagregação”. In: __ (Dir.). História geral da civilização brasileira. O Brasil Monárquico. São Paulo: Difel, 1985, t. II, v. 1; Maria Odila da Silva Dias. “A interiorização da Metrópole”. In: Carlos Guilherme Mota (Org.). op. cit; Alcir Lenharo. As tropas da moderação. Rio de Janeiro: Biblioteca Carioca, 2003, apontando importantes elementos que revigoram a análise sobre a temática. Caio Prado Júnior chamou a atenção para as diferentes formas pelas quais as províncias do Centro-Sul e as do Norte perceberam a instalação da corte no Brasil. Evolução política do Brasil e outros estudos. 6. ed. São Paulo, Brasiliense, 1969.

${ }^{25}$ Entre os acompanhantes do príncipe encontravam-se a rainha d. Maria, d. Carlota Joaquina, Antônio Araújo de Azevedo, futuro conde da Barca, conselheiro José Egídio, futuro marquês de Santo Amaro, o desembargador Tomás António Corte Real e d. Fernando José de Portugal, futuro marquês de Aguiar, que havia governado a Bahia no período de 18 de abril de 1788 a 23 de setembro de 1801. A esquadra real compunha-se de 3 naus e uma fragata. APEB. Curiosidades sobre a Bahia, s.l., s.d., s.a.. Setor de Microfilmes, $n^{\circ} 58$ (Documento original consta do acervo da Biblioteca Nacional do Rio de Janeiro)

${ }^{26}$ Correspondência do governador da Bahia ao juiz de fora presidente e vereadores do Senado da Câmara, em 23 de janeiro de 1808. Ignácio Accioli, op. cit., v. III, p. 47.
} 
geral do cível foi determinado a "escolha das melhores casas que estiverem desocupadas, mandando-as espanar e assear, com participação dos senhorios delas, das quais me remeterá uma relação para, no caso de serem precisas, saber-se que há prontas”, entre outras disposições. ${ }^{27}$

Se os habitantes de outras partes da capitania prestigiaram também as manifestações de júbilo pela presença de visitantes tão ilustres é difícil saber, mas, de qualquer maneira os do Recôncavo não ficaram totalmente alheios à movimentação tendo em vista que às autoridades das vilas foram requisitadas remessas de farinha, grãos (milho, feijão e arroz), gêneros comestíveis, galinhas, frangos, patos, leitões e capados. Para as vilas de São Francisco, Santo Amaro e Cachoeira, o governador requereu ainda 60 bois “de seus engenhos e outros de seu distrito", além de ter repreendido o sargento-mor de Cachoeira que enviara o gado destinado à Feira de Capuame em vez de retirá-lo de seus próprios engenhos e nos dos vizinhos. ${ }^{28}$ Certamente, a agitação daqueles dias sinalizava algum tipo de mudança e o clima de festividade na capital não se dava apenas em razão da simpatia de seus habitantes seduzidos pela imponência da realeza.

Do ponto de vista político, a permanência do príncipe na Bahia adquire importância por duas questões essenciais. Para alguns residentes, a situação incomum exigia demonstrações de submissão e contentamento por sua decisão de residir na América, mas também, e prioritariamente, significava a ocasião oportuna para o encaminhamento de antigas aspirações que, naquela conjuntura, poderiam ser concretizadas. Para a Coroa portuguesa, o momento de extrema fragilidade política demandava intervenções táticas que pudessem solidificar os vínculos com a possessão americana na tentativa de amenizar o impacto de uma crise de grandes proporções que punha em risco o seu poder. E, para isso, o príncipe dispunha de conselheiros régios sempre atentos não somente às alterações da conjuntura externa, como também às informações necessárias sobre a situação interna dos domínios e, em especial, sobre a Bahia.

Nesse sentido, a preparação prévia para o estabelecimento da corte na América e a recepção que aqui obteve de seus habitantes, foi de extrema importância para que o empreendimento pudesse ser bem-sucedido, a despeito de alguns revezes. ${ }^{29}$ Isso significa dizer que muitas das decisões tomadas por d. João estavam em pleno acordo com o

\footnotetext{
${ }^{27}$ Citado por Wanderley Pinho, op. cit., p. 50.

${ }^{28}$ Citado por Wanderley Pinho, op. cit., p. 51.

${ }^{29}$ Cf. Kenneth Maxwell. "A geração de 1790 e a idéia do império luso-brasileiro”. In: piratas e outros malandros. Ensaios tropicais. São Paulo: Paz e Terra, 1999, p. 157-207. Chocolate,
} 
projeto político de fixação na América que pressupunha, entre outras coisas, fortalecer as relações da Coroa com os seus súditos. Pouco tempo após o seu desembarque, alguns membros das classes proprietárias, gozando da prerrogativa de proximidade com o regente, foram portadores de variadas demandas locais expressando desejos individuais e coletivos reavivados nesse momento.

O teor dessas petições indica que esses homens depositavam extrema confiança nas expectativas políticas e econômicas que, concretamente, a presença do príncipe na América poderia proporcionar. Esse também é o sentimento manifestado pelo autor anônimo de uma carta escrita logo após a partida de d. João de Lisboa, na qual procura relatar os acontecimentos no Reino português com a entrada do exército de Junot. O missivista, natural da Bahia, ao mesmo tempo em que dirige profundas críticas aos franceses e à sua ambição expansionista, não esconde seu contentamento pela sábia decisão do príncipe de estabelecer a sede da corte na América: "E agora que temos por timbre o forte Escudo da real Casa de Bragança, entregue pela benéfica Mão do nosso amado PRÍNCIPE, que não duvidando da nossa lealdade, foi com toda a Real Família viver entre nós; sim, entre os novos Lusitanos desse novo Império [...]”. ${ }^{30}$ Era, e não apenas para ele, um sinal de novos tempos.

Seus patrícios não tinham dúvidas que a Bahia, por sua reconhecida importância e potencialidades, não poderia ser menosprezada no novo arranjo político do Império português. Além do mais, estavam cientes de o que significaria para a capitania privilégio que outrora já havia vivenciado -, caso Salvador ostentasse o título de sede administrativa da corte. Assim, uma das primeiras representações encaminhada pelo corpo do comércio a d. João manifestava a aspiração de que ele permanecesse em definitivo na cidade. De acordo os peticionários, a capitania dispunha das condições estratégicas necessárias não apenas para uma defesa segura do trono, mas sobretudo para o engrandecimento e a ampliação da riqueza do Império português:

O memorável dia 22 de Janeiro em que a Providência trouxe a V.A. a esta cidade do Salvador, encheu a todos os seus fiéis vassalos da maior alegria e contentamento que se não pode exprimir: Ela foi a primeira terra do Brasil povoada, e a sua capital foi também a primeira que saiu a receber seu Soberano, o senhor pai da pátria para beijar a Régia e Augusta mão. A sua elevada posição parece ter sido desenhada pela natureza com o destino de aí erigir o trono do maior dos Soberanos. A abertura do porto

\footnotetext{
${ }^{30}$ Carta escrita por L.P.A.P. a um seu patrício da cidade da Bahia. Lisboa, na nova Officina de João Rodrigues Neves. Anno MDCCCVIII, com licença da Mesa do Desembargo do Paço, p. 28 (Acervo do IEB) (destaque no original).
} 
por seu vistoso arquipélago onde podem ancorar todas as armadas do mundo, vários e navegáveis rios, que nele entram por muitas fozes, e que banham as povoações do Recôncavo, oferecem apreciáveis gêneros da sua industriosa cultura, que produzem a abastança dos gêneros da primeira necessidade, e de luxo, e lhe asseguram uma riqueza inexaurível. Vastas matarias ao sul estão convidando aos povos a administrar a variedade das suas grossas, e pesadas madeiras, atraindo-os ao trabalho de fabricar tão respeitável marinha que segure não só a estabilidade do trono Lusitano, mas uma superioridade que ganhe respeito e admiração das nações que habitam na Europa. O seu incomparável porto, o mais belo do mundo, está como no centro das colônias de V.A. que dominando a África, lhe abre uma comunicação tanto mais fácil e breve com a Ásia, como com as nações aliadas da Europa, quanto fica sendo o seu comércio mais ativo, na reprodução dos variados ramos da sua agricultura [...]. ${ }^{31}$

A descrição dos fartos recursos, assim como o oferecimento de facilidades para a sua instalação, que incluía a edificação de um palácio majestoso, entretanto, não foram suficientes para modificar a decisão do príncipe de residir no Rio de Janeiro, conforme tornara público pelo decreto de 27 de novembro de 1807. Uma das razões para isso teria sido a pouca segurança da capital em função da sua localização em uma ampla baía que a deixava extremamente exposta a ataques externos. Contudo, outras solicitações tiveram imediato acolhimento, dentre elas: a criação de uma escola de cirurgia, o funcionamento de uma fábrica de vidros - eliminando o alvará de 5 de janeiro de 1785 que impedia qualquer iniciativa nesse sentido -, a implantação da primeira companhia de seguros a pedido dos negociantes locais. Em 8 de fevereiro, os membros do Senado da Câmara da cidade de Salvador e indivíduos pertencentes à "nobreza" da cidade foram condecorados com o hábito da Ordem de Cristo. ${ }^{32}$

Disposições referentes à segurança da capitania "principalmente nas circunstâncias tão críticas em que se acha a Europa” também não foram esquecidas. Entre as providências, o príncipe autorizou a criação de uma fábrica de pólvora, uma fundição para refundir peças fora de uso, a ampliação dos regimentos de infantaria e de cavalaria, a “abertura de estradas, com especialidade para o Rio de Janeiro, pela direção que se julgar conveniente”, além de instituir uma Junta de Defesa para auxiliar o governador nas

\footnotetext{
${ }^{31}$ Súplica que mandou-se da cidade da Bahia pedindo que fosse transferida para aqui a séde da corte estabelecida no Rio de Janeiro. Ignácio Accioli, op. cit., v. III, p. 231-232 (documento incompleto). Braz do Amaral informa que Balthazar da Silva Lisboa, irmão de José da Silva Lisboa, teria sido o portador da petição.

${ }^{32}$ A cópia do decreto de condecoração do hábito da ordem de Cristo para os membros do Senado consta em Pinto de Aguiar. A abertura dos portos. Cairu e os ingleses, Salvador: Livraria Progresso Editora, 1960. Sobre as decisões tomadas na Bahia: Ignácio Accioli, op. cit., v. III, p. 51 e passim; Luis Henrique Dias Tavares, op. cit., 2001, p. 211-213.
} 
reformas militares necessárias. ${ }^{33}$ Embora as medidas, no conjunto, pareçam apenas corresponder a uma parte da população sequiosa por benefícios, essencialmente atendiam ao projeto de reestruturação do Império português na América no limiar do Oitocentos e não deixa de ser significante que algumas das intervenções mais importantes tenham sido tomadas na Bahia.

Nessa perspectiva, a decisão de maior alcance disposta pelo príncipe poucos dias depois da sua chegada, em 28 de Janeiro, foi a assinatura da carta régia que autorizou a abertura dos portos do Brasil às nações amigas eliminando o domínio exclusivo exercido pelo comércio português na colônia. A capitania vivenciava uma situação difícil em virtude da determinação para impedir a saída de navios do porto de Salvador por conta do agravamento da crise política na Europa. Na representação entregue ao príncipe, um dia antes do decreto régio, o governador descreveu os abalos causados à economia local e, “em nome do Comércio, da Lavoura e benefício de todos estes habitantes, e a bem dos Rendimentos Reais”, requerendo a suspensão do embargo sobre a circulação livre de navios: "fazendo-se público na Praça comerciante que são nossos Inimigos França e Espanha e nossa aliada a Grã-Bretanha e que debaixo dessa hipótese se permita navegar livremente para Portos que ou as notícias públicas ou as particulares de seus correspondentes lhes indiquem mais vantajosas às suas especulações”. ${ }^{34}$

Diante de as circunstâncias políticas e econômicas enfrentadas pela Coroa portuguesa não parece que a medida tenha sido em decorrência da intervenção do economista José da Silva Lisboa, natural da Bahia e então Secretário da Mesa de Inspeção em Salvador, junto ao príncipe. De qualquer maneira, é inconteste que a defesa que fazia das doutrinas liberais, além de o profundo conhecimento sobre a situação econômica colonial, causou grande impressão em d. João a ponto de ser criada uma cadeira de Economia Política no Rio de Janeiro para que Lisboa assumisse como professor em razão de ter "dado provas de ser muito hábil pra o ensino daquela ciência, sem a qual se caminha às cegas e com passos mui lentos, e às vezes contrários nas matérias de governo". ${ }^{35}$ Mais uma vez é sintomática a criação dessa "aula” de economia, antes mesmo

\footnotetext{
${ }^{33}$ Correspondência do príncipe regente ao conde da Ponte, em 24 de fevereiro de 1808. Ignácio Accioli, op. cit., v. III, p. 51; Hendrik Kraay. Race, State and Armed Forces in Independence-era Brazil. Bahia, 1790s1840s. Stanford: Stanford University Press, 2001, p. 31.

${ }^{34}$ Representação do conde da Ponte ao príncipe regente, em 27 de janeiro de 1808. Wanderley Pinho, op. cit., p. 55-56.

${ }^{35}$ Decreto Régio de 23 de fevereiro de 1808. Cria na cidade do Rio de Janeiro uma cadeira de Ciência Econômica (disponível em www.câmara.gov.br). Alguns autores, embora possuam diferenças sobre a atuação do futuro visconde de Cairu nesse contexto, não desprezam a sua importância. Entre os que dão maior destaque a sua participação para a abertura dos portos, encontram-se Pinto de Aguiar (op. cit.) e
} 
da existência de um curso semelhante em Portugal, denotando o esforço do governo em agregar funcionários régios preparados nos seus quadros administrativos num período especialmente crítico para a monarquia portuguesa. ${ }^{36}$

Para Silva Lisboa, a abertura dos portos era inevitável diante da impossibilidade de subsistência do sistema colonial e mesmo das condições críticas do período, já que era preciso “Criar um Novo Império sobre bases mais firmes”. Em razão disso, não tinha dúvidas quanto à autoria: “O Senhor D. João Resolveu o Fazer tanto Bem sem esperar pelos Conselheiros de Estado, que se tinham desvairado em rumo, pela dispersão da tempestade nas costas de Portugal. É pois inteiramente Obra Sua a Carta Régia, Foral Novo do Brasil [...]”. ${ }^{37}$ Segundo ele, a medida possuía uma importância não apenas no campo econômico ao facultar a implantação do livre-comércio, mas também políticosocial, tendo em vista que poderia possibilitar a "conciliação de classes" ou de “interesses” entre aqueles que integravam o amplo e complexo econômico português. A Coroa, desse modo, dava os primeiros passos para assegurar a prosperidade futura da antiga colônia, correspondendo aos anseios daqueles que defendiam um sistema econômico sustentado em alguns princípios liberais, mesmo que não vissem nenhuma incompatibilidade nessa adoção com a manutenção da monarquia, como era o caso do próprio José da Silva Lisboa. ${ }^{38}$

Embora se argumente que o comércio feito de maneira ilícita de há muito rompia com as amarras do sistema colonial e que, portanto, o documento apenas reconheceria uma prática corriqueira, a decisão, efetivamente, integrou o processo de reordenamento do quadro econômico da monarquia lusa como um recurso importante para salvaguardar os seus interesses em uma conjuntura bastante adversa. Afinal de contas, em virtude do bloqueio continental decretado por Bonaparte e da invasão de Portugal, os principais portos portugueses estavam sob o controle da França impedindo que intermediassem o comércio entre as possessões portuguesas e a Europa. Era preciso

Wanderley Pinho (op. cit.). José Jobson de Andrade Arruda (op. cit.) sublinha a sua importância nesse contexto, mas não o considera como o responsável pela medida. Antônio Penalves Rocha ressalta o significado de José da Silva Lisboa para a difusão da Economia Política do Brasil na qual o seu estudo Princípios de Economia Política ocupa lugar importante e investiga o processo de elaboração das suas concepções nesse campo. Cf. A economia política na sociedade escravista. São Paulo: Hucitec;USP, 1996. Sobre as medidas cruciais tomadas pela Coroa em razão da sua fixação na América: Andréa Slemian; João Paulo G. Pimenta, op. cit., 2008.

${ }^{36}$ Cf. Antônio Penalves Rocha, op. cit., p. 36.

37 José da Silva Lisboa. Memórias dos benefícios políticos do governo de El-Rey Nosso Senhor D. João VI. Rio de Janeiro: na Impressão Régia , 1818, p. 68-69 (grifos no original).

${ }^{38}$ Antônio Penalves Rocha, op. cit., p. 105 e “Economia política e política no período joanino”. In: Tamás Szmrecsányi; José Roberto do Amaral Lapa (Orgs.), op. cit., 1996a, p. 31. O autor discute as bases de formação do pensamento econômico de Silva Lisboa. 
garantir a continuidade das conexões entre a Coroa e os mercados europeus. ${ }^{39}$ Na visão do comerciante inglês Thomas Lindley, que esteve na Bahia nos anos de 1802-1803, a despeito do rigor para conter a presença de estrangeiros, impedidos de "embarcar produtos da colônia nem mesmo em navios portugueses”, não era raro ocorrer o contrabando, “freqüentemente praticado pelo próprio tenente e demais funcionários nomeados para impedi-lo, ou por indivíduos com eles acumpliciados”. Observa, porém, que as leis de contenção estavam sendo "rigorosamente aplicadas”, com punições aos funcionários, além de novos decretos proibindo "a venda de mercadorias estrangeiras na Bahia, até mesmo para o pagamento de despesas portuárias, sendo obrigatória a remessa de tais mercadorias a Lisboa a fim de serem aí negociadas”. ${ }^{40}$ Seja como for, não se pode perder de vista o significado político da medida tanto no quadro de redefinição do Império português quanto para os habitantes da América portuguesa. E, nesse caso, não apenas pela perspectiva de novas rotas de comércio.

Se, por um lado, a abertura dos portos ao comércio exterior reposicionava o lugar ocupado pela possessão americana nos quadros econômicos do período ao permitir que dispusesse de novas condições comerciais, por outro, punha em evidência uma inquietação para parte da classe proprietária da Bahia, qual seja, a possibilidade de ampliação no número de comerciantes estrangeiros, particularmente da Grã-Bretanha, em Salvador. É o que expressa uma das representações entregues ao príncipe antes de seguir viagem para o Rio de Janeiro:

A agricultura é a fonte da riqueza, mas o comércio é que põe em giro o fruto da indústria do agricultor. Este aperfeiçoa e anima o que aquela fez existir à custa de suas fadigas [...].E há de ser esta indústria e fadiga nacional a que eleve a Inglaterra à grandeza, de que hoje se vangloria? Qual era antes que Portugal cooperasse para sua elevação, e qual é hoje enriquecida com o nosso comércio e tirando dele as incalculáveis vantagens de que goza, os fastos, os anais, as décadas testificam. Por que não vêm participar das fadigas da agricultura e querem ter só a primazia no comércio?

Todos sabem qual seja o seu sistema. Não há argumento mais forte que a experiência. Portugal tem visto que, no princípio, vendem os ingleses barato e compram caro. Mas, depois que ficam em desfalecimento as produções do país e que a inércia levanta o estandarte do seu império, seguem sistema contrário e quando a calamidade pública transtorna, como agora, desorganiza e dilacera o estabelecimento primitivo, eles salvam o

\footnotetext{
${ }^{39}$ Cf. Antônio Penalves Rocha, op. cit., 1996, p. 104-105. Sobre o contrabando: Wanderley Pinho, op. cit.; José Jobson de Arruda, op. cit.

${ }^{40}$ Thomas Lindley. Narrativa de uma viagem ao Brasil. São Paulo: Companhia Editora Nacional, 1969, p. 24.
} 
seu velocino e os comerciantes nacionais se depauperam para enriquecêlo.

Que coisa mais justa, Senhor, do que V.A.R. que é o pai da pátria e que olha, como agora ternamente experimentamos, para o seu povo como para a sua numerosa família, que vem humilde congratular-se aos seus pés, beijar-lhe a mão augusta, buscar o refúgio da sua beneficiência, abrir uma porta franca à felicidade dos comerciantes nacionais, não permitindo que se estabeleçam estrangeiros com casas de negócio nos domínios do Brasil, mas sim mandar que sejam tratados com os ofícios da hospitalidade nas ocasiões necessárias e oportunas, e que se pratique com todos igualmente o Direito das Gentes, sem aquela singularidade que vai constituir o prejuízo dos mesmos negociantes [...]. ${ }^{41}$

O documento sinaliza, portanto, uma questão de singular importância nesse novo contexto: o deslocamento de um dos eixos do debate político que, a partir desse momento, deixava de ser um confronto entre os defensores do exclusivo e os do livrecomércio, para se restringir entre os partidários do livre-comércio e os do protecionismo. Isso significa que outros elementos postos pelas novas condições, de abertura dos portos e domínio dos ingleses, exigiam redefinição quanto ao papel que o Estado deveria exercer na economia. Um ponto fundamental, pois a sua resolução não apenas atingia os interesses de ingleses e portugueses europeus como também os dos portugueses americanos que, a partir da trasladação da Coroa, viram abertas amplas perspectivas para sua ascensão. ${ }^{42}$ Além disso, indica que existiam profundas divergências entre os proprietários sobre o grau de intervenção a ser desempenhado pelo Estado na vida econômica, como bem o demonstra Felisberto Caldeira Brant Pontes, senhor de engenho e inspetor geral das tropas da Bahia, anos mais tarde numa carta enviada a José da Silva Lisboa:

Os invejosos e ignorantes na falta de boas razões para combater os sólidos princípios de economia política com que V.S. de longos anos procura felicitar a Nação têm constantemente recorrido ao exemplo de Inglaterra, que apesar de ser a Pátria de [Adam] Smith nunca adotou o sistema liberal, mas não sei que dirão agora à vista da famosa petição dos negociantes ingleses apresentada ao Parlamento contra todos esses chamados favores a benefício da indústria nacional. ${ }^{43}$

\footnotetext{
${ }^{41}$ Representação que fez em 1808, o corpo do comércio da Bahia, pedindo ao Príncipe Regente, que os estrangeiros se não estabeleçam, com casas de negócio nos domínios do Brasil para os não prejudicar. Biblioteca Nacional do Rio de Janeiro. Divisão de Manuscritos, Ms. I - 31,28,26. Trechos desse documento encontram-se publicados em Maria Beatriz Nizza da Silva. A primeira gazeta da Bahia: Idade d'Ouro do Brazil, op. cit., p. 150-151.

${ }^{42}$ István Jancsó; João Paulo G. Pimenta, op. cit., p. 152-153.

${ }^{43}$ Cartas de Felisberto Caldeira Brant Pontes, marquês de Barbacena. Economia açucareira da Bahia em 1820. Ministério da Justiça. Arquivo Nacional. Publicação destinada ao III Congresso de História da Bahia, Junho de 1973. A carta para José da Silva Lisboa data de 2 de outubro de 1820.
} 
Adiante complementava: "Estava a ponto de copiar a petição para mandar a V.S. quando recebi a terceira parte dos Estudos do Bem Comum, pela qual vejo que V.S. já tinha conhecimento da dita petição", evidenciando o quanto esses homens estavam informados sobre as transformações liberais nas primeiras décadas dos anos 1820.

Certamente a Coroa bragantina, mesmo antes, não ignorava essa questão. Mas, na conturbada conjuntura do período, era preciso estar ainda mais atento às alterações político-econômicas sem perder de vista as especificidades das partes americanas. É o que se tentará fazer a partir do Rio de Janeiro, novo locus de elaboração das intervenções políticas do poder monárquico português. Ao deixar a Bahia, em 26 de fevereiro, o príncipe havia lançado as bases para que um novo rearranjo político se estabelecesse entre a Coroa e parte de seus habitantes. ${ }^{44}$ Nos anos que se seguiram, buscou-se assegurar que o frágil equilíbrio político se mantivesse, embora as manifestações da crise estivessem cada vez mais próximas das fronteiras da América portuguesa.

Em função disso, o quadro de incertezas no cenário europeu exigia que a montagem do aparato de defesa das possessões portuguesas, sobretudo àquelas que ocupavam uma posição extremamente estratégica e que, portanto, aguçavam a cobiça das nações rivais, como era o caso da Bahia, fosse condizente com as novas circunstâncias. As variadas medidas referentes às inovações militares indicam uma crescente preocupação em dotá-la de requisitos necessários a uma estrutura de defesa eficiente sobretudo após 1808. ${ }^{45}$ Nesse aspecto, era de sobremaneira importante o conhecimento detalhado das condições de segurança oferecidas pela capitania, bem como das necessidades mais prementes de seus corpos militares.

Isso fica evidenciado na ordem régia enviada ao conde da Ponte, em 24 de março de 1808, portanto, pouco tempo depois da instalação do príncipe na corte, na qual se requer informações minuciosas sobre a situação da Bahia, tendo em vista a criação de

\footnotetext{
${ }^{44}$ O padre Perereca (Luiz Gonçalves dos Santos), panegirista de d. João, dimensiona o lamento dos baianos com a partida do príncipe para o Rio de Janeiro em 26 de fevereiro: "lavados de tristes e saudosas lágrimas pela sua ausência, e que não cessaram de acompanhar com a vista, e ainda mais com o coração, as régias naus, que lhes roubavam os seus soberanos, privando-os da sua constante real presença na antiga capital da América portuguesa”. Cf. Luis Gonçalves dos Santos. Memórias para servir à História do Reino do Brasil. Belo Horizonte: Itatiaia; São Paulo: Edusp, 1981, p. 172. No que é completado por Luís Norton: "E o povo baiano gemia, desiludido, a inútil e súplice cantilena: Meu príncipe regente, Não saias daqui, Cá ficamos chorando, Por Deus e por ti”. Op. cit., p. 24. D. João chegou ao Rio de Janeiro em 7 de março e posteriormente teria confessado que preferiria Salvador para sua residência por ser mais salubre "mas não pensava em mudar para lá a sede do Governo". Citado por Tobias Monteiro. História do Império. A elaboração da Independência. Rio de Janeiro: F. Briguiet e Cia. Editores, t. 1, 1927, p. 194.

${ }^{45}$ Para as medidas de segurança no Rio de Janeiro antes da vinda do príncipe, ver Maria Fernanda Baptista Bicalho. A cidade e o império. O Rio de Janeiro no século XVIII. Rio de Janeiro: Civilização Brasileira, 2003 e após 1808, Andréa Slemian, op. cit.
} 
“uma nova Repartição de Guerra de todo o seu principado do Brasil, prontamente com a Repartição dos Negócios Estrangeiros”. Ao longo de doze itens, exige-se que o governador apresente, em quadros e tabelas separados, dados sobre a população "em Brancos, Mulatos e Negros”; o número dos Regimentos de Linha, Infantaria, Cavalaria e Artilharia, a sua força efetiva, o estado do fardamento e a situação dos soldos; sobre os regimentos de milícias e suas respectivas forças, formas de recrutamento e de despesa; “a relação fiel do que monta a Despesa geral do Exército da capitania, do estado em que está, se há atraso nos seus pagamentos, e a qual soma, unindo-lhe a conta da Despesa da Tesouraria nos últimos três anos”; a quantidade de portos; “a relação específica e muito circunstanciada dos oficiais reformados, agregados, e adidos que há em cada Arma”; o número e postos de todos os engenheiros, e, por último, a quantidade de pólvora nos armazéns, além de requerer a remessa de "mapas e cartas geográficas, e topográficas que houver na Capitania, com o nome de seus Autores”. A urgência do repertório, no entanto, não deveria significar negligência quanto à veracidade das informações:

S.A.R. manda recomendar a V.Exa. que não mande estes quadros separados, mas que procure mandá-los todos juntamente e isso com a possível brevidade e sobretudo recomenda S.A.R. que sejam trabalhados com a maior exação, e que todos os anos sejam renovados, notando-se as alterações que houver, ou a continuação do mesmo estado de coisas; ficando V.Exa. responsável por qualquer erro voluntário ou descuido que haja nos mesmos quadros e relações e referente dano ou ao Real serviço na parte do Militar ou a Real Fazenda. V.Exa. dará conta de haver recebido este Aviso, e do tempo que necessitará para lhe dar a sua perfeita execução. ${ }^{46}$

O alcance do devassamento pretendido fornece a medida das preocupações que, naquele momento, cercavam o governo sediado no Rio de Janeiro. Em $1^{\circ}$. de maio do mesmo ano, a Coroa declarou guerra à França. No mês seguinte (9 de junho), foram enviadas cópias do manifesto para o conde da Ponte, com a recomendação de publicá-lo e distribuí-lo "por todas as Corporações, e Pessoas de Cargos Públicos Militares e Civis” dentro da capitania, além de orientá-los que deveriam "ter e guardar os ditos Exemplares, não só como um Papel Legislativo, e Diplomático, mas como uma prova a mais autêntica do Amor Paternal de um Príncipe, que o Céu nos concedeu para nossa felicidade". ${ }^{47}$ No manifesto, constante de dez páginas impressas, são expostos os motivos que agravaram as

\footnotetext{
${ }^{46}$ Correspondência de d. Rodrigo de Sousa Coutinho ao conde da Ponte, em 24 de março de 1808. APEB. Seção de Arquivo Colonial e Provincial. Ordens Régias. Maço: 106 (1808-1809).

${ }^{47}$ Correspondência de $d$. Rodrigo de Sousa Coutinho ao conde da Ponte, em 9 de junho de 1808. APEB. Seção de Arquivo Colonial e Provincial. Ordens Régias. Maço: 106 (1808-1809). Em outra correspondência, datada de 14 de julho de 1808, consta a informação do envio de 200 exemplares do manifesto.
} 
relações políticas com a França “desde o principio da Revolução até a época da Invasão de Portugal”, esclarecendo sobre a posição de neutralidade que o Reino português tomara no decorrer da guerra, a atitude traiçoeira da Espanha que "não somente se esqueceu do seu Aliado" mas aproveitou-se "até das forças da França para se apropriar de uma pequena extensão de Território da Província de Alentejo da parte de Olivença”, a fidelidade da Grã-Bretanha e, principalmente, a arrogância do imperador francês que violou todos os tratados estabelecidos com o regente.

Esse, ao contrário, teria agido sempre com prudência e feito os maiores sacrifícios para evitar o sofrimento dos fiéis súditos. Por ocasião da presença do irmão do Imperador francês na Bahia "foi ali recebido com toda a maior atenção; a Esquadra recebeu toda a qualidade de refrescos, e o que é contudo digno de observação é, que na mesma época, em que o Governo Francês recebia da parte de Portugal tantas demonstrações de amizade e de consideração, a Esquadra queimou alguns Navios Portugueses para encobrir a sua direção, com promessa de indenizar os Proprietários, o que já mais se cumpriu de modo algum”. Além de ter introduzido um novo governo em Portugal, “assim como a cobrança de uma contribuição desmedida, exigida de um país, que não opôs resistência alguma à entrada das Tropas Francesas, e que, por isso mesmo não podia considerar-se em estado de guerra”. ${ }^{48}$ Dessa forma, a Portugal não restou outra alternativa senão tomar partido no conflito.

O documento é, assim, uma tentativa de justificar a atitude do príncipe por ter abandonado o Reino português e, principalmente, de afirmar, perante seus súditos e a Europa, sua disposição em se opor, sob a liderança da Grã-Bretanha, ao projeto expansionista da França. Ao exigir, por meio do seu principal ministro e secretário de Estado dos negócios estrangeiros e da guerra, d. Rodrigo de Sousa Coutinho, que as autoridades régias da Bahia adotassem as providências condizentes com a situação de crise do período, deixava claro que a capitania era parte essencial no delineamento do projeto político da Coroa. ${ }^{49}$

\footnotetext{
${ }^{48}$ MANIFESTO, ou Exposição Fundada, e Justificativa do procedimento da Corte de Portugal a respeito da França desde o princípio da Revolução até a época da Invasão de Portugal; e dos motivos, que a obrigarão a declarar a Guerra ao Imperador dos Franceses, pelo fato da Invasão, e da subseqüente Declaração de Guerra feita em conseqüência do Relatório do Ministro das Relações Exteriores. APEB. Seção de Arquivo Colonial e Provincial. Ordens Régias. Maço: 106 (1808-1809).

${ }^{49}$ Pelo decreto de 11 de março de 1808 novos ministros assumiram as secretarias no Rio de Janeiro. Poucos dias depois o Visconde de Anadia comunicou ao governo da Bahia que "o Príncipe Regente [ordenara] que eu continue a exercer o emprego de Ministro e Secretário de Estado dos Negócios da Marinha e Domínios Ultramarinos, desanexando desta Repartição o Continente do Brasil. E Havendo o mesmo Senhor por bem Nomear o Senhor D. Fernando José de Portugal e o Senhor D. Rodrigo de Sousa Coutinho para as duas outras Repartições dos Negócios do Continente e Erário e Negócios Estrangeiros e da Guerra, dirigirá V.Exa.
} 
A política externa da corte iria mais além. As tensões entre França e a GrãBretanha no plano europeu possuíam desdobramentos diretos no projeto de d. João de estender os seus domínios na América após a sua fixação no Rio de Janeiro, aprofundando, assim, os conflitos com a Espanha. Além do mais, depois de ter declarado guerra à França era preciso assegurar a proteção dos domínios americanos evitando a permanência de uma colônia francesa em sua fronteira ao norte. A determinação para ocupar Caiena (1809) e, mais especificamente, a Banda Oriental (1811), tornou ainda mais complexa a situação política no cenário de crise do Antigo Regime. Seguindo a orientação do conde de Linhares as bases da política portuguesa estariam assentadas, a partir de então, na defesa preventiva da expansão territorial. Temendo represálias, a Coroa contraíra, inclusive, um empréstimo com um dos grandes negociantes da Bahia, Pedro Rodrigues Bandeira (filho), no valor de 40 contos de réis, a juros de 5\%, para auxiliar na segurança da capitania. Em agosto de 1811, “em retribuição ao oferecimento que este fez de empréstimos para compra de armamento”, o valoroso súdito foi contemplado com a comenda da Ordem de Cristo e foro de fidalgo. ${ }^{50}$

No contexto dessas intervenções, a produção da pólvora e do salitre constituiu outra questão importante para as autoridades régias. Já em maio de 1808, d. Rodrigo de Sousa Coutinho lembrou ao conde da Ponte a importância da fábrica de pólvora que o príncipe determinara para funcionar na Bahia, “onde com toda a perfeição e brevidade possível se manufature aquela quantidade necessária, não só para os diferentes objetos do Meu Real Serviço, mas para o consumo dos Particulares em todos os Meus Domínios do Continente do Brazil, e ultramarinos”. Depois de indicar os responsáveis pela "criação e inspeção deste importante estabelecimento”, lembrava que uma das atribuições dos mesmos era observar a quantidade da substância que deveria ser fornecida "para o Serviço

daqui em diante todos os seus ofícios e Representações pelas três Repartições competentes, segundo a natureza dos objetos de que fizeram menção; ficando portanto pertencendo a esta Secretaria de Estado a mesma Jurisdição e Inspeção que tinha na Europa, respectivamente à Marinha. O que V.Exa. fará constar nessa Capitania e nas que lhe são subordinadas para que chegue ao conhecimento de todas as Pessoas”. Correspondência do visconde de Anadia ao governador da Bahia, em 14 de março de 1808. APEB. Seção de Arquivo Colonial e Provincial. Ordens Régias. Maço: 108 (1807-1810).

50 Ofício do conde de Aguiar ao conde dos Arcos, em agosto de 1811. Anais da Biblioteca Nacional. Catálogo de documentos sobre a Bahia existentes na Biblioteca Nacional. Rio de Janeiro, Divisão de Obras Raras e publicações, v. 68, p. 176; Luiz Alberto Moniz Bandeira. O feudo. A casa da Torre de Garcia d'Ávila: da conquista dos Sertões à Independência do Brasil. Rio de Janeiro: Civilização Brasileira, 2000, p. 366. O desembargador João Severiano Maciel da Costa assumiu a intendência em Caiena cuja devolução à França se deu em 8 de novembro de 1818 com a assinatura do tratado de 28 de agosto de 1817. No sul, aproveitou-se dos conflitos militares no Prata e anexou Montevidéu. Os conflitos políticos envolvendo as Américas hispânica e portuguesa no contexto de crise do Antigo Regime são analisados por João Paulo Garrido Pimenta, op. cit., 2002 e 2003. 
de Artilharia, Praças, Tropas e Marinha Real, segundo esta última Repartição requerer; e indicará que sem detrimento do Meu Real Serviço, se poderá facilitar de venda [...]”. 51

Os registros apontam que a correspondência sobre esse tema foi constante denotando a preocupação das autoridades com a disponibilidade do produto. Em fins de novembro de 1808, o ministro comunicou a aprovação pela decisão do governo da Bahia de adquirir pólvora de particulares a um preço que não considerou exorbitante podendo, assim, a fazenda real, obter um lucro com a sua venda "por grosso a dezoito mil réis a arroba”. Em um período marcado por conflitos militares, a procura deveria justificar os cálculos. Além disso, a pólvora era um produto cujo comércio era monopólio da Coroa. Por isso, o documento lembrava ao conde da Ponte que

“a Carta Régia de vinte e oito de Janeiro do Corrente ano sobre a liberdade do Comércio não assegura às Nações amigas a venda de tudo quanto trouxeram os seus Navios; e sendo a compra e venda da pólvora privativos da Real Fazenda, claro fica que a ninguém é permitido um tal comércio senão ao Estado, que todavia não é obrigado a comprar senão a que necessita, devendo o excedente ser exportada para outro qualquer porto onde se permite a venda da mesma”. ${ }^{2}$

No ano seguinte, novas recomendações foram transmitidas ao governo. Dessa vez, exigia-se maior atenção quanto à administração do produto cuidando para que a quantidade disponível fosse suficiente "tanto para a defesa da capitania no caso de ataque, como para os exercícios de Tropa de Linha, Miliciana e Artilharia”. 53

Ao lado dessas providências, era preciso dispor de indivíduos dedicados ao projeto de defesa da Coroa. Essa movimentação nas esferas do governo tinha, certamente, ressonância direta entre os interessados na ocupação dos diversos cargos surgidos com a ampliação das estruturas burocrática, administrativa e militar ou ainda remoção para antigas funções. A proposta de criação de um corpo de cavalaria na Bahia, em 1809, pode ser citada como exemplo. Copiosas e extensas petições foram encaminhadas à corte do

\footnotetext{
${ }^{51}$ Correspondência de d. Rodrigo de Sousa Coutinho ao conde da Ponte, em 13 de maio de 1808. APEB. Seção de Arquivo Colonial e Provincial. Ordens Régias. Maço: 106 (1808-1809).

${ }^{52}$ Correspondência de d. Rodrigo de Sousa Coutinho ao conde da Ponte, em 25 de novembro de 1808. APEB. Seção de Arquivo Colonial e Provincial. Ordens Régias. Maço: 106 (1808-1809). Em correspondência à corte em 10 de outubro de 1808, o capitão José Joaquim Vellozo encaminhou uma "Relação dos barris de Pólvora pertencentes à Praça, que se extraíram para esta cidade, Recôncavo, Pernambuco, Angola e outros lugares desde 15 de Agosto de 1798 até 9 de Outubro do corrente ano, com declaração dos que saíram em cada ano". Segundo o documento, a quantidade extraída foi "De 15 de Agosto

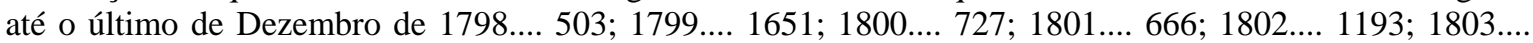
1013; 1804... 1552; 1805... 1450; 1806... 860; 1807.... 1136; De Janeiro até 9 de Outubro de 1808....45”, demonstrando uma sensível redução nos últimos anos. Idem, Ibidem.

${ }^{53}$ Correspondência de d. Rodrigo de Sousa Coutinho ao conde da Ponte, em 8 de janeiro de 1809. Idem, Ibidem.
} 
Rio de Janeiro detalhando as razões pelas quais os requerentes deveriam contar com o beneplácito do príncipe para ocupar os principais cargos dos 255 previstos para a nova corporação. ${ }^{54}$ Em um dos pedidos, Manoel Ignácio da Cunha e Menezes, "filho legítimo do Coronel de Lumiares, Manoel da Cunha e Menezes, já falecido”, soube da novidade em Lisboa e revelava seu desejo em assumir o posto de capitão por dispor dos requisitos necessários; Outro, José Maria de Gouveia Portugal, pretendia seguir o exemplo do seu pai, coronel agregado do $1^{\circ}$. Regimento de Linha Pedro Alexandrino de Souza Portugal, “que consta 40 anos de serviço”, do avô, brigadeiro Antônio José de Souza Portugal, “que contou no Real Serviço perto de sessenta e três anos até o dia da sua Reforma” e do bisavô “Manoel Domingues Portugal, coronel que foi do mesmo $1^{\circ}$. Regimento de Linha, em cujo posto faleceu com perto de 55 anos de Serviço”. Além de antepassados tão virtuosos, o requerente tencionava dar "prova de fidelidade", uma vez que fora "um dos primeiros voluntários que se veio oferecer” quando o governador publicou um bando, “que em data de 20 de março de 1808 fazia conhecer aos seus habitantes a necessidade que havia de aumentar a tropa para a defesa dela [capitania]”. ${ }^{55}$ Joaquim José dos Passos, capitão do terço das ordenanças da companhia da primeira divisão da Freguesia do Senhor do Bonfim da Matta da cidade da Bahia, desejava assumir o posto de sargento-mor e fundamentou o seu requerimento, em julho de 1809, alegando a dedicação com que havia servido há oito anos, efetuando prisões “de alguns facínoras, e até dos levantados negros à força de armas com considerável risco da sua vida e à custa da sua própria fazenda”. Afirmava ter mandado "erguer uma igreja no sítio de Pirajá [...] que teve a honra de oferecê-la a Vossa Alteza Real na ocasião em que felizmente chegara à mesma cidade da Bahia” e, aproveitava também para requerer a "Mercê do Hábito de São Bento de Aviz”. 56 Digno de atenção também é o pedido de Joaquim Pedro Rodrigues Fróes, “morador na fazenda do Curralinho entre os distritos das Vilas de Maragogipe e Cachoeira, Comarca e Capitania da Cidade da Bahia”, onde exercia a função de alferes das ordenanças. A sua representação se destaca pela articulação dos argumentos utilizados

\footnotetext{
${ }^{54}$ Conforme plano detalhado incluso junto a um dos pedidos no qual consta além da relação do armamento a ser utilizado observações quanto ao fardamento e valores dos vencimentos em períodos de paz e de guerra. Plano de Cavalaria proposto. Idem, ibidem.

${ }^{55}$ Representação de José Maria de Gouveia Portugal ao príncipe regente, s/d. Idem, ibidem. Frederic Morton observa que os militares constituíam praticamente uma casta repassando de pai para filho a prestação do serviço em nome da Coroa: "alguns da aristocracia açucareira, notavelmente os Menezes Dória, Argolos e Muniz Barretos produziram oficiais em cada geração [...]. Estas eram certamente famílias bem-nascidas que viviam do emprego oficial e militar, como os Balthasar das Silveiras e Matos Telles de Meneses”. Cf. The Conservative Revolution of Independence: Economy, society and politics in Bahia (1790-1840). Oxford, University of Oxford, 1974, p. 77.

${ }^{56}$ Requerimento de Joaquim José dos Passos ao príncipe regente, s/d. Idem, ibidem
} 
talvez em função de ser descendente "de pessoas que sempre tiveram a honra de ocupar os Cargos mais honoríficos e distintos das Armas e das Letras, no Serviço do Estado e de V.A.R.”. Joaquim Fróes demonstra que estava ciente da dimensão dos últimos acontecimentos e do papel que lhe caberia desempenhar: "em uma Conjuntura qual a presente em que se trata de criar um novo Império pela felicidade de que gozarão todos os habitantes desta América com a Real Presença de V.A.R. [...]”. ${ }^{57}$

As solicitações, direcionadas ao príncipe, vinham quase sempre acompanhadas de documentos comprobatórios da idoneidade do requerente. Pelo visto, o aumento dos pedidos exigiu certo controle das autoridades para confirmar a concessão, cuja aprovação poderia ser essencial para a confirmação do pleito. Isso pressupõe que além dos requisitos para exercer as funções pretendidas, possuir algum tipo de vínculo com as autoridades seria de grande valia. Ao prestar informações sobre Domingos Rodrigues Guimarães, o governo da Bahia contestou as suas pretensões em ocupar o cargo de Patrão-mor da Barra de Cotinguiba argumentando "que o Suplicante só pode pretender aquele Emprego por especial Graça, e não por Justiça, a razão por lhe faltarem as circunstâncias de provar ter os necessários conhecimentos marítimos, ou exercícios tais que o habilitaram e fizessem digno de se propor a uma semelhante súplica para a qual em coisa alguma os documentos o favorecem”. ${ }^{58}$ Outro pedido contou com o reforço do inspetor do arsenal da marinha de Salvador, Bernardino José de Castro, que atestou a competência do suplicante para trabalhar no dito arsenal lembrando que na capitania "afirmativamente se pode dizer que há os melhores práticos de construções de navios”, e que necessitava dos seus conhecimentos sobre madeiras. ${ }^{59}$ Já um certo Manuel de Freitas Varella Pinto Pinheiro, não somente teve seu pedido para assumir o cargo de tenente coronel do $1^{0}$. Regimento de Infantaria de Linha de Salvador atendido pelo príncipe, como foi dispensado "na formalidade estabelecida da apresentação da sua patente para poder assentar praça e ter o seu conveniente exercício”, exigência que para muitos deveria ser cumprida à risca. ${ }^{60}$

O tempo de serviço dedicado à carreira militar constituía um dado importante na disputa por uma promoção pelo menos para as funções que exigia menos conhecimento

\footnotetext{
${ }^{57}$ Requerimento de Joaquim Pedro de Rodrigues Fróes ao príncipe regente, s/d. Idem, ibidem.

${ }^{58}$ Informações sobre o requerimento de Domingos Rodrigues Guimarães, em 5 de julho de 1810. APEB. Seção de Arquivo Colonial e Provincial. Ordens Régias. Maço: 108 (1807-1810).

59 APEB. Seção de Arquivo Colonial e Provincial. Ordens Régias. Maço: 106 (1808-1809). Realmente, a Bahia possuía uma das maiores produções de navios, em número e em tamanho, ultrapassando outros centros na América portuguesa, em virtude, principalmente, "da abundância, excelência e proximidade de sua madeira”, nas palavras de Frederic Morton, op. cit., p. 44.

${ }^{60}$ Correspondência de d. Rodrigo de Sousa Coutinho ao conde da Ponte, em 17 de maio de 1808. Idem, ibidem.
} 
técnico e mais experiência na oficialidade. Disso resultam as extensas justificativas dos serviços prestados à Coroa como no caso do aspirante ao posto de $1^{\circ}$ tenente da marinha, José Francisco de Oliveira, que servira nas tropas de linha da praça da Bahia "25 anos, um mês e 12 dias”. Sem dúvida, um procedimento utilizado pelos oficiais para reafirmarem a cumplicidade que os vinculava ao monarca, como ressaltou Hendrik Kraay. ${ }^{61}$

Para aqueles que, entretanto, não tinham opções de escolha, o ingresso nos quadros da nova estrutura militar se dava por caminhos bem mais tortuosos. Em 23 de novembro de 1808, o arsenal real da marinha do Rio de Janeiro requisitou "até cem” índios para os "grandes trabalhos" que deveriam realizar "apenas por um tempo de dois anos, no fim dos quais se revezarão por outros e tanto a vinda quanto a volta serão convenientemente vestidos por conta da Real Fazenda”. ${ }^{2}$ Em princípios do ano seguinte, um novo reforço do pedido é encaminhado com a observação do regente de que "não perdendo de vista os meios de brandura já recomendados, e conciliando-os com o bem do Real Serviço, procure remeter o número que lhe for possível desta gente para o dito arsenal [...]”. ${ }^{63}$ Na mesma direção, a requisição de grumetes, feitas ao governo da Bahia pelo almirante general da marinha, em 14 de junho de 1809, procurava conciliar a falta de homens para o serviço militar com o enquadramento daqueles tidos por perniciosos ao Estado:

Sendo mais do que provável que no vosso governo exista gente ociosa e vadia que perturbando ai o sossego público e a marcha do governo pode aliás servir a bordo e talvez corrigir-se, com grande proveito do Estado, confio [...] que em todas as ocasiões possíveis, envieis recrutas dessa gente para o sobre mencionado serviço, as quais deverão ser entregues ao Inspetor de Arsenal desta cidade”. ${ }^{64}$

Cerca de um mês depois, d. Rodrigo de Sousa Coutinho reforçava as medidas necessárias para a segurança da capitania exigindo informações detalhadas sobre os meios de prevenção adotados "para segurar esse porto e cidade contra qualquer invasão ou surpresa de uma esquadra inimiga acompanhada de grandes forças de desembarque e que

\footnotetext{
${ }^{61}$ Requerimento de José Francisco de Oliveira ao príncipe regente, em 17 de março de 1809. Idem, Ibidem. Hendrik Kraay, op. cit., p. 38.

${ }^{62}$ Correspondência de d. Rodrigo de Sousa Coutinho ao conde da Ponte, em 23 de novembro de 1808. Idem, ibidem.

${ }^{63}$ Correspondência de d. Rodrigo de Sousa Coutinho ao conde da Ponte, em 14 de abril de 1809. Idem, ibidem.

${ }^{64}$ Correspondência de d. Rodrigo de Sousa Coutinho ao governo da Bahia, em 14 de junho de 1809. Idem, ibidem.
} 
tudo aquilo que esse Governo interino, ouvindo os oficiais Engenheiros e Artilheiros, julgar necessário para conseguir este fim, principie logo a fazê-lo executar”. 65

Nos anos seguintes, os requerimentos mantiveram-se com alguma constância e em número considerável. E, obviamente, não diziam respeito apenas aos postos militares ainda que esses dominassem as petições em virtude da turbulenta conjuntura de guerra, como referido. Nesse aspecto, é importante destacar que se as condições necessárias ao funcionamento da sede do Império português impuseram ao Rio de Janeiro amplas mudanças em um curto espaço de tempo, na Bahia, as alterações processaram-se numa outra dimensão na medida em que a concretização desse projeto absorveu não apenas as áreas próximas à corte, como também àquelas mais distantes que, por seu prestígio econômico ou político, demandavam atenção peculiar. Para alguns residentes, sobretudo os membros das classes proprietárias, isso significou a possibilidade de ampliar a sua esfera de influência e, de algum modo, buscaram se aferrar às alternativas criadas. Cargos de desembargadores nas casas de suplicação ou na relação da Bahia, ofícios vitalícios de tabelião e escrivão da câmara e órfãos, ouvidor, intendente do ouro, investimentos para ampliar a produção econômica, assim como as comendas do hábito da ordem de Cristo, estão entre os variados pedidos que permeiam a documentação.

Embora as numerosas medidas implementadas pela Coroa e pelo governo local diziam respeito imediato às convulsões da conjuntura externa que impuseram um reordenamento do império português na América, não se pode dizer que internamente, na capitania, o ambiente era de total cumplicidade. É bem verdade que após o ensaio de sedição de 1798, quando um grupo de militares, artesãos e escravos reivindicaram os ideais de "liberdade, igualdade e fraternidade" para todos os bahienses, as possibilidades de contestação ficaram ainda mais restritas. Afinal, a violenta repressão que se abateu sobre os quatro líderes do movimento, alguns anos antes da passagem do príncipe pela capitania, deixara explícita a intolerância da Coroa para comportamentos considerados perniciosos à integridade da monarquia. Ainda assim, as autoridades sabiam que a vigilância não poderia ser relaxada sobretudo em um cenário no qual a celeridade das mudanças políticas recomendava extrema cautela. Por isso mesmo, o acompanhamento dos conflitos externos e os cuidados com a segurança interna relacionavam-se, taticamente, à tentativa de contenção dos efeitos de uma crise que ganhava contornos cada vez mais amplos e profundos.

\footnotetext{
${ }^{65}$ Correspondência de d. Rodrigo de Sousa Coutinho ao governo da Bahia, em 7 de julho de 1809. Ignácio Accioli, op. cit., v. III, p. 192.
} 


\subsection{A construção do espaço da política}

Ao desembarcar em Salvador, em janeiro de 1808, d. João encontrou uma cidade bastante movimentada. Segundo uma correspondência do conde da Ponte no ano anterior, o último alistamento feito indicava "25.502 pretos quando o número de brancos não excede a 14.260 e o de pardos a 11.350”, totalizando, portanto, 51.112 habitantes. ${ }^{66}$ Outros dados afirmam que, em fins do século XVIII, a capital possuía, juntamente com o Recôncavo, cerca de 150 mil habitantes e na primeira década do seguinte o conjunto da população da capitania seria “de mais 400 mil pessoas, dos quais um terço era de escravos” ${ }^{67}$ Por mais de dois séculos, a cidade da Bahia, como então era conhecida, havia ocupado a sede de Vice-Reino, e a capitania tornara-se uma das principais possessões econômicas do império português. Diversos navios e embarcações pequenas circulavam pelos seus portos impulsionando um intenso comércio local, de exportação e importação, com destaque para um dos mais poderosos mercados de escravos do mundo colonial, o que faziam da urbe e do seu hinterland uma das regiões mais dinâmicas para os padrões do período.

\footnotetext{
${ }^{66}$ Correspondência do conde da Ponte ao Visconde de Anadia, em 16 de julho de 1807. Ignácio Accioli, op. cit., v. III, p. 228.

${ }^{67}$ Cf. Stuart Schwartz. “Cantos e quilombos numa conspiração de escravos haussás. Bahia, 1814”. In: João José Reis; Flávio dos Santos Gomes. (Orgs.). Liberdade por um fio: história dos quilombos no Brasil. São Paulo: Companhia das Letras, 1996, p. 374. Para os dados de Salvador e Recôncavo: Bert J. Barickman. Um contraponto baiano. Açúcar, fumo, mandioca e escravidão no Recôncavo, 1780-1860. Rio de Janeiro: Civilização Brasileira, 2003. Em razão da falta de números mais precisos nos censos sobre a população da Bahia em fins do século XVIII e início do seguinte, existem divergências nas estimativas. Luis dos Santos Vilhena indicou que a cidade de Salvador e o Recôncavo possuíam cerca de 110 mil habitantes em 1798 (A Bahia no século XVIII. Notas e comentários de Braz do Amaral. Salvador: Itapuã, 1969, p. 503), dado considerado defasado por João José Reis ao confrontá-lo com um censo feito em 1808 que contabilizou uma população de 249.314, excluindo as vilas de Cachoeira e de Santo Amaro. Também entre os viajantes que estiveram em Salvador no início do século XIX há diferenças: Thomas Lindley, em 1803, apontou uma população de 100.000 habitantes (op. cit., p. 143), mesmo dado indicado pelo príncipe Maximiliano de WiedNewied anos depois, em 1817 (Viagem ao Brasil. São Paulo: Companhia Editora Nacional, 1940, p. 449); Spix e Martius indicaram para Salvador e seus arredores, entre 1817-1820, 115.000 pessoas, superestimando o número de habitantes (Johann B. von Spix; Karl F.P. von Martius. Viagem pelo Brasil. Belo Horizonte: Itatiaia; São Paulo: Edusp, 1989, v. II, p. 149). Kátia M. de Queirós Mattoso discorda dessas estimativas. Para ela, entre 1812 e 1820, as evidências demonstram que Salvador possuía de 49 a 55 mil habitantes. Cf. Bahia século XIX: uma província no Império. 2 ed. Rio de Janeiro: Nova Fronteira, 1992, p. 112. Avaliando os dados disponíveis, João José Reis estima para Salvador a presença de 65.500 pessoas em 1835, ano em que ocorreu a rebelião dos malês. Rebelião escrava no Brasil. A história do levante dos Malês em 1835. Ed. revista e ampliada. São Paulo: Companhia das Letras, 2003, p. 22. O autor analisa a proporção de escravos, livres e libertos na sociedade da Bahia nesse período concordando com a assertiva de que o número de afrodescendentes foi a população que mais cresceu no Brasil no século XIX. Uma análise sobre os dados populacionais da Bahia pode ser vista também em Sylvio C. Bandeira de Mello e Silva et al. Urbanização e metropolização no Estado da Bahia. Evolução e dinâmica. Salvador: Centro Editorial e Didático da UFBa, 1989.
} 
Salvador estava dividida em onze freguesias (ou paróquias), com destaque para as mais populosas situadas na parte alta da urbe, Sé, São Pedro, Sant'Anna e Santo Antônio Além do Carmo e a da Conceição da Praia que ficava na parte baixa concentrando a vida comercial e financeira da capitania. Ao que parece, não era muito fácil, inclusive para os contemporâneos, delimitar com precisão os contornos da área urbana de Salvador diferenciando-a dos espaços suburbanos. Kátia Mattoso assinala que “para os vereadores do século XIX, a cidade e seus distritos formavam um todo. A vida nas paróquias suburbanas era um prolongamento da vida nas cidades, e a Câmara Municipal não via razão para delimitar os contornos da urbe propriamente dita” ${ }^{68}$ Por esses lugares circulavam numerosas pessoas - escravos, libertos e homens livres - que forneciam à cidade as características de um dos principais centros do novo mundo.

Mesmo após a transferência da capital para o Rio de Janeiro em 1763, Salvador permaneceu usufruindo a posição de núcleo político-administrativo de toda a capitania. Além do mais, dois anos antes de perder a sede, em 1761, teve as antigas capitanias de Ilhéus e Porto Seguro incorporadas ao seu território que incluía ainda o norte do Espírito Santo e Sergipe (até 1820). Como sede de comarca e capital, abrigava diversos serviços jurídico-administrativos como o Tribunal da Relação, Chancelaria, Ouvidoria Geral do Cível, Alfândega, Mesa de Inspeção, Intendência Geral do Ouro, Senado da Câmara e o Arcebispado, pioneiro no Brasil, entre outros, bem como as forças de defesa.

Do ponto de vista econômico, a cidade desempenhava um papel fundamental no relacionamento com as vilas e povoações situadas no interior da província por meio de Cachoeira - a principal vila do Recôncavo - e das estradas que ligavam a capital às capitanias do Norte. Na descrição feita pelo príncipe Maximiliano de Wied-Newied, em 1817, a movimentação econômica era perceptível:

O comércio da Baía é muito ativo; essa cidade serve de entreposto para os produtos do Sertão, os quais exporta para as diversas partes do mundo; encontram-se em seu porto navios de todas as nacionalidades. Navios de passageiros mantém comunicação constante com Portugal e Rio de Janeiro e, como bons veleiros que são, fazem a travessia em muito curto tempo. Os habitantes das praias vizinhas trazem todos os produtos de suas plantações para a capital, afim de trocá-los por mercadorias de diversos países. Essas trocas constantes e ativas rapidamente fizeram da Baía uma

\footnotetext{
${ }^{68}$ Kátia M. de Queirós Mattoso, op. cit., p. 102. Sobre a importância político-administrativa da cidade de Salvador, ver ainda: Affonso Ruy. História da Câmara Municipal de Salvador. Salvador: Câmara Municipal, 1953. Avanete Pereira Sousa. Poder político local e cotidiano: a Câmara de Salvador no século XVIII. Salvador, Universidade Federal da Bahia, 1996 (Dissertação de Mestrado).
} 
importante cidade, que deve exceder em muito em tamanho, o Rio de Janeiro. ${ }^{69}$

Desse modo, seja atuando como intermediária na distribuição de produtos manufaturados, receptadora de gêneros alimentícios seja fornecendo escravos indispensáveis para o funcionamento da capitania, Salvador, exercia pleno domínio sobre os demais centros produtivos. E nesse aspecto, a sua importância ia mais além. As áreas de contato com um vasto território que incluía Minas Gerais, Goiás e Pernambuco possibilitaram que a sua influência agisse sobre "uma região muito mais vasta que sua hinterlândia imediata”, fazendo da capitania um importante eixo de circulação de homens e mercadorias principalmente em períodos de efervescência econômica nessas áreas, a exemplo da descoberta do ouro em Minas e em Goiás. ${ }^{70}$ Ainda em princípios do século XIX, a cidade da Bahia era a mais populosa da América portuguesa, posição que perdeu para o Rio de Janeiro somente após a vinda da corte, ${ }^{71}$ resultando em grande impacto na reordenação das partes americanas.

Com efeito, se anteriormente, as áreas coloniais do espaço luso-americano se percebiam vinculadas a Lisboa enquanto locus de materialização da unidade entre as partes do continente do Brasil, a presença do príncipe regente em solo americano redefiniu o centro de peregrinação para o Rio de Janeiro estabelecendo novos parâmetros de articulação política e econômica. Em decorrência, o desequilíbrio entre as regiões nos processos de beneficiamento pela sua aproximação em relação à sede da Corte, sobretudo entre as capitanias do Norte e do Centro-Sul, provocou sérias tensões e conseqüências práticas. $^{72}$

Mas, a complexa ordenação territorial das dependências americanas, que incidia sobre o uso político e econômico que se fazia dos espaços, fora motivação de conflitos outros, expressão da conformação de identidades coletivas de diferentes partes do

\footnotetext{
${ }^{69}$ Maximiliano de Wied-Newied, op. cit., p. 449.

${ }^{70}$ Kátia M. de Queirós Mattoso, op. cit., p. 78, Sylvio C. Bandeira de Mello et al, op. cit. Sobre a relação da Bahia com as áreas mineradoras: Mafalda Zemella. O abastecimento das Minas Gerais no século XVIII. 2. ed. São Paulo: Hucitec; Edusp, 1990; Luis Palacin. Goiás - 1722/1822: estrutura e conjuntura numa capitania de Minas. Goiânia, 1972. Na descrição de Ferdinand Denis, que viveu no Brasil entre 1816 e 1831, a localização da Bahia era privilegiada: "Como centro comercial, sua posição é admirável; confina ao norte com Sergipe del Rei e com a Província de Pernambuco, da qual é separada pelo Rio São Francisco; ao sul, são as Províncias de Porto Seguro e de Minas Gerais que formam seus limites; pelo poente, toca ainda na região de Pernambuco; a leste, o oceano a banha e lhe forma portos magníficos”. Brasil. Belo Horizonte: Itatiaia; São Paulo: Edusp, 1980, p. 242.

${ }^{71}$ Bert J. Barickman, op. cit., p. 98.

${ }^{72}$ Cf. István Jancsó; João Paulo G. Pimenta, op. cit. Ver também: Andréa Slemian, op. cit. Algumas análises sobre a tensa relação entre a corte do Rio de Janeiro e outras partes americanas constam das coletâneas organizadas por István Jancsó, op. cit., 2003 e 2005.
} 
universo luso-americano. No caso da Bahia, variadas foram as formas de disputa não apenas no interior da capitania mas também com as autoridades régias das áreas fronteiriças, cuja trama sinaliza "a complexidade crescente do sistema e do seu manejo político" ${ }^{73}$

Nessa perspectiva, investigar as vicissitudes políticas na Bahia nos primeiros anos do Oitocentos requer a apropriação do processo de constituição dessa territorialidade específica, ainda que em linhas gerais, como pressuposto fundamental à compreensão do movimento de conformação do espaço da política. De fato, a concretização de uma estrutura político-administrativa consubstanciada na política econômica colonial da Coroa portuguesa, sobretudo em fins do século XVIII com desdobramentos no seguinte, vinculava-se às exigências de manutenção e de exploração da sua colônia americana que, no seu reverso, promovia os elementos indicadores da crise do sistema. ${ }^{74}$ Desse modo, interessa, inicialmente, traçar um quadro do espaço da capitania que, em suas linhas mestras, poderá fornecer elementos importantes para a investigação das práticas políticas dos seus habitantes. ${ }^{75}$

As pesquisas sobre a economia colonial na América portuguesa já atestaram a importância da capitania da Bahia, ao lado de Pernambuco, como fornecedora do principal produto de exportação na balança comercial a partir do século XVI até meados do século XIX, e mesmo durante o apogeu das descobertas auríferas. ${ }^{76}$ A produção do açúcar atendia as exigências do mercado externo resultando em oscilações que dependiam das conjunturas econômicas e políticas dos países europeus. Assim, é possível verificar que a partir da década de 1780, após a Independência dos Estados Unidos da América do Norte e tempos depois com os conflitos nas Antilhas (1792), os preços do produto tiveram uma rápida

\footnotetext{
${ }^{73}$ István Jancsó; João Paulo G. Pimenta, op. cit., p. 138.

${ }^{74}$ Fernando A. Novais, op. cit., 1983.

${ }^{75}$ Adotamos aqui a definição de espaço da política utilizada por Denis Antônio de Mendonça Bernardes, op. cit., (especialmente capítulo 1).

${ }^{76}$ Cf. Stuart Schwartz. Segredos internos: engenhos e escravos na sociedade colonial. São Paulo: Companhia das Letras, 1988; (especialmente cap. 7); Bert J. Barickman, op. cit., Kátia M. de Queirós Mattoso, op.cit. e Bahia: a cidade do Salvador e seu mercado no século XIX. São Paulo: Hucitec; Salvador: Secretaria Municipal de Educação e Cultura, 1978; Vera Lúcia Amaral Ferlini. Terra, trabalho e poder. São Paulo: Brasiliense, 1988.
} 
elevação contrastando com o declínio verificado no período anterior em virtude da concorrência estrangeira. ${ }^{77}$

Por essa época, o continente do Brasil já não podia ser considerado um produtor exclusivo de açúcar. Realmente, pois, no caso específico da Bahia, além do açúcar e do tabaco, diversos outros produtos integravam a pauta de exportação da capitania: algodão, café, cacau, couros, madeiras, diamantes, entre outros, aparentando uma diversidade na produção que, entretanto, era dominada sobretudo pelos dois primeiros gêneros citados. Em razão disso, a posição ocupada pelo açúcar ao longo dos séculos indica que uma conjuntura adversa para a comercialização do produto significava a queda na economia de exportação. $^{78}$

Assim como o açúcar, o tabaco de há muito atuava como um gênero importante no comércio de exportação. Estudos indicam que na primeira metade do século XVII o fumo já era comercializado e em princípios do seguinte já havia conquistado mercados na Europa, Ásia e América do Norte, somente perdendo para o algodão o segundo lugar na pauta de exportação no final do XVIII quando a lavoura algodoeira conheceu impulso significativo. Cultivado principalmente na Bahia, sobretudo nas imediações de Cachoeira, Inhambupe e em Santo Amaro da Purificação, o tabaco era exportado para Portugal e o refugo (fumo de baixa qualidade) enviado para a África Ocidental onde era utilizado no escambo de escravos. A partir de 1815, com a aprovação do tratado entre Portugal e GrãBretanha que proibia o tráfico de escravos ao norte do Equador, as exportações começaram a cair e mesmo com a reanimação nos anos seguintes, a tendência permaneceu decrescente. $^{79}$

\footnotetext{
${ }^{77}$ Stuart Schwartz ao analisar dados estatísticos sobre o comércio de exportação do açúcar baiano, conclui que: "Na Bahia, os preços do açúcar subiram constantemente até 1782, sofreram um grande declínio até 1785 (embora os níveis permanecessem elevados) e a seguir tornaram a subir. Com o irromper da revolução haitiana em 1792 e finalmente a eliminação da ilha como produtora de açúcar, o preço desse produto elevouse tremendamente nos mercados europeus, permanecendo alto até por volta de 1800, quando passou a cair até 1803 e então a recuperar-se até 1809”. Para o autor, esse crescimento pode ser verificado pelo aumento do número de engenhos: 166 em 1759, dos quais 122 na Bahia e 44 em Sergipe; cerca de 400 em 1798, com 260 na Bahia e em 1820 em torno de 500 moendas. Op. cit., p. 343. Ver também Vera Lúcia A. Ferlini, op. cit; Maria José Rapassi Mascarenhas. Fortunas coloniais. Elite e riqueza em Salvador, 1760-1808. São Paulo, Universidade de São Paulo, 1988 (tese de Doutorado); Bert J. Barickman, op. cit., p. 74 (tabela 2).

${ }^{78}$ Bert J. Barickman apresenta uma relação dos principais produtos de exportações da Bahia, no período de 1796 a 1860, na qual o açúcar e o fumo, apesar das oscilações, aparecem com peso significativo seguidos pelo algodão. Op. cit., p. 56-57 (tabela 1).

${ }^{79}$ Sobre o cultivo do tabaco na Bahia e a sua função no escambo de escravos, ver: Caio Prado Júnior. História econômica do Brasil. 14. ed. São Paulo: Brasiliense, 1971 e Formação do Brasil Contemporâneo. 22. ed. São Paulo: Brasiliense, 1992; Stuart Schwartz, op. cit.; Bert J. Barickman, op. cit.; Albertina Lima Vasconcelos. Ouro: conquistas, tensões, poder. Mineração e escravidão - Bahia do século XVIII. São Paulo, Universidade Estadual de Campinas, 2003 (Tese de Doutorado).
} 
Entre os produtos destinados à exportação, o algodão desempenhou papel fundamental na articulação da produção colonial e o mercado mundial com a especificidade de ter, internamente, impulsionado essa conexão para o interior da América portuguesa. Cultivado na esteira da demanda das praças mercantis de Liverpool e Manchester em fins do Setecentos, a produção algodoeira se disseminou por amplas áreas da colônia americana, provocando importantes mudanças nas relações entre os cultivadores pobres livres e o mercado mais amplo de capital mercantil. Em razão disso, muitos produtores na Bahia, até então responsáveis pela infraestrutura do complexo agroexportador escravista por meio do cultivo de gêneros de primeira necessidade, passaram a dedicar-se ao novo produto, entre outros difundidos na mesma época, exigindo medidas de racionalização por parte dos poderes lusitanos com o intuito de conter as freqüentes queixas relacionadas ao abastecimento. É o que consta, por exemplo, na portaria de d. Fernando José de Portugal, então governador, ao ouvidor da comarca, em 1799, recomendando

que obrigue os lavradores da sua comarca, não só a plantarem a mandioca, mas feijão e milho, para sustentação d'esses povos e dos d'esta cidade, que presentemente se acham em precisão de um gênero de primeira necessidade, procurando V. Mcê. animar, quanto for possível uma importante lavoura, expedindo as ordens que para esse efeito julgar conveniente às câmaras respectivas $[. . .]^{80}$

Aproveitando-se das condições do clima mais seco adequado ao cultivo do produto, agricultores das áreas sertanejas tornaram-se fornecedores de algodão disseminando o seu cultivo por uma ampla faixa das regiões limítrofes à capitania de Minas Gerais, no Alto Sertão da Bahia, incorporando-a no circuito de comercialização externa do sistema colonial. Dentre os principais produtos exportados para a metrópole, o algodão e o couro eram, em grande parte, provenientes dessa região. ${ }^{81}$ Em fins do século XVIII, José de Sá Bittencourt, proprietário de terras nas margens do rio de Contas, remeteu notícias promissoras para d. Rodrigo de Sousa Coutinho, então secretário de Estado dos negócios ultramarinos, sobre a riqueza do solo sertanejo para o cultivo do produto "como

\footnotetext{
${ }^{80}$ Portaria do governador d. Fernando José de Portugal dirigida ao ouvidor da comarca da Bahia sobre a plantação de mandioca, feijões e milho, em 26 de agosto de 1799. Anais da Biblioteca Nacional, Rio de Janeiro, 1916, v. 36, p. 181. A criação do celeiro público em Salvador, em 1785, no governo de d. Rodrigo José de Menezes, pretendia suprir a carência dos gêneros de primeira necessidade, sobretudo a farinha, em virtude dos descaminhos do produto e da diminuição do seu cultivo. Ofício do governador d. Rodrigo José de Menezes, dirigido à câmara desta cidade, relativamente ao celeiro público, em 7 de setembro de 1785 . Ignácio Accioli, op. cit, v. III, p. 72.

${ }^{81}$ Cf. Erivaldo Fagundes Neves. Estrutura fundiária e dinâmica mercantil. Alto Sertão da Bahia, séculos XVIII e XIX. Salvador: EDUFBA; UEFS, 2005. Sobre a produção do algodão, ver ainda: Caio Prado Júnior, 1971 e 1992, op. cit.; Bert J. Barickman, op. cit.
} 
um dos maiores ramos do nosso comércio para felicidade da Nação e riqueza da capitania” ${ }^{82}$ Informação corroborada nos relatos de viajantes que estiveram na região anos depois. $^{83}$

Distanciando-se das áreas mais qualificadas destinadas às culturas tradicionais e beneficiada pela demanda da indústria têxtil européia, a lavoura algodoeira modificou profundamente os padrões de inserção da economia sertaneja e do comércio inter-regional, reiterando o papel desempenhado pela colônia americana nas oscilações do mercado mundial. Articulação atestada também quando a remessa do produto para a Europa caiu bruscamente em virtude das exportações oriundas do sul dos Estados Unidos no início do século XIX para novamente ascender durante a guerra de secessão americana na década de $1860 .^{84}$ De qualquer forma, verifica-se que o equilíbrio internacional interferiu sobremaneira nas formas de apropriação e produção econômica da América portuguesa e, como resultante, nos mecanismos de conhecimento e controle dos espaços coloniais.

Na segunda metade do século XVIII profundas alterações ocorreram nas formulações políticas dos burocratas metropolitanos modificando o relacionamento de Portugal com seus domínios americanos, sem, contudo, pretender alterar as posições ocupadas no sistema colonial. As razões das novas reorientações, em grande medida, devem ser atribuídas às mudanças políticas e econômicas do contexto internacional desse período que exigiram tomada de posição do Reino português frente às demais potências

\footnotetext{
${ }^{82}$ Citado por Luís Amaral. História geral da agricultura brasileira. São Paulo: Cia. Editora Nacional, v. 2, 1940, p. 241. Sobre a produção de Caetité, Bittencourt ressaltou: “O arraial de Caetité, que fica trinta léguas, ou pouco menos, do primeiro porto de embarque, que é na vila de Cachoeira [...] hoje é o mais rico daqueles sertões, depois que deram princípio à cultura do algodão, onde há grandes lavradores pela facilidade e segurança de fazerem descer, por uma estrada cultivada, os seus gêneros”. Op. cit., p. 253.

${ }^{83}$ "Caetité (ou Vila Nova do Príncipe), devido à semelhança de seu clima e da sua vegetação com os de Minas Novas, desde vinte anos se dedica em grande escala ao cultivo do algodoeiro, e tornou-se, assim, um dos mais ricos lugares do sertão da Bahia. [...]. O algodão remetido daqui não é, entretanto, produzido somente nos arredores, porém vem igualmente do extremo ocidental de Minas Gerais. As regiões do norte e do leste daquela província despacham o seu algodão do lugar de saída, no arraial do Rio Pardo, para a Bahia, por duas estradas recentemente abertas, via Conquista e Gavião". Cf. Johann B. von Spix; Karl Friedrich P. Von Martius, op. cit., p. 122. Informações sobre o escoamento da produção sertaneja, sobretudo gado e algodão, também foram fornecidas pelo príncipe Maximiliano em fins da década de 1810. Cf. Maximiliano de Wied-Newied, op. cit. Caetité, ao lado da vila de Rio de Contas, localizadas no Alto Sertão da Bahia, desempenharam um papel importante nos conflitos políticos na década de 1820. Cf. Argemiro Ribeiro de Souza Filho, op. cit.

${ }^{84}$ Segundo Bert J. Barickman, entre as últimas décadas do século XVIII e as primeiras do seguinte, as exportações do algodão a partir de Salvador tiveram um aumento vertiginoso: "Passaram de menos de cem arrobas por ano na década de 1770 para uma média anual de quase quarenta mil arrobas na segunda metade da década de 1790. As exportações continuaram a crescer durante as três décadas seguintes; dali em diante, porém, caíram bruscamente, passando de um total de quase trezentas mil arrobas em 1829 para uma média anual inferior a 45 mil arrobas na década de 1850”. O autor observa, porém, que é possível que comerciantes dessa praça exportassem o produto vindo de outras capitanias, o que, todavia, não alterava a participação da Bahia no comércio. Op. cit., p. 59.
} 
européias em franca ascensão - Grã-Bretanha, França e os Países Baixos -, e dos acontecimentos que anunciavam importantes rupturas no seio do colonialismo. ${ }^{85}$

A atuação do marquês de Pombal - Sebastião José de Carvalho e Melo, ministro dos negócios estrangeiros e da guerra no governo de d. José I (1750-1777) - assinala o início de amplas reformas no campo da administração, da fiscalidade e da economia colonial que, a despeito do seu afastamento após a morte do monarca, foram aprofundadas nos anos que se seguiram no compasso da dilatação da crise do sistema colonial. Dessa maneira, a intensificação das intervenções, na passagem do século XVIII, acompanha os resultados concretos das reformas pombalinas, sobretudo, no que diz respeito às iniciativas voltadas para diversificação da pauta de exportações, entre outras medidas de reforço dos vínculos mantidos com a colônia americana levadas a efeito pelos agentes da administração lusitana. ${ }^{86}$

As intervenções políticas e práticas no sentido de diversificar os produtos agrícolas na colônia resultam desse conjunto de providências concebidas em Portugal para evitar a desestabilização do Estado e expressam o esforço dos dirigentes metropolitanos em, a partir do ideário iluminista do século XVIII, elaborar instrumentos para o conhecimento da realidade colonial de maneira a estimular as condições de produção utilitária da terra. Assim, nos últimos decênios do Setecentos e no início do século seguinte, diversos escritos foram elaborados com esse objetivo imediato, não por acaso, grande parte deles integrantes das Memórias econômicas da Academia real de Ciências de Lisboa. $^{87}$

Ainda que o açúcar permanecesse como o produto principal no rol das exportações da Bahia, obtendo elevados preços no mercado internacional após a crise na

\footnotetext{
${ }^{85}$ Fernando A. Novais, op. cit., 1983.

${ }^{86}$ Nas palavras de Fernando A. Novais: “[...] O consulado pombalino, cremos, pode ser encarado como o mais sério esforço levado a efeito pela metrópole portuguesa para pôr em funcionamento a exploração econômica do ultramar e o concomitante desenvolvimento da economia metropolitana, em moldes mercantilistas clássicos”. Op. cit., p. 10. Ao analisar as reformas pombalinas no contexto da crise do antigo sistema colonial, Francisco Falcón adverte que: "Por mais importantes que tenham sido, e isso ir-se-ia tornar mais claro a médio e longo prazo, as reformas de todos os tipos que formam o conjunto dessa prática ilustrada não queriam de fato demolir ou subverter o edifício social. Como em outras sociedades da época, tudo se resumia afinal numa 'atualização', talvez violenta nas formas mas destinada muito mais a garantir a essência do statu quo do que a promover a sua queda”. Francisco J. C. Falcón. A época pombalina: política econômica e monarquia ilustrada. São Paulo: Ática, 1982, p. 488-489. Sobre a administração de Pombal, ver ainda do mesmo autor: "Pombal e o Brasil”. In: José Tengarinha (Org.). História de Portugal. São Paulo: Unesp; Bauru: Edusc; Portugal: Instituto Camões, p. 149-161. Wilma Peres Costa fornece importantes elementos para o estudo da fiscalidade no processo de organização político-administrativo e econômica da colônia. Cf. "Do domínio à Nação: os impasses da fiscalidade no processo da Independência”. In: István Jancsó. (Org.), op. cit., 2003, p. 143-193.

${ }^{87}$ Fernando A. Novais, op. cit., 1983. Emanuel Araújo. Introdução. In: Luis dos Santos Vilhena. Pensamentos políticos sobre a colônia. Rio de Janeiro: Arquivo Nacional, 1987.
} 
ilha de São Domingos, a qual interrompera o seu cultivo nas Antilhas nos anos de 1790; desde a década anterior, novos produtos foram inseridos no circuito comercial ao lado de outros tradicionais como o fumo e o couro, ou pelo menos teve o seu cultivo impulsionado com esse fim, como por exemplo, o algodão, já referido, o cacau, a pimenta, a canela, e o café.

Na colônia americana, a tentativa de incremento agrícola pode ser verificada não apenas nas introduções de novas lavouras e atividades econômicas em áreas até então desocupadas ou povoadas por grupos indígenas e posseiros, que alteraram acentuadamente a fisionomia produtiva das regiões, ${ }^{88}$ como também na avultante correspondência oficial entre os administradores lusitanos que se empenhavam em implementar as novas técnicas agrárias. Em carta do ministro dos negócios ultramarinos, d. Rodrigo de Sousa Coutinho, para o governador da Bahia, d. Fernando José de Portugal, em 1798, por exemplo, várias orientações são transmitidas visando ao melhor aproveitamento dos produtos fornecidos pela capitania em "benefício à Real Fazenda” (uso do arado, modelo de fornalhas, corte de madeiras), além de recomendar a cultura da canela ("para que em poucos anos venha a ser um grande artigo de comércio, em benefício dessa capitania”) e da pimenta (“que espero, venha toda em pouco tempo do Brasil em lugar de vir da Ásia”). ${ }^{89}$

Dois anos mais tarde, o governador dava notícias sobre as perspectivas das novas culturas:

O Padre Francisco Agostinho Gomes e seu sócio Manoel José de Mello desejando promover a cultura da Pimenta me dirigiram a Representação inclusa em que se obrigam a pagar toda a Pimenta que produzir esta Capitania pelo preço de duzentos e oitenta réis o arrátel rogando-me que assim o fizesse constar aqueles Lavradores que quisessem cuidar da plantação, e parecendo-me este meio um dos mais próprios para ela se promover, passo a expedir as ordens necessárias a este respeito, pois de outra sorte não é natural que lavradores acostumados a tirar vantagens que já lhe são conhecidas do Açúcar, Tabaco, Algodão e Café, gêneros mais principais da exportação desta Capitania, hajam de se inclinar a uma cultura, cujos lucros consideram por ora incertos e duvidosos, podendo acontecer que não julguem ainda suficiente aquele preço, o que a experiência melhor decidirá. $^{90}$

\footnotetext{
${ }^{88}$ Cecília Helena L de Salles Oliveira, op. cit. (capítulo II).

${ }^{89}$ Correspondência de d. Rodrigo Coutinho a d. Fernando José de Portugal, em 18 de outubro de 1798. Ignácio Accioli, op. cit., v. III, p. 208.

${ }^{90}$ Ofício de d. Fernando José de Portugal a d. Rodrigo de Sousa Coutinho, em 7 de junho de 1800. Marianne Reisewitz. Dom Fernando José de Portugal: prática ilustrada na colônia (1788-1801). São Paulo, Universidade de São Paulo, 2003 (Dissertação de Mestrado), p. 257.
} 
A freqüente comunicação entre a Coroa portuguesa e os governadores, e bem como destes com as diversas autoridades espalhadas pelo interior da capitania, manifesta que, se Portugal, após a queda do marquês de Pombal, permaneceu dispondo de ministros diligentes na elaboração de uma nova política colonialista, a Bahia correspondia com governadores bastante devotados à expansão do comércio agrícola e ao controle rígido da população. ${ }^{91}$ As instruções aos agentes coloniais constituem uma documentação importante na percepção das atenções dedicadas pelo poder metropolitano às condições de produção e comércio da capitania, bem como do acompanhamento cuidadoso de sua organização socioeconômica e de suas possibilidades de aperfeiçoamento, dada a amplitude dos objetos tratados com o propósito rigorosamente definido de ampliar as rendas da Coroa e o domínio sobre o território. Afinal, não se pode esquecer que a Bahia, embora não ostentasse mais os índices de produção açucareira outrora experimentados, permanecia como uma das principais fontes de sustentação da riqueza colonial.

Contemporaneamente, a capitania forneceu outros nomes importantes na discussão sobre o comércio e sobre a agricultura entre outras questões de interesse para a economia do período. Este é o caso, por exemplo, de José da Silva Lisboa, futuro visconde de Cairu e profundo conhecedor do ideário liberal, como mencionado acima. Em fins do século XVIII já havia redigido Princípios de Direito Mercantil e Leis da Marinha e em 1804 publicado o primeiro livro sobre o tema: Princípios de Economia Política. Ocupando o cargo de secretário da Mesa de Inspeção da Bahia, em 1798 encaminhou um relatório a Domingos Vandelli, diretor do Real Jardim Botânico em Lisboa, na qual presta importantes informações sobre o cultivo da mandioca, algodão, café, arroz, sem deixar de observar que: "Mas estes e outros ramos de comércio da Capitania, não tem proporção com o do tabaco e açúcar, que são principais e antigas bases da prosperidade e progressiva opulência d'esta colônia e foram os primitivos objetos da criação e intendência da Mesa da Inspeção". 92

João Rodrigues de Brito, desembargador da Relação da Bahia, também deixou registradas suas crenças sobre as vantagens da liberdade de comércio e as razões dos males da lavoura na capitania, sugerindo medidas para sua valorização e tecendo severas críticas sobre o controle da comercialização dos produtos e das diversas obrigações a que os

\footnotetext{
${ }^{91}$ Nesse período: Rodrigo José de Menezes, marquês de Lavradio, (1783/1788); Fernando José de Portugal e Castro, marquês de Aguiar, (1788/1801); João de Saldanha da Gama, conde da Ponte (1805/1809). Cf. Ignácio Accioli, op. cit. Sobre a política do marquês de Aguiar, ver: Marianne Reisewitz, op. cit.

${ }_{92}$ Carta muito interessante do advogado da Bahia, José da Silva Lisboa, para o Dr. Domingos Vandelli, Diretor do Real Jardim Botânico de Lisboa, em que lhe dá notícia desenvolvida sobre a Bahia. RIGHBa, Salvador, n. 76, 1950-1951, p. 99-125.
} 
lavradores estavam submetidos. Suas idéias, juntamente com as concepções de Manoel Ferreira da Câmara, José Diogo Ferreira Castelo Branco e Joaquim Inácio de Siqueira Bulcão, redigidas em 1807 e publicadas em 1821, constituem material importante para conhecimento da tomada de consciência dos colonos sobre o comércio metropolitano. ${ }^{93}$

Nessa complexa rede de produção econômica, a área situada no Recôncavo ocupava um lugar central. O cronista Luis dos Santos Vilhena, profundo conhecedor da realidade da Bahia, descreveu o lugar como abrangendo a cidade de Salvador, com suas freguesias, e as vilas que rodeavam a baía de Todos os Santos: São Francisco do Conde e Santo Amaro da Purificação, ao norte; Cachoeira, a oeste, e Maragogipe e Jaguaripe, ao Sul. ${ }^{94}$ Ou seja, Salvador e sua hinterlândia agrícola são vistas como estreitamente ligados. Para Kátia Mattoso, é impossível percebê-los separado: “pois é seu mercado e seu elo com o mundo exterior. Não há uma só família da cidade que não tenha laços com uma família do interior; não há tempestade na baía que não faça subir as águas dos rios do Recôncavo; não há má colheita lá que não cause pobreza aqui. Ontem, como hoje, Salvador não era somente um porto que se estendia ao longo da Cidade Baixa. Era uma cidade em que os limites administrativos quase não contavam”. ${ }^{95}$

É nessa área que desde cedo vai se desenvolver a cultura canavieira proporcionada pelos férteis solos de massapê, sobretudo ao norte, onde se situavam os maiores e mais antigos engenhos da Bahia. É no Recôncavo também que milhares de escravos, trazidos forçosamente da África, serão utilizados por mais de três séculos como mão-de-obra na cana-de-açúcar e em várias outras atividades destinadas à sustentação da economia exportadora. Por sua condição produtiva, "manteve-se, durante todo o século XIX, como a região mais densamente povoada da província e a mais importante do ponto de vista econômico", além do mais, a proximidade e a constância do contato com a cidade de Salvador tiveram influência importante na vida de seus habitantes. Em função dessas

\footnotetext{
${ }^{93}$ João Rodrigues de Brito et al. Cartas econômico-políticas sobre agricultura e comércio da Bahia: Lisboa: Imprensa Nacional, 1821. Amaral Lapa transcreve e comenta documentos elaborados por Joaquim Amorim Castro sobre o cultivo do tabaco na Bahia em fins do século XVIII nos quais avalia questões relacionadas ao plantio, comércio e tributação do produto. José Roberto do Amaral Lapa. "Um agricultor ilustrado do século XVIII”. In:_. Economia colonial. São Paulo: Perspectiva, 1973, p. 141-213. Na mesma linha pode ser visto o Discurso preliminar, histórico, introdutivo com natureza de descrição econômica da comarca e cidade da Bahia... (c. 1790). Anais da Biblioteca Nacional. Rio de Janeiro, 1905, v. XXVII, p. 283-348, provavelmente redigido por Luis Antônio de Oliveira Mendes. Rafael de Bívar Marquese situa as condições de produção dos escritos sobre a administração das propriedades rurais escravistas, em fins do século XVIII e princípios do seguinte e analisa as propostas apresentadas para gerenciamento das terras e dos capitais. Administração $e$ escravidão. Idéias sobre a gestão da agricultura escravista brasileira. São Paulo: Hucitec; Fapesp, 1999 (especialmente capítulo II).

${ }_{94}^{94}$ Luis dos Santos Vilhena, op. cit., v. II, 1969, p. 477-486.

${ }^{95}$ Kátia M. de Queiroz Mattoso, op. cit, 1992, p. 51.
} 
características, o Recôncavo se distinguia das áreas situadas no interior, com seus amplos sertões semi-áridos e daquelas localizadas no litoral sul, com forte presença de densas florestas em decorrência de altos índices pluviométricos, como ressalta Bert Barickman. ${ }^{96}$

A Bahia sempre teve um lugar de destaque na historiografia sobre os processos de organização política e econômica das partes luso-americanas. Todavia, a atenção dos estudiosos voltou-se especialmente para as áreas produtoras dos principais gêneros de exportação - Salvador e seu Recôncavo - referindo-se às regiões distantes dessa circunscrição territorial apenas para assinalar a criação extensiva de gado e as descobertas de ouro, no caso dos sertões, ou as condições favoráveis de navegação e a produção para o abastecimento, em se tratando das vilas e povoações localizadas no sul da capitania. ${ }^{97}$

Em certa medida, esta ênfase é compreensível levando-se em consideração a natureza do sistema colonial, posto que a acumulação originária dava-se no âmbito externo, o que não significa recusar a permanência na colônia de uma porção excedente, porém, com um baixo nível dessa acumulação. O alargamento das pesquisas ancoradas em novas proposições metodológicas possui o mérito de chamar a atenção para a dinamicidade e amplitude do mercado interno, desenvolvido nas franjas da economia escravista e por isso mesmo prenhe de diversidade e peculiaridades. ${ }^{98}$

Se num plano mais amplo, o espaço de realização das mercadorias coloniais se dava no mercado europeu ou no continente africano, no plano mais interno, a complexidade da vida econômica esgarça as fronteiras destinadas à produção exportadora e instaura novas rotas de mercadorias e articulações regionais engendrando outra configuração no território colonial. No caso específico da capitania da Bahia, essas transformações - verificadas anteriormente com a descoberta do ouro nas Minas Gerais,

\footnotetext{
${ }^{96}$ Bert J. Barickman, op. cit., p. 38-39. Com base em ampla pesquisa, o historiador desenvolve uma análise rigorosa sobre a economia escravista na região. Segundo ele: "Juntas, as freguesias suburbanas de Salvador, as duas vilas de São Francisco do Conde e Santo Amaro e a freguesia do Iguape constituíam os principais centros da produção açucareira do Recôncavo. Aproximadamente $90 \%$ dos 221 engenhos que fabricavam açúcar na Bahia em meados da década de 1790 se localizavam nesses distritos”. Op. cit., p. 40. Nas palavras de Thomas Lindley: "Embora seja uma das menores subdivisões do Brasil, é a mais fértil, populosa e luxuriante, produzindo incalculáveis riquezas”. Op. cit., p. 173.

${ }^{97}$ Frederic Morton caracteriza a importância econômica do Recôncavo, centrada na indústria açucareira, e ressalta as diferenças de riqueza entre essa região e os sertões, predominantemente produtores de gado. Chama a atenção, no entanto, para o grau de interdependência que existia entre as regiões da capitania. Op. cit., p. 31.

${ }^{98}$ João Fragoso; Manolo Florentino. O arcaísmo como projeto. Mercado atlântico, sociedade agrária e elite mercantil em uma economia colonial tardia. Rio de Janeiro: Civilização Brasileira, 2001. Bert Barickman, op. cit., Erivaldo Fagundes Neves, op. cit. Para uma atualização do debate historiográfico sobre o tema: José Jobson de Andrade Arruda,. "O sentido da colônia. Revisitando a crise do antigo sistema colonial no Brasil". In: José Tengarrinha (Org.). História de Portugal. Bauru: Edusc; São Paulo: Unesp; Portugal: Instituto Camões, 2000, p. 167-183.
} 
início do século XVIII, e mesmo antes, no processo de expansão do gado para os sertões adquirem um novo sentido no final desse período, o que implica em maior aprofundamento do conceito de crise pelo que expressa de vínculo com a subversão na estrutura do Antigo Regime, como também pelas dimensões das possibilidades de alteração política em condições coloniais. ${ }^{99}$

Mafalda Zemella ao estudar o abastecimento da capitania de Minas Gerais no século XVIII esclarece sobre a movimentação que a exploração aurífera provocou na Bahia dada a imensa facilidade de comunicações terrestres e fluvial por meio do rio São Francisco e de sua rede de afluentes. O fornecimento de gêneros, apesar da importância para as populações mineiras, fora proibido em 1702 numa tentativa de impedir os descaminhos do ouro e o comércio de negros. Medidas que, na prática, revelaram-se ineficazes ante os variados recursos utilizados sobretudo para o contrabando do metal precioso. ${ }^{100}$ Ademais, a falta de mantimentos na Bahia e no Rio de Janeiro em virtude do comércio com as minas era outro problema a ser enfrentado pelas autoridades. O governador do Rio de Janeiro socorria-se com as remessas vindas da Bahia, recurso que, no entanto, não agradava ao governo dessa capitania:

Suponho que Vossa Mercê deve entender que os moradores da Bahia são somente obrigados a plantar Roças para o sustento dos do Rio de Janeiro, pois se assim não fora houvera mais cuidado e diligência em se obrigarem os dessa Capitania a que todos cultivassem os mantimentos de que carecem como fazem os do Recôncavo e sertões desta cidade à custa do incansável desvelo com que os obrigo a fazer as plantas necessárias na forma das ordens de Sua Magestade que Deus guarde, que também hão de estar nesse Governo; mas como é melhor lavrar ouro, que plantar Mandiocas não me espanto de que experimente tanta falta de farinhas $[\ldots] .{ }^{101}$

A impossibilidade de conter o contrabando pelos caminhos do sertão, segundo um registro coetâneo anônimo, era o fato de os moradores das minas e dos sertões serem todos "tão absolutos que qualquer vaqueiro ou Paulista metido com a sua escopeta pelos matos daqueles sertões, nem todos os exércitos da Europa parece serão bastante para o impedirem que entre e saia por onde quiser”. ${ }^{102}$ Além disso, os caminhos que ligavam as

\footnotetext{
${ }^{99}$ István Jancsó. Na Bahia, contra o Império. História do ensaio de sedição de 1798. São Paulo: Hucitec; Salvador: EDUFBa, 1996; Carlos Guilherme Mota. Idéia de revolução no Brasil (1789-1801). 4. ed. Estudo das formas de pensamento. São Paulo: Ática, 1996.

${ }^{100}$ Mafalda Zemella, op. cit.

${ }^{101}$ Citado por Mafalda Zemella, op. cit, p. 66.

102 Citado por Mafalda Zemella, op. cit., p. 72. Somente o comércio de gado era permitido dado que os mercados paulistas e do Rio de Janeiro não estavam em condições de atender a demanda das cidades mineiras. O capítulo XVII do Regimento das Minas determinava: "Nem uma pessoa do distrito da Bahia
} 
duas regiões, ainda de acordo com o registro, ofereciam imensas vantagens para os viajantes: “água em abundância, farinha em quantidade, carnes de toda espécie, frutas, laticínios, cavalos para se transportarem, pastos para as cavalgaduras, e casas para se recolherem, sem risco de Tapuyas nem de outros inimigos". ${ }^{103}$

A Bahia era uma zona de povoamento antigo e, ao longo do tempo, uma ampla rede de sustentação da economia colonial desenvolveu-se resultando numa estrutura socioeconômica extremamente complexa. A concentração da produção econômica voltada para a exportação foi dilatada com a implantação das lavouras de algodão, pelas imensas fazendas de criação de gado, além da exploração do ouro proveniente das minas descobertas em Jacobina e Rio de Contas no início do século XVIII. Ao lado disso, a circulação interna de mercadorias e a diversidade dos produtos explorados exigiam dos agentes metropolitanos intensas intervenções necessárias ao controle das populações e ordenamento dos espaços territoriais. ${ }^{104}$ Como o aprofundamento da crise em princípios dos anos 1820 incidiu na percepção que os antigos colonos, ou pelo menos parte deles, possuíam sobre territorialidade, identidade e legitimidade, é uma das questões a ser tratada adiante. $^{105}$

As atividades econômicas desenvolvidas no interior da capitania contribuíram para ampliar o número de núcleos urbanos, paulatinamente, bem como o crescimento da população local, modificando profundamente a paisagem de inóspitas regiões até então habitadas por variados grupos indígenas. Aos poucos, as vilas se espalharam pelo

poderá levar às minas pelo caminho do Sertão outras fazendas ou gêneros que não sejam gados, e querendo trazer outras fazendas as naveguem pela barra do Rio de Janeiro e as poderão conduzir por Taubaté ou São Paulo". Op. cit., p. 70.

${ }^{103}$ Citado por Mafalda Zemella, op. cit, p. 126.

${ }^{104}$ A criação extensiva de gado e a produção de alimentos para abastecer mercados consumidores foram discutidos, entre outros, por Manuel Correia de Andrade. "A pecuária e a produção de alimentos no período colonial”. In: Tamás Szmrecányi (Org.), op. cit, p. 99-108; Maria Yedda Linhares. “A pecuária e a produção de alimentos na colônia”. In: Tamás Szmrecányi (Org.), op. cit., p. 109-121; Francisco Carlos Teixeira da Silva. "Pecuária, agricultura de alimentos e recursos naturais no Brasil-colônia”. In: Tamás Szmrecányi (Org.), op. cit., p. 123-159; Erivaldo Fagundes Neves. Uma comunidade sertaneja. Da sesmaria ao minifúndio (um estudo de história regional e local). Salvador: Edufba; Feira de Santana: UEFS, 1998; Basílio de Magalhães. Expansão geográfica do Brasil colonial. São Paulo: Companhia Editora Nacional, 1958; Felisbello Freire. História territorial do Brasil (Bahia, Sergipe e Espírito Santo). Salvador: Secretaria da Cultura e Turismo/Instituto Geográfico e Histórico da Bahia, 1988 (Edição facsimilada). Sobre a descoberta de ouro em Rio de Contas e Jacobina e as medidas de controle efetivadas pelo governo luso-americano, ver Albertina Lima Vasconcelos, op. cit.

${ }^{105}$ Nos situamos aqui na linha de investigação proposta por Denis Antônio de Mendonça Bernardes ao discutir as lutas políticas em Pernambuco nos primeiros anos de 1820. Op. cit. 
território escassamente povoado de tal modo que entre os séculos XVI e XVII apenas dez vilas foram criadas enquanto no século XVIII esse número ultrapassava a trinta. ${ }^{106}$ Ao que tudo indica, a criação de novos municípios desencadeava conflitos no âmbito das localidades resultando em risco para a estabilidade institucional. Pelo menos é o que informa o governador d. Lourenço de Almeida ao monarca português, d. João V, no início do século XVIII:

Pela experiência que tenho dos povos destas Minas, dei conta a Vossa Majestade pela frota da Bahia, que por nenhum caso convém ao real serviço de Vossa Majestade que se criem de novo mais vilas, porque todos estes povos enquanto são arraiais vivem sossegadamente, por não terem ambição de entrarem nas governanças, porque, em sendo vilas, logo se formam parcialidades sobre quem há de ser juiz e vereadores, e o pior é que tomando o pretexto do bem comum e do povo, não querem consentir nada que seja em conveniência do real serviço de Vossa Majestade e aumento da sua real fazenda [...]. ${ }^{107}$

Por outro lado, nem sempre a arregimentação de povoadores era tarefa fácil. Não se pode esquecer que muitos desses núcleos foram criados com a expulsão e dizimação violenta dos índios ocasionando a fuga de outros tantos sobreviventes. O ouvidor de Porto Seguro, Machado Monteiro, em 1773, reclamava da dificuldade em se povoar três vilas que havia planejado:

porque se erigi-las me é fácil, o povoa-las me é muito difícil. Do sertão não desce gentio manso, nem eu tenho meios de suprir a despesa de os mandar lá catequizar. Os degradados são poucos que mal me poderão chegar (porque alguns fogem) para fornecer as 3 vilas novas que fiz. Estas povoações seriam fundamentais para uma estrada que nas minhas Instruções se me adverte faça abrir para comunicação, e comércio dessa capitania com a do Espírito Santo. ${ }^{108}$

\footnotetext{
106 Sylvio C. Bandeira de Mello e Silva et al, op. cit.

${ }^{107}$ Citado por Caio César Boschi. "Colonialismo, poder e urbanização no Brasil setecentista”. In: Anais do I Colóquio de Estudos Históricos Brasil-Portugal. Belo Horizonte: PUC-MG, 1994, p. 105. Os conflitos entre autoridades pela anexação de novos territórios ou contra a divisão das fronteiras já demarcadas constituem um aspecto importante na história da expansão territorial do Brasil ainda pouco estudado. A Revista do Instituto Geográfico e Histórico da Bahia traz algumas análises sobre esses conflitos que se prolongaram por séculos adentro. Cf. "Estudo sobre os limites entre os Estados da Bahia e do Espírito Santo". RIGHBa., 1895, ano II, v. 2, n. 5; p. 267-273 e n. 6, p. 395-401; “Limites entre a Bahia e Pernambuco”. RIGHBa., 1896, Ano III, v. 3, n. 8. Para discussão das divergências envolvendo a criação da vila de Caetité, no alto sertão da Bahia, e da Imperial vila da Vitória, ver Maria Aparecida Silva de Sousa. A conquista do Sertão da Ressaca. Povoamento e posse da terra no interior da Bahia. Vitória da Conquista: Ed. UESB, 2001. A complexa trama entre a construção de territórios e a formação das identidades coletivas é discutida por István Jancsó; João Paulo G. Pimenta, op. cit.

${ }^{108}$ Citado por Maria Helena Ochi Flexor. “Criação da rede urbana na capitania da Bahia no século XVIII”. Actas do Colóquio Internacional Universo Urbanístico Português, 1715-1822. Lisboa: Comissão Nacional para as comemorações dos descobrimentos portugueses, 2001, p. 545. A autora comenta que o ouvidor, entre
} 
Mesmo considerando essas dificuldades, novas vilas foram implementadas sendo recorrente a orientação do governo para que os agentes coloniais se empenhassem no povoamento de áreas consideradas estratégicas ao aumento das rendas da Coroa ou na implementação de medidas que visassem disciplinar os habitantes da capitania. Não por acaso, em 1777, o governo da Bahia ordenou ao ouvidor de Porto Seguro que se criassem vilas e povoações de seis em seis léguas, "em vista da necessidade de comunicar-se a Bahia com o Rio de Janeiro, por via terrestre, e porque os avisos correm em grande risco na travessia deserta desde a última vila até o rio Doce e daí até a primeira vila do Espírito Santo”. ${ }^{109}$ Em fins desse século, a sugestão de d. Fernando José de Portugal a d. Rodrigo de Sousa Coutinho, era a criação de um juiz de fora na vila de Rio de Contas, “por ser a mais povoada daquela comarca e a mais interessante pela lavoura do algodão e seu comércio”. Ao mesmo tempo comunicava a sua decisão em criar uma vila no arraial da Tapera, comarca de Jacobina, autorizado que estava pela carta régia de 22 de julho de 1766, a qual determinava que "por causa dos insultos que nos sertões nesta Capitania cometiam os vadios facinorosos, que todos os homens que nele se achassem vagabundos ou em sítios volantes, fossem logo obrigados a escolherem lugares acomodados para viverem juntos em povoações civis que pelo menos tenham de 50 fogos para cima, com juiz ordinário, vereadores e procurador do conselho [...]”. ${ }^{110}$ Pela intensificação das denúncias de violência e intranqüilidade nos sertões da Bahia, a situação parece ter se agravado anos depois dessa recomendação.

A fundação de vilas ou cidades na América portuguesa implicava na instalação da câmara municipal responsável pelo desempenho de funções político-administrativas, judiciais, fazendárias e de polícia. A organização do governo e da administração local pautava-se pelas mesmas leis metropolitanas que, entre outras regulamentações, determinava a escolha dos representantes do poder camarário entre os "homens bons" da urbe, aqueles indivíduos revestidos de condição nobiliárquica e que possuíssem bens de

tantas solicitações, recomenda às autoridades para que fosse aplicado a "Lei de Polícia” na cidade e Recôncavo encaminhando os degredados, vadios e ociosos para povoamento das novas vilas porque faziam "subir a farinha a extraordinário preço, e seria melhor a fizessem lavrar aonde tanta se pode produzir”. Loc. cit.

${ }^{109}$ Citado por Maria Helena Ochi Flexor, op. cit., p. 548.

${ }^{110}$ Ofício do Governador d. Fernando José de Portugal para d. Rodrigo de Sousa Coutinho, no qual se refere à prisão de um grupo de facínoras. Anais da Biblioteca Nacional, Rio de Janeiro, 1916, v. 36, p. 145. O conteúdo da carta demonstrava claramente o objetivo de controlar a dispersão populacional no interior da capitania. Para as autoridades, esses itinerantes, "não podem levar à paciência que se fundem vilas ou povoações que lhes tire a liberdade de viverem dispersos e vadiando, e talvez por este motivo se oponham”. Citado por Emanuel Araújo, op. cit., p. 25. Segundo Araújo, a carta régia, ou Lei dos Sítios Volantes, fora encaminhada para as capitanias de São Paulo, Minas Gerais, Bahia, Pernambuco e Goiás. 
raiz. Mesmo considerando diferenças de riqueza, parece evidente que os homens aptos a ocupar os "cargos da governança” possuíam determinados atributos que os distinguiam dos demais habitantes das municipalidades. Ainda assim, é preciso levar em consideração a profunda diversidade econômica, espacial, populacional entre as várias regiões que certamente influía na caracterização dos grupos dirigentes locais. A despeito dessas especificidades, a rigor, os órgãos camarários constituíram um instrumento importante de interlocução das populações locais com o poder central e de intervenção na sociedade. ${ }^{111}$ Por meio da correspondência entre as autoridades das vilas interioranas e os governadores da Bahia não é difícil perceber que uma das queixas recorrentes, nas primeiras décadas do Oitocentos, era o crescente desassossego dos moradores em virtude de ataques promovidos por grupos ou indivíduos errantes. ${ }^{112}$

O deslocamento dessas populações era problema antigo a exigir solução das autoridades. Luis dos Santos Vilhena demonstrou enorme preocupação com esse contingente ocioso que vagava não apenas pelos sertões da capitania, como também pelo meio urbano. Seus escritos, em fins do século XVIII, além de apontar os prejuízos que os “vadios” poderiam causar ao equilíbrio colonial, apresentavam formas de resolução do problema em benefício da metrópole, tendo em vista que não estava interessado no rompimento do pacto. Assim, sugeriu o povoamento das amplas áreas vazias do interior da colônia americana, bem como propôs a criação de uma “lei agrária”, uma forma de repartição das sesmarias em pequenos lotes distribuídos entre os habitantes que se encontravam à margem da produção. Por fim, a riqueza produzida seria incorporada ao fluxo do comércio português, complementando os sustentáculos necessários à preservação do sistema. ${ }^{113}$

\footnotetext{
${ }^{111} \mathrm{O}$ estudo da instituição camarária como pilar do Império português evidencia que as câmaras ocuparam lugar de destaque na estrutura político-administrativa da monarquia não somente como um complexo mecanismo de controle da América portuguesa, como também nas demais possessões da África e Ásia. Cf. Charles R. Boxer. O império colonial português (1415-1825). Lisboa: Edições 70, 1981; A. J. R. RusselWood. "O governo local na América portuguesa: um estudo de divergência cultural". Revista de História, São Paulo, v. LV, ano XXVIII, 1977, p. 25-79; Stuart B. Schwartz. Burocracia e sociedade no Brasil colonial. São Paulo: Perspectiva, 1979. A historiografia brasileira apresenta diferentes interpretações sobre a extensão de poderes e atribuições dos órgãos camarários na América Portuguesa, a exemplo de Oliveira Vianna. Instituições políticas brasileiras. Belo Horizonte: Itatiaia; São Paulo: EDUSP; Niterói: EDUFF, v. 1, 1987; Caio Prado Junior, op. cit., 1992; Raymundo Faoro. Os donos do poder. Formação do patronato político brasileiro. 10. ed. São Paulo: Globo, v. 1, 1996.

${ }_{112}$ Argemiro Ribeiro de Souza Filho, op. cit.;. Maria Aparecida Silva de Sousa. O senado da Câmara de Caetité: apontamentos para o estudo da história política dos sertões baianos. Comunicação apresentada no Seminário Formação do Estado Nacional Brasileiro, Salvador: Cedic; Fundação Clemente Mariani, 2002 (Texto mimeog.).

${ }^{113}$ Luis dos Santos Vilhena, op. cit., 1997, p. 27-28.
} 
Na descrição de Thomas Lindley, apenas cinco anos antes da chegada do regente, a mendicidade era um dado incontornável da capitania: “Quer a cidade, quer o campo, vivem infestados de mendigos, num quadro de miséria real ou fingida que se oferece a cada instante”. ${ }^{114}$ Ao que parece, essa situação realmente se intensificou a partir da retração econômica das áreas que anteriormente desempenharam papel de destaque no cenário econômico da capitania, a exemplo das vilas de Rio de Contas e Jacobina. O fim da exploração aurífera nessas localidades sertanejas, assim como nas Minas Gerais, provocou enorme impacto nas populações que se dedicavam ao trabalho de extração do minério ou em atividades secundárias relacionadas ao abastecimento. De outro modo, como entender o destino de numerosas pessoas que se viram destituídas das possibilidades de sobrevivência com a decadência das minas ou mesmo em períodos de crise sobretudo nas áreas distantes dos maiores centros produtores ${ }^{115}$ Não se pode esquecer que ao lado desses homens considerados perniciosos aos interesses do Estado, o enquadramento dos escravos e dos índios, constituía em problema essencial nos projetos de reajustamentos promovidos pela Coroa portuguesa. Questões importantes que estarão na base do ordenamento da sociedade "como fundamento da boa ordem baseada na natural e necessária desigualdade entre os homens”. ${ }^{116}$

Desse modo, o conhecimento sobre o território da capitania era condição sinequa-non para as medidas intervencionistas. A incessante correspondência mantida entre os ministros da Coroa portuguesa e os governadores da capitania com informações sobre população, estradas, regimentos de linha e milícias, áreas produtivas, comércio , entre outros dados, expressa o desejo de devassamento do território com vistas à implementação de medidas intervencionistas nem sempre bem-sucedidas. ${ }^{117}$

\footnotetext{
114 Thomas Lindley, op. cit., p. 175.

${ }^{115}$ Basílio de Magalhães afirma que grande parte de criadores de gado originou-se da decadência das minas auríferas, buscando alternativas de sobrevivência na pecuária e na agricultura. Op. cit., p. 150-151. Argemiro Ribeiro avalia como as dissensões políticas no Alto Sertão, por ocasião da crise no início dos anos 1820 exacerbaram as manifestações identitárias desses segmentos. Op. cit. Correspondência de autoridades da capitania da Bahia dando conta de assassinatos, roubos, desordens cometidos por "facinorosos", em princípios do século XIX, em algumas vilas do interior da Bahia pode ser encontrada nos Anais da Biblioteca Nacional do Rio de Janeiro. Inventário dos documentos relativos ao Brasil existentes no Arquivo de Marinha e Ultramar de Lisboa, op. cit.; Ignácio Accioli de Cerqueira e Silva, op. cit, v. III; Anais da Biblioteca Nacional do Rio de Janeiro, op. cit., v. 68.

${ }^{116}$ István Jancsó; João Paulo G. Pimenta, op. cit., p.141.

${ }^{117}$ Sobre as tentativas de ligação do Sertão da ressaca com o litoral sul da Bahia e o norte de Minas Gerais por meio da abertura de estradas para facilitação do comércio inter-regional, bem como outras intervenções que visavam a ocupação econômica da região, incluindo a dizimação dos grupos indígenas locais, destruição de quilombos e a implantação de núcleos de colonos estrangeiros, ver Maria Aparecida Silva de Sousa, op. cit., 2001 Ignácio Accioli e Braz do Amaral transcrevem farta documentação sobre algumas dessas iniciativas em fins do século XVIII e princípios do seguinte. Ignácio Acioli, op. cit., v. III. A gazeta Idade d’Ouro do Brazil acompanhou de perto as iniciativas do governo para aprofundar o povoamento e a ocupação dos
} 
Nesse conjunto de demandas, o exame das condições de apropriação da terra, da produção e do controle das populações externas às áreas exportadoras da Bahia, por meio de uma racionalidade administrativa, indica a existência de uma ampla conexão fundamental no movimento de reiteração do sistema que, se por um lado derivava das intervenções no âmbito da organização sócio-política e econômica, por outro apresentava sérios empecilhos dada a sua complexa estrutura. Isso pressupõe admitir que o governo português, de há muito empenhado na organização eficiente da exploração ultramarina, não se limitou a implementar mecanismos para o desenvolvimento da capitania apenas na faixa que compreendia a capital e o Recôncavo ou nas áreas de mineração (Rio de Contas e Jacobina). As diversas tentativas de devassamento, controle e ordenamento informam sobre um plano de apropriação e efetiva dominação de populações e territórios sobretudo na segunda metade do século XVIII e, ao que parece, aprofundadas nas primeiras décadas do Oitocentos após a instalação da Coroa portuguesa na América.

Em 21 de maio de 1808, d. Rodrigo de Sousa Coutinho, encaminhou ao governo da Bahia cópia da carta régia que ordenava a guerra ofensiva aos índios botocudos existentes na capitania de Minas Gerais. Pelo decreto, de 13 de maio desse ano, o príncipe determinava que “a raça antropófaga” deveria se sujeitar “ao doce jugo das leis” e, desse modo, "prometendo viver em sociedade", tornando-se "vassalos fiéis" como "as imensas variedades de índios” aldeados que viviam em “estado social”. Mas, como o documento deixava claro mais adiante, o objetivo final era mesmo a eliminação dos botocudos. Para isso, os comandantes mais dedicados seriam bem recompensados:

Terá mais meio soldo aquele comandante que, no decurso de um ano, mostrar que não somente no seu distrito não houve invasão alguma de índios Botocudos, nem de outros quaisquer índios bravos, de que resultasse morte de portugueses, ou destruição de suas plantações, mas que aprisionou e destruiu no mesmo tempo maior número do que qualquer outro comandante. ${ }^{118}$

Na correspondência, enviada ao conde da Ponte, o ministro reforçava a rigorosa observância das ordens do príncipe por parte da capitania da Bahia, “a fim de que a sua perseguição e ataque seja geral em todos os pontos, onde possam aparecer respeite

sertões, bem como a ampliação da rede de comunicação entre as regiões interioranas, terrestre e fluvial, e os contatos estabelecidos pelos desbravadores com as populações indígenas. Cf. Maria Beatriz Nizza da Silva, op. cit. (capítulo 2).

${ }^{118}$ Decreto de 13 de maio de 1808 - Manda fazer guerra aos índios botocudos. Disponível no site da câmara dos deputados (www.camara.gov.br). Maria Hilda Baqueiro Paraíso discute as mudanças ocorridas nos territórios indígenas com a vinda da família real para a América, enfatizando as diferenças da prática da guerra justa em Minas, Bahia e Espírito Santo. Cf. O tempo da dor e do trabalho. A conquista dos territórios indígenas nos sertões do Leste. São Paulo, Universidade de São Paulo, 1998 (tese de doutorado). 
contudo aquela Divisão destes gentios que ficam vizinhos ao Rio Jequitinhonha os quais parece que mais civilizados tem abandonado parte da sua ferocidade [...]”, alertando que as patrulhas não deveriam ultrapassar o rio Pardo, "salvo se se manifestarem de novo as barbaridades dos referidos Índios naquelas vizinhanças”. 119

Anos mais tarde, em 1818, a gazeta Idade d'Ouro do Brazil, criada na Bahia em 1811, felicitava os resultados positivos das capitanias de Minas e Bahia em relação à operação contra os índios: “Os Botocudos despiram a sua natural ferocidade, perderam o medo dos brancos e, excitados pelo seu exemplo, cultivam a terra e se prestam a qualquer gênero de trabalho. Têm-se estabelecido colonos em distâncias proporcionais até o Salto Grande e Belmonte, os quais ajudam a conduzir as canoas por terra naqueles sítios em que as cachoeiras não deixam vagar o rio”. ${ }^{120}$ Como assinala Maria Beatriz Nizza da Silva, o redator freqüentemente mostrava-se entusiasta do processo de dominação imposto aos índios e o significado disso para o florescimento da América portuguesa e da capitania da Bahia em particular, criticando as missões jesuíticas e defendendo uma ação civil e militar rigorosa:

Parece de absoluta necessidade instruir os novos colonos nos princípios da religião, que em todos os tempos foi o primeiro móvel da civilização, mas o sistema atual das missões é de mui pouco proveito, como a experiência tem mostrado com os jesuítas. Os índios que atualmente existem debaixo das missões nem se aumentam em número, nem se fazem úteis ao Estado por sua indústria e trabalho (falando nós desta capitania), donde se colhe que eles não tiram das idéias da religião aquele amor à ordem, ao trabalho e aos bons costumes, objeto que a religião inspira quando é bem ensinada e dirigida.

É de esperar que estas coisas se remedeiem brevemente e que a sabedoria do governo aplique todos os meios necessários ao objeto desejado, que é a civilização dos Botocudos, a cultura das terras, a fácil transitabilidade do rio, a cópia de gêneros no porto de Canavieiras e, por conseqüência, a comunicação freqüente de Minas com a Bahia e a fartura de víveres de que esta cidade carece. $^{121}$

Certamente o periódico reproduzia não apenas o pensamento da Coroa e de seus funcionários, como também de grande parte dos residentes nos domínios americanos que viam na subjugação dos segmentos tidos como impeditivos ao desenvolvimento do Império português a condição fundamental para a sua expansão. Nessa direção, é

\footnotetext{
${ }^{119}$ Correspondência de d. Rodrigo de Sousa Coutinho ao conde da Ponte, em 21 de maio de 1808. APEB. Seção de Arquivo Colonial e provincial. Ordens Régias. Maço: 106 (1808-1809).

${ }^{120}$ Idade d'Ouro do Brazil, n. 38, de 12 de maio de 1818. Bahia: na Tipografia de Manoel Antônio da Silva Serva. Disponível no site da biblioteca nacional (www.bn.br).

${ }^{121}$ Idem, Ibidem.
} 
significativo o fato de os protagonistas das lutas pela independência combaterem a suposta tentativa de recolonização pelas cortes lisboetas, anos mais tarde, ao mesmo tempo em que permaneceriam reivindicando a legitimidade para, internamente, dominar índios, escravos e homens pobres livres, a imensa maioria da população.

Como alguns estudiosos observaram anteriormente, definir a composição social da capitania da Bahia não é tarefa das mais fáceis dada a complexidade das relações entre seus variados segmentos. ${ }^{122}$ No entanto, o estudo das estruturas básicas da colonização na América portuguesa não pode prescindir das categorias centrais que corporificavam as relações sociais de dominação: os senhores e os escravos. Relação dominante essencial para o processo de acumulação externa de capital numa fase específica de desenvolvimento do capitalismo comercial e elemento fundante da sociedade colonial.

Como referido, a Bahia era uma das regiões produtoras de açúcar mais importante das Américas, cuja economia, sustentada pela mão-de-obra escrava, produziu um enorme fosso entre a classe dominante - os senhores de engenho - e os trabalhadores cativos executores de numerosas ocupações e completamente submetidos aos seus proprietários. Nesse universo, não se pode esquecer de que a utilização do trabalho escravo estava amplamente disseminada na sociedade da época, da lavoura às cidades, dos grandes aos pequenos proprietários, do litoral aos sertões da Bahia resultando em dinâmicas diferenciadas no interior do sistema ainda que o seu eixo central permanecesse o mesmo: a propriedade do escravo como mercadoria.

Todavia, apreender a essência dessa realidade significa identificar as mediações que permitiram a reprodução e o funcionamento da sociedade que não se esgotavam em seus pilares centrais de organização. Uma análise sobre a documentação de fins do século XVIII (correspondência de funcionários régios, relatos, relatórios) indica o registro crescente, e preocupante como mencionado acima, desses segmentos intermediários constituídos por homens livres e muitos ex-escravos envolvidos em variadas atividades produtivas quando não se encontravam desprovidos de qualquer meio de subsistência, mas que em variados momentos de tensão estiveram presentes na cena pública movidos pelas necessidades imediatas. ${ }^{123}$ Esses setores freqüentemente se viam constrangidos, seja pela violência do recrutamento forçado, do atraso no soldo das tropas, da falta de ocupação, da fome que os rondava ainda mais em períodos prolongados de secas, seja pela origem racial que discriminava muitos deles nas poucas oportunidades, sobretudo, no que diz

\footnotetext{
122 João José Reis, op. cit., 2003; Frederic Morton, op. cit.

${ }^{123}$ Cf. João José Reis, op. cit., 2003 (especialmente capítulo I).
} 
respeito à organização das tropas. Mas, nessa complexa estrutura assimétrica, a desigualdade experimentada pelos escravos, “mercadoria especial”, era "radicalmente desigual” dada a sua condição no interior da hierarquia social. ${ }^{124}$ Dito desse modo, afirmase que a dominância da relação social requeria a existência de relações intermediárias que, se por um lado, evidenciavam a complexa estrutura do sistema, por outro, informavam as condições de integração e conflito desse conjunto social. Afinal, como já se observou de maneira perspicaz: "O conflito é também uma forma de articulação". 125

Numa visão mais abrangente da sociedade baiana, mas levando em consideração o fator econômico como elemento diferenciador das funções ocupadas pelos sujeitos na estrutura social, os grandes negociantes figuravam abaixo dos senhores de engenho, indivíduos que, não raro, atuavam em diferentes setores. Diversas outras atividades eram desenvolvidas por uma parcela da população nesse universo dos grupos econômicos. A partir de uma investigação realizada pelo historiador João José Reis sobre a hierarquia econômico-ocupacional de Salvador no século XIX, é possível confirmar o profundo desnível na distribuição de renda cujo valor médio da riqueza (em mil réis) indica no topo o senhor de engenho seguido pelo negociante (82.980 e 19.731) e no outro extremo, o pequeno comerciante e o artesão (com índices de 1.984 e 931 respectivamente) intermediados por outras ocupações como fazendeiro, funcionário, religioso, oficial militar etc. $^{126}$

Agrupando os indivíduos para verificar os níveis de concentração de riqueza, com base em inventários no período de 1800-1850, Reis concluiu que os $10 \%$ mais ricos estavam no controle de $67 \%$ da riqueza: "Se isolarmos apenas os 5\% do topo, verificamos que possuíam $53 \%$ da riqueza”, enquanto os 30\% da escala mais inferior do levantamento controlavam apenas 1,1\%. Embora esses dados sejam uma amostragem e possam expressar uma distribuição menos desigual do que a realmente existente, como bem alerta o pesquisador, não restam dúvidas que evidenciam uma sociedade profundamente desigual com uma imensa concentração de riqueza contrastando com elevados índices de pobreza da população. ${ }^{127}$ Certamente um estudo sobre a distribuição de riqueza para

\footnotetext{
${ }^{124}$ Cf. István Jancsó, op. cit., 1996, p. 124.

${ }^{125}$ Fernando A. Novais. “Condições de privacidade na colônia”. In: Laura de Mello e Souza (Org.). História da vida privada no Brasil. Cotidiano e vida privada na América portuguesa. (Coleção dirigida por Fernando A. Novais). São Paulo: Companhia das Letras, 1997, p. 38.

${ }^{126}$ João José Reis. A morte é uma festa: ritos fúnebres e revolta popular no Brasil no século XIX. São Paulo: Companhia das Letras, 1991, p. 38. Os dados também constam no estudo de István Jancsó, op. cit., 1996, p. 86.

${ }^{127}$ Cf. João José Reis, op. cit., 2003, p. 30-31. O historiador analisou 395 inventários entre 1800 e 1850 esclarecendo que "se trata de uma amostra de pessoas que deixaram algum legado, o que não significa que
} 
outras regiões da província poderia dimensionar o grau de sua concentração, levando-se em consideração as especificidades das atividades ali desenvolvidas. Mas, de qualquer maneira, para o conjunto da sociedade do período que se refere a investimentos produtivos os senhores de engenho "constituíam, indiscutivelmente, o maior poder econômico da Bahia”. 128

Em outras palavras, se a sociedade escravista desse período possuía diferentes dimensões, o núcleo central da sua estrutura econômica assentava-se na oposição entre senhores e escravos e os problemas decorrentes desse sistema estarão sempre presentes nos conflitos verificados na capitania e posterior província da Bahia. Todavia, a partir do final do século XVIII, os princípios que norteiam as manifestações, sobretudo em 1789 (Minas Gerais) e 1798 (Bahia), adquirem um diferencial de extrema importância se comparadas às revoltas do período anterior: a crítica a forma de organização do poder "e a sua substituição por outra afirma-se como o objetivo que move os homens”. Os desdobramentos da crise do Antigo Regime se faziam sentir na América portuguesa esgarçando as contradições do sistema colonial e, embora respondessem a necessidades específicas, expressavam os nexos de tentativa de superação da mesma crise. ${ }^{129}$

\subsection{Experiências políticas em situação colonial}

Certamente, ao chegar a Salvador em 22 de janeiro de 1808, d. João, além de conhecer a cidade que fora o centro das decisões políticas na América portuguesa por mais de dois séculos, identificava também o lugar que poucos anos antes havia sido palco

todas fossem afluentes. Estão ali representados do rico senhor de engenho ao humilde artesão africano. Mas enquanto o senhor de engenho representa bem sua classe, o africano figura provavelmente como alguém bem-sucedido dentro de sua comunidade. Em outras palavras, o perfil de distribuição aqui retratado, na verdade, é melhor, menos desigual do que o existente então. $\mathrm{E}$ o que aqui se mostra é uma sociedade profundamente desigual”. Idem, ibidem, p. 30.

${ }^{128}$ Idem, ibidem, p. 31. No caso do Sertão da Ressaca, é possível conferir a concentração da riqueza nas mãos da família Gonçalves da Costa, responsável pelo desbravamento e ocupação da região, por meio da posse de terras, gado e escravos ainda que em níveis bastante inferiores das áreas produtoras para exportação. Da mesma maneira, os registros sobre a desocupação de parte dos seus moradores, conflitos pela posse de terra e as poucas possibilidades de inserção no mundo do trabalho para os homens livres dão conta desse desequilíbrio econômico. Realidade que certamente não diferia de outras localidades do interior da Bahia. Cf. Maria Aparecida Silva de Sousa, op. cit., 2001. Sobre concentração fundiária nos sertões da Bahia, ver ainda: Erivaldo Fagundes Neves, op. cit., 1998 e 2005.

${ }^{129}$ István Jancsó. “A sedução da liberdade”. In: Laura de Mello e Souza (Org.)., op. cit., 1997, p. 389. Jancsó denomina as novas manifestações emergentes no final do século XVIII como sedição: "entendendo-se por esta [...] a ação organizada visando a revolução. A sedição é, e todos a percebem dessa maneira. O conjunto das práticas de natureza subversivas que, referidas à revolução, anunciam-na enquanto possibilidade, mesmo quando se concretizam apenas no simplesmente fazê-lo. A sedição é, então, a revolução desejada, o futuro anunciado, a política do futuro nos interstícios do presente”. Idem, loc.cit. 
de uma das principais articulações que desafiaram a Coroa portuguesa em seus domínios americanos. Com efeito, o ensaio de sedição, ocorrido dez anos antes, mobilizou as autoridades régias em razão sobretudo do conteúdo de suas proposições, constituindo-se uma referência fundamental no quadro das ações políticas de contestação ao Estado que tiveram lugar na Bahia com a participação das camadas populares, além de um marco decisivo no longo processo de elaboração de alternativas políticas no Brasil. Mas essa experiência não foi a única que ocorrera pouco antes do desembarque do príncipe. Ainda mais recente, em 1807, registrou-se uma tentativa de rebelião protagonizada pelos escravos haussás que, da mesma maneira, deixou o governo local em estado de alerta sobretudo depois das mudanças surpreendentes no mundo atlântico desde fins do século anterior. Esses acontecimentos, com destaque para 1798, já foram objeto de profunda análise pelos estudiosos. Aqui, interessa retomá-los como parte da complexa conjuntura de crise do Antigo Regime na América dando ênfase a um aspecto importante: ao mesmo tempo em que se apresentam como sinais dessa desagregação, e a despeito do seu aniquilamento, resultaram em práticas fundamentais para a construção de um ambiente propício à formação de uma nova cultura política entre os habitantes da Bahia nos anos de 1808-1823, marcos desse trabalho, e não apenas para os homens e mulheres envolvidos diretamente em sua elaboração e/ou materialização.

Nessa direção, a punição exemplar desferida pelo Estado português contra as principais lideranças de 1798 ou das revoltas escravas, ou mesmo o controle rígido sobre a circulação de homens e idéias tidas por subversivas, indicam duas questões importantes mas ainda pouco assinaladas: por um lado, o grau de tensão social vivenciado pela capitania que demandava rígido controle por parte das autoridades num conturbado contexto de mudanças revolucionárias; por outro, os variados caminhos percorridos por uma parcela da população que possibilitaram algum tipo de aprendizado, não obstante a persistência das condições desfavoráveis para a elaboração e prática de alternativas políticas distintas. $^{130}$

Um levantamento preliminar das revoltas ocorridas depois da Independência, entre 1824 e 1837/1838, somente em Salvador e no Recôncavo, indica que, por motivações diversas, a inquietação latente ou manifesta era um componente indiscutível

\footnotetext{
130 Jacques Godechot argumenta que a monarquia portuguesa, diferentemente da Espanhola, possuía traços ainda mais absolutos. Enquanto naquela as cortes haviam se reunido em 1714, 1724, 1760 e 1789, em Portugal foram convocadas pela última vez em 1698. Conforme diz, durante o ministério de Pombal, a penetração das "luzes” não ultrapassou o restrito círculo da aristocracia e da alta burguesia. Assim, "Portugal permanecera mais impermeável que a Espanha à propaganda revolucionária”. Op. cit., p. 148.
} 
no cotidiano de parte da sua população. Conflitos militares, rebeliões escravas, revolta de marinheiros, distúrbios antilusitanos, violência política, ano após ano, desautorizam a caracterização de uma sociedade harmoniosa e apática no contexto do Império do Brasil. Todavia, a natureza política, avanços e recuos dessas manifestações exigem estudos específicos sobre o tema até agora feitos apenas parcialmente. ${ }^{131}$

Como esses movimentos filiaram-se às experiências ocorridas anteriormente e que envolveram segmentos da população de baixa renda e escravos, é um dado a ser considerado. Afinal de contas, não se pode esquecer que muitas das questões políticas e sociais ali presentes permaneceram insolúveis nos anos seguintes. No caso do ensaio de sedição de 1798, não somente algumas de suas motivações persistiram como também personagens envolvidas ou denunciadas voltaram à cena política posteriormente, como, por exemplo, o cirurgião Cipriano José Barata de Almeida, o oficial Hermógenes Aguillar de Pantoja, o proprietário de engenhos e de escravos Joaquim Inácio de Siqueira Bulcão ou o padre Agostinho Gomes, entre outros. O que parece importante perceber é a natureza desses conflitos que, vistos numa perspectiva mais ampla, denotaram as fissuras e as contradições internas de uma sociedade marcadamente perversa e desigual cujas perspectivas, ainda que respondessem às especificidades da capitania, não se encontravam desconectadas das mudanças revolucionárias no mundo ocidental nesse período. ${ }^{132}$

A influência dos acontecimentos externos de fins do Setecentos na elaboração do projeto dos sediciosos de 1798 já foi objeto de importantes estudos que destacaram a repercussão, sobretudo da Revolução Francesa, na formulação pelos protagonistas do ideal de "liberdade, igualdade e fraternidade". Momento crucial que se insere em um processo mais amplo, ou seja, da própria crise do Antigo Regime, o movimento revolucionário francês ajudou a maturação política da crítica direta ao sistema colonial. Nesse processo, é provável que a Bahia tenha sido mais estimulada que em outras partes americanas considerando os contatos de franceses com a capitania referidos acima. ${ }^{133}$

\footnotetext{
${ }^{131}$ Cf. João José Reis. “A elite baiana face os movimentos sociais, Bahia: 1824-1840”. Revista de História, v. LIV, n. 108, ano: XXVII, São Paulo, Outubro-Dezembro, 1976, p. 347-351. Reis considera o levantamento incompleto mesmo para as áreas de Salvador e do Recôncavo. Com alguns acréscimos, Paulo César Souza apresenta um levantamento semelhante: A sabinada. A revolta separatista da Bahia (1837). São Paulo: Brasiliense, 1987, p. 19-23.

132 Para uma análise das condições socioeconômicas e políticas da Bahia no contexto de emergência da sedição de 1798 como expressão da crise do Antigo Regime, ver: István Jancsó, op. cit., 1996.

${ }^{133}$ Kátia M. de Queirós Mattoso. Presença francesa no movimento democrático baiano de 1798. Salvador: Itapuã, 1969; Frederic Morton, op. cit.; Affonso Ruy. A primeira revolução social brasileira (1798). 2 ed. Companhia Editora Nacional, 1978; István Jancsó, op. cit., 1996 e 1997 Carlos Guilherme Mota, op. cit., 1996; Luis Henrique Dias Tavares. Da sedição de 1798 à revolta de 1824 na Bahia. Salvador: Edufba; São Paulo: Unesp, 2003. Ver também: Osvaldo Coggiola (Org.), op. cit, em especial o artigo de Kátia Mattoso:
} 
Fundamental nesse deslocamento foram os meios de absorção das idéias revolucionárias do período a despeito do controle exercido pelas autoridades portuguesas para evitar a circulação de material sob censura. Um dos aspectos ressaltado pelos estudiosos é justamente a condição social de algumas das lideranças oriundas dos segmentos populares da cidade de Salvador e, portanto, com maior dificuldade para adquirir livros ou informações proibidas, o que não as impediu de ter acesso às novas idéias em circulação na época e elaborar suas próprias opiniões acerca das diferenças existentes no interior da sociedade apontando para um caminho possível de superação. A rede de sociabilidade política que se instaurou, driblando os impedimentos determinados pelo governo, configura novas formas de articulação ao reunir homens de diversas esferas da sociedade atados em um plano de sedição contra o sistema colonial, ainda que as condições dos envolvidos implicassem em perspectivas diferentes de futuro. De fato, não se deve perder de vista que os variados segmentos da capitania da Bahia no período absorveram os ideais iluministas, que sacudiam os pilares das monarquias absolutas na Europa, a partir da posição ocupada no interior dessa sociedade e o seu impacto produziu algo completamente novo entre os habitantes. ${ }^{134}$

Um dos canais importantes no processo de formação desse novo pensamento foi a experiência de alguns indivíduos da capitania na Universidade de Coimbra desde 1772. Da mesma maneira, o contato com estrangeiros que freqüentemente circulavam por Salvador divulgando os últimos acontecimentos na Europa, assim como a presença de livros proibidos entre figuras de destaque na sociedade local como um Francisco Agostinho Gomes e Pedro Gomes Ferrão Castelo Branco, constituem elementos fundamentais na apreensão das formas de sociabilidade existentes em fins do XVIII. Muitas dessas questões já foram devidamente abordadas pela historiografia sobre o tema. Mas, o que deve ser destacada, é justamente a novidade da constituição “de um grupo de jovens integrantes da elite colonial, ou próximos a esta, poderosamente seduzidos pelos

\footnotetext{
"Bahia 1798: os panfletos revolucionários. Proposta de uma nova leitura”, p. 341-356. As diferentes interpretações sobre a natureza do evento de 1798 foram devidamente tratadas por István Jancsó em "Na Bahia, contra o Império", op. cit., (Introdução) e com elementos novos para a discussão em "Bahia 1798: a hipótese de auxílio francês ou a cor dos gatos”. In: Júnia Ferreira Furtado (Org.). Diálogos Oceânicos. Minas Gerais e as novas abordagens para uma história do Império ultramarino português. Belo Horizonte: Editora UFMG, 2001, p. 361-387.

${ }^{134}$ As formas de socialização das novas idéias em meio às dificuldades impostas pelos governos para sua circulação são analisadas por István Jancsó, op. cit., 1997, p. 388-437. Ver também Frederic Morton, op. cit., p. 112 e Carlos Guilherme Mota, op. cit, 1996. Para este autor: "Estudar as formas de pensamento sem considerar suas origens sociais bem como as camadas da sociedade em que tais formas ganham sentido pode redundar em perda de visão do problema central. É a análise da base social que torna possível a compreensão do surgimento, veiculação ou adaptação de conceitos e expressões”. Op. cit., p. 56.
} 
sucessos da Revolução Francesa. Esse grupo esboçava sua face mediante o recurso a formas de sociabilidade política de tipo novo, tornando-se agente de uma cultura política contraposta à do absolutismo, fazendo circular informações e idéias à margem do controle oficial”, conforme observou István Jancsó. ${ }^{135}$

Segundo algumas informações, a presença do comandante francês Antoine René Larcher na cidade, em 1787, possibilitou o contato de algumas dessas pessoas como, por exemplo, Cipriano Barata, Hermógenes Aguillar, João Ladislau de Figueiredo Melo, Agostinho Gomes, José da Silva Lisboa, Joaquim Inácio de Siqueira Bulcão e Francisco Moniz Barreto, este último professor na vila de Rio de Contas, a mais populosa do interior. Isso teria não apenas resultado na elaboração de um projeto pelo militar francês após seu retorno a Paris, no qual apresentava as chances de uma aliança política entre franceses e luso-americanos visando à eliminação do poder absoluto do governo, como também à criação de uma loja maçônica “Cavaleiros da Luz” responsável pela difusão dos princípios revolucionários na Bahia. ${ }^{136}$

De qualquer modo, as evidências indicam que a Coroa portuguesa tinha grande preocupação com a propagação dos abomináveis princípios franceses que pode ser medida na intensidade das comunicações entre as autoridades régias principalmente no decorrer das investigações acerca do ensaio de sedição. Numa delas, o ministro d. Rodrigo de Sousa Coutinho refere-se às notícias que circulavam em Lisboa dando conta de que as pessoas consideradas de Salvador "por uma loucura incompreensível e por não entenderem seus interesses” se achavam “infectas” por essas idéias. Uma das razões para isso estaria na "indisciplina, falta de subordinação, mal estado em que se acha a Tropa dessa cidade” e o perigo daí advindo, pois “chega-se aqui a dizer que se aí aparecessem algumas Tropas Francesas nem a Tropa resistiria”. ${ }^{137}$ Mais tarde, o governador da Bahia, d. Fernando José de Portugal, procurava tranqüilizar a corte desacreditando que as “pessoas principais desta capitania” seguiriam os detestáveis princípios, “pois não tenho motivos para discorrer deste modo nem a respeito do corpo do comércio, nem dos homens

\footnotetext{
${ }^{135}$ István Jancsó, op. cit., 2001, p. 370-371.

${ }^{136}$ Cf. Marco Morel; István Jancsó. "Novas perspectivas sobre a presença francesa na Bahia em torno de 1798”. Topoi, Rio de Janeiro, v. 8, p. 206-232, 2007. As indicações sobre a existência da associação secreta ainda carecem de aprofundamento. Sobre a passagem do comandante francês por Salvador e a presumida aliança entre franceses e americanos, ver Luis Henrique Dias Tavares, op. cit., 2003 e István Jancsó, op. cit., 2001. Sobre o papel das maçonarias: José Honório Rodriques. Independência: Revolução e ContraRevolução. Rio de Janeiro: Francisco Alves, 1975, v. 1, p. 17-30; Marco Morel. As transformações dos espaços públicos. Imprensa, atores políticos e sociabilidades na cidade imperial (1820-1840). São Paulo: Hucitec, 2005.

${ }^{137}$ Correspondência de d. Rodrigo de Sousa Coutinho a d. Fernando José de Portugal, em 4 de outubro de 1798. Ignácio Accioli, op. cit., v. III, p. 95. Ver também Carlos Guilherme Mota, op. cit., 1996, p. 52-53.
} 
empregados nas ocupações públicas, nem dos homens de bem”. Não deixando, contudo, de ponderar: "posto que também se acham presos por aquele feito dois Tenentes, por haver contra eles algum indício”. ${ }^{138}$

Embora o governo insistisse em atribuir a responsabilidade por tamanha ousadia aos indivíduos de menor condição, a rainha de Portugal, d. Maria I, reafirmava a necessidade de vigilância escrupulosa sobre a "conduta dos empregados nessa capitania e que vendo em qualquer deles, por grande que seja o seu merecimento, indícios de se achar contaminado de princípios jacobinos e revoltosos, dê logo conta, indicando os motivos que tiver de suspeita”. ${ }^{139}$ Manoel Querino, sem mencionar a fonte, diz que os estudantes mais distintos também eram espionados de acordo com as recomendações dadas aos governadores: “vigilância sobre os indivíduos simpáticos às idéias políticas que desolam a França, enviando informações secretas dos que estiverem contaminados dos princípios jacobinos e revoltosos”. 140

Já em junho de 1798, o governador, novamente respondendo aos questionamentos de d. Rodrigo de Sousa Coutinho sobre a possível existência de pessoas jacobinas na capitania, a despeito da sua negação, evidenciaria as amplas possibilidades para a circulação de novas idéias nesse período:

Não duvido que, supostas as circunstâncias do século e lição dos papéis públicos, como por exemplo, correios da Europa, gazetas inglesas, que não são proibidos, e outros que excitam a curiosidade, em que se descrevem os sucessos do mundo com reflexões bastantemente livres, haja como acontece em toda a parte, uma ou outra pessoa, especialmente entre a mocidade, menos cordata e leve de entendimento, que discorra com mais alguma liberdade ou leveza sobre os mesmos acontecimentos da Europa, mas nem por isso se tem aqui introduzido princípios da Europa, nem espécies de sociedade ou ajuntamentos perniciosos, podendo segurar V.Exa. que por cautela tenho chamado algumas vezes à minha presença um ou outro mancebo, só por me dizerem que pensa com mais liberdade ou com menos instrução nos verdadeiros princípios de religião, prevenindo-os e repreendendo-os asperamente, contentando-me com semelhante providência, enquanto o caso não pede outra maior, pelo

\footnotetext{
${ }^{138}$ Correspondência de d. Fernando José de Portugal a d. Rodrigo de Sousa Coutinho, em 13 de fevereiro de 1799. Idem, ibidem, p. 134. Ver também István Jancsó, op. cit., 1996b, p. 18.

139 Correspondência de d. Rodrigo de Sousa Coutinho a d. Fernando José de Portugal, em 2 de julho de 1799. Idem, ibidem, p. 95-96.

${ }^{140}$ Manoel Querino. A Bahia de outrora. Vultos e factos populares. 2. edição revista e aumentada. Bahia: Livraria econômica, 1922, p. 267.
} 
desejo que tenho de não dar corpo (para me explicar assim) às cousas, enquanto elas o não merecem [...]. ${ }^{141}$

Assim, o aparecimento de pasquins sediciosos em 12 de agosto daquele ano desafiando explicitamente o poder absoluto da monarquia e conclamando a população para a instauração da República Bahinense cujo pilar de sustentação seria a "liberdade nacional” e a eliminação das diferenças "mormente os homens pardos e pretos que vivem escornados e abandonados”, ${ }^{142}$ exigiu imediata reação do governo local. E a repressão não tardou. De posse das denúncias e informações sobre os envolvidos, o governador desencadeou uma onda de prisões e interrogatórios, hierarquizando a culpa dos implicados e dando especial atenção aos segmentos inferiores que deveriam ser punidos exemplarmente enquanto buscava preservar os que poderiam ser reincorporados no sistema. Nunca é demais lembrar que quatro dos condenados foram enforcados e esquartejados na Praça da Piedade e tiveram seus corpos expostos em pontos estratégicos da cidade do Salvador em 8 de novembro de 1799, reproduzindo a punição atribuída a Joaquim José da Silva Xavier, o Tiradentes, anos antes. Um deles, o aprendiz de alfaiate Manuel Faustino dos Santos Lira, pardo, tinha apenas 18 anos de idade. ${ }^{143}$

As autoridades régias na América portuguesa tinham várias razões para acompanhar com cuidado as profundas mudanças que se propagavam pelo mundo atlântico naquele final de século. Uma delas, especialmente, dizia respeito à presença maciça dos escravos africanos. No bojo dos acontecimentos revolucionários na França, teve início, em 1791, a rebelião dos escravos na colônia francesa de São Domingos, a mais produtiva das Américas, que se desdobrou em um violento conflito até a independência da ilha caribenha em 1804 (atual Haiti) com a destruição do sistema escravista. Isso faria com que, a partir de então, os escravos não fossem vistos apenas

${ }^{141}$ Ofício do governador d. Fernando José de Portugal para d. Rodrigo de Sousa Coutinho, no qual se refere a uma denúncia em que se acusavam certas pessoas de serem jacobinas, em 17 de junho de 1798. Anais da Biblioteca Nacional do Rio de Janeiro, v. 36, 1916, p. 35.

${ }^{142}$ Conforme um dos papéis sediciosos publicados por Braz do Amaral em Ignácio Accioli, op. cit., v. III, p. 111.

143 Os demais foram: Luiz Gonzaga das Virgens e Veiga (soldado), Lucas Dantas do Amorim Torres (soldado) e João de Deus do Nascimento (alfaiate). O quinto condenado à pena capital, Luis Pires (lavrante) conseguiu fugir da cidade. Além desses, onze foram degredados para a África em lugares não sujeitos aos domínios portugueses, entre outras penas menores. István Jancsó acompanha com argúcia as ações repressivas desencadeadas pelo governo local e as estratégias formuladas para preservação da boa ordem da sociedade baiana colonial, cuja concepção política adquiriu um “senso pedagógico”. Op. cit., 1996 (especialmente capítulo IV). Numa carta encaminhada pelo ministro d. Rodrigo de Sousa Coutinho, em 4 de outubro de 1798, ao governador d. Fernando José de Portugal, as determinações para conter as idéias abomináveis foram bastante explícitas: “[...] Repito novamente a V.Ex., de ordem de Sua Magestade, que prêmio e castigo são os dois Pólos sobre que estriba toda a Máquina Política e que no momento presente toda a vigilância contra os maus é indispensável e absolutamente necessária e que V. Sa. Será responsável de toda a frouxidão que houver na execução destas Reais ordens [...]”. Ignácio Accioli, op. cit., v. III, p. 95. 
como indivíduos coisificados, mas como sujeito coletivo, e como tal, propenso a rebeliões. Além disso, a expansão da agricultura na colônia americana propiciou o aumento da população cativa, especialmente de escravos africanos da mesma etnia, favorecendo a ampliação das revoltas no decorrer do Oitocentos. Kátia Mattoso, analisando 53 inventários com descrição de 582 escravos para os biênios de 1805-1806 e 1810-1811, cujos testamentos foram registrados em tabelionatos de Salvador, conclui pela existência de uma porcentagem menor de crioulos (nascidos na América portuguesa) o que indicaria, para ela, certa tendência em períodos de prosperidade. ${ }^{144}$

Possivelmente embasado pelas ocorrências em São Domingos e pela participação de escravos no ensaio de sedição em 1798, pouco tempo depois o governador da Bahia deixava explícito o porquê temia a difusão dos princípios franceses: "O que sempre se receou nas colônias é a Escravatura em razão de sua condição e porque é o maior número de habitantes delas não sendo tão natural que os homens empregados e estabelecidos que têm bens e propriedade, queiram concorrer para uma conspiração ou atentado de que resultariam péssimas conseqüências, vendo-se até expostos a serem assassinados pelos seus próprios Escravos”. ${ }^{145}$ O mesmo temor aparecerá nos discursos de alguns dos protagonistas das lutas pela independência na província duas décadas mais tarde, como se verá.

No entanto, até que ponto a experiência dos escravos caribenhos povoou as cabeças das lideranças cativas na perspectiva de executar um movimento semelhante, é difícil mensurar com clareza. Referências a essa possibilidade são encontradas entre a documentação, ainda que esparsas, mas que não deixam de sinalizar o receio que a suspeita provocava entre os senhores, considerando a natureza de algumas reações individuais ou coletivas da escravaria. Anos mais tarde, Cipriano Barata diria que o uso

\footnotetext{
${ }^{144}$ Segundo a autora, 30,8\% de escravos crioulos para os anos de 1805-1806 e apenas 19,5\% em 1810-1811. Kátia M. de Queirós Mattoso. "Os escravos na Bahia no alvorecer do século XIX”. Revista de História, v. XLVIII, n. 97, ano XXV, São Paulo, 1974, p. 116. Sobre o medo da haitianização no Brasil: Sobre o medo da haitianização no Brasil: Luiz Mott. Escravidão, homossexualidade e demonologia. São Paulo: Ícone, 1988, p. 11-18; João José Reis. "Nos achamos em campo a tratar da liberdade": a resistência negra no Brasil Oitocentista. In: Carlos Guilherme Mota (Org.), op. cit., 2000, p. 241-263. Para o caso da Bahia, conforme assinala o autor, o maior número de escravos haussás e nagôs, muito mais aguerridos que outros grupos étnicos, propiciou o aumento de revoltas que somente "na primeira metade do século XIX, [seria] em número superior a duas dezenas". Op. cit., p. 246; Jaime Rodrigues. Infame comércio. Propostas e experiências no final do tráfico de africanos para o Brasil (1800-1850). Campinas: Ed. da Unicamp/Cecult, 2000, p. 50-62. Para uma análise ampla sobre a crise do escravismo no contexto da era das revoluções: Robin Blackburn. A queda do escravismo colonial: 1776-1848. Rio de Janeiro; São Paulo, 2002. Conforme esse autor, "em 1770 os escravos das Américas eram explorados mais intensamente do que qualquer outro grupo do mesmo tamanho em toda a história”. Op. cit., p. 32.

${ }_{145}$ Correspondência de d. Fernando José de Portugal a d. Rodrigo de Sousa Coutinho, em 13 de fevereiro de 1799. Ignácio Accioli, op. cit., v. III, p. 134.
} 
desses exemplos no decorrer dos anos servia como recurso para que algumas autoridades pudesse atingir seus objetivos políticos perseguindo adversários: "não há quem ignore que essa parte do plano do tal Gabinete Secreto, consistia em trazer o povo repetidas vezes amedrontado por esses quiméricos levantamentos de Escravos contra os Senhores, metendo-nos os Agentes do Governo pelos olhos os sucessos da Ilha de São Domingos, ou Haiti [...]”. ${ }^{146}$ É possível que o argumento sobre a dimensão das revoltas possa ter sido utilizado também no sentido de potencializar a manutenção da ordem, ampliando a segurança dos senhores e de suas propriedades, como anteriormente argumentou João José Reis. $^{147}$

De qualquer maneira, uma tentativa de rebelião envolvendo escravos haussás de Salvador e do Recôncavo no ano anterior à vinda de d. João demandou empenho das autoridades para desbaratá-la. Respondia pelo governo da Bahia à época, em 1807, o $6^{\circ}$. conde da Ponte, o mesmo que recepcionou o príncipe regente, conhecido pela maneira severa com que tratava as questões referentes aos escravos na capitania. Morgado da casa da Ponte, João de Saldanha também era reconhecido como um dos mais ricos proprietários de escravos, de fazendas, de gado, de engenhos no Recôncavo e nos sertões da Bahia adentro, como também em Portugal. Em sua opinião, os escravos africanos “Gêges, Ussás e Nagôs" estavam entre as "Nações as mais guerreiras da Costa do Leste” e a capitania da Bahia ficava com a maior parte das importações que foram mais de 8 mil em 1806. Acreditava que era preciso endurecer o controle sobre os cativos informando à corte de Lisboa que havia implementado, desde que assumira o governo, uma série de providências "sobre a vigilância e rigorosa subordinação em que deve manter-se a imensa Escravatura”. 148

Contando com a delação de um escravo, o governador conseguiu reprimir os escravos rebeldes, cujas lideranças foram sentenciadas a muitos açoites e penas de degredo, cumprindo a decisão de Lisboa para que aplicasse as penas de maneira que os sediciosos aprendessem a não "violar os direitos de seus respectivos Senhores, mas também [não] perturbar a segurança e o sossego público, de que depende a conservação dos Estados”. 149 Depois disso, restringiu ainda mais a circulação de escravos e libertos,

\footnotetext{
${ }^{146}$ Manifesto. Rio de Janeiro: na Tipografia de Torres, 1831, p. 5 (Acervo da Fundação Clemente Mariani)

${ }^{147}$ Cf. João José Reis. "Nos achamos em campo a tratar da liberdade”. In: Carlos Guilherme Mota (Org.), op. cit., 2000, p. 241-263.

${ }^{148}$ Correspondência do conde da Ponte ao Visconde de Anadia, em 16 de julho de 1807. Ignácio Accioli, op. cit., v. III, p. 230.

${ }^{149}$ Idem, loc. cit. Em princípios do século XIX o porto de Salvador receberia anualmente "cerca de 8 mil a 10 mil africanos", de acordo os dados fornecidos por Stuart Schwartz. "Entre dois terços e três quartos desses
} 
além de proibir as reuniões e festas africanas. Mas parece que isso não foi o suficiente para intimidar os escravos pois, em 25 de janeiro de 1808, o governador foi informado que o príncipe regente estava ciente sobre o considerável número de escravos que havia fugido de alguns engenhos de Salvador e da povoação de Nazaré, praticando diversos crimes como roubos e assassinatos. Em função disso, d. João havia aprovado as providências que havia tomado determinando que continuasse as diligências para a captura dos demais fugitivos espalhados pela capitania. No ano seguinte um novo levante de escravos foi registrado na capitania. Apesar de estarem em número mais expressivo que as sublevações anteriores, os rebeldes foram eliminados durante as ações repressivas do governo. ${ }^{150}$ Entre as punições, foram obrigados a trabalhar acorrentados no serviço de aterro da futura praça do teatro. Diante de uma outra sublevação em fevereiro de 1810, o regente ordenou os açoites públicos e a venda dos cativos para outras capitanias “considerando que os trabalhos forçados aos quais estes escravos acorrentados foram condenados não são uma punição suficiente pelo crime atroz perpetrado por estes negros insolentes". 151

Certamente os movimentos de maior impacto registrados na capitania com a participação de habitantes de menor condição da Bahia e de escravos aconteceram nos agitados anos da década de 1830: a Rebelião dos Malês (1835), a Cemiterada (1836) e a Sabinada (1837/1838). Porém, mesmo antes disso, várias manifestações e outras formas de contestação protagonizadas por militares, populares e, sobretudo, por escravos, como se verá, ocorreram nesse intervalo. Ora de maneira organizada, ora espontânea, esses movimentos expressaram uma crescente insatisfação que punha a sociedade escravista em permanente alerta e faria da província uma das regiões mais convulsionadas do Brasil. Em 1822, por ocasião das lutas pela Independência, novos confrontos tiveram lugar na Bahia redefinindo os objetivos e as condições de intervenção política e, em função disso,

africanos vinham do Golfo de Benin ou do que os portugueses chamavam de Costa da Mina”. Op. cit., 1996, p. 374.

${ }^{150}$ Correspondência do visconde de Anadia ao conde da Ponte, em 25 de janeiro de 1808. APEB. Seção de Arquivo Colonial e Provincial. Ordens Régias. Maço: 105 (1808-1809). Entre as providências do conde da Ponte constava a destruição do quilombo formado pelos escravos quando foram apreendidos três machos e doze fêmeas. A atuação do conde da Ponte na repressão aos escravos na Bahia foi analisada por João Reis em "Rebelião escrava do Brasil”, op. cit., e "Escravos e coiteiros no quilombo do Oitizeiro. Bahia, 1806”. In: ; Flávio dos Santos Gomes. Liberdade por um fio. História dos quilombos no Brasil. São Paulo: Companhia das Letras, 1996, p. 332-372. Aqui, nos valemos dos seus estudos sobre o tema. Ver também: Pierre Verger, op. cit; Kátia M. de Queirós Mattoso. Ser escravo no Brasil. São Paulo: Brasiliense, 1982, p. 165. Erivaldo Fagundes Neves discute o morgado da casa da Ponte, op. cit., 2005.

${ }^{151}$ Citado por Pierre Verger, op. cit., p. 333. 
tornando ainda mais complexo o ambiente político da capitania, inclusive com a participação de cativos.

Nesse sentido, João Reis chama a atenção para o caráter das rebeliões escravas do início do Oitocentos. Interessado em sua composição étnica e como isso pode ter interferido nas formas de articulação e de organização política dos cativos, sublinha a importância não apenas das tentativas de rebelião de maior impacto, mas também das diversas outras formas de resistência ao regime escravocrata que demarcaram uma tradição rebelde dos escravos na Bahia e que estarão na base de movimentos importantes posteriormente. Em suas palavras: "Invariavelmente os rebeldes foram derrotados, em alguns casos de maneira brutal, mas essa insubmissão permanente criou uma tradição de audácia que impregnaria as relações escravistas na Bahia nesse período. Quando os malês organizaram a rebelião de 1835, eles o fizeram, em grande parte, como herdeiros dessa tradição”. 152

Essa é uma questão fundamental pois implica em reconhecer um rastro de aprendizado político que foi se sedimentando na capitania e que, em determinadas conjunturas mais favoráveis, aflorou de maneira mais intensa propiciada pelas incertezas características de períodos de crise. Se para homens livres e libertos a década de 1820 permitiu o refinamento das elaborações políticas e, por isso mesmo, a proposição de alternativas distintas de superação da crise; para a população escrava, essa movimentação também não passaria despercebida e, de algum modo, esteve inscrita em suas perspectivas políticas de organização. ${ }^{153}$ Mais do que isso, as numerosas e variadas formas de manifestações dos residentes da Bahia no Oitocentos foram tributárias das ações políticas pioneiras que marcaram a virada do século.

Por outro lado, impressiona como essas primeiras experiências políticas que envolveram a participação das camadas populares e escravos foram suprimidas da memória da população. No caso de 1798, por exemplo, prevalece um silêncio absoluto. A eliminação física dos condenados serviu para extirpar também qualquer referência que pudesse ser feita ao evento e isso não apenas no que se refere aos registros oficiais, como também em relação à outros escritos. Durante a efervescência política nas lutas pela independência em que se ampliou consideravelmente o número de panfletos políticos, ao

\footnotetext{
152 João José Reis, op. cit., 2003, p. 69.

${ }^{153}$ Ainda segundo Reis, "além do fator africano, cuja importância aliás declinaria com o fim do tráfico, um ambiente francamente favorável à rebeldia escrava foi-se formando ao longo do século XIX em torno dos movimentos pela independência, das revoltas regionais, da circulação de ideologias liberais e mais tarde abolicionistas”. João José Reis. "Nos achamos em campo a tratar da liberdade”. In: Carlos Guilherme Mota (Org.), op. cit., 2000, p. 247.
} 
que parece, nenhuma palavra foi dita sobre aquele acontecimento que mobilizou as atenções dos moradores de Salvador em agosto de 1798, a despeito das causas que o originaram estarem novamente em evidência, assim como alguns dos indivíduos daquela época, como dito acima. No caso destes, István Jancsó lembra que, pelo visto, nenhum dos letrados como Domingos Borges de Barros, Francisco Agostinho Gomes, Cipriano Barata ou José da Silva Lisboa, deixaram qualquer testemunho sobre o ensaio de sedição. Do mesmo modo pode se dizer sobre a historiografia coeva. O que não deixa de ser bastante significativo. ${ }^{154}$

Mas, retornemos à conjuntura dos primeiros anos de 1800 .

Ao contrário da ausência de registros sobre as ocorrências de fins do século anterior, as recomendações quanto à presença de viajantes suspeitos, provenientes principalmente da França, intensificaram-se. Em maio de 1808, d. Rodrigo de Sousa Coutinho remeteu para o conde da Ponte um alerta sobre um espião francês, o negociante Paulo Moton, que saíra de Lisboa em um navio americano e poderia ter aportado na capitania. As advertências foram bem precisas: “as maiores indagações” para descobri-lo e, nesse caso, "prendê-lo e apreender seus papéis dando de tudo conta a esta Secretaria de Estado. Porém, quando aconteça que nada por ora aí se encontre a este respeito, fica V.Exa. prevenido por esta Real Ordem para tomar todas as medidas convenientes para que ele não possa evadir-se, no caso que com efeito aí desembarque indo em algum Navio Americano ou de qualquer outra Nação”. ${ }^{155}$ No mês seguinte, novas informações sobre um “certo francês” que, empregado da polícia de Lisboa, obtivera passaporte do general Junot para vir ao Brasil. Segundo a correspondência, constava que o mesmo tinha pretensões "sinistras, e infames de perturbar a tranqüilidade pública deste Estado e de espiar tudo que nele se faz”. Assim, recomendava aos empregados dos portos da capitania "para que em qualquer parte que se apresente seja logo preso, apreendendo e [!] os seus papéis e correspondência” e adiante reforçava as ordens para que não se permitisse o

\footnotetext{
${ }^{154}$ István Jancsó, op. cit., 1996, p. 18. Braz do Amaral também ressaltou a perda da memória sobre os acontecimentos ocorridos em 1798: “A conjuração dos revolucionários bahianos de 1798 foi rigorosamente abafada e o governo conseguiu sumir-lhe a lembrança, pelo perigo que traz a divulgação de tais exemplos, ou, no estilo do ministro D. Rodrigo de Sousa Coutinho, para que os falsos princípios dos implicados na conspiração não contaminassem os outros fiéis súditos da coroa portuguesa”. Anotações...In: Ignácio Accioli, op. cit., v. III, p. 90 (grifos do autor).

${ }^{155}$ Correspondência de d. Rodrigo de Sousa Coutinho ao conde da Ponte, em 23 de maio de 1808. APEB. Seção de Arquivo Colonial e provincial. Ordens Régias. Maço: 106 (1808-1809).
} 
desembarque de "francês algum" ou que se fizesse "logo sair outra vez ou procedendo a detê-lo em prisão pública e examinar os seus papéis”. 156

No mês de setembro, os alertas traziam uma novidade, além de, mais uma vez, reafirmarem a necessidade de vigilância sobre os estrangeiros que aparecessem na capitania. O ministro chamava a atenção "particularmente [para] Franceses e Italianos, mais que todos suspeitosos e temíveis”. Reiterando a necessidade de uma indispensável vigilância, ressaltava “que o Imperador dos Franceses não omitirá todas as diligências por enviar Espias sobre o Continente do Brasil”. Dois meses depois, o ministro comunicava a aprovação, pelo príncipe, das medidas e cautelas tomadas na capitania pelo governador, entre elas, a prisão do francês Pedro Bento Domingues. Segundo informa, o suspeito havia sido morto durante as investidas sob circunstâncias que, infelizmente, não foram esclarecidas. ${ }^{157}$

Em fins do ano seguinte, as indicações sobre o assunto seriam ainda mais incisivas. Dessa vez, a Coroa solicitava informações sobre o domicílio de vários franceses em Salvador desde que a esquadra de Jerônimo Bonaparte ali aportara, em 1806, assim como a presença de "um certo abade francês que professa e publica opiniões perigosas e que podem conduzir a sérias conseqüências a que também se une o dizer-se que na Bahia há um grande número secreto de pessoas vendidas ao Partido Francês”. Exigiam-se a prisão do abade e o seu envio para a corte, a expulsão dos franceses do Brasil caso se confirmassem as suspeitas e o imediato conhecimento sobre os partidários da França. A ênfase na importância e na rapidez das medidas que deveriam ser adotadas revelava a rigidez com a qual a Coroa tratava a questão: "S.A.R. julga escusado significar a V.Exa. e Sas. que serão responsáveis de qualquer frouxidão ou descuido que possa haver na execução destas Reais Ordens e que S.A.R. espera sem perda de tempo o resultado das averiguações e exames a que ordena que V.Exa. e Sas. procedam sem perda de tempo e sem menor descuido". 158

O cuidado com a entrada de estrangeiros não era exclusivo da Bahia. No Rio de Janeiro, variados foram os casos de prisão e deportação desses indivíduos considerados perniciosos aos interesses do Estado. Preocupação que não era recente em virtude da posição estratégica ocupada por essas capitanias na América, mas que, na conjuntura pós-

\footnotetext{
${ }^{156}$ Correspondência de d. Rodrigo de Sousa Coutinho ao conde da Ponte, em 28 de junho de 1808. Idem, ibidem.

${ }^{157}$ Correspondência de d. Rodrigo de Sousa Coutinho ao conde da Ponte, em 10 de setembro de 1808. Idem, ibidem.

${ }^{158}$ Correspondência de d. Rodrigo de Sousa Coutinho ao governo da Bahia, em 17 de novembro de 1809. Ignácio Accioli, op. cit., v. III, p. 234.
} 
1808, recomendava renovados cuidados para a preservação dos domínios bragantinos. ${ }^{159}$ Desse modo, não restam dúvidas que as autoridades estavam cientes da magnitude das mudanças que se processavam no plano externo e que uma nova cultura política contrária aos fundamentos do absolutismo se formava entre seus habitantes, particularmente na Bahia. Era preciso, então, operar novos instrumentos que fortalecessem sua vinculação à Coroa sem perder de vista esses elementos.

\footnotetext{
${ }^{159}$ Sobre a prisão de estrangeiros no Rio de Janeiro no mesmo período, ver Kirsten Schultz, op. cit.; Andréa Slemian, op. cit.; João Paulo Garrido Pimenta, op. cit., 2003. Em 23 de junho de 1808, d. Fernando José de Portugal comunicou ao governador da Bahia que o príncipe regente havia criado o posto de "Intendente Geral de Polícia da Corte e do Estado do Brasil, igual ao que havia em Portugal, e sendo conveniente ao serviço do mesmo senhor, que as determinações desse magistrado fossem efetivamente cumpridas, mandou que lhe participasse que, quando esse magistrado emitisse ordens, que auxiliasse no seu cumprimento”. APEB. Seção de Arquivo Colonial e Provincial. Ordens Régias. Maço: 105 (1808-1809).
} 


\section{Capítulo 2}

\section{Administração política no tempo do $8^{\circ}$. Conde dos Arcos, 1810-1818}

Os anos que se seguiram à fixação da corte portuguesa no Rio de Janeiro evidenciaram uma permanente tentativa de solidificação dos vínculos entre os habitantes da Bahia e o príncipe regente que permitiu ostentar uma aparente estabilidade política em meio ao aprofundamento da crise do Antigo Regime. No plano externo, a vitória das potências aliadas sobre a França napoleônica demarcava o início do reordenamento político europeu com a restauração das monarquias absolutas que haviam sido destronadas no decorrer dos acontecimentos revolucionários. Em razão disso, impunha também a previsibilidade do retorno do príncipe regente para Portugal. Entretanto, a dimensão das alterações políticas propiciadas pela difusão das idéias liberais era um dado incontornável na década de 1810. Foi nesse período que os colonos hispano-americanos recrudesceram os movimentos pela independência exigindo atenção redobrada da Coroa portuguesa receosa dos perigos para a sua preservação. Assim, é no interior dessa conturbada conjuntura que deve ser vista a elevação do Brasil à categoria de Reino em 1815. Um momento de singular importância pelo que representou na tentativa de revigoramento do Império português e, paradoxalmente, potencializou os descontentamentos no interior dos dois Reinos cujo ápice foi o movimento liderado pelos habitantes de Pernambuco dois anos depois e que teve a Bahia como uma aliada em potencial.

Entretanto, as diligências provenientes da corte do Rio de Janeiro visando assegurar a estabilidade política da monarquia tiveram outros contornos. De fato, um elemento importante dessa articulação foi a ampliação das condições de mobilidade para muitos residentes dentro das estruturas do Estado, assim como o atendimento de algumas das suas demandas, favorecendo os laços de adesão entre a capitania, especificamente, e a Coroa bragantina. Para isso, foi necessária a intermediação de uma personagem importante na condução do poder político local. Desse modo, os anos de estabelecimento da Coroa na América e de redefinição das monarquias absolutas coincidem, na Bahia, com a administração política de d. Marcos de Noronha e Brito (1810-1818), o 8º . conde dos Arcos, um funcionário régio dotado de atributos essenciais para a concretização desse projeto de aliança. Em que medida as suas intervenções, reforçadas por outros mecanismos de mediação, permitiram renovar os vínculos entre os residentes da Bahia e a 
Coroa contornando os solavancos da crise na capitania é o que se discute nas páginas seguintes.

\subsection{A Política de Acomodação: A Bahia e a Corte}

Após a morte do conde da Ponte, ocorrida em 24 de maio de 1809, a Bahia passou a ser administrada por um governo interino, prática comumente utilizada na América portuguesa até a indicação de um novo governador. Pouco mais de um ano depois, em 30 de setembro de 1810, tomava posse o $8^{\circ}$. conde dos Arcos. ${ }^{1}$

Descendente de uma família nobre e de administradores do Estado português, cujo título nobiliárquico fora concedido pela primeira vez em 1620, d. Marcos de Noronha e Brito nascera em 7 de julho de 1771, em Lisboa, e desde cedo se dedicou às armas. Aos 32 anos, em 1803, assumiu o governo da capitania do Grão-Pará e São José do Rio Negro, dando início à sua trajetória política na América portuguesa assim como fizera seu avô no século anterior, d. Marcos José de Noronha e Brito, $6^{\circ}$. conde dos Arcos, que fora governador de Pernambuco e Goiás e ocupara o cargo de vice-rei do Brasil com sede na Bahia (1755-1760). Cerca de três anos depois (1806) foi designado para o governo da cidade de São Sebastião do Rio de Janeiro, sede do Vice-Reino, em substituição a d. Fernando José de Portugal, cargo que ocupou até a chegada do príncipe regente. No entanto, apesar de seu empenho para dotar a cidade dos requisitos necessários ao abrigo da corte portuguesa, não chegou a ser indicado para qualquer ministério e, ao que consta, teria ficado bastante desapontado ao ver que era preterido pelos antigos funcionários régios de Portugal, a exemplo de d. Rodrigo de Sousa Coutinho (conde de Linhares), d. João Rodrigues de Sá de Meneses (visconde de Anadia) e o próprio d. Fernando José de Portugal (depois marquês de Aguiar), que passaram a ocupar os altos cargos na América. ${ }^{2}$

\footnotetext{
${ }^{1}$ Pouco antes de morrer, em 23 de janeiro de 1809, o conde da Ponte foi informado que o príncipe estava ciente sobre o prazo de três anos da sua posse no governo, ressaltando que, "ainda que os governadores e capitães generais do Brasil fossem providos por três anos, deveriam continuar a exercitar seus empregos, enquanto não fossem enviados os seus sucessores”. APEB. Seção de Arquivo Colonial e Provincial. Ordens Régias. Maço: 105 (1808-1809). Em correspondência datada de 01 de julho de 1809, o conde de Anadia lamentou a morte do conde da Ponte expressando seu desejo de que a capitania não sofra demais "os incômodos que, aliás, podem trazer consigo a falta de um Chefe, que tanto se desvelava pela Causa Pública". APEB. Seção de Arquivo Colonial e Provincial. Ordens Régias. Maço: 108 (1807-1810). Integraram o governo interino o arcebispo d. Frei José de Santa Escolástica, o chanceler Antônio Luiz Pereira da Cunha e o marechal João Batista Vieira Godinho. Cf. Ignácio Accioli, v. III, op. cit., p. 52. Sobre o governo interino, Graça Salgado (Org.)., op. cit., p. 115.

2 Jaime Nascimento. "O $8^{\circ}$ conde dos Arcos. 200 anos da chegada ao Brasil". RIGHBa, Salvador, v. 99, 2004, p. 233-243. Rocha Martins. O último vice-rei do Brasil. Lisboa: Oficina Gráfica do ABC, s/d.
} 
A despeito disso, mais tarde fora promovido a coronel e major-general e indicado para o governo da Bahia, então a capitania mais importante depois da sede da corte. Experiente e graduado, olhando em retrospecto, parece que suas distinções corresponderam plenamente aos objetivos da Coroa em estabelecer uma relação mediadora com os habitantes da Bahia, de tal modo que, durante os quase oito anos da sua administração (1810-1818) os laços de adesão entre o regente e a capitania aparentaram estar bem fortalecidos.

Nesse contexto, é significativo lembrar que no mesmo ano em que o conde dos Arcos assumiu o governo da Bahia, em 1810, a conjuntura política na América hispânica apresentara fortes revezes para o absolutismo espanhol. Na esteira das mobilizações no decorrer da crise do Antigo Regime nas colônias americanas, importantes cabildos instituíram Juntas Provisórias de Governo com o propósito de substituir os representantes designados pelo poder metropolitano: Caracas (19 de abril); Buenos Aires (25 de maio); Bogotá (20 de julho) e Santiago do Chile em 18 de setembro. Experiências posteriormente incorporadas nas partes americanas do Reino por ocasião das lutas pela independência. ${ }^{3}$

Além do mais, nesse mesmo ano a Coroa portuguesa assinou o Tratado de Comércio com a Grã-Bretanha estabelecendo o porcentual de 15\% sobre as mercadorias importadas para o Brasil, favorecendo-a em detrimento dos comerciantes portugueses, em grande maioria europeus, que até 1818 pagariam 16\% sobre suas importações. O tratado reconhecia, na prática, o apoio que o príncipe regente recebera da poderosa rival da França, reforçando os laços de aliança estabelecidos desde o aprofundamento da crise na península Ibérica. A medida desagradou sobremaneira os portugueses que se viram preteridos diante das vantagens concedidas aos ingleses, cuja penetração no comércio da Bahia já havia sido criticada quando o príncipe regente esteve na capitania, como mencionado acima.

Já em fins de 1808, d. Fernando José de Portugal, a pedido do príncipe regente, remetera para o conde da Ponte uma carta do cônsul geral da Inglaterra queixando-se do tratamento recebido pelos ingleses em Salvador e em Pernambuco, requerendo informações sobre o assunto. Além disso, determinava que a alfândega cumprisse os

\footnotetext{
${ }^{3}$ Para uma análise sobre as experiências das juntas de governo de Santiago do Chile e da Bahia no contexto de crise do Antigo Regime, ver: Maria Aparecida Silva de Sousa. "Independência e soberania nacional na América luso-espanhola (apontamentos sobre as experiências dos governos provisórios de Santiago do Chile e da Bahia nas lutas pela Independência)”. In: Wilma Peres Costa; Cecília Helena de Salles Oliveira (Orgs.). De um Império a outro. Formação do Brasil, séculos XVIII e XIX. São Paulo: Hucitec; Fapesp, 2007, p. 2550.
} 
avisos em benefício dos ingleses conforme havia sido anteriormente expedido. ${ }^{4}$ Desse modo, as céleres mudanças no cenário mundial e as alterações decorrentes internamente recomendavam cautela e habilidade nas intervenções. Governar uma das principais possessões do Império português em uma conjuntura amplamente desfavorável para a Coroa demandava mais do que eficiência administrativa. Era preciso gozar de certos atributos que permitissem estabelecer uma relação mediadora entre o príncipe e os residentes da capitania e, ao que tudo sugere, a indicação do conde dos Arcos aparece como parte de uma estratégia política mais ampla: o reordenamento da monarquia bragantina na América.

Na configuração político-administrativa da América portuguesa, a figura do governador e capitão general possuía enorme relevo já que era o chefe supremo da capitania. Ainda que não fosse um militar de formação, atuava como o comandante de todas as forças armadas das áreas sob a sua jurisdição, incluindo as capitanias subalternas. Contudo, suas atribuições iam mais além. Era o grande responsável por toda a administração e estava sujeito às normas e prescrições estabelecidas pela Coroa que buscavam controlar as suas atividades. A despeito disso, não raras vezes, os governadores se viam à mercê de situações específicas e conjunturais que demandavam a recriação das práticas do mando em situação colonial. De qualquer maneira, as funções que desempenhava eram amplas e essenciais para a preservação da distante autoridade real garantindo a ordem política no interior da capitania. Para isso, dispunha de poderes consideráveis conforme salientou Caio Prado Jr.: "nenhuma outra autoridade da colônia se lhes emparelha, e nenhuma dispõe como ele do conjunto das forças armadas”. 5 O cargo de governador somente foi extinto no decurso das alterações políticas propiciadas pelo movimento constitucionalista em princípios dos anos 1820.

Em estudo recente, Laura de Mello e Souza retomou a discussão sobre a política administrativa do Império português para a América colonial Setecentista dando ênfase aos significados do mando a partir de situações específicas sem, contudo, perder de vista os fundamentos estruturais mais amplos. Sua análise contribui para uma perspectiva inovadora das práticas administrativas no período ao realçar a lógica das ações de

\footnotetext{
${ }^{4}$ Correspondência de Fernando José de Portugal ao conde da Ponte, em 15 de novembro de 1808. APEB. Seção de Arquivo Colonial e Provincial. Ordens Régias. Maço: 105 (1808-1809).

${ }^{5}$ Caio Prado Júnior, op. cit., 1992, p. 309.
} 
determinados governantes, dimensionando o papel político desses indivíduos no interior da complexa natureza do poder metropolitano implementado na colônia. ${ }^{6}$

Ocorre que, se o distanciamento do rei influía na dinâmica das práticas administrativas no cotidiano colonial, sua presença em terras americanas, e com ele todo um arsenal burocrático do Estado português que até então se localizava em Lisboa, alterou as relações com os residentes e com os governantes dado às novas condições advindas da sede da corte estabelecida no Rio de Janeiro. ${ }^{7}$ No entanto, parece provável que a nomeação de algumas autoridades permaneceu correspondendo às necessidades de assegurar a manutenção do equilíbrio político da monarquia bragantina, agora sob outra conjuntura, sobretudo àquelas capitanias que reclamavam maior atenção por parte da Coroa. Desse modo, a trajetória do conde dos Arcos na Bahia ajuda a entender como suas intervenções se relacionam ao movimento mais geral de crise do absolutismo - foi durante o seu governo que o Brasil foi elevado à categoria de Reino e ocorreu a Revolução pernambucana -, ao mesmo tempo em que responde à dinâmica interna da capitania fornecendo outros significados à sua atuação política.

Boa parte dos escritos sobre o conde dos Arcos (cujo governo se encerrou em 26 de janeiro de 1818) destaca o seu espírito empreendedor responsável por uma gestão dinâmica e intervencionista que se diferenciaria dos governantes anteriores. De fato, suas ações demarcam um período de intensos investimentos na capitania nos mais diversos setores que, no entanto, não podem ser vistos desconectados das questões mais amplas vinculadas ao reordenamento da Coroa portuguesa em terras americanas. ${ }^{8}$ Quem primeiro, provavelmente, alertou para a importância política dos anos que antecederam o movimento de Independência na Bahia foi o historiador canadense Frederic W. Orde Morton. Autor de um paper pouco conhecido sobre o governo do conde dos Arcos, fruto da sua tese de doutorado defendida em 1974 e ainda não publicada, Morton alerta para o

\footnotetext{
${ }^{6}$ Cf. Laura de Mello e Souza. O sol e a sombra. Política e administração na América portuguesa do século XVIII. São Paulo: Companhia das Letras, 2006.

${ }^{7}$ Maria de Fátima Silva Gouveia. "As bases institucionais da construção da unidade. Dos poderes do Rio de Janeiro joanino: administração e governabilidade no Império luso-brasileiro”. In: István Jancsó (Org.), 2005, p. 707-752.

${ }^{8}$ Alguns exemplos: Rocha Martins, op. cit.; Sebastião Pagano. O conde dos Arcos e a revolução de 1817; Marcus de Noronha da Costa. Administração civil, política, militar e econômica do $8^{\circ}$. Conde dos Arcos na Bahia. RIGHBa, Salvador, n. 93, p. 91-183, dez. 1997; Ignácio Accioli, op. cit., v. III, p. 53 e passim; Pedro Calmon, op. cit., p. 1417 e passim.
} 
equívoco de enfatizar as suas realizações práticas perdendo de vista as profundas mudanças na vida política e econômica do período. ${ }^{9}$

Com efeito, seu empenho em aprofundar e ampliar as mudanças que a Bahia experimentava desde fins do XVIII sugere a concretização de um projeto político mais amplo: a mediação das relações entre parte dos residentes, especialmente as classes proprietárias, e a corte, possibilitando, por um lado, dotar a capitania dos recursos necessários condizentes com os novos tempos e, por outro, solidificar os vínculos com o príncipe regente garantindo, assim, algum tipo de estabilidade política. É sintomático que muitas das intervenções realizadas caminham pari passu ao projeto de mobilização e de fortalecimento da monarquia bragantina em curso no Rio de Janeiro e, nesse aspecto, reafirmam a singularidade da Bahia no quadro das possessões portuguesas. Nessa direção, negociantes, senhores de engenho e indivíduos particulares renovaram as expectativas de assegurar seus interesses aproveitando as oportunidades propiciadas pelas novas circunstâncias.

A conhecida trajetória de Manoel Antônio da Silva Serva é bastante reveladora dessas possibilidades de ascensão. Estabelecido na Bahia desde abril de 1797, o negociante soube aproveitar as condições para implantação de uma tipografia num momento em que a transferência da corte portuguesa para a América sinalizava boas perspectivas de investimentos. No ano seguinte, em 1809, ele já estava na Europa adquirindo o material necessário à implantação da imprensa. Autorizada por meio da carta régia de 5 de fevereiro de 1811, após sua solicitação percorrer os trâmites legais, a gazeta Idade d'Ouro do Brazil, a primeira da Bahia e a segunda do Brasil, começou a circular poucos meses depois constituindo-se na principal fonte de informação dos habitantes a despeito da censura a que era submetida, como se verá. ${ }^{10}$

Mesmo após a instalação da tipografia, Silva Serva procurou, por diversas vezes, obter apoio régio para expandir o seu empreendimento, seja por meio de empréstimos ("considerando [...] que todas as vezes que estes estabelecimentos se não manejam com grandes cabedais é absolutamente impraticável colher interesses e torná-los vantajosos ao país”), seja requerendo autorização para o corte de pau-brasil com vistas à sua exportação e posterior investimento no negócio, ou ainda requerendo licença para estabelecer uma fábrica de fundição e refundição de letras para composição e impressão evitando, assim,

\footnotetext{
${ }^{9}$ Frederic W.O. Morton. The governorship of the Count of Arcos in Bahia, 1810-1818. Enlightened despotism in an age of revolution, Toronto, outubro de 1986 (texto mimeog.). Agradeço ao prof. João José Reis a cessão da cópia desse texto.

${ }^{10}$ Sobre o assunto, ver Maria Beatriz Nizza da Silva, op. cit.
} 
sua importação. ${ }^{11}$ A ampliação da tipografia e a falta de mão-de-obra especializada estimularam também Silva Serva a trazer de Lisboa um “hábil mestre livreiro”, bem como a admitir aprendizes interessados na arte da oficina. Desde o início de funcionamento da tipografia, seus empregados já gozavam da isenção de recrutamento para as tropas de linha e de milícias, benefício que o negociante pretendeu estender aos demais de acordo petição encaminhada ao governo:

[...] recorre o suplicante à providência de V.A.R. a graça de ampliar a isenção dos recrutamentos das Tropas de Linha e de Milícias ao sobredito mestre livreiro e aos oficiais e aprendizes que se forem admitindo [...]. Dignando-se V.A.R. outrossim de mandar declarar que a isenção de empregados na tipografia é compreensiva e igualmente se estende relativamente aos caixeiros e escriturários [...] tanto aqueles que servem dentro e fora daquela oficina como os que se empregam na administração e escrituração da loja de papéis e livros, onde se vendem os impressos da dita tipografia e outros sortimentos da casa. ${ }^{12}$

Em uma das petições ao príncipe regente requerendo ajuda financeira, Silva Serva mencionou o favorecimento feito anteriormente a Francisco Ignácio de Siqueira (ou Sequeira) Nobre para a instalação de uma fábrica de vidros e, em função disso, se via no direito de gozar da mesma prerrogativa. Parece que o argumento obteve acolhida, pois, em 1815, a gazeta divulgou a obtenção de um empréstimo régio pelo cofre da Junta da Fazenda da capitania da Bahia, "garantido por fiança idônea”, no valor de quatro contos de réis. $\mathrm{O}$ pagamento seria feito em prestações anuais de quatrocentos mil réis decorridos cinco anos da dívida. ${ }^{13}$

De fato, Siqueira Nobre, um dos maiores negociantes da capitania, também aparece nos documentos como um dos beneficiários da fixação da Coroa na América. Ainda quando o príncipe esteve na Bahia, ele encaminhou uma petição requisitando autorização para trazer artífices da Inglaterra a serem utilizados em duas fábricas de fiar, tecer e estampar que pretendia estabelecer. Pelo teor do documento, a implementação do projeto dependia apenas do consentimento do regente, pois a disposição para dirigir o negócio não lhe faltava:

\footnotetext{
${ }^{11}$ Idem, ibidem, p. 25-26. Em 29 de abril, o marquês de Aguiar comunicou ao conde dos Arcos o indeferimento do pedido de Silva Serva "para cortar seis mil quintais de pau-brasil, e um dom gratuito a fim de ampliar a sua tipografia”. Anais da Biblioteca Nacional do Rio de Janeiro, op. cit., v. 68, p. 193.

${ }^{12}$ Citado por Maria Beatriz Nizza da Silva, op. cit., p. 31.

${ }^{13}$ Idade d'Ouro do Brazil, n. 27, de 04 de abril de 1815 (disponível em www.bn.br). Em 1828, ainda constava a dívida ao Estado do empréstimo feito a Francisco Ignácio de Siqueira e ao casal Silva Serva nos valores de quinhentos mil e quatrocentos mil réis, respectivamente, de acordo com a relação das dívidas ativas da província da Bahia naquele ano. Miguel Calmon du Pin e Almeida. Relatório do Ministério da Fazenda apresentado à Assembléia Geral Legislativa do Império do Brasil. Brasil/Ministério da Fazenda, 1829. Agradeço a profa. Wilma Peres Costa a cessão de cópia desse documento.
} 
Senhor, um comerciante da primeira ordem, que deixa sua cara esposa, suas três tenras filhinhas, seus navios, sua fazenda, arrisca sua própria pessoa ao impulso dos mares, levando consigo debaixo do mesmo risco seus tenros filhos e sobrinho para melhor educação, é sem dúvida conhecido o ardente desejo que tem de ser V.A.R. e para o futuro a este grande império, assim como a ser o primeiro que rompa a marcha, abrir o caminho do comércio, animar os meus companheiros, finalmente a fazer ver quais são as minas da Inglaterra, que se reduzem ao comércio e manufaturas [...]. ${ }^{14}$

No entanto, ao invés da manufatura têxtil, o negociante implantou uma fábrica de vidros. Em 1811, três anos após a autorização régia para o seu funcionamento, o conde dos Arcos remeteu carta aos ouvidores das comarcas de Salvador, Sergipe, Ilhéus, Porto Seguro e Jacobina, determinando que o negociante iria adquirir todas as cinzas e as potassas produzidas naquelas localidades, indicando os valores em alqueire e quintal que seriam cobrados de maneira a garantir a prosperidade da dita fábrica. ${ }^{15}$ Em seu primeiro número, o Idade d'Ouro do Brazil registrava o sucesso do empreendimento: “A fábrica de vidros de Francisco Ignácio de Sequeira Nobre erigida na capitania continua a trabalhar com atividade e bom conceito; sendo muito para notar que naquela circunvizinhança apareceram a maior parte dos difíceis materiais para a construção dos fornos, e dos símplices que entram na composição do vidro”. ${ }^{16}$

A gazeta publicava avisos divulgando os variados tipos de vidros fabricados que se encontravam à venda, denotando a diversificação e o aumento da produção. Em 1813, o proprietário avisava a abertura de um armazém na Cidade Baixa para vender vidros mais baratos “com pouca diferença aos da Europa”. Três anos depois, por ocasião do aniversário de d. João, a fábrica anunciou possuir 80.000 luminárias disponíveis para comercializar. Sorte do proprietário que se beneficiava com a determinação do governo para que os habitantes iluminassem suas janelas em sinal de reverência ao príncipe o que deveria lhe render bons lucros. ${ }^{17}$ Prova disso é que nesse mesmo ano solicitou a compra do prédio onde a fábrica funcionava e mais tarde estabeleceu uma sociedade comercial

\footnotetext{
${ }^{14}$ Citado por Maria Beatriz Nizza da Silva, op. cit., p. 136.

${ }^{15}$ Correspondência do conde dos Arcos aos desembargadores de Salvador, Sergipe, Ilhéus, Porto Seguro e Jacobina, em 4 de janeiro de 1811. Ignácio Accioli, op. cit., v. III, p. 232.

${ }^{16}$ Idade d'Ouro do Brazil, n. 1, de 14 de maio de 1811 (disponível em www.bn.br).

${ }^{17}$ Idem, ibidem (n. 40, 18 de maio de 1813). Entre avisos de luminárias, panelas de vidro, bombas de vidro para extração de leite de mulheres entumescidas, um destacava: "Na fábrica de vidros desta cidade fabricamse frascos de abordagem, com que se costumam incendiar embarcações quando intentam abordar a outras, de que os espanhóis muito se servem e mandaram fazer várias encomendas em outro tempo na dita fábrica, cujos frascos, à maneira de dois globos unidos, são circulados com um moirão aceso, os quais ateando-se ao pano, ou dentro das embarcações, logo formam incêndio, os quais vende-se por preço cômodo”. Cf. Maria Beatriz Nizza da Silva, op. cit., p. 141. A referência sobre as luminárias consta na página 192.
} 
com seu sobrinho, Manoel Joaquim de Carvalho Siqueira Nobre, garantindo "em tudo e por tudo as transações feitas com o dito seu Sobrinho e sócio, por 6 anos”. ${ }^{18}$ Provavelmente animado pelas condições propícias, Siqueira Nobre também teria tentado introduzir o cultivo do bicho-da-seda na capitania mas, ao que parece, não obteve o mesmo êxito.

Desde o seu primeiro número, em 14 de maio de 1811, as páginas do Idade d'Ouro registravam o vai e vem do comércio da capitania e o redator não escondia seu entusiasmo pelas mudanças em curso. No aviso sobre a bem-sucedida fábrica de cordas, de propriedade de Antônio Vieira da Costa, destaca que a importância do estabelecimento seria: “ $1^{\circ}$. Dispensar para o futuro os maçames e cabos da Rússia, se esta Potência persistir na adesão ao sistema que oprime a Europa; e $2^{\circ}$. Aproveitar as espécies sem número de vegetais filamentosos até agora inúteis, de que abunda este nosso Continente”. Poucas semanas depois informava que o mesmo empreendedor havia recebido "benévolas demonstrações de SAR concedendo-lhe todos os Privilégios, Graças e indultos” para o seu negócio. A preferência pela mercadoria em razão do preço, em detrimento a da Rússia, não era somente na Praça da Bahia como também do Rio de Janeiro. ${ }^{19}$

O periódico assumia, assim, a condição de testemunha das transformações políticas e econômicas no período e colocava-se como um instrumento essencial na propagação do saber útil entre os habitantes da Bahia visando a seu pleno desenvolvimento. A movimentação de Silva Serva entre as autoridades e no contato com os segmentos que se tornariam o alvo preferencial da gazeta revelam sua confiança nesse sentido:

O Redator implora a todas as Pessoas, especialmente aos Senhores Comerciantes, cujas relações com outras Praças assim Nacionais como Estrangeiras são mais amplas, a bondade de lhe comunicar todos os artigos que nas suas Cartas acharem dignos de merecer a atenção do Público, ou sejam tendentes ao melhoramento das Artes e Ciências, ou úteis ao Comércio, e que possam servir de sintomas do estado atual dos Negócios políticos de todo o Mundo. Os desejos do Redator, de que a nossa folha Idade d'Ouro do Brazil mereça conceito, e aprovação geral e os vivos esforços para que o seu contexto corresponda ao brilhante título,

\footnotetext{
${ }^{18}$ Idade d'Ouro do Brazil, n. 99, de 16 de dezembro de 1817 (disponível em www.bn.br). Ofício do marquês de Aguiar ao conde dos Arcos solicitando parecer sobre Francisco Inácio de Siqueira Nobre, em 20 de março de 1816. Anais da Biblioteca Nacional do Rio de Janeiro, op. cit., v. 68, p. 200-201. Kátia Mattoso também destaca as experiências de Siqueira Nobre, op. cit., 1992, p. 491.

${ }^{19}$ Idade d'Ouro do Brazil, n. 1, de 14 de maio de 1811 e n. 6, 31 de maio de 1831. Bahia: na Tipografia de Manoel da Silva Serva (disponível em www.bn.br).
} 
serão baldados se o mesmo Público não coadjuvar uns e outros subministrando alguns elementos para a instrução geral. ${ }^{20}$

A intensa movimentação das operações mercantis na Bahia, nesse período, pode ser distinguida pela iniciativa do conde dos Arcos ao requerer do governo do Rio de Janeiro autorização para construir a Praça do Comércio - um lugar destinado a reunir os membros dessa corporação para tratar de negócios -, cujas obras tiveram início em maio de 1811, sendo inaugurada seis anos depois, significativamente em 28 de janeiro, ocasião que lembrava a data de abertura dos portos. Uma cerimônia marcou os festejos solenes de inauguração e contou com a presença expressiva de negociantes, autoridades civis e eclesiásticas. O Investigador Português, periódico editado na Inglaterra, descreveu assim a solenidade:

Pelas dez horas da manhã apareceu na Praça em luzido e numeroso concurso de Negociantes, empregados públicos, e autoridades religiosas e civis; e o batalhão que fornecia as sentinelas, manteve a melhor ordem que se podia esperar. As salas da nova casa estavam suntuosamente adornadas, sobressaindo ali um magnífico retrato de Sua Magestade Fidelíssima [...]. ${ }^{21}$

De fato, a implantação da praça foi um grande acontecimento para os negociantes da Bahia e, ao que tudo indica, era uma demanda antiga desse segmento como se pode observar nos escritos do desembargador João Rodrigues de Brito em 1807. Segundo ele, a instituição seria de suma importância não apenas para facilitar as comunicações e as transações mercantis reunindo os comerciantes, como também por contribuir para "a difusão das luzes comerciais, e para a moralidade dos Negociantes, que receando verem-se argüidos publicamente perante seus Colegas da falta de pontual cumprimento das suas obrigações, e quebrar por isso alguma parte do seu crédito, e mais circunspectos em suas promessas". ${ }^{22}$ Em reconhecimento pela dedicação do "mais decidido Protetor dos seus interesses todas as vezes que para isso se apresenta ocasião”, o conde dos Arcos foi presenteado com uma espada de ouro “a qual Servirá para lembrar a

\footnotetext{
${ }^{20}$ Idem, Ibidem.

${ }^{21}$ O Investigador Português em Inglaterra ou jornal literário, político, \& c., n. 1, n. LXXIII, v. XIX, julho de 1817, p. 80 (disponível em www.googlebooks.com.br). O Idade d'Ouro do Brazil (n. 9, de 31 de janeiro de 1817) também divulgou o evento: "Terça-feira, 28 do corrente, dia sempre memorável ao Brasil, pelo sábio e precioso Diploma com que o nosso augusto soberano franqueou os portos a todas as nações, fez-se a solene abertura da nova Praça do Comércio [....]" (disponível em www.bn.br). Em 25 de janeiro de 1817, o conde dos Arcos enviou convite ao cabido arquiepiscopal da Sé para a solenidade e benção do edifício. Ignácio Accioli, op. cit., v. III, p. 236-237 (nota 35). Já em 1811, o redator da gazeta expressava a importância da praça para animar os negociantes da cidade: “[...] Da reunião dos agentes seguir-se-á necessariamente a maior atividade do comércio e quem há que se ignore que pelo giro deste se regula a prosperidade dos Estados?”. Citado por Maria Beatriz Nizza da Silva, op. cit., p. 154.

${ }^{22}$ João Rodrigues de Brito et al, op. cit., p. 53-54.
} 
V.Exa. a filial afeição que sempre tributarão a V.Exa. e fazer recordar a todos os Negociantes portugueses [...] a primeira Praça do Comércio que houve no extenso Reino do Brasil”. ${ }^{23}$ Pelo visto, as expectativas quanto aos negócios que poderiam ser realizados ali pareciam ser as melhores possíveis.

O Idade d'Ouro publicou em alguns de seus números os nomes dos subscritores e as quantias doadas para colaborar na construção da praça, em grande maioria constituída por negociantes da cidade. Já em 1811, quando a idéia foi apresentada, a gazeta divulgou 112 nomes com doações que variavam entre $2 \$ 000$ e $400 \$ 000$. Entre os poucos doadores dessa última quantia, nomes como o do tenente-coronel Francisco Dias Coelho, o brigadeiro Felisberto Caldeira Brant Pontes, o brigadeiro José Inácio Acciavoli de Vasconcelos Brandão e Manuel José de Melo. ${ }^{24}$ Anos mais tarde, em 7 de abril de 1815, com as obras em andamento, uma nova relação foi divulgada constando de 100 nomes de contribuintes com suas respectivas doações. Dessa vez, as quantias oscilaram entre $20 \$ 000$ e $100 \$ 000 .^{25}$ Entre os doadores, o negociante Manoel João dos Reis, um dos acionistas da filial do banco do Brasil. O imponente prédio dispunha, inclusive, de uma sala com respectivo pregoeiro destinada aos leilões e utilizada ainda no ano de 1817 para venda das "fazendas secas e molhadas, escravos e mais gêneros pertencentes às embarcações que se dirigiam a Pernambuco, e que por estar bloqueado descarregaram nesta cidade da Baía”, em virtude da insurreição ocorrida naquela capitania. ${ }^{26}$

Anos antes, em 1815, havia sido introduzida a primeira máquina a vapor para os engenhos da capitania cuja iniciativa partira do tenente-coronel Pedro Antônio Cardoso, cunhado do brigadeiro Felisberto Caldeira Brant Pontes, condecorado com uma comenda da Ordem de Cristo pelo príncipe regente e agraciado pelo governador com “um jantar esplêndido em memória da introdução da máquina a vapor neste país. E convidou aqueles senhores de engenho do seu maior conhecimento para celebrar com eles uma época tão memorável na história agronômica do Brasil”. ${ }^{27}$ A introdução de alguns métodos que

\footnotetext{
${ }^{23}$ Os signatários do documento foram os negociantes e administradores da praça: Manoel José de Melo, Manoel Ferreira da Silva e Francisco Alves Guimarães. De acordo uma correspondência divulgada no Correio Braziliense, a espada, fabricada na Inglaterra, possuía o valor de um conto e duzentos mil réis (1:200\$000) e aguardava a melhor ocasião para ser enviada à Bahia "a fim de ser apresentada ao Conde dos Arcos no dia da abertura da Praça do Comércio”. Correio Braziliense ou Armazém Literário. Londres, impresso por W. Lewis na Officina do Correio Braziliense, 1816, v. XVI, n. 92, p. 104.

${ }^{24}$ O tenente-coronel também emprestaria 600\$000, além de “91 pedras de cantaria que mandou vir de Lisboa em o navio Fortaleza, o qual se perdeu no Rio Real”. Cf. Maria Beatriz Nizza da Silva, op. cit., p. 78-79.

${ }^{25}$ Idade d'Ouro do Brazil, n. 28, de 7 de abril de 1815 (disponível em www.bn.br).

${ }^{26}$ Citado por Maria Beatriz Nizza da Silva (Coord.). O Império Luso-Brasileiro (1750-1822). Lisboa: Editorial Estampa, 1986, v. VIII, p. 245.

${ }^{27}$ Idade d'Ouro do Brazil, n. 25, 28 de março de 1815 (disponível em www.bn.br).
} 
pudessem incrementar a produção da cana parece não ter sido incorporada sem alguma resistência por parte dos senhores de engenho. Bert Barickman e Frederic Morton demonstraram como esse processo foi lento na Bahia, algo que, no entanto, não deve ser visto como um conservadorismo dos proprietários. Para Barickman, entre 1780 e 1860 pouca coisa se alterou na rotina de limpeza dos terrenos, abertura dos sulcos e plantio e talvez uma das poucas inovações tenha sido a introdução da “cana caiana” ocorrida provavelmente entre 1810 e 1820. Isso não significa dizer que inexistia na Bahia uma parcela de senhores interessados no aprimoramento da produção e a iniciativa de Pedro Antônio Cardoso, seguido por outros, inclusive pelo próprio Caldeira Brant, é reveladora nesse aspecto. ${ }^{28}$

O editor do Idade d'Ouro, sempre com um olhar crítico sobre o comportamento inerte dos senhores, reconhecia o pioneirismo de Brant e Cardoso, além de Pedro Rodrigues Bandeira, considerados como os verdadeiros "patriotas que tentam o melhoramento deste país e que tem conseguido em alguns respeitos”, ao mesmo tempo em que condenava a grande maioria por não ter sequer ido visitar o engenho a vapor de Pedro Cardoso localizado em Itaparica. ${ }^{29}$ De fato, esses homens, mas não apenas eles como se verá, teriam presença destacada na dinâmica da Bahia naquele período. Pedro Rodrigues Bandeira e Felisberto Caldeira Brant Pontes, por exemplo, ao lado do negociante Manoel João dos Reis e de Pedro Ferreira Bandeira, esse como supranumerário, assumiriam a direção da caixa filial do Banco do Brasil, implantada na esteira do movimento comercial e financeiro por meio da carta régia de 16 de fevereiro de $1816 .^{30}$

O documento, após expor as justificativas para a criação de filiais da Caixa Central do Banco do Brasil no Reino, esclarece que

de acordo com a Assembléia Geral do mesmo Banco, que já se reputava com suficientes forças para estabelecer na cidade da Bahia uma Caixa de

\footnotetext{
${ }^{28}$ Bert J. Barickman, op. cit., p. 282. Dados apresentados pelo autor indicam que, em 1834, o número de engenhos a vapor na Bahia chegava a 46 ampliando para $282 \mathrm{em} \mathrm{1873,} \mathrm{"quando} \mathrm{cerca} \mathrm{de} \mathrm{dois} \mathrm{quintos} \mathrm{dos}$ engenhos do Recôncavo utilizavam máquina a vapor”. Op. cit., p. 287. Barickman acompanha com pormenor as mudanças tecnológicas introduzidas na indústria açucareira na Bahia. Ver também, Frederic Morton, op. cit., 1974.

${ }^{29}$ Idade d'Ouro do Brazil, n. 24, 23 de março de 1813 (disponível em www.bn.br). Apesar de ter sido adquirida anos antes, a inauguração do engenho com máquina a vapor somente foi noticiada em 1815. Maria Beatriz Nizza da Silva, 2005, op. cit., p. 163.

${ }^{30}$ Carta de Lei de 16 de fevereiro de 1816. As operações tiveram início em janeiro de 1817 mesmo ano de inauguração da Praça do Comércio. No Rio de Janeiro o Banco do Brasil havia sido criado em 12 de outubro de 1808, conforme decreto régio (disponível em www.câmara.gov.br). Em carta dirigida ao conde da Ponte, em 23 de janeiro de 1809, o príncipe comunicou a instalação do banco naquela capital "para estimular o comércio" ordenando que os negociantes da Bahia fossem convocados "para que entrassem como acionistas do Banco" concorrendo, assim, para o seu estabelecimento. APEB. Seção Colonial e Provincial. Ordens Régias. Maço: 105 (1808-1809).
} 
Descontos que muito era desejada, e lhe fora pedida por alguns dos principais Negociantes daquela Praça, para facilidade das operações mercantis, extensão do comércio, e prosperidade da agricultura [...], ${ }^{31}$

o príncipe ordenava o estabelecimento da filial. Mas, certamente, dentre esses ativos negociantes, Caldeira Brant desempenhará um papel fundamental no decorrer do governo do conde dos Arcos não apenas por seu empreendedorismo no campo econômico, como também pelo trabalho desenvolvido à frente da Inspetoria Geral de Tropas da Bahia na década de 1810.

Nascido na capitania de Minas Gerais, no arraial de São Sebastião próximo a Mariana, em 19 de setembro de 1772, Caldeira Brant fez seus estudos na Academia da Marinha de Lisboa, assumindo o posto de capitão de mar e guerra aos 19 anos. Serviu em Angola durante dois anos e somente se fixou na Bahia em 1801 como tenente-coronel do regimento local. Paralelo às suas atividades como militar, investiu na área comercial tornando-se um dos maiores proprietários da capitania, aspecto a ser discutido adiante. Segundo algumas informações, na passagem da esquadra inglesa pela Bahia, em 1805, teria feito um vultuoso empréstimo (de 67:000\$000) ao almirante, sem juros, recebendo como pagamento letras sobre o tesouro inglês. Da mesma maneira, fora bastante obsequioso no tratamento com Jerônimo Bonaparte quando sua esquadra também ancorou nos portos da capitania. Esse comportamento ajudar-lhe-ia posteriormente nos contatos externos para o reconhecimento da Independência do Brasil dos quais seria um dos protagonistas. ${ }^{32}$ Não restam dúvidas que também foi um dos beneficiários das mudanças propiciadas na Bahia no campo político e econômico em razão da conjuntura dos primeiros anos do Oitocentos. Por ora, interessa destacar sua atuação ao lado do conde dos Arcos na condução de uma das mais importantes possessões do Império português.

\footnotetext{
${ }^{31}$ Carta de Lei de 16 de fevereiro de 1816, loc. cit. O Idade d'Ouro divulgou a instalação da filial do Banco do Brasil na Bahia por Carta de Lei na edição de 14 de maio de 1816, n. 39. APEB. Setor de Microfilmes. Na edição de 14 de janeiro do ano seguinte (n. 4) comunicou: "Havendo El Rei Nosso Senhor concedido a esta Cidade o estabelecimento de uma Caixa de Descontos como já participamos em outro número; e sendo este objeto sumamente recomendável assim pela Real Beneficiência, como pelo interesse público, que daí pode resultar, anunciamos agora que os Diretores principiam a 15 do corrente o giro da mencionada Caixa desde às 9 horas até às 2 da tarde” (disponível em www.câmara.gov.br). Em correspondência de 5 de junho de 1816 enviada ao governo da Bahia, o marquês de Aguiar confirmou a nomeação dos diretores para a filial do Banco do Brasil. APEB. Seção Colonial e Provincial. Cartas enviadas à capitania da Bahia. Maço: 118 (1816).

${ }^{32}$ João Pandiá Calógeras. O marquês de Barbacena. São Paulo: Companhia Editora Nacional, 1932; S. A. Sisson. Galeria dos brasileiros ilustres (os contemporâneos). São Paulo: Livraria Martins Editora S.A., v. XVIII, 1948. Em 01 de abril de 1808, portanto, pouco tempo depois da chegada do príncipe, d. Rodrigo de Sousa Coutinho comunicou ao governo da Bahia que Felisberto Caldeira Brant Pontes havia sido provido no posto de coronel agregado ao $1^{\circ}$. Regimento de Infantaria de Salvador. APEB. Seção de Arquivo Colonial e Provincial. Ordens Régias. Maço: 106 (1808-1809).
} 
Nesse sentido, é possível indicar que as intervenções promovidas pelo governador dar-se-iam também no campo do aprimoramento da segurança local e de novas estratégias para assegurar a preservação da ordem interna e de eventuais ataques de inimigos externos, aprofundando as alterações que já vinham sendo implantadas desde o estabelecimento da Coroa na América. A ampliação considerável das forças militares, bem como as discussões sobre o papel das forças armadas durante a sua administração, no entanto, apontam para uma valorização ainda mais ampla desse segmento. Dados fornecidos por Hendrik Kraay apontam que a guarnição da Bahia teve um crescimento de cerca de 40\% entre 1808-1818. Perspectiva que, obviamente, contava com o amplo apoio dos proprietários locais motivados mais pelo receio das rebeliões escravas do que um possível ataque de forças inimigas externas, e isso tinha vinculação direta sobre a natureza das forças armadas que se pretendia implementar. ${ }^{33}$

De qualquer maneira, a atuação do brigadeiro Felisberto Caldeira Brant Pontes como inspetor geral, ele próprio um grande proprietário de terras e escravos, mostra que a questão da segurança na Bahia, a despeito das constantes queixas para atingir o rigor desejado entre os oficiais, teve nesse período uma centralidade fundamental. Além disso, é preciso ressaltar que, embora o debate sobre as forças armadas não tenha sido isento de tensões entre o Estado e os proprietários, como argumenta Hendrik Kraay, ambos se mantiveram coesos ao lado do monarca e contrários a qualquer ameaça vinda dos homens de menor condição. ${ }^{34}$ A gazeta Idade d'Ouro do Brazil publicou, em alguns números no decorrer do ano de 1811, uma relação dos membros da corporação miliciana que havia cedido mão-de-obra escrava para a construção das baterias de Jequititaia e de Santo Alberto. A lista, encabeçada pelo governador, dispunha o número de dias que os cativos ficariam à disposição do serviço, variando de 1 a 60 dias ou "enquanto durar a obra”. A relação totalizava 198 escravos. Para o redator, essa iniciativa era mais uma demonstração da lealdade da capitania: “A defesa da Pátria é um dos primeiros deveres do Cidadão; e quando todos espontaneamente concorrem para os meios da segurança pública é sinal infalível de que o egoísmo ou não entrou, ou não está ainda arraigado naquele Povo. A prova de que a Bahia não tem desmerecido um ápice da lealdade Portuguesa”. 35

\footnotetext{
${ }^{33}$ Hendrik Kraay, op. cit., p. 44-45. O autor menciona uma queixa do conde dos Arcos, em 1811, na qual denuncia a relutância dos capitalistas da Bahia em contribuir nas subscrições para a aquisição de armas. Segundo ele, ao que parece, os comerciantes não acreditavam no risco de uma ameaça militar contrariando o governo. Op. cit., p. 45.

${ }^{34}$ Idem, ibidem, p. 32.

${ }^{35}$ Idade d’Ouro do Brazil, n. 6, 31 de maio de 1811. Bahia, Tipografia de Manuel da Silva Serva (disponível em www.bn.br).
} 
Além disso, as fontes documentais demonstram que Caldeira Brant buscou imprimir nas forças armadas uma disciplina e organização que via como fundamentais para a instituição de uma força militar coerente com as necessidades de preservação da ordem e garantia da segurança. Não foram poucas as vezes que reclamou das dificuldades para efetivar seu intento. Altos índices de deserção e de pedidos de baixa, indisciplina, oficiais despreparados, irregularidades no provimento dos postos estão entre alguns dos problemas que identificou nos corpos militares na Bahia no momento em que assumiu a inspetoria, em 1811, portanto, um ano após o conde dos Arcos ter ocupado o governo da capitania

A rigor, o discurso do inspetor geral evidencia seu intento em dotar a Bahia de uma força armada capaz de corresponder não apenas às necessidades de uma conjuntura imprevisível, como também de garantir permanentemente a tranqüilidade de uma capitania que, como dito, possuía amplas razões para tirar o sossego das autoridades. Alguns dos procedimentos utilizados anteriormente pela Coroa portuguesa para assegurar os seus vínculos com as classes proprietárias locais permaneciam, como por exemplo, sua cooptação por meio da ocupação de postos principais e na concessão de honras. Morton argumenta que até mesmo o estímulo às rivalidades entre essas “elites” ao privilegiar uma minoria de portugueses europeus, assim como a adoção de práticas burocráticas para legitimar o poder da Coroa, constituíam também aspectos importantes dessa estratégia de adesão. ${ }^{36}$ A forma de organização das forças militares, divididas em tropas de linha, milícias (a mais popular) e ordenanças, bem como os processos de alistamento em suas fileiras que incluíam divisão por cor, status e meios distintos de ingresso (voluntário, serviço obrigatório e recrutamento), também se instituirão enquanto espaços de conflitos, razão pela qual eram objeto de atenção da Coroa, sobretudo em situações de crise aguda. Não à toa, nos anos 1820, os militares desempenharão um papel fundamental nos conflitos políticos, cujas lideranças, na maior parte, seriam também os grandes proprietários de engenho da Bahia. ${ }^{37}$

Nesse momento, o que parece distinguir o conjunto das forças armadas na Bahia não se restringe apenas às inovações decorrentes da crise política vivenciada pelas monarquias absolutas, e que seriam verificadas em outras áreas estratégicas da antiga

\footnotetext{
${ }^{36}$ Frederic Morton, op. cit., 1974, p. 79.

${ }^{37}$ Ao analisar a lista dos oficiais dos regimentos de Santo Amaro e São Francisco do Conde, em 1810, Morton ressalta a posição dominante exercida pelos senhores de engenho da zona açucareira que, segundo ele, além de deter o monopólio das principais posições também estavam bem representados naquelas mais baixas. Op. cit., p. 83. O principal estudo sobre as forças armadas na Bahia foi elaborado por Hendrik Kraay, op. cit.
} 
colônia, mas também o empenho do inspetor geral das tropas para corresponder a esse aprimoramento. Além disso, não deixa de ser relevante que seus propósitos reformistas tenham sido simultâneos às intervenções do conde dos Arcos no governo. Alguns exemplos evidenciam esse movimento.

Em 25 de janeiro de 1814, Manoel Luis da Cunha, oficial do Regimento de Pirajá, requereu dispensa do serviço “durante a safra, isto é, para sempre” justificando que a mesma ocorria no verão e no inverno não se faziam exercícios, alegando ainda que era proprietário do Engenho Cotegipe e que o governador já havia dispensado do serviço “tutores, caixeiros e mais serventes dos Engenhos de açúcar”. Em seu parecer sobre o assunto, Caldeira Brant diz ignorar que os serventes dos engenhos haviam sido dispensados, mas que, em sua opinião, nem esses e nem mesmo os proprietários deveriam gozar do benefício tendo em vista que os alegados exercícios eram feitos apenas uma vez ao mês, durante o verão, e aos domingos, quando os engenhos não funcionavam. Adiante, denunciava:

Se, estes homens, que tem cavalgaduras, e todos os meios e cômodos de comparecer forem dispensados desta obrigação, com maior justiça e razão devem ser todos que andam a pé e aproveitam até os mesmos domingos para cavar a terra e cuidar da subsistência de suas famílias. A suavidade do Serviço e os Privilégios concedidos me faziam persuadir de alguma mudança na opinião pública, mais este e outros [...] requerimentos convencem que ninguém quer o serviço de Linha e quase ninguém o de Milícias. $^{38}$

No mês seguinte, foi a vez do sargento-mor das ordenanças de um distrito de Maragogipe, Joaquim Ignácio da Costa, requerer a criação de um Regimento de Milícias naquele termo cuja povoação teria "130 almas", considerando a comodidade que resultaria para os habitantes em função do desmembramento de Cachoeira. Para isso, requeria também “o posto de Coronel e oferece para a ajuda de custo dos preparativos do Regimento 1:000\$000 [um conto de réis]”. Quantia nada desprezível. No entanto, o inspetor não foi convencido pelos argumentos do pleiteante. Para ele, a povoação de Maragogipe talvez até excederia o número de habitantes indicado, mas era “composta pela maior parte de pretos, e toda espalhada em tão grande extensão de terreno pelo interior do país que não tem por ora as circunstâncias necessárias para a Criação de um Regimento”. Além disso, o Regimento de Cachoeira não ficava tão distante assim (“apenas 4 léguas”) com comunicação por mar e por terra anulando os inconvenientes apontados. Por fim,

\footnotetext{
${ }^{38}$ Parecer do Inspetor Geral de Armas, em 25 de janeiro de 1814. APEB. Seção de Arquivo Colonial e Provincial. Inspetoria Geral das Tropas. Maço: 247 - 9 (1814/1815).
} 
eliminava qualquer possibilidade de ser favorável ao pedido: “Não tenho bastante conhecimento do Suplicante, mas o insignificante oferecimento de 1:000\$000, e as circunstâncias da povoação sumamente espalhada nas matas, decidem quanto a mim que não tem lugar o seu requerimento". 39

O cadete de artilharia, José Pires de Carvalho e Albuquerque também não teve muita sorte ao solicitar baixa do serviço "que voluntariamente procurara” por "padecer de moléstia”. Segundo Caldeira Brant, o mesmo havia servido pouco mais de ano e em 1810 fora para o Rio de Janeiro solicitando diferentes despachos sem obter nenhum deles, além de ter sido julgado réu de $1^{\mathrm{a}}$. deserção simples em tempo de paz por excesso de licença, e, portanto, "longe de obter a baixa que pede, deve ser preso e remetido para o seu Regimento" ${ }^{40}$ Semelhante foi o caso de Francisco Antonio de Carvalhaes, cadete no $1^{0}$. Regimento, que requereu dispensa enquanto solicitava demissão do serviço ao príncipe alegando possuir enfermidades que o impossibilitavam de servir. Mais uma vez o inspetor contesta as justificativas utilizadas argumentando que: “O Suplicante é homem moço, de excelente cor, e ao que parece muito robusto. Os Professores do Hospital atestando ser verdade a existência de roturas, não acrescentam que o Suplicante seja por isso incapaz, e todos sabem que a maior parte da Tropa padece daquele mal. A maior enfermidade do Suplicante é seu mau comportamento, e o remédio mais próprio não é descanso e vadiação, mas correção e castigo”. ${ }^{41}$

Requerimentos com o mesmo teor preenchem a documentação da Inspetoria Geral de Tropas denotando a repulsa dos alistados por esse tipo de serviço. Diversas vezes, Caldeira Brant reclamou da dificuldade para impor a disciplina e organizar a tropa em virtude da alta incidência de pedidos de dispensa, entre outros problemas. De acordo Hendrik Kraay, isso não constituiu impedimento para a atuação dos regimentos de milícias nas cidades. O pesquisador afirma que milhares de homens foram alistados na milícia de Salvador que chegou a ter, em 1812, mais de 4.000 integrantes, número mantido em 1818, acrescentando que "este número provavelmente está muito próximo do total dos homens adultos livres e capazes da cidade que não serviam no Exército”. ${ }^{2}$ Ao que parece, o empenho de Caldeira Brant para manter uma defesa que, aparentemente,

\footnotetext{
${ }^{39}$ Parecer do Inspetor Geral de Armas, em 4 de fevereiro de 1814. Idem, ibidem.

${ }^{40}$ Parecer do Inspetor Geral de Armas, em 18 de setembro de 1815. Idem, ibidem. Correspondência de 18 de setembro de 1815. O cadete, no entanto, conseguiu a demissão pretendida no ano seguinte conforme indica a carta régia encaminhada ao conde dos Arcos em 10 de maio de 1816. APEB. Seção de Arquivo Colonial e Provincial. Cartas régias enviadas à capitania da Bahia. Maço: 118 (1816).

${ }^{41}$ Parecer do Inspetor Geral de Armas, em 21 de outubro de 1816. Idem, ibidem.

${ }^{42}$ Hendrik Kraay, op. cit., p. 87. O autor discute alguns dos problemas das milícias na Bahia identificados desde a colônia.
} 
estaria direcionada para assegurar os interesses do Estado em caso de ataques externos foi compensado em 1817, quando as forças armadas da Bahia atuaram de maneira exemplar na repressão aos revoltosos de Pernambuco sob o comando geral do conde dos Arcos. ${ }^{43}$ Agindo conjuntamente nessa ocasião, inspetor e governador, no entanto, já haviam tido sérias desavenças no tratamento de outra questão: os métodos a serem utilizados na preservação da ordem escravista.

Em correspondência a d. Fernando José de Portugal, escrita provavelmente em 1811, o governador demonstrou não temer a afamada rebeldia dos escravos da capitania:

Prepara-te para ouvir milhões de mentiras sobre Negros com a chegada desta Embarcação, umas ditas por pura ignorância, outras por impura e mais refinada malícia. Acerca destas últimas parece-me a propósito prevenir-te que talvez haja quem queira saber para assustar nosso Amo... Haverá enquanto a Vingança for o crime mais natural à raça humana, Escravos que matem Senhores, Feitores e Agressores. Haverá [...] Senhores que se assustem a ponto de perder-se a tranqüilidade pública por momentos.

Haverá finalmente como haverão sempre em todo o Brasil, Erupções de escravos e mesmo serão estas agora mais freqüentes: Motivos porém de susto, com a mesma verdade com que te tenho declarado que já não presto para nada te declaro agora que os não haverá nunca enquanto eu tiver Sangue no Corpo. Bem estou vendo que has de presentir alguma imprudenciazinha nesta expressão.

E eu mesmo confesso que há, mas enfim cada um tem a sua borbulha que quando se lhe toca salta para o rr. $^{44}$

Adiante acrescentava: “Tenho por aqui ouvido tornar que tu não és grande amigo de Felisberto que vai agora a essa Corte. Ele tem sido sempre de opinião contrária à minha sobre Negros mas não importa; é bom servidor do Príncipe, e tu has de o acolher amigavelmente até por me fazer favor”. As ocorrências algum tempo depois dessas declarações certamente o fariam mudar de idéia.

O conde dos Arcos estava convencido que para o controle da escravaria era necessário fazer algum tipo de concessão, como por exemplo, modificar as condições severas de punição a que eram submetidos, além de permitir que pudessem expressar suas práticas culturais por meio das danças e batuques; contrariando frontalmente as

\footnotetext{
${ }^{43}$ Em correspondência de 24 de novembro de 1816, Felisberto Caldeira Brant Pontes solicitou ao Rio de Janeiro armamentos para os Regimentos de Linha e Milícias da província, a exceção do Regimento da Torre, esclarecendo que na portaria de concessão se declarasse também "que os comandantes do $1^{\circ}$. Regimento e Artilharia deverão entregar o armamento e correame de que usam, e a Legião só as espingardas, os quais objetos sendo consertados poderão servir para a Milícia do Interior”. Em relação anexa consta a quantidade necessária de espingardas, baionetas, pistolas com os respectivos regimentos. APEB. Seção de Arquivo Colonial e Provincial. Inspetoria Geral das Tropas. Maço: 247 - 9 (1814/1815).

${ }^{44}$ Citado por Rocha Martins, op. cit., p. 34.
} 
determinações do seu antecessor, o conde da Ponte, que não abria mão da rigidez punitiva sobre os cativos. Segundo ele: "em toda cidade civilizada do mundo, os divertimentos públicos são autorizados, mesmo às pessoas das mais baixas classes”. Além do mais, acreditava que a separação dos cativos para promover seus "batuques" favoreceria a sua desunião dificultando uma revolta mais ampla. ${ }^{45}$ Ao buscar mediar a relação entre senhorescravo, o governador utilizava outros mecanismos para refrear o potencial irruptivo dos cativos. Isso não significa que tenha deixado de utilizar a violência do aparelho estatal para reprimir manifestações de rebeldia. Para Cipriano Barata, embora não pretendesse que os milicianos matassem os escravos, mais de trezentos foram mortos em conflitos nesse período. $^{46}$

João José Reis observa que apesar dos seus métodos menos rigorosos, o governador realmente não conseguiu evitar que revoltas importantes ocorressem durante sua gestão. Em princípios de 1814 houve uma grande tentativa de rebelião envolvendo novamente os escravos haussás de armações de pesca do norte da cidade que pretendiam seguir para o Recôncavo possivelmente para se juntar a outros adeptos. Os rebeldes foram duramente reprimidos por tropas de cavalaria recém-criadas e, posteriormente, muitos foram punidos de maneira severa pelo governo: "Quatro escravos foram mais tarde condenados à morte e enforcados; muitos punidos com penas de açoite, inclusive quatro mulheres; 23 homens foram deportados para colônias penais em Benguela, na África portuguesa. Além desses, mais de duas dezenas morreram nas prisões vítimas de maustratos". 47

Em março daquele ano um novo levante foi registrado na região do Iguape, no Recôncavo, sendo imediatamente derrotado. No final de maio, uma denúncia contra outro levante, que supostamente pretendia reunir diferentes grupos étnicos, permitiu sua dispersão e, dois anos depois, em 1816, escravos se rebelaram em Santo Amaro e em São Francisco do Conde dando início a uma onda de ataques a casas e a pessoas, além de incêndios a engenhos da região que duraram quatro dias. Apesar de ter sido rapidamente eliminado, Reis considera que esse representa “o levante escravo mais sério até então ocorrido no Recôncavo”. O pânico provocado mesmo após sua derrota levou os

\footnotetext{
${ }^{45}$ Citado por Pierre Verger, op. cit., p. 334-335.

${ }^{46}$ Cf. Manifesto, op. cit., p. 18.

47 João José Reis, op. cit., 2003, p. 83.
} 
proprietários a adotarem suas próprias medidas, além de se organizarem para propor “soluções políticas mais duradouras” ao governo da Bahia. ${ }^{48}$

Já em 1814 os negociantes da Bahia, entre outras pessoas, haviam se queixado ao príncipe regente sobre a dificuldade em manter a disciplina dos escravos na capitania diante de algumas deliberações do governo em garantir seus batuques em dois distritos da cidade, Graça e Barbalho, mesmo depois de terem se rebelado no início daquele ano. Talvez em função disso, o marquês de Aguiar lembrava ao conde dos Arcos que no Rio de Janeiro, “[...] além de não ter havido até agora desordens, bem sabe V.Exa. que há uma grande diferença entre os Negros Angolas e Benguelas nesta Capital e os dessa Cidade, que são muito mais resolutos, intrépidos e capazes de qualquer empresa, particularmente os de Nação Aussá”, 49 exigindo melhor controle da escravaria.

Na avaliação de Stuart Schwartz, por volta de 1814, as principais revoltas ocorridas na Bahia já possuíam características bem definidas: “organização étnica, tentativas de ligar cidade e áreas de engenho, contato com quilombos e repressão governamental”. ${ }^{50}$ Sintomaticamente, dois anos depois (em 14 de novembro de 1816), o conde dos Arcos foi incumbido pelo ministro para recolher na capitania um folheto, impresso em Lisboa e reimpresso na Imprensa Régia, intitulado "O preto e o bugio no mato”. De acordo com a orientação, os discursos do folheto "são mui pouco próprios para serem divulgados nesse Reino onde há muitos escravos. É Sua Magestade servido que V.Exa. pela maneira que lhe parecer mais conveniente faça recolher os exemplares que aparecerem nessa capitania, evitando todavia a publicidade desta cautelosa medida”. ${ }^{1}$

Certamente a decisão não era descabida. O folheto anônimo "O Preto e o Bugio, ambos no mato, discorrendo sobre a arte de ter dinheiro sem ir ao Brazil. Diálogo, em que o Bugio com evidentes razões convence ao Preto sobre a verdade desta proposição” é um libelo contra a escravidão. ${ }^{52}$ Redigido em forma de diálogo, o texto mostra o encontro

\footnotetext{
${ }^{48}$ Idem, ibidem, p. 91. Em duas cartas encaminhadas ao conde dos Arcos, em setembro de 1816, o marquês de Aguiar afirma estar ciente sobre a liberação de alguns escravos que erroneamente haviam sido presos como envolvidos no levante da vila de São Francisco, inclusive quatro cativos pertencentes a Salvador Pires de Carvalho. APEB. Seção de Arquivo Colonial e Provincial. Cartas régias enviadas à capitania da Bahia. Maço: 118 (1816). Sobre a movimentação dos escravos nos primeiros anos do século XIX e, especialmente, em 1814, ver Stuart Schwartz, op. cit.

${ }^{49}$ Citado por João José Reis, op. cit., 2000, p. 247.

50 Stuart Schwartz, op. cit., 1996, p. 380.

51 APEB. Seção de Arquivo Colonial e Provincial. Cartas régias enviadas à capitania da Bahia. Maço: 118 (1816). A mesma orientação foi dada a outras capitanias.

52 O Preto, e o Bugio ambos no mato, discorrendo sobre a arte de ter dinheiro sem ir ao Brazil. Dialogo, em que o Bugio com evidentes razões convence ao Preto sobre a verdade desta Proposição. Primeira, e Segunda Parte. Lisboa: Na Impressão Régia, Anno: 1816, 21 p. (disponível no site: www.caminhosdoromance.iel.unicamp.br).
} 
entre um escravo fugitivo e um macaco sábio em uma floresta no Brasil, um lugar habitado por seres livres que contrastava com o trabalho escravo realizado nas minas e nas roças. A questão central é a opressão vivida pelos escravos e a possibilidade de rompimento dessa condição diante dos esclarecimentos sobre o verdadeiro papel que os homens (e os animais) poderiam e deveriam desempenhar na natureza. O desenrolar do diálogo expressa como a forma distinta de existência entre os dois interlocutores interferia na percepção de cada um sobre o sentido pleno da vida. O macaco se apresenta como um animal livre, esclarecido por influência do seu dono (“Aprendi muito dele, porque a minha curiosidade me incitava a escutar todas as conversações que ele tinha com outros homens de letras”), expondo seus argumentos de maneira clara diferentemente do escravo fugitivo que ainda detinha uma visão de mundo herdeira do seu convívio com os senhores, expressando-se num português em fase de adaptação: "Si vozo non sá riabo, ao meno sá pla mim huns coisa novo. Diga vozo, plo ventura recoie-se nos casa como nozo, e tem Sioro, que governa sore toro os família, e que fá trabaiá toro o ria nos mina, nos roça, e nos engenha pala faze clecer sua dinheiro, e ser hum Sioro glandes?” Ao longo da conversa, o bugio tenta convencer o escravo sobre a anomalia da escravidão descrevendo os benefícios oferecidos pela natureza, única fonte de realização do ideal de liberdade, da qual os homens afastaram-se por pura ganância:

Eu pelo que conjecturo, tu es Preto fugido de poucos dias dos grilhões duros de algum Branco, em cujo poder cahiste desgraçadamente captivo, depois de seres vendido, e trocado a rolos de tabaco nas Costas de África, e mandado para estes sertões trabalhar para Senhor branco; e como só comias angu, e tomavas de tarde em tarde a tua cachaça, e nada disto encontras nestes matos, por isso te admiras”. Ora ouve, e repara: a Natureza he providentíssima para com todos os viventes: nestes mesmos bosques usando eu da minha liberdade, sou mais feliz, que os Reis abafados com montes de negócios, como escravos de seus vassalos. ${ }^{53}$

O encontro permite ao escravo conceber outra forma de existência questionar sobre a atividade do trabalho nessa nova condição. De acordo com seu interlocutor, a natureza era pródiga e fornecera ao homem os meios essenciais para que pudesse viver de maneira prazerosa, conforme suas necessidades, “e conseguir o cabedal preciso na sua pátria, sem ir buscar a sepultura nas ondas do mar, ou debaixo das abobedas das minas”. Para isso, bastaria que os homens cumprissem duas regras: "Primeira Regra. Seguir o gênio, e cultivar os talentos de que o adornou a Natureza. Segunda Regra. Evitar os

\footnotetext{
${ }^{53}$ Idem, ibidem, p. 4-5.
} 
excessos de prodigalidade, e também da avareza”. ${ }^{4}$ Depois de algumas explicações e em um segundo encontro, o escravo apropria-se dos argumentos utilizados pelo bugio: "Se aqui apalacera agola huns Blanco, que pole escreve os maravioso doutrina, que vozo platicá, e toro os gente ouvire cós oreia aberto, faria ete ao família toro do mundo hum favoro, que meoro non pore imagina”. 55

O texto, de 21 páginas, foi escrito em 1789 e reimpresso em 1816 integrando um conjunto de obras teatrais que em fins do século XVIII e início do seguinte buscava reproduzir em Portugal o debate sobre a abolição da escravatura. O prefácio do editor diz que o raro manuscrito foi encontrado "na Bibliotheca de um Americano sábio" e que por seu argumento mereceria ser divulgado. Considerado como uma importante obra desse período, “o preto e o bugio do mato...” diferencia-se de algumas peças da época por suas “perspectivas mais atrevidas e utópicas”, nas palavras de uma estudiosa do tema. ${ }^{56}$ Não deixa de ser significativo que circulasse na América portuguesa e, muito provavelmente na Bahia, tantos anos depois de sua primeira edição, numa conjuntura de grandes movimentações. A determinação da Coroa para que o folheto fosse recolhido indica que permanecia atenta quanto à divulgação de material considerado nocivo à ordem pública, porém essa censura mostrou-se sempre infrutífera sobretudo depois da abertura dos portos, em 1808, que favoreceu ainda mais a penetração de novas idéias. Infelizmente, não temos registro sobre os resultados dos mecanismos utilizados pelo governo para apreensão do folheto que poderiam revelar maiores detalhes sobre a sua circulação em um momento em que as revoltas escravas na Bahia tinham se ampliado.

Além disso, o número expressivo de escravos nos arredores de Salvador e no Recôncavo era motivo de tensão entre os reclamantes e o caráter cada vez mais violento dos levantes deixava-os em constante alerta. As turbulências de 1816 reforçavam a necessidade que os senhores sentiam de aprofundar as medidas de repressão contra os cativos, conforme deliberaram em 27 de fevereiro daquele ano reunidos em São Francisco do Conde, posicionando-se frontalmente contrários aos métodos de aperfeiçoamento no controle das relações escravistas defendidas pelo conde dos Arcos.

De qualquer maneira, tudo indica que as decisões tomadas pelo conde dos Arcos nessa conjuntura estariam na origem das divergências entre ele e o comandante militar da

\footnotetext{
${ }^{54}$ Idem, ibidem, p. 9.

${ }^{55}$ Idem, ibidem, p. 19.

${ }^{56}$ Anne-Marie Pascal. A abolição da escravatura e o teatro português (XVIII- XIX): A polêmica, o exemplo, e a utopia (Disponível em www.geocities.com/ail_br/aabolicaodaescravatura.htm). O Correio Braziliense anunciou a venda do folheto "O Preto e o Bugio no mato" por $100 \$ 00$ (cem réis), o que atesta sua ampla divulgação. Cf. Correio Braziliense ou Armazém Literário, 1816, v. XVI, n. 97, p. 585.
} 
Bahia, Felisberto Caldeira Brant Pontes, que em apoio aos proprietários de escravos, ou em seu próprio nome, já que era um deles, foi pessoalmente ao Rio de Janeiro obter autorização do príncipe regente para implementar parte das medidas de controle dos escravos sugeridas pela classe senhorial baiana que incluía a instituição de uma milícia particular. No seu retorno, Caldeira Brant fora preso pelo governador sob a alegação de que o mesmo o desacatara, sendo liberado pouco tempo depois. ${ }^{57}$ Não obstante os desentendimentos entre ambos, no ano seguinte estavam juntos no combate contra os envolvidos na maior insurreição ocorrida na América portuguesa. Para João Reis: "Do ponto de vista do conde, esta, sim, era uma insurreição verdadeiramente perigosa". ${ }^{8}$ A considerar a agilidade e a violência com que se dedicou nas ações contra os rebeldes, ele realmente parecia ter fortes razões para refreá-la.

De maneira contraditória, o governador buscava conciliar sua visão reformadora da sociedade com a defesa do poder absoluto do rei português demonstrando certa ambigüidade em seu comportamento político. Se, por um lado, poderia ser considerado um simpatizante das idéias ilustradas, liderando o projeto reformista de adequação da capitania às condições impostas pelos novos tempos e, ao que tudo indica, indo mais além; por outro, não titubeou quando teve que assegurar o predomínio político da monarquia bragantina seriamente ameaçado em 1817, assim como teve uma reação dúbia com o movimento constitucionalista anos depois. Isso produziu implicações importantes em sua trajetória política que oportunamente serão enfatizadas. O fato é que suas intervenções contribuíram para a consolidação de um ambiente societário em Salvador correspondendo às demandas de uma parcela dos habitantes que, não por acaso, teria uma presença importante nos eventos políticos posteriores.

\footnotetext{
${ }^{57}$ Em carta ao governo, em 11 de setembro de 1816, o marquês de Aguiar comunicou que o príncipe estava "inteirado de tudo o que V.Exa. expõe sobre este objeto não foi indiferente ao Mesmo Senhor a ordem de soltura que V.Exa. expediu imediatamente que recebeu o Régio Aviso que lhe remeti pelo mesmo Brigadeiro”. APEB. Seção de Arquivo Colonial e Provincial. Cartas régias enviadas à capitania da Bahia. Maço: 118 (1816). Braz do Amaral, em suas anotações, se refere às queixas ao príncipe regente formuladas em 1814 pelo corpo do comércio da Bahia contra o governador, assim como os atritos entre este e o comandante Felisberto Caldeira Brant Pontes. Cf. Ignácio Accioli, op. cit., p. 235 (nota 34). O documento encontra-se transcrito em Maria Beatriz Nizza da Silva, op. cit., p. 173-177. A autora lembra que o Idade d'Ouro não traz nenhum comentário sobre esses acontecimentos provavelmente em razão da censura exercida pelo conde dos Arcos. João José Reis discute as revoltas escravas ocorridas durante a administração do conde dos Arcos e as suas divergências com a classe senhorial baiana, em especial, Caldeira Brant. Op. cit., 2003, p. 81-93. Tempos depois, como se verá, o periódico Sentinella Bahiense descreveria esses eventos para realçar o comportamento contraditório de alguns membros da classe senhorial, nessa época e durante a conjuntura conflituosa dos anos 1820 no que se refere à questão dos escravos. Cf. Sentinella Bahiense, n. 8, quarta-feira, 21 de agosto de 1822. Bahia: Tipografia da Viúva Serva e Carvalho (Acervo do Centro de Estudos Baianos da UFBa).

58 João José Reis, op. cit., 2003, p. 93.
} 
Um aspecto importante nessa perspectiva foi a implantação da biblioteca pública inaugurada no dia 13 de maio de 1811, data do aniversário do príncipe regente e um dia antes da edição do primeiro número da gazeta Idade d'Ouro do Brazil. Ao lado desta, a instituição constituiu um marco importante na difusão da informação entre os indivíduos letrados da cidade de Salvador. A sugestão inicial para sua criação partira do senhor de engenho Pedro Gomes Ferrão Castelo Branco, que, para isso, apresentou ao conde dos Arcos um plano em 28 de abril daquele ano, portanto, poucos dias antes da inauguração do local evidenciando que já existia algum tipo de articulação com esse intento.

No texto da proposta, Castelo Branco exalta os benefícios de d. João “com todos os vassalos deste novo Império”, a exemplo da concessão da imprensa, realçando a importância do empreendimento para assegurar a promoção da instrução e da virtude, pelos quais os príncipes conquistariam o verdadeiro amor de seus fiéis súditos, assim como a motivação do governador. A biblioteca viria suprir a "falta de meios para entrarmos em relação de idéias com os Escritores da Europa” sem as quais não se poderia “conservar as idéias adquiridas, e muito menos promovê-las a benefício da sociedade”. A partir de então, propunha a criação de um fundo para subsidiar a remessa de Londres "e de quaisquer outros Países, que tiverem relações com esta Cidade os Periódicos de melhor reputação literária, e de mais ampla instrução” que deveriam, antes de sua divulgação, serem submetidos aos censores. Todos os funcionários - serventes, porteiro e bibliotecário - deveriam saber ler, escrever e contar, sendo que ao último seria desejável também que tivesse conhecimento das línguas latina, inglesa e francesa. Para afirmar sua disposição em levar o projeto adiante, doou todos os seus livros “em dom perpétuo” e cinqüenta mil réis para o fundo, sendo acompanhado por outros letrados da capitania que integraram uma lista de subscrição com 124 nomes. ${ }^{59}$ Entretanto nem todos cumpriram com as doações. Três anos depois, d. João autorizou a extração de uma loteria em benefício da biblioteca por um prazo semelhante para cobrir uma dívida indicada em um 1:646\$400

\footnotetext{
${ }^{59}$ Plano para o estabelecimento de huma bibliotheca pública na Cidade de S. Salvador Bahia de Todos os Santos, offerecido à approvação do Illustrissimo e Excellentissimo Senhor Conde dos Arcos, Governador e Capitão General desta Capitania. Bahia 26 de Abril de 1811. Biblioteca Pública do Estado da Bahia. Setor de Periódicos Raros. Em seu primeiro número, a gazeta Idade d’Ouro do Brazil relatou sobre a criação da biblioteca. APEB. Setor de Microfilmes. Idade d'Ouro do Brazil, n. 1, 14 de maio de 1811 (disponível em www.bn.br). O periódico informou também os nomes dos doadores que incluíam alguns estrangeiros e outros baianos residentes fora da capitania: "Clemente Ferreira França, desembargador da Suplicação do Brasil e ouvidor de Pernambuco, movido de sentimentos patrióticos que o distinguem pelo bem do Estado e desejando concorrer para o desta cidade, sua pátria, fez doação de 50\$000 Réis em dinheiro e 38 volumes de diversas obras de merecimento, a benefício da Livraria Pública dela, o que se dá a saber em sinal de gratidão e em observância dos Estatutos da mesma livraria”. Idade d'Ouro do Brazil, n. 29, 10 de abril de 1812, loc. cit. Sobre o assunto: Maria Beatriz Nizza da Silva, op. cit., p. 207.
} 
(um conto, seiscentos quarenta e seis mil e quatrocentos réis), conforme representação apresentada pelo governador. ${ }^{60}$

Importante ressaltar que Pedro Gomes Ferrão Castelo Branco era filho do antigo secretário da Academia Brasílica dos Renascidos, Antônio Gomes Ferrão Castelo Branco, inaugurada em Salvador no dia 6 de junho de 1759, data em que se comemorava o aniversário de d. José I. A academia, fundada depois do desaparecimento da Academia Brasílica dos Esquecidos (1724), possuía entre seus objetivos a reflexão sobre a história da América portuguesa na perspectiva de formação de uma identidade. Segundo Íris Kantor, os renascidos tinham como compromisso “'servir à pátria'(a pátria imperial), reunindo eruditos versados em todas as matérias” que tanto pudessem, por meio de um centro de formação, elaborar uma memória histórica americana quanto servir de instrumento para a instrução dos seus sócios. A idéia de constituição de uma biblioteca constava dos estatutos da academia "todavia, na falta de local adequado, os manuscritos e livros seriam guardados na casa do diretor, com acesso liberado a todos os sócios”. 61

Criada muito tempo depois daquele projeto inicial, a biblioteca possuía um acervo considerável na avaliação de alguns viajantes estrangeiros. Em 1817, o príncipe austríaco Maximiliano de Wied-Newied registrou uma coleção de 7.000 volumes incluindo "várias obras sobre todos os ramos do conhecimento", no mesmo ano em que o negociante francês Louis-François de Tollenare deixou uma descrição mais minuciosa:

Não passa ainda de uma pequena coleção de 4.000 volumes, mas todos de obras bem escolhidas [...]. Encontram-se ali quase todos os nossos bons clássicos, desde o século de Luiz XIV até os nossos dias. [...]. A biblioteca possui jornais, gazetas francesas e inglesas, mas, atrasadas e incompletas; sobre as mesas encontram-se os três grandes jornais portugueses que se imprimem em Londres: O Investigador, O Português, e o Correio Braziliense. São testemunhas da tolerância do governo e quase que da inteira liberdade da imprensa, porquanto sabe-se que são escritos com toda a independência e mesmo licença, que caracteriza as gazetas inglesas. A própria nação francesa não tem grande facilidade em saber o que se passa no mundo político. ${ }^{62}$

\footnotetext{
${ }^{60}$ De acordo o decreto, a biblioteca encontrava-se “em estado de não poder manter-se, por lhe faltarem muitos dos seus subscritores com a anual consignação com que voluntariamente prometeram contribuir [...]”, determinando, além da extração da loteria, que o débito fosse cobrado (disponível em www.camara.gov.br).

${ }^{61}$ Cf. Íris Kantor. Esquecidos e Renascidos. Historiografia acadêmica luso-americana (1724-1759). São Paulo: Hucitec; Salvador: Centro de Estudos Baianos/UFBa, 2004.

${ }^{62}$ Louis-François de Tollenare. Notas dominicais. Recife: Secretaria de Educação e Cultura/Departamento de Cultura, (Coleção Pernambucana, v. XVI), 1978, p. 239. Maximiliano de Wied-Newied, op. cit., p. 448. Anos mais tarde, em 1820, os bávaros Spix e Martius diriam que a coleção ultrapassava a 12.000 volumes. Op. cit., p. 145. Já no Rio de Janeiro como ministro, o conde dos Arcos remeteu para a biblioteca de Salvador, em 2
} 
Algumas pessoas também possuíam seus acervos particulares, com destaque para o padre Francisco Agostinho Gomes, tido por proprietário de uma coleção "reputada como a maior e mais completa da capitania” recebendo elogios por parte daqueles que a conheceram. ${ }^{63}$ Um ano depois de instalada a biblioteca, foi aberto ao público o Teatro de São João, cujo nome e data da inauguração (novamente 13 de maio) homenageavam o príncipe. A construção “de arquitetura arrojada e acomodações que superariam a tudo que até então se havia feito na América” havia sido iniciada no governo anterior e durante todo o século XIX o local tornou-se o centro de convergência da aristocracia local. Outras iniciativas no mesmo período reafirmam a existência de um ambiente propício à criação e à circulação de idéias. Em 1810, por exemplo, houve a tentativa de se criar uma Sociedade Bahiense de Homens de Letras sob o comando de Luis Antônio de Oliveira Mendes Dias Lobato, sócio da Academia Real de Ciências de Lisboa e advogado na cidade da Bahia, mas, ao que parece, não foi adiante. Dois anos mais tarde, começou a circular uma revista literária: As Variedades, ou Ensaios Periódicos de Literatura, que, no entanto, teria tido curta existência. De acordo algumas indicações, a revista era redigida por Diogo Soares da Silva de Bivar e seria "a primeira publicação periódica de caráter literário aparecida no Brasil, porquanto precedeu de quase um ano a O Patriota, jornal literário, político e mercantil do Rio de Janeiro, ao qual se tem arrogado este título, mas que só começou a sair em Janeiro de 1813”. ${ }^{64}$

A trajetória do seu redator é curiosa. Natural de Portugal e formado em direito pela Universidade de Coimbra, Diogo Bivar fora um dos fundadores e secretário da Sociedade Literária Tubuciana, em 1802, na vila de Abrantes. Com a ocupação do reino europeu pelo exército francês, teria hospedado o general Junot e aceito o cargo de juiz-defora da vila, razão pela qual fora preso e deportado para a África em 1810. Viera, então, de Portugal para Moçambique mas com a intervenção do conde dos Arcos teve a sua pena de degredo comutada para a Bahia, “apesar de acusado de jacobinismo e de 'partidista'

de julho de 1818, 17 caixas de livros recomendando a conservação necessária dos mesmos. APEB. Seção de Arquivo Colonial e Provincial. Ordens régias enviadas à capitania da Bahia. Maço: 119 (1818).

63 István Jancsó, op. cit., 1996, p. 144. Suspeito de participação na Sedição de 1798, Agostinho Gomes era conhecido por suas idéias ilustradas e teria sido apontado pelo conde dos Arcos como um dos envolvidos no plano de adesão da Bahia à Revolução pernambucana. Cf. Luiz Henrique Dias Tavares. "O desconhecido Francisco Agostinho Gomes”. In: __. Da sedição de 1798 à revolta de 1824 na Bahia, op. cit., p. 125-141.

${ }^{64}$ Hélio Vianna. Contribuição à história da imprensa brasileira (1812-1869). Rio de Janeiro: Imprensa Nacional, 1945, p. 15. Sobre o teatro: Affonso Ruy. História do teatro na Bahia.Salvador: Publicações da Universidade da Bahia, 1959, p. 33; Referências sobre a Sociedade bahiense de homens de Letras podem ser encontradas em Francisco Adolfo de Varnhagen, op. cit., 1953, p. 103; Maria Beatriz Nizza da Silva, op. cit., p. 218-219. Para uma discussão sobre alguns espaços de sociabilidade e seu uso político no Rio de Janeiro, ver Marco Morel, op. cit., 2005. 
dos franceses, permanecendo preso até 1821 quando foi solto e nomeado censor da imprensa local pela Junta Provisória de Governo. Residindo posteriormente no Rio de Janeiro, aí ocupou diversos cargos de instituições culturais falecendo aos 80 anos de idade em 1865. Pedro Calmon o inclui entre os prováveis membros da maçonaria em Salvador. ${ }^{65}$

Desse modo, é importante destacar que a dimensão desse ambiente cultural não se restringe apenas a tentativa de inserção da capitania nos novos padrões possibilitados pela presença do príncipe na América, mas, principalmente, pela possibilidade de constituição de uma rede de sociabilização num período de aceleradas transformações políticas. De fato, a existência desse processo de formação, ainda que encoberto e aparentemente restrito ao mundo dos letrados permitiu, no interior das condições do sistema, a elaboração de um universo conceitual coerente com a situação real desses sujeitos antecedendo as manifestações mais vigorosas características do movimento constitucionalista dos anos $1820 .^{66}$

Além do mais, é significativo que ao lado dessa movimentação tenha se ampliado as condições para a formação especializada de muitos dos filhos oriundos das classes proprietárias, seja com a criação da Faculdade de Medicina (em 1810), seja na implantação das cadeiras de comércio, agricultura e arquitetura naval. O envio de estudantes para a Universidade de Coimbra, com destaque para a Faculdade de Direito, também foi intensificado superando, inclusive, qualquer outra capitania entre os anos de 1811 (depois da liberação de Portugal) e $1821{ }^{67}$ A rigor, após o retorno, muitos desses estudantes se envolveriam no processo de construção do Império do Brasil, assim como os indivíduos que estiveram atentos às mudanças ocorridas nessas primeiras décadas do Oitocentos.

\footnotetext{
${ }^{65}$ Hélio Vianna, op. cit., p. 19-20. Pedro Calmon, op. cit., p. 1439. Sobre Diogo Bivar, o conde dos Arcos teria dito que tinha cerca de 24 anos, hábil, pois havia lido "escritos seus em várias matérias cheias de erudição, compostos no cárcere onde passa a vida lendo e escrevendo”. Cf. Maria Beatriz Nizza da Silva, op. cit., p. 229. A autora transcreve a portaria de nomeação da comissão de censura em 1821. Op. cit., p. 52. Em 22 de março de 1814, o marquês de Aguiar enviou ofício ao conde dos Arcos concordando com o parecer contrário a que o mesmo fizesse passeios fora da prisão alegando estar doente. Anais da Biblioteca Nacional do Rio de Janeiro, op. cit., v. 68, p. 192.

${ }^{66}$ De acordo a formulação de Denis Antônio de Mendonça Bernardes, op. cit. (especialmente capítulo 2).

${ }^{67}$ Frederic Morton, op. cit., 1986, p. 5. Mello Moraes relaciona os estudantes do Brasil formados em Coimbra nos anos 1818-1822. A capitania da Bahia, com 31 concluintes em Leis, 2 em Medicina e 2 em Matemática, se distancia de todas as outras. Cf. História do Brasil-Reino e do Brasil Império. Belo Horizonte: Itatiaia; São Paulo: Edusp, 1982, t. 2, p. 281-283. A gazeta Idade d'Ouro do Brazil (2 de abril, 1816, n. 27) traz a relação de 33 estudantes da Bahia matriculados na Universidade de Coimbra nesse ano nos cursos de Direito, Matemática e Filosofia. APEB. Setor de Microfilmes. Sobre a implantação de aulas régias em algumas vilas do interior. Ignácio Accioli, op. cit. v. III, p. 53.
} 
Todavia, a despeito dessas alterações, não se pode perder de vista o movimento mais amplo de mediação entre a Coroa e os habitantes da capitania cujos laços de adesão garantidores da unidade do Império necessitavam permanentemente de reforço. Para além das concessões, um elemento importante nesse aspecto, e ainda pouco estudado para o caso da Bahia, foram as celebrações cívicas que buscaram reavivar a ligação afetiva do príncipe e de toda a família real com seus súditos. Desse modo, diversos acontecimentos vinculados à realeza deveriam ser rememorados pela população legitimando, por um lado, o poder do regente ao mesmo tempo em que renovavam os seus vínculos com o monarca. ${ }^{68}$ As festas religiosas ou cívicas, os símbolos e os monumentos adquirem, assim, uma função político-pedagógica coesiva e para os residentes americanos, provavelmente, possuíam uma significância ainda maior tendo em vista a proximidade da corte. O Idade d'Ouro do Brazil divulgou muitas dessas comemorações - casamentos, nascimentos, aniversários, envolvendo membros da família real - ocorridas não apenas em Salvador e no Recôncavo, mas também nas vilas do interior, além de transcrever as notícias do Rio de Janeiro sobre o mesmo assunto. Por certo, a importância atribuída a esses eventos pode ser medida pelos gastos investidos em sua realização se comparados àqueles destinados às obras públicas: entre 1809 e 1812, por exemplo, enquanto as festividades somavam 12:521\$670 (doze contos, quinhentos e vinte e um mil, seiscentos e setenta réis), as obras totalizavam 12:021\$273 (doze contos, vinte e um mil, duzentos e setenta e três réis). ${ }^{69}$ Já em 1807, o desembargador João Rodrigues de Brito, ao comentar sobre as péssimas condições dos caminhos para o transporte de mercadorias diria que: "Bastaria a despesa que se gasta numa procissão para fazer desaparecer todas essas ladeiras”. E, pelo visto, os cortejos eram muitos. Ao lado da Igreja, o Senado da Câmara era responsável não apenas pelos festejos cívicos, mas também por certas datas religiosas. A suntuosidade dessas comemorações, particularmente as últimas, constituía, no dizer do redator da gazeta, um dos traços distintivos dos residentes da capitania, sem esquecer de assinalar: "A adesão respeitosa ao Culto estabelecido é um dos sinais indefectíveis da submissão voluntária a Deus que o exige, e às Leis que o ordenam”. ${ }^{70}$ De fato, no decorrer do século XVIII, várias foram as comemorações de acontecimentos considerados importantes para a

\footnotetext{
${ }^{68}$ Carla Simon Chamon. “O Tejuco faz a festa. Festejo cívico no arraial do Tejuco em 1815”. In: István Jancsó; Íris Kantor (Orgs.). Festa: cultura e sociabilidade na América portuguesa. São Paulo: Imprensa Oficial; Fapesp; Hucitec; Edusp, v. 2, 2001, p. 587-599. Para uma análise sobre as festividades na Bahia Setecentista: Avanete Pereira Sousa, op. cit.

${ }^{69}$ Idade d'Ouro do Brazil, n. 30, 13 de abril de 1813. Bahia, Tipografia de Manuel da Silva Serva (disponível em www.bn.br); Maria Beatriz Nizza da Silva, op. cit., p. 191.

${ }^{70}$ Idade d'Ouro do Brazil, n. 11, 18 de junho de 1811. Bahia, Tipografia de Manuel da Silva Serva (disponível em www.bn.br). João Rodrigues de Brito et al, op. cit., p. 50.
} 
monarquia, ocorridos aquém ou além-mar: expulsão dos franceses do Rio de Janeiro; tratado de paz celebrado com a França; aclamações de d. Pedro II e d. João V. Nessas ocasiões, exigia-se a presença vigorosa da população “que, no caso de Aclamações de Reis e Rainhas, era obrigada a pôr luminárias nas janelas durante três dias consecutivos, sob pena de os desobedientes pagarem 6 mil réis de multa e serem presos por trinta dias em cadeia”. 71

Relevante também é a correspondência mantida entre o governador, o Senado da Câmara e as autoridades régias da corte sobre as providências a serem tomadas para a plena realização das comemorações. Em 20 de março de 1816, por exemplo, o marquês de Aguiar comunicou ao conde dos Arcos a morte da rainha d. Maria I e, de acordo com a determinação do príncipe, era necessário realizar as “demonstrações do justo sentimento de tão grande perda; ordenando que nas terras desse governo mande V.Exa. fazer todas as honras fúnebres que são do estilo em semelhantes ocasiões. E o luto geral que o Mesmo Senhor mandou que se tomasse há de ser por tempo de um ano, seis meses rigorosos e seis meses aliviado". ${ }^{72}$ A notícia do falecimento da rainha foi divulgada pela Idade d'Ouro do Brazil na edição de 7 de junho que relatava também a mobilização das autoridades para a realização das exéquias. Poucos dias depois o periódico trazia a descrição da "cerimônia dos escudos quebrados como é estilo antigo" realizada pelo Senado da Câmara de Salvador que contou com a presença, entre outros, do arcebispo, do governador, do corpo da relação e da oficialidade militar. Segundo o redator: "O público tem mostrado os mais vivos sentimentos pela preciosa memória de uma RAINHA que fez uma das mais brilhantes épocas da monarquia”. No decorrer dos meses seguintes, várias notícias sobre as celebrações que aconteciam na capitania eram registradas pelo periódico. ${ }^{73} \mathrm{Em}$ fins desse ano o governador recebeu novo comunicado da corte esclarecendo que o dia 6 de abril fora fixado para as comemorações devidas e auto solene em homenagem à monarquia e como era desejo de d. João "que todos os seus vassalos que por ausentes não podem ter a honra de assistir a tão Augusta Cerimônia” pudessem também “dirigir ao Onipotente pela conformação de Sua Augusta Pessoa e Família e pela prosperidade do Reino Unido”, avisava com antecedência a realização da dita celebração. Atribuições que

\footnotetext{
${ }^{71}$ Avanete Pereira Sousa, op. cit., p. 209.

${ }^{72}$ Correspondência do marquês de Aguiar ao conde dos Arcos, em 20 de março de 1816. APEB. Seção de Arquivo Colonial e Provincial. Cartas Régias enviadas à capitania da Bahia. Maço: 118 (1816). D. Maria I faleceu nesse dia, aos 81 anos de idade.

${ }^{73}$ Idade d'Ouro do Brazil (1816, nº 46 e 47). APEB. Setor de Microfilmes (destaque no original).
} 
o governador cumpria com retidão e cada vez mais com aparato tendo em vista as modificações que se processavam no espaço urbano da cidade. ${ }^{74}$

Não restam dúvidas que depois de 1808 os residentes da Bahia presenciaram rápidas transformações na capitania, em muitos aspectos ainda mais notáveis após a chegada do conde dos Arcos. É bem verdade que não se deve atribuir a ele a exclusividade por essas alterações, mesmo porque, como mencionado, muitas delas já estavam em curso quando assumiu o governo. Mas as circunstâncias históricas do período demandaram intervenções - e interventores -, que pudessem assegurar alguma estabilidade política naquela crítica conjuntura das primeiras décadas do Oitocentos. Não à toa, o príncipe regente ansiava "sempre o seu parecer em tudo que diz respeito ao seu real serviço nesta capitania”, nas palavras de um ministro em $1811 .{ }^{75}$ E o padre perereca exaltava as mudanças condizentes com os novos tempos promissores: "Na cidade da Bahia assaz se tem desenvolvido o patriotismo dos seus habitantes, não só em melhorar, e fortificar aquela antiga metrópole do Brasil, mas também em fazer prosperar a agricultura, estender o seu comércio, e animar a indústria [...]”. ${ }^{76}$ Fruto de uma situação histórica específica, provavelmente o conde dos Arcos conseguiu perceber de maneira mais ampliada as especificidades da Bahia e de seus habitantes e soube articulá-las às exigências políticas de seu tempo. Uma condição essencial para reforçar a união das partes do Império português. Pelo menos até o aprofundamento da crise no interior do Reino Unido de Portugal, Brasil e Algarves instituído durante o seu governo.

\subsection{Brasil Reino: crise e reordenamento político}

Em 16 de dezembro de 1815, oito anos após a família real ter deixado o Reino de Portugal, d. João assinou, no palácio do Rio de Janeiro, a Carta de Lei que regulamentou a constituição do Brasil Reino. Em suas passagens centrais o documento reconhecia a riqueza e a vastidão dos domínios portugueses na América e as vantagens de “uma perfeita união e identidade” entre estes e os Reinos de Portugal e Algarves

\footnotetext{
${ }^{74}$ Correspondência do marquês de Aguiar ao conde dos Arcos, em 11 de dezembro de 1816. APEB. Seção de Arquivo Colonial e Provincial. Cartas Régias enviadas à capitania da Bahia. Maço: 118 (1816). O casamento de d. Pedro com a princesa Leopoldina também foi amplamente comemorado inclusive pela população da distante vila de Rio de Contas, fato divulgado com entusiasmo pelo Idade d'Ouro (1817, ${ }^{\mathrm{o}} \mathrm{s} 72$ e 76). APEB. Setor de Microfilmes. Sobre a realização desses eventos descritos pelo periódico: Maria Beatriz Nizza da Silva, op. cit., p. 187-192.

${ }^{75}$ Citado por Rocha Martins, op. cit., p. 37.

${ }^{76}$ Luiz Gonçalves dos Santos (padre perereca), op. cit., p. 335.
} 
justificando, assim, a sua decisão. A partir de então oficializava-se, na prática, o fim do estatuto colonial para os americanos. ${ }^{77}$

Apesar de sua importância no conjunto das alterações mais significativas que resultaram da instalação da corte no Brasil em 1808, a medida, no entanto, não obteve a atenção merecida por parte da historiografia sobre a Independência e ainda hoje permanece como um acontecimento de menor importância quando não totalmente ignorado nos bancos escolares. $^{78}$

Na contramão dos seus pares, em março de 1917, numa conferência no Instituto Geográfico e Histórico da Bahia, Braz do Amaral alertava que a carta representou o acontecimento mais notável e decidido para impulsionar a vida política no país depois da abertura dos portos e da vinda da família real, sem deixar de acrescentar, "e o mais decisivo preparo para a sua independência”. ${ }^{79}$ Como se nota, se por um lado repôs o significado da medida, por outro, estabeleceu uma associação direta entre a elevação do Brasil à categoria de Reino e o rompimento da unidade da nação luso-brasileira, servindo o primeiro como um passo decisivo na conquista da autonomia política já antevista a partir da unificação.

Essa interpretação, que estabelece de maneira anacrônica a inevitabilidade da Independência do Brasil em 1822, ainda tão vicejante na produção histórica atual, obscurece a dinâmica das relações políticas e simplifica as contradições de um processo prenhe de conflitos, alianças, rupturas e permanências que denota o grau de complexidade da crise do Antigo Regime na América portuguesa e os meandros de sua manifestação nos vários aspectos da vida social e política do Brasil nos primeiros anos do Oitocentos.

De fato, boa parte da historiografia brasileira sobre a Independência tem acentuado a importância de 1808 como marco fundamental no processo de eliminação da

\footnotetext{
${ }^{77}$ Carta de Lei de 16 de dezembro de 1815 - Eleva o estado do Brazil à graduação e categoria de Reino (disponível em www.camara.org.br). Varnhagen registra que o documento foi publicado pela Gazeta do Rio de Janeiro em 10 de janeiro de 1816. Op. cit, 1953, p. 121.

${ }^{78}$ Esta observação foi feita anteriormente por Maria de Lourdes Viana Lyra, op. cit., p. 159. Uma discussão recente sobre o assunto encontra-se em Ana Rosa Cloclet da Silva, op. cit., p. 250 e seq. O historiador Francisco Adolfo de Varnhagen, por exemplo, considera que a medida foi apenas um importante ato diplomático, pois o Brasil era tido por reino emancipado desde 1808. História Geral do Brasil. Antes da sua separação e independência de Portugal. Revisão e Notas de Rodolfo Garcia. 4. ed. São Paulo: Melhoramentos, 1953, v. 5, p. 121. Apesar disso, posteriormente considerou que o evento "veio a ser o segundo passo dado para formar das capitanias dos dois antigos Estados uma só nação", depois do estabelecimento da sede do trono português na América, sem adentrar o assunto. História da Independência do Brasil até ao reconhecimento pela antiga metrópole, compreendendo, separadamente, a dos sucessos ocorridos em algumas províncias até essa data. 4. ed. Revista e anotada por Hélio Vianna. São Paulo: Edições Melhoramentos, s/d, p. 17-18. Tobias Monteiro acompanha as articulações na corte quanto ao futuro da monarquia bragantina. Op. cit.

${ }^{79}$ Ignácio Accioli, op. cit., v. III, p. 240 (nota 37).
} 
situação colonial do Brasil sustentada pelo estabelecimento da monarquia portuguesa no Rio de Janeiro e da nova configuração da sociedade daí decorrente. Embora com interpretações distintas calcadas em marcos cronológicos diferenciados, ora estabelecendo 1822 como um acontecimento decisório nessa ruptura, ora afirmando 1831 como o encerramento de uma fase fundamental nos confrontos políticos ou indo além, os estudos mais alentados sobre o tema não desconsideram o peso da transferência da família real no aprofundamento das contradições entre a metrópole portuguesa e sua colônia americana. ${ }^{80}$ Muito provavelmente, em função dessa perspectiva analítica, na qual 1808 aparece como o ponto de inflexão no processo de Independência, é que a criação do Reino Unido é considerada uma decisão meramente legalista, de conformação de uma situação já estabelecida que, portanto, não obtivera grandes repercussões entre as populações então reunidas sob o mesmo estatuto de igualdade política.

Entretanto, as questões subjacentes a essa tomada de posição demandam maior clareza sobre a dinâmica política do período. Com efeito, a decisão da Coroa portuguesa não decorreu simplesmente de um reconhecimento da grandiosidade da América para o futuro da monarquia bragantina. Muito menos fora uma dádiva de um príncipe benevolente em agradecimento aos súditos fiéis. O seu significado político é muito mais amplo e relaciona-se às vicissitudes impostas pela conjuntura que por essa época ganhava novos e importantes contornos com a restauração das monarquias européias no pósderrota napoleônica, como também o recrudescimento dos movimentos nacionalistas na América hispânica. Além do mais, a possibilidade dessa unificação não era inteiramente nova e o debate sobre a questão demonstra que preocupações de fundo envolvendo os interesses da monarquia portuguesa permaneciam ocupando as cabeças dos conselheiros régios sobretudo nessas primeiras décadas do século XIX.

\footnotetext{
${ }^{80}$ É certo que autores como João Armitage (História do Brasil. Belo Horizonte: Itatiaia; São Paulo: Edusp, 1981) e Francisco Adolfo de Varnhagen (op. cit., s/d), embora com perspectivas diferentes sobre a colonização portuguesa, dimensionaram o caráter nacionalista manifestado na Independência tendo em vista seu interesse em demarcar a origem da Nação brasileira. Todavia, enquanto o primeiro reconheceu a importância da transferência da Corte portuguesa para o avanço da sociedade rumo ao progresso, destacando a Independência como uma "revolução" associada à separação política de Portugal e à emergência de uma "nação", o segundo concebeu que a conquista da autonomia política teria se dado sem maiores sobressaltos uma vez que a "nacionalidade brasileira" estaria em curso desde 1808. Historiadores como Caio Prado Júnior (op. cit., 1969), Sérgio Buarque de Holanda (op. cit), Maria Emília Viotti da Costa ("Introdução ao estudo da emancipação política do Brasil”. In: Carlos Guilherme Mota (Org.). Brasil em perspectiva. 19. ed. Rio de Janeiro: Bertrand, 1990) não perderam de vista a dimensão da instalação da corte bragantina e a perspectiva que se abriu para os antigos reinóis e os coloniais ante a estrutura imperial que começou a ser erigida. Para uma análise dos principais estudos sobre o processo de Independência do Brasil, ver: Wilma Peres Costa. "A Independência na historiografia brasileira”. In: István Jancsó (Org.), op. cit, 2005, p. 53-118; Cecília Helena de Salles Oliveira, op. cit., (especialmente capítulo I).
} 
Na história dos conflitos europeus, iniciados com a ascensão napoleônica ao trono francês em fins do Setecentos, 1815 adquire uma dimensão fundamental para os Estados aliados. Afinal, foi nesse ano que o general Napoleão Bonaparte amargou sua última derrota na batalha de Waterloo, em 18 de junho, após uma seqüência de vitórias que pôs em suspenso uma Europa continental absolutista e aristocrática provocando mudanças profundas não apenas nas áreas envolvidas diretamente nas guerras, mas em amplas partes do mundo. Mesmo antes da sua queda definitiva, as principais potências (Inglaterra, Rússia, Áustria e Prússia), por meio de seus mandatários diplomáticos, já estavam reunidas no Congresso de Viena desde o mês de outubro do ano anterior com o intuito de redefinir o mapa da Europa, restaurar as monarquias destituídas dos seus tronos e deliberar acerca de outras medidas preventivas. ${ }^{81}$

O rumo das decisões correspondia a orientação do "princípio da legitimidade” proposto por Charles Maurice de Talleyrand, delegado do rei da França depois de ter sido o poderoso chanceler de Napoleão. Portugal, como um dos maiores interessados nas decisões do evento, também esteve representado por meio de seus plenipotenciários: o conde de Palmela (d. Pedro de Sousa e Holstein), chefe da missão, d. Antonio de Saldanha da Gama e d. Joaquim Lôbo da Silveira, designados para influirem nas negociações de maneira a preservar os interesses da monarquia bragantina que também estivera diretamente envolvida no torvelinho da expansão napoleônica. ${ }^{82}$

Nesse contexto, é possível admitir que as articulações promovidas pela corte do Rio de Janeiro no congresso envolveram uma estratégia mais ampla de reestruturação política do Império português cuja elevação do Brasil à condição de Reino Unido constitui uma das deliberações fundamentais de sua política externa. No plano mais específico, essa definição teria desdobramentos imprevisíveis entre os habitantes do Reino luso-americano

\footnotetext{
${ }^{81}$ Depois da desastrada campanha na Rússia, em 1812, Napoleão Bonaparte (1769-1821) participou ainda de grandes batalhas mas foi obrigado a renunciar ao trono em abril de 1814, sendo exilado na ilha de Elba de onde fugiria no enquanto as potências vitoriosas discutiam o futuro da Europa no Congresso de Viena. Com a sua derrota final no ano seguinte, a monarquia dos Bourbons, deposta em 1792, foi restaurada reassumindo o trono Luiz XVIII, entre outras mudanças significativas para o reordenamento do sistema internacional. O eximperador francês foi aprisionado na ilha de Santa Helena, a quilômetros de distância da Europa, vindo a falecer em 05 de maio de 1821. Portugal contestou o local de sua reclusão em razão da proximidade da ilha das suas possessões africana e americana. Cf. Oliveira Lima, op. cit. De fato, em 31 de Janeiro de 1816, o ministro dos Negócios Estrangeiros encaminhou correspondência ao governador da Bahia alertando-o sobre a proibição de os navios circularem na área da ilha de Santa Helena e requerendo que todos os comerciantes daquela praça fossem comunicados. APEB. Seção de Arquivo Colonial e Provincial. Cartas do Senado à sua Majestade. Maço: 132 (1742-1823).

${ }^{82}$ Sobre os representantes de Portugal em Viena: Oliveira Lima, op. cit., (especialmente caps. XII e XIII); Pedro Calmon. História do Brasil. Rio de Janeiro: Livraria José Olympio Editora, 1959, v. IV, p. 1404-1405. Valentim Alexandre. Os sentidos do Império. Questão nacional e questão colonial na crise do Antigo Regime português. Porto: Ed. Afrontamento, 1993.
} 
surpreendendo, certamente, até os mais incrédulos quanto a uma possível coesão no interior da nação portuguesa. Não é fácil mensurar o real impacto que a nova condição política do Brasil e, por extensão, a afirmação da sua importância política e econômica, teve sobre os portugueses americanos alimentados em sua perspectiva de dominar o aparelho de Estado sob outros parâmetros. No entanto, o desenrolar dos acontecimentos demonstra que a reunião dos reinos possuía significados distintos não apenas para os residentes d'aquém e d'além-mar mas também no interior das suas partes. Vejamos, de início, o movimento do ponto de vista da Coroa.

Com base na ampla correspondência mantida entre os ministros e o príncipe regente, Valentim Alexandre discute em profundidade as estratégias definidas pela corte sediada no Rio de Janeiro para o Congresso de Viena que, na interpretação dos funcionários régios, significaria não apenas a redefinição da situação internacional após o fim do Império napoleônico mas, principalmente, a possibilidade de Portugal estabelecer contatos com outras potências ampliando suas bases de apoio até então restritas à Inglaterra. É nessa perspectiva que realça o papel desempenhado por d. Fernando José de Portugal e, sobretudo, por Antônio de Araújo de Azevedo, o conde da Barca, que havia ocupado a secretaria de negócios da marinha e ultramar em $1814 .^{83}$

Alexandre afirma que as instruções diplomáticas para os representantes de Portugal foram elaboradas em junho de 1814 ainda sem o conhecimento preciso do rumo das negociações em curso na Europa assumindo, em função disso, um tom de previsibilidade política. É nesse sentido que a Rússia, que havia dado imenso contributo para a derrota do exército napoleônico, seria vista como uma grande potência a rivalizar com a Inglaterra o domínio da Europa e aos diplomatas portugueses não deveria escapar esse importante dado da conjuntura mundial. Questões como a abolição do tráfico de escravos, de maior relevância, a devolução da Guiana Francesa e a restituição de

\footnotetext{
${ }^{83}$ Valentim Alexandre, op. cit. Pedro Calmon também ressalta a preeminência de Araújo de Azevedo, conde da Barca em 17 de dezembro de 1815, nas negociações desenroladas em Viena. Op. cit., p. 1405-1407. Segundo Pedro Octávio C. da Cunha, o conde da Barca era um dos que mais se enraizara na corte. "Quando faleceu [21 de junho de] (1817), o Português de Londres, jornal que tentava competir com o Correio Brasiliense disse que a sua política era um 'sistema pródigo de destruir Portugal para aumentar o Brasil'. Já então Barca se empenhara, tanto como D. João, na aventura do Prata; mas, entre outros fatos, - somados no maior que era a simples permanência da Corte - a elevação do Brasil a reino era o que mais devia justificar a censura”. Cf. Pedro Octávio Carneiro da Cunha. "A fundação de um império liberal”. In: Sérgio Buarque de Holanda (Org.). História geral da Civilização Brasileira. O Brasil Monárquico. O processo de Emancipação. São Paulo: Difel, 1985, p. 149-150. Ver também, Oliveira Lima, op. cit.
} 
Olivença, que implicava em delicadas negociações com a Espanha nesse último caso, mobilizaram os plenipotenciários. ${ }^{84}$

No que se refere ao primeiro ponto, as instruções previam uma articulação entre os países interessados na continuidade do comércio negreiro - Portugal, Espanha e a França -, contra as pressões inglesas, além de uma possível aliança com o czar russo para uma abolição gradual. Resistindo a toda forma de pressão pela abolição do tráfico, que na Grã-Bretanha acomodar-se-ia sob a forma de campanhas humanitárias, a Coroa portuguesa manteria inalterada sua posição contrária a eliminação do tráfico mesmo levando-se em consideração a possibilidade de indenização dos proprietários. Para Valentim Alexandre, a intransigência nessa questão, como também sobre a Guiana, reflete uma percepção equivocada tanto das relações de força no cenário internacional após a derrota napoleônica quanto do lugar ocupado pelo Império português nessa conjuntura. Além disso, a perspectiva de uma aliança com a Rússia que poderia contrabalançar o poderio inglês, na prática não surtiu efeito. Da mesma maneira, a avaliação que Portugal compartilharia do prestígio das nações vitoriosas sobre a França napoleônica contradizia com a imagem internacional "de um país sob tutela ou protectorado da Grã-Bretanha”, ${ }^{85}$ Todavia, a posição da Coroa portuguesa, sobretudo no que diz respeito à questão do tráfico, não parece ter sido de completa submissão às exigências dos britânicos, como será visto adiante.

Para alguns estudiosos, a atuação de Palmela fora fundamental para os arranjos em que se buscou preservar a imagem externa de Portugal - elemento de crucial importância na definição da hierarquia das potências no sistema internacional - diante de um cenário de forças bastante desfavorável aos interesses da monarquia portuguesa. Oliveira Lima avalia que o conde, ao lado do diplomata francês, foi a grande expressão do congresso dada a sua habilidade na costura das negociações nas quais tentou assegurar que Portugal não fosse profundamente atingido em seus interesses. As concessões feitas que resultaram na extinção do comércio negreiro a norte do Equador, consagrada no tratado de 21 de janeiro de 1815, foram de certa maneira minimizadas ante as circunstâncias em que se encontrava. Da mesma forma que a eliminação do tratado de 1810 com a Grã-Bretanha pareceu-lhe “obtenções de tal importância em si mesmas, e tão

\footnotetext{
${ }^{84}$ A questão do tráfico era, do ponto de vista econômico, a mais grave e Portugal, segundo Oliveira Lima, se via numa posição de quase desamparo já que a França assumira abolir no prazo de cinco anos e a Espanha disposta a fazê-lo em oito. As demais potências (Rússia, Prússia e Áustria) poderiam atender a Inglaterra sem arcar com perdas. Oliveira Lima, op. cit., p. 310.

${ }^{85}$ Valentim Alexandre, op. cit., p. 304. A Grã-Bretanha aboliu o tráfico interno em 1807.
} 
incomparavelmente superiores ao que cediam, que mal podíamos acreditar o termo-las conseguido [...]”. ${ }^{86}$

Com relação à Guiana, deliberou-se pela sua restituição e discussão posterior com a França sobre a fixação das fronteiras entre os territórios. Por último, a negociação sobre a reintegração de Olivença a Portugal demandou novas articulações com a Espanha interessada no posicionamento da Coroa com relação aos movimentos autonomistas nas colônias da América hispânica. Nessa questão os enviados portugueses não obtiveram o intento desejado, caracterizando uma derrota mais uma vez minimizada na avaliação sobre os resultados do congresso encaminhada à Corte do Rio de Janeiro em 22 de junho de 1815. Aqui, realçavam a posição política ocupada pelo Reino que gozara de consideração entre as principais potências sendo invejado pelas demais, ao mesmo tempo em que assumiam o isolamento português no cenário internacional, bem como a inviabilidade do apoio da Rússia, dificultando as negociações com as potências “[...] e fomos obrigados a lutar, por assim dizer, com as nossas próprias forças sucessivamente contra a Inglaterra, contra a França e a Espanha”. 87

Não obstante as resultantes do congresso, as negociações remetem para uma ampla movimentação dos Estados europeus e, em particular, da Coroa portuguesa, na tentativa de evitar que as transformações políticas em curso aprofundassem a crise do sistema cujo passado recente dava mostras do abalo sentido pelas monarquias absolutas. Nesse aspecto, as linhas definidas apontavam para um reordenamento das forças políticas, mas a dinâmica dos acontecimentos exigia permanente cautela e perspicácia nas estratégias adotadas.

De fato, se a conjuntura havia novamente sacudido os alicerces políticos do continente europeu fornecendo alguma tranqüilidade aos reis absolutos, as implicações advindas com a fixação da corte portuguesa no Rio de Janeiro sinalizavam que novos reajustamentos deveriam ser pensados objetivando a preservação da monarquia. Além do mais, os acontecimentos registrados na América hispânica esgarçavam os limites impostos

\footnotetext{
${ }^{86}$ Citado por Valentim Alexandre, op. cit., p. 316. Para Oliveira Lima, as grandes expressões políticas do congresso, a despeito dos resultados obtidos, foram Talleyrand e Palmela. Op. cit., p. 306.

${ }^{87}$ Op. cit., p. 327. Sobre essa questão, ver: Oliveira Lima, op. cit. Avaliando os resultados do congresso, Francisco Adolfo de Varnhagen reduz a participação dos plenipotenciários portugueses. Em suas palavras: "Muito menos feliz esteve a diplomacia portuguesa no Congresso de Viena, do qual absolutamente nenhuma indenização sacou, em troco do muito sangue português derrubado contra a França. [...] Para remate da sua boa obra os preconizados negociadores assinaram um documento que continha um artigo dando por abolido $o$ tráfico ao norte do Equador, providência que sabiam com toda a certeza ser contrária à política da corte, que aí os mandara”. Cf. Francisco Adolfo de Varnhagen. História Geral do Brasil. Antes da sua separação e independência de Portugal. Revisão e Notas de Rodolfo Garcia. 4. ed. São Paulo: Melhoramentos, 1953, v. 5, p. 118.
} 
pelo absolutismo, pondo a nu a crise do Antigo Regime ao possibilitar formas diferenciadas de práticas políticas exercitadas pelas populações coloniais, um forte indício de que, em alguns aspectos, as mudanças eram irrefutáveis. Esses elementos certamente não seriam desprezados pelos ministros de d. João em suas formulações sobre o futuro da dinastia de Bragança. De qualquer maneira, era presumível que o restabelecimento do equilíbrio europeu reascendesse a discussão sobre o retorno da corte para Portugal que, desde 1812, havia se libertado completamente da ocupação francesa. No entanto, as indecisões da Coroa sobre essa questão indicam que a estabilidade política ainda era algo distante de ser vislumbrado.

Não cabe aqui mencionar as profundas alterações decorrentes da instalação da sede da monarquia no Rio de Janeiro, objeto de farta bibliografia. ${ }^{88}$ Porém, é preciso assinalar que as intervenções daí advindas resultaram em transformações de largo alcance para a antiga colônia, o que não deixou de provocar reações de descontentamento nos portugueses europeus ao mesmo tempo em que sedimentavam os interesses de parte dos residentes no Centro-Sul por meio da conformação do Rio de Janeiro como novo centro de poder.

A posição de Luis Joaquim dos Santos Marrocos, funcionário da Biblioteca Real do Rio de Janeiro que chegou à cidade em 1811, é reveladora dessa mudança de perspectiva tanto para a Coroa quanto para alguns habitantes da corte. Por meio da análise de sua correspondência pessoal, Andréa Slemian descreve como essas mudanças vão interferir na percepção de Marrocos sobre os acontecimentos que naqueles anos possuíam extrema fluidez: "De terra espúria e indolente, o Rio de Janeiro se transformara em alternativa em face das dificuldades passadas pela sua família em Portugal. [...]. Não era por acaso que, já de algum tempo, Marrocos se referia ao Rio de Janeiro como Corte” 89

Para o que nos interessa diretamente, é digno de atenção o fato de o missivista registrar a possibilidade de o retorno da família real a Portugal em 1812, para o qual, segundo informa, se preparava embarcações, sendo que, dois anos mais tarde, modificaria completamente a sua percepção. Os investimentos em construção feitos pelos funcionários régios eram, para ele, um sinal de que o regresso estava cada vez mais distante: “Antônio de Araújo está com grandes obras nas suas casas, que lhe levarão uns poucos meses. O

\footnotetext{
${ }^{88}$ Ver capítulo 1, nota 20.

${ }^{89}$ Cf. Andréa Slemian, op. cit., p. 32. Além de funcionário na Biblioteca Real, Marrocos era oficial da Secretaria dos Negócios do Reino do Brasil e, posteriormente, oficial-maior da Secretaria de Estado dos Negócios do Império, cargo que ocupou de 1824 até 1838, ano da sua morte, confirmando as suas previsões de possibilidade de ascensão na Corte. Francisco Adolfo de Varnhagen, op. cit., 1953, p. 107-108.
} 
conde de Cavaleiros há poucos dias comprou umas boas casas com sua chacra. Tudo o mais está em sossego ou antes mortuório, que denota muito longa permanência neste país, e quase que há proibição política de falar-se na ida para Lisboa: Deus sabe quando será”. 90 Por outro lado, a ausência prolongada do príncipe do Reino português começou a impacientar os seus habitantes. Por meio dos governadores, variados pedidos foram encaminhados ao Rio de Janeiro, nos quais relatavam a situação de penúria em que se encontravam, reclamando o seu retorno. ${ }^{91}$

A questão era, de fato, complexa e o príncipe não estava convicto da melhor decisão a ser tomada naquelas circunstâncias. Prova disso é que, em 1814, teria ordenado a execução de obras no palácio da Ajuda, em Lisboa, para que pudesse abrigar a família real após seu retorno. Tobias Monteiro registra que "as obras foram encetadas com ardor, chegando-se a elevar a mais de quinhentos o número dos operários”, 92 no intuito de receber o príncipe. Mas a conjuntura política recomendava cautela na avaliação dos conselheiros régios sobretudo após o recrudescimento das lutas nas colônias hispânicas no início dos anos 1810.

De fato, a organização das Juntas Provisórias de Governo no decorrer das lutas políticas na América hispânica confrontava diretamente com os princípios de sustentação do poder absoluto e ainda que não fizessem uma declaração explícita à sua independência, antes reiterava a lealdade ao monarca, eram expressões de significativas alterações políticas. O impacto das mudanças resultantes do ciclo revolucionário do século anterior acentua-se nesse momento de crise da legitimidade, na qual a proliferação dos periódicos evidencia um novo ambiente político prenhe de "expressões das alternativas e projetos políticos que se punham aos homens da época como possibilidades de solução de uma crise que, ainda que nem sempre tomada como tal, afetava a todos, constituindo-se em problema coletivo”, nas palavras de João Paulo Garrido Pimenta. ${ }^{93}$ Se a proximidade dessas localidades e, portanto, as diversas possibilidades de comunicação, eram um dado a ser considerado, a novidade das proposições políticas certamente justificaria ainda mais as hesitações de d. João.

O receio de que os residentes da Bahia, particularmente, pudessem ser contagiados pelas perniciosas idéias pode ser medido por meio das orientações repassadas ao conde dos Arcos para que permanecesse atento quanto à movimentação interna. Por

\footnotetext{
${ }^{90}$ Citado por Oliveira Lima, op. cit., p. 350.

${ }^{91}$ Tobias Monteiro, op. cit., p. 191.

${ }^{92}$ Idem, ibidem, p. 198.

93 João Paulo G. Pimenta, op. cit., 2002, p. 68.
} 
essa época, as atenções continuavam voltadas, principalmente, para os possíveis espiões franceses, por isso, em 4 de julho de 1811, o conde de Linhares alertou ao governador que Napoleão Bonaparte pretendia enviar emissários ao Brasil via os Estados Unidos recomendando total vigilância a qualquer passageiro oriundo dessa localidade que estivesse sem o passaporte do encarregado de negócios do príncipe em Filadélfia. Chamava a atenção, em especial, para a possível entrada na capitania de "Sebastião e Vicente Navarro de Andrade, Irmãos de Rodrigo Navarro, Encarregado de Negócios em S. Petersburg, Domingos Borges de Barros, da Bahia, primo de José Egydio Álvares de Almeida, e João Pereira de Souza Caldas, da Casa Caldas, do Rio de Janeiro, e que vem de Nova York ou de Filadélfia”. Além de pedir o mais absoluto segredo sobre a execução da ordem, reafirmava que a tranqüilidade e a segurança do Estado eram "graças às ativas providências que Sua Alteza Real não cessa de dar, poderá assim ficar livre do flagelo terrível, de que tantas nações do globo, são infelizes vítimas”. ${ }^{94}$ Depois dos processos investigatórios ocorridos no Rio de Janeiro, concluiu-se que os acusados eram inocentes. Três meses depois, o mesmo conde dos Linhares, de posse dessas informações, solicitava a soltura de Vicente Navarro de Andrade “desde que os outros seus companheiros, como ele suspeitos de serem emissários de Napoleão Bonaparte, já foram soltos, por ter sido reconhecida sua inocência” e, em outra correspondência, alertava sobre o envio de "uma imprensa e duas caixas de tipo” que haviam sido embarcados em Londres, conforme indicações do embaixador português Domingos de Sousa Coutinho, solicitando a sua apreensão. ${ }^{95}$

No entanto a preocupação central nesse período parece ter sido mesmo com a entrada de espanhóis. Na sede da corte, em razão de ser a cidade mais populosa e com maior movimentação portuária, esse controle foi feito de maneira ainda mais intensa. Em outubro de 1810, o conde de Linhares solicitou do intendente de polícia informações sobre dois espanhóis sendo que um deles, Luis Altolaguirre teria chegado da Bahia e tinha se retirado “para Buenos Aires ou Montevidéu com despachos do seu embaixador”, mesmo

\footnotetext{
${ }^{94}$ Braz do Amaral. Anotações... In: Ignácio Accioli, op. cit., p. 136-137. Em carta dois dias depois, o conde de Linhares acrescenta ter sido informado pela Gazeta da Bahia, n. 9, sobre a chegada dos mencionados portugueses acompanhados de um emissário de Napoleão, ordenando a sua prisão e apreensão dos seus papéis. Loc. cit. A ordem de prisão havia sido enviada também ao Rio de Janeiro. Andréa Slemian, op. cit., p. 85. Domingos Borges de Barros foi posteriormente nomeado como diretor do Passeio Público na Bahia, segundo Pedro Calmon, sob recomendação do conde de Linhares ao governador da Bahia. Op. cit., p. 1419.

${ }_{95}$ Ofício do conde de Linhares ao conde dos Arcos, em 4 de setembro de 1811. Anais da Biblioteca Nacional do Rio de Janeiro, op. cit., v. 68, p. 176.
} 
não tendo maiores indícios que o pudesse incriminar. ${ }^{96}$ Apesar do controle, as notícias sobre os acontecimentos políticos nas áreas vizinhas penetravam entre os residentes. $\mathrm{Na}$ edição de 14 de maio de 1811, o Idade d'Ouro divulgava a chegada no porto da Bahia do bergantim Fênix vindo de Montevidéu. Segundo o periódico, “a carga desta embarcação vem por baldeação. Por ela se receberão notícias do prosseguimento da revolução; e diz-se que marcharão Tropas de Monte Video contra os de Buenos Aires, e Maldonado [...]”. ${ }^{97}$ Já em 16 de janeiro de 1814, a orientação era para vigiar a entrada do negociante Tristão da Cunha oriundo da Colônia do Sacramento ordenando que todos seus papéis fossem apreendidos e, “uma vez que neles encontre coisa que possa causar suspeita contra a conduta deste homem”, encaminhasse a sua prisão. Dois anos depois, o marquês de Aguiar fornecia instruções ao governo da Bahia para investigar a escuna espanhola $L a$ Independência que se destinava às costas daquela capitania e de Pernambuco. ${ }^{98}$

Nessas condições, os dilemas então enfrentados pelo Império português para assegurar alguma estabilidade política no interior dos seus domínios podem ser identificados na análise empreendida por Silvestre Pinheiro Ferreira. O conselheiro, atendendo a um pedido de d. João, sugeriu um conjunto de medidas políticoadministrativas, em 22 de abril de 1814, que visava conter o avanço do movimento revolucionário nas possessões da Coroa portuguesa preservando a integridade da monarquia. A situação internacional no momento em que escreve ainda é bastante nebulosa a despeito da abdicação de Napoleão Bonaparte, do fim da guerra peninsular, formalizado em 19 desse e, em decorrência, do retorno ao trono dos soberanos espanhol e francês. Com efeito, ao reassumir o poder, Fernando VII eliminou, sob forte repressão, muitas das conquistas efetuadas pelos liberais na península e na América hispânica, anulando, inclusive, a constituição de 1812. Enquanto isso, na França, a monarquia dos Bourbons foi restaurada com Luiz XVIII que outorgou uma constituição, baseado no princípio do "livre exercício da autoridade real”, sob a forte perseguição dos opositores. ${ }^{99}$ Todavia, as tentativas em interromper as mudanças políticas produziram um movimento inverso ao desejado resultando no aprofundamento dos conflitos internos. No caso da América hispânica, os movimentos pela independência recrudesceram em toda parte

\footnotetext{
${ }^{96}$ Citado por João Paulo G. Pimenta, op. cit., 2003, p. 97. O autor aborda a vigilância exercida na corte sobre os estrangeiros principalmente àqueles oriundos da América espanhola. Andréa Slemian, op. cit.

${ }^{97}$ Idade d'Ouro do Brazil, n. 1, 14 de maio de 1811 (disponível em www.bn.br).

${ }^{98}$ Ofício do marquês de Aguiar ao conde dos Arcos, em 13 de dezembro de 1816. Anais da Biblioteca Nacional do Rio de Janeiro, op. cit., v. 68, p. 202; Braz do Amaral. Anotações... In: Ignácio Accioli, op. cit., p. 137.

${ }_{99}^{99}$ Maria de Lourdes Viana Lyra, op. cit., p. 170.
} 
fornecendo novos elementos para as lutas dos colonos. Na avaliação de João Paulo G. Pimenta: “O declínio de Napoleão, o fim da guerra peninsular e a restauração européia não representavam garantia de sucesso na busca da ordem desejada, pois as novas contingências que o mundo da política imprimia sobre o Império português não eram mais apenas européias, e sim cada vez mais também americanas”. 100

Diante de uma conjuntura extremamente conturbada e imprevisível, a posição do conselheiro foi muita precisa: era necessário cessar o descontentamento dos portugueses europeus em razão da presença do monarca na América, ao mesmo tempo em que o seu retorno poderia provocar a emancipação das colônias. Para ele, o problema sobre o regresso da corte era dos mais importantes "que jamais soberano algum teve de resolver” porque não se tratava apenas de decidir sobre a futura residência do rei no interior de seus vastos domínios, mas sim de "suspender, e dissipar a torrente de males com que a vertigem revolucionária do Século, o exemplo de Povos vizinhos, e a mal entendida Política que vai devastando a Europa, ameaçam de uma próxima dissolução, e de total ruína os Estados de V.A.R. espalhados pelas cinco partes do mundo”. Para evitar tamanho perigo, Silvestre Pinheiro sugeria então que o monarca permanecesse no Brasil e enviasse d. Pedro para exercer a regência de Portugal e Ilhas dos Açores, Madeira e Porto Santo até a morte da rainha, d. Maria I, quando então d. João assumiria o "Título de Imperador do Brasil, Soberano de Portugal” e o seu filho "Rei de Portugal, Herdeiro da Coroa do Brasil”, definindo as atribuições de cada um de maneira a não contradizer com os princípios da monarquia absoluta. ${ }^{101}$

Silvestre Pinheiro, como um funcionário de Estado bem informado sobre os acontecimentos externos e adepto das intervenções reformistas, estava totalmente convencido de que aquela época era de grandes transformações e, nesse caso, as estratégias políticas também deveriam ser excepcionais:

Em tempos ordinários, Senhor, bastam providências ordinárias; mas nas extraordinárias, e sobremaneira críticas circunstâncias, em que se acha

\footnotetext{
100 João Paulo G. Pimenta, op. cit., 2003, p. 178.

${ }^{101}$ Proposta autographa sobre o regresso da Corte para Portugal e providências convenientes para prevenir a revolução, e tomar a iniciativa da reforma política, por Silvestre Pinheiro Ferreira. Biblioteca Nacional do Rio de Janeiro. Documentos para a Independência, v. I, Lisboa/Rio de Janeiro, 1923, p. 129-134. Silvestre Pinheiro Ferreira, considerado um dos principais conselheiros que acompanhou o príncipe regente na vinda para o Rio de Janeiro, foi um destacado ilustrado reformista que procurou fortalecer o Estado para preservar a unidade luso-brasileira. Cf. Maria de Lourdes Viana Lyra, op. cit., p. 151. Lyra observa que as sugestões de Silvestre Pinheiro seguiam na direção do sistema político sugerido por Rodrigo de Sousa Coutinho em fins do século XVIII. Todavia, “a inversão da posição entre Portugal e Brasil, acontecida em 1808, havia modificado tão profundamente a composição no império que a diretriz principal e urgente consistia em definir com precisão a composição do novo Estado”. Op. cit., p. 152.
} 
Portugal, a Europa, o Mundo inteiro, são precisas grandes e extraordinárias providências para assegurar a integridade da Monarquia, sustentar a Dignidade do Trono, e manter o sossego e a felicidade dos Povos. ${ }^{102}$

Entretanto, se em razão da provisoriedade política da Coroa portuguesa ainda era possível pensar numa possibilidade de retorno da família real, a decisão, quase dois anos após o escrito de Silvestre Pinheiro Ferreira, refreou ainda mais essa condição pelo menos até os acontecimentos decorrentes do constitucionalismo de 1820. A opção pela porção americana do Reino significava não apenas o reconhecimento da parte mais promissora do Império, como também a oficialização da emancipação da ex-colônia estabelecendo que Portugal, Brasil e Algarves constituiriam um só corpo político. ${ }^{103}$

As articulações iniciais para a consecução da medida parecem ter partido das negociações entre os plenipotenciários portugueses e o representante francês no Congresso de Viena. Braz do Amaral afirma que a sugestão de Talleyrand fora então acatada pelos diplomatas como se poderia depreender na passagem de uma correspondência reservada entre Saldanha da Gama e Lobo da Silveira datada de 25 de janeiro de 1815. Diz o primeiro:

Falando assim se exprimiu o príncipe de Benevento: As colônias espanholas, pelo mau governo atualmente daquela monarquia, podem-se contar quase como perdidas para a Europa e em tais circunstâncias eu consideraria como uma fortuna que se estreitasse por todos os meios possíveis o nexo entre Portugal e o Brasil, devendo este país, para lisonjear os seus povos e destruir a idéia de colônia, receber o título de Reino e vosso soberano ser Rei de Portugal e do Brasil.

Podeis, acrescentou ele, se julgardes conveniente, manifestar que vos sugeri estas idéias, e que tal é o meu voto decidido. ${ }^{104}$

Embora Braz do Amaral reafirme a proeminência do embaixador da França na proposta de criação do Reino Unido - seguido por Pedro Calmon - e Oliveira Lima argumente que a idéia partira do conde de Palmela, não se pode desprezar as formulações anteriores sobre a questão como evidências de que a necessidade de reformas no interior do sistema estava sempre presente no horizonte dos estadistas portugueses. ${ }^{105}$ As

\footnotetext{
${ }^{102}$ Proposta autographa..., op. cit., p. 129.

${ }^{103}$ Valentim Alexandre vê na constituição do Brasil Reino “o melhor símbolo dessa opção americana”, assim como "o renascimento da tentação expansionista do Brasil, não recuando mesmo perante o risco de um conflito com a Espanha, que poderia vir a pôr em perigo o reino de Portugal”. Op. cit., p. 338.

${ }^{104}$ Braz do Amaral. “O Brasil no Congresso de Viena”. RIHGB, v. 175, Rio de Janeiro, 1940-1941, p. 523.

${ }^{105}$ Idem, Ibidem; Pedro Calmon, op. cit., p. 1405; Oliveira Lima, op. cit., p. 335-336. Sobre a originalidade de Silvério Pinheiro Ferreira, ver também: Maria Beatriz Nizza da Silva (Coord.). O Império Luso-Brasileiro (1750-1822). Lisboa: Editorial Estampa, 1986, v. VIII, p. 296.
} 
condições históricas do contexto de restauração possibilitaram a efetivação de algumas dessas proposições nas quais a nova posição política adquirida pelo Brasil constitui uma das mais relevantes.

De qualquer maneira, o apoio deliberado de Talleyrand indicava não apenas a efetivação de uma tática que interessava tanto ao projeto mais estratégico de fortalecimento do Império português, como também a presença da monarquia bragantina na porção americana do Reino servindo de contraponto aos movimentos independentistas na América hispânica ao assegurar a coesão de seus domínios. Como sublinha Pedro Octávio da Cunha, a intenção era a defesa da "presença da Europa e da realeza - então sinônimas - na América” quando as áreas anteriormente submetidas à Inglaterra e à Espanha já se encontravam "em grande parte em mãos republicanas”. ${ }^{106}$ A importância da medida para a Coroa portuguesa buscava, desse modo, conciliar a consecução de uma reforma política que atendesse as mudanças conjunturais do período sustentada na preservação do princípio da legitimidade dinástica. As circunstâncias assim o exigiam e à monarquia bragantina não restava outra alternativa.

Parece claro que a fonte de inspiração para o modelo de Reino a ser instituído fora o Reino Unido da Grã-Bretanha e Irlanda sem levar em conta as especificidades históricas do processo de formação e nem mesmo as distâncias das partes da monarquia portuguesa que, a partir de então, se fundiriam no mesmo Império. Sobre essa questão, Maria de Lourdes Viana Lyra interroga: “A concepção original de novo império não fora elaborada justamente para permitir a união atlântica entre parcelas territoriais interligadas por interesses recíprocos?”. ${ }^{107}$ Mas a reação manifestada pelos portugueses de além-mar indicaria que a decisão estava longe de ser vista como um passo consensual entre as partes.

\footnotetext{
${ }^{106}$ Cf. Pedro Octávio Carneiro da Cunha, op. cit., p. 149.

${ }^{107}$ Maria de Lourdes Viana Lyra, op. cit., p. 160. A Carta de lei de 13 de maio de 1816 criou as armas ao Reino do Brasil, integrando o brasão único da Monarquia portuguesa. Sobre os efeitos simbólicos dessa mudança. Ana Cristina Bartolomeu Araújo ressalta: "A carta [...] fixou como símbolo distintivo do Reino do Brasil, uma esfera armilar de ouro em campo azul. A esfera que abarcava todas as direções da expansão e do domínio português no mundo foi atribuída, como expressão de universalidade e poder, àquela que fora a colônia mais poderosa de Portugal. O Reino Unido passava assim a ser representado pela inscrição do escudo português e a coroa real da casa de Bragança sobre a esfera armilar do Brasil. A combinação encontrada representava uma espécie de recapitulação simbólica da história do Império colonial português e valia sobretudo como consagração do seu ponto de chegada. A coesão política do Reino Unido tinha, na sua matriz totalizadora, o valor de signo de uma identidade comum, ilusão difícil de sustentar num tempo de ocaso do regime imperial português”. Ressalta ainda que a Regência de Portugal se opôs à utilização do novo escudo real nos documentos oficiais do Estado. Cf. "Um Império, um reino e uma monarquia na América: às vésperas da Independência do Brasil”. In: István Jancsó (Org.)., op. cit., 2005, p. 265-266. Francisco Adolfo de Varnhagen transcreve os artigos da mencionada carta. Op. cit., 1953, p. 121 (nota 33).
} 
Pode-se considerar que pelos encaminhamentos que se seguiram desde a vinda da família real, os portugueses europeus receassem quanto a efetiva possibilidade de seu retorno a Lisboa. Afinal de contas, muitas das medidas tomadas pelo governo do Rio de Janeiro afirmavam o enraizamento, cada vez mais ampliado, da corte na nova sede que não deixara de provocar reações contrárias sempre combatidas pelos governadores do Reino em Portugal. Mas, a chegada de notícias sobre a criação do Reino Unido dissipou as dúvidas quanto à possível dubiedade do príncipe regente impulsionando as reações contrárias à autonomia da ex-colônia principalmente por parte de setores da burguesia portuguesa que se viram seriamente ameaçados com a oficialização da relação desigual mantida entre as duas partes do Reino. Certamente que a recusa em aceitar a unidade no interior do mesmo corpo político resultava em um cenário altamente desfavorável para o governo do Rio de Janeiro, empenhado que estava na promoção da aliança entre portugueses europeus e americanos.

As manifestações de descontentamento não tardaram, caracterizando-se como expressão de um nacionalismo que privilegiava a soberania da nação portuguesa em detrimento do projeto imperial luso-brasileiro. A elevação, na perspectiva de alguns grupos do Reino europeu, ao mesmo tempo em que atestava a importância do Brasil, assinalava também a condição rebaixada de Portugal dentro do Império. Cartas enviadas ao Rio de Janeiro pelos governadores do Reino, campanhas realizadas pelos jornais portugueses publicados no exílio e a conspiração militar liderada por Gomes Freire de Andrade, em 1817 (“o primeiro sinal concreto de que as tensões no interior do sistema político luso-brasileiro se aproximavam do ponto de ruptura”), ${ }^{108}$ rapidamente reprimida, traduziram as fissuras no esforço para a manutenção da unidade entre os domínios da monarquia lusa.

Todavia, enquanto em Portugal, os setores mercantil e manufatureiro, além da nobreza, reclamavam a ausência do monarca e reagiam contra a nova medida agravando ainda mais o clima de insatisfação; no Brasil, a notícia da elevação foi recebida com celebrações e regozijos em diversas vilas e cidades. No Rio de Janeiro, os principais da corte reuniram-se em um festivo beija-mão e a cidade ficou iluminada durante três dias.

\footnotetext{
${ }^{108}$ Valentim Alexandre examina as queixas sobre a situação política e econômica de Portugal - aprofundadas após a submissão política do antigo Reino ao Brasil - oriundas dos setores mercantil e manufateiro, além da nobreza, que se sentiam prejudicados ante a ausência do rei e das medidas tomadas no Rio de Janeiro desde a sua instalação. Op. cit (especialmente capítulo I, parte IV). A citação consta da página 445. Ver também: Ana Cristina B. de Araújo, op. cit., 1992; Márcia Regina Berbel. A Nação como artefato. Deputados do Brasil nas Cortes portuguesas, 1821-1822. São Paulo: Hucitec/Fapesp, 1999; Wilma Peres Costa, op. cit., 2003; Ana Rosa Clocet da Silva, op. cit.
} 
Em Pernambuco, o governador ordenou festejos à altura do evento. Recife e Olinda foram iluminadas, realizou-se o Te-Deum e uma das praças foi rebatizada com o nome de Praça da União. Em São Paulo, os vereadores, em meio às comemorações, registraram o reconhecimento dos habitantes pela elevação. Câmaras de diversas vilas e cidades enviaram seus representantes para cumprimentar o príncipe regente demonstrando a importância da medida para os habitantes da parte americana do Reino. ${ }^{109}$

O conde dos Arcos foi comunicado da decisão por meio da correspondência de 29 de dezembro de 1815 enviada pelo marquês de Aguiar. No ano seguinte (27 de fevereiro), a Idade d'Ouro do Brazil noticiou os festejos em comemoração ao ato de elevação do Brasil à categoria de Reino. O Senado da Câmara convocou todos os moradores a iluminarem as casas por três noites consecutivas e, entre outras solenidades, celebrou-se o Te deum em presença do governador e demais autoridades, além de enviar dois representantes para cumprimentar o príncipe por tão sábia decisão. A cidade, segundo a gazeta, estava em festa em reconhecimento "à Beneficiência do Soberano”. ${ }^{110}$ Os residentes eram convidados a participar dos festejos por meio da divulgação do edital da câmara conclamando-os para as festas e uma lista de pessoas que celebraram a decisão, encabeçada pelo brigadeiro Felisberto Caldeira Brant Pontes, foi publicada. Na edição de $1^{0}$. de março, o periódico registrou também que "os Navios surtos neste Porto se embandeiraram com muita variedade, e galhardia; e a maior parte deles deram estrondosas salvas por várias vezes, sem que o Senado fizesse nisso a menor despesa. Foi pura devoção, e reconhecimento particular de seus Donos”. ${ }^{111}$ Mas a chegada da notícia sobre a morte da Rainha d. Maria I, ocorrida em 20 de março, interrompeu os festejos que pelo visto, seriam prolongados pois, em maio desse ano, o governo deliberou por "mandar suspender as demonstrações públicas que se faziam do regozijo das disposições para as ulteriores festas que se projetavam pela elevação do Brasil a Reino logo que nessa cidade

\footnotetext{
${ }^{109}$ Os registros sobre as diversas comemorações podem ser vistas em: Maria de Lourdes Viana Lyra, op. cit., p. 158-159; Pedro Calmon, op. cit., p. 1405 (nota 45); Luis Gonçalves da Silva (padre Perereca), op. cit., p. 347.

${ }^{110}$ Idade d'Ouro do Brazil, n. 17, 27 de fevereiro de 1816. Bahia: na Tipografia de Manoel da Silva Serva (disponível em www.bn.br). Em 15 de março de 1816 o Senado da Câmara de Salvador relatou ao príncipe Regente os festejos ocorridos na cidade. APEB. Seção de Arquivo Colonial e Provincial. Cartas do Senado a Sua Majestade. Maço: 132 (1742-1823). No ano anterior (15 de janeiro), o conselho já havia comunicado ao príncipe a aprovação da construção de um monumento em praça pública em homenagem à chegada da família real na cidade. O primeiro a ser inaugurado no Brasil, segundo Pedro Calmon. Op. cit., p. 1419.

${ }^{111}$ Idade d'Ouro do Brazil, n. 18, $1^{\circ}$. de março de 1816. Bahia: na Tipografia de Manoel da Silva Serva (disponível em www.bn.br). Sobre os festejos: Idade d'Ouro do Brazil, n. 17, 27 de fevereiro de 1816. Bahia: na Tipografia de Manoel da Silva Serva. APEB. Setor de Microfilmes.
} 
se espalhou a infausta notícia do falecimento da Augusta Senhora Rainha”, conforme referido em carta do marquês de Aguiar, obtendo plena aprovação do regente. ${ }^{112}$

Ao elevar o Brasil a Reino, d. João buscava conciliar os interesses dos habitantes da parte mais proeminente da monarquia lusitana ao mesmo tempo em que reforçava a coesão do Império português. Para o novo Reino, a questão não era meramente formal ou de certificação de uma situação posta desde 1808. O acontecimento ampliou as perspectivas abertas anos antes, além de reafirmar a sua importância no conjunto dos domínios portugueses. Reunidos sob o mesmo estatuto político, europeus e americanos exercitariam diferentes formas de construção da unidade no interior da mesma nação portuguesa. Para alguns contemporâneos, a exemplo do economista José da Silva Lisboa e do padre Perereca, a condição econômica do Brasil era incompatível com a denominação de colônia, além do que seus habitantes possuíam os mesmos laços de sangue, vínculos de família, religião, língua e eram súditos do mesmo rei. A carta de lei desfazia, portanto, uma anomalia política oriunda do sistema colonial. ${ }^{113}$ Para a Coroa, a medida poderia trazer benefícios não apenas para a monarquia bragantina como tentou demonstrar o representante português em Madri ao tentar angariar apoio do ministro espanhol Cevallos. Segundo ele, a elevação devia ser “considerada por S.M. não só como muito vantajosa para a Coroa portuguesa em geral, mas como podendo essencialmente contribuir para a tranqüilidade, e segurança da Monarquia Espanhola”. 114

Mas, como era de se esperar, a elevação não dissipou a expectativa pelo retorno do príncipe a Portugal que somente se agravaria nos anos seguintes. Tobias Monteiro diz que no processo de negociações com a Áustria para encaminhar o casamento de d. Pedro com uma das herdeiras daquele trono, d. João transmitiu instruções confidenciais ao marquês de Marialva, embaixador português na Áustria a fim de dissuadir Francisco I de que a corte portuguesa pretendesse permanecer ainda por muito tempo na América. Por meio delas, Marialva deveria transmitir a intenção de El Rei de voltar à Europa "logo que houvesse conseguido preservar o Brasil do contagioso espírito revolucionário que conflagrava pelas colônias espanholas e, outrossim, tivesse inteiramente estabelecido e

\footnotetext{
${ }^{112}$ Correspondência do marquês de Aguiar ao conde dos Arcos, em 11 de junho de 1816. APEB. Seção de Arquivo Colonial e Provincial. Cartas Régias enviadas à capitania da Bahia. Maço: 118 (1816)

${ }^{113}$ Cf. Luis Gonçalves dos Santos (Padre Perereca), op cit., p. 347-348; José da Silva Lisboa, op. cit., 1818, p. 116.

${ }^{114}$ Citado por João Paulo G. Pimenta, op. cit., 2003, p. 191.
} 
consolidado o novo sistema que tinha começado a pôr em prática para o fim de estreitar os enlaces entre Portugal, o Brasil e as demais possessões da coroa”. ${ }^{115}$

Por outro lado, um ano depois da oficialização do Reino Unido, o viajante francês Louis-François de Tollenare, após passar um curto período em Portugal, esteve em Pernambuco onde acompanhou os encaminhamentos do movimento revolucionário naquela província e depois seguiu para a Bahia permanecendo até o início de 1818. Em 31 de agosto de 1817 registrou em seu diário:

Sabe-se que o rei de Portugal, cessando de considerar o Brasil como uma colônia, desde que para aqui transferiu a sede do governo, elevou-o à dignidade de reino, e reuniu as suas possessões da Europa, Brasil e Algarves. Daí resultou que os portugueses e os brasileiros se tornaram concidadãos e se lhes recomenda que se tratem como irmãos. Como é, pois, que a administração trata os dois países como estranhos um ao outro? $?^{116}$

Como negociante da cultura do algodão, Tollenare questionava as diferenças de taxas e tributos de algumas mercadorias, como por exemplo, o fumo e o algodão, que lhe pareciam inconcebíveis após a unificação implementada pela Coroa portuguesa. De fato, esse constitui um dos aspectos fundamentais na relação estabelecida entre as partes do Reino depois de 1815. A falta de uniformidade interna, impedindo que as regiões realizassem maior comunicação entre si em razão das diferenças tarifárias, assim como a permanência da estrutura administrativa anterior, reforçam a leitura que a criação do Reino Unido não teve significância na prática. ${ }^{117}$ Todavia, para além dessa problemática, é lícito interrogar: Qual o real dimensionamento da institucionalização do Brasil Reino para os habitantes da sua porção americana? Essa questão adquire uma importância essencial na compreensão dos processos de aprendizado e de maturação políticos que se agudizaram no momento em que o aprofundamento da crise de sustentação do Império luso-americano - como expressão da desestruturação do Antigo Regime na América aparece para os protagonistas como possibilidades de exercício das alternativas políticas possíveis. $\mathrm{O}$ ato em si pode não ter tido maiores conseqüências práticas a ponto de estudiosos importantes do período não se manifestarem a respeito, como já mencionado. No entanto, o que passou despercebido em grande parte das análises sobre o assunto foi o amplo sentido político da determinação, tanto no que diz respeito à sua dimensão

\footnotetext{
${ }^{115}$ Citado por Tobias Monteiro, op. cit., p. 227.

${ }^{116}$ Louis-François de Tollenare, op. cit., p. 228.

${ }^{117}$ Maria Beatriz Nizza da Silva; Kenneth Maxwell. “A Política”. In: Maria Beatriz Nizza da Silva (Coord.)., op. cit., 1986, p. 333-395.
} 
estratégica no conjunto das relações internacionais quanto no âmbito interno para os habitantes do Brasil Reino. ${ }^{118}$

Assim como 1808, a elevação do Brasil a Reino, possui uma significância que extrapola os interesses circunstanciais da Coroa portuguesa pois ambos vinculam-se às demandas de um mundo convulsionado nessas primeiras décadas do Oitocentos. Afinal, não se pode perder de vista que esses acontecimentos ocorreram simultaneamente às alterações no plano internacional relacionando-se, num primeiro momento, à expansão do Império napoleônico e, em conseqüência, da ampliação das guerras; e num segundo, ao contexto do restauracionismo sustentado pelas decisões do Congresso de Viena. ${ }^{119}$

A conjuntura no pós-guerra demandou novos posicionamentos da monarquia portuguesa sobretudo em suas articulações políticas no continente europeu. De fato, a relação com a Espanha somente deteriorou nos anos seguintes exigindo novas articulações com a Inglaterra dado que Portugal necessitaria do seu apoio para solucionar os conflitos que se agravavam na Bacia do Prata. Por essa época, os residentes do Brasil presenciavam, cada vez mais, a dilatação do papel desempenhado pela cidade do Rio de Janeiro como centro de convergência do Império, o que certamente não deixaria de provocar reações de portugueses do velho reino e, internamente, das capitanias do Norte, aprofundando as transformações políticas no interior do recém-criado Reino Unido.

\subsection{A política da desagregação: a Bahia e a revolução pernambucana}

Em 14 de março de 1817, o tenente-coronel e comandante da comarca de Alagoas, Antônio José Vitoriano Borges da Fonseca, encaminhou uma correspondência ao conde dos Arcos com o seguinte teor:

No dia 12 do Corrente mês recebi da Câmara da Vila de Maceió um ofício em que me comunicava o que consta da declaração que junta vai. Esperava eu algumas notícias mais certas; e por me ter participado o Ouvidor e Corregedor da Comarca que mandou prender os dois homens que fizeram a declaração inclusa, não quis logo dar parte a V.Exa. o que agora faço por ter repetida esta notícia hoje com a parte que agora recebo do Capitão-mor da Vila do Porto de Pedras, cuja cópia também inclusa

\footnotetext{
${ }^{118}$ István Jancsó; João Paulo G. Pimenta, op. cit.; Ana Rosa Cloclet da Silva, op. cit., (notadamente capítulo 4).

${ }^{119}$ Demétrio Magnoli. O corpo da pátria. Imaginação geográfica e política externa do Brasil (1808-1912). São Paulo: Editora da Unesp-Moderna, 1997.
} 
vai por mim assinada, ficando-me o original, à vista do que V.Exa. verá a atenção que elas merecem. ${ }^{120}$

As notícias davam conta das últimas ocorrências em Pernambuco e comprovam que as autoridades vizinhas, sobretudo o governador da Bahia, foram logo informadas sobre a dimensão do movimento iniciado no dia 6 daquele mês. As alterações políticas instituídas na capitania confirmavam as suspeitas do vigor e do perigo de suas motivações para a estabilidade da monarquia portuguesa resultando, a partir de então, na mobilização das forças de resistência.

As condições que propiciaram a emergência da Revolução pernambucana e a sua natureza política continuam a desafiar os estudiosos dada a riqueza de elementos que ainda demandam investigação. Essa perspectiva contrasta com as interpretações que insistem em limitar o acontecimento a seu viés regional e que, em função disso, não teria tido maior expressão no conjunto das possessões do Brasil Reino e, mais particularmente, nas capitanias do Norte, sendo tratado no mais das vezes com certo desprezo. ${ }^{121}$ Não cabe aqui discutir essas questões, ainda que não se possa furtar ao registro dos princípios defendidos pelos protagonistas do movimento e a sua importância para o tema em estudo. Além do mais, uma presumível articulação entre os líderes revolucionários e pessoas proeminentes na Bahia é um dado que não pode ser menosprezado a despeito de algumas questões ainda permanecerem obscuras. É nesse aspecto que reside nosso principal interesse.

Pernambuco era uma das regiões mais prósperas do Império português mas, ao lado das capitanias genericamente denominadas do Norte, foi perdendo prestígio principalmente após a instalação da Corte portuguesa no Rio de Janeiro. Entretanto, nas primeiras décadas do Oitocentos ainda ocupava um papel econômico de grande relevância, além de dispor de uma ampla rede administrativa que cobria vasta região. A capitania, que à época incluía a comarca de Alagoas, também sempre fora um espaço de ebulição

\footnotetext{
${ }^{120}$ APEB. Seção de Arquivo Colonial e Província. Cartas ao Governo. Maço: 235 (1817-1818).

${ }^{121}$ Francisco Adolfo de Varnhagen, por exemplo, não esconde sua repulsa pelo tema: "É um assunto para o nosso ânimo tão pouco simpático que, se nos fora permitido passar por ele um véu, o deixaríamos fora do quadro que nos propusemos traçar”. Op. cit., 1953, p. 150. Para uma análise mais recente e rigorosa, ver: Denis Antônio Bernardes de Mendonça, op. cit. (especialmente capítulo III). João Paulo Garrido Pimenta retoma a discussão sobre 1817 apontando novos elementos sobre a sua importância no contexto de crise do Antigo Regime (op. cit., 2003). Nessa direção, ver também: Luiz Geraldo Santos da Silva. "O avesso da Independência: Pernambuco (1817-1814)”. In: Jurandir Malerba (Org.)., op. cit., p. 343-384. O estudo pioneiro realizado por Carlos Guilherme Mota permanece indispensável: Nordeste 1817. Estrutura e argumentos. São Paulo: Perspectiva, 1972a. Ver também: Evaldo Cabral de Mello. A outra independência. O federalismo pernambucano de 1817 a 1824. São Paulo: Editora 34, 2004; Amaro Quintas. "A agitação republicana no Nordeste”. In: Sérgio Buarque de Holanda (Dir.), op. cit., p. 206-237. Pedro Calmon, op. cit. Ignácio Accioli, op. cit., v. III. Relatos coevos sobre o acontecimento encontram-se em Louis-François de Tollenare, op. cit.
} 
política; daí alguns estudiosos se recusarem a circunscrever a insurreição a uma datação precisa por considerar que certas questões centrais do movimento antecederam a 1817 e ultrapassaram essa data, retornando em manifestações posteriores. Além disso, a violenta e duradoura repressão desencadeada pelas autoridades régias, mesmo após a derrota dos rebelados, evidencia que o seu significado foi efetivamente mais amplo do que o seu período de vigência. ${ }^{122}$

De qualquer maneira, foi em 6 de março que estourou o motim militar na capital, Recife, sede do centro administrativo e de grande dinamismo comercial já que possuía um dos principais portos que centralizava os negócios de uma vasta área, dando início a um amplo movimento que abalou os fundamentos do Estado português. No dia seguinte, um governo provisório foi constituído com a representação dos principais segmentos da sociedade: agricultura, comércio, forças armadas, clero, magistratura e, de imediato, implementou uma série de medidas para a sustentação do novo governo. A orientação das lideranças era pela adoção do sistema republicanista e, nesse sentido, "nova bandeira, novos tratamentos e novos costumes deveriam ser implantados”, assim como o estabelecimento de determinados princípios que o diferenciaria da monarquia absolutista, a exemplo da liberdade de consciência, de imprensa, da necessidade de uma assembléia constituinte para elaboração da constituição e da desregulamentação do alvará que tratava sobre a tributação de vários produtos. O governo recém-instituído desde o início procurou não apenas se fortalecer internamente buscando o apoio da população por meio de suas decisões, como também pretendeu espalhar sua influência pela Paraíba, Rio Grande do Norte e Ceará evidenciando que o projeto almejava a uma grande articulação para edificar uma só República, além de expor que outros vínculos econômicos, políticos, sociais, estabeleciam-se para além dos marcos territoriais da capitania de Pernambuco. Ademais, buscou auxílio externo enviando representantes para os Estados Unidos e provavelmente para a Grã-Bretanha. ${ }^{123}$

\footnotetext{
${ }^{122}$ Denis Antônio de Mendonça Bernardes, op. cit; Carlos Guilherme Mota, 1972a, op. cit.

${ }^{123}$ Idem, Ibidem. João Paulo Garrido Pimenta contesta a informação que um emissário do governo (Félix José Tavares de Lima) teria sido enviado também a Buenos Aires, sem, contudo, desprezar o interesse em estabelecer contato com as lideranças do Prata. Op. cit., 2003, p. 221. A Junta Governamental de 5 membros foi formada por: Domingos José Martins, representando o comércio; João Ribeiro de Pessoa de Mello e Montenegro, o clero; Manoel Correia de Araújo, os proprietários de terras; José Luiz de Mendonça, a Justiça e Domingos Teotônio Jorge, o exército. Esse último, ao lado de Francisco de Paula, foi um dos mais importantes líderes militares da rebelião. A junta foi dissolvida em 18 de maio de 1817 com o avanço das forças realistas e a recusa do acordo de capitulação, delegando amplos poderes a Domingos Teotônio Jorge. Para o historiador Marco Morel, a inspiração matricial do movimento era: "o Diretório da Revolução Francesa (com sua República colegiada e repúdio simultâneo ao absolutismo tradicional e ao radicalismo revolucionário), bem como no federalismo norte-americano (republicano e híbrido entre aristocracia
} 
As razões imediatas para a eclosão do movimento apontadas pela historiografia indicam a conjunção de alguns fatores que confluíram para a insatisfação de indivíduos de diferentes grupos, com destaque para a diminuição da renda das classes proprietárias agrícolas devido à queda de preços de seus produtos e ao aumento do custo da importação de escravos, bem como o encarecimento de produtos de subsistência dificultando a vida da população em geral que ressentia do aumento de impostos ocorrido após a instalação da família real portuguesa no Brasil. De fato, o mecanismo de arrecadação fiscal também seria ajustado nessa nova conjuntura cujo centro político, agora instalado no Rio de Janeiro, necessitava se impor sobre as outras partes da América. Já em 1808 o governo do Rio de Janeiro determinou a cobrança do imposto de $600 \$ 00$ (seiscentos réis) por arroba de algodão exportada e de $400 \$ 00$ (quatrocentos réis) por arroba de tabaco, inclusive aquela consumida pelos residentes de Bahia e de Pernambuco. A Carta Régia de 17 de outubro de 1812, fixou o montante da remessa mensal em dinheiro que as duas capitanias, além do Maranhão, deveriam enviar para a corte a partir de janeiro do ano seguinte. Segundo o documento, a quantia, de 35:000\$000 (trinta e cinco mil contos de réis) para as duas primeiras e 25:000\$000 (vinte e cinco mil contos de réis) para a última, não deveria ser utilizada para "fazer pagamento algum de qualquer natureza que seja pertencente às despesas da mesma capitania, sem que esta quantia mensal [...] se ache completa no cofre, e à disposição do meu Real Erário”. ${ }^{124}$ Além do mais, Pernambuco, ao lado da Bahia, era uma das capitanias que mais acumulava tributações em nome da Coroa. Certamente essas questões, entre outros sinais de debilidade, somados a um universo de difusão dos ideais liberais propiciado pela formação de espaços de sociabilidade, sobretudo com a criação do seminário de Olinda alguns anos antes da chegada da família real à América, foram fundamentais na maturação do movimento contra o Império português. ${ }^{125}$

escravista e democracia política), sem esquecer a evidente sintonia com as guerras de independência na América hispânica”. Cf. Marco Morel. “República de 1817” (disponível em www.historiacolonial.arquivonacional.org.br).

${ }^{124}$ Carta Régia de 17 de outubro de 1812 - Fixa as consignações mensais em dinheiro que as capitanias da Bahia, Pernambuco e Maranhão devem remeter ao Real Erário (disponível em www.camara.org.br). Sobre os impostos do tabaco e do algodão. APEB. Seção de Arquivo Colonial e Provincial. Ordens Régias. Maço: 105 (1808-1809).

125 Denis Bernardes, op. cit.; João Paulo Garrido Pimenta, op. cit., 2003. A capitania fora uma das responsáveis pela participação na expedição enviada para a conquista de Caiena. Documento citado por Denis Bernardes informa que " 547 praças tirados dos regimentos de infantaria do Recife e de artilharia de Olinda, e dos regimentos auxiliares de brancos, pardos e pretos de segunda linha [...]” seguiram para esse destino, ressaltando que foi no regimento de artilharia que teve início a revolução, "na qual a participação do citado regimento foi praticamente unânime, o que motivou sua posterior dissolução”. Segundo João Manuel Pereira da Silva, ao chegarem na pequena cidade de Caiena, os portugueses encontraram duas tipografias que funcionavam regularmente, "enquanto que nenhuma possuía as cidades muito mais populosas do Rio de Janeiro, Bahia e Pernambuco durante todo o período colonial”. História da fundação do Império brasileiro. 
Para o historiador Luiz Geraldo Santos da Silva, no entanto, os fatores essencialmente fiscais e econômicos devem ser relativizados nas tentativas de explicação da ruptura com o poder monárquico em 1817. Conforme afirma, o principal elemento nesse processo seria um sistema de representação mental caracterizado por distintas fases desde o século XVII com a Guerra de Restauração (1650) e que no contexto do Reino Unido se manifestou como “o mais importante instrumento ideológico de justificação do fim do domínio da coroa lusitana no norte da América portuguesa em 1817”. Da mesma maneira, contesta a interpretação que atribui ao antilusitanismo um dos componentes manifestos nas lutas políticas em Pernambuco no período de 1817-1822, considerando que entre portugueses do Brasil e portugueses de Portugal a unidade foi "uma meta constante e firmemente perseguida”. ${ }^{126}$ Questão importante nessa conjuntura política. Mas, por ora, é preciso reter que nem todos os residentes, especialmente das capitanias do Norte, pareciam satisfeitos com a presumida tranqüilidade do Brasil Reino poucos anos após a sua criação. E, no caso específico de Pernambuco, o arco de alianças envolvendo desde grandes proprietários de terras, como os irmãos Cavalcante; figuras expressivas da sociedade local, como Antônio Carlos Ribeiro de Andrada então respondendo pela ouvidoria da comarca de Olinda e Antônio Morais e Silva (o dicionarista que mais tarde passaria para as fileiras da contra-revolução); padres (com destaque para João Ribeiro de Pessoa de Mello e Montenegro); militares; homens livres pobres e escravos, indicam que as questões mobilizadoras eram também amplas e, certamente, teriam implicações na condução do movimento.

Desse modo, além das motivações dos rebeldes, a natureza do processo revolucionário, com seus avanços e recuos, constitui também uma questão dissonante. A diversidade de posições políticas dos insurretos - um aspecto inerente aos momentos de ruptura - e entre os próprios líderes, muitos deles oriundos de setores proprietários da capitania, resultou na expressão de tendências mais radicalizadas e posições mais moderadas. Isso, segundo Carlos Guilherme Mota, teria influenciado na tomada de decisão sobre a escravidão o que acabou "por provocar atropelos e, finalmente, retração nos próprios insurgentes mais opulentos”. Para esse historiador, a possibilidade de abolição da

Rio de Janeiro: B. L. Garnier Editor, 1865, p. 72. Wilma Peres Costa analisa o peso e o significado das tributações no processo de Independência do Brasil. In: István Jancsó (Org.)., op. cit., 2003, p. 143-193.

${ }^{126}$ Luiz Geraldo Santos da Silva, op. cit., p. 362 e 372. Tobias Monteiro lembra que na proclamação dos rebeldes direcionada ao povo "não continha a palavra Brasil, nem a palavra Independência, nem a palavra República; não aludia a nenhuma província, no fim dizia que a pátria era comum e todos os seus filhos descendiam dos valorosos lusos: 'Sois portugueses, sois americanos, sois brasileiros, sois pernambucanos". Cf. História do Império. O Primeiro Reinado. Belo Horizonte: Itatiaia; São Paulo: Edusp, t. 1, 1982, p. 54. 
escravatura era questão controversa entre as lideranças e o incitamento de negros por parte de alguns propiciara a quebra da frágil unidade dos grandes proprietários, abrindo espaço para a contra-revolução. ${ }^{127}$ Em outras palavras, havia diferentes perspectivas no interior do processo revolucionário e na medida em que uma tendência mais radical, popular, pretendeu aprofundar os rumos do movimento, foi obliterada pelos defensores do sistema liberal favorecendo a rearticulação das forças repressivas do Estado.

Nessa discussão, Denis Bernardes considera que mesmo com os limites sociais e políticos do movimento, não se pode diminuir o alcance da sua transgressão nos marcos de uma deslegitimação do poder real. Em suas palavras: "O sentido essencial de 1817 reside neste aspecto: a possibilidade de instauração de uma nova ordem política, autolegitimada, independente e contra tudo o que até então fundara a existência do poder e das identidades políticas dos súditos da monarquia”. ${ }^{28}$ Ou seja, as condições de organização política da sociedade pernambucana, e de suas aliadas, foram colocadas pelo avesso, ou pelo menos, assim foram concebidas no decreto de convocação de uma Assembléia Constituinte, mas que já apresentava alguns aspectos de regulação dos poderes do novo Estado republicano.

Como a posição ambígua por parte de determinadas lideranças acerca da escravidão interferiu na condução e na radicalidade do movimento, é um ponto importante a ser considerado na análise sobre suas contradições internas. Ainda assim, parece indiscutível que a experiência política vivenciada por ampla parcela da população foi extremamente significativa e inovadora considerando as circunstâncias de submissão política a que estava submetida até então e a dimensão da ameaça à ordem monárquica absolutista. Mais do que isso, é fundamental apreender a dimensão desse acontecimento no conjunto das transformações políticas que tiveram lugar desde fins do século XVIII e que foram absorvidas de maneiras distintas em amplas áreas do mundo Ocidental mas que possuíam uma mesma base referencial. É nessa direção que João Paulo Garrido Pimenta aponta para o significado político da Revolução pernambucana enquanto um componente expressivo da conjuntura de desestruturação do Antigo Regime na América revelando "a profundidade da modalidade luso-americana” dessa crise, "não apenas receada, mas sobretudo constatada a partir da aproximação do Brasil com o mundo hispanoamericano". ${ }^{129}$ Em sua análise, não se pode negar que independente de os homens da época serem partidários ou não das alterações incorporadas ao universo da política do período

\footnotetext{
${ }^{127}$ Carlos Guilherme Mota, op. cit., 1972a, p. 69.

${ }^{128}$ Denis Antônio de Mendonça Bernardes, op. cit., p. 206.

129 João Paulo Garrido Pimenta, op. cit., 2003, p. 222 (grifos do autor).
} 
“percebiam-nas como produto de um tempo em acelerado ritmo de transformação. É desse modo que o movimento pernambucano é por todos assumido como, efetivamente, uma revolução no sentido mais moderno do termo, associado a uma subversão radical no estado das coisas tal qual aquele momento existente". ${ }^{130}$

A partir dessa perspectiva é que se pode presumir que alguns residentes da Bahia, além de perceber essas rápidas alterações também compartilhavam a crença de que algum tipo de mudança pudesse ser efetivada no Reino americano. De fato, existem indícios sobre o possível envolvimento de pessoas da capitania que teriam sido cogitadas pelos rebeldes de Pernambuco como aliadas em potencial para consumar a ampliação do movimento nessa localidade. Caso contrário, como entender o envio de um dos emissários do governo provisório para a capitania poucos dias depois de o movimento ter se iniciado? Ou ainda: O que explicaria a violência da repressão comandada pelo governo local senão uma tentativa de conter a consumação dessa aliança?

Numa das cartas encaminhadas ao governador da Bahia em 14 de março de 1817, em caráter de urgência, o tenente-coronel da comarca de Alagoas, Antônio José Vitoriano Borges da Fonseca, transcreveu parte das notícias transmitidas pelo capitão-mor da Vila de Porto das Pedras, Nicolau Paz Sarmento, em Pernambuco:

Hoje quarta feira 12 do corrente Março recebo a infausta notícia que me dá o Juiz Manoel de Moraes de que no dia 6 do corrente, 5a. feira, houvera um levante em Pernambuco onde mataram vários oficiais e Militares dos principais e grande mortandade no Povo, e que o Ilmo. e Exmo. Sr. Governador se refugiou em a Fortaleza do Brum com alguns cabos principais, o que participo a V.Sa. fazendo expedir três soldados de cavalo de três em três léguas. V.S. me determinará as suas ordens no entanto [ilegível] mando por em todos os lugares povoados presídios reforçados para não passar pessoa alguma e não saírem e nem entrarem Jangadas para fora. A pressa me não dá mais lugar senão em participar V.Sa. ao menos o que me diz o dito juiz. [...]. Era só o que continha a dita parte que fica em minha mão. ${ }^{131}$

Ao que tudo indica foi por meio dessas comunicações, que envolveram também o capitão general e governador da capitania de Sergipe d’El Rey, Luiz Antônio da Fonseca Machado, que o conde dos Arcos foi informado com antecedência sobre a dimensão do movimento e a necessidade de prevenção de possíveis contatos dos rebeldes com a capitania. O documento alerta para a necessidade de proibir a entrada de pessoas e de jangadas e, certamente, isso responde a presteza com que o governador aprisionou o padre

\footnotetext{
${ }^{130}$ Idem, ibidem, p. 125 (grifos do autor).

131 APEB. Seção de Arquivo Colonial e Província. Cartas ao Governo. Maço: 235 (1817-1818).
} 
José Inácio Ribeiro de Abreu e Lima (o padre Roma) que, utilizando esse meio de transporte, foi surpreendido ao desembarcar no porto de Itapoan em Salvador no dia 26 de março. Logo após a sua prisão foi instituído um tribunal militar presidido pelo próprio governador e que teve a participação do major Manoel Pedro de Freitas Guimarães e do brigadeiro Felisberto Caldeira Brant Pontes, entre outros. Julgado e condenado por unanimidade numa rápida ação, o religioso foi fuzilado três dias depois no Campo da Pólvora, antes mesmo de a sentença ser confirmada pelo rei. ${ }^{132}$ Existiriam razões mais contundentes que justificassem a celeridade e inclemência do governador?

No mesmo período, um dos filhos do padre Roma, José Inácio de Abreu e Lima, encontrava-se preso em Salvador desde fevereiro de 1817 acusado de indisciplina na Academia Militar do Rio de Janeiro, se juntando ao pai e a um irmão mais jovem que estava em sua companhia. Mais tarde, após ser libertado tornar-se-ia um dos principais generais de Simon Bolívar nas lutas pela independência da América hispânica. Anos depois, escreveu um Compêndio da História do Brasil, entre outras obras, publicado em 1843, registrando sua compreensão sobre o processo de construção da nação brasileira a despeito de ressaltar a parcialidade da sua análise em virtude da contemporaneidade de muitos fatos abordados, deixando-os, como alerta, para julgamento posterior dos historiadores. Da mesma maneira, esclarece sobre a omissão dos nomes das principais personagens evitando, assim, dissabores.

Ao falar sobre a Revolução de Pernambuco, embora admita que recorreu a alguns escritos sobre o tema, não deixa de emitir suas próprias opiniões considerando a sua experiência política e o fato de ter tido contato com um dos partícipes direto do movimento pouco antes de ser submetido à pena capital. Para ele, as causas principais do movimento foram a rivalidade crescente entre portugueses e brasileiros e a situação política de Portugal que permanecia submetido à sujeição do marechal inglês Beresford. Ademais, a corte do Rio de Janeiro em vez de eliminar os conflitos entre os mesmos súditos

\footnotetext{
${ }^{132}$ Braz do Amaral. Anotações... In: Ignácio Accioli de Cerqueira e Silva, op. cit., p. 249. Luis Henrique Dias Tavares menciona a passagem também por Salvador do pernambucano Manuel Moreira Magalhães que teria por incumbência tomar providências sobre o movimento sem, contudo, fornecer maiores referências. Op. cit., 2001, p. 215. Na primeira notícia sobre os acontecimentos ocorridos em Pernambuco, em $1^{\circ}$. de abril de 1817, a gazeta Idade d'ouro do Brazil divulgou a morte do Padre Roma: “[...] Um sacerdote natural do Recife, já conhecido por sua execranda conduta, denominado José Inácio Romano [...] depois de figurar nesta horrenda cena [o 6 de março em Pernambuco], passou às Alagoas, dizendo que trazia 3.000 homens atrás de si, achou outros como ele, atemorizou o povo e completou ali a sua infernal missão. Quis a Providência que este malvado saltasse na barra da Bahia no dia 26 de março, aonde foi preso e conduzido ao segredo. E exposto a uma comissão militar, provados com a maior evidência os seus crimes, sofreu sábado a pena de morte. Iremos dando ao público o que se passar a tal respeito. Nesta cidade resta a maior vigilância no governo, a mais incansável lida na segurança pública e a mais reconhecida fidelidade em todos os habitantes”. Citado por Maria Beatriz Nizza da Silva, op. cit., 2005, p. 283-284.
} 
“fomentava-se, crendo que só a desunião dos ânimos poderia perpetuar o seu domínio". ${ }^{33}$ O plano para a sublevação havia sido traçado pela maçonaria para ser executado em Portugal, verificado com a conspiração de Gomes Freire de Andrade, e no Brasil, denotando a insatisfação existente nos dois lados do Reino. Na parte americana o descontentamento era crescente e era previsível que mais cedo ou mais tarde conflitos violentos viriam à tona. Como conhecedor das transformações políticas ocorridas nas Américas acreditava que era impossível o Brasil permanecer inerte "diante de exemplos tão estimulantes como os Estados Unidos e as disputas nas colônias espanholas”134 e Pernambuco, por possuir o maior número de loges, reunia as condições favoráveis para a consecução do projeto.

Naturalmente Abreu e Lima daria destaque à atuação de seu pai, sobretudo sua passagem infeliz por Salvador. Segundo ele, apesar de o movimento ter se ampliado para a Paraíba e Rio Grande do Norte, ainda necessitava de impulso “pela parte do Sul” e onde era "justamente tudo havia que recear". O fracasso da missão do padre Roma pode ser atribuído à sua inexperiência, assim como de seus correligionários, "nos manejos ocultos das revoltas", a despeito do seu vasto conhecimento, pois, "sem nenhum disfarce apresentou-se sempre, desde que saiu do Recife, como se fosse o emissário de um governo autorizado”. No entanto, essa imperícia não significa que cumpria a missão sem nenhuma referência das pessoas a quem deveria recorrer. Abreu e Lima não apenas afirma que o emissário levava documentos ("não só proclamações como várias cartas para indivíduos relacionados com os liberais de Pernambuco”), que foram jogados à água num rasgo de perspicácia, como também mostra-se indignado ao constatar que "isto só serviu para alentar na covardia aqueles mesmos, que o deixaram sacrificar sem nenhuma mostra de gratidão”. Segundo informa, o conde dos Arcos possuía a cópia da ata da eleição do governo provisório de Pernambuco cujo nome do padre José Inácio aparecia em segundo lugar. ${ }^{135}$

\footnotetext{
133 J. I. de Abreu e Lima. Compêndio da História do Brasil. Rio de Janeiro: Eduardo e Henrique Laemmert, t. 1, 1843, p. 272-273. O livro é dedicado ao Imperador D. Pedro II "em sinal de profundo respeito e da mais pura afeição e lealdade”. Ao explicitar o seu método de abordagem, Abreu e Lima afirma que fez uso de algumas obras para compor o primeiro compêndio da História do Brasil que, por ser uma jovem nação, ainda não possuía uma literatura própria.

${ }^{134}$ Idem, ibidem, p. 273.

${ }^{135}$ Idem, ibidem, p. 284. Em nota de rodapé, Abreu e Lima descreve os últimos dias do Padre Roma: "Meu pai foi preso ao anoitecer de 26 de Março; no dia seguinte fizeram-se todas as perguntas do costume, confrontação de testemunhas, e nomeou-se a Comissão Militar, que o devia julgar; no dia 28 foi condenado à morte, e passou para o Oratório às três horas da tarde; foi fuzilado às oito da manhã do dia 29. No momento em que escrevo estas linhas, assalta-me todo o horror daquela tremenda noite, em que fui quase companheiro da vítima: era eu que parecia o condenado, e não ela. Tenho visto morrer milhares de homens nos campos de
} 
Ainda que se argumente que as motivações filiais influíram na sobrevalorização de Abreu e Lima quanto ao papel desempenhado por seu pai, é preciso admitir que o seu testemunho é perfeitamente condizente com as possibilidades colocadas naquele momento, quais sejam, a presença de indivíduos na Bahia partidários dos mesmos ideais dos líderes de Pernambuco. Em carta de 15 de junho de 1817, João Lopes Cardoso Machado, físicomor de Recife, informou que o padre Roma "não declarou os nomes das pessoas para quem iam sessenta cartas, que levou sem nome, mas assinadas por Domingos Martins e o [Governo] provisório”. ${ }^{136}$ O fato de o movimento não ter se consumado na Bahia indica que as estratégias utilizadas pelas autoridades régias foram mais eficientes do que uma possível articulação entre os simpatizantes do movimento, não obstante a capitania ter sido considerada pelos patriotas, como se autodenominavam os rebeldes pernambucanos, uma importante aliada. E certamente, como já dito, essa avaliação não era de toda descabida. Um dos participantes da revolução, o padre Francisco de Sales Pereira da Silva, encarcerado em Salvador, ao ser interrogado sobre sua saída pelas ruas da vila do Limoeiro (em Pernambuco),

[...] com uma carta fechada na mão, dizendo que nela seu irmão the mandara dizer, que a cidade da Bahia era a favor de seu novo Estado de Rebeldes, e que também o era o exército que dela vinha, e que sua majestade a quem dava o nome de Pai João não tinha se não uma fragata velha e que indo algumas pessoas na sua casa para que lhe deixasse ler, ele lhes dissera que a queimara, mas que perguntassem a Domingos Mendes, que o tinha lido. Respondeu, que não saia à rua com carta alguma fechada, na sua mão, nem disse a pessoa alguma que a tinha queimado, e perguntassem a Domingos Mendes o que ela continha, nem disse coisa alguma da Bahia, e exército, nem também da Fragata de sua majestade, que sempre respeitou, e nunca lhe tratou por Pai João. ${ }^{137}$

\footnotetext{
batalha, e muitos nos suplícios, mas nunca presenciei tanta coragem, tanta abnegação da vida, tanta confiança nos futuros destinos da sua pátria, tanta resignação enfim; era meu pai que me animava, porque eu parecia inconsolável [...]. Durante o Conselho protestou contra a sua competência, defendeu-se sem inculpar ninguém, e negou-se a todas as sugestões, que lhe fizeram, para descobrir o objeto da sua missão; no Oratório ninguém lhe ouviu uma queixa contra pessoa alguma, e no lugar do suplício excedeu em longanimidade a todos quantos o precederam na mesma desgraçada sorte. Os Baianos viram como morreu o homem livre, a lição devia ficar-lhe impressa”. Idem, ibidem, p. 284-285. Em 1861 Constantino do Amaral Tavares retratou os últimos momentos do padre Roma no drama histórico: Tempos da Independência. Instituto Geográfico e Histórico da Bahia. Salvador, 2000 (Edição fac-similar).

${ }^{136}$ Citado por Denis Bernardes, op. cit., p. 182 (nota 121).

137 Auto de perguntas ao padre Francisco de Sales sobre sua participação durante a revolução pernambucana de 1817, em 23 de janeiro de 1819, Arquivo Nacional, códice 7, v. 9. "Francisco de Sales Pereira da Silva era natural do Recife, morador da vila do Limoeiro, da comarca de Olinda, e vigário condecorado com o Hábito de Cristo. Durante a insurreição pernambucana, exortou o movimento, chegando a entoar o Te Deum em louvor à revolução em sua igreja matriz. Continuou lutando pela causa revolucionária, mesmo após o capitão-mor da mesma vila e arredores voltar-se para a causa dos realistas. Chegou a ser preso como um dos chefes da Revolução e teria sido julgado pela Alçada, não fosse sua
} 
Desse modo, parece admissível a existência de um ambiente político na capitania que favorecesse a expansão do movimento e que necessitava de ser intimidado pelo Estado. Afinal de contas, a Bahia era reconhecida como uma capitania inquieta e muitos de seus habitantes cultivavam o desejo de aprofundar algumas mudanças, evidenciando que a instabilidade política não se limitava a um tumulto isolado da capitania pernambucana. É possível que entre os simpatizantes da Revolução estivessem pessoas ligadas à maçonaria local. Pedro Calmon afirma que, em Salvador, essas organizações secretas tinham entre seus dirigentes Felisberto Caldeira Brant Pontes, Hermógenes Francisco de Aguillar Pantoja, provavelmente Diogo Soares da Silva de Bivar e “com certeza Cipriano Barata”. Reproduz também de uma listagem os nomes de algumas pessoas que estariam comprometidas com o movimento na Bahia constando, além de Felisberto Caldeira Brant e Hermógenes Pantoja, Joaquim Anselmo Álvares Branco, Manuel Inácio da Cunha Menezes, Antônio Ferreira França, Alexandre Gomes Ferrão, Joaquim Inácio de Siqueira Bulcão, entre outros. Militares, senhores de engenho, pessoas ilustradas da capitania que teriam papel significante posteriormente por ocasião do movimento constitucionalista dos anos $1820{ }^{138}$ Novamente um indicativo de que esses indivíduos, de algum modo, experimentavam desde antes um processo de formação política.

De acordo com algumas referências, o conde dos Arcos, após a prisão do padre Roma, teria alertado - e intimidado - algumas pessoas que supostamente poderiam ter algum tipo de envolvimento naquela movimentação. Segundo um dos seus biógrafos, “sem alarde lançou as suas vistas para os que sabia partícipes das idéias revolucionárias, pensou em vigiá-los melhor. Constatou-se ser desnecessário. Eles vinham, quase todos, como bichanos arteiros e ronronantes, minguar-se, apagar-se, sumir-se. Tributavam elogios, apregoavam fidelidades ao soberano, ao melhor dos reis, a Sua Magestade D. João VI”. ${ }^{139}$ Para o historiador Marco Morel, não restam dúvidas que o inquieto Cipriano Barata, por exemplo, estaria entre os conspiradores; fora poupado da violência da repressão e, posteriormente, estaria de volta à cena política da província inclusive denunciando aqueles

\footnotetext{
libertação em virtude da Revolução do Porto, em 1821” (disponível em: www.historiacolonial.arquivonacional.org.br).

${ }^{138}$ Pedro Calmon, op. cit., p. 1440. A citação consta na página 1439.

${ }^{139}$ Rocha Martins, op. cit., p. 59. Além de Cipriano Barata, o conde dos Arcos teria repreendido também o boticário e coronel João Ladislau de Figueiredo e Melo. Marco Morel. Cipriano Barata na Sentinela da Liberdade. Salvador: Academia de Letras da Bahia: Assembléia Legislativa do Estado da Bahia, 2001, p. 95. Ver também Luis Henrique Dias Tavares, op. cit., 2001, p. 215.
} 
que renegavam a experiência de $1817 .{ }^{140}$ Teríamos aqui um comportamento semelhante ao que ocorrera em 1798? Em outras palavras, é possível admitir um recuo de indivíduos que sabidamente compartilhavam das idéias propagadas pelos rebeldes? Talvez. Seja como for, importa destacar que as ações efetuadas pelo governador tiveram um impacto vigoroso tanto no abortamento de uma provável tentativa de adesão da Bahia, quanto no desbaratamento das forças rebeldes em Pernambuco. Essa habilidade e a eficácia de seus instrumentos repressivos fariam dele um dos principais responsáveis pela dizimação do movimento, o que valeria seu devido reconhecimento pela Coroa portuguesa. Pedro Calmon avalia que as ações do governador impediram que a revolução penetrasse, inclusive, no Vale do São Francisco e nas serras de Minas Gerais, consolidando-se. Infelizmente não dispomos de maiores dados que possam atestar essa possibilidade de articulação. Mas as evidências indicam que o receio de a capitania da Bahia pudesse ceder aos apelos de Pernambuco era um sentimento presente na corte do Rio de Janeiro. ${ }^{141}$

É possível também que o conde dos Arcos tenha recebido outras informações sobre Pernambuco ainda antes de a carta enviada pelo tenente-coronel da comarca de Alagoas, pois, em correspondência datada de 28 de março de 1817, d. Antônio de Araújo Azevedo, transmitiu ao governador da Bahia a aprovação do príncipe regente pelas providências que havia tomado para "atalhar a propagação daquele contágio" conforme relatara nos ofícios “de 14 e 16 do corrente”. De acordo com as palavras do conde da Barca, d. João estava muito satisfeito com o seu comportamento inclusive com o fato de ter mandado bloquear o porto de Pernambuco "sem fazer-se cargos de limites de jurisdição", considerando que naquelas circunstâncias nenhum "Funcionário público precisa ser autorizado expressamente quando se trata de manter os direitos da Coroa de S. M. que se acham afrontados pela revolta mais atroz contra as Autoridades constituídas”. ${ }^{142}$ Em outra correspondência, de 6 de abril, o ministro novamente reforçava o apoio do príncipe às decisões do governador ao se antecipar em algumas determinações régias, o que

\footnotetext{
${ }^{140}$ Marco Morel, op. cit., 2001. Sobre a trajetória de Cipriano Barata, ver também: Caio Prado Júnior., op. cit., 1969, p. 201-205; Paulo Garcia. Cipriano Barata ou a liberdade acima de tudo. Rio de Janeiro: Topbooks, 1997; Luis Henrique Dias Tavares, op. cit, 2003, p. 143-185.

${ }^{141}$ Pedro Calmon, op. cit., p. 1438. Alguns dos documentos utilizados aqui constam da biografia do conde dos Arcos escrita por Rocha Martins, "O último vice-rei do Brasil" (op. cit.), com o claro objetivo de enaltecer a sua trajetória política. Ocorre que o autor teve acesso ao arquivo particular de Arcos e transcreve documentos importantes, parcial ou integralmente, que ajudam a compor uma visão mais ampla sobre o biografado numa outra perspectiva, além de tornar mais acessível o contato com essas fontes que, de outro modo, seria muito mais difícil conforme observou anteriormente Frederic Morton, op. cit., 1986.

${ }^{142}$ Correspondência do conde da Barca ao conde dos Arcos, em 28 de março de 1817. Rocha Martins, op. cit., p. 224-225. Segundo esse autor, o alagoano Manuel Ferreira Lima teria denunciado ao governador o envio do padre Roma com as proclamações. Op. cit., p. 56.
} 
evidenciava "sua mui distinta adesão aos interesses de Sua Real Coroa”. Na avaliação do regente, as suas iniciativas eram plenamente justificadas "não só por que a V.Exa. cumpria pela situação da Capitania do seu Governo, a tomar logo medidas para evitar a comunicação do contágio sedicioso da Capitania vizinha, mas também por que muito há de concorrer para o bom êxito o arbítrio de V.Exa. em lançar mão imediatamente dos recursos que à sua disposição para punir um tão sacrílego atentado à dignidade do Trono”. ${ }^{143}$ Isso significa dizer que os meios adotados pelo governador para destruir qualquer tentativa de expansão do movimento teriam total assentimento da Coroa numa clara demonstração de que as providências deveriam ser condizentes com uma situação real de ameaça, tanto da disposição das lideranças rebeldes em concretizar a aliança, quanto do acolhimento que poderiam obter por parte dos residentes na Bahia. A posição da corte fica ainda mais evidenciada com a anuência do príncipe às penalidades impostas ao padre Roma "imperiosamente ditadas pela gravidade das circunstâncias de momento", cujo procedimento do governador, em sua avaliação, "muito terá influído no ânimo dos seus parciais". 144

Desse modo, atuando na Bahia ou em Pernambuco não deixa de impressionar a violência da repressão capitaneada pelo conde dos Arcos, o que repõe a significância desses acontecimentos como manifestação da instabilidade política do recém-criado Reino Unido no contexto de uma crise política mais ampla. A sua determinação em retomar o controle da capitania fica ainda mais evidente na leitura de uma das proclamações distribuída durante o avanço das tropas para Pernambuco:

Habitantes de Pernambuco! Marcham para a comarca das Alagoas, Bandeiras Portuguesas, e soldados Baianos, para a cercar em toda a extensão dessa capitania. Todo o habitante de Pernambuco que as não seguir rapidamente e marchar junto a elas será fuzilado. As forças navais ora à vista e no bloqueio do Porto têm ordem para arrasar a cidade e passar tudo à espada se imediatamente não foram extauradas [sic] as leis de Sua Majestade El-Rei Nosso Senhor. Nenhuma negociação será atendida em que presida como preliminar a entrega dos chefes da revolta a bordo ou certeza de sua morte, ficando na inteligência de que a todos é lícito atirar-lhe à espingarda como a lobos. Bahia, 29 de Março de $1817 .^{145}$

\footnotetext{
${ }^{143}$ Correspondência do conde da Barca ao conde dos Arcos, em 6 de abril de 1817. Idem, ibidem, p. 223.

${ }^{144}$ Citado por Rocha Martins, op. cit., p. 80.

${ }^{145}$ O Investigador Português em Inglaterra ou jornal literário, político, \& c., n. 1, n. LXXIII, v. XIX, julho de 1817 (disponível em www.googlebooks.com.br). Ver também: Denis Antônio de Mendonça Bernardes, op. cit., p. 242 (nota 96).
} 
O Investigador Português transcreveu a proclamação do governador tecendo alguns comentários sobre seu significado naquele contexto político. De acordo com o redator, não restavam dúvidas quanto à atuação do conde dos Arcos naquele "caso crítico", ressaltando, porém, que não poderia deixar de registrar que o manifesto fora "uma das medidas mais imprudentes, e até mais impróprias da sua autoridade, que ele podia conceber e executar”. Isso devido ao fato de a população de Pernambuco não estar, em sua maior parte, envolvida com "naquele delírio de revolta” e, portanto, o governo da Bahia não poderia ameaçá-la sob o risco de "criar esforços de desesperação, que em todo caso são fatais e perigosos". Sendo conhecido que os habitantes repudiaram a rebelião, "para que fim era então semelhante Proclamação, em que indistintamente se ameaçam os bons e os maus cidadãos?”. Por fim, concluía:

Foi a mesma medida imprópria e superior à sua jurisdição; por que donde pode um Governador da Bahia deduzir uma legítima autoridade para ameaçar ou ordenar que uma cidade do Reino Unido Português seja arrasada, e seus habitantes passados ao fio da espada? Isto só pertence a soberania, e em mui poucos casos, e mui bem ponderados. A única desculpa que pode ter o Exmo. Conde dos Arcos é que esta sua Proclamação foi o efeito espontâneo de um zelo excessivo pela causa pública: porém o demasiado zelo, sem prudência, é muitas vezes mais fatal que a inação, ou um delito. ${ }^{146}$

Além disso, a rápida mobilização do esquadrão de cavalaria, regimentos de artilharia e infantaria e o seu envio para Pernambuco foram fundamentais para desarticular qualquer possibilidade de reação do governo provisório. Sob o comando do marechal Joaquim de Melo Leite Cogominho de Lacerda que tinha como um dos ajudantes de ordens o major José Egídio Gordilho de Barbuda - futuro visconde de Camamu e presidente da província da Bahia com participação destacada nos conflitos políticos dos anos 1820 -, as tropas realistas se esforçaram para cumprir o desejo de triunfo do governador. De acordo Rocha Martins, o próprio marechal Cogominho era suspeito de participar da maçonaria, em função disso, o conde dos Arcos teria lhe dado o comando das armas mas colocado dois oficiais defensores da autoridade da Coroa e que gozavam de sua plena confiança (Barbuda e Salvador José Maciel) como vigilantes. Ocorre que, empenhado em remover qualquer desconfiança sobre ele num período assaz perigoso, teria se empenhado ainda mais no cumprimento de suas obrigações militares. ${ }^{147}$ As forças realistas dispunham de 800 homens

\footnotetext{
146 O Investigador Português... op. cit., p. 114-115.

${ }^{147}$ Rocha Martins, op. cit., p. 66. De acordo Hendrik Kraay, os generais possuíam uma boa condição de vida material. O marechal Joaquim de Melo Leite Cogominho de Lacerda, por exemplo, ao morrer, em 1818, deixou 25 escravos, um sobrado em Salvador "e uma pequena fazenda que servia como retiro de verão e
} 
ampliadas com os reforços de Sergipe e de Alagoas, inclusive com a participação de índios. No conjunto, tiveram um total de 2.664 indivíduos, conforme destaca o historiador Denis Bernardes que acompanha as ações estratégicas montadas pelo governador da Bahia para eliminar qualquer manifestação associada ao movimento, bem como as tentativas de resistência esboçadas pelo governo provisório. ${ }^{148}$

A intensa correspondência com as autoridades de Sergipe d’El Rey mostra as articulações do conde dos Arcos para o ataque a Pernambuco mas, por outro lado, também evidencia as dificuldades encontradas para a concretização de seus intentos e que apenas reforçam a hipótese do temor causado pela possibilidade de ampliação do movimento pernambucano. Em 29 de março, o primeiro sargento comandante do destacamento de Vila Nova, Francisco Manoel da Rocha Nascimento, comunicou ao governador de Sergipe que remetia alguns presos “que se dirigiam em canoas para a Vila do Penedo” após chamá-los "para que voltassem para a parte desta Vila e não para a inconfidente do Penedo" e que haviam recusado. ${ }^{149}$ Uma das preocupações centrais era o abastecimento das tropas. Numa correspondência enviada ao governador de Sergipe, o ouvidor da comarca, José Teixeira da Matta Bacellar, alertava:

Apesar das providências que tenho dado para remediar a grande necessidade de víveres que há nesta cidade, nada tenho podido obter o que verá V.Exa. do ofício incluso do capitão-mor da Estância, e porque receio que a fome vá a mais e seja causa de alguma desesperação, rogo a V.Exa. mande quanto antes algum abastecimento de farinha e grãos para esta cidade. Neste instante chega a notícia, ainda que não oficial, de se achar amotinada a Vila do Penedo a mais próxima desta comarca. Entre as medidas de segurança que se tem tomado é uma posta desde o Rio de S. Francisco até esta cidade, e de acordo com o Governador tendo mandado dar aos soldados de cavalaria miliciana que a ocupam de ajuda de custo um soldo igual aos da cavalaria de linha. Para minha instrução desejo que V.Exa. me declare se devo ou não continuar com este

\footnotetext{
fonte de suprimentos alimentares para a casa urbana”. Op. cit., p. 42. Gordilho de Barbuda assumiu a presidência da província em 1827 sendo assassinado três anos depois. Cf. Ignácio Accioli, op. cit., v. III; Daniel Afonso da Silva. Histórias de Bahia.Histórias de Brasil. Apontamentos para o estudo da crise política do Primeiro Reinado na Bahia (1828-1831). São Paulo, 2007 (Dissertação).

${ }^{148}$ Denis Antônio de Mendonça Bernardes, op. cit., p. 241.

${ }^{149}$ Correspondência do $1^{\circ}$. sargento Francisco Manoel da Rocha Nascimento ao governador de Sergipe, em 29 de março de 1817. APEB. Seção de Arquivo Colonial e Província. Cartas ao Governo. Maço: 235 (18171818). Na relação dos presos que segue junto ao ofício constam 4 nomes: Américo [!] José do Nascimento Tambor/Manoel Pereira/ João Dionísio/Manoel de Jesus. Logo abaixo está registrado: "Cativos prisioneiros na mesma ocasião. Manoel/Joaquim/Antônio/Maria/Maria mais pequena” mas, infelizmente, a correspondência não presta nenhuma informação sobre os mesmos.
} 
suprimento ou com outro qualquer que for necessário aos mais milicianos. ${ }^{150}$

Em outro comunicado, o desembargador da comarca afirma não ter condições de fornecer "duzentos alqueires de farinha” para as tropas, incluindo a que "se supõe vir da Bahia”, tendo em vista que "na presente época se me faz impraticável semelhante medida por não encontrar nesta vila e seu termo remessa algumas”. Segundo ele, apesar de todas as diligências feitas, as autoridades competentes não tinham condições de fornecer o gênero pelo esgotamento das mandiocas “de sorte que muitos lavradores já tem sido violentados pelos sertanejos a desmancharem para lhes vender alguns restos que reservavam para sustentação das suas famílias, para de uma vez dizer tudo, basta expor a V.S. que estando a farinha aqui a 3.840 réis o alqueire não apareça um grão”. ${ }^{151}$ Além disso, o receio das autoridades sugere a possibilidade de auxílio dos habitantes da capitania de Sergipe aos rebeldes pernambucanos. Em 9 de abril, o governador e capitão general Luiz Antônio da Fonseca Machado informou ao conde dos Arcos ter recebido o seu ofício através do qual mandava advertir os moradores "o crime em que incorrem e o modo de seu castigo a aquele que conduzir farinha ou víveres para Pernambuco durante o estado em que se acha”, também comunicava que já havia ordenado sua publicação pelo ouvidor da comarca. ${ }^{152}$

A julgar pelas informações das autoridades régias, as deserções parecem ter se constituído numa outra questão relevante durante os conflitos demandando maior aprofundamento. É possível que em função disso o conde dos Arcos tenha reagido de maneira tão rigorosa diante da deserção do soldado Manuel de Tesses Canoto do segundo Regimento de Milícias: “fugiu da corveta Mercúrio que parte para bloquear Pernambuco publicando seu vergonhoso crime. Hei por castigado mui severamente o infame réu que o cometera assegurando a corporação dos fiéis e honrados milicianos da Bahia que ele já lhe não pertence”. ${ }^{153}$ Da mesma maneira, contestava a possibilidade de uma suposta ajuda dos Estados Unidos à causa dos rebeldes buscando debilitar a crença dos soldados:

\footnotetext{
${ }^{150}$ Correspondência do ouvidor da comarca José Teixeira da Matta Bacelar ao governador de Sergipe, em 31 de março de 1817. Idem, ibidem.

${ }^{151}$ Idem, ibidem. O ofício, de 30 de março, está assinado pelo desembargador Vicente José da Silva Portella. De acordo um residente de Pernambuco, em razão do bloqueio militar por terra e mar, a fome se alastrou na capitania "porque o que tinha entrado antes do bloqueio era só para a tropa. [...]. o [governo] provisório é verdade que mandou logo ordem para se plantar mandioca, feijão, milho e arroz, e com efeito todos plantavam; mas isso foi em março, e como havia de haver em abril farinha? Como a há de haver ainda agora? Para os meus não morrerem de fome cheguei a comprar por empenhos a $16 \$$ e a $18 \$$ o alqueire”. A carta, destinada a um compadre do Rio de Janeiro, foi escrita em 15 de junho de 1817 e transcrita por Mello Morais, op. cit., t. 1, p. 448.

152 Idem, ibidem.

${ }^{153}$ Citado por Denis Antônio de Mendonça Bernardes, op. cit., p. 242.
} 
A facilidade, com que todos os homens, em tais circunstâncias, podem ser fascinados, obriga-me a gritar-vos que aquele governo (o americano) tem dado muitas provas de perspicácia ante o mundo todo, para que seja lícito suspeitar que há de proteger o mais vil dos crimes perpetrado por meia dúzia de bandidos, que nasceram na escuridade e indigência donde não virão mais sair senão por força dos delitos que há de cometer. ${ }^{154}$

Nesse contexto, não deve estranhar, portanto, as palavras ameaçadoras do conde dos Arcos de que aplicaria aos líderes a punição dada sempre "a todos os famosos chefes de revoluções”. Ademais, como já havia dado mostras da severidade de seus métodos em Salvador, o terror repressivo do capitão general não ficou apenas no discurso intimidador e, certamente, muito em função disso é que a notícia sobre a sua morte teria sido bastante comemorada entre os rebeldes. Em 29 de abril, o conde da Barca transmitia-lhe que o príncipe regente via nessas manifestações "uma prova do muito que eles se receiam das medidas rigorosas que V.Exa. tem empregado para os punir” e esperava que os resultados fossem correspondentes ao "zelo e atividade de V.Exa. e aos esforços dos povos dessa Capitania que V.Exa. tão habilmente tem dirigido”. ${ }^{155}$

Assim, não se pode desconsiderar as informações que apontam para um recuo de potenciais aliados na Bahia ou supostamente envolvidos que, pressionados pelo governador, teriam retrocedido em seu intento de efetivar a adesão da capitania ao movimento, enquanto outros, além disso, concederiam vultosas quantias utilizadas no envio de homens e embarcações para o epicentro da revolução, somando-se aos auxílios oriundos do Rio de Janeiro. ${ }^{156}$

Em uma proclamação que teria sido dirigida aos patriotas residentes na Bahia pelos rebeldes, a perspectiva de que os líderes do movimento acreditavam em uma possível aliança fica ainda mais evidenciada:

Denodados patriotas baianos! - Já sabeis os resultados do faustíssimo dia 6 de março, que restituiu aos seus perdidos direitos vossos irmãos de Pernambuco. Já o sabeis e ainda hesitais! Nós pasmamos, caros irmãos, que alguns dentre vós não corram ao nosso seio, e venham estreitar laços que a identidade de religião, costumes e moradia, e a simpatia de sentimentos, criara entre nós. Vós, que tendes marchado sempre dianteiros na estrada da civilização e cultura, não nos seguireis ao menos na carreira da glória, e não partilhareis os riscos e lidas a que gostosos nos

\footnotetext{
${ }^{154}$ Citado por Rocha Martins, op. cit., p. 65.

${ }^{155}$ Correspondência do conde da Barca ao conde dos Arcos, em 29 de abril de 1817. Rocha Martins, op. cit., p. 223 (grifos nossos).

${ }^{156} \mathrm{O}$ corpo do comércio, por exemplo, contribuíra com quatrocentos mil cruzados, cem mil a menos do que fora arrecadado pelos comerciantes da corte. Pedro Calmon, op. cit., p. 1440.
} 
sujeitamos para sacudir um jugo odioso e recuperar o título de homem livre?

Acaso podem empecer os arremessos de vossa indignação as insípidas roncas e vãs bravatas do fútil general que ainda vos tem acurvados? Fátuo! O tempo dos prestígios é passado. Fidelidade aos tiranos é cumplicidade em seus delitos, é atraiçoar a grande causa do gênero humano [...].

Ah! Corai, baianos; correi-vos da injúria que faz o vosso entendimento e a vosso coração o vosso proclamador; não pode ser a divisa de um povo nobre e generoso fidelidade a um déspota baixo e opressor. Mostrai-lhe que são mentirosas suas gratuitas asserções, que os vossos peitos são o santuário de Vesta, onde nunca se extinguiu o fogo sagrado da liberdade, e que o sopro dos tiranos, se pôde diminuir-lhe a força, não conseguiu abafar-lo de todo.

Respondei prontos aos gritos de vossos consangüíneos, de vossos conterrâneos. [...]. Juntai os vossos aos nossos esforços, ultimemos a obra tão felizmente começada, salvemos o Brasil que descorado o atenta em nós e em nós escora sua nutante liberdade.

Baianos, acordai a vossas às nossas vozes; entoemos o santo hino - Viva a religião! Viva a pátria! Viva a liberdade! ${ }^{157}$

Anos mais tarde, em agosto de 1822, por ocasião das lutas pela Independência que se desenrolavam na Bahia, o Sentinella Bahiense, periódico vinculado às tropas portuguesas estacionadas em Salvador, ao criticar alguns deputados oriundos da capitania e que nas Cortes haviam se posicionado contrários ao envio de reforços militares argumentando que a escravaria não causava receio, diria que em 1816 os mesmos senhores foram favoráveis ao aumento das tropas para a segurança interna e, estranhamente, teriam mudado de idéia. Para o redator, desde aquele ano a população branca em nada havia aumentado ao contrário da importação de escravos. Em razão disso, questionava:

Logo, devo concluir, como o conde dos Arcos, que aqueles Srs. tinham em vista, na criação do corpo de 2.000 pedestres, não conter os negros, mas aclamarem a independência; tanto mais se aumentam as minhas presunções a este respeito, quando considera que daí a um ano houve a expulsão pernambucana. Quem sabe se havia plano combinado com a Bahia? [...] julgavam aqueles Srs. que era necessário tropas, e agora não? De duas uma, ou naquele tempo eram mentecaptos, ou o são agora; se me negam este dilema, devo concluir que pretendiam em 1817 proclamarem a independência com o auxílio dos 2.000 pedestres, ou a querem proclamar agora removendo as Tropas Européias, porque se opõe a seus planos. $^{158}$

\footnotetext{
${ }^{157}$ A proclamação, sem data, encontra-se transcrita em Mello Morais, op. cit., t. 1, p. 474-475.

${ }^{158}$ Sentinella Bahiense, n. 8, 21 de agosto de 1822, op. cit. (grifos no original). Agradeço a indicação desse documento a Argemiro Ribeiro de Souza Filho. Ver também Consuelo Pondé de Sena. A imprensa reacionária na Independência. Sentinella Bahiense. Salvador: Centro de Estudos Baianos/Publicação da UFBa, n. 100, 1983.
} 
A posição do periódico reflete as divergências no contexto do constitucionalismo que oportunamente serão tratadas. Mas sua indagação não parece ser totalmente destituída de sentido. Em um documento anônimo escrito nessa época, provavelmente por um espião francês de d. João VI, conforme indicação do pesquisador Luiz Mott, o autor, ao avaliar a dinâmica política do Brasil nas primeiras décadas do Oitocentos, afirma que antes do constitucionalismo dos anos 1820 já existiam "restos do Partido Revolucionário, o qual fizera sua primeira explosão em Pernambuco, em 1817, e cujos núcleos principais continuavam a estar em Pernambuco e na Bahia”. Revela ainda que, seguindo as ordens da Coroa, tinha “conhecimento não só dos principais chefes e todas suas ramificações, mas inclusive enviei um de meus agentes aos Estados Unidos, junto ao Cruz [Antônio Gonçalo da Cruz], um dos principais chefes do partido, encarregado do dinheiro destinado à compra de armas, munições e construções para o serviço dos rebeldes”. ${ }^{159}$ É bastante razoável que num contexto de crise política aguda como a que vimos tratando, a Coroa dispusesse de informações importantes e sigilosas que diziam respeito, sobretudo, à segurança política do Estado. Nesse sentido, a provável existência de um ambiente propício à expansão do movimento na Bahia fora realmente considerado e, por isso mesmo, estrategicamente reprimido pelo governo local. É, de fato, possível, que o movimento tenha irrompido de maneira abrupta sem uma articulação anterior com as capitanias vizinhas. Isso também pode ter contribuído para que a reação fosse mais ágil e mais bem-sucedida em sua ofensiva. $^{160}$

Entre os dias 19 e 20 de maio de 1817 os rebeldes capitularam em Pernambuco frente às forças realistas que incluíam entre seus comandantes o almirante Rodrigo José Ferreira Lobo vindo do Rio de Janeiro. Poucos dias depois, o conde dos Arcos reproduzia mensagem recebida pelo marechal Cogominho na qual dava conta da destruição do “exército denominado dos soldados insurgentes”, a apreensão da caixa militar, de peças de artilharia, munições de guerra e da bandeira adotada pelo governo revolucionário, ressaltando ainda o fato de terem ficado no chão "quase todos os cadáveres dos infames que compunham tão monstruoso exército”. Para assinalar o triunfo, convidava os militares

\footnotetext{
${ }^{159}$ Luiz Mott. "Um documento inédito para a história da Independência”. In: Carlos Guilherme Mota (Org.), op. cit., 1972, p. 477 (tradução do autor).

${ }^{160}$ Para Tobias Monteiro, "a falta de marinha teria tornado dificílimo ou impossível o seu triunfo mas, se o plano de uma ação simultânea, da Bahia ao Ceará, houvera se concertado previamente, não seria tão efêmera aquela aurora de emancipação”. Cf. História do Império. O Primeiro Reinado, op. cit., p. 54.
} 
a irem "todos juntos render graças ao Deus dos exércitos, o que terá lugar hoje [29 de maio] ao meio-dia na igreja do colégio [...]”. ${ }^{161}$

A partir de então, a reação aprofundaria os métodos repressivos instaurando um clima de delações, punições, prisões e a eliminação física de muitos dos participantes e suspeitos de envolvimento. Na avaliação de Denis Bernardes, a Revolução pernambucana superou todos os movimentos de contestação ao Estado monárquico ocorridos na América portuguesa não apenas pela efetividade das ações e idealizações que proporcionou, como também pela sua extensão territorial, sendo superada apenas pelos acontecimentos dos anos 1820-1823. ${ }^{162}$ A despeito disso, a análise sobre o significado político dessa experiência que marcou profundamente a história da capitania e a vida de seus habitantes permanece ainda no âmbito de uma historiografia regional, reproduzindo a desvalorização com que o tema foi tratado no período. Em um artigo publicado no Investigador Português, em 1818, por exemplo, o movimento liderado pelo pernambucanos foi considerado totalmente despropositado. Ao apresentar as razões pelas quais Lisboa possuía as condições mais apropriadas para sediar a corte portuguesa, inclusive, no que dizia respeito à segurança, o autor esclarece que o Brasil não teria a mesma capacidade para defender Portugal caso isso fosse necessário. Entre seus argumentos, observa que durante a guerra travada contra a França, o Brasil em nada auxiliou Portugal porque não poderia fazê-lo. Ao contrário, o Reino europeu enviava recursos para a América. Adiante avalia:

E quem poderia sufocar a rebelião de Pernambuco, se ela não tivesse sido tão insignificante? As tropas de Portugal; que talvez mais depressa ainda lá pudessem chegar do que as poucas e mui inferiores que se pudessem mandar do Rio de Janeiro. Felizmente o caso de Pernambuco não foi se não uma mera estultícia de meia dúzia de loucos, auxiliados por algumas tropas descalças e esfarrapadas, e por isso pôde momentaneamente ser sufocado pela pouca gente mandada da Bahia. Mas se o caso fosse mais sério; e se a revolução em vez de rebentar em Pernambuco, província falta de meios, rebentasse em outra qualquer Capitania, aonde tinha o Brasil forças para sufoca-la? Havia necessariamente de recorrer a Portugal e a Lisboa; o que tudo prova que Portugal pode defender o Brasil, e que este

\footnotetext{
${ }^{161}$ Ordem do dia do conde dos Arcos, em 29 de maio de 1817. Mello Moraes, op. cit., t. 1, p. 480. Rodrigo José Ferreira Lobo assumiu o comando militar e político de Pernambuco entre os dias 20 de maio e 27 de junho de 1817 até a chegada em Recife do novo governador nomeado Luís do Rego Barreto. Denis Antônio de Mendonça Bernardes, op. cit., p. 244.

${ }^{162}$ Denis Antônio de Mendonça Bernardes, op. cit., p. 257. Para demonstrar o alcance da repressão após a derrota da revolução, o historiador reproduz um ofício da câmara de Recife, de 16 de julho de 1817, encaminhado a d. João VI, na tentativa de obter a sua clemência: "Na Bahia os réus mais criminosos têm sofrido a pena última; aqui padeceram o mesmo castigo e o sofrerão alguns que aparecerem dignos dele: muitos mais de mil têm sido punidos com açoites que as leis mandam dar aos que escaparam à punição capital”. Op. cit., p. 231-232 (grifo do autor).
} 
não pode defender Portugal, como bem o mostrou já em a nossa guerra dos sete anos contra a França. ${ }^{163}$

Importante ressaltar que o papel desempenhado pela capitania da Bahia não se circunscreveu apenas aos acontecimentos durante os meses em que durou o conflito. Após o fim do movimento, autoridades locais, a exemplo do coronel Luis Paulino de Oliveira Pinto da França e do oficial Manuel Pedro de Freitas Guimarães, participaram dos julgamentos e condenação à morte dos principais líderes como membros da comissão militar. Em sua edição de 17 de junho de 1817, o Idade d'Ouro divulgava: "Dos presos que aqui se acham de Pernambuco, já três sofreram pena de morte condenados pela comissão militar: a saber, o negociante Martim, o letrado Mendonça e o padre Miguel”. ${ }^{64}$ Curiosamente, poucos anos depois desses episódios, Luis Paulino e Manuel Pedro atuaram como partícipes diretos no movimento constitucionalista na Bahia decorrente da Revolução do Porto. A capitania também recebeu centenas de presos políticos (cerca de trezentos réus) que lotaram os cárceres da capital, além da alçada responsável pela devassa inicialmente instalada em Pernambuco e quase um ano depois transferida para a Bahia. A presença desse número significativo de prisioneiros em Salvador, entre os quais se encontrava parte das lideranças do movimento como Francisco José Martins, frei Joaquim do Amor Divino e Rabelo (frei Caneca) e Antônio Carlos Ribeiro de Andrada Machado, certamente alterou a dinâmica da prisão, além de aproximá-los de algumas pessoas presumivelmente simpatizantes da revolução. É o que ocorrera com Cipriano Barata que teria organizado grupos de apoio material para os presos, inclusive levado a queixa destes sobre a péssima qualidade da comida servida, por meio de um abaixo-assinado, ao responsável pela guarda penitenciária. A conquista de alguma melhoria e a mobilização entre os presos permitiram, inclusive, a organização de uma escola dentro da masmorra:

\footnotetext{
163 O Investigador Português em Inglaterra ou jornal literário, político, \& c., n. 4, n. LXXXIV, v. XXI, junho 1818, p. 515-516 (disponível em www.google.books.com.br).

${ }_{164}$ Idade d'Ouro do Brazil, 17 de junho de 1817, n. 47. APEB. Setor de Microfilmes. Manoel Pedro de Freitas Guimarães e Felisberto Caldeira Brant Pontes, como mencionado, integraram a comissão militar que condenou o padre Roma à morte. Desse modo, além da execução de José Inácio de Abreu e Lima (o padre Roma), foram condenados e mortos na Bahia José Luis de Mendonça, Domingos José Martins e o padre Miguel Joaquim de Almeida e Castro. Em Recife foram nove, quatro nativos de Pernambuco e cinco da Paraíba. A repressão que se seguiu em Pernambuco marcou a memória dos seus habitantes. Nas palavras de Denis Bernardes: "Ainda nos momentos iniciais da restauração, e sob a égide da Comissão Militar, outras execuções foram realizadas, com o mesmo ritual de decepação dos corpos, exposição de suas partes em lugares públicos, até a consumação. Ou, então, os exemplares castigos de açoites públicos, preferencialmente contra negros e mulatos, inclusive mulheres, e cuja lista é por demais longa”. O autor registra as punições sofridas por algumas dessas vítimas. Op. cit., p. 226-235; Sobre a sentença de morte imposta aos condenados, ver também: Mello Moraes, op. cit., t. 1, p. 345-347.
} 
Fenômeno raríssimo! A habitação das trevas transformou-se em asilo da luz! A maior sala daquela cadeia assemelhava-se à sala de um liceu: ali moços e velhos com edificante assiduidade consagravam o dia inteiro à aplicação literária; o maior número entregava-se ao estudo das línguas, outros dedicavam-se às Matemáticas; e alguns à Filosofia Racional, e Moral, mutuamente comunicando uns aos outros os seus conhecimentos. ${ }^{165}$

De fato, em suas memórias, Antônio Pereira Rebouças registra que José Antônio da Silva Castro havia lhe confessado que "sendo preso na cidade da Bahia por questões de partilha [...], teve por fortuna achar-se na prisão com o desembargador Antônio Carlos de Machado e Silva, que geralmente instruía nas humanidades e ciências sociais e políticas aos seus companheiros de infortúnio; e com o capitão-mor de Suassuna, varão de têmpera espartana, que simplesmente o doutrinara nos deveres do patriotismo e amor da liberdade”. ${ }^{166}$ Em que medida essa aproximação estreitou os laços entre adversários da monarquia absolutista aprofundando as críticas ao domínio da Coroa portuguesa ou mesmo explicitou as divergências sobre suas concepções políticas acerca da organização do Estado, são questões difíceis de serem apreendidas. Anos depois, em 1823, Cipriano Barata e Antônio Carlos de Andrada, por exemplo, estariam em campos opostos. Barata, ao criticá-lo pelo fato de apoiar d. Pedro I integrando o seu governo, diria que:

Mas agora eu quero envergonhar Antônio Carlos: dize homem alucinado pela soberba; não tens peio de favorecer o Governo Absoluto e de promoveres o despotismo? Tu que em 1817 andastes puxando pelas ruas atado em cordas com as mãos para trás, cuspido, vituperado, sujo no rosto com xichelos do monturo, e gatos mortos, assuviado e apupado; tu te atreves a favorecer o Despotismo? [...] Tu gemeste em Segredo mais de 3 ou 4 anos entre as injúrias e impropérios dos carcereiros; carregado de ferro, grilhões, algemas e correntes, morto de fome e sede, comido de piolhos; e mil insetos e sevandijas, tu te atreves a patrocinar o Governo Absoluto? ${ }^{167}$

No entanto, a análise empreendida por Carlos Guilherme Mota sobre o universo conceitual e a extração social dos principais líderes da revolução encarcerados em Salvador

\footnotetext{
165 Citado por Denis Antônio de Mendonça Bernardes lembrando ser essa a primeira escola a funcionar dentro de uma cadeia no Brasil. Op. cit., p. 189.

${ }^{166}$ Antônio Pereira Rebouças. "Recordações Patrióticas. 1821-22”. RIGHBa, n. 48, 1923, p. 478. José Antônio da Silva Castro foi o comandante do Batalhão dos Periquitos que se insurgiu em 1824 em Salvador. Sobre o assunto, ver: O levante dos periquitos. In: Luis Henrique Dias Tavares, op. cit., 2003, p. 194. O capitão-mor de Suassuna era o senhor de engenho Francisco de Paula Cavalcanti de Alburquerque, um dos suspeitos de promover a "conspiração dos Suassunas", em 1801, em Pernambuco, tendo participado também em 1817 e levado preso para a Bahia. Evaldo Cabral e Mello, op. cit., p. 25 e passim.

${ }^{167}$ Citado por Marco Morel, op. cit., 2001, p. 98-99. Evaldo Cabral de Mello ressalta que os encarcerados de 1817 na Bahia saíram da prisão assim como haviam entrado "isto é, divididos nas preferências políticas, embora muitos radicais houvessem transitado para posições moderadas”. Op. cit., p. 82.
} 
mostra a existência de um traço social que os distinguia enquanto: "representantes significativos da elite dirigente que pela primeira vez tentou afirmar-se nos horizontes estruturais da sociedade ainda largamente marcada pela situação colonial [...]”. ${ }^{168}$ Nessas circunstâncias, não deixa de ser de extrema importância o exame que faz sobre uma discussão ocorrida entre os presos por ocasião das mudanças no ambiente da cadeia resultantes das queixas feitas anteriormente. O novo supervisor, o capitão Boaventura Ferraz, encaminhou-lhes um bilhete no qual orientava a divisão do grupo em "classes” para facilitar a distribuição dos alimentos. A presença do termo na mensagem gerou controvérsias entre os presos que, após formarem um conselho presidido por Antônio Carlos, concluíram tratar-se de uma palavra equivalente à hierarquia.

Depois disso, não sem algumas dificuldades e contestações, os presos foram divididos em três classes nas quais a formação militar foi um dos critérios fundamentais de distinção. Mota conclui, em função desse episódio, que a desigualdade reinante no período da revolução se reproduzira na prisão onde até mesmo a cor influenciou na distribuição dos integrantes de cada classe "inclusive para tornar dois paisanos oficiais superiores e transformar a dois oficiais superiores em simples soldados”, referindo-se à promoção de dois prisioneiros que não possuíam posições militares, porém pertenciam aos setores dominantes "pelo parentesco e pela extração social" ao mesmo tempo em que dois integrantes superiores do regimento Henrique Dias, formado por negros, foram rebaixados. ${ }^{169}$ Digna de atenção também foi a maneira pela qual o supervisor reagiu após o desfecho da discussão:

Senhores, a lista da maneira que está organizada, em nada me facilita na distribuição da comida, o meu pensamento era que os Snrs. se reunissem em grupos de 5, 6 até 8 pessoas mais intímas: por exemplo um Pai que tem dous filhos com mais dous parentes e alguns amigos eis um grupo. Constame que aqui há trez irmãos, com mais dous primos e alguns dos seus comprovicianos, eis outro grupo. Os Snrs. Eclesiásticos talvez quisessem reunir-se em uma ou mesma mesa etc. ${ }^{170}$

Essa experiência, longe de ser vista como um acontecimento de menor importância, ajuda a redimensionar o papel desempenhado pelos protagonistas na dinâmica política do Brasil Reino a partir de suas concepções sobre a organização da sociedade. Nos

\footnotetext{
${ }^{168}$ Carlos Guilherme Mota, 1972a, op. cit., p. 133. O autor reproduz a informação de Francisco Muniz Tavares, um dos presos e autor da obra História da Revolução de Pernambuco em 1817, na qual se baseia como uma das principais fontes, "que os eclesiásticos eram os mais desunidos entre os presos". Loc. cit. ${ }^{169}$ Idem, ibid., p. 138.

${ }^{170}$ Citado por Carlos Guilherme Mota, 1972a, op. cit., p. 138. "Para tornar claro o seu propósito, o Capitão, após verificar o número total de prisioneiros, resolveu mandar doze tabuleiros, cada um para oito pessoas, e mais um para sete pessoas”. Idem, ibid., p. 139.
} 
anos 1820 muitos estarão de volta à cena política apresentando linhas de intervenção heterogêneas e mesmo alguns deles se beneficiarão da estrutura político-administrativa do Estado Imperial. Para o caso da Bahia, a trajetória de pessoas como Cipriano Barata, Agostinho Gomes, Luis Paulino Ferreira da França, Lino Coutinho e tantos outros, expressa o vigor das alterações políticas nas primeiras décadas do Oitocentos ao mesmo tempo em que fornece elementos para a compreensão dos diferentes projetos políticos forjados em meio ao aprofundamento da crise no interior da nação luso-americana.

Quando a discussão envolvendo os presos políticos ocorreu, o conde dos Arcos já havia deixado o governo da Bahia que fora então assumido pelo conde da Palma, d. Francisco de Assis Mascarenhas, em 26 de janeiro de 1818. O antigo governador havia sido designado para o cargo de ministro e secretário de Estado dos Negócios da Marinha e Ultramar (decreto de 23 de junho de 1817) no governo de d. João VI - aclamado rei do Brasil, Portugal e dos Algarves em 6 de fevereiro desse ano -, numa clara demonstração de reconhecimento por seu desempenho na preservação dos interesses da Coroa. Existe certo consenso entre os historiadores ao concluírem que a intervenção enérgica do conde dos Arcos na restauração monárquica em Pernambuco fora uma oportunidade para que pudesse alavancar seu prestígio junto ao monarca e, ao mesmo tempo, desacreditar os adversários políticos que possuía no Rio de Janeiro, principalmente Thomaz Antônio de Villanova Portugal, conselheiro de grande credibilidade junto a d. João. Isso explicaria, em parte, seu empenho na dizimação do movimento. O ministro, "o mais modesto em pompas mas o mais poderoso na privança do rei”, seria responsável por denunciar as ambições políticas de Arcos sobretudo em função de sua proximidade com o príncipe herdeiro d. Pedro , reforçada depois da sua ida para a corte, e teria sido o único a não lhe render homenagens por sua atuação em Pernambuco. ${ }^{171}$ As divergências entre ambos poucos anos depois ganhariam maior densidade. Mas, no momento em que o governador recebia as honrarias em Salvador, coube a ele comunicar sua indicação para o ministério. Em carta de 16 de julho de 1817 felicitava-o pela escolha assim como "pela glória” obtida com a expedição a

\footnotetext{
${ }^{171}$ Rocha Martins, op. cit., p. 78. Oliveira Lima afirma que a escolha do conde dos Arcos fora, de fato, como recompensa pelos seus inestimáveis serviços em nome da Coroa, como também para agradar aos nacionais, "que por certo estimariam ver elevado ao poder um antigo residente e perfeito conhecedor do reino americano e suas necessidades”, mas era o ministro Thomaz Antônio Villanova Portugal que gozava da estreita confiança do monarca. Op. cit., p. 572; Braz do Amaral. Anotações...In: Ignácio Accioli, op. cit., v. III, p. 248 (nota 37).
} 
Pernambuco e a maneira segura "em que deixou uma tão importante Capitania ao Senhor Conde da Palma”. ${ }^{172}$

Os registros sobre as homenagens feitas por ocasião da despedida do conde dos Arcos evidenciam que membros das classes proprietárias da capitania sentiram-se expressamente agradecidos por suas ações no governo. Numa correspondência datada de 27 de junho, vários subscritores da Praça do Comércio comunicaram-lhe as resoluções que haviam tomado em reconhecimento ao "seu Justíssimo e Iluminado Governo Credor do Reconhecimento Público, maior e mais eminentemente o era nesta ocasião pelos Ilustres feitos de Março, e Abril, em conseqüência dos quais salvara Pernambuco do furor revolucionário [...]”. Entre as decisões, a realização de uma festa com a presença das pessoas ilustres da cidade e do Recôncavo "que estão nas circunstâncias de merecer tão honrosa distinção"; a fixação de um retrato do homenageado no salão da praça e a distribuição de um exemplar aos convivas "para que em todo o tempo sejam as casas desta Província honradas com a Esfinge do Restaurador de Pernambuco e Herói da Bahia” e a concessão de um vínculo na Caixa de Descontos da cidade no valor considerável de cem contos de réis. Segundo o comunicado, a direção da festa e a arrecadação dos fundos ficariam a cargos dos negociantes Pedro Rodrigues Bandeira, José Ignácio Acciaivoli de Vasconcelos Brandão, Antônio da Silva Paranhos e Francisco Martins da Costa. Além desses, subscreveram o documento: Manoel João dos Reis, Felisberto Caldeira Brant Pontes, João Gonçalves Cezimbra, Domingos Borges de Barros (com procuração), Alexandre Gomes Ferrão Castello Branco, Pedro Antônio Cardoso (com procuração), entre outros, num total de 63 assinaturas. ${ }^{173}$

Em ofício encaminhado a d. João VI, os mesmos negociantes responsáveis pelas homenagens ao governador requereram a aprovação do benefício que "os habitantes da Bahia resolveram fazer ao Exmo. Conde dos Arcos”, tendo em vista serem

devedores da honra sem par, que nesta ocasião ganharam, dando a V.M. mais um autêntico testemunho da sua fidelidade e amor, qualidades que V.M. já pessoalmente reconheceu quando, para a salvação da Europa e futuro engrandecimento do Brasil, felizmente aportou a Bahia, mas que não podiam ter tão brilhante desenvolvimento, nem ser coroada de tão

\footnotetext{
172 Correspondência de Thomaz Antonio Villanova Portugal ao conde dos Arcos, em 16 de julho de 1817. Rocha Martins, op. cit., p. 86. Ignácio Accioli registra que se por um lado as medidas do governador pareceram violentas, por outro elas evitaram "o dano daqueles que se lhe dizia fazerem parte nos princípios de tal revolução”. Op. cit, v. III, p. 70.

173 Correspondência dos negociantes da praça da Bahia ao conde dos Arcos, em 27 de junho de 1817. Rocha Martins , op. cit., p. 225-227. Segundo Mello Moraes, além do vínculo no Banco do Brasil, os negociantes mandaram construir o palácio no Rio de Janeiro que serviu de residência ao conde. Op. cit., t. 1, p. 445.
} 
feliz sucesso sem a direção do sobredito General: pelo que os suplicantes, per si e por seus constituintes, submissamente se apresentam a V.M. e Pedem que haja por bem aprovar a instituição de um vínculo, a benefício do Exmo. Conde dos Arcos e seus descendentes, no valor de cem contos de reis, em ações do Banco do Brasil, acumulando-se esta soma ao fundo que o mesmo Banco já tem na Caixa dos descontos da Cidade da Bahia. ${ }^{174}$

Da capitania de Pernambuco, os negociantes também encaminharam saudações pelo pronto restabelecimento de sua praça. O governador da capitania de Sergipe d’El Rey parabenizava-o pelas "Sábias Providências que V.Exa. tão rapidamente Se Dignou Ministrar contra os malvados Insurgentes de Pernambuco; e cheio da maior glória beijo a Mão de V.Exa. como fiel Súdito que teve a fortuna de ser por V.Exa. Mandado executar algumas daquelas respeitadas ordens”, assim como o fizeram o desembargador e o ouvidor daquela comarca. ${ }^{175}$ Nas palavras do seu biógrafo, junto aos numerosos elogios recebidos pelo conde dos Arcos ecoavam os versos insossos da quadrinha cantada pelos habitantes da Bahia:

\author{
Baía é cidade \\ Pernambuco é grota \\ Viva o conde dos Arcos \\ Morra os patriotas. ${ }^{176}$
}

A festa de despedida foi realizada na Praça do Comércio em 7 de setembro de 1817. Conforme previsto, na ocasião um retrato de corpo inteiro do governador foi colocado na sala e uma gravura distribuída entre os convidados. O negociante LouisFrançois de Tollenare, então um dos partícipes, registrou suas impressões sobre os atrativos da noite:

O número de cavalheiros subia a cerca de 200; os portugueses trajavam quase todos a casaca de seda à francesa, bolsa e espada: era um tanto serôdio. A solenidade do dia exigia discursos e recitativos; o pobre do Conde teve que suportá-los, e foi incensado por tal forma que, por maior que fossem os seus méritos, não podemos deixar de lamentá-lo

\footnotetext{
${ }^{174}$ Correio Braziliense, ou Armazém Literário, v. XVI, Londres, 1816, p. 103-104 (disponível no site www.googlebooks.com.br).

${ }^{175}$ Correspondência do governador de Sergipe ao conde dos Arcos, em 9 de junho de 1817. APEB. Seção de Arquivo Colonial e Província. Cartas ao Governo. Maço: 235 (1817-1818). A correspondência em nome dos negociantes de Pernambuco, assinada por José Gonçalves Marques, é datada de 15 de setembro. Rocha Martins, op. cit., p. 227. Alguns negociantes dessa praça haviam se refugiado na Bahia durante os conflitos. O Idade d'Ouro de 15 de abril de 1817 (n. 29, suplemento extraordinário) trouxe o seguinte aviso: "José Joaquim Carneiro Leal, negociante da praça de Pernambuco, faz certo ao público, que por causa da revolução sucedida naquele país [...] emigrou com a sua família, e se acha residindo nesta praça da Bahia [...] e em sua companhia também negociante Manoel José Pereira Graça”.

${ }^{176}$ Rocha Martins, op. cit., p. 72. A gazeta Idade d'Ouro do Brazil divulgou várias notícias sobre as comemorações pela restauração de Pernambuco, inclusive em outras vilas como Cachoeira, São Félix, Nazaré e Senhor do Bonfim. APEB. Setor de Microfilmes.
} 
participando do seu aborrecimento. Aliás, como eram [de] praxe, foi preciso ouvi-los.

Após falar sobre o concerto de piano, as danças, os 400 talheres e as mesas cintilantes de velas e cristais, o francês concluiu: "Em resumo, a festa foi tão bela e organizada com tanto cuidado como sê-lo-ia em uma das nossas cidades provinciais da França; nesta ver-se-iam somente menos diamante e menos vestidos guarnecidos de prata e ouro". 177

O conde dos Arcos deixava o governo reconciliado com a classe proprietária e gozando de aprovação junto ao monarca d. João VI. Se realmente fora subornado para livrar alguns ricos proprietários da acusação de envolvimento com os revoltosos de Pernambuco, é uma questão ainda em aberto, mas não destituída de sentido . Tempos depois, o embaixador austríaco no Rio de Janeiro diria que José Egídio Gordilho de Barbuda, um dos principais auxiliares do governador na dizimação dos rebeldes, era "um homem degenerado, ávido de dinheiro e conhecido por exações inauditas, praticadas após a revolução de Pernambuco em 17, onde vendeu a acusados documentos que os comprometiam. O fato tornou-se notório a ponto de terem-no apelidado de 'Quanto vale'. Todos os possuidores de meios para comprar-lhe a impunidade escaparam ao rigor da lei”. ${ }^{178}$

Todavia, no início dos anos 1820, quando o prestígio da Coroa portuguesa parecia estar assegurado na América, no dizer de Oliveira Lima, ${ }^{179}$ a conjuntura política modificar-se-ia novamente, resultando na adesão da Bahia ao movimento constitucionalista e expondo, de maneira mais clara, as fissuras entre os segmentos da sociedade, ao mesmo tempo em que parte dela, instruída pela experiência política, recorria aos instrumentais reformistas para conformação de uma nova ordem. Nesse novo cenário, o antigo governador não apenas se viu excluído das articulações como foi expulso da capitania denotando a rapidez com que as alterações políticas do período desfizeram posições aparentemente sólidas. Antes de discutirmos essas questões, porém, faz-se necessário

\footnotetext{
${ }^{177}$ Louis-François de Tollenare, op. cit., p. 231. A Gazeta de Lisboa e o Idade d'Ouro do Brazil noticiaram o acontecimento. O último registrou que: "A música acompanhou sempre a ceia, entoando alegres hinos em que se fazia alusão aos baianos na sua fidelidade e zelo por ocasião da revolta de Pernambuco". Citado por Maria Beatriz Nizza da Silva, op. cit., 2005, p. 83. Sobre o periódico de Lisboa e uma descrição em detalhes da festa, inclusive assinalando ser o flautista o filho alferes de Felisberto Caldeira Brant Pontes: Rocha Martins, op. cit., p. 81-84.

${ }^{178}$ Citado por Tobias Monteiro. História do Império. O Primeiro Reinado. Belo Horizonte: Ed. Itatiaia; São Paulo: Edusp, t. 2, 1982, p. 157. Daniel Afonso da Silva, op. cit., p. 25. Sobre a hipótese do suborno, ver João José Reis, op. cit., 2003, p. 93.

${ }^{179}$ Oliveira Lima, op. cit., p. 549.
} 
destacar outros elementos importantes na configuração político-econômica da Bahia na segunda década do Oitocentos. 


\section{Capítulo 3}

Crise e crescimento na Bahia nos anos 1810

Se no campo político e social os anos que antecederam 1820 tiveram forte impacto sobre a capitania da Bahia, no aspecto econômico as alterações não foram menos significativas. Os arranjos políticos encetados pela Coroa portuguesa desde a sua partida da Europa, sobretudo com a Grã-Bretanha, e as exigências impostas pela fixação da corte na América, pressupunham novas disposições econômicas com a sua antiga colônia cuja abertura dos portos fora um dos marcos iniciais, como mencionado acima. O tratado de 1810 e o fim do tráfico de escravos ao norte do Equador, em 1815, entre outras intervenções decorrentes das articulações políticas num cenário de aguda crise, resultaram em modificações na configuração econômica da capitania fornecendo maior complexidade à conformação das classes proprietárias locais e em sua relação com o Estado. Nesse contexto, sobressai o comportamento de alguns indivíduos que, aproveitando as possibilidades abertas com as novas condições, ampliaram ou se firmaram como grandes capitalistas construindo amplas redes de negócio e de investimentos, além de expressar sua concepção de Estado e de sociedade nesses primeiros decênios do século XIX.. Acompanhando essa movimentação, ao mesmo tempo em que noticiava os acontecimentos políticos externos, a gazeta Idade d'Ouro do Brasil buscava traduzir àqueles anos como de intensa prosperidade para o Brasil, em o lugar ocupado pela capitania da Bahia estaria assegurado bastando, para isso, cumprir os desígnios propostos pelo ideal de civilização e de desenvolvimento dos novos tempos. Em sua perspectiva, as conquistas políticas e econômicas obtidas pelo Brasil Reino serviam como um anteparo à crise que assolava a Europa e a América hispânica.

\subsection{Conjuntura econômica em tempos de crise}

O desenrolar do conflito na Europa era acompanhado na corte do Rio de Janeiro com grande atenção na medida em que as notícias chegavam pelas embarcações. Já em 9 de dezembro de 1808, o ministro d. Fernando José de Portugal comunicou ao conde da Ponte que fora informado das duas vitórias que os ingleses e portugueses haviam infligido ao exército francês e da capitulação do general Junot e que todos os dias aguardava "navio 
de Lisboa para obter notícias sobre a restauração daquela capital e de todo o Reino”. Pouco dias depois, um novo comunicado afirmava a completa restauração dos reinos de Portugal e Algarves salientando que o "acontecimento fosse festejado, com as demonstrações de aplauso e contentamento de costume, em semelhantes ocasiões de prazer e satisfação". ${ }^{2}$ A partir de então, a capitania poderia enviar seus navios para os portos de Portugal. Ocorre que Portugal ainda seria ocupado outras vezes pelo exército francês libertando-se definitivamente somente em 1812. Dois anos mais tarde, por ocasião da abdicação de Napoleão Bonaparte em 06 de abril de 1814, as notícias foram ainda mais promissoras e o príncipe regente ordenava que diante do término das hostilidades entre as potências beligerantes:

[...] de [hoje] em diante nos portos dessa capitania todas as embarcações francesas e das outras potências que por se acharem sujeitas ao seu domínio ou influência se consideravam inimigas de Portugal, determinando que tais embarcações se recebam como amigas, facilitandose-lhes aquele comércio que está permitido atualmente às nações em paz e amizade com esta corte; e em reciprocidade ficam habilitados todos os vassalos Portugueses para seguirem com os seus navios a qualquer portos pertencentes aos domínios daquelas nações $[. . .]^{3}$

Alguns meses depois desse comunicado tiveram início as articulações entre as potências no Congresso de Viena. Dentre as questões em pauta que diziam respeito à nova configuração político-econômica do mundo Ocidental naqueles tumultuados anos, uma em especial possuía relevância para os proprietários da Praça da Bahia: as negociações com a Grã-Bretanha relacionadas sobretudo ao tráfico de escravos africanos. No decorrer da década de 1810, o príncipe regente estabeleceu três acordos diplomáticos com a Coroa britânica envolvendo esse assunto. Pelo Tratado de Aliança e Amizade, assinado em 1810, restringiu-se o comércio de africanos às possessões portuguesas na costa da África (artigo

\footnotetext{
${ }^{1}$ Correspondência de d. Fernando José de Portugal ao conde dos Arcos, em 9 de dezembro de 1808. APEB. Seção de Arquivo Colonial e Provincial. Ordens Régias. Maço: 105 (1808-1809).

${ }^{2}$ Correspondência de 20 de dezembro de 1808 . Idem, ibidem. No mesmo dia, o príncipe requeria as listas dos donativos que os lavradores de tabaco de Cachoeira ofereceram aos habitantes de Portugal, enquanto durasse a guerra, sugerindo que a cobrança fosse feita a outros lavradores que se comprometeram com a mesma oferta. Mas parece que a contribuição não foi efetuada pois em fevereiro do ano seguinte uma nova determinação do príncipe foi feita ao governo da Bahia para que se efetuasse a cobrança dos donativos. Loc. cit. De acordo Mello Moraes, a iniciativa das contribuições partiu do juiz de fora da vila, José Raimundo de Passos de Porbem Barbosa, que cedeu seus ordenados devidos pela Fazenda Real nos anos de 1808 e 1809, sendo seguido por Antônio João Belo, grande proprietário que cedeu $400 \$ 000$ "e os lavradores e enroladores de tabaco, não só da vila como do seu termo" que colaboraram com "a quantia que rendesse do tabaco, avaliado cada rolo em 600 réis tendo isso principio em janeiro de 1808 enquanto durasse a guerra, contandose de oito a nove mil rolos de tabaco, termo médio das safras do Distrito de Cachoeira”. Op. cit., 1, p. 433434.

${ }^{3}$ Carta de Antônio de Araújo de Azevedo para o conde dos Arcos, em 18 de junho de 1814. Ignácio Accioli, op. cit., v. III, p. 192-193.
} 
X); Em 22 de janeiro de 1815 decidiu-se, em virtude dos acordos estabelecidos em Viena, pela proibição do tráfico ao norte da linha do Equador e, finalmente, dois anos depois (28 de julho de 1817), a Coroa portuguesa assinou uma convenção adicional ao tratado anterior que previa a inspeção recíproca dos navios, além da formação de tribunais mistos destinados a julgar as apreensões realizadas nas costas da África e em alto-mar. ${ }^{4}$

Ao investigar os bastidores dessa negociação e os desdobramentos decorrentes da proibição do tráfico, Guilherme de Paula Costa Santos contesta algumas interpretações sobre o tema que, segundo ele, subestimaram o papel desempenhado pela diplomacia portuguesa ao conferirem maior importância à pressão britânica. Interessado especialmente na Convenção de 1817, o autor procura desvendar os mecanismos que permitiram a sua assinatura como resultante dos múltiplos interesses corporificados no documento, indicando que as intervenções promovidas pela corte no Rio de Janeiro iam muito mais além do que simplesmente acatar das decisões do governo britânico. ${ }^{5}$ Desse modo, a sua perspectiva analítica nos interessa na medida em que realça as questões políticas subjacentes ao reordenamento da monarquia portuguesa no período, como também a importância dessas definições para os residentes na América completamente envolvidos no comércio de escravos e em outros empreendimentos econômicos a ele vinculados, especialmente na Bahia. Nesse sentido, é sintomático que os negociantes dessa praça se pronunciassem no decorrer das deliberações sobre o assunto evidenciando a movimentação desses indivíduos quando seus interesses econômicos estavam em jogo.

A rigor, a capacidade de articulação das classes proprietárias não era algo inusitado na capitania. Já em 1723, o vice-rei Vasco Fernandes Cezar de Menezes (17201735) havia sido favorável à criação de uma Mesa do Bem Comum dos negociantes da Bahia justificando para isso o fato de a capitania ser "cabeça de Estado e achando-se com mais negócio que nenhuma outra do Reino, porque o tinha com Lisboa, Porto, Cenna, Ilhas de Madeira e dos Açores, e com todas as conquistas de Angola, Costa da Mina, Cacheu, Ilhas de São Tomé e do Príncipe, e do Cabo verde, e também com todos os portos do Brasil”. Concordava, assim, com a instalação do órgão determinando que fosse praticado “o mesmo Regimento e Estilos que se observam nas da Corte e Cidade do Porto, enquanto Sua Magestade não mandar o contrário”. ${ }^{6}$ Alguns anos depois, em 1752, os senhores de

\footnotetext{
${ }^{4}$ Cf. Guilherme de Paula Costa Santos. A Convenção de 1817: debate político e diplomático sobre o tráfico de escravos durante o governo de d. João no Rio de Janeiro. São Paulo, Universidade de São Paulo, 2007 (Dissertação de Mestrado), p. 13.

${ }^{5}$ Idem, ibidem, p. 18-62.

${ }^{6}$ Citado por Pierre Verger, op. cit., p. 67.
} 
engenho, lavradores de canas e tabacos da Bahia, encaminharam uma petição ao rei de Portugal, assinada por 81 proprietários de terra e de escravos, na qual avaliavam as causas dos problemas enfrentados pelas lavouras na colônia americana, além de propor intervenções para a reestruturação do tráfico de escravos tanto no âmbito transatlântico quanto entre as capitanias de maneira que não "venha a desfalecer e decair o Estado do Brasil, e o Reino em conseqüência”. ${ }^{7}$ Em fins desse século, 38 negociantes encaminharam uma outra petição ao príncipe regente requerendo mudanças no Regimento das Arqueações que regulava o transporte de escravos da África para o Brasil, e que fora estabelecido em 18 de março de 1684, por considerarem-no desatualizado frente às mudanças no comércio. Ao se pronunciar sobre essa e outras questões a pedido da corte de Lisboa, o então governador da Bahia d. Fernando José de Portugal sugeriu algumas medidas que, no seu modo de ver, poderiam atenuar os males causados aos cativos pela "ambição" e "cobiça” dos comerciantes que os impedia "às vezes de conhecer bem os seus verdadeiros interesses”, sem atentar contra os interesses da Coroa. O governador posicionou-se, também, sobre uma das demandas dos negociantes da Bahia: a liberação da obrigatoriedade dos traficantes daquela praça de fazerem escala nas ilhas de São Tomé e Príncipe em virtude dos prejuízos ocasionados com a demora no transporte e a perda de muitos cativos. Para ilustrar o volume das perdas ocorridas em diferentes ocasiões, menciona o caso do Bergantim Tristão "que chegando a Ilha do Príncipe com 373 cativos vivos e só 13 mortos, demorando-se aí dois meses por falta de mantimentos que não havia na terra, lhes deu o mal de Bexigas, e Escorbuto, de que morreram 153, embarcando os outros infeccionados de forma que ao todo falecerão até a entrada nesta cidade 342”. Da mesma maneira que havia ocorrido com o Brigue Americano que perdera nas ilhas 73 escravos "em menos de um mês, e ao todo até entrar neste Porto 114, por causa daquela escala”. 8

Em 1807, foi a vez de João Rodrigues de Brito tecer críticas sobre esse ponto. Para ele, quem mais sofria com as perdas dos cativos eram os lavradores considerando que os negociantes tinham meios de indenizarem-se das despesas aumentando o custo do escravo. No ano seguinte, a Mesa de Inspeção de Agricultura e Comércio da Bahia encaminhou uma representação ao regente reiterando o pedido de liberação da referida escala para os negociantes. Não deixa de ser significativo que a isenção tenha sido

\footnotetext{
${ }^{7}$ Citado por István Jancsó. “Independência, independências”. In: (Org.). op. cit., 2005, p. 26.

${ }^{8}$ Marianne Reisewitz, op. cit., p. 240. O documento, com importantes informações sobre a prática do tráfico de escravos no período, encontra-se transcrito na íntegra nesse estudo (apêndice, p. 236-255). O ofício enviado pelo príncipe regente ao governador da Bahia consta em Pierre Verger, op. cit., p. 113-115.
} 
concedida por meio da Carta Régia de 13 de abril de 1808, portanto, poucos meses após a instalação do príncipe regente no Rio de Janeiro, com a determinação, entretanto, de o pagamento dos direitos a ser feito naquelas ilhas fosse efetuado em Salvador. ${ }^{9}$ Mesmo depois disso, parece que a grande quantidade de escravos importados permaneceu ocasionando um número significativo de mortes. Em 14 de janeiro de 1812, a gazeta Idade d'Ouro do Brazil registrou que o navio Espírito Santo, de propriedade de Manoel José Machado e Companhia, que saíra da Ilha do Príncipe com escala em Pernambuco com uma carga de 605 cativos dera entrada no porto da Bahia com um índice de 492 mortos. $^{10}$

A autorização do príncipe para a instalação de companhias de seguro, em Salvador, destinadas a proteger os traficantes de eventuais prejuízos constitui outro indício da política econômica da Coroa com vistas a atender as necessidades desse segmento. Ainda em 1808 foram criadas duas companhias: Boa Fé e Conceito Público. Em edição de 24 de maio de 1811, a gazeta da Bahia exultava pela expulsão dos franceses do Reino europeu e também pelas atividades das seguradoras:

Graças imortais ao nosso adorável soberano [...] O Reino está salvo, e à sombra de tão potentes aliados tudo renasceu, e prospera neste Estado. A prova são os lucros incompreensíveis da Casa de Seguros desta Cidade, um dos meios de maior riqueza dela, e um dos motivos de eterna gratidão pelo Real Decreto de 24 de Fevereiro de 1808. No curto espaço de menos de três anos se erigiram 4 Companhias denominadas pela sua ordem: a $1^{\text {a }}$. Boa Fé; a $2^{\mathrm{a}}$. Conceito público, a $3^{\mathrm{a}}$. Bem comum, e a $4^{\mathrm{a}}$. Comércio da Bahia. Tem sido tal a afluência dos seguros em recíproco aproveitamento do Público e dos Acionistas concorrendo segurados não só do Rio de Janeiro, Pernambuco, Maranhão etc., mas até mesmo de Lisboa [....$^{11}$

De qualquer modo, os exemplos denotam que as articulações dos interesses mercantis de poderosos negociantes estabeleceram-se antes mesmo da transferência da corte para a América. As perspectivas, a partir de então, indicavam pela expansão das oportunidades que poderiam resultar dessa mudança considerando a situação de

\footnotetext{
${ }^{9}$ Carta Régia de 13 de abril de 1808 - Isenta os navios da Capitania da Bahia do comércio da escravatura da Costa da Mina, de fazerem escalas pelas ilhas do Príncipe e São Tomé (disponível em www.camara.org.br). João Rodrigues de Brito et al, op. cit., p. 42. A passagem pela ilha de São Tomé incorria no pagamento de uma taxa de 1.000 réis por escravo determinado pela Carta Régia de 1699. Cf. Wilma Peres Costa, op. cit., 2003, p. 159.

${ }^{10}$ Idade d'Ouro do Brazil, n. 4, 14 de janeiro de 1812. Bahia: na Tipografia de Manoel da Silva Serva (disponível em www.bn.br).

${ }^{11}$ Idade d'Ouro do Brazil, n. 4, 24 de maio de 1811. Bahia: na Tipografia de Manoel da Silva Serva (disponível em www.bn.br). Maria Beatriz afirma que em 1811 eram quatro casas de seguro em atividade: “Boa Fé [1808], Conceito Público [1808], Bem Comum [1809] e Comércio da Bahia [1810]”, mas, no ano seguinte, apenas a companhia Conceito Público subsistia de acordo o Almanaque para a cidade da Bahia referente ao ano de 1812. Op. cit., 2005, p. 159. Em 9 de junho de 1808, a corte confirmou a nomeação do poderoso negociante Antônio da Silva Lisboa para ofício de provedor e corretor de seguros da companhia Boa Fé. APEB. Seção de Arquivo Colonial e Provincial. Ordens Régias. Maço: 105 (1808-1809).
} 
instabilidade da Coroa portuguesa. Certamente isso foi fundamental para que pudessem reagir de maneiras diversas às pressões britânicas pela abolição do tráfico. ${ }^{12}$

O tráfico de escravos se constituía numa poderosa e complexa fonte de riqueza para os negociantes, assim como uma prestigiosa fonte de receita para o Estado por meio das variadas taxas de cobrança. O seu crescimento na capitania da Bahia a partir do século XVI quando os primeiros cativos importados da África foram introduzidos, indica não apenas a essencialidade da mão-de-obra escrava para o funcionamento da economia colonial como também os imensos lucros advindos desse tipo de comércio. Ademais, a maior parte dos negociantes estava envolvida em outros negócios como a venda de gêneros de primeira necessidade e mercadorias importadas, a concessão de empréstimos, a aquisição de terras, entre outros, diversificando os investimentos oriundos do tráfico. Integravam, assim, uma vasta rede mercantil, além de possibilitar uma importante acumulação endógena na qual o comércio de homens era o eixo central dessa dinâmica. ${ }^{13}$

A significância política e a econômica do tráfico de negros no contexto de formação da sociedade brasileira vai muito além do trâmite comercial (compra, transporte e venda) na análise de Luiz Felipe de Alencastro, tendo em vista as implicações decisivas que exercem sobre o conjunto da América portuguesa. Ao investigar a dimensão desse comércio em suas origens, destaca a sua importância tanto para os vínculos que se estabeleceram entre Portugal e o Médio e Extremo Oriente, como para a arrecadação de fontes fiscais para o Tesouro Régio e enquanto mecanismo essencial na produção da agricultura nas ilhas atlânticas. A dinâmica do trato negreiro no Atlântico Sul ao longo dos séculos, por meio do trato negreiro entre a África e a América, permitiu a reprodução de elementos essenciais na conformação da sociedade americana que demarcaram a originalidade da constituição histórica do Brasil. Para Alencastro, esses “condicionantes atlânticos, africanos - distintos dos vínculos europeus”, somente desaparecem na segunda metade do século XIX com o fim do tráfico. ${ }^{14}$ Questões que extrapolam o objeto desse trabalho mas servem para realçar o peso desse comércio para a reprodução das bases de

\footnotetext{
${ }^{12}$ Como sugerem João Fragoso; Manolo Florentino, op. cit.; Luis Felipe de Alencastro ( $O$ trato dos viventes. Formação do Brasil no Atlântico Sul. São Paulo: Companhia das Letras, 2000) para o Rio de Janeiro; Guilherme de Paula Costa Santos, op. cit.

${ }^{13}$ Para uma análise dessa acumulação interna promovida pelos traficantes de escravos no Rio de Janeiro: João Fragoso; Manolo Florentino, op. cit. Sobre a trajetória de um traficante de escravos na Bahia e a vasta rede de empreendimentos que estava envolvido, ver: Cristiana Ferreira Lyrio Ximenes. Joaquim Pereira Marinho: perfil de um contrabandista de escravos na Bahia, 1818-1887. Salvador, Universidade Federal da Bahia, 1998 (Dissertação de Mestrado).

${ }^{14}$ Luis Felipe de Alencastro, op. cit., p. 21 e seq.
} 
sustentação da sociedade luso-americana e, particularmente, no cenário das alterações nas primeiras décadas do Oitocentos.

Nesse sentido, o que chama a atenção no período são, por um lado, as articulações da Coroa portuguesa para se desvencilhar de alguma medida que pudesse pôr em risco os interesses de poderosos súditos e, portanto, dos seus próprios e, por outro, essa predisposição dos negociantes em expressar sua reação diante do que consideravam prejudicial a seus negócios, associados aos interesses da Coroa, exigindo uma tomada de posição do Estado português. A assinatura do Tratado de Aliança e Comércio de 1810 serve como exemplificação. Elaborado no contexto das negociações entre a Grã-Bretanha e Portugal desde a transferência da família real para a América, o artigo X previa a restrição do comércio de escravos somente nas possessões portuguesas na África, sob o risco de apreensão das embarcações. Para Guilherme de Paula, na avaliação dos conselheiros do príncipe, essa cláusula, além de corresponder aos desejos da Coroa portuguesa de regulamentar o comércio nas áreas sob o seu domínio promovendo a arrecadação de direitos e evitando o contrabando, não resultava em qualquer prejuízo aos negociantes de escravos. Um exemplo disso teria sido a correspondência encaminhada pelo secretário de negócios estrangeiros e da guerra, d. Rodrigo de Sousa Coutinho, ao governador da Bahia, em 13 de julho de 1811, autorizando-o a dar continuidade às negociações entabuladas com os representantes dos reis de Ardra e Daomé sobre o mencionado artigo. Ressalta-se que os ditos territórios não integravam os domínios de Portugal na África. ${ }^{15}$ Ademais, o tratado, além de não especificar prazos para o término do tráfico pela corte do Rio de Janeiro que se comprometera apenas a uma "abolição gradual”, teve um significado ainda mais amplo: permitiu conciliar interesses das duas Coroas, pois, para a britânica, serviu como uma resposta às pressões políticas e econômicas internas com vistas ao fim do tráfico; para a portuguesa, a preservação da aliança com a Grã-Bretanha num cenário de crise e a regularização de sua administração em territórios africanos. ${ }^{16}$

Não obstante, a marinha britânica realizou algumas apreensões de embarcações portuguesas na África Ocidental com base no artigo X do Tratado de Aliança gerando muitos descontentamentos. Numa das representações encaminhadas pelos negociantes da Bahia ao príncipe regente, em 1813, os queixosos questionam a legitimidade da Grã-

\footnotetext{
${ }^{15}$ Guilherme de Paula Costa Santos, op. cit., p. 76. O autor menciona o parecer do conselheiro Manuel Jacinto que ressaltava o fato de o território para o tráfico ter, inclusive, se ampliado "pois compreendia os domínios portugueses na África, os portos de Ajuda e da Costa da Mina, além dos territórios de Cabinda e Molembo, antes proibidos pelos ingleses e disputados pelos franceses”. Op. cit., p. 75. Pierre Verger acompanha o estabelecimento das ditas embaixadas na Bahia. Op. cit., p. 279-283.

${ }^{16}$ Idem, ibidem, p. 76.
} 
Bretanha em utilizar esse procedimento, além de fundamentar seus argumentos realçando os prejuízos que poderiam advir não apenas para os mesmos mas principalmente para o Estado português:

[...] esta Mina Senhor levou na sua exploração a fortuna de muitos particulares, e de muitas famílias, paralisou o comércio do Brasil sobre a costa d’África, e tirou à circulação geral o importantíssimo cabedal de dois milhões de cruzados com outras conseqüências de gravíssimo prejuízo para o Estado e para o Brasil, quais são a diminuição da Marinha Mercantil, o princípio da destruição da lavoura do tabaco, a decadência de toda a outra lavoura brasílica pela falta de braços tão fortes como os dos negros em comparação dos indígenos; a diminuição dos direitos, dízimos, e impostos que pagão o tabaco, as aguas-ardentes [...] em troco dos quais se importa tão bem o ouro em pó que vem a aumentar a circulação do numerário, e ultimamente a aniilação das rendas reais. ${ }^{17}$

De fato, vários impostos incidiam sobre o comércio de escravos: direitos de saída, de entrada, de baldeação e de saúde. Sobre o primeiro, por exemplo, estavam inclusos todos os produtos utilizados no comércio realizado na Costa africana. Desde maio de 1808 que a tributação sobre o tabaco de corda havia sido fixada em quatrocentos réis por arroba, tanto para consumo na capitania quanto o que entrasse por mar ou por terra, conforme determinação do príncipe regente ao governo da Bahia. Decisão que teria ocasionado "muitas e ardentes reclamações". ${ }^{18}$ Certamente a Coroa tinha tanto interesse quanto os negociantes em solucionar a questão. De acordo Alan Manchester, 17 navios, de 32 provenientes da Bahia haviam sido apreendidos por cruzadores ingleses em 1811, o mesmo acontecendo provavelmente com outros. Em decorrência, cinco importantes casas comerciais teriam falido no ano seguinte, ampliando a reação dos negociantes contra a Inglaterra. Em vista disso, o ministro britânico no Rio de Janeiro, lord Strangford, aconselhara a seu governo para amenizar os esforços visando à supressão do tráfico ao consider "o perigo muito real de rebelião naquela província [que] ameaçava a unidade da colônia”. Por essa época, teria também escrito ao cônsul inglês na Bahia manifestando seu estranhamento em relação às presas, além de esclarecer que o governo da Grã-Bretanha

\footnotetext{
${ }^{17}$ Citado por Guilherme de Paula Costa Santos, op. cit., p. 80-81 (grifos do autor).

${ }^{18}$ Francisco Marques de Góes Calmon. "Contribuição para o estudo da vida econômico-financeira da Bahia no começo do século XIX. Subsídios para a História”. In: João Rodrigues de Brito et al, op. cit., p. 12. APEB. Seção de Arquivo Colonial e Provincial. Ordens Régias. Maço: 105 (1808-1809). Guilherme de Paula Costa Santos, op. cit., p. 81.
} 
não estava de acordo com esses procedimentos. Ainda assim, entre maio de 1811 e junho de 1814 entraram somente na Bahia cerca de 24 mil escravos. ${ }^{19}$

Para os negociantes da Bahia era necessário delimitar as intervenções protagonizadas pela Grã-Bretanha, além de exigir as devidas reparações. Nesse sentido, os argumentos utilizados na representação evidenciam o quanto esses homens estavam cientes das bases racionais sob as quais se assentavam as alterações recentes no mundo Ocidental sem, contudo, ver nisso alguma contradição com a manutenção do trabalho escravo e a racionalização dos seus lucros:

[...] Os negociantes do Brasil proclamão a face do Mundo inteiro os mesmos sentimentos de Humanidade, e de Philantropia, de que tanto se gaba, e ostenta a Nação Inglesa para conseguir a abolição do tráfico indecoroso da Escravatura, offensivo da lei natural, e dos Direitos do homem, mas elles assim como os Negociantes Inglezes que outrora pediram vinte anos ao seu governo para a sucessiva, e gradual abolição, reconhecem que este saudável resultado da Ilustração do Século, e dos bem entendidos interesses da sociedade não pode surtir efeito se não por hum andar lento, e vagoroso, e não por hum golpe decepador, $e$ subversivo de princípios estabelecidos, e já arreigados pela diuturnidadde do Tempo, e pela velhisse dos prejuízos [...]. ${ }^{20}$

Disposto a esclarecer os objetivos do artigo $\mathrm{X}$ do tratado e, ao mesmo tempo, expor os sentimentos dos proprietários da capitania, o editor da gazeta Idade d'Ouro do Brazil, em edição de maio de 1812 trouxe um longo artigo expondo a justeza do fim da escravidão "entre as nações iluminadas” amparadas em dois fundamentos: primeiro, por ser “contrária ao Direito Natural e aos sentimentos da humanidade” e, segundo, por se opor “aos interesses da nação”, ao estimular a preguiça em virtude do desprezo pelo trabalho manifestado pelos nacionais. O redator então concluía: “Logo a escravidão, além de injusta, é também antipolítica”. 21

No entanto, em sua visão, era preciso ter cautela na tomada de decisões tão importantes e, nesse caso, “tolerar alguns males para evitar outros piores”, recorrendo aos exemplos de Portugal e da própria Inglaterra para afirmar que o processo de libertação dos escravos se dera de maneira mais parcimoniosa. O Brasil ainda não possuía as condições

\footnotetext{
19 Alan Manchester. Preeminência inglesa no Brasil. São Paulo: Editora Brasiliense, 1973, p. 151. A referência à carta do ministro britânico ao cônsul na Bahia encontra-se em Maria Beatriz Nizza da Silva, op. cit., 2005, p. 120-121.

${ }^{20}$ Citado por Guilherme de Paula Costa Santos, op. cit., p. 84-85 (grifos do autor). De acordo Pierre Verger, o conde dos Arcos encaminhou a petição dos negociantes ao príncipe regente em 30 de março de 1812, informando que as perdas da praça da Bahia estimavam em oitocentos mil cruzados. Op. cit., p. 302.

${ }^{21}$ Citado por Maria Beatriz Nizza da Silva, op. cit., 2005, p. 121.
} 
(braços) suficientes para esse avanço e, nesse caso, "seria antipolítica e arruinadora a abolição da escravidão”. ${ }^{22}$

Durante o Congresso de Viena, as negociações sobre o tráfico de escravos constituíram um dos temas centrais do debate marcado pelos diferentes entendimentos sobre o tema entre os representantes da Grã-Bretanha e de Portugal, cuja importância do assunto influenciara a escolha dos diplomatas pela corte instalada na América. Como já mencionado, a tática elaborada pela Coroa portuguesa de uma possível aliança com a Rússia para fazer frente as propostas dos britânicos não foi adiante. No entanto, mesmo enfraquecidos, os diplomatas portugueses não cederam as pressões para abolição do tráfico mesmo considerando a possibilidade de indenização dos proprietários. Apesar de extensa, a fala do ministro português (marquês de Aguiar) é reveladora da posição do governo no Rio de Janeiro e bastante convergente com as perspectivas dos negociantes:

Sua Alteza Real não se pode persuadir de que se ache um equivalente que indenize os seus vassalos habitantes desta rica e vastíssima colônia; pelo que semelhante projecto seria tão ruinoso como a simples abolição, e mais indecente e estranhável por meio de proposições de compensação. [...] Não há compensação alguma equivalente ao que sofreria o Brasil com a perda de braços necessários para a sua agricultura. Esta verdade é tão notória e óbvia, que um Soberano não poderia tratar e cumprir amigavelmente com outra Potência uma estipulação tão ruinosa, sem esperar da parte dos seus vassalos um descontentamento correspondente aos prejuízos que sofreriam. Semelhantes considerações são dignas da mais séria ponderação; nem Sua Alteza Real pode capacitar-se de que o Ministério da sua antiga e fiel aliada, depois de tantos sacrifícios que Portugal tem feito, queira por meios contrários ao bem da nação diminuir o amor exemplar que Sua Alteza Real tem sempre experimentado da parte de seus vassalos e substituí-lo por um desgosto geral, fundado no conhecimento da sua infalível e próxima ruína. ${ }^{23}$

A avaliação do ministro denota que a Coroa sabia dos riscos políticos e econômicos que poderiam decorrer de uma medida contrária aos interesses dos negociantes de escravos e, portanto, primava por um jogo de articulações no qual pudesse assegurar seus vínculos na América sem perder de vista as alianças externas. Como resultado dos acordos, deliberou-se, em 22 de janeiro de 1815, pela abolição do tráfico ao norte do Equador e a não interferência da Grã-Bretanha sobre o comércio de escravos ao sul da linha equinocial; uma indenização dos navios portugueses apreendidos após o tratado de 1810 e a elaboração futura de um acordo diplomático para abolição do tráfico, entre outras

\footnotetext{
${ }^{22}$ Idem, ibidem, p. 122.

${ }^{23}$ Citado por Valentim Alexandre, op. cit., p. 302.
} 
decisões. Os atos foram ratificados pelo príncipe regente em 8 de junho do mesmo ano. Em novembro de 1817 foi elaborada a Convenção adicional ao tratado de 1815, confirmando as suas disposições. ${ }^{24}$

Em uma consulta feita pelo conde dos Arcos ao governo do Rio de Janeiro sobre a saída do castelo de Ajudá, na Costa da África, tendo em vista a proibição do tráfico nessa área, e o destino dos funcionários que ainda serviam no local, as determinações da Coroa foram bastante precisas: os empregados seriam mantidos considerando que o comércio ali estabelecido não poderia se limitar ao tráfico de escravos, devendo "prosseguir em quaisquer outros ramos que ofereça aquele mercado”. Adiante observava: “Aos conhecimentos e penetração de V.Ex. não pode ser desconhecida a política e importância desta medida, e por isso confia S.A.R. que V.Exa., longe de admitir a idéia de abandono daquele comércio, procurará cuidadosamente inculcá-lo e promovê-lo por todos os meios que o seu zelo lhe sugerir, aproveitando habilmente o gênio especulador e industrioso dos habitantes dessa praça”, ${ }^{25}$

Na edição de $1^{\circ}$ de agosto de 1815, a gazeta Idade d'Ouro do Brazil divulgou a ratificação do tratado sobre a extinção do tráfico ao Norte do Equador, bem como os termos da convenção assinada pelos diplomatas portugueses. Uma semana depois esclarecia que: "Na folha de terça-feira passada esqueceu-nos de inserir um artigo adicional do tratado sobre os escravos; pelo qual se concede a qualquer pessoa estabelecida na costa de África ou na América levar consigo para onde quiser aqueles escravos que já eram do seu serviço antes da ratificação do Tratado, contando, que tal condução não seja feita em navio destinado ao tráfico proibido pelo Tratado". ${ }^{26}$ Em fins desse mês, o periódico informava que a conversão e o documento sobre a abolição que haviam sido

\footnotetext{
${ }^{24}$ Dentre as decisões estabelecidas em 1815 constavam o não pagamento à Grã-Bretanha de parte do débito de 600 mil libras que fora contraído pela Coroa portuguesa em 1809, além da anulação de parte do tratado assinado em 1810. Cf. Guilherme de Paula Costa Santos, op. cit., p. 100. De acordo o autor, a Convenção de 1817 reiterou: a proibição do tráfico ao norte do Equador; definição dos portos que poderiam realizar o tráfico ao sul da linha; preenchimento de um passaporte para a realização do comércio e determinação de penas aos transgressores por meio de um alvará. Op. cit., p. 134. Para Alan Manchester, apesar de todos os esforços dos embaixadores britânicos para levar adiante as propostas reformadoras de interesse da GrãBretanha desde o tratado de 1810, não foram bem-sucedidos na tentativa de impor a corte do Rio de Janeiro o ultimato para o fim do tráfico ou mesmo para cumprir as determinações da Convenção de 1817, "pois nem o ministério nem o povo do Brasil queriam destronar o deus econômico, a escravidão, ou cortar a fonte da qual o deus se alimentava. Entre 1808 e 1822, o Ministério do Exterior britânico restringiu o tráfico escravo português no papel, mas levar essas restrições até a abolição total do tráfico, ou mesmo torná-las efetivas, estava além do seu poder. Entraram mais escravos no Brasil em 1821 do que em 1808”. Op. cit., 1973, p. 164. Conforme argumenta Costa Santos, absorvido pela idéia de supremacia dos britânicos, Manchester não questiona as razões do seu dito insucesso. Op. cit., 1973, p. 38.

${ }^{25}$ Citado por Pierre Verger, op. cit., p. 305 . A consulta do governador da Bahia foi feita em $1^{\circ}$. de outubro de 1815.

${ }^{26}$ Idade d'Ouro do Brazil, 8 de agosto de 1815, n. 63. APEB. Setor de Microfilmes.
} 
assinados em Viena em 21 e 22 de janeiro encontravam-se “à venda na loja de José Felipe dos Santos [...], assim como o Tratado de Amizade e Aliança assinado no Rio de Janeiro em fevereiro de 1810 ". ${ }^{27}$ Uma demonstração de que as deliberações sobre o assunto eram de interesse do seu público ledor, dentre os quais provavelmente encontravam-se muitos negociantes com amplas e justificadas razões para acompanhar de perto os resultados dos acordos diplomáticos. Afinal, apenas em 1816-1817, o número de escravos no Recôncavo, a área mais densamente povoada dessa população, teria chegado a 89 mil. Para Pierre Verger, a despeito da vigilância dos navios britânicos, os negociantes da Bahia continuaram praticando o tráfico nas áreas proibidas e no decorrer de trinta e cinco anos "iriam prosseguir suas atividades, e com uma intensidade maior do que na época em que o tráfico era legal”. ${ }^{28}$

Ocorre que não foram apenas as alterações no tocante ao tráfico de escravos, como decorrência dos reposicionamentos político e econômico do mundo Ocidental, que motivaram as articulações da classe proprietária na Bahia nesse começo do século XIX. Já em 1808, logo após a chegada de d. João a Salvador, os comerciantes dessa praça se mostraram bastante preocupados com o aumento do número de estrangeiros, em especial ingleses, e o prejuízo que poderia advir dessa concorrência com a abertura dos portos às nações amigas, como mencionado acima. Atitude também tomada pelos negociantes do Rio de Janeiro assim que o regente estabeleceu-se na nova sede da corte. Em 8 de abril desse ano, d. Fernando José de Portugal comunicou ao conde da Ponte que o príncipe regente aprovara a sua medida em não efetuar a ronda militar e o auto-exame em uma galera inglesa tendo em vista que essas ordens estavam suspensas desde a permissão para a

\footnotetext{
${ }^{27}$ Idade d'Ouro do Brazil, n. 61 (1º de agosto de 1815) e n. 69 (29 de agosto de 1815) (disponíveis em: www.bn.br). Em 31 de agosto de 1831, o ministro Thomaz Antônio de Villanova Portugal comunicou ao governo da Bahia que o príncipe estava ciente quanto às providências que havia tomado para dar execução aos termos da convenção adicional do tratado de 22 de janeiro de 1815, celebrada em Londres em 28 de julho. Esclarecia ainda que as instruções sobre os passaportes necessários para as embarcações envolvidas no tráfico de escravos haviam sido repassadas à repartição da Marinha. No mês seguinte (26 de setembro) enviou dois exemplares da convenção adicional e cópias do decreto acerca do lugar de reunião da comissão mista firmada entre a Grã-Bretanha e Portugal. APEB. Seção de Arquivo Colonial e Provincial. Ordens Régias enviadas à capitania da Bahia. Maço: 119 (1818).

${ }^{28}$ Pierre Verger, op. cit., p. 305. Os dados sobre a entrada de escravos são fornecidos por Bert Barickman, op. cit., p. 216. Segundo Alan Manchester, "1811 até 1818, quase cento e quarenta mil escravos desembarcaram realmente no Rio de Janeiro, enquanto relatórios muito incompletos da Bahia diziam que quase trinta mil entraram neste porto, apesar da atividade dos cruzadores britânicos, que tão mal reprimiram este tráfico”. Op. cit. p. 159. Para Catherine Lugar, as restrições tiveram impacto para os plantadores na Bahia que passaram a disputar escravos com os proprietários do Rio de Janeiro e de outras áreas que experimentavam um crescimento econômico no período, ocasionando o aumento da demanda pela mão-deobra cativa. Op. cit. p. 83.
} 
entrada de navios estrangeiros nos portos do Brasil. ${ }^{29}$ As primeiras mudanças começavam a ser sentidas no mundo dos negociantes.

Mesmo considerando que a Grã-Bretanha não tenha sido a única a beneficiar-se com a abertura pois, a rigor, a Coroa necessitava de alguma autonomia a despeito de suas condições políticas, dados indicam que após essa data e sobretudo depois de 1810 houve uma maior penetração do capital inglês na Bahia. A partir de então, Salvador não somente viu a primazia do seu porto ser ultrapassada pela nova sede da corte, como também a diminuição de seu tradicional comércio com Portugal e a presença de estrangeiros nas rotas de comércio envolvendo a Europa e a América do Norte. Nas palavras do cônsul inglês na Bahia, Frederic Lindeman: “Desde a abertura dos portos deste continente, os navios de Hamburgo, Bremen, Amsterdam, Gotemburg e de diversos portos franceses aventuraramse aqui para obter algodão”. ${ }^{30}$ Curiosa também é a notícia divulgada pelo Idade d'Ouro no dia 11 de junho de 1811 divulgando a ocorrência de um jantar “com toda a grandeza, e aparato” no qual o corpo do comércio britânico reuniu-se para comemorar o aniversário do rei da Grã-Bretanha. A festa ocorreu na propriedade de Antonio da Silva Lisboa, um dos maiores negociantes da Bahia que na ocasião ocupava o cargo de provedor de seguros. De acordo com a gazeta, foram feitos vários brindes, entre eles: ao rei; aos príncipes regentes do Reino Unido e de Portugal; ao conde dos Arcos e à cidade da Bahia e à "Perpétua amizade entre Portugal, e a Grã Bretanha, os dois mais antigos, e fiéis Aliados existentes no Universo [...]”. ${ }^{31}$ Ao que tudo indica, nem todos estavam insatisfeitos com algumas mudanças.

Nessa direção, José da Silva Lisboa, ao comentar o tratado de 1810, criticou frontalmente aqueles que, segundo ele, não conseguiam enxergar os benefícios que a decisão do príncipe havia propiciado, entre as quais, a fortuita presença dos britânicos no Brasil,

\footnotetext{
${ }^{29}$ Correspondência de d. Fernando José de Portugal ao conde dos Arcos, em 8 de abril de 1808. APEB. Seção de Arquivo Colonial e Provincial. Ordens Régias. Maço: 105 (1808-1809). Sobre as representações dos comerciantes na Bahia e no Rio de Janeiro: Andréa Slemian; João Paulo G. Pimenta, op. cit., 2008.

${ }^{30}$ Citado por Pierre Verger, op. cit., p. 298. O cônsul esteve na Bahia entre os anos de 1811 e 1815. Catherine Lugar ressalta que entre 1798 e 1810, a média de entrada anual de navios no porto de Salvador foi de 301 e de partida, 298; de 1808 a 1810, a média de entrada anual registrada foi de 419 e de partida, 354, caracterizando um aumento na média de chegada de 39 por cento e de partida de 19 por cento. Op. cit., p. 75. Henri Hill, comerciante e enviado dos Estados Unidos, estava na cidade de Salvador quando o príncipe aí aportou. Após a abertura dos portos escreveu ao secretário de Estado americano sobre as possibilidades econômicas entre os EUA e o Brasil. Cf. Luis Henrique Dias Tavares, op. cit., 2001, p. 212.

${ }^{31}$ Idade d'Ouro do Brazil, n. 9, 11 de junho de 1811. Bahia: na Tipografia de Manoel da Silva Serva (disponível em www.bn.br).
} 
maiormente na Corte, e seus subúrbios, onde há mais concurso de Ingleses, apresenta uma face brilhante, e amostras categóricas da prosperidade pública. Em vez de se fecharem as loges dos mercadores, e se diminuírem as Casas dos Negociantes Nacionais, e Artistas mecânicos (como se predizia) tem-se, ao contrário, multiplicado e engrandecido. Mais Edifícios se tem levantado; mais Navios e Embarcações construído; mais terras aberto; mais estabelecimentos de indústria tentado; mais reditos particulares e públicos crescido; mais suprimentos do necessário e cômodo à vida gozado, ainda nas classes ínfimas. Tudo isso anuncia acumulação de capitais, e estado progressivo, e não estacionário, e menos retrogrado, da Opulência do Brasil. $\mathrm{E}$ he de notar, que todas essas vantagens cresceram a despeito dos males da guerra. ${ }^{32}$

De qualquer forma, as novas disposições relacionadas ao comércio externo parecem ter gerado algum tipo de pressão dos negociantes para que a Coroa regulamentasse o comércio desenvolvido sobretudo pelos britânicos a considerar uma série de medidas no âmbito da política econômica que tentava normatizar esse tipo de prática. A Carta Régia de 18 de outubro de 1808 sobre a baldeação para os negociantes ingleses; a forma de concessão de passaportes para os navios determinada no mês seguinte (10 de novembro), e a proibição do comércio de cabotagem pelos estrangeiros em 1814 sinalizam um movimento nessa direção. Do mesmo modo foi a decisão tomada em 22 de julho de 1817, através da qual declarava que os estrangeiros poderiam exportar os produtos de suas lavouras desde que o transporte fosse feito em navios portugueses. Por outro lado, o decreto que isentou do pagamento de impostos nas Alfândegas do Brasil das mercadorias estrangeiras despachadas em Lisboa e Porto, em 1809, se comprovadas o recolhimento dos direitos nessas cidades; a isenção de impostos para as fazendas produzidas nas fábricas do Reino de Portugal, assim como o estabelecimento do monopólio de venda para as tropas, em 1817, sugerem também uma tentativa de contemplar a fração dos mercadores portugueses europeus. ${ }^{33}$ Em outras palavras, tudo indica que a Coroa buscava um difícil equilíbrio para atender as distintas frações das classes proprietárias de maneira a assegurar alguma estabilidade em meio a uma conjuntura de mudanças constantes.

Talvez em função disso é que o redator do periódico Investigador português tenha estranhado o comportamento dos negociantes da Bahia quando estes, no momento

\footnotetext{
${ }^{32}$ José da Silva Lisboa, op. cit., 1818, p. 151. Para Morton, enquanto os mercadores oriundos de Portugal e que possuíam fortes vínculos com o reino ficaram desconfiados, outros perceberam as possibilidades de ganho com o novo sistema. Op. cit., 1974, p. 187-188.

${ }_{33}$ Disponíveis em www.camara.gov.br. Ver também Pedro Calmon, op. cit., p. 1382. Em carta de 7 de fevereiro de 1809, o conde de Aguiar enviou ao governador da Bahia três exemplares do decreto sobre isenção para observação na alfândega daquela praça. APEB. Seção de Arquivo Colonial e Provincial. Ordens Régias. Maço: 105 (1808-1809).
} 
de inauguração da Praça do Comércio em Salvador, presentearam o conde dos Arcos com “uma rica e bem executada espada, feita em Londres”. Sem duvidar dos merecimentos do governador, questiona:

Mas para que havia de ser feita em Londres essa rica espada? Se em todo o Brasil não havia um artífice, que fosse capaz de a fazer, o havia certamente em Portugal. [...].

Os negociantes da Bahia tem sido dos primeiros (e com muita razão), que tem lamentado esse monopólio de indústria estrangeira, que sufoca ou extingue a industria nacional: e então porque haviam de empregar estranhos em cousa que podiam fazer os nacionais? Se quisermos que as boas doutrinas aproveitem é preciso pregá-las com o exemplo; só as palavras não bastam. Gritar que os estrangeiros nos roubam nossa indústria, quando nós somos os primeiros que para isso os convidamos, é pelo menos sermos muito inconseqüentes. ${ }^{34}$

A rigor, se o dinamismo do comércio no quadro econômico da Bahia nos primeiros anos do Oitocentos era devido à atuação de grandes negociantes lusoamericanos, ou seja, portugueses europeus que residiam na capitania ou então seus descendentes, com a abertura dos portos, no entanto, essa configuração vai se modificando pela inserção de novos protagonistas estrangeiros eliminando o monopólio que até então exerciam na capitania, embora não tenham deixado de aproveitar as possibilidades abertas com a fixação da corte no Rio de Janeiro, inclusive alguns novos empreendedores. Exemplo disso são os registros da Real Junta do Comércio do Rio de Janeiro que indicam, para os anos entre 1809 e 1821, um total de 140 negociantes de grosso trato da Praça da Bahia reconhecidos pelo órgão. Número que poderia ser ainda maior segundo algumas avaliações. ${ }^{35}$ Em novembro de 1815, o Idade d'Ouro noticiava que:

${ }^{34}$ O Investigador Português em Inglaterra ou jornal literário, político, \& c., n. 1, n. LXXIII, v. XIX, julho de 1817, p. 113-114 (disponível em www.googlebooks.com.br) (grifos no original).

${ }^{35}$ De acordo dados apresentados por Maria Beatriz Nizza da Silva:

\begin{tabular}{|cccccccccccccc|}
\hline 1809 & 1810 & 1811 & 1812 & 1813 & 1814 & 1815 & 1816 & 1817 & 1818 & 1819 & 1820 & 1821 & Total \\
\hline 2 & 9 & 8 & 14 & 5 & 15 & 20 & 17 & 7 & 6 & 20 & 11 & 6 & 140 \\
\hline
\end{tabular}

Segundo a autora, a consulta de outras fontes demonstra que o número de negociantes de grosso trato da Bahia "nestes anos que antecederam a independência era de 372". Op. cit., 1996, p. 243. Sobre a presença de estrangeiros na capitania ver o estudo de Kátia Maria de Queirós Mattoso, no qual afirma que rapidamente os negociantes ingleses ascenderam sobre os portugueses: "em 1815, os recibos alfandegários pagos por eles representavam $24 \%$ do conjunto; em 1825, chegavam a $69 \%$. Por outro lado, entre os 20 maiores negociantes em 1815, apenas quatro eram ingleses. Em 1825 eles eram doze”. Op. cit., 1992, p. 492. Abaixo dos comerciantes ingleses, de acordo Wanderley Pinho, vinham os alemães cuja praça teria recebido do Brasil 52 navios, em 1820, dos quais, 38 provenientes da Bahia, 12 do Rio de Janeiro conduzindo "15.802 caixas de açúcar, sendo da Bahia 13.500, do Rio 1.740 e de Pernambuco 562”. "Bahia, 1808-1856”. In: Sérgio Buarque de Holanda (Dir.). História geral da civilização brasileira. O Brasil Monárquico. Dispersão e Unidade. São Paulo: Difel, 1985, p. 290. 
Os diferentes Estaleiros desta Cidade, estão permanentemente ocupados em construir embarcações mercantis. Isto prova que o nosso Comércio vai em marcha progressiva; e que será para o futuro de muito maior consideração, se os diversos ramos da Agricultura tomarem maior atividade. A construção naval tem chegado aqui a um grande ponto de perfeição; e a Bahia leva uma vantagem decidida aos outros portos do Brasil, não só na perfeição como em número de navios, que anualmente saem de seus estaleiros [...]. ${ }^{36}$

Ao final, o artigo traz uma relação das diversas embarcações construídas nos estaleiros da cidade - galeras, brigues, sumacas, escunas, lancha - entre os meses de janeiro de 1812 e outubro de 1815, totalizando 40 tipos de transporte mercantil. Como observa a historiadora Maria Beatriz Nizza da Silva, é possível traçar um quadro da movimentação da frota mercantil em Salvador a partir dos dados fornecidos pelo periódico na seção de Avisos que anunciava as partidas das embarcações para o exterior muitas vezes acompanhadas de informações sobre o frete das mercadorias. ${ }^{37}$

Ao identificar os elementos que gradualmente favoreceram a configuração de uma classe mercantil em Salvador, Catherine Lugar afirma que algumas condições propiciadoras de seu crescimento foram maiores aí se comparadas a qualquer outra cidade portuária do Brasil. Isso devido, principalmente, ao vigor produtivo da agricultura local, as vantagens econômicas obtidas com o comércio de escravos que incluía a exportação de tabaco e a permanência de uma coesão dos mercadores locais para a garantia dos interesses do grupo. ${ }^{38}$ As alterações verificadas a partir de 1808 foram ainda mais incisivas com a assinatura do Tratado de Comércio e Navegação entre Portugal e Grã-Bretanha dois anos depois que assegurou vantagens importantes para a última. Conforme dados apresentados por Lugar, isso pode ser verificado na proporção de embarcações comerciais originárias da Europa que deram entrada no porto de Salvador em 1819: 38\% contra os 18\% em 1800, sendo que os navios saídos dos portos ingleses contavam 16\% do total e dos portugueses, $13 \%{ }^{39}$ Ao que parece, no decorrer dos anos anteriores a 1820, a Coroa fez uso de uma política que tanto visava atender as necessidades do seu realinhamento externo quanto as

\footnotetext{
${ }^{36}$ Idade d'Ouro do Brazil, n. 91, 14 de novembro de 1811. Bahia: na Tipografia de Manoel da Silva Serva (disponível em www.br.br). Ver também Maria Beatriz Nizza da Silva, op. cit., 2005, p. 131.

${ }^{37}$ Maria Beatriz Nizza da Silva, op. cit., 2005, p. 133. Em 24 de maio de 1811 (n. 4), a gazeta trouxe o anúncio: "para Liverpool a Galera Inglesa [...] de quinhentas e cinquenta toneladas, armada em guerra, e equipagem competente. Quem quiser carregar nela dirija-se a casa dos Senhores John Rigg e Co. [..] Frete de algodão 3200 réis, açúcar 400 réis, sebo 400 réis. Couros do Rio grande 400 réis. Couros de Buenos Aires 450 réis, e 5 por 100 de primagem” (disponível em www.br.bn).

${ }^{38}$ Catherine Lugar, op. cit., p. 57.

${ }^{39}$ Idem, ibidem, p. 79 . Em 15 de outubro de 1810 o conde de Aguiar remeteu ao conde dos Arcos cópias impressas do tratado assinado nesse ano para que o mesmo fosse observado pelo provedor da Alfândega da Bahia. Anais da Biblioteca Nacional do Rio de Janeiro, op. cit., v. 68, p. 171.
} 
demandas internas das classes proprietárias. No entanto, muitas de suas intervenções foram determinadas pelas alterações políticas e econômicas no mundo Ocidental e que extrapolavam os mecanismos internos de sustentação da monarquia bragantina na América, “embora o ajustamento se tenha dado em função das bases estruturais em que estava montada a vida econômica da ex-colônia". 40 Seja como for, os antigos privilégios dos comerciantes de Salvador sofreram forte abalo com as concessões feitas aos britânicos ainda que se considere a força do monopólio do comércio exercido quase que totalmente pelos portugueses europeus e com grande importância no funcionamento da cadeia econômica da capitania:

[...] este comércio comprava aos estrangeiros suas mercadorias e fazia vir da Inglaterra as Máquinas e utensílios para as serventias dos Engenhos, mas quase tudo era fiado. Fazia vir da costa d’África escravatura, do Rio Grande as Carnes, e de outras partes Farinhas. Toda a ação e movimento daquele comércio, se dirigia a proporcionar-se artigos e meios para suprir e adiantar fundos aos Senrs. de Engenhos, estes que recebiam adiantados qto precisavam para o andamento de suas fabricas, hipotecando aos Negociantes Portugueses sua safra por contratos tácitos ou expressos. Os Negociantes Portugueses ato contínuo a hipotecavam aos estrangeiros para pagamento dos gêneros e Máquinas que lhes tinham tomado fiadas. O Sistema depravado de economia dos Snrs. de Engenho, fazia com que Recebessem cada ano muito mais do que a importância da sua Safra, acontecendo quase sempre, que as hipotecavam a três e a quatro ao mesmo tempo, passando com tudo miseravelmente, e sendo com isto um foco de querelas e demandas. ${ }^{41}$

A relação entre proprietários de engenhos e de escravos e mercadores caracterizava-se por sua interdependência econômica que certamente incluía eventuais conflitos dada a própria essência de reprodução do sistema. Com efeito, se por um lado os senhores de engenho necessitavam da mão-de-obra escrava para a produção da principal mercadoria da capitania - o açúcar - e do financiamento propiciado pelos negociantes; por outro, a demanda pelo produto no mercado externo impulsionava o aumento na introdução de cativos, a ampliação do comércio de tabaco e a concessão de empréstimos, além de o fornecimento de mercadorias vindas da Europa. Ocorre que, ao controlarem o capital comercial necessário para movimentar uma ampla e complexa engrenagem econômica, esses negociantes mantinham sob seu domínio a chave que permitia a

\footnotetext{
${ }^{40}$ Cf. Carlos Guilherme Mota. “Europeus no Brasil à Época da Independência”. In. (Org.)., op. cit., 1972, p. 63.

${ }^{41}$ Francisco de Sierra y Mariscal. "Idéas geraes sobre a Revolução do Brazil e suas conseqüências”. Anais da Biblioteca Nacional do Rio de Janeiro, v. 43-44, p. 61. Ver também Carlos Guilherme Mota, 1972b, op. cit.
} 
dinamização da economia primário-exportadora. Para João Rodrigues de Brito, essa era mais uma das dificuldades enfrentadas pelos lavradores de tabaco que viviam "quase todos na dependência dos Negociantes, que lhes assistem com os seus capitais, a ponto de se verem obrigados a entregar-lhes o tabaco sem estipulação de preço, não se abrindo este às vezes, senão depois que da Europa chega a notícia daquele, por que lá se vendeu”. ${ }^{2}$

De acordo Pinto de Aguiar, à medida que os homens envolvidos com o setor agrícola ampliavam seus contatos com o exterior, seja por meio das transações dos mercados, seja em função da leitura de livros e jornais, aumentava também a sua insatisfação com os procedimentos das casas que intermediavam o comércio importador e exportador na capitania. Por outro lado, os portugueses europeus resistiriam, inclusive, às tentativas de entrada dos americanos nas operações comerciais. Do mesmo modo, teriam sido contrários à implantação de um banco de crédito agrícola, em Salvador, em 1799, que poderia afrouxar a dependência de capital dos proprietários rurais. Os desdobramentos dessa relação comercial, não por acaso, terão um impacto importante no decorrer dos conflitos políticos dos anos $1820 .{ }^{43}$

Em 21 de janeiro de 1809, provavelmente em virtude dessa situação, a Coroa decidiu, por meio de um alvará, proteger os proprietários de ficarem à mercê de seus credores ao impedir a execução de sua propriedade, fábrica e lavoura em caso de endividamento, determinando que a cobrança recaísse em uma parte de seus rendimentos. Essa atitude certamente aproximou ainda mais esses indivíduos do príncipe regente pois, "assim favorecido, tornou-se um servidor leal, e mais que muito aderente às instituições monárquicas, porque, garantido e respeitado, tinha de rigorosa necessidade obedecer àquele que tantos favores lhe concedia”. ${ }^{44}$

As definições da política econômica da Coroa portuguesa, desse modo, revestem-se de fundamental importância não apenas por evidenciar os seus movimentos estratégicos no sentido de amenizar os efeitos da crise, como também por indicar as articulações entre os grupos econômicos locais e o príncipe regente no contexto de crise

\footnotetext{
${ }^{42}$ João Rodrigues de Brito, op. cit., p. 42.

${ }^{43}$ Cf. Pinto de Aguiar. "O movimento da Independência na Bahia (aspectos sócio-econômicos)". Revista de História, v. LIII, n. 105, São Paulo, 1976, p. 231-237. Ver também, João José Reis, op. cit., 2003, p. 35. Catherine Lugar considera que alguma tensão entre mercador-credor e plantador-devedor era inevitável, mas, em períodos de crescimento econômico as relações entre ambos eram atenuadas. Op. cit., p. 159. Para Morton, os mercadores poderiam constituir a fonte mais importante de renovação dos senhores de engenho em virtude do capital que possuíam mas, ao que tudo indica, essa passagem não foi tão freqüente. Assim, identifica apenas 16 mercadores nos registros dos engenhos da Bahia entre 1807 e 1821. Op. cit., 1974, p. 46 e seq.

${ }^{44}$ Mello Moraes, op. cit., t. 1, p. 416.
} 
do absolutismo monárquico e de reordenamento do Império português. Ciosos do lugar que ocupavam nessa estrutura, os proprietários da Bahia estavam convictos quanto à preservação dos interesses da Coroa, porém, desde que os seus pudessem também ser contemplados. Isso não significou a inexistência de conflitos entre as suas frações em momentos de aprofundamento da crise política, na qual a elaboração de distintos projetos alternativos emergiu com maior vigor, assim como o estabelecimento de alianças diante de situações reais de ameaça do seu statu quo econômico e político sobretudo quando oriundas dos segmentos da população que ansiavam pela incorporação de outras mudanças.

Um aspecto importante nesse cenário de mudanças e ajustamentos diz respeito à situação econômica mais ampla da capitania. Com efeito, a despeito da crise que mobilizava as autoridades régias em várias direções, alguns estudos demonstram que o último decênio do século XVIII e os primeiros do Oitocentos presenciaram alguma estabilidade econômica e mesmo crescimento. No caso da Bahia, Kátia Mattoso acredita que entre 1790 e 1817 houve um período de grande prosperidade devido à produção do tabaco e do algodão, mas principalmente à produção açucareira estimulada por alguns fatores internos e externos. No primeiro caso, destaca a redução paulatina de taxas e cobranças que incidiam sobre os produtos e que eram característicos do "regime exclusivo" do mercantilismo desse período; a atuação da Mesa de Inspeção de Agricultura e Comércio que controlava a qualidade dos produtos voltados para a exportação, assim como a introdução de novas técnicas de produção mencionadas acima. No plano externo, as guerras decorrentes da Revolução Francesa e seu impacto sobre as colônias produtoras de açúcar nas Antilhas impulsionando a sua produção na América portuguesa, além de uma situação econômica internacional bastante favorável no mesmo período. Para Mattoso, a ocupação de Portugal pelo exército francês e a transferência da família real para a América não interferiram no quadro econômico favorável da capitania da Bahia. ${ }^{45}$

É certo que os efeitos decorrentes das pressões francesas sobre as nações européias, e especialmente sobre Portugal, produziram sérias oscilações para a economia colonial, mormente os embargos impostos pelo Império francês. Em 25 de março de 1808, o príncipe regente determinou ao governador da Bahia que, a fim de animar e proteger o

\footnotetext{
${ }^{45}$ Kátia M. de Queirós Mattoso. "Os escravos na Bahia no alvorecer do século XIX. (Estudo de um grupo social)”. Revista de História, São Paulo, ano XXV, v. XLVIII, n. 97, p. 109-135. A análise de Fréderic Mauro sobre a conjuntura econômica da América portuguesa nos anos que antecederam a Independência também vai na mesma direção: "A conjuntura atlântica e a Independência do Brasil”. In: Carlos Guilherme Mota (Org.), op. cit., 1972, p. 38-47.
} 
comércio, informasse aos negociantes daquela praça para aprontarem os navios com destino às ilhas dos Açores e portos da Inglaterra e Gibraltar, aproveitando algumas embarcações de guerra em passagem por aquele porto. Em 1811, o Idade d'Ouro do Brazil informava aos negociantes daquela praça que desejassem enviar seus produtos a Liverpool que a Galera Ingleza com quinhentos e cinquenta toneladas, "armada em guerra, e equipagem competente”, estava prestes a partir: “Quem quiser carregar nela dirija-se a casa dos Senhores John Rigg e Co. [..] Frete de algodão 3200 réis, açúcar 400 réis, sebo 400 réis. Couros do Rio Grande 400 réis. Couros de Buenos Aires 450 réis, e 5 por 100 de primagem". ${ }^{46}$ Decisões como essa procuravam driblar as condições adversas ao funcionamento do comércio de exportação. Contudo, de qualquer modo, a abertura dos portos teve um peso importante na "rápida recuperação das receitas das exportações, em 1808, e seu crescimento entre 1809 e 1816”. ${ }^{47}$ O açúcar, de longe o produto mais importante no comércio de exportação da capitania, superou um longo período de depressão e nas últimas décadas do século XVIII iniciou um processo de crescimento somente interrompido em princípios dos anos 1820 por ocasião da guerra de Independência na Bahia e de mudanças na conjuntura econômica externa - o aumento da produção de açúcar na ilha caribenha de Cuba e do açúcar de beterraba na Europa - quando a economia local sofreu novos abalos. Por outro lado, as exigências do mercado de exportação influíam na produção de alimentos que, embora também tivesse se ampliado no período, não fora o bastante para sustentar uma crescente população constituída por escravos e livres. ${ }^{48}$ Mas, do ponto de vista das classes proprietárias, parece não haver dúvidas que o novo século iniciava com grandes perspectivas de expansão econômica. É o que se nota na avaliação de João Rodrigues de Brito, em 1807:

Que a Lavoura desta Capitania tem recebido progressivo aumento, é uma verdade incontestável, que se evidencia pelos mapas do rendimento dos dízimos, e de cada um dos outros impostos assentados sobre a produção, pelos da exportação, e importação, pela maior abundância das comodidades da vida, e geral riqueza mais difundida, e pelo visível

\footnotetext{
${ }^{46}$ Idade d’Ouro do Brazil, n. 4, 24 de maio de 1811. Bahia, Tipografia de Manuel da Silva Serva (disponível em www.bn.br).

47 Bert J. Barickman, op. cit., p. 53. O pesquisador chama a atenção, no entanto, para a ausência de informações oficiais sobre o valor total das exportações dificultando conclusões mais precisas "sobre o desempenho da economia de exportação baiana durante o longo período que se estende de 1817 a 1847 ”. Loc. cit.

48 João José Reis observa que antes da guerra de Independência na Bahia, a exportação de fumo chegava a 800 mil arrobas, na década seguinte, havia decaído para menos de 100 mil. Op. cit., 2003, p. 34-35; Frederic Morton, op. cit., 1974, p. 118.
} 
acréscimo da povoação, e do preço das carnes, lenhas, e madeiras, sintomas que acompanham aquele progresso. ${ }^{49}$

Alguns anos mais tarde, a inserção no mercado internacional de venda de açúcar de um dos grandes proprietários de engenhos da Bahia e também inspetor geral das tropas, Felisberto Caldeira Brant Pontes, confirmava a boa fase para os produtores da mercadoria. Por meio de sua correspondência enviada para casas comerciais de Hamburgo, França e Lisboa, é possível apreender não somente os amplos vínculos mantidos com outras praças, como também sua permanente atenção quanto à necessidade de aperfeiçoar a qualidade do produto de maneira a assegurar os melhores preços diante da competição mercantil. Em uma das cartas, datada de 19 de maio de 1820, solicita a seu correspondente na GrãBretanha que providencie um bom mestre refinador de açúcar uma vez que considerava que a péssima qualidade do açúcar produzido era "em parte devida a ignorância em que estamos sobre fornalhas, e mais ainda sobre cozimento e purgação" e uma pessoa talentosa nesse ofício poderia ensinar “a fazer açúcar tal qual o da Jamaica, e de Havana”. Após reforçar as exigências quanto ao pretendido, esclarece que as despesas do transporte do dito mestre será por sua custa e o seu sustento “em dinheiro três chilins por dia”.Valor que, no entanto, poderia ser ajustado pelo contratador desde que não enviasse "um ignorante". Ao final, concluía: "Parece-me que um bom Refinador saberia igualmente tomar um bom ponto no cozimento do caldo. Enfim, para V.mercê não são precisas muitas palavras, conhece minha pretensão, e caráter, e isto basta”. ${ }^{50}$

Três meses antes, em fevereiro, informara a um correspondente do Rio de Janeiro que os preços do bom açúcar mascavado estavam “a 900 em arroba, e os brancos de 1500 a 1600”. Diante disso, para ele, parecia “indubitável lucrar-se muito em Hamburgo”. E Caldeira Brant não estava sozinho nessas articulações. Em carta de 4 de março daquele ano enviada a um provável sócio na França, informa que:

Já disse que espero o resultado das embarcações [...] para me decidir sobre a preferência entre os portos de Nantes, ou Hamburgo, mas o meu prezado amigo Pedro Rodrigues Bandeira manda a vossa mercê pouco mais de cem caixas para outra semelhante experiência. Nós ambos tomamos a resolução de continuar a embarcar o produto dos nossos engenhos; e se os preços de França e vantagens da sua correspondência

\footnotetext{
${ }^{49}$ João Rodrigues de Brito et al, op. cit., p. 86. Para melhor fundamentar seus argumentos, o desembargador indica as razões - leis, fertilidade, capital estrangeiro - que contribuíram para beneficiar as lavouras da Bahia. Loc. cit.

${ }^{50}$ Cartas de Felisberto Caldeira Brant Pontes, marquês de Barbacena, op. cit. De acordo Bert Barickman, Caldeira Brant era proprietário de um grande engenho na comarca de Ilhéus e nesse ano, 1820, encomendara duas moendas horizontais de cana à empresa inglesa Grahan, Buxton and Company, seguindo o exemplo do seu cunhado Pedro Antônio Cardoso. Op. cit., p. 288.
} 
nos decidissem a preferir o porto de Nantes, poderia vossa mercê receber de ambos para cima de 1.400 caixas". ${ }^{5}$

Nesse movimentado cenário econômico, não deixa de chamar a atenção os outros pedidos feitos por Caldeira Brant aos seus contatos na Europa. Para seu sócio em Hamburgo requer o envio de "cinco dezenas do fabuloso vinho" que lhe havia presenteado; de Londres, “um piano para minha filha (de custo médio); da França, “50 garrafas de vinho champagne branco, e uma harpa de pouco valor, e tamanho proporcionado para uma menina de 8 anos que quer aprender. Quando souber e tiver 12 anos pedirei outra maior e rica”. Também para a filha, "24 pares de meias de linha, 24 das de seda”. ${ }^{52}$ Além de revelar outros aspectos da vida social desses indivíduos, essas demandas também podem sinalizar um período de grande confiança em seus negócios.

Não à toa, Caldeira Brant mencionava Pedro Rodrigues Bandeira como um de seus cúmplices nos negócios açucareiros. Afinal, ambos podem ser considerados como grandes representantes do segmento empreendedor dos proprietários como referido no capítulo anterior. A gazeta Idade d'Ouro, em dezembro de 1818, trouxe um comunicado sobre o decreto real (3 de agosto desse ano) pelo qual d. João VI concedia a ambos, juntamente com o capitão-mor Manoel Bento de Souza Guimarães, “o Privilégio exclusivo por tempo de quatorze anos para que só eles possam ter barcos de vapor nos rios, e costas da Província da Bahia, dentro da condição expressa de realizarem a introdução do primeiro barco no ano de 1819”. ${ }^{53}$ Bert Barickman observa que Rodrigues Bandeira, que possuía fortes ligações com o tráfico negreiro, adquiriu o engenho Vitória, situado na freguesia de Santiago do Iguape, em 1814, até então um estabelecimento de tamanho abaixo da média. Com os investimentos feitos pelo novo proprietário, o engenho aumentou consideravelmente sua capacidade de produção "de tal modo que ao morrer, em 1835, deixou no Vitória 242 escravos”, significando “um aumento de mais de 400\% em relação aos 48 escravos que haviam trabalhado na propriedade em 1786”. ${ }^{44}$ Mas não apenas isso. Filho de um comerciante português europeu, Pedro Rodrigues Bandeira era tido como um dos maiores (senão o maior) negociantes da Bahia. Envolvido em atividades comerciais diversificadas, seria o principal remetente de tabaco e de aguardente de Cachoeira para Salvador. Em 1807, processara a Corte inglesa visando recuperar os prejuízos pela

\footnotetext{
${ }^{51}$ Idem, ibidem.

52 Carta de Felisberto Caldeira Brant Pontes, marquês de Barbacema, op. cit.

${ }^{53}$ Idade d'Ouro do Brazil, n. 102, 2[!] de dezembro de 1818. Bahia: na Tipografia de Manoel Antonio da Silva Serva. Biblioteca Pública do Estado da Bahia. Setor de Periódicos Raros.

${ }^{54}$ Bert barickman, op. cit., p. 172.
} 
apreensão de um de seus navios que fazia o tráfico de escravos na Costa da África, cujas perdas foram estipuladas em 124:000\$000 (cento e vinte e quatro mil contos de réis). ${ }^{55}$ Vale relembrar que concedera um empréstimo de quase um terço dessa quantia para a Coroa portuguesa em 1811, o que possibilita dimensionar o volume da sua riqueza.

Outro senhor de engenho que nesse período parecia ter motivos para se vangloriar era Luis Paulino d'Oliveira Pinto da França. Com efeito, escrevendo do Rio de Janeiro para o seu cunhado em 15 de março de 1818, o marechal-de-campo demonstrava contentamento por gozar da confiança de d. João, embora as suas atribuições na corte como comandante do $1^{\circ}$. regimento de cavalaria o impedisse de vir à Bahia acompanhar de perto seus negócios:

El Rei nosso senhor cada dia me dá mais provas da sua magnânima e paternal bondade; e parece querer-me aqui: como ei de eu, pois, fazer a Sua Majestade o mais pequeno requerimento para ir para fora? Seguro-te que eu conheço que me é indispensável ir a essa terra ver os meus bens [...], e estou com medo de pedir a El Rei quatro ou cinco meses de licença. ${ }^{56}$

Mas, mesmo à distância, fornecia instruções sobre os encaminhamentos que deveriam ser tomados em seu Engenho de Aramaré, localizado em Santo Amaro, no Recôncavo, e pedia cautela quanto à construção de um novo engenho porque tinha interesse em acompanhar a obra. Aproveitava para informar que o preço do açúcar poderia subir "segundo as notícias de Lisboa e segundo o estado geral da Europa” e mesmo aos escravos "que nessa terra [Bahia] estão a 170 e 180 mil réis [...] devo dizer-te que há muito tempo não entrou nesta cidade tanta escravatura como agora”. Conforme lhe disseram, “escolhidos, se achavam escravos a 130\$000". ${ }^{57}$ Pinto da França, no entanto, parecia particularmente satisfeito pela concessão que havia conseguido para implementar um estabelecimento em Aramaré, “de maior vantagem para a minha casa”, ainda mais porque o monarca não havia mandado proceder qualquer “ouvidorias ou informações” sobre o assunto e "decididamente determinou fazer-me quanto eu pedia, e se passou logo o real decreto para se expedirem todas as ordens". ${ }^{58}$

\footnotetext{
${ }^{55}$ John Norman Kennedy. "Bahian Elites, 1750-1822”. HAHR, n. 3, v. 53, agosto de 1973, p. 421. Segundo o autor, ao morrer, o negociante deixou um patrimônio considerável entre navios, engenhos, prédios urbanos, papéis de crédito etc.

56 António d'Oliveira Pinto da França. Cartas baianas, 1821-1824. São Paulo: Companhia Editora Nacional; Rio de Janeiro: Núcleo Editorial da Universidade do Estado do Rio de Janeiro, 1980, p. 153.

${ }^{57}$ Idem, ibidem, p. 148

${ }^{58}$ Idem, ibidem, p. 153.
} 
Por meio do decreto, datado de 9 de agosto de 1819, d. João VI autorizou o estabelecimento de uma feira semanal nas terras do marechal-de-campo justificando as dificuldades para a circulação e venda de "boiadas, cavalarias e mais gêneros, assim de consumo da cidade e das vilas do Recôncavo” pela ausência de estradas e de pontos centrais de comercialização, resultando em "ramificações clandestinas e contrárias aos interesses fiscais". O proprietário comprometia-se a construir "à sua custa, as primeiras acomodações, rancharias, currais e pastos fechados e abertos” para efetivar o estabelecimento que serviria para o "aumento e prosperidade do comércio interno daquela capitania, e ao novo impulso que com o seu aumento deve conseqüentemente receber a agricultura, que muito desejo promover, como o primeiro manancial da riqueza”. ${ }^{59}$

Esses homens integravam amplas redes de negócio que envolviam abundantes capitais e, certamente, sua área de atuação e de influência não estava demarcada pelo local de nascimento. Portugueses europeus ou americanos, de há muito haviam constituído estreitos vínculos assentados, sobretudo, na manutenção de seus interesses econômicos. Isso não significa dizer a inexistência de conflitos entre as frações desses proprietários que buscavam assegurar as melhores condições para a reprodução de seus benefícios. Diferenças que no decorrer das agitações políticas dos anos 1820 intensificaram-se profundamente por razões oportunamente discutidas. No entanto, no conjunto, poderosos senhores de engenho, grandes negociantes, membros da alta burocracia administrativa e militar, compunham o núcleo da classe dominante da Bahia ansiosa por assegurar e ampliar seu prestígio econômico e social. ${ }^{60}$

Desse modo, tudo indica que a capitania da Bahia vivencia nos primeiros decênios do Oitocentos uma fase de crescimento no setor exportador, busca aprimorar as técnicas de produção e amplia a integração mercantil por meio do mercado interno expandindo as possibilidades de inserção econômica e social para uma parte de seus residentes. Condições econômicas que, como mencionado, foram potencializadas com o estabelecimento da Coroa portuguesa no Rio de Janeiro cujo ritmo, no entanto, estava definido antes mesmo da sua transferência. ${ }^{61}$ Como essas alterações foram apreendidas pelos coevos é o que se discute a seguir.

\footnotetext{
${ }^{59}$ Idem, ibidem, p. 162-163.

${ }^{60}$ Cf. John Norman Kennedy, op. cit., p. 416.

${ }^{61}$ A antecedência das mudanças econômicas para o Rio de Janeiro foi realçada por Cecília Helena L. de Salles Oliveira, op. cit., 1999.
} 


\subsection{Idéias de reforma e de conservação}

No mesmo escrito em que destacou o crescimento da lavoura na capitania da Bahia, em 28 de maio de 1807, portanto, no ano anterior à chegada da família real ao Brasil, João Rodrigues de Brito também registrou:

Em geral todas as vezes que a Administração pública se intromete a prescrever aos Cidadãos o emprego que eles hão de fazer em suas terras, braços e capitais, ela desarranja o equilíbrio, e natural distribuição daqueles agentes da produção de riquezas, cujo uso ninguém pode melhor dirigir que o próprio dono, que é nisso o mais interessado, e que por essa razão faz deles o objeto das suas meditações. ${ }^{62}$

O então desembargador do Tribunal da Relação da Bahia respondia a uma série de questionamentos feitos pelo Senado da Câmara de Salvador, poucos dias antes, sobre as condições de desenvolvimento da lavoura local. No decorrer de suas observações, não apenas relaciona os elementos que considera vitais para a promoção da riqueza e do progresso da capitania, como também fundamenta as suas proposições com base nos escritos dos economistas europeus de fins do século XVIII, a exemplo de Adam Smith e Jean-Baptiste Say e, citados ao longo do texto. Ele se mostra plenamente convencido de que os empecilhos enfrentados pelos produtores agrícolas, tanto no que se refere à produção quanto no estabelecimento dos preços das mercadorias, advém da interferência do Estado, sugerindo a adoção de uma política reformista que propicie as condições necessárias para a superação desses entraves. O governo, em sua perspectiva e "segundo os melhores economistas” deveria se ocupar das questões agrícolas estritamente em três aspectos: "liberdades, facilidades e instruções". A incorporação de algumas medidas reformistas não apenas poderia propiciar o desenvolvimento da agricultura e, portanto, da arrecadação real, como também, permitir “aos capitalistas o exercício do seu direito de propriedade”. Assim, condenava qualquer mecanismo - tabelamento de preços, proibições contra caixeiros viajantes e comissários volantes, obrigação de plantar mandiocas, execuções hipotecárias, entre outros - que impedissem o proprietário de decidir sobre os seus investimentos.

As idéias de Rodrigues de Brito integram um quadro mais amplo de difusão dos princípios da economia política na América portuguesa, em fins do século XVIII e início do Oitocentos, que adquiriram um sentido pragmático no contexto econômico desse

\footnotetext{
${ }^{62}$ João Rodrigues de Brito et al, op.cit., p. 30.
} 
período. Aqui, especialmente, seu posicionamento ganha relevância por dois pontos essenciais. Primeiro, a defesa intransigente do distanciamento do governo nos negócios agrícolas não significava uma desvinculação com o Reino de Portugal. Ou seja, a adoção de medidas que assegurassem a liberdade dos plantadores em seus negócios poderia ser coadunada com a política mercantilista da metrópole portuguesa. Para Kenneth Maxwell, o fato do açúcar produzido no Brasil ser comercializado no mercado europeu com a indispensável intermediação de Lisboa constituía um dado importante a ser levado em consideração. Afinal de contas, “a Inglaterra, a candidata mais provável para qualquer relação de livre-comércio externa ao sistema comercial luso-brasileiro, aplicava tributos proibitivos sobre a importação do açúcar brasileiro, no interesse de suas próprias colônias açucareiras das Índias Ocidentais”. 63

O segundo aspecto indica que a sua percepção quanto às reformas consideradas essenciais para o aumento da lavoura coaduna com uma perspectiva de intervenção coletiva dos proprietários, exposta por meio de um documento não somente bem fundamentado, como também calcado numa concepção de mundo ajustada a esses interesses. Nesse sentido, não deixa de ser significativo os mecanismos sugeridos com o intuito de solidificar o poder de coesão e de intervenção dos agricultores, se antecipando, inclusive, na formulação de algumas proposições posteriormente adotadas pelo governo da Bahia na década seguinte em benefício dos proprietários locais. A certa altura afirma que: “As liberdades, e as facilidades concedidas aos Lavradores para o exercício de sua indústria serão medíocres vantagens, se eles não forem instruídos nos métodos mais cômodos de se aproveitarem delas”. Em razão disso, a inexistência de uma praça de comércio, uma cadeira de economia política, instrução, museu, biblioteca, horto botânico, uma sociedade econômica literária que pudesse "reanimar o patriotismo, fomentar a indústria do povo, ensinar-lhes os melhores métodos de cultura e artes”, constituíam sérios empecilhos ao desenvolvimento da economia agrícola. A criação de uma cadeira de economia política logo após a chegada de d. João teria sido em decorrência de sua defesa. Para ele, o estudo dessa ciência era indispensável na resolução de muitos dos problemas identificados, recomendando fortemente a leitura dos escritos do economista Jean-Baptiste Say, cujo tratado, se conhecido "pela centésima parte dos nossos Compatriotas” resultaria, seguramente, “que a amada Pátria subirá logo a um grau superior de properidade”. No entanto, constata criticamente que os moradores de Salvador preferiam gastar

\footnotetext{
${ }^{63}$ Kenneth Maxwell, op. cit., 1996, p. 174.
} 
“espontaneamente mais de meio milhão por ano em funerais, e festas d'Igreja”, não destinando qualquer quantia para obras mais convenientes. Quanto a isso, os prejuízos advindos eram imensos: "Se em vez de lerem vidas de Santos cheias de piedosas fraudes, lessem livros dessa ciência sublime, suas despesas se encaminhariam como na GrãBretanha, para dockes, e outras obras patrióticas”. ${ }^{64}$

João Rodrigues de Brito, formado em direito pela Universidade de Coimbra, demonstra plena convicção em suas proposições, combatendo com veemência não somente as regulações promovidas pelo Estado como também outros males da vida social (mendicidade, recrutamento, reclusão do sexo feminino) que, em sua perspectiva, também contribuiriam para atravancar o progresso econômico. A solução era aplicar as medidas corretas considerando que a natureza era prodigiosa: "Ver um povo tão numeroso submergido na pobreza, podendo com o trabalho de uma semana bem dirigido abrir os mananciais da abundância, e da felicidade! É uma fortuna em um tal estado de cousas ignorar os princípios da Ciência econômica”. ${ }^{65}$ Ao que tudo indica, não chegou a produzir outros escritos e mesmo no decorrer das agitações dos anos 1820 não parece ter tido alguma inserção política embora seja incluído, de maneira equívoca, como um dos deputados eleitos pela Bahia para as Cortes portuguesas de Lisboa, ${ }^{66}$ possivelmente em razão de um seu homônimo representante da Província do Alentejo.

Ainda que não seja possível estabelecer o grau de difusão que as idéias de reforma ocuparam entre indivíduos letrados na Bahia, certamente João Rodrigues de Brito não estava sozinho em muitas de suas posições. Não se pode esquecer que antes mesmo de expor suas convicções, o maior entusiasta da economia política nesse período - José da Silva Lisboa - havia publicado, em 1804, o primeiro livro que tinha essa temática como eixo central. Ambos podem ser identificados, assim, como os defensores pioneiros da utilização do saber da ciência econômica como um instrumento necessário e essencial à boa administração pública. O próprio Rodrigues de Brito menciona seu compatriota nessa obra para reafirmar sua conviç̧ão de que "governa melhor aquele, que menos governa”. 67 Mas, o que importa ressaltar, é que ele buscou sintetizar os sentimentos de uma parcela dos grandes proprietários que certamente partilhavam, além das condições materiais e imateriais de inserção econômica e social, a perspectiva de efetivação de determinadas

\footnotetext{
${ }^{64}$ Idem, ibidem, p. 78 e seq. Sobre sua influência para a criação da aula de economia, ver José Honório Rodrigues. História da História do Brasil (1 ${ }^{\mathrm{a}}$. parte). Historiografia colonial. 2. ed. São Paulo: Companhia Editora Nacional, 1979, p. 413.

${ }^{65}$ João Rodrigues de Brito et al, op cit., p. 50-51.

${ }^{66}$ José Honório Rodrigues, op. cit., 1979, p. 411.

${ }^{67}$ Idem, ibidem, p. 84. Sobre o pioneirismo de ambos: Antonio Penalves Rocha, op. cit., p. 1996, p. 39.
} 
mudanças em benefício de seus interesses comuns. Ao criticar o excesso de regulamentações e cobranças a que os lavradores eram submetidos afirma que os maiores empecilhos para a prosperidade da lavoura e do comércio na capitania provinham justamente “dos regulamentos e posturas desse respeitável Senado; e creio que neste ponto está de acordo comigo a voz do público: deverá por ventura daí concluir-se que se deva abolir o Governo municipal?”. ${ }^{68}$ Certamente para justificar seu posicionamento incisivo, Rodrigues de Brito alertou que o mesmo não deveria ser visto como sinal de qualquer desmerecimento àquele órgão camarário, mas antes como o cumprimento de um dever

que me liga a expor francamente toda a verdade, que julgo interessante ao público, e Real serviço de S.A.R. numa ocasião em que se digna ouvirnos, deixando ver as suas paternais intenções de corrigir os abusos, que oprimem a Lavoura, e Comércio desta Capitania. Em tais circunstâncias o silêncio seria um crime, que me tornaria responsável dos danos ocasionados por qualquer abuso, que deixasse de corrigir-se por falta de manifestação. ${ }^{69}$

Em um texto mais conciso, Manuel Ferreira da Câmara também se posicionou sobre as questões suscitadas pelo Senado da Câmara de Salvador sobre os progressos da lavoura. Proprietário de um grande engenho no Recôncavo adquirido provavelmente em 1804 de seu tio João Ferreira de Bittencourt e Sá e com uma trajetória de muitos serviços prestados à Coroa Portuguesa, sobretudo na área de mineralogia, produziu alguns estudos acerca da economia do período. Da mesma maneira que Rodrigues de Brito, em seu parecer mostra-se seduzido pelos ensinamentos da economia política clássica destacando também a importância do pensamento de Adam Smith e de Jean-Baptiste Say para reflexão do tema: "Se a intervenção do Governo é um mal [...], um bom Governo a fará tão raras vezes que lhe for possível”. Contudo, embora manifeste pontos em comum com o desembargador, a exemplo da crítica ao excesso de leis e de regulamentos para o funcionamento da lavoura e quanto à obrigação do lavrador de plantar mandioca em terrenos de massapé ("não planto um só pé de Mandioca, para não cair no absurdo de renunciar a melhor cultura do País pelo pior que nela há, e para não obstar a uma por outra cultura, e complicar trabalhos de natureza diferente”), ${ }^{70}$ Câmara expressa algumas opiniões

\footnotetext{
${ }^{68}$ Idem, ibidem, p. 92.

${ }^{69}$ Idem, ibidem, p. 94. Conforme esclarece Bert Barickman, o termo "lavrador", constante nas fontes do período e na historiografia, refere-se ao lavrador de cana, embora possa designar também "quase qualquer tipo de agricultor, inclusive os produtores de fumo e de mandioca”. Op. cit., p. 41.

${ }^{70}$ Manoel Ferreira da Câmara. "Carta II”. In: João Rodrigues de Brito et al, op. cit., p. 98-100. O último considerou um absurdo obrigar o lavrador "a ocupar com a mesquinha plantação de mandioca [...] os raros e preciosos torrões de massapé, aos quais a natureza deu o privilégio de produzirem muito bom açúcar, e outros gêneros de grande valor”. Loc. cit., p. 29. Essa resistência dos senhores de engenho em cultivar
} 
distintas. Para ele, a Mesa de Inspeção do açúcar, do tabaco e do algodão e o Celeiro Público, criado em 1785 durante o governo de d. Rodrigo José de Menezes, devido a "um zelo mais religioso que político", para tentar garantir o fornecimento de alguns gêneros à população, somente contrariavam os interesses de lavradores e comerciantes, condenando veementemente os meios pelos quais ambos tentavam controlar a produção e a venda local. Acreditava ser impossível “que se faça bem a alguém, obrigando-o”, além de duvidar que o governo conseguisse, por esse meio, efetivar qualquer objetivo. Desse modo, seria mais proveitoso se cada indivíduo pudesse "fazer o que mais lhe convier; e o que mais lhe convier é o que mais convém ao Estado, e ao Soberano, que tem partilha em todos os seus lucros, e interesses". ${ }^{71}$

Nascido em Minas Gerais, Manoel Ferreira da Câmara, juntamente com seu irmão José de Sá Bittencourt Accioli, sempre manteve fortes ligações com a Bahia onde residiam alguns de seus poderosos familiares. Logo após ter se formado na Universidade de Coimbra, em 1788, acompanhara seu colega José Bonifácio de Andrada e Silva em viagens de pesquisa científica pela Europa patrocinadas pelo governo português. No ano seguinte, apresentou a memória “Ensaio de Descrição Física e Econômica da Comarca dos Ilhéus na Bahia”, denotando que já possuía algum conhecimento sobre aquele território. Por essa época, de acordo Kenneth Maxwell, a Coroa já sabia que seu irmão mais velho, José Accioli, havia sido implicado na conspiração em Minas Gerais. ${ }^{72}$ Curiosamente, alguns anos mais tarde, em 1800, Câmara foi nomeado Intendente Geral das Minas na

produtos de subsistência foram confirmadas por Bert Barickman ao analisar 150 inventários post- mortem dos principais distritos de cana-de-açúcar do Recôncavo, no período de 1780-1860. Pela amostra, constatouse que uma pequena proporção de lavradores de cana possuíam os acessórios necessários a esse tipo de cultivo. "Torna-se evidente que muitos senhores de engenho e lavradores de cana não cultivavam mandioca alguma”. Op. cit., p. 107. De acordo Barickman, mais tarde, em função da crise econômica do final da década de 1820 e início da seguinte, Ferreira Câmara mudaria sua opinião. Op. cit., p. 144.

${ }^{71}$ Manoel Ferreira da Câmara, op. cit., p. 106. José Honório Rodrigues, op. cit., p. 414-415. Kenneth Maxwell, op. cit., p. 173. José da Silva Lisboa, ao prestar informações sobre a Bahia para Domingos Vandelli em 1781, diria que a Mesa de Inspeção era “composta de deputados, parte lavradores, parte negociantes". Sobre a taxação do tabaco distintos por 3 qualidades (1a. e 2a. folha e a de refugo) esclarecia: "Aquela taxa nem sempre é feita à boa fé e com conhecimento de causa. Às vezes por imperícia e a maior parte das vezes por fraude se danificam os lavradores ou se beneficiam, à proporção de que o interesse do Inspetor taxante ou do subalterno, a quem ele se confia, exige a ruína ou vantagem do dito lavrador, invertendo-se caluniosamente a ordem dos valores, taxando-se de refugo, o que não é ou o contrário disso”. José da Silva Lisboa, op. cit., 1950-1951, p. 112.

${ }^{72}$ Kenneth Maxwell, op. cit., 1999, p. 179. Após a denúncia, José de Sá Bittencourt Accioli fugiu para a Bahia, onde possuía poderosos parentes, pelo sertão. Absolvido, ao que consta com a intervenção de um poderoso parente, foi designado para explorar as minas de salitre em Monte Alto, sendo posteriormente agraciado com uma sesmaria na região de Rio de Contas. Waldir Freitas Oliveira. "A história baiana dos Ferreira da Câmara Bittencourt e Sá”. RIGHBa, Salvador, v. 97, 2002, p. 61-72. Vale ressaltar que Accioli estabeleceu contato com João Gonçalves da Costa, conhecido explorador dos sertões da Bahia, que se relacionara também com o seu tio João Ferreira de Bittencourt e Sá. Cf. Maria Aparecida Silva de Sousa, op. cit., 2001. 
mesma capitania e dos diamantes do Serro Frio produzindo alguns trabalhos nos quais recomendava a implementação de reformas para a mineração. Ocupou ainda uma vaga na Assembléia Constituinte, eleito por Minas e retornou a Bahia assumindo a primeira presidência da Sociedade de Agricultura, Comércio e Indústria da Província da Bahia, em 1832, até a sua morte ocorrida em Salvador três anos depois. Ao redigir sua resposta aos camaristas, em 1807, encontrava-se administrando seu engenho da Ponta, na Bahia, e já era tido como um dos portadores das “conhecidas luzes e talentos” de que o Senado da Câmara necessitava para dar resposta às suas questões. ${ }^{73}$

No entanto, ao que tudo indica, nem todos acreditavam que a Câmara de Salvador estava mesmo disposta a solucionar alguns problemas da capitania. Nesse sentido, a crítica formulada por João Rodrigues de Brito àquela instituição ganha maior consistência em um outro documento do mesmo período. De fato, dois meses depois de ter redigido seu parecer aos membros daquele órgão, em 31 de julho de 1807, uma petição assinada por 41 "Vivandeiros e Condutores da Capitania da Bahia, e mais habitantes de diversas classes dela” foi dirigida ao príncipe regente em Lisboa. De acordo os signatários, por várias vezes haviam encaminhado súplicas ao "Real Trono” nas quais se queixavam “contra a falta de economia pública e contra os abusos, pelos quais sofrem vexames incríveis, e sem número, e especialmente pela indolência e tolerância da Câmara” da capital. Essa teria, inclusive, dificultado a isenção das taxas sob os víveres concedida pelo regente em 1799. A partir de então, o documento expõe uma série de razões pelas quais os suplicantes consideravam os membros do Senado como "sinistros interpretes das Leis justas ou, para melhor dizer, atorvadores da felicidade pública”, questionando a legitimidade de sua atuação diante de cobranças de taxas abusivas, a má aplicação das posturas, além de conservarem “um verdugo sobre os miseráveis povos pelo interesse de sua renda, que ficava ressarcida se não no todo, ao menos em parte com as condenações que fizessem os Almotacés nas suas Correições”. Os reclamantes, conforme denunciam, estavam submetidos a uma verdadeira "tortura” promovida pela Câmara por meio da execução de “mais de 200” posturas constantes de um “Caderno” quando "apenas poderão servir de 40 a 50”. Requeriam, assim, que o príncipe se dignasse a "mandar examinar as muitas nulidades, e inutilidades” das mencionadas taxações conforme as observações que seguiam anexas "emendadas, acrescentadas, e dispostas com as cautelas, que se puderam

\footnotetext{
${ }^{73}$ Waldir Freitas Oliveira, op. cit., p. 61. João Rodrigues de Brito et al, op. cit., p. 25. Dois outros grandes proprietários responderam ao Senado: José Diogo Gomes Ferrão Castello Branco e Joaquim Inácio de Siqueira Bulcão. As respostas breves reproduzem algumas das soluções indicadas pelos anteriores.
} 
lembrar por pessoas inteligentes do mecanismo, interessadas na felicidade pública, objeto inseparável do Trono de V. A. R" ${ }^{74}$

O Requerimento evidencia questões importantes relacionadas ao papel exercido pelo Senado da Câmara no interior de uma urbe, como se verá. Por ora, interessa reter outros aspectos de seu conteúdo. Os signatários desenvolviam atividades vinculadas ao pequeno comércio na capital da capitania e, portanto, diferenciavam-se do segmento representado por João Rodrigues de Brito e Manuel Ferreira Câmara e os demais que elaboraram os pareceres sobre a lavoura. Para preservar os seus interesses, viam no comportamento do Senado da Câmara e em sua resistência em reformar o código de posturas um dos problemas centrais para a organização das arrecadações e, em razão disso, recorreram diretamente ao príncipe por se sentirem "desenganados que da Câmara da Bahia, relutante e aferrada em sistemas reprovados, e desculpas frívolas e paliativas, jamais terão deferimento favorável ao vexame geral”. ${ }^{75}$

Os vivandeiros e condutores reclamavam, entre outras coisas, de a Câmara não taxar devidamente os regateiros e regatões, indivíduos que se dedicavam à venda de produtos nas ruas de Salvador, motivo pelo qual se sentiam prejudicados pelo pagamento de taxas e pela falta de condições para o trabalho, tendo em vista que os vendedores ocupavam os locais - ruas públicas e lugares a beira-mar - que deveriam ser destinados aos condutores. A razão para isso era que os camaristas não desejavam fazer uso "dos verdadeiros princípios da boa economia” mas antes estava pronta a “ceder por dinheiro” os lugares que lhes deveria pertencer. Essa atitude da Câmara tornava-a suspeita "na sustentação dos seus caprichos, e na confusão das suas deliberações para melhor aumento das suas rendas, e utilidade do seu Escrivão, Porteiro e Aferidores poderosos”, que se opunham a reforma das posturas "por verem que feita ela lhes dissipa muita parte das extorsões que eles mesmos têm introduzido nos seus ofícios com a falsa máscara do zelo público". ${ }^{76}$

Pelo visto, a situação era ainda mais complexa. Já no século XVIII, os regateiros e regatões, constituía o maior grupo de indivíduos que exerciam atividades no meio urbano em Salvador. Formado por "escravos, libertos e, em menor proporção, por brancos pobres", esses vendedores perambulavam pela cidade oferecendo diversos gêneros

\footnotetext{
${ }^{74}$ Requerimento dos vivandeiros, condutores e mais habitantes de diversas classes de Cidadãos da Bahia, dirigido ao Príncipe Regente, contra a falta de economia pública e contra os abusos pelos quais sofrem vexames. Bahia, 31 de julho de 1807. APEB. Seção de Arquivo Colonial e Provincial. Setor de Microfilmes (Original consta do acervo da BNRJ).

${ }^{75}$ Idem, ibidem.

${ }^{76}$ Requerimento dos vivandeiros... Loc. cit.
} 
alimentícios e, por conta disso, muitas vezes foram objeto de atenção do Senado da Câmara sobretudo no decorrer dos anos $1760 .^{77}$

As pretensões do poder camarário eram não somente permitir que as ruas fossem liberadas desse tipo de comércio ambulante, como também exercer maior controle sobre esses indivíduos por meio da aplicação das regulamentações locais: as leis e posturas do município. No entanto, as investidas do conselho nem sempre eram bem-sucedidas,

pois os lugares indicados não satisfaziam nem aos fornecedores, isto é, as regateiras e os regatões, que ficavam privados da liberdade de ir e vir, de circular mais e vender melhor os seus produtos, nem aos compradores, premidos a vencerem as dificuldades de distância e tempo para adquirir o que antes vinha-lhes comodamente à porta. Ademais, quase sempre, os que alugavam quitandas e cabanas se queixavam do preço do aluguel cobrado pela Câmara, preferindo assim continuar a comerciar de porta em porta. ${ }^{78}$

Em 1775, os vendedores de rua encaminharam uma petição aos vereadores requerendo autorização para que pudessem novamente comerciar sem os impedimentos a que estavam sujeitos como era procedimento no Reino. Entretanto a situação parece ter se agravado ainda mais pois, em fins desse século, uma reclamação do procurador da Câmara dava conta que

em relação ao embaraço em que se achava os serventes das obras da Ladeira da Misericórdia e cadeia nas conduções dos materiais para as ditas obras por terem tomado o passo público as vendeiras e regatões que ali se acham com as suas vendagens e mercadorias que nem uma só pessoa podia passar acontecendo sucessivas desordens e questões que resultavam clamor público. ${ }^{79}$

Embora sujeitos a um maior número das normas citadinas, como aponta Avanete Pereira Sousa, a submissão dos vendedores às regulamentações não se revelou uma tarefa fácil, resultando em um estado de permanente tensão entre esses e o Senado da Câmara no decorrer do Setecentos. ${ }^{80}$ A petição dos vivandeiros e condutores indica que os conflitos não somente adentraram pelo século seguinte como também as queixas foram ampliadas incorporando outros segmentos da capitania da Bahia. Além do mais, não se pode perder de vista os interesses mais amplos do governo local em enquadrar os indivíduos envolvidos em um comércio indesejado, seja para limitar ou eliminar a competição aos grandes

\footnotetext{
${ }^{77}$ Avanete Pereira Sousa, op.cit., p. 100.

${ }^{78}$ Idem, ibidem, p. 101-102.

${ }^{79}$ Citado por Avanete Pereira Sousa, op. cit., p. 102. A autora apresenta um quadro das posturas no período de 1699 a 1742 evidenciando a sua maior incidência sobre o comércio ambulante.

${ }^{80}$ Idem, ibidem, p. 110.
} 
mercadores, seja para regulamentar a arrecadação das taxas em nome da Coroa. Nesse sentido, ambos poderiam ser amplamente beneficiados com as regulações. ${ }^{81}$

O problema da fiscalidade de há muito integrava os programas de reformas dos conselheiros régios. Na interpretação de Wilma Peres Costa, o tema é de fundamental importância na discussão sobre o sistema colonial haja vista as contradições inerentes ao processo de arrecadação fiscal como parte do domínio da Coroa:

a fiscalidade é cerne do conflito entre colonos e colonizadores, mas é também espaço da invenção dos colonos (impostos e taxas locais). As funções que ela engendra no plano "privado" (contratadores, arrecadadores) e "público" (os múltiplos funcionários da burocracia fazendária no espaço metropolitano e colonial) abrem, sobretudo depois de Pombal, importante campo de tráfico de influências, de conciliação de interesses e de disputas, entre as elites coloniais e os funcionários metropolitanos no interior do aparelho administrativo. ${ }^{82}$

Em razão de sua produção econômica, a Bahia era uma das capitanias com a maior carga de tributos, ficando atrás apenas do Rio de Janeiro e de Pernambuco. E as atividades que incidiam tributação não eram poucas. Situação que somente foi potencializada com a vinda da corte, conforme aponta a autora. ${ }^{83}$ No segundo decênio do Oitocentos, o cônsul inglês na Bahia deixou registrado sua má impressão sobre as finanças da capitania. Segundo ele, a corte requeria tanto dinheiro, "que tão logo as taxas e os direitos entram, são gastos com as letras de câmbio que a corte emite constantemente sobre o tesouro da Bahia; algumas vezes as faturas não podem ser honradas, mesmo muitos meses depois de terem sido debitadas". ${ }^{84}$

Seja como for, as tentativas de uma parcela dos residentes de Salvador ao elaborar e propor medidas de reorganização do comércio local indicam que a despeito dos canais estreitos de participação política, em variados momentos alguns espaços de experimentação coletiva foram forcejados propiciando um maior dinamismo à sociedade da Bahia nos anos que antecederam a década de 1820. Além disso, para os indivíduos que

\footnotetext{
${ }^{81}$ John Norman Kennedy, op. cit., p. 422. Ainda em 1822, em meio a guerra civil na Bahia, o Senado da Câmara de Salvador decidiu abolir "todas as licenças que até agora se davam para se vender pelas ruas, ficando em seu vigor a determinação do Regimento de 1709 a respeito das que se davam aos que vendem de Porta aberta, pois que o referido Regimento só fala destas e não daquelas" e convidar "homens bons e inteligentes para aconselharem sobre alguns objetos da utilidade pública [...]”. Termo de Vereação, de 6 de março de 1822. Documentos da Municipalidade de Salvador relacionados com a Independência do Brasil. 1821-1823. Salvador: Prefeitura Municipal/Departamento de Cultura da SMEC, 1972, p. 55.

${ }^{82}$ Wilma Peres Costa In: István Jancsó (Org.)., op. cit., 2003, p. 170-171.

${ }^{83}$ Idem, ibidem, p. 171. O artigo traz importantes dados sobre os impostos cobrados nas províncias. A esse respeito, tratando especificamente da capitania da Bahia, ver Avanete Pereira Sousa. Poder local, cidade e atividades econômicas (Bahia, século XVIII). São Paulo, 2003 (Tese de doutorado).

${ }^{84}$ Citado por Pierre Verger, op. cit., p. 299.
} 
ansiavam por algum tipo de alteração no âmbito político-econômico da capitania, a presença do príncipe em terras americanas seguramente reavivou a crença de que o atendimento de suas aspirações estava muito mais próximo, gerando expectativas positivas. Alguns anos mais tarde, algumas figuras letradas não tinham dúvidas quanto à dimensão das mudanças ocorridas e que ainda poderiam acontecer.

Esta é, por exemplo, a perspectiva de Antonio Luiz de Brito Aragão e Vasconcellos, advogado natural da Bahia, que formado pela Universidade de Coimbra, assumiu a defesa de grande parte dos presos políticos da Revolução de Pernambuco de 1817. Os argumentos utilizados por ele no decorrer do processo foram analisados por Carlos Guilherme Mota no intuito de apreender a percepção de um indivíduo letrado que viveu em um período de intensas transformações políticas poucos anos antes da Independência. Mota considera que a sua atuação foi decisiva para atenuar as penalidades dos rebeldes, demonstrando o amplo conhecimento que possuía de direito, filosofia e literatura cuja bibliografia utilizada "impressiona pela quantidade e pela qualidade, nela não faltando nem mesmo Aristóteles e Platão, Rousseau, Mably e Bentham”. ${ }^{85}$ Esses e outros autores serviriam para fundamentar a sua concepção de revolução, sociedade e povo buscando esclarecer as razões essenciais pelas quais os indivíduos se envolviam em processos dessa natureza. Embora apresente formulações acerca da organização típica de uma sociedade de Antigo Regime, a sua concepção de mundo não significa um confronto com àquela apregoada pelos setores dominantes: “o tribuno não se confunde em momento algum com o 'povo rústico e ignorante'”, ${ }^{86}$ Mas o seu pensamento agudo não deixava de absorver as múltiplas e amplas alterações daquele período.

Com efeito, em 1814, Aragão e Vasconcellos redigiu as suas “Memórias sobre o estabelecimento do Império do Brazil, ou novo Império Lusitano”, oferecidas ao conde dos Arcos, governador da Bahia, que aparece registrado no frontispício da obra como seu mecenas. Para ele, os conhecimentos dos indivíduos precisavam ser publicados oferecendo memórias ao Estado "a fim utilizarmos a Pátria, melhorarmos e instruirmos os nossos Concidadãos”. E a época era bastante favorável para isso, uma vez que contava com a presença de um "Soberano Afável, Benigno e Protetor das Ciências”, conselheiros e ministros sábios, além do aumento do Estado. A partir de então, o advogado propõe um plano de intervenções necessário à efetivação desse Império a ser apresentado sob a forma

\footnotetext{
${ }^{85}$ Carlos Guilherme Mota, op. cit., 1972a, p. 210 e seq. Segundo Pedro Calmon, Aragão e Vasconcellos se formara em Coimbra em 1805 e cinco anos depois teria retornado para a Bahia. Op. cit., p. 1444.

${ }^{86}$ Idem, ibidem, p. 231.
} 
de memórias. Em sua introdução, esclarece que a primeira memória trataria dos meios de ampliar a população do Brasil, “porque não pode ser grande, e Poderoso um Império que só conta uma extensão quase infinita de território inabitado”. As demais abordariam temas importantes como a promoção da agricultura e do comércio, "as duas principais colunas que sustentam o Estado"; a educação e as forças armadas, ambas "necessárias a uma Nação que quer passar por civilizada e ser respeitada”; o aumento das finanças; as conquistas e domínios que poderiam ou não ser conservadas na África e na Ásia, assim como a abolição da escravatura e a "conveniência que disso resulta ao Estado, e o meio de o conservar sem incômodo público" e, por fim, os meios de conservar o reino de Portugal “e de fazer a guerra com vantagem não só ao Imperador dos Franceses, Capital Inimigo de todos os Governos, como qualquer outra Nação que pretenda conquistar". ${ }^{87}$ Todavia, tudo indica que apenas a primeira memória veio a público. Nela, Aragão e Vasconcellos demonstra ampla confiança nas possibilidades de construção desse novo Império do Brasil:

Chegou finalmente a época em que o Soberano de Portugal deve tomar o Título de Imperador, que justamente corresponde à Magestade de Sua Pessoa, ao Heroísmo de seus Augustos Progenitores, e a extensão de seus Estados. O Brasil soberbo por conter hoje em o Imortal Príncipe, que nele se dignou estabelecer o seu Assento, adquire um tesouro mais precioso, que o áureo metal, que desentranha, e os diamantes, e rubis que o matizam. Ele já não será uma Colônia marítima isenta do comércio das Nações, como até agora, mas sim um poderoso Império, que virá a ser moderado da Europa, o árbitro da Ásia, e o dominador da África. ${ }^{88}$

O Brasil reunia, assim, as condições econômicas e geopolíticas essenciais para essa transformação que fora iniciada com a transferência da corte portuguesa para a América. Essa atitude teria sido um importante passo político pois, além de salvar a família real de seus inimigos, possuía outras “incomensuráveis vantagens”. Entre elas, o fato de o Brasil poder alterar a posição de Portugal que de "pequeno Reino” tornar-se-ia “um grande e poderoso Império” favorecido pela grandeza de sua antiga colônia. Do contrário, o Reino europeu jamais conseguiria figurar "na Balança política da Europa, como Potência de primeira ordem”. ${ }^{89}$ Como foi observado por Carlos Guilherme Mota acerca de seus escritos na defesa dos prisioneiros de 1817, aqui também o autor fundamenta sua análise evidenciando um conhecimento vasto sobre a formação das nações e de seus processos

\footnotetext{
${ }^{87}$ Antonio Luiz de Brito Aragão e Vasconcellos. "Memórias sobre o estabelecimento do Império do Brazil, ou novo Império Lusitano". Anais da Biblioteca Nacional do Rio de Janeiro, v. XLIII-XLIV, 1931, p. 6 e seq. Ao final do texto consta a observação sobre a possível inexistência da continuação das memórias (p. 48). Sobre seu escrito, Frederic Morton, op. cit., 1974, p. 190.

${ }^{88}$ Idem, ibidem, p. 7. Ver também István Jancsó, op. cit., 2002, p. 26.

${ }^{89}$ Antonio Luiz de Brito Aragão e Vasconcellos, op. cit., p. 8-9.
} 
políticos. Convicto quanto à precisão de suas formulações, afirma que mesmo com a morte de Napoleão Bonaparte, “o fogo revolucionário” seria reacendido porque os franceses tinham propensão a revolução e por isso mesmo tinham produzido o general. Assim, "os anarquistas, os Republicanos e os Candidatos do Império se hão de então debater, e os Estados da Europa oprimida se verão livres do jugo Francês, e poderão outra vez revocar os seus Direitos, e Constituições. Esta predição política é deduzida de comparações tiradas da História Universal das Nações, e se falhar será um acontecimento inesperado e inaudito”. Mas, o príncipe não precisaria temer qualquer que fosse o resultado da guerra em curso, visto que escolhera "a parte mais segura e essencial de seus Estados”. ${ }^{90}$

Desse modo, as sugestões apresentadas pelo bacharel nessa primeira memória reiteram a visão que o Estado necessitaria empregar medidas necessárias para promover o aumento da população e, ao mesmo tempo, cuidar para que esse crescimento fosse direcionado ao estabelecimento de “um grande, rico e poderoso Império”. As condições para isso já estavam dadas, era preciso aperfeiçoá-las. Sua plena confiança no futuro do Império lusitano, considerando as condições que experimentava nesse segundo decênio do Oitocentos, encontrava ressonância em um outro autor também oriundo da capitania.

Em 1818, José da Silva Lisboa publicou uma obra que, conforme esclarece, pretendia fixar os grandes feitos de d. João VI, desde que assumira a regência até a sua coroação ocorrida nesse mesmo ano. A relevância desse trabalho - Memórias dos Benefícios Políticos do governo de El-Rey Nosso Senhor D. João VI - para o que aqui se discute reside em sua compreensão sobre as alterações fundamentais verificadas no decorrer desse período e, sobretudo, o papel ocupado pelo Reino do Brasil. Silva Lisboa, então ocupando os cargos de deputado da Real Junta do Comércio e desembargador da Casa de Suplicação, alerta que embora a memória não possua “o caráter de História”, pretendia realçar os grandes benefícios feitos pelo monarca para assim "afervorar os espíritos dos compatriotas, afim de fazerem cordiais e perenes votos de ser longo e próspero o reinado de El-Rey Nosso Senhor”. O texto é, desse modo, também um ato de louvor ao monarca, no entanto, reafirma a posição do economista e sua crença na promoção do crescimento do Império português que, àquela altura, havia dado largos passos em seu entendimento. ${ }^{91}$

O futuro visconde de Cairu pode ser considerado como um dos principais entusiastas da economia política e, como tantos outros, vivenciou uma época em que não

\footnotetext{
${ }^{90}$ Idem, ibidem, p. 10.

91 José da Silva Lisboa, op. cit., 1818, p. 5.
} 
somente os princípios dessa ciência estavam sendo difundidos no Brasil, como também a América portuguesa passava por mudanças significativas. Em razão disso, a produção da economia política adquiriu certas particularidades tratadas anteriormente, conforme aponta estudos específicos. $^{92}$

Ao longo da obra, o autor expressa as suas principais referências, Adam Smith, Jeremy Benthan, Montesquieu, e procurar demonstrar como as decisões tomadas pela Coroa favoreceram para estabelecer um sistema econômico liberal no Brasil que, apesar de reunir as condições propícias a seu desenvolvimento, apenas foram efetivamente destravadas após a chegada do príncipe regente em 1808. Foram muitas as intervenções feitas desde essa data e diversos foram os campos de atuação. A memória traz ao final uma sinopse da legislação criada no período como uma prova de que o soberano considerava que as luzes constituíam não somente o esplendor dos povos, “mas também o apoio do Trono”. Afinal, segundo Silva Lisboa, a experiência já havia demonstrado que homens rudes eram os "mais difíceis de se regerem, e mais sujeitos a serem iludidos por cabalas de ambiciosos e turbulentos” e, ao contrário, quanto mais conheciam seus direitos e deveres, mais confiança depositavam no governo e o obedecia "pela evidência do comum interesse na manutenção da Ordem Civil, e Constituição do Estado”. 93

Para atingir esse estado de mudanças, o príncipe havia sido obrigado a tomar decisões importantes diante da crise que se abateu na Europa em fins do século XVIII. Mesmo enfrentando as condições mais adversas, soube tomar as decisões mais acertadas como a saída de Portugal em 1807. O significado desse acontecimento para portugueses europeus e americanos certamente fora diferenciado. Enquanto para os primeiros seria mais difícil de exprimir seu sentimento naquelas circunstâncias; para os residentes do Brasil, “ainda que uníssonos aos da mãe-pátria nos pontos essenciais”, pode ser melhor apreendido tendo em vista que não enfrentavam “o terror da invasão” e eram "recebedores do Grande Benefício da Presença de Seu Príncipe”. ${ }^{94}$

A partir de então, o autor destaca as principais medidas tomadas pelo regente que imprimiram uma outra feição política e econômica à colônia. A primeira delas, e uma das mais importantes, seria, sem dúvida, a abertura dos portos em 1808, na Bahia, intuído pelas mais benéficas condições para o desenvolvimento do comércio universal, possibilitando, assim, a suspensão do sistema colonial. A decisão consumou-se pelo decreto de 18 de

\footnotetext{
${ }^{92}$ Sobre o tema, ver Antonio Penalves Rocha, op. cit., 1996, p. 33 e seq.

93 Idem, ibidem, p. 21.

${ }^{94}$ Idem, ibidem, p. 64.
} 
junho de 1815 após o equilíbrio europeu. Para Silva Lisboa, depois disso foi possível “experimentar, na sua latitude e intensidade, o impulsivo Principio do Sistema Liberal”, contra a luta “em vão” dos partidários do sistema mercantil. Ele não tinha dúvidas de que a preferência do gênero humano "é, e será sempre, o preferir a quem vender melhor, e de menor preço". 95

Com a elevação do Brasil a Reino Unido, o sistema colonial foi efetivamente eliminado corrigindo, assim, uma anomalia que caracterizava essa parte do Império português. Silva Lisboa acreditava ser um grande absurdo "nas atuais circunstâncias antolhar a uma porção do Globo, que tanto avulta no Mapa do Mundo, como simples Feitoria Comercial, estreita Ilha de Sotavento, ou agreste Sesmaria dos Trópicos”. ${ }^{96}$ Do seu ponto de vista, as vantagens da nova condição já eram visíveis. No conjunto dessas alterações, o tratado estabelecido com a Inglaterra em 1810 também fora de grande importância. Reafirmando a sua crença na desregulamentação do comércio, o economista apresenta as razões por que considera que o sistema liberal seria muito mais proveitoso para os governos que, caso já o tivessem adotado, não necessitariam de tratados de comércio. Além disso, ao Brasil não restava muita escolha naquela ocasião em que estabelecera a negociação com a Inglaterra. Afinal de contas, o governo britânico necessitava de rendas para sustentar a guerra contra os franceses e, por outro lado, os ingleses eram os únicos negociantes que poderiam introduzir os gêneros produzidos no Brasil em todos os mercados. A decisão da Coroa portuguesa teria sido não apenas econômica como também política, em função daquela conjuntura. Nesse ponto, mais uma vez, o economista censura o comportamento dos críticos à medida:

O Livro de Razão dos Soberanos não é o dos Mercadores. Os Grandes Negócios das Nações regem-se pela sua imensidade. Os Gabinetes nas Transações Diplomáticas só atendem à Aritmética política, que não calcula asses, óbolos, e frações de artigos infinitamente pequenos, que mal entram em linha de conta em telônios de Publicanos, e Escritórios de Tabuada vulgar”.

Quanto mais que, no Sistema de esclarecida Finanças, dois e dois, em vez de somar quatro, freqüentemente dão menos de um. Os que ainda ora de lastimam de se não ter sobrecarregado de Direitos as mercadorias e Embarcações Inglesas, não atendem aos verdadeiros interesses do Estado. É reconhecido, ainda por noviço em Economia política, que a minoração nos Direitos na Alfândega, não é tanto favor ao importador, como

\footnotetext{
${ }^{95}$ Idem, ibidem, p. 97.

${ }^{96}$ Idem, ibidem, p. 115.
} 
benefício ao Consumidor, isto é, do corpo principal do povo. O Estado nada perde, mas ganha. ${ }^{97}$

As questões suscitadas aqui revelam a dimensão das alterações efetivadas na América portuguesa, seja na maneira de apreensão de alguns indivíduos dessas mudanças antes mesmo da transferência da corte para o Brasil, seja na defesa de intervenções político-econômicas já em um cenário de estabelecimento da nova sede do Império. De qualquer modo, expressam percepções sobre um período de crise bem como as distintas considerações para a sua resolução. Um problema que também foi abordado pela gazeta da Bahia.

\subsection{A conjuntura política nas páginas da Gazeta Idade d'Ouro do Brazil}

Nos primeiros meses de 1811, os residentes de Salvador foram informados sobre a implantação de uma tipografia na cidade e a criação da primeira gazeta da Bahia. As motivações para o empreendimento constaram de um prospecto distribuído ao público um dia antes de lançamento do primeiro número, em 13 de maio:

A predileção, com que S.A.R. o Príncipe Regente N.S. distinguiu sempre esta Cidade desde o feliz momento, em que seu Pavilhão Real assombrou esta Bahia, tem sido o manancial de Graças sucessivas, que nos fazem augurar a concessão de outras cada vez maiores. [...]. Desta Cidade foi, que dimanavam para todos as deste novo Império os primeiros orvalhos re-animadores das Ciências, e Artes amortecidas, e nela se quebraram primeiro os vínculos que até então agrilhoavam o Comércio circunscrito, e monopolizado. Por este modo parecer, que recobrava a nossa Cidade aquela primazia, que a sua posição, e as circunstâncias do seu estabelecimento lhe guardarão por mais de dois séculos a respeito de todas as mais da América Portuguesa. Foi a primeira do Brasil, que viu o seu Augusto Soberano, que o acolheu com aplausos, e que desempenhou a denominação de Cidade do Salvador. Talvez que por este motivo a Munificência verdadeiramente Régia não se satisfez com o Favor distinto de visitá-la, e enobrecê-la, Quer diariamente cumular sobre este Povo Benefícios, e Mercês. ${ }^{98}$

O longo comunicado afirmava que a despeito do estado convulsivo e devastador que as "Nações civilizadas do Universo inteiro" atravessavam, o "vasto império do Brasil” gozava da maior tranqüilidade e progresso que poderiam ser medidas por suas recentes transformações: “As Ciências diariamente se promovem, a agricultura se dilata, as Artes se

\footnotetext{
${ }^{97}$ Idem, ibidem, p. 143. A posição de José da Silva Lisboa sobre o tratado de 1810 é tratada por Guilherme de Paula Costa Santos, op. cit., p. 184 e seq.

${ }^{98}$ Prospecto da Gazeta da Bahia, op. cit.
} 
estendem, as Fábricas se erigem, o Comércio floresce, e as Quinas Portuguesas são consideradas com respeito nos mares do novo, e velho mundo. As riquezas afluem de toda a parte, as comodidades aumentam-se cada dia, a Justiça, e a Paz deram se amigavelmente as mãos para nossa felicidade”. Esta era, portanto, uma verdadeira "idade de ouro" e não poderia ser outro o nome escolhido para uma gazeta que pretendia acompanhar de perto esse crescimento do Brasil, pois "nem a crítica mais severa tem que repugnar à bem merecida aplicação de um nome tão especioso”. Tantas alterações eram devidas às virtudes de um príncipe magnânimo e sua "providentíssima Regência” distintos de qualquer outro, em qualquer tempo "que se assemelhe ao que a Providência suscitou em nossos dias para Fundador deste Império Brazílico”. O governador da Bahia, d. Marcos de Noronha e Brito, também era parte importante nesse quadro de mudanças e, por isso, a gazeta se comprometia a ter "um padrão durável, que anuncie as gerações futuras as desveladas fadigas do seu Governo". De acordo com o prospecto, a gazeta circularia duas vezes por semana, às terças e às sextas-feiras, ao custo de oitenta réis e, ocasionalmente, com suplementos extraordinários. O enfoque do noticiário dar-se-ia sobre as decisões ministeriais e sobre os acontecimentos "do tempo presente assim Nacionais, como Estrangeiras; desta Cidade, e de todas as deste Continente” e, nesse sentido, uma atenção especial seria dada à prosperidade do comércio interno e externo, assim como a todo “Invento útil nas Ciências, nas Artes, nas Manufaturas, \&c.”.99

Embora o editor esclarecesse que ao prometer imparcialidade se denunciava indiretamente a sua falta e que "todo o homem honesto, muito mais o instrutivo redator, deve a si próprio, e ao Público a mais estrita veracidade”, o conteúdo da gazeta estava submetido à revisão de um censor, cargo que por algum tempo foi ocupado pelo próprio governador da Bahia. Além disso, a portaria de 5 de maio de 1811 expôs as regras que o periódico deveria seguir, entre elas, a determinação de “contar as notícias Políticas, sempre de maneira mais singela, anunciando simplesmente os Fatos, sem interpor quaisquer Reflexões, que tendam direta ou indiretamente a dar qualquer inflexão à opinião pública”. ${ }^{100}$

Foi com essa caracterização que o Idade d'Ouro do Brazil começou a circular em 14 de maio de 1811 e durante dez anos, com apenas uma interrupção temporária, foi a

\footnotetext{
${ }^{99}$ Idem, ibidem.

100 Citado por Maria Beatriz Nizza da Silva, op. cit., 2005, p. 26. Ver também, Aloysio de Carvalho. “A imprensa na Bahia em 100 anos”. Diário Oficial do Estado da Bahia. Edição comemorativa do Centenário da Independência. Salvador, 1923. Biblioteca Pública do Estado da Bahia. Setor de Periódicos Raros.
} 
principal fonte de informações dos habitantes da capitania da Bahia. ${ }^{101}$ De acordo Rocha Martins, outro jornal teria circulado algum tempo depois, sem citar nome, cujo conteúdo de alguns artigos resultara em uma repreensão do conde das Galveias, um dos alvos de sua crítica, ao conde dos Arcos, alertando que não se poderia permitir a publicação “de notícias de natureza tal que possam comprometer o governo e produzir discussões desagradáveis, que se devem prevenir”. Em sua resposta, o governador referia-se à aprovação que teria dado aos ditos artigos, no entanto, contestava que o ocorrido pudesse gerar alguma desconfiança sobre o seu comportamento. Segundo ele,

o mais mortífero desgosto que pode sofrer um Vassalo que não visa outro algum prêmio de seus serviços, que a glória de bem servir ao Soberano que adora, põe-me em circunstâncias de dever a V.Exa. de expor, na Muita Augusta Presença de Sua Alteza Real [...] que o meu entendimento está firmíssimo em que houve naqueles dois lugares [gazetas $n^{\circ} \mathrm{s} 58$ e 61] matéria digna de justa repreensão, mas que, a meu juízo, não é possível afiança-la do que poderá nascer alguma reincidência, a qual desde já protesto que não será culposa por isso que não é possível que ela tenha outra origem senão a fraqueza de minhas faculdades intelectuais. ${ }^{102}$

Mesmo que se considere esse controle exercido pelas autoridades régias sobre o conteúdo do Idade d'Ouro, típico das publicações existentes no Antigo Regime, a gazeta desempenhou um papel importante sobretudo no ambiente societário de Salvador que, nesse período, passava por significativas alterações descritas acima. É certo que a conjuntura política dos anos 1820 teve um grande impacto sobre a constituição da imprensa local, como de resto ocorreu em outras partes, mas não se pode desconsiderar as condições em que os elementos de uma vigorosa crise foram apreendidas por uma parcela dos residentes da Bahia antes mesmo do seu aprofundamento.

O segundo decênio do Oitocentos foi um período de definições fundamentais para as monarquias européias e para a Coroa portuguesa em particular. Questões políticas e econômicas atravessaram esse período e, certamente, as suas resultantes não interessavam apenas aos círculos estreitos na corte do Rio de Janeiro. De várias maneiras, as notícias davam conta sobre os últimos acontecimentos e era por meio delas que os indivíduos apercebiam-se das mudanças em curso. Pretende-se, aqui, indicar a linha de abordagem

\footnotetext{
${ }^{101}$ Segundo Maria Beatriz Nizza da Silva, o periódico possuía assinantes em outras localidades do interior, a exemplo da Vila de Cachoeira e também era enviada para o Rio de Janeiro. Op. cit., 2005, p. 59.

102 Rocha Martins, op. cit., p. 38. Nas palavras desse autor: "Logo apareceu um outro jornal, onde se publicavam coisas que desagradavam no Rio de Janeiro ao antigo aposentador-mor, conde das Galvéias, a quem chamavam o doido, e que geria as pastas vagas pelo falecimento do Anadia”. Loc. cit. Não localizamos outras indicações sobre esse periódico.
} 
que a gazeta imprimiu às manifestações da crise política mundial nesse período a despeito dos limites a que estava submetida.

O estilo de apresentação da notícia não se alterou muito no decorrer desses anos. Relatos descritivos a partir da transcrição de outros periódicos da Europa constituíam as primeiras informações da gazeta que trazia também, ocasionalmente, algumas pequenas inserções com comentários do redator. Nos primeiros meses de 1811, o que prevalece são as notícias acerca da expulsão do exército francês de Portugal. Já em seu primeiro número, o periódico registra a mudança da situação para os invasores: “Aqueles que foram insultados violentamente pelos inimigos, não lhes dão agora quartel, e os passam irremissívelmente à espada. A vingança é instinto natural do homem, e a pena de Talião a primeira e anterior a todos os Códigos penais”. Na edição seguinte, as informações recebidas eram ainda mais auspiciosas: "Chegou no dia 14 do corrente um navio do Porto que nos traz as notícias mais satisfatórias [...]. Diz o Diário: 'Coimbra, 14 de março de 1811. Está decidida a demanda a nosso favor: Escapou Coimbra do ataque, e a Nação está livre da escravidão!'”. ${ }^{103}$ Dois meses depois a gazeta referia-se à Proclamação dos Governadores do Reino ao Povo português que, pelo seu teor, era digna de ser memorizada por ser "um resumo de todas as nossas vitórias; uma explosão do regozijo patriótico; um testemunho de gratidão, e reconhecimento aos cooperadores da restauração da Pátria, e da glória da Nação”, transcrevendo o documento em suplemento extraordinário no dia seguinte. ${ }^{104}$ Da mesma maneira, a reação do parlamento britânico ao feito das tropas portuguesas é destacada em alguns de seus números, inclusive, a proposta de concessão de dois milhões de esterlinas para auxiliar as rendas públicas de Portugal. Diante de tamanha benevolência, o redator perguntava: "Depois de um tão decisivo fato que mais se não pode esperar da lealdade da Grã-Bretanha?”. ${ }^{105}$

Ao que parece o entusiasmo da gazeta pela vitória do Reino europeu sobre o exército francês só seria superado pelas informações promissoras acerca das desventuras de Napoleão Bonaparte na tentativa de invasão da Rússia. As notícias eram divulgadas à medida que novos periódicos eram recebidos e, pelo visto, o interesse despertado pelos acontecimentos externos independia das rápidas mudanças na conjuntura política e, em razão disso, do descompasso entre as ocorrências dos fatos e a sua recepção na capitania. Pelo suplemento extraordinário de 8 de janeiro de 1812, os leitores ficaram sabendo da

\footnotetext{
${ }^{103}$ Idade d'Ouro do Brazil, n. 1 (14 de maio de 1811) e n. 2 (17 de maio de 1811). Bahia: Tipografia de Manuel da Silva Serva (disponível em www.bn.br).

${ }^{104}$ Idem, ibidem (n. 4, 24 de maio de 1811).

${ }^{105}$ Idem, ibidem (n. 6, 31 de maio de 1811).
} 
chegada dos periódicos vindos de Londres, entre os quais: Courier (desde 7 de setembro até 8 de novembro); Morning Chronicle (de 9 de setembro a 9 de novembro), Times (mesmo período), The Weekly Messenger (desde 6 de janeiro até 3 de Novembro), além de o Investigador Português (outubro e novembro) e o Correio Braziliense (setembro e outubro). Era por meio deles que se obtinha os relatos sobre a movimentação do exército francês e das tropas aliadas. Mas, no que se referia às guerras no continente europeu, o redator manifestava a sua predileção pela gazeta inglesa Times, justificando o fato por a mesma gozar de "conceito universal” o que o obrigava "a extrair dela tudo, que nos pode instruir sobre o estado atual da Europa”. ${ }^{106}$

A cada número, o Idade d'Ouro reproduzia o alvoroço pela "liberdade da Europa” a partir da surpreendente atuação dos soldados e da população russa. Mesmo alertando que os desdobramentos das ações militares ainda eram desconhecidos por aqui, o redator reafirmava sua disposição em expor fielmente "a seu tempo de tudo, que for digno de memória”. Ainda assim, seguindo a tendência do periódico inglês, acreditava que o conflito na Rússia estava decidido e aproveitava para manifestar suas condolências a todos os partidários de Napoleão Bonaparte. A descrição da campanha da Rússia ocupou várias páginas da gazeta e mesmo de alguns suplementos extraordinários. Em um dos números, o redator esclareceu que embora o registro amplo dado ao tema parecesse fastidioso, respondendo possivelmente a queixa de alguns leitores, o resultado daquelas operações militares teria conseqüências importantes sobre os destinos da Europa e, por isso mesmo, mereceriam ser acompanhadas com atenção. ${ }^{107}$ Mesmo após a derrota do exército napoleônico naquele território, a gazeta permaneceu acompanhando os passos do Imperador francês reproduzindo artigos que o descreviam de maneira ainda mais repulsiva ou introduzindo pequenos comentários que reforçavam essa percepção. Na edição de 24 de junho de 1814, o enfoque é dado sobre a sua abdicação em Fointanebleau. A essa altura, Luiz XVIII havia retomado o trono e os soldados não mais lhe deviam obediência. $\mathrm{O}$ redator avalia que esse desfecho de Bonaparte já era esperado e por isso Montesquieu tinha toda razão quando afirmou que: “o excesso do despotismo é o princípio da liberdade”. ${ }^{108}$

A partir de então, o periódico reproduz algumas notícias sobre as deliberações do Congresso de Viena e os esforços da Europa para "restituir as coisas do modo possível a

\footnotetext{
${ }^{106}$ Idem, ibidem (n. 2, 8 de janeiro de 1812; n. 16, 23 de fevereiro de 1813).

${ }^{107}$ Idem, ibidem (n. 11, 5 de fevereiro de 1813; n. 17, 26 de fevereiro de 1813). Em post-scriptum, o último número informava que: "Chegou aqui o paquete de Londres, e dá a feliz notícia de que a guerra da Rússia ficava concluída pela total derrota do Exército francês. Bonaparte escapou com o seu Estado maior, e tinha entrado em Paris no mês de Dezembro”.

${ }^{108}$ Idem, ibidem (n. 50, 24 de junho de 1814).
} 
aquele estado, em que se achavam antes da revolução, e banir a terrível mania dos inovadores, que tem querido curar os males da espécie humana com remédios que só servem de agravar as moléstias. Quando não se sabe o que se deve fazer, é melhor não fazer nada”. Aos poucos o comércio de exportação também retomava seu ritmo, conforme informações que chegavam da França dando conta de que “muitos Navios Portugueses” deram entrada em seu porto "e de outras Nações, dando nova atividade ao Comércio paralisado há tantos anos pelo Sistema Continental”. ${ }^{109}$ A notícia sobre a elevação do Brasil à condição de Reino Unido ocorrida em 16 de dezembro de 1815 foi dada com grande destaque juntamente com as muitas comemorações promovidas pelo Senado da Câmara nos primeiros meses do ano seguinte. Segundo a gazeta, a cidade foi iluminada por oito noites consecutivas, assim como a fortaleza do mar que deu várias salvas de tiro. Como parte dos festejos, “publicou-se um bando pelo qual se concederam máscaras, farsas decentes e bailes [...]”. ${ }^{110}$

Os números do Idade d'Ouro pesquisados, no entanto, demonstram que as notícias sobre os acontecimentos vinculados à América espanhola eram bem mais restritas do que às destinadas aos desdobramentos na Europa. As poucas referências são dadas às operações militares na Península Ibérica e, ocasionalmente, poucas informações sobre algumas colônias da Espanha. Não se pode esquecer que as convulsões políticas atingiram particularmente esse território, o qual, a partir de 1810, experimentou um aguçamento das lutas, inclusive com o aparecimento de importantes periódicos. ${ }^{111}$ Certamente a reserva da gazeta explica-se pela censura mais vigorosa a que estava submetida tendo em vista a natureza dos movimentos vivenciados pelas populações hispano-americanas. É o que se percebe em um comunicado de 1812:

A Biblioteca Pública recebeu os periódicos e folhas de Londres até o princípio de setembro. Além daqueles de que é subscritora, subscreveu de novo a um intitulado $O$ Espanhol. Este periódico parece bem escrito e divisa-se nele muita imparcialidade e muita doutrina, que inspira aos povos o amor da pátria e do governo e que os faz detestar a mania revolucionária e o subversivo sistema com que a França pretende infelicitar o mundo com o pretexto de o regenerar. ${ }^{112}$

\footnotetext{
${ }^{109}$ Idem, ibidem (n. 60, 29 de julho de 1814; n. 69, 30 de agosto de 1814). Em 7 de abril do ano seguinte (n. 28), o redator esclareceu que: "Recebemos a notícias de que o Congresso de Viena se tinha terminado com muita harmonia como dissemos a folha passada; mas esta notícia é de algumas cartas e não parece verdadeira”. Loc. cit.

${ }^{110}$ Idem ibidem (n. 17, 27 de fevereiro de 1816)

${ }^{111}$ João Paulo Garrido Pimenta, op. cit., 2002, p. 78.

${ }^{112}$ Citado por Maria Beatriz Nizza da Silva, op. cit., 2005, p. 40.
} 
Ao comentar um outro artigo desse periódico, o redator reproduzia a sua posição - e concordava - de "que princípios gerais de política não valem nada em mil casos particulares; e que o Francesismo, que tem esquentado alguns cérebros está tão longe de gerar a felicidade dos povos, que antes ele é essencialmente gerador de escravidão, e de sangue”. ${ }^{113}$ De qualquer modo, algumas informações foram divulgadas ainda que a perspectiva fosse sempre a da inevitável derrota dos insurretos, além de uma crítica aguda sobre as suas proposições de alteração dos princípios políticos em vigor. Ainda em 1813, o redator divulgou que "pelas Gazetas de Havana” ficou-se sabendo que “a insurreição da América espanhola ao Norte” havia sido de todo pacificada e o povo aquietado-se. Sem deixar de acrescentar: "O número de vítimas sacrificadas pelo ferro, e a fome enquanto durou a revolução faz arrepiar os cabelos; e ainda quando aquela louca insurreição sortisse o melhor efeito, que se pode imaginar, não valia a pena de tanto sangue, tantas calamidades”. ${ }^{114}$ Após o retorno de Fernando VII ao trono, o enfoque era novamente dado à tentativa de restabelecimento do equilíbrio político por um monarca amplamente apoiado pelos espanhóis que demonstravam "a mais viva satisfação em festas públicas animadas da piedade e Religião, que tanto os tem distinguido”.

Embora as notícias sobre o reordenamento da Europa fossem mais expressivas, certas informações evidenciavam que nem tudo estava totalmente controlado pelos soberanos. Na edição de 28 de novembro de 1815, por exemplo, noticiou-se uma tentativa frustrada de conspiração na Coruna e na Galiza contra o governo da Espanha o que, segundo o artigo, era uma demonstração de que a população estava satisfeita com o seu Rei. Os insurretos teriam publicado a Constituição das Cortes Extraordinárias, mas foram sufocados antes que tivessem qualquer êxito. No ano seguinte, a gazeta referia-se a um documento diplomático sobre o estado da França no qual os ministros reconheciam a persistência de alguns germes revolucionários, “contudo, esperam que o Governo paternal de Luiz XVIII evite qualquer revolução. Tão persuadidos estão de que se deve governar com moderação e amor”. 115

A rigor, o que deve ser ressaltado, é que a despeito desse desprezo do Idade d'Ouro sobre as alterações em curso na América espanhola não se pode afirmar o desconhecimento desses fatos pelos portugueses americanos. Ao analisar o comportamento da Gazeta do Rio de Janeiro no decorrer da conjuntura dos anos 1810, João Paulo Garrido

\footnotetext{
${ }^{113}$ Idade d'Ouro do Brazil, n. 10, 2 de fevereiro de 1813 (suplemento extraordinário). Bahia: Tipografia de Manuel da Silva Serva (disponível em www.bn.br).

${ }^{114}$ Idem, ibidem (n. 17, 26 de fevereiro de 1813).

${ }^{115}$ Idem, ibidem (n. 95, 28 de novembro de 1815 e n. 26, 29 de março de 1816).
} 
Pimenta conclui que os desdobramentos da política hispano-americana eram acompanhados com grande interesse não apenas pelas autoridades régias como também pelos indivíduos interessados em política nos centros mais importantes da América portuguesa. Um dos elementos indicadores dessa percepção é a incorporação de um novo vocabulário político condizente com as convulsões do período. Nessa direção, o horizonte de expectativas dos protagonistas referido a um espaço de experiência que remonta aos processos revolucionários de fins do século XVIII, sinaliza uma violenta crise das instituições monárquicas e a busca de alternativas que visa a sua superação. A manifestação dessa crise dar-se-ia de maneira distinta nos impérios espanhol e português e, por isso mesmo, resultaria em tentativas de soluções também diferenciadas como referido acima. $^{116}$

O tipo de enfoque dado pela Gazeta do Rio de Janeiro aos acontecimentos políticos da América hispânica, conforme analisado por Garrido Pimenta, é muito semelhante ao encontrado na gazeta Idade d'Ouro do Brazil. Termos como "revoluções, insurreições, sublevações” são utilizados para expressar as ocorrências no período, sempre com uma conotação negativa, e relacionam-se às diversas formas de intervenção de seus portadores, incluindo aí também os homens do Estado português. Não poderia ser diferente uma vez que os dois periódicos foram criados sob as condições de vigência do Antigo Regime e com o claro propósito de reafirmar a política da monarquia portuguesa. Os vocábulos sinonimizam, assim, “a ameaça de que as convulsões políticas da América espanhola pudessem atingir a ordem vigente na América portuguesa, o que por seu turno equivale ao reconhecimento de algum tipo de fissura interna nesta”. ${ }^{117}$ Com essa perspectiva, é possível supor que o movimento ocorrido em Pernambuco, em 1817, representaria a possibilidade de concretização de um abalo das estruturas de poder do Estado monárquico referenciado anteriormente pelo vocabulário político. ${ }^{118}$

Ao que tudo indica, o Idade d'Ouro não deu muita atenção ao que ocorria na capitania do Norte até o momento em que já não era mais possível ignorar a dimensão dos acontecimentos. Para o redator, a gazeta havia tentado não se "enxovalhar” com aqueles atentados, mas, diante dos desdobramentos, passou a dar-lhes cada vez mais destaque um

\footnotetext{
116 João Paulo Garrido Pimenta, op. cit., 2003, p. 125 e do mesmo autor "a política hispano-americana e o império português (1810-1817): Vocabulário político e conjuntura”. In: István Jancsó (Org.)., op. cit., 2003, p. 123-139. Sobre a incorporação de um novo vocabulário político no contexto do constitucionalismo dos anos 1820: Lúcia Maria Bastos Pereira das Neves. Corcundas e constitucionais. A cultura política da Independência (1820-1822). Rio de Janeiro: Revan; Faperj, 2003.

117 João Paulo Garrido Pimenta, op. cit., 2003, p. 130.

118 Idem, ibidem, p. 132.
} 
mês após os eventos iniciados em 6 de março. Na passagem abaixo fica evidenciada a aproximação estabelecida entre as pretensões dos “infames” rebeldes de Pernambuco e os envolvidos nos conflitos políticos da América hispânica:

Segundo notícias mui averiguadas de Pernambuco contamos com a maior probabilidade que a detestável rebelião daquele país é só perigosa e terrível para os seus infames agentes. A fome já principia a consternar o povo e a desfazer dos olhos a venda que os tapou para não verem as fatais conseqüências da ignorância e maldade que presidiu ao conselho infernal dos traidores. A peça que se representa no Recife é uma verdadeira tragicomédia, que já toca o último ato do entremez pelo aleivoso casamento do infame [Domingos José] Martins com a filha de um negociante que teve a desgraça de ser rico para ser presa de um salteador, que talvez não visasse na sua rebelião senão a posse de uma noiva que não podia conseguir de outra maneira. Que homem! Que homens! Desfaça-se a máscara do filosofismo pedantesco, e ressoe o clarim da verdade por toda a extensão da terra: 'Povos inocentes e mal-avisados, que por ocupados em vosso comércio e lavoura não tendes tempo de estudar e conhecer os mistérios da iniqüidade! Desenganai-vos, que o nome de patriota, já em voga em alguns pontos da América, é sinônimo de impostor, de perturbador e velhaco. Os patriotas não se lembram do bem público, lembram-se da sua fortuna particular. Não tem pena dos vossos males; tem inveja dos vossos bens. São Robespierres e Marats, conhecei-os e fugi-os. ${ }^{119}$

Aqui também é possível estabelecer uma conexão entre as referências feitas aos partícipes do movimento - “criminosos”, “rebeldes”, “malvados”, “facinorosos” - e a posição tomada pela Gazeta do Rio de Janeiro, embora o enfoque dessa última tenha se dado somente após o controle da situação pelas tropas realistas. Tanto essa postura de depreciação quanto o silêncio inicial em relação aos acontecimentos faziam parte de uma estratégia importante do governo, qual seja, a de não tornar público eventos que atentavam contra a legitimidade política do monarca. ${ }^{120} \mathrm{Na}$ visão dos periódicos, seja na Bahia ou no Rio de Janeiro, a "funesta rebelião de Pernambuco" era fruto "da trama de alguns malvados” e não havia contado com o apoio da população que muitas vezes dera mostras de sua vassalagem ao soberano. Mas, mesmo assim, alguns sinais denotam que o evento político não era considerado tão insignificante como muitas vezes se tentou passar. Ainda em outubro de 1817, o Idade d'Ouro se referiu à dimensão do perigo naqueles dias turbulentos:

\footnotetext{
119 Citado por Maria Beatriz Nizza da Silva, op. cit., 2005, p. 284-285. A autora transcreve trechos dos artigos da gazeta sobre os eventos em Pernambuco servindo aqui de referência.

${ }^{120}$ João Paulo Garrido Pimenta, op. cit., 2003, p. 133.
} 
No Recife tem-se castigado até agora muitos negros e mulatos, os quais, apesar de não serem revolucionários, aproveitaram-se das desordens dos provisórios para cometerem toda a espécie de insolência, de tal sorte que, se dura mais alguns meses aquela infame facção, ficava perdida de todo aquela cidade, porque os insolentes entravam de mão armada pelas casas, atacando a honestidade e roubando sem distinção. Quanto é perigosa (maiormente em país de escravatura) uma louca insurreição, que transtorna os princípios da ordem pública!. ${ }^{121}$

Após esses acontecimentos, a gazeta permaneceu acompanhando as intervenções para restabelecimento do equilíbrio europeu. Em suas páginas, o recente Brasil Reino também seguia o seu ritmo progressivo $\mathrm{O}$ conteúdo do periódico assumia, assim, a perspectiva anunciada pelo prospecto em maio de 1811, a de valorização das potencialidades do Reino e, em particular da Bahia cujas condições para efetivação da sua riqueza estavam ainda mais propícias nos últimos anos dessa década. A aclamação de d. João VI no Rio de Janeiro, “de quem todos se julgam mais filhos do que vassalos”, em 6 de fevereiro de 1818, confirmava as boas perspectivas. Nesse mesmo dia, um decreto determinou a suspensão das devassas resultantes dos acontecimentos de Pernambuco. Ao avaliar a iniciativa do monarca, o gazeteiro afirma que o seu comportamento supera a outros reis na história: “Mas para que havemos nós gastar palavras em louvar um Rasgo de Bondade dos Nossos Reis? Quem não sabe o que eles sempre foram? Ninguém o ignora”. 122

É possível supor, todavia, que algumas notícias despertassem ainda mais a atenção daqueles mais atentos às alterações em curso. Em dezembro de 1818, por exemplo, ao referir-se sobre o modo como a França buscava recuperar a prosperidade da nação, diria que a academia francesa estava empenhava em produzir instrumentos de literatura que propiciassem esse objetivo. Para isso, concederia valiosos prêmios a quem escrevesse uma memória tratando sobre alguns assuntos sugeridos, entre eles: “a Abolição gradual da escravatura, desde os povos da antiguidade até nós; ou determinação da superioridade das instituições novas sobre as antigas, relativamente à liberdade geral dos homens [...]; a duplicada influência de uma Monarquia Constitucional em França sobre os maiores

\footnotetext{
${ }^{121}$ Maria Beatriz Nizza da Silva, op. cit., 2005, p. 301.

${ }^{122}$ Idade d'Ouro do Brazil, n. 28, 7 de abril de 1818. Bahia: na Tipografia de Manoel Antonio da Silva Serva (disponível em www.bn.br). As festas pela aclamação de d. João VI, ocorridas inclusive em algumas vilas no interior, ocuparam vários números do periódico ao longo desse ano.
} 
progressos das Ciências, e Artes; e de um desenvolvimento maior de toda a Ciência humana sobre o aperfeiçoamento da Monarquia Constitucional”. ${ }^{123}$

Além do mais, o suceder dos anos também aprofundaria a insatisfação dos portugueses d'além-mar pela permanência do monarca em terras americanas, algo que, até esse momento, não merecera nenhum comentário do Idade d'Ouro. No entanto, já na proclamação dos governadores do Reino de 6 de agosto de 1814, reproduzida pela gazeta dois meses depois, os subscritores salientaram as mudanças recentes em Portugal e o empenho dos seus residentes e das forças aliadas sobre os franceses. Depois disso, tinham plena ciência dos passos que deveriam ser dados para que o Reino europeu também retomasse o seu desejado equilíbrio:

[...] para último remate de um período tão glorioso para Portugal só resta que o Céu satisfaça o mais ardente de nossos votos, restituindo o nosso Augusto e Amado Príncipe e Senhor aos seus Domínios da Europa. Neste dia o mais feliz da nossa vida, depondo humildemente aos Reais Pés de Sua Alteza Real a porção de autoridade que Foi Servido confiar-nos, oferecemos na Sua Real Presença a fiel exposição dos extraordinários Serviços com que todos seus leais Vassalos sustentaram a estabilidade do Trono, e a honra da Nação Portuguesa. ${ }^{124}$

A irrupção do movimento constitucionalista no Porto em princípios dos anos 1820 evidenciou os limites do Estado absolutista para conter as vigorosas tensões, até então amortecidas, no interior do Reino Unido. Nessa nova conjuntura, a representação de uma idade de ouro consagrada nas páginas da gazeta dissolveu-se propiciando a expressão de distintas perspectivas políticas resultantes do agravamento da crise. A partir de então, novos elementos estarão em jogo e com eles a redefinição do lugar a ser ocupado por uma Bahia convulsionada.

${ }^{123}$ Idade d'Ouro do Brasil, n. 102, 2[!] de dezembro de 1818. Bahia: na Tipografia de Manoel Antonio da Silva Serva. Loc. cit.

${ }_{124}$ Idade d'Ouro do Brasil, n. 83, 18 de outubro de 1814. Bahia: na Tipografia de Manoel Antonio da Silva Serva. Loc. cit. 


\section{Capítulo 4}

\section{O aprofundamento da crise e as tentativas de superação, 1820-1823}

O início dos anos 1820 foi de grande riqueza política para os contemporâneos. Num plano mais geral, as idéias liberais ganhavam força a despeito das medidas reacionárias definidas pelo Congresso de Viena poucos anos antes. Em diversas partes da Europa, as lutas movidas por um forte sentimento nacionalista, a exemplo da Grécia, e por tentativas de incorporação de mecanismos limitadores do poder absolutista dos monarcas, ocorridas, sobretudo, em França, Alemanha, Rússia, Nápoles, adquiriam novos contornos. Nesse contexto, a Península Ibérica potencializou o seu dinamismo político. Com efeito, numa tentativa de ampliar as conquistas obtidas na década anterior, os espanhóis impulsionaram o movimento contra a política de reação de Fernando VII e, em Portugal, a indefinição quanto aos rumos do Reino europeu agravada pela permanência de d. João VI no Brasil após o fim da guerra peninsular favoreceu a difusão dos ideais do constitucionalismo culminando na Revolução do Porto em 20 de agosto de 1820. No dizer de um contemporâneo, por essa época ainda ressoava no Reino europeu “o eco do celebrado dito de Napoleão Bonaparte - a Idade das Constituições chegou -“. ${ }^{1}$ Do outro lado do Atlântico, os residentes dos antigos vice-reinos da Espanha continuavam vivenciando uma violenta crise política com ressonância em variados aspectos da vida local, inclusive econômica, potencializando a perspectiva independentista que era, a essa altura, um dado incontornável.

Nesse cenário, a Coroa portuguesa passou a admitir a possibilidade de os residentes do Brasil Reino serem, cada vez mais, expostos ao contágio das idéias liberais cujos desdobramentos, todavia, não lhes era permitido conhecer de antemão. Certamente, a absorção das idéias liberais propagadas pelo movimento constitucionalista português entre os residentes da província da Bahia foi um duro golpe para a Monarquia bragantina, pelo menos até que as alternativas possíveis de encaminhamento da crise ganhassem um pouco mais de nitidez.

\footnotetext{
${ }^{1}$ José da Silva Lisboa. História dos principais sucessos políticos do Império do Brasil dedicada ao Senhor D. Pedro I. Parte 10. Rio de Janeiro: Tipografia Imperial e Nacional, 1827, p. 21.
} 


\subsection{O constitucionalismo na Bahia: experiência política e expectativas de mudança}

Em 1827 foi publicada parte de mais uma obra redigida por José da Silva Lisboa - História dos principais sucessos políticos do Império do Brasil - dessa vez dedicada a d. Pedro I que havia também encomendado o trabalho. Dentre os vários assuntos tratados um, em especial, ganhava relevância em virtude da proximidade dos acontecimentos e da alteração política que proporcionou no reordenamento do Estado português: a Revolução do Porto e o seu impacto no Brasil Reino. O então senador descreve as condições pelas quais entendia que os anos pretéritos ao constitucionalismo no Reino americano foram de grande dinamismo e amplas perspectivas de crescimento em suas várias partes. Segundo ele, a despeito das revoluções que se desenrolavam nos territórios vizinhos, elas não provocavam qualquer ilusão entre as "pessoas cordatas" que estavam cientes dos "horrores da anarquia”, além de lembrarem-se da "catástrofe” ocorrida na França pela “insana tentativa” de implantar a democracia em um Estado tão vasto e um governo representativo em um país regido secularmente por uma Monarquia absoluta. Na Banda Oriental do Rio da Prata, a ocupação de Montevidéu pelo “Exército Pacificador” garantia a segurança da fronteira “contra os assaltos dos Revolucionários limítrofes”. Desse modo, d. João VI estava seguro quanto à estabilidade do Reino "e dava mostras de realizar o Plano do Restaurador da Monarquia D. João IV e de estar persuadido da solidez da opinião dos maiores Estadistas Portugueses Cunha e Pombal, de que se devia definitivamente estabelecer no Brasil a Sede da Monarquia Lusitana”. ${ }^{2}$ Pouco tempo depois, no entanto, toda essa aparente solidez não resistiria às turbulências políticas no interior do Reino Unido.

Semelhante à análise de Silva Lisboa, o seu compatriota Francisco Marques de Góes Calmon viu nas agitações políticas dos anos 1820 uma interrupção da linha ascendente vivenciada pela Bahia. Numa introdução à obra que reúne as Cartas econômico-políticas sobre a agricultura e comércio da Bahia, redigida em 1923, traça um panorama da capitania nas duas décadas anteriores realçando o vigor que havia sido empreendido nesse período, sobretudo, a partir do estabelecimento da nova sede da corte portuguesa. Para ele, a Bahia havia sido imensamente desfavorecida na segunda metade do século anterior com a mudança da capital de Vice-Reino para o Rio de Janeiro em 1763, inclusive, pelo peso dos encargos fiscais que a oneravam. O século XIX, no entanto,

\footnotetext{
${ }^{2}$ Idem, ibidem, p. 7-9.
} 
iniciou trazendo a vivacidade das atividades empreendedoras interrompidas trinta e sete anos antes. A abertura dos portos, em 1808, seria a primeira delas. A partir de então e contando com a presença de indivíduos "predestinados” a revolucionar os métodos de produção e trabalho, além da inventividade de governadores como o $8^{\circ}$. conde dos Arcos, o futuro reservado para a Bahia era dos mais promissores. Ocorre que, quando "tudo fazia prever a continuidade de uma curva ascendente de desenvolvimento indefinido" e o "abalo econômico e social, que proviera da mudança da Capital em 1763, parecia conjurado”, a situação política mudou completamente, e a desorganização daí decorrente abalou "fundamentalmente a obra construtiva, que o novo século tão bem iniciara”. 3

Via de regra, essa é uma interpretação corrente quanto às conseqüências produzidas pelo constitucionalismo na capitania da Bahia: a brusca interrupção de uma fase próspera e promissora. Nessa perspectiva, uma pergunta é inevitável: por que os residentes da Bahia, supostamente vivenciando uma época de intensas e positivas transformações, teriam se manifestado favoravelmente ao movimento iniciado em Portugal e, mais do que isso, rejeitado, a princípio, os apelos oriundos do Rio de Janeiro? As questões suscitadas nos capítulos anteriores buscaram sinalizar que para além de um período de florescimento propiciado pela presença da corte em terras americanas, existia um ambiente de fermentação política represada em decorrência do controle exercido pelas autoridades realistas. Ocorre que, no momento em que as condições propícias para a sua liberação foram dadas, essa ebulição não tardou em vir à tona. Nesse sentido, a conjunção de alguns elementos externos e internos atuou favoravelmente para a aceleração dos acontecimentos na capitania. Vejamos rapidamente alguns aspectos da conjuntura no Reino europeu.

Como mencionado anteriormente, a situação de Portugal de há muito reclamava atenção. A rigor, desde que o príncipe partira para a América em 1807, os portugueses europeus manifestaram seu descontentamento agravado após a tomada de decisões como a abertura dos portos no ano seguinte e os tratados de 1810 favorecendo a entrada de produtos ingleses no Brasil. Todavia, o quadro de guerras que se estabeleceu até a derrota definitiva de Napoleão Bonaparte em 1815 não permitiu que medidas remediadoras pudessem ser efetivadas. Os governadores do Reino reprimiam vigorosamente qualquer tipo de reação contrária à instabilidade política mas não puderam impedir a organização clandestina de núcleos de oposição, bem como a circulação de jornais como $O$

\footnotetext{
${ }^{3}$ Francisco Marques de Góes Calmon. “Contribuição para o estudo da vida econômica-financeira da Bahia no começo do século XIX. Subsídios para a história. In: João Rodrigues de Brito et al, op. cit., p. 18.
} 
Investigador Português em Inglaterra, O Português e O Campeão Português. Segundo alguns estudiosos, isso teria sido fundamental para a formação de um pensamento liberal em Portugal entre os anos de 1808 e $1810 .^{4}$

Em 24 de agosto de 1820, por meio da articulação do Sinédrio, grupo fortemente influenciado pelo liberalismo espanhol, teve início o movimento constitucionalista do Porto posteriormente ampliado para Lisboa, resultando na formação de respectivas Juntas Provisionais de Governo. Dentre os reclames de seus integrantes, a situação de abandono político e as precárias condições econômicas de Portugal, bem como a intromissão da GrãBretanha nos assuntos do Reino. Para discutir esses e outros problemas, propunham a convocação das Cortes Gerais não mais como a representação dos três Estados - clero, nobreza e povo - que se reuniram pela última vez em 1698, mas agora como expressão da nação portuguesa. É certo que o encaminhamento dessas questões, dada a heterogeneidade política dos protagonistas, não se deu sem maiores tensões no interior do Reino europeu, porém, de uma maneira geral, os traços justificadores do movimento emprestaram-lhe uma importante coesão. Para o que nos interessa, importa ressaltar o fato de que a organização das Cortes Gerais, Extraordinárias e Constituintes da Nação Portuguesa, instaladas em 26 de janeiro do ano seguinte com a representação inicial de cem deputados do Reino de Portugal, demarcou um período de importantes alterações políticas para os portugueses dos dois lados do Atlântico e, em particular, para os residentes da Bahia. ${ }^{5}$

A atitude inicial de d. João VI com relação aos acontecimentos em Portugal foi de um certo descrédito sobre a real soberania reivindicada para as Cortes convocadas pelos liberais do Reino. Ancorado na opinião do seu principal ministro, Tomás Antonio de Villanova Portugal, para quem era preciso dizer aos povos que as Cortes não possuíam autoridade para conferir leis ao trono, o monarca expediu uma carta régia apontando a ilegalidade daquela convocação. Perspectiva que já havia sido utilizada pelos governadores do Reino em sua proclamação aos portugueses. A intenção da Coroa era assegurar que a antiga definição de Cortes portuguesas fosse mantida e, dessa forma, eliminar a pretensão deliberativa preservando apenas o seu caráter consultivo. ${ }^{6}$ Parecia mesmo haver uma crença de que seria possível contornar o desequilíbrio sem maiores sobressaltos. Antes mesmo de o movimento eclodir no Porto, Villanova Portugal havia defendido a introdução

\footnotetext{
${ }^{4}$ A respeito ver, Márcia Regina Berbel, op. cit., p. 37 e seq.

${ }^{5}$ Idem, ibidem; Ana Rosa Cloclet da Silva, op. cit., p. 289. Para Denis Bernardes, esse processo "significou a consolidação do movimento vintista e a institucionalização de um poder soberano separado e independente do poder real e, até, na prática, superior a ele, pelo menos até a virada de 1823”, op. cit., p. 322-323.

${ }^{6}$ Cf. Maria Beatriz Nizza da Silva. Movimento constitucional e separatismo no Brasil (1821-1822). Lisboa: Livros Horizonte, 1988 (Coleção Horizonte Histórico), p. 7.
} 
de um conjunto de medidas econômicas como uma estratégia para acalentar a sociedade portuguesa e, assim, isolar o Reino europeu da crise que deixava "todas as Nações inquietas". 7 Todavia, à medida que informações mais precisas sobre os acontecimentos d'além-mar, bem como a maneira como estavam sendo recepcionadas, ficavam conhecidas na corte, a dimensão do problema ganhou maior visibilidade e, com ele, as divergências no interior do ministério quanto às decisões mais adequadas a serem tomadas. Mello Moraes afirma que as notícias dos acontecimentos em Portugal chegaram ao Rio de Janeiro em 12 de novembro de 1820, alguns dias depois de terem se espalhado pela Bahia, segundo informação encontrada em um manuscrito do ministro Tomás Antônio Villanova Portugal. Certamente foi antes disso pois, em 9 desse mês, a Gazeta do Rio de Janeiro trouxe estampada a proclamação dos governadores do Reino europeu sobre a eclosão da Revolução liberal, conforme observou José da Silva Lisboa que estranhou a inércia do monarca. ${ }^{8}$ Para ele, não era difícil prever "que o espírito de vertigem transmigraria à Ultramar, e que o Brasil não tardaria a ser envolvido no Vórtice no Turbilhão revolucionário”. Entretanto, d. João VI “permaneceu tranqüilo, esperando participações oficiais e circunstanciadas da Regência de Portugal”. ${ }^{9}$ Com efeito, as notícias sobre a evolução dos eventos políticos davam conta que o movimento tomava contornos, nos dois lados do Atlântico, que agravavam ainda mais a instabilidade do Império português. Na parte americana do Reino era de sobremaneira preocupante a situação da Bahia que sabidamente ocupava uma posição política e econômica extremamente importante para a Coroa. Naquela altura dos acontecimentos já não se poderia ignorar que alguma mudança irrefreável estava no horizonte de seus habitantes, não obstante a falta de clareza sobre as concepções políticas em razão da novidade das medidas impostas pela agitada conjuntura.

Possivelmente, o impulso para a tomada de algumas decisões mais precisas foi dado após os relatos feitos pelo conde de Palmela ao chegar ao Rio de Janeiro vindo de Londres, onde havia exercido a função de embaixador, em 20 de dezembro de 1820, depois de ter passado por Portugal e feito escala na Bahia. Palmela, então designado para ocupar o

\footnotetext{
${ }^{7}$ Citado por Valentim Alexandre, op. cit., p. 492.

${ }^{8}$ Gazeta do Rio de Janeiro, n. 8, 9 de novembro de 1820. Edição Extraordinária (disponível em www.bn.br). Mello Moraes, op. cit., t. 1, p. 136. Para uma análise do posicionamento e das divergências dos ministros do rei quanto às medidas a serem adotadas nessa conjuntura, com a publicação de vários documentos, ver Valentim Alexandre, op. cit., p. 445-539.

${ }^{9}$ José da Silva Lisboa, op. cit., 1827, p. 10. Em sua definição: “A revolução de Portugal foi a Restauração das Cabalas Jacobínica, e Maçônica, que pareciam extintas em 1817 com a pena capital do Tenente General Gomes Freire de Andrade, e outros conspiradores, que nesse ano se arrojaram à infame tentativa de expelirem a Regência do Reino, e subverterem a Constituição da Monarquia, conforme as luzes do século". Op. cit., 1827, p.12.
} 
cargo de ministro dos Negócios Estrangeiros e da Guerra no Brasil, procurou demonstrar ao rei que as perspectivas políticas para os governos absolutos não eram das melhores diante de a "tendência geral de todas as nações da Europa para a forma de governo representativo”. Ele estava totalmente convencido que d. João VI não teria muitas possibilidades de escolha a não ser seguir essa inclinação. Para isso, era preciso anunciar “a intenção de formar um governo constitucional fundado sob os princípios que se adotam em quase toda a Europa e conservando aqueles atributos do poder que são inerentes à existência e dignidade da Coroa”. ${ }^{10}$ Não à toa esse recurso havia sido utilizado por Luis XVIII na França e Fernando VII na Espanha. Além disso, a introdução de um mecanismo que pudesse refrear o poder absoluto do monarca - a Carta Constitucional - era uma realidade em alguns Estados nos continentes europeu e americano, nesse período, não obstante as tentativas de reação das potências conservadoras desde o Congresso de Viena em 1815. ${ }^{11}$ Palmela também retratou a situação de animosidade que presenciou na Bahia e a disposição positiva de parte de seus residentes para as alterações políticas que ocorriam no ultramar. A Coroa não poderia ficar alheia diante dessas ocorrências. Não se pode esquecer que as experiências na América espanhola também estavam muito próximas e, se até aquele momento, havia sido possível assegurar alguma estabilidade política no Brasil Reino, o rápido desenrolar dos acontecimentos, no entanto, não permitia muita margem de segurança sobre o porvir.

De qualquer modo, algumas decisões foram tomadas pela Coroa visando conter o ímpeto das mudanças como, por exemplo, a vigilância sobre a entrada de estrangeiros que ficou ainda mais rigorosa depois do decreto de 2 de dezembro. Outras medidas administrativas como a elevação de vilas, a criação de comarcas, a implantação do tribunal de justiça na vila do Recife, uma antiga requisição dos residentes que precisavam se dirigir à Relação da Bahia, visavam assegurar a tranqüilidade do Reino americano. Todavia, diante da real situação das capitanias essas intervenções de nada adiantaram. José da Silva Lisboa assinala que as queixas sobre as péssimas condições de funcionamento e a venalidade dos ocupantes de cargos da administração, assim como a violência exercida por alguns governadores eram constantes. Afora isso, diz ele, "circulavam com devassidão no Brasil, não só papéis incendiários de Portugal e Espanha, mas também os Livros e Periódicos da França, cheios de doutrinas e sugestões revolucionárias, cujos efeitos eram

\footnotetext{
${ }^{10}$ Citado por Maria Beatriz Nizza da Silva, op. cit., 1988, p. 8-9.

${ }^{11}$ João Armitage, op. cit.; Andréa Slemian; João Paulo G. Pimenta, op. cit., 2003.
} 
mais velozes e mortíferos que os das pestes do Levante. Era portanto moralmente impossível que o Brasil escapasse à Praga da Revolução”. ${ }^{12}$

Talvez por isso, uma das primeiras preocupações de d. João e do seu ministério foi assegurar a lealdade das tropas realistas determinando, por meio do decreto de 10 de fevereiro, o pagamento dos soldos em atraso dos "militares despachados para as diferentes partes”, como também um adiantamento dos "3 meses dos seus respectivos soldos [...]”. 13 No que diz respeito à Bahia, não deixa de ser significativa a indicação do conde de Vila Flor, Antônio José de Sousa Manuel de Meneses Severim de Noronha, proposta por Villanova Portugal, para assumir o governo local. O fato de o conde ser "um militar de prestígio e de confiança da tropa” parece ter pesado nessa opção para substituir o então governador da capitania Francisco de Assis Mascarenhas, o conde da Palma. Além do que denota que havia um forte receio de que ali o movimento pudesse adquirir maior fôlego e estender-se para as outras capitanias do Norte. Na avaliação do ministro, era preciso tomar as medidas mais ponderadas "e, se não o fizer, expõe-se a perder a Bahia, e principiar a revolução no Brasil”. ${ }^{14}$ No entanto, a sugestão de Villanova não foi aceita pelo conde dos Arcos gerando algum tipo de constrangimento entre os ministros que já não gozavam de uma boa relação. Isso, na avaliação de Mello Moraes, teria retardado ainda mais a tomada de decisão por parte de d. João VI para evitar a contaminação dos princípios liberais entre as tropas portuguesas na Bahia e no Rio de Janeiro. Ao não enviar Vila Flor a tempo para o governo da Bahia, a Coroa não pôde impedir que a corporação militar desse início ao movimento. ${ }^{15}$ O governador nomeado nem sequer chegou a ir à Bahia. No entanto, mesmo que isso se verificasse com a antecedência desejada provavelmente a situação política permaneceria com dificuldades para ser controlada. A conjectura do ministro Tomás Antônio de Villanova Portugal parece não ter levado em consideração a real disposição dos residentes daquela capitania. Internamente, as expectativas entre parte dos residentes para a implementação de algumas mudanças estavam bastante acentuadas.

As primeiras notícias sobre as alterações políticas ocorridas em Portugal chegaram a Salvador possivelmente em outubro de 1820, a considerar as informações registradas por Felisberto Caldeira Brant Pontes em duas cartas enviadas para Lisboa. Na

\footnotetext{
${ }^{12}$ José da Silva Lisboa, op. cit., 1827, p. 35-36. Os textos dos decretos sobre as intervenções feitas no Brasil Reino encontram-se disponíveis em www.camara.gov.br.

${ }^{13}$ Cf. Mello Moraes, op. cit, t. 1, p. 58-59.

${ }^{14}$ Citado por Francisco Adolfo de Varnhagen, op. cit., p. 24 (grifos do autor). Possivelmente o conde da Palma, então governador da Bahia, tinha relatado para d. João VI a agitação política local pelo que se deduz de um documento enviado pela Junta de governo da Bahia meses depois e transcrito em Braz do Amaral, op. cit., 1957, p. 47-49.

${ }^{15}$ Mello Moraes, op. cit., t. 1, p, 498.
} 
primeira, endereçada a Joaquim Pereira d'Almeida e Cia., provavelmente um dos seus sócios, o Inspetor Geral das Tropas escreveu que no dia 27 daquele mês "fomos surpreendidos com a infausta nota da Revolução do Porto, que acreditei a vista da Proclamação dos Governadores do Reino em data de 29 de agosto” trazida por um paquete inglês que aportou em Salvador. Caldeira Brant também acreditava que “a peste revolucionária parece ser a moléstia do nosso século, e se ela lavrou além do Porto, espero eu que V.S. teria a prevenção de mandar quanto antes meu filho para o Rio ou para Londres”. Contudo, diante do inesperado, "nenhuma providência antecipada” poderia ser tomada a respeito. Na segunda carta, destinada ao filho, também expressa suas incertezas: "Se os Exmos. Governadores do Reino tiverem conseguido sufocar o mal na sua origem, bem está, se porém lavrou pelo resto do Reino, espero eu que aproveitaria a primeira oportunidade de embarcar para o Rio ou para a Inglaterra. Para ali seria uma ação que agradaria a El Rei N. Sr. e tenho algum pressentimento de que o farias na Companhia do Exmo. Sr. Conde de Palmella, mas para Londres seria mais útil afim de acabar os teus estudos". 16

Na proclamação referida, os governadores do Reino denunciavam que uns "poucos Indivíduos mal intencionados" haviam quebrado o "Juramento de fidelidade ao Seu Rei”, além de terem constituído na cidade do Porto "um Governo a que dão o título de Governo Supremo do Reino”. O documento procurava dissuadir os portugueses dos objetivos dos "revoltosos" que anunciavam "mudanças e alterações” convocando uma Corte completamente ilegal uma vez que essa prerrogativa caberia somente ao soberano. Por fim, convocava todos os portugueses a conservarem a obediência ao rei e a manterem a tranqüilidade pública até que a ordem fosse plenamente restabelecida. ${ }^{17}$

A despeito do tom depreciativo do texto sobre os envolvidos e o movimento, como seria de esperar, é possível que Caldeira Brant, um homem experiente e bemarticulado, estava convencido de que algo realmente notável havia se processado no Reino europeu. Ocupando o cargo de Inspetor Geral das Tropas da capitania desde 1811 e com amplos contatos comerciais na Europa, acreditava que "a peste revolucionária” se alastrava pelo mundo Ocidental. Posteriormente, os próprios governadores do Reino português aderiram ao movimento. No entanto, como ele mesmo havia afirmado em sua missiva, o espoucar dessas situações tinha como característica a imprevisibilidade. Assim, é possível

\footnotetext{
${ }^{16}$ Cartas de Felisberto Caldeira Brant Pontes, marquês de Barbacena, op. cit.

${ }^{17}$ APEB. Seção de Arquivo Colonial e Provincial. Proclamação contra a Revolução Constitucionalista de 1820. Maço: 584 (1820).
} 
que a rapidez com que as idéias liberais ganharam força na Bahia tenha surpreendido até mesmo os sabedores do potencial irruptivo de seus residentes.

De acordo algumas indicações, em sua passagem pela Bahia, o conde de Palmela havia tido longas conversas com Caldeira Brant sobre o seu projeto político de implantar no Reino Unido um governo de aristocratas semelhante ao modelo inglês. Ambicioso, teria prometido ao inspetor e proprietário um lugar garantido após a efetivação da sua proposta. Palmela não tinha interesse na revolução e muito menos na independência do Brasil. Pretendia assegurar a união do Reino “e formar também no Brasil, dentre as pessoas da sua escolha, os instrumentos desta aristocracia, da qual seria ele o chefe". ${ }^{18} \mathrm{~A}$ hesitação inicial de Caldeira Brant no decorrer dos acontecimentos na Bahia teria sido em função desse contato com o conde de Palmela que o havia convencido dos inconvenientes de uma revolução e da necessidade de garantir a permanência de d. João no Brasil. ${ }^{19}$

Como se supunha, a iniciativa do movimento de adesão ao constitucionalismo português partiu dos oficiais da tropa de linha sob o comando, entre outros, do tenentecoronel Manuel Pedro de Freitas Guimarães no dia 10 de fevereiro de 1821. O manifesto destinado aos corpos militares clamava pela união com os portugueses europeus pela causa liberal tendo em vista que os males experimentados eram os mesmos no interior do Reino: “[...] a agricultura, comércio e navegação arruinados, violentos tributos arbitrários, corrupção dos magistrados, pobreza dos povos, miséria dos soldados e toda a casta de opressão, despotismo e tirania”. A demora da corte do Rio de Janeiro em se pronunciar sobre os acontecimentos em Portugal também foi criticada: "Nós somos os salvadores do nosso país: a demora é prejudicial, o despotismo e a traição do Rio de Janeiro maquinam contra nós, não devemos consentir que o Brasil fique nos ferros da escravidão”. ${ }^{20} \mathrm{O}$ objetivo principal era a adoção de uma constituição junto com o rei e as Cortes. Enquanto isso, seria adotada interinamente a constituição da Espanha. Pretendia-se, assim, a implantação de uma Monarquia constitucional ao mesmo tempo em que jurava uma carta que ainda estava para ser elaborada. ${ }^{21}$

Não obstante o movimento ter principiado no seio dos corpos militares de Salvador, em pouco tempo os ideais pretendidos difundiram-se entre outros segmentos

\footnotetext{
${ }^{18}$ Mello Moraes, op. cit., t. 1, p. 501.

${ }^{19}$ Braz do Amaral, op. cit., 1957, p. 18. Ver também Ignácio Accioli, op. cit., v. III, p. 269.

${ }^{20}$ Citado por Braz do Amaral, op. cit., p. 16. Ver também Ignácio Accioli, op. cit., v. III, p. 269.

${ }^{21}$ Em Sergipe, houve resistência por parte do governador e a adesão ao sistema constitucional somente foi conseguida após o envio de tropas pela Junta provisional comandadas pelo coronel Bento da França Pinto de Oliveira. Sobre os estudos que, sob diferentes enfoques, tratam da repercussão da Revolução constitucionalista na Bahia ver introdução (nota 13).
} 
evidenciando que, concretamente, algum tipo de expectativas quanto às possíveis mudanças vicejava entre uma parcela dos residentes da Bahia. Na opinião de José da Silva Lisboa, o fato de a Bahia possuir fortes vínculos comerciais com as Praças do Porto e de Lisboa favoreceu a rápida introdução das notícias “incendiárias”. Para ele, ainda que a Bahia, depois do Rio de Janeiro, visivelmente havia tido um crescimento admirável, “mais que dobrando os produtos da agricultura da Capitania, e estendendo-se a navegação, principalmente a de Cabotage”, a capitania, "sendo quase uma Colônia do Minho, tomou vivo interesse na Revolução do Porto: e o Corpo dos Negociantes, inteiramente se dedicou à Causa do seu País, com tanta mais cordialidade, quanta era a certeza de haver sido abraçada pelos Governadores do Reino de Portugal”. 22

A partir de então, uma nova dinâmica política estabeleceu-se propiciando a dilatação do aprendizado político e, como corolário, a expressão de conflitos individuais e coletivos característicos de períodos de profunda crise. Era preciso não perder de vista o rumo das alterações pretendidas. A rigor, apesar de a situação ser inteiramente nova, não se pode esquecer de que tanto as autoridades régias quanto as principais lideranças do movimento tinham plena ciência de que o alargamento do espaço público poderia trazer indesejáveis surpresas. ${ }^{23}$ Por isso mesmo, os próximos passos deveriam ser dados com a máxima cautela. Os participantes já haviam dado provas de que pretendiam seguir adiante com as suas proposições ao enfrentarem as tropas do governo comandadas por Felisberto Caldeira Brant Pontes que foram obrigadas a recuar. Nesse conflito, foi morto o major Hermógenes Francisco de Aguillar Pantoja, um dos participantes da sedição de 1798 e um dos suspeitos de apoiar a Revolução de Pernambuco de 1817, entre outros civis e militares. A conselho do marechal Luiz Paulino Pinto da França, que se encontrava na cidade, o Inspetor Geral das Tropas teria concordado "que seria muito mais prudente ouvir o parecer das pessoas mais circunspectas e ilustradas” reunidas no Senado da Câmara da cidade, nas palavras de Ignácio Accioli. $^{24}$

Ainda no dia 10, foi oficializada a adesão da Bahia ao governo de Portugal, na presença do governador, conde da Palma, d. Francisco de Assis Mascarenhas, e organizado uma Junta Provisória destinada a conduzir a província até o juramento da constituição pelo

\footnotetext{
22 José da Silva Lisboa, op. cit., 1827, p. 43-44.

${ }^{23}$ István Jancsó e João Paulo G. Pimenta, op. cit.

${ }^{24}$ Ignácio Accioli afirma que as tropas, ao seguirem para o Senado da Câmara, teriam se recusado marchar sob o comando de Caldeira Brant seguindo sob o do marechal Luiz Paulino. Op. cit., v. II, p. 271-272. Na descrição que a gazeta Idade d'Ouro do Brazil fez dos eventos do dia 10 de fevereiro, a posição do marechal Caldeira Brant é bastante criticada. Na visão do redator, Caldeira Brant teria agido de maneira furiosa e com desprezo pelo movimento o que, de alguma maneira, havia exacerbado as tensões. Idem, ibidem, p. 276-277.
} 
monarca. A composição do governo provisório refletiu o desejo de manter certa estabilidade política incluindo a representação dos principais segmentos da sociedade: clero, milícia, comércio, agricultura e cidade. O próprio governador, reconhecendo a inevitabilidade das mudanças, além de sua evidente falta de apoio, não opôs qualquer resistência, declarando em ata ter assumido junto ao rei "entregar esta capitania, no mesmo estado em que a recebeu". No entanto, "seria obrigado a ceder às circunstâncias que, segundo a expressão geral da vontade do povo, são irresistíveis; não só tem cedido pelo motivo da dita coação a assinar a dita resolução, mas a prestar o juramento na forma dos sobreditos da mesma resolução”. ${ }^{25}$ Com essa atitude, se dava por encerrada a função do último governador e capitão-general da Bahia, cargo que existia desde a fundação da cidade de Salvador há mais de dois séculos. Alguns dias depois, o conde da Palma retirouse para o Rio de Janeiro acompanhado de Felisberto Caldeira Brant Pontes. Esse último teria, contrariando sua posição anterior, proposto a total separação de Portugal enfrentando forte oposição. ${ }^{26}$

No manifesto dos comandantes e oficiais da tropa de linha de Salvador ficava mais explícito que as articulações feitas visavam conter a exacerbação dos ânimos e uma indesejada "efusão de sangue, que infelizmente podia resultar de motins, originados do receio do povo" de ver frustrado seu intento em se reunir aos "irmãos de Portugal, a quem desejam estar perpetuamente unidos, e participar com eles dos benefícios da constituição liberal, que ora se faz em Lisboa”. Dentre as deliberações de obediência ao rei, o juramento da constituição, a formação de uma Junta de governo, entre outras, o documento conclui com um apelo: “Que o dia de hoje seja de reconciliação geral entre os habitantes desta

\footnotetext{
${ }^{25}$ Ata de 10 de Fevereiro de 1821. Ignácio Accioli, op. cit., v. III, p. 272-273. Segundo José da Silva Lisboa, a Junta ofereceu a presidência para o conde da Palma que a recusou. Op. cit., 1827, p. 46. Os membros indicados para a Junta de governo foram: o Reverendo deão José Fernandes da Silva Freire (clero), os tenentes-coronéis Francisco de Paula e Oliveira e Francisco José Pereira (milícia), Francisco Antonio Filgueiras e José Antonio Rodrigues Vianna (comércio); Paulo José de Mello Azevedo e Brito (agricultura), o desembargador Luiz Manuel de Moura Cabral (cidade), como secretários do governo: o desembargador José Caetano de Paiva e o bacharel José Lino Coutinho. Desses, eram naturais da Bahia, o reverendo Freire, Paulo Brito e Lino Coutinho. Antônio Pereira Rebouças, op. cit., p. 458. Sobre Luiz Manoel Cabral, que viria a assumir a presidência da Junta, José da Silva Lisboa diria que: "tinha por si os Europeus influentes do Corpo do Comércio, sendo ele o Presidente da Mesa da Inspeção da Praça”. Op. cit., 1827, p. 47.

${ }^{26}$ Antônio Pereira Rebouças afirma que Caldeira Brant teria dito não acreditar "que houvesse tanta disposição, como a que via manifestar-se, por uma nova ordem de cousas políticas, e que assim seria melhor fazer-se logo obra de brasileiros [...]", ouvindo imediatamente os gritos de "fora e morra". Ainda assim, partira dele a proposição para que na ata constasse a expressão adesão e não sujeição da Bahia a Portugal. Após a reunião, teria orientado Manuel Pedro sobre a saída de notícias para o Rio de Janeiro de maneira a evitar o envio de forças realistas da corte. Op. cit., p. 457-458. Retirando-se da Bahia, o marechal chegou ao Rio de Janeiro em 22 de fevereiro "a tempo para presenciar na Capital do Reino revolução idêntica a da Bahia, e pelos mesmos motivos”. O certo é que se aproximando de d. Pedro, Caldeira Brant desempenharia mais tarde importante papel no processo de reconhecimento da Independência do Brasil pelos países Europeus. João Pandiá Calogeras, op. cit., p. 23.
} 
Província, que por qualquer diferença de opinião política estejam discordes até agora”.27 Era uma clara evidência de que, se a perspectiva mais geral apontava para uma grande unidade com vistas a assegurar as mudanças propostas pelo Reino europeu, o caminho a ser percorrido indicava que as divergências políticas precisavam ser aparadas de maneira a evitar tumultos indesejáveis.

Entretanto essa não seria uma tarefa de fácil execução. Logo de início, os residentes que se encontravam na praça da Câmara exigiram a incorporação do tenentecoronel Manuel Pedro de Freitas Guimarães, uma das lideranças do movimento, à Junta de governo, sendo encarregado imediatamente do comando das armas. É importante relembrar que tanto Freitas Guimarães quanto o marechal Luiz Paulino Pinto da França poucos anos antes foram integrantes da comissão militar que condenou os envolvidos na Revolução de Pernambuco de 1817. Nessa conjuntura, desempenhariam papéis importantes nos encaminhamentos políticos da Bahia, além de terem presenciado a soltura dos presos daquele movimento que outrora haviam questionado as bases de sustentação do governo absolutista. A rigor, a oscilação de posições políticas foi uma forte característica de muitos protagonistas das lutas no decorrer dos anos seguintes.

Uma das primeiras medidas tomadas pelo novo governo, no dia seguinte à sua instalação (11 de fevereiro), foi a expedição de um manifesto a d. João VI expondo as razões do movimento e os objetivos que propunha. Pela importância do seu conteúdo, merece ser transcrito na íntegra:

Os honrados habitantes da Bahia, apurados por mil incidentes e motivos, desejavam há muito o estabelecimento de um governo liberal e justo, que coarctasse a a carreira dos seus males, e promovesse a sua felicidade: mas eles dotados de um caráter mando e sossegado, continuavam a viver debaixo do pesado jugo que os oprimia, imprecando tão somente à Providência, afim de que ela inspirasse ao nosso muito amado rei, o senhor D. João VI, a feliz idéia de nos dar voluntariamente a constituição de Portugal. Tais eram seus desígnios e modos de obrar, quando o governo do Rio de Janeiro, por uma medida indiscreta, e com vistas secundárias de terror e opressão, nomeava para governador desta Província ao conde de Villa-Flor, militar moço e fogoso, de quem os periódicos de Lisboa tinham feito o mais horroroso quadro. Foi nestas apertadas conjunturas que os bravos soldados da Bahia, vendo perdida a

\footnotetext{
${ }^{27}$ Manifesto dos militares de Salvador, em 10 de fevereiro de 1821. Ignácio Accioli, op. cit., v. III, p. 274. O manifesto traz a assinatura do conde da Palma, Felisberto Caldeira Brant Pontes, Luiz Paulino Pinto da França, Ignácio Luiz Madeira de Mello, Manoel Pedro de Freitas Guimarães, entre muitos outros. De acordo Ubiratan Castro de Araújo, como medida de controle dos soldados negros e mulatos, a Junta imediatamente regularizou o pagamento de soldos e de etapas, além de decretar o aumento de soldos e conceder promoções. O comércio fora o responsável pela arrecadação de dinheiro para suprir essas despesas. Op. cit., p. 21.
} 
Pátria, pretenderam salva-la, e com animosidade e denodo até agora nunca visto, proclamaram a mesma constituição de Portugal, convocaram a Câmara e instalaram este governo, até que S.M. assentindo à opinião geral dos povos, conceda a todos os seus domínios a constituição, que com as armas nas mãos se tem proclamado. Seguindo o exemplo de seus irmãos de Portugal, os habitantes da Bahia tem jurado com eles fidelidade ao nosso bom rei, o senhor D. João VI e toda a sua dinastia, obediência à constituição de Portugal e interinamente a de Espanha, conservação e respeito à religião de nossos pais.

Tais são os sentimentos gerais de todo o povo da Bahia, e tais os deste governo que incessantemente trabalhará pelo bem da causa pública, a fim de desempenhar a confiança que nele hão posto os seus concidadãos. ${ }^{28}$

Como mencionado anteriormente, a disposição para concretizar a adesão da Bahia ao constitucionalismo português parece que era muito mais forte do que se pensava na corte do Rio de Janeiro. As decisões imediatas reiteram essa perspectiva. A Junta determinou que as vilas e comarcas da Bahia confirmassem a adesão às Cortes liberais, aumentou os soldos das tropas, decretou que a imprensa local ficaria sob a censura de uma comissão da qual fazia parte Diogo Soares da Silva de Bivar. Diante da resistência do governador de Sergipe, Luis Antonio da Fonseca Machado, que havia conquistado a independência da Bahia no ano anterior, a Junta enviou uma tropa comandada por Bento da França Pinto de Oliveira, um dos filhos do marechal Luis Paulino, para submeter a capitania. É sintomático ainda que os membros da Junta tenham feito contato também com o governador de Pernambuco, Luís do Rego Barreto, lembrando-lhe que não era "menos Português que General valoroso e inteligente”. A partir de então relatavam as últimas ocorrências na Bahia ao mesmo tempo em que requisitavam a sua cooperação em benefício da "pública tranqüilidade do País”, considerando que desconheciam se possuía "os mesmos sentimentos que os que sinceramente nos animam”. ${ }^{29}$ É possível que a estratégia do governo provisório não apenas visava ampliar o movimento para uma província importante como Pernambuco, como também se precaver de uma reação negativa do governador que poderia resultar em um ataque das forças realistas sobre a Bahia inversamente ao que ocorrera em 1817, ainda mais que, ao que consta, exercia uma rígida disciplina sobre a tropa. $^{30}$

\footnotetext{
${ }^{28}$ Manifesto, em 11 de fevereiro de 1811. Ignácio Accioli, op. cit., v. III, p. 280.

${ }^{29}$ Carta dirigida ao governador de Pernambuco, general Luis do Rego Barreto, em 21 de fevereiro de 1821. Braz do Amaral, op. cit., 1957, p. 46. Segundo o autor, além desse comunicado, Luis do Rego teria recebido também uma carta de Luis Paulino sugerindo que ele aderisse à causa constitucional. Op. cit., p. 47. A dinâmica de Sergipe nesse período é tratada por Fernando...

${ }^{30}$ José da Silva Lisboa, op. cit., 1827, p. 48. Thomas Wisiak, op. cit., p. 63.
} 
Nesse sentido, é importante salientar que essas e outras intervenções promovidas pelo governo provisório potencializaram a formação de um ambiente político, não apenas restrito à capital e ao Recôncavo, que propiciou a exacerbação de muitos desejos represados fornecendo maior complexidade à manifestação da crise em território baiano. Além disso, os desdobramentos das mudanças políticas em Portugal e no Rio de Janeiro e mesmo internamente exigiam tomadas de posição da Junta que nem sempre obtinham o resultado esperado. É nessa intricada rede de tensões, conflitos e busca de alternativas possíveis que reside os sinais de uma crise profunda nem sempre percebida com clareza pelos coevos.

A despeito disso, não é possível admitir que os residentes da capitania absorveram as perspectivas de mudanças políticas apenas movidos pelos acontecimentos ocorridos no ultramar. As condições pelas quais esses indivíduos, cujas lideranças em sua maior parte eram detentoras de poder econômico e político - negociantes, militares, funcionários da justiça -, predispuseram-se a abraçar o apelo do Reino europeu indicam que anteriormente existia uma forte tendência para que um deslocamento dessa natureza pudesse ser efetivado. Ademais, mesmo que se considere a participação expressiva de portugueses europeus nessa mobilização, tendo em vista as questões específicas que buscavam solucionar, certamente não eram os únicos que ansiavam por implementar algum tipo de mudança no Estado monárquico. Para isso, é preciso não perder de vista as diversas possibilidades de discussão sobre a natureza dos governos políticos permitindo a troca de informações e, conseqüentemente, a difusão de idéias “perigosas”. O que, de resto, era uma prática já conhecida dos residentes da capitania, como discutido acima. A própria gazeta Idade d'Ouro do Brazil, até então uma publicação oficial da Monarquia bragantina, procurou ressaltar que o movimento na província não tinha caráter estritamente militar mas que era fruto da opinião: “Os atuais sucessos da Bahia não são filhos de um ou outro gênio distinto por sua coragem, e sabedoria; não, são a obra da opinião, e do tempo. Os governos constitucionais são uma conquista que os povos têm ganhado, e que os tiranos não lhes podem mais arrancar". ${ }^{31}$ A expressão de diferentes horizontes de expectativas que informam sobre esse aprendizado ficará ainda mais evidente na medida em que a crise política ganha novos contornos.

\footnotetext{
${ }^{31}$ Citado por Maria Beatriz Nizza da Silva. "Repercussões do movimento constitucional português de 1820 na Bahia e no Rio de Janeiro". Anais do Arquivo Público do Estado da Bahia, v. 51, 1994, Salvador-Bahia, p. 183.
} 
De fato, a intensidade dos conflitos e a tentativa de assegurar proposições políticas que não extrapolassem determinados limites produziram uma valiosa documentação sobre as perspectivas individuais e coletivas na Bahia do período. Numa situação de crise, as soluções encontradas muitas vezes aprofundaram ainda mais as tensões expondo mais claramente as contradições profundas da sociedade, como se verá. Por ora, é preciso reter que o longo aprendizado vivenciado pelos residentes da Bahia nos últimos decênios encontrou nesse período uma conjuntura altamente favorável para que pudesse ser exercitado de uma maneira vigorosa. Não à toa, a posição a ser tomada pela província era algo que interessava tanto à Coroa no Rio de Janeiro quanto às Cortes reunidas em Lisboa e a concretização desse vínculo foi disputado intensamente no decorrer dos anos seguintes.

Na correspondência enviada pela Junta provisória a d. João VI dois dias após a sua instalação, os membros do governo declararam que os habitantes da Bahia permaneciam na mais completa obediência e lealdade ao trono. Prova disso, diz o texto, foram os numerosos e primeiros testemunhos de adoração que o soberano recebera quando esteve na capitania anos antes. Outra demonstração nesse sentido, foi terem conservado intacta a sua fidelidade “a despeito do exemplo e das sugestões de uma Província limítrofe”. Ao contrário, atuaram no sentido "de reduzir a mesma Província à devida obediência ao governo e Autoridade de Vossa Magestade”. No entanto, esses mesmos vassalos tão submissos não poderiam "ser indiferentes aos últimos, memoráveis e gloriosos acontecimentos de Portugal”. ${ }^{2}$

A adesão da província aos reclames do Reino português era justificada pelo fato de serem "Vassalos comuns de uma Pátria comum", fruto de uma "unidade política" assegurada pelo próprio monarca e, em razão disso, partilhavam dos males originados de uma administração ineficaz e defeituosa. Desse modo, os problemas que enfrentavam eram obscurecidos pela atuação de conselheiros pérfidos como ficou evidenciado na tentativa de substituição de “um Governador tranquilo e benéfico” por outro de caráter violento, mesmo cientes sobre o estado e os desejos dos habitantes da província. Além disso, faltavam a verdade quando afirmavam que ao jurar a constituição o rei teria seu poder de representação diminuído “aos olhos do seu Povo, e do Universo”. Para os signatários do documento, os exemplos recentes mostravam o oposto:

\footnotetext{
${ }^{32}$ Carta que a Junta provisional de Governo da Província da Bahia dirigiu ao Muito Alto e Muito Poderoso Rei Senhor D. João VI, em 12 de fevereiro de 1821. Braz do Amaral, op. cit., 1957, p. 47.
} 
Lance Vossa Magestade os olhos para a Grã-Bretanha e verá se há coisa que mais engrandeça, poderio e respeito que se possa comparar com o Soberano daquela Nação [...]. Escudado com a Égide Sagrada da Grande Carta, ele se assemelha a um rochedo, contra o qual em vão se quebram as ondas do Oceano. Olha Vossa Magestade para o Rei Fernando, Seu Augusto Parente e verá que ele nunca mereceu o nome de Fernando, o Grande, e de Pai da Pátria, senão depois que jurou a Constituição Política da Espanha; repare finalmente Vossa Magestade no Rei de Nápoles e vêlo-á à maneira dos antigos Patriarcas, cercado por numerosos filhos, determinados a morrerem pelo que há de mais sagrado para homens livres - a Pátria -.

[...] Vossa Magestade jurando e mantendo a Constituição que respeitosamente lhe apresentarem os Deputados da Nação, marcará época a mais afortunada e a mais gloriosa do Lusitano Império, e receberá dos Seus Povos nas quatro partes do Mundo que eles habitam o tributo mais digno dos Grandes Reis - o nome de Pai da Pátria. ${ }^{33}$

A capitania do Grão-Pará foi a primeira da América a manifestar adesão às Cortes portuguesas, em 01 de janeiro de 1821. Ocorre que essa informação foi recebida primeiro em Lisboa, em razão das relações anteriormente mantidas com a metrópole, e posteriormente no Rio de Janeiro, depois da chegada sobre as notícias da Bahia. Em função disso, Braz do Amaral diz que o movimento constitucionalista nessa província foi essencial para desencadear a mobilização dos residentes na corte. ${ }^{34}$ De qualquer modo, as decisões tomadas pela Coroa, antes mesmo de o Rio de Janeiro decidir pela adesão ao constitucionalismo interferiram diretamente na movimentação política da Bahia. Não cabe aqui acompanhar em detalhes as ações da Junta provisória nesse contexto. Mesmo porque a dinâmica impunha uma série de providências cotidianas que somente foram ampliadas com o passar do tempo em função de variadas demandas. No entanto, para o que nos interessa, é preciso traçar as linhas gerais que sinalizavam um agravamento das tensões no interior da província e, como corolário, o engendramento de novos elementos fundamentais para a apreensão da natureza e da dimensão dessa mesma crise.

Contrariando as expectativas do governo provisório da Bahia de assegurar, em uma nova ordem constitucional, a igualdade política conquistada na elevação do Brasil à condição de Reino, d. João VI determinou, em 18 de fevereiro, que a constituição a ser elaborada pelas Cortes deveria ser adaptada às conveniências do Brasil, ilhas e domínios ultramarinos após análise dos seus artigos por uma comissão de procuradores com poderes para propor reformas no texto e outras providências consideradas necessárias. Era de se

\footnotetext{
${ }^{33}$ Idem, ibidem, p. 49. Ver também Francisco Adolfo de Varnhagen, op. cit., s/d, p. 261-263.

${ }^{34}$ Braz do Amaral, op. cit., 1957, p. 60. Sobre o processo de Independência no Pará, ver o estudo de André Roberto de A. Machado. A quebra da mola real das sociedades: a crise política do Antigo Regime português na Província do Grão-Pará (1821-1825). São Paulo, Universidade de São Paulo, 2006 (tese de doutorado).
} 
esperar que a reação a essa medida fosse virulenta. E ela não tardou. Um mês depois a Junta divulgou um manifesto atacando fortemente a proposta da corte do Rio de Janeiro. Segundo o texto, a intenção da mesma era "dividir para imperar” mas já era tarde para recorrer a essa sentença: "Bahianos! Vós conheceis bem que a nossa força consiste na comunhão de interesses, vistas e instituições com o país de vossa origem. Vós sabeis que são vossos inimigos os que pretendem dilacerar as saudáveis fachas que vos unem”. Como era possível, perguntavam os constitucionalistas, introduzirem um mecanismo de tratamento diferenciado provocando "cisão entre partes homogêneas do mesmo povo que aliás coincidem em costumes, religião, espírito geral, cultura mental e moral e civilização sociável?”. ${ }^{35}$

Em correspondência à Junta, o Senado da Câmara de Salvador também manifestou seu repúdio ao decreto e ratificou juramento de adesão àquele governo. De acordo os vereadores, a proposta de reformas na constituição só poderia ter sido feita pelos conselheiros do rei que desejavam separar os portugueses "para melhor subjugá-los". Acreditavam que d. João VI já havia dado provas suficientes “do seu amor paternal” unindo-os em um único Reino que, todavia, não teria qualquer efeito se a constituição não fosse a mesma para Portugal, Brasil e Argarves. Dessa forma, o conselho estava decidido a empregar "todas as suas forças para não consentir nem direta, nem indiretamente na mais pequena separação entre os Portugueses da Europa, das ilhas e do Brasil e África; e que a Constituição que as Cortes em Lisboa estão organizando será irrevogavelmente aquela que deverá reger esta Província”. ${ }^{6}$ Os documentos deixam antevê algumas questões importantes. As reações da Junta e do Senado da Câmara apresentam os primeiros indícios de que as ações políticas na Bahia começavam a tomar uma dimensão mais ampla motivada, nesse momento, pelas atitudes vindas da corte. Contudo, o rei continuava poupado das críticas uma vez que, na visão dos signatários, ainda estava sob a influência dos seus pérfidos conselheiros. Por fim, o significado da igualdade política obtida por meio da elevação do Brasil à condição de Reino emerge nessas circunstâncias com toda a força denotando a importância dos efeitos daquela medida para os portugueses americanos. Esse último dado assume maior relevância na medida em que se considera que a defesa da manutenção do Reino Unido somente foi abandonada quando as condições para isso se mostraram completamente inviáveis algum tempo depois.

\footnotetext{
${ }^{35}$ Manifesto da Junta Provisória de Governo, em 18 de março de 1821. Braz do Amaral, op. cit., p. 53-54.

${ }^{36}$ Manifestação da Câmara da Capital da Bahia sobre o decreto de 18 de fevereiro, em 21 de março de 1821. Braz do Amaral, op. cit., p. 55-56.
} 
A situação política no Rio de Janeiro também se agravava a cada dia. Em 26 de fevereiro, a tropa portuguesa decidiu aderir ao constitucionalismo português exigindo do monarca a organização de um novo governo. Nessa ocasião, Tomás Antônio de Villanova Portugal teria dito ao rei que era necessário tomar medidas firmes para aplainar a crise. Uma de suas propostas era que um novo ministério fosse formado com alguns dos indivíduos que exigiam reformas: "Se eles são revolucionários hoje deixarão de o ser amanhã se forem ministros, e servirão a Vossa Magestade com zelo" ${ }^{37}$ Não à toa Villanova era tido por d. João VI como um ministro de grande perspicácia no qual depositava plena confiança.

Atendendo as exigências das Cortes de Lisboa, o monarca declarou seu retorno à Europa por meio do decreto de 7 de Março e deixaria seu filho, d. Pedro, como regente. No documento, reconhecia que a adoção de uma constituição política para o Reino Unido de Portugal, Brasil e Algarves era incontestável “conforme aos princípios liberais, que pelo incremento das luzes se acham geralmente recebidos por todas as nações”. Afirmava ainda que para extirpar o estado de incerteza em que se encontrava sobretudo os vassalos do Reino do Brasil, garantia a sua absoluta aprovação da constituição “para ser geralmente cumprida e executada, sem alteração nem diferença, em todos os Estados da minha real coroa” ${ }^{38}$ Pela carta régia de 28 desse mês, d. João VI comunicou à Junta Provisional de Governo da Bahia sua aprovação ao juramento feito em Salvador à constituição que estava sendo elaborada em Portugal. De alguma maneira, justificava a demora na tomada de posição ao afirmar que a mudança da forma de governo para uma Monarquia constitucional era matéria de grande importância que "exigia as mais sérias meditações e combinações para que, sem se ofender essencialmente o depósito sagrado da Autoridade Real [...] se conseguissem os resultados felizes de um Governo Representativo”. Todavia, deixava claro que quando já havia tomado as providências adequadas soubera da decisão da Bahia de se antecipar com a resolução de 10 de fevereiro. A despeito do lamento, a

\footnotetext{
${ }^{37}$ Citado por Mello Moraes, op. cit., t. 1, p. 501. Em 24 de fevereiro, d. João VI já havia decretado a aprovação da constituição que estava sendo feita em Portugal para todos os seus domínios (disponível em www.camara.gov.br).

${ }^{38}$ Decreto de 7 de Março de 1821 (disponível em www.camara.org.br). D. João VI retornou a Portugal em 26 de abril de 1821, deixando seu filho d. Pedro como príncipe regente. Segundo Mello Moraes, a opinião de Tomás Villanova era sempre no sentido de "salvar o Brasil do vórtice da revolução". No entanto, não dava a mesma importância a Portugal que, acreditava, iria se arrepender e retornar à obediência do rei. "Depois disto feito poderia então el-rei fazer as reformas que bem lhe parecesse. Em todo caso aconselhava a el-rei de não voltar para Portugal”. Op. cit., t. 1, p. 501. Em 17 de outubro de 1821, a Junta Provisional de Governo da Bahia comunicou as vilas a chegada de d. João VI a Portugal, em 3 de julho, assim como o juramento que havia prestado às Bases da constituição. Braz do Amaral, op. cit., 1957, p. 56.
} 
atitude do monarca pareceu aos constitucionalistas da Bahia um sinal de que começavam a assegurar as suas primeiras conquistas.

Ao assumir o governo, d. Pedro buscou contornar o ambiente de agitação política crescente na corte do Rio de Janeiro. Na obra laudatória de José da Silva Lisboa, o príncipe aparece como um líder sensato que teria aprendido “a não confundir a conveniência de Reformas necessárias de Instituições defeituosas com a extravagância das Inovações atrabilárias nas Leis Fundamentais das Monarquias”. Contava com a lealdade de seu ministro e secretário dos Negócios do Reino e Estrangeiros, d. Marcos de Noronha e Brito, o conde dos Arcos: "amigo esperto, fiel, e determinado, de quem esperava em tão extraordinárias ocorrências conselhos superiores à rotina do Gabinete”. ${ }^{39}$ As divergências políticas no interior do governo, no entanto, se intensificaram, sobretudo entre esse ministro e o conde de Louzã, d. Diogo de Menezes - muito mais próximo das tropas portuguesas - resultando na demissão de Arcos em 5 de junho de 1821. As razões imediatas para a sua saída teriam sido a demora do regente em jurar as bases da constituição, sob a influência do conde dos Arcos, aprovadas pelo congresso em Lisboa e chegadas ao Rio de Janeiro em fins de maio, conforme relato feito pela Gazeta do Rio de Janeiro. ${ }^{40}$ Antes disso, uma das primeiras medidas do ministro no governo de d. Pedro foi a abolição do imposto pago sobre o sal transportado para o interior do Reino. Decisão que foi vista pelas tropas portuguesas como uma tentativa de favorecer os naturais da América e, dessa forma, fortalecer os vínculos com o conde para os seus propósitos políticos. ${ }^{41}$ Em função dessas questões, os constitucionalistas da corte exigiram seu afastamento e a nomeação de uma junta provisória constituída nesse mesmo dia, alterando completamente o destino político do ministro.

O conde dos Arcos foi então enviado preso para Lisboa fazendo escala na Bahia em 20 de junho de 1821. Não deixa de ser relevante o fato de o antigo governador daquela província que poucos anos antes havia deixado o governo sob gloriosas homenagens e prêmios, tenha sido totalmente repelido pelos membros da Junta Provisória a ponto de não autorizarem sequer o seu desembarque. Ademais, esse episódio fornece outros elementos que podem ajudar a esclarecer as ligações da Bahia com a Revolução pernambucana de 1817. Que razões mais intensas justificariam o comportamento de alguns residentes da província? Ao que parece, ele próprio não pretendia aportar aí sinalizando que sabia de

\footnotetext{
39 José da Silva Lisboa, op. cit., 1827, p. 2.

${ }^{40}$ Citado por Mello Moraes, op. cit., t. 1, p. 160-161.

${ }^{41}$ Rocha Martins, op. cit., p. 153.
} 
antemão que não seria ali bem recebido. Conforme as informações fornecidas pela Junta ao governo português, o conde dos Arcos era acusado de tramar contra a união de portugueses europeus e americanos e contaria na província com “um partido de servis” para esse objetivo. Por isso, recomendava "a mais desvelada segurança sobre a pessoa do dito conde, tido como chefe da mais execranda conspiração contra os interesses comuns da nação e do rei”. Como prova de segurança, a Junta exigiu do comandante do brigue Treze de Maio que transportava o ex-ministro a assinatura de um termo no qual se comprometia a não atracar no porto de Pernambuco como estava previsto, entre outras coisas, pela conhecida “conduta anticonstitucional” do governador daquela província. ${ }^{42}$ Segundo seu biógrafo, a despeito dos serviços prestados a d. Pedro, o conde dos Arcos recebeu do regente uma ordem para que embarcasse o mais depressa. Saiu do Rio de Janeiro acompanhado de sua filha sem ter tido tempo para cuidar de suas posses. Entendeu aquele aviso como "um grande perigo para a situação real - e obedeceu”, deixando um patrimônio considerável: “o seu magnífico palácio no Campo de Sant'Ana, os cem contos no banco com mais algum dinheiro, a bela fazenda da Olaria, na estrada de S. Clemente, além de outras casas mandadas construir no mesmo sítio”. ${ }^{43}$

A atitude do governo provisório da Bahia é vista por parte da historiografia como um ato despropositado tendo em vista o honroso papel desempenhado anteriormente pelo conde na administração local. Mello Moraes, por exemplo, diz que a Bahia "Ihe devia inúmeros favores” e “o acusou injustamente”. Além disso, muitos dos que o atacavam demonstravam a sua ingratidão pelo que o ex-governador havia feito em 1817. Segundo afirma, ciente dos planos revolucionários, Arcos não apenas evitou o comprometimento da Bahia, como salvou os comprometidos "fazendo que os que eram militares marchassem com a força que expediu para Pernambuco; e que os outros, que pertenciam às outras classes da sociedade, fossem empregados por meios diversos, em modo que ninguém ficou comprometido”. ${ }^{44}$ Braz do Amaral também ressalta que o conde "noutro tempo amado" sofreu ataques inclusive da "arraia-miúda” e, caso tivesse desembarcado, era provável que sofreria insultos nos mesmos lugares em que anteriormente se realizaram tantas festas em seu reconhecimento. Entretanto, esse historiador ressalta que os sentimentos dos residentes

\footnotetext{
${ }^{42}$ Termo de segurança do conde dos Arcos, em 21 de junho de 1821. Mello Moraes, op. cit., t. 1, p. 166-167. Sobre a resistência do conde dos Arcos em aportar na Bahia. Rocha Martins, op. cit., p. 167.

${ }^{43}$ Rocha Martins, op. cit., p. 166.

${ }^{44}$ Mello Moraes, op. cit., t. 1, p. 164-165.
} 
da Bahia haviam mudado, uma característica da "inconstância dos afetos populares”. ${ }^{45}$ Certamente, uma questão fundamental diz respeito aos posicionamentos políticos assumidos numa conjuntura de aceleradas mudanças. O conde dos Arcos representava, naquele momento, a defesa de um projeto que pressupunha o rompimento dos vínculos com o Reino europeu. Foi desse modo pelo menos que interpretaram seu comportamento político. E a Junta Provisória de Governo já havia dado demonstrações do seu empenho para preservar a unidade dos Reinos dos dois hemisférios. Além disso, não se pode desprezar também que o ex-governador possuía adversários na província, inclusive, por sua atuação em 1817 o que, muito provavelmente, contribuiu para que o seu posicionamento na corte adquirisse um significado político mais amplo.

De fato, Rocha Martins afirma que um dos principais membros da Junta Provisório, o secretário Lino Coutinho, conhecido por suas posições liberais e um dos possíveis implicados em 1817, foi o primeiro a incriminar Arcos no que foi seguido por outros, inclusive Paulo José de Melo Azevedo e Brito, vice-presidente da Junta e outrora um dos autores dos poemas enaltecedores do antigo governador. Em Lisboa, um dos defensores do conde, Inocêncio Antonio de Miranda, o abade de Medrões, questionava no congresso a legitimidade da sua prisão. Recorrendo às bases da constituição, diria que as mesmas determinavam "que pessoa alguma seja presa sem culpa formada”. Todavia, o conde dos Arcos, segundo ele, não possuía culpa formada "e até ignora o grau da sua culpa”. Afirmava que o ex-ministro havia saído solto da corte do Rio de Janeiro e preso na Bahia porque, entre outras razões, no tempo em que ocupara o governo "teve motivos de indisposição com um dos atuais membros da Junta”, propondo, então, a sua soltura e o envio para um lugar distante de Lisboa "como se praticou com os Fidalgos que acompanharam a Sua Magestade”. O deputado não mencionou qualquer nome relacionado às divergências na Bahia. Caso o tivesse feito, observa Rocha Martins com razão, poderia “atear uma grande cólera constitucional contra o repressor das audácias liberais de 1817 tão agradáveis ao Congresso”. 46

O caso de Arcos foi objeto de muitas discussões nas Cortes e tinha em Manuel Fernandes Tomaz, o principal líder do movimento vintista, um crítico poderoso. Entre os seus defensores, o deputado João Rodrigues de Brito afirmaria que o conhecera na Bahia

\footnotetext{
${ }^{45}$ Braz do Amaral, op. cit, 1957, p. 37. Na ocasião, o retrato do conde dos Arcos existente na Praça do Comércio teria sido retirado pelos manifestantes contrários à sua presença na província. Inácio Accioli, op. cit., v. II, p. 288.

${ }^{46}$ Rocha Martins, op. cit., p. 174. Varnhagen informa que Paulo Azevedo e Brito foi a "alma e diretor principal da junta”. Natural da Bahia, posteriormente ocupou o cargo de senador. Op. cit., s/d, p. 264.
} 
“muito liberal e ser[ia] impossível que se afastasse daqueles princípios”. Uma devassa foi aberta para verificar a sua real implicação em uma "horrenda conspiração" que pretendia desunir os portugueses dos dois hemisférios "e separar os interesses comuns da nação e do reino” depois da sua recusa em jurar as bases da constituição e orientar o príncipe regente nesse sentido. ${ }^{47}$ Em 29 de novembro de 1821, d. João VI, após deliberação do congresso

acerca da suposta conspiração que a Junta de Governo da Bahia imputou ao Conde dos Arcos na sua Carta de 20 de Junho do Presente ano; e tendo justamente presentes a memória e documentos justificativos oferecidos pelo mesmo conde de que tudo se mostra a falta de fundamento daquela imputação, em que a Junta se reporta a Cartas, que não manda, recebidas do Rio de Janeiro, de pessoas que nem nomeia, acrescentando que o conde vinha em custódia no Brigue "13 de Maio" quando é evidente por seus documentos que vinha para Portugal com sua filha por licença do Príncipe Real, resolve que o Conde dos Arcos seja imediatamente restituído à sua inteira e absoluta liberdade. ${ }^{48}$

A essa altura, outros encaminhamentos políticos nas Cortes referentes às partes americanas do Reino tinham propiciado a manifestação de novos e importantes elementos. Desde julho de 1821, a orientação era para que a Junta Provisional da Bahia permanecesse encaminhando "suas contas, e representações ao governo estabelecido em Lisboa, como centro único da Monarquia, e assento da representação nacional, e do trono português, donde receberá as competentes ordens, sem dependência do governo do Rio de Janeiro”. 49 A rigor, com o retorno de d. João VI à Europa e o estabelecimento da regência de d. Pedro, em abril desse ano, a Junta da Bahia já havia decidido se submeter às Cortes de Lisboa e não mais ao governo do Rio de Janeiro argumentando que o monarca "não podia delegar um poder que já estava nas Cortes, desde que ele as havia reconhecido”. ${ }^{50}$ Os decretos de 29 de setembro, $1^{0}$. e 18 de outubro indicavam alterações significativas ao reconhecerem como legítimas os governos das Juntas Provisórias, determinando a eleição de novas Juntas; estabelecerem a nomeação de governadores das armas submetidos ao rei e às Cortes, além de exigirem o retorno do príncipe regente para a Europa e extinguir os

\footnotetext{
${ }^{47}$ Idem, ibidem, p. 177-178.

${ }^{48}$ Portaria de d. João VI, em 29 de novembro de 1821. Inácio Accioli, op. cit., v. III, p. 288. Ver também Rocha Martins, op. cit., p. 185.

${ }^{49}$ Correspondência das Cortes Gerais para a Junta Provisional de Governo da Bahia, em 18 de julho de 1821. Ignácio Accioli, v. II, p. 280-281.

${ }^{50}$ Francisco Adolfo de Varnhagen, op. cit., s/d, p. 264. Ignácio Accioli, op. cit., v. III, p. 287. Para José da Silva Lisboa, a Junta Provisional da Bahia "se deu ares de importância, teve dois Secretários, um para os Negócios do Interior, e outro para os Negócios Estrangeiros. Logo procedeu ao despotismo de se declarar independente do Governo Real do Rio de Janeiro, para só receber ordens do Governo de Portugal; e de expedir Batalhões a se apoderar da Comarca do Norte, que El-Rei havia antes formado em Capitania separada do Governo da Bahia”. Op. cit., 1827, p. 47.
} 
tribunais que haviam sido criados no Rio de Janeiro. Para John Armitage, as duas últimas medidas das Cortes indicavam claramente a sua disposição em não permitir o estabelecimento de um governo central no Centro-Sul sob o comando de d. Pedro. ${ }^{51}$ A maneira como essas medidas foram absorvidas pelas lideranças políticas na Bahia potencializam a quebra da frágil unidade constituída no momento de adesão da província ao constitucionalismo português. $\mathrm{O}$ aprofundamento da crise apenas exporia mais claramente as divergências e, mais do que isso, dada às condições de extrema fluidez, alteraria posições de acordo as perspectivas das mudanças. ${ }^{52}$

No dia 3 de setembro de 1821 foram eleitos os deputados da Bahia às Cortes Gerais reunidas em Lisboa após um longo processo de escolha dos candidatos, acompanhado de perto pelos periódicos. Não se pode esquecer que era a primeira vez que se realizavam eleições no Brasil e na Bahia. Dentre os escolhidos, Francisco Agostinho Gomes, José Lino Coutinho, Cipriano José Barata de Almeida, Domingos Borges de Barros, Luiz Paulino de Oliveira Pinto da França, Alexandre Gomes Ferrão Castelo Branco, Pedro Rodrigues Bandeira e Marcos Antônio de Sousa. Com exceção de Gomes Ferrão, que nascera na Vila de São Francisco da Barra de Sergipe do Conde, e Borges de Barros, proveniente da vila de Santo Amaro, os demais tinham suas origens na cidade de Salvador, e a maior parte era bastante conhecida no cenário político e econômico da Bahia. ${ }^{53}$ Certamente não constituíam um grupo com posições políticas homogêneas. Com sua visão pragmática, sem deixar, contudo, de manifestar suas escolhas políticas, José da Silva Lisboa criticou a pressa da "Junta usurpadora” em realizar a eleição e a escolha de indivíduos que não possuíam a formação em direito considerando que se destinavam discutir a reforma da legislação monárquica. Além disso, considerava inaceitável que um dos escolhidos "fosse o cirurgião Cipriano José Barata, reconhecido por turbulento e amotinador; como se houvesse penúria de seletos Representantes da província”. ${ }^{54}$

Poucos dias depois da eleição, em 14 de setembro, o Idade d'Ouro publicou uma longa proclamação das Cortes Gerais às províncias do Reino americano ressaltando a

\footnotetext{
${ }^{51}$ John Armitage, op. cit., p. 49.

${ }^{52}$ Para a discussão sobre a provisoriedade política numa conjuntura de crise, ver: István Jancsó e João Paulo G. Pimenta.

${ }^{53}$ Thomas Wisiak, op. cit., 2001, p. 86. O autor discute os meandros desse processo eleitoral, fornecendo informações importantes sobre os eleitos. Ver também Luiz Alberto Moniz Bandeira, op. cit., p. 384-385. Sobre a participação dos deputados do Brasil nas Cortes: Márcia Regina Berbel, op. cit. e, especificamente, sobre os deputados da Bahia: Antônio de Araújo de Aragão Bulcão Sobrinho. A Bahia nas Cortes Gerais de Lisboa de 1821. Salvador, 1955; Zélia Cavalcanti, op. cit.; Thomas Wisiak, op. cit., 2001 e do mesmo autor "Itinerário da Bahia na Independência do Brasil, 1821-1823”. In: István Jancsó (Org.), op. cit., 2005, p. 447474.

${ }^{54}$ José da Silva Lisboa, op. cit., 1827, p. 53.
} 
importância de os homens evitarem os excessos em suas atitudes políticas e, desse modo, as malfadadas revoluções. Depois de salientar as alterações benéficas que haviam sido implementadas para todos os portugueses desde a instalação do congresso, o texto alertava que a história já havia dado exemplos suficientes dos resultados negativos da anarquia e de suas consequências. Por isso, conclamava aos habitantes que cultivassem a moderação, pois, somente "no sossego e na união dos sentimentos patrióticos, que se formam os costumes, e se adquirem esses hábitos, essencialmente necessários para a mudança, que fazemos”. ${ }^{55}$ As palavras sinalizam que o ambiente político em algumas províncias estava conturbado.

De fato, uma das principais manifestações das profundas divergências políticas no interior do movimento foi exposta dois meses depois (3 de novembro) quando alguns indivíduos tentaram depor a Junta Provisória acusada de praticar atitudes conciliatórias com as medidas aprovadas pelas Cortes que atentavam contra os interesses locais. Pelo menos foram essas as acusações dos manifestantes, em grande maioria militares, a exemplo dos tenentes-coronéis José Egídio Gordilho de Barbuda, de origem portuguesa e futuro presidente da província baiana, Felisberto Gomes Caldeira, o major Elói Pessoa e Silva e o cadete João Primo, naturais da América portuguesa, entre outros. Poucos dias depois foram aprisionados panfletos com "o fim de amotinar, ou ao menos, aterrar os Povos” contendo profundas críticas à condução do governo cuja autoria de dois deles seria atribuída ao cadete, que se revelaria um participante político na Bahia e um dos líderes do movimento federalista em $1837 .{ }^{56}$ O Senado da Câmara, que teve a sessão suspensa em função do protesto, registrou em ata quatro dias depois que "Militares e Paisanos" gritavam "Viva a Constituição, Vivam as Cortes, Viva El Rey D. João 6 ., Vivam os nossos irmãos de Portugal” e que pretendiam “depor os membros atuais do Governo para lhe substituir

\footnotetext{
${ }^{55}$ Idade d'Ouro do Brazil, n. 100, 14 de setembro de 1821. Bahia: na Tipografia da Viúva Serva e Carvalho. Biblioteca Pública do Estado da Bahia. Setor de Periódicos Raros. A data da proclamação é de 13 de julho desse ano.

${ }^{56}$ O primeiro desses escritos, de 3 de novembro de 1821, constituía uma "Proclamação assinada por João Primo"; o segundo, que teria a mesma caligrafia, com a data de 14 do mesmo mês era intitulado: "Cidadãos beneméritos e verdadeiros Constitucionais respondem às fabulosas Proclamações dos agonizantes Bachás! Senhores déspotas do novo modelo!" e subscrito pelos "Amantes do bem público" e o último tratava-se de uma carta dirigida, em $1^{\circ}$ de dezembro, "aos Observadores e Célebres Constitucionais". Devassa de escritos inflamatórios e Sediciosos encontrados em mãos de João Crioulo, escravo de Antonio José Pereira Rocha, e Francisco Antonio de Souza. Citados por Argemiro Ribeiro de Souza Filho. "Projetos políticos na revolução constitucionalista na Bahia (1821-1822). Almanack Braziliense, São Paulo, n. 7, maio de 2008, p. 102-118 (disponível em www.almanack.usp.br).
} 
outros que fossem da satisfação do Povo que não estava, diziam eles, satisfeitos com os atuais". 57

Presos alguns dos envolvidos e encaminhados para Lisboa, cerca de 16, a Junta Provisional tratou de registrar sua posição sobre o episódio. De acordo com os seus membros, "meia dúzia de monstros sem pátria, nem religião, iludindo a poucos homens crédulos" havia tentado contra o governo por esse não ter cedido "a insaciável sede de torpes lucros”. O documento também fornece algumas pistas sobre a dimensão daquele acontecimento. Os manifestantes teriam se apresentado

nos paços do conselho, acompanhados de alguma gente da plebe, raros oficiais de linha, e pouquíssimos paisanos sem representação civil [...], e violando o respeito devido ao palácio do governo, invadirão-no armados com punhais, e pistolas, que bem se viam escondidas por entre seus vestidos, e quiseram obrigar a Junta a demitir-se, e (o que mais é) a autoriza-los para a seu sabor estabelecerem um novo governo, que, fartando-lhes sua venenosa ambição, vos lançaria sem dúvida no pélago da anarquia. ${ }^{58}$

O governo denunciava que os integrantes estariam vinculados ao "Partido Felisbertino" cujas sinistras pretensões incluíam a separação entre os Reinos de Brasil e Portugal. Para as Cortes Gerais em Lisboa, esclarecia ainda que, a seu modo de ver, a conspiração havia sido pensada juntamente com o Rio de Janeiro para provocar a cisão dos Reinos "plano que havia estabelecido o Conde dos Arcos e o Conde de Palmela; e que aqui seguiu adotado pelo marechal Felisberto Caldeira e seus satélites”. ${ }^{9}$ Em razão desse acontecimento, o nome do antigo governador voltava a ficar em evidência. Para o redator do Idade d'Ouro, não havia dúvidas com relação aos vínculos mantidos entre Arcos e os revoltosos. Ao se defender contra as críticas feitas ao ex-ministro, diria: “o nosso governo foi o mais injusto e caluniador em ofícios às Cortes contra o 'incomparável' conde; cometeu o maior atentado em mandar rondar as casas dos seus amigos, na noite em que ali chegou do Rio de Janeiro; tal era a linguagem dos conspiradores e agora vemos que aqueles dos que foram rondados naquela noite entraram muitos nesta conspiração". 60

\footnotetext{
${ }^{57}$ Termo de Vereação, de 7 de Novembro de 1821. Documentos da Municipalidade de Salvador relacionados com a Independência do Brasil, 1821-1823, op. cit., p. 13-14. Sobre o assunto, ver: Luis Henrique Dias Tavares, op. cit., 2005. Além disso, antes mesmo desse episódio teria ocorrido fortes desentendimentos entre os soldados naturais da Bahia e militares portugueses europeus em razão de privilégios concedidos pelas Cortes liberais aos últimos. Cf. Ubiratan Castro de Araújo, op. cit.

${ }^{58}$ Manifesto da Junta Provisional de Governo aos habitantes da Bahia, em 4 de novembro de 1821. Ignácio Accioli, op. cit., v. III, p. 291-292.

${ }^{59}$ Citado por Rocha Martins, op. cit., p. 180.

${ }^{60}$ Idem, ibidem, p. 181-182. Um dos quais seria José Egídio Gordilho de Barbuda, informa Francisco Adolfo de Varnhagen, op. cit., s/d, p. 265.
} 
Quando essas informações chegaram em Lisboa, o conde dos Arcos já não se encontrava preso na Torre de Belém. Do contrário, a sua situação poderia ter se agravado, observa Rocha Martins. $^{61}$

Seja como for, é provável, como salienta Luis Henrique Dias Tavares, que por essa época já existissem na Bahia indivíduos que defendessem um governo sob o comando de d. Pedro, como demonstrariam ainda os acontecimentos verificados na província dois meses depois desse episódio. No entanto, isso não significava a existência de um projeto político de autonomia em relação às Cortes Gerais de Lisboa e de concretização da Independência do Brasil. ${ }^{62}$ Pelo menos até que a exacerbação dos conflitos apontasse essa condição como uma alternativa possível para a crise. Nesse sentido, o alerta feito pelo Idade d'Ouro seis dias depois da tentativa de deposição do Governo Provisional serve, por um lado, como um indicativo sobre a natureza das divergências políticas propiciadas pelas circunstâncias do período e, por outro, significa que questões relacionadas ao universo da política adquiriam cada vez mais uma ampla disseminação entre os residentes da província. Sem dúvida, um aspecto de grande importância para o que vimos tratando.

A persuasão em que estão alguns de que o povo pode depor o governo não só tem por principio a malícia dos revolucionários, como também a ignorância daqueles, que não tem estudado estas matérias. Quando nas Bases da Constituição se diz, que a soberania reside essencialmente em a nação, não se quer dizer, que o povo inteiro de uma província é soberano, mas sim os povos de todas as províncias, que formam a nação, aliás teríamos tantas soberanias quantas Províncias, o que seria ridículo absurdo, e desgraçada anarquia. O povo pois de uma Província quando se sente mal com o seu governo, ou com qualquer empregado público, deve recorrer ao Congresso Nacional, aonde reside formalmente a soberania da nação. A nação tem o poder na essência, e não se forma. A forma de desenvolvimento do poder é aquela, que foi prescrita no método das eleições; e o povo de cada Província perdeu a forma da sua representação desde que elegeu compromissários, ficando-lhe só a essência do poder para o tornar a desenvolver nas eleições seguintes. $O$ povo de uma Província não só não pode depor um governo, como nenhum ministro, ou outro qualquer empregado. $\mathrm{O}$ povo pode eleger deputados pela forma, que a Constituição determina, e quando se publicar nossa futura Constituição terá também o povo o poder de eleger os membros do Governo Provincial, mas isto não há de ser como o povo quiser, há de ser como a Constituição ordenar. ${ }^{63}$

\footnotetext{
${ }^{61}$ Idem, ibidem, p. 185.

${ }^{62}$ Luis Henrique Dias Tavares, op. cit., 2005, p. 29.

${ }^{63}$ Maria Beatriz Nizza da Silva, op. cit., 1988, p. 42-43.
} 


\subsection{O aprofundamento da crise e a refundação das alianças}

Na proclamação enviada pela Junta Provisional da Bahia às Cortes Gerais portuguesas, em 18 de fevereiro de 1821, portanto, poucos dias após a sua instalação, os membros do governo expressaram com clareza a sua disposição em assegurar a unidade dos portugueses dos dois hemisférios marcada até então pela “conformidade de Crença, de Leis, de costumes, e de hábitos”. A Revolução Constitucionalista do Porto e a adesão dos residentes da Bahia a seus propósitos consolidariam, entretanto, a unidade política para "todos os Portugueses, qualquer que seja a terra que lhe desse o nascimento, fazendo a todos Cidadãos, aliás Concidadãos, comuns de uma Pátria comum”. ${ }^{64} \mathrm{~A}$ idéia de unidade, igualdade e identidade presente em muitos dos documentos que circularam nesse período ganhou concretude nas partes americanas com a elevação do Brasil à condição de Reino em 1815. A partir de então, os discursos das autoridades régias do governo joanino foram reorientados no sentido da elaboração de políticas condizentes com o novo estatuto do Brasil, o que dizia respeito, entre outras questões, ao lugar a ser ocupado pela sede da Monarquia portuguesa nesse novo cenário, conforme analisado por Ana Rosa Cloclet da Silva. ${ }^{65}$ Todavia, se entre os anos que separam a elevação do Brasil Reino e a adesão da Bahia ao constitucionalismo essas complexas noções tinham ficado restritas, principalmente, ao universo dos estadistas defensores do projeto de um império lusobrasileiro, a conjuntura política do início da década de 1820 vai intensificar o debate sobre as idéias liberais, por meio de variados folhetos e periódicos produzidos em Portugal e no Brasil, cuja necessidade de preservação dos vínculos entre os dois Reinos numa conjuntura política que rapidamente apresentava novos elementos se apresentava como uma das questões centrais. ${ }^{66}$ Essa é, por exemplo, a linha adotada por três documentos importantes elaborados em meio às discussões ocorridas nas Cortes Gerais, dois dos quais produzidos antes das divergências políticas entre os representantes dos portugueses europeus e americanos sobre os temas relacionados à natureza da nação luso-brasileira que se pretendia instituir. O mérito dos textos reside tanto na forma de apreensão da instabilidade

\footnotetext{
${ }^{64}$ Citado por José da Silva Lisboa, op. cit., 1827, p. 50.

${ }^{65}$ Ana Rosa Cloclet da Silva, op. cit., p. 253.

${ }^{66}$ Lúcia Maria Bastos Pereira da Neves identifica e analisa numerosos folhetos políticos e jornais que circularam sobretudo em Portugal, Rio de Janeiro e na Bahia nesse período. Op. cit. Marco Morel discute alguns mecanismos de difusão de um ideário político que não passava necessariamente por espaços reconhecidos para transmitir a informação. Op. cit., 2005, p. 223 e seq. De fato, na Bahia, em momentos de maior tensão, panfletos e proclamações apareceram afixados em alguns locais públicos, prática que havia sido utilizada também em 1798 no ensaio de sedição.
} 
política por parte dos seus autores, quanto no conteúdo das propostas apresentadas para resolução da crise política e o fortalecimento da Monarquia portuguesa.

O primeiro documento, de autoria de Antônio d'Oliva de Sousa Sequeira, tenente do $6^{\circ}$ Regimento de Infantaria e estudante do $4^{\circ}$ ano de matemática na Universidade de Coimbra, intitulado Projeto para o estabelecimento político do ReinoUnido de Portugal, Brasil e Algarves, oferecido aos ilustres legisladores em Cortes Gerais e Extraordinárias foi publicado na real imprensa da mesma universidade em 1821 e teve a sua venda divulgada no Diário do Estado do Rio de Janeiro, em 31 de julho de $1821 .^{67}$ Como explicita o título, a intenção era fornecer aos legisladores fundamentos que contribuíssem para a discussão sobre os rumos da Monarquia portuguesa na qual o lugar a ser ocupado pela sede da corte constitui um dos eixos principais. Partindo dessa premissa, o autor realizou uma breve, porém incisiva, análise da história recente de Portugal procurando demonstrar que a origem dos males de seus habitantes não advinha do estabelecimento da família real no Brasil, mas da política efetuada por ministros e diplomatas “ignorantes, malversados e egoístas, nos fazia ter pequena consideração da Europa; nos fazia assinar tratados vergonhosos, e ter demasiada condescendência com os Estrangeiros; nos fazia pequenos de grandes, que já fomos, em valor, em política, e em riqueza”, alertando para a necessidade de medidas sábias que pudessem definir o futuro da Monarquia portuguesa no cenário mundial.

Antônio d'Oliva não tem dúvidas que a manutenção da unidade entre Brasil e Portugal constitui o fundamento da grandeza do Império e a importância dessa decisão nas circunstâncias (“tão melindrosas”) pela qual passava o Reino Unido exigia a atenuação dos ânimos. Para fundamentar sua posição, formula três questões: $1^{\mathrm{a}}$. Será interessante $a$ Portugal a união com o Brasil? Ao que responde: “interessantíssima”. Portugal, conforme afirma, é um Reino limitado se comparado às demais potências da Europa. Em razão disso, procurará sempre outra que o ajude na defesa. Ocorre que isso não aconteceria se o Brasil estivesse entre as "primeiras nações do mundo" considerando todo o seu potencial, daí a necessidade da adesão entre os dois Reinos; $2^{\text {a }}$. Será interessante ao Brasil ligar-se com Portugal? Em seu entendimento, no presente sim, em função da necessidade que teria de Portugal para incrementar as suas riquezas, mas futuramente a união lhe seria indiferente: "Por maiores que sejam ao presente as dependências do Brasil, por maior colaboração, que

\footnotetext{
${ }^{67}$ Antonio d'Oliva de Sousa Sequeira. Projecto para o estabelecimento político do Reino-Unido de Portugal, Brasil e Algarves oferecido aos ilustres legisladores em Cortes Gerais e Extraordinárias. Coimbra: Real Imprensa da Universidade, 1821 (Acervo do IEB). A informação sobre a venda do folheto encontra-se em Lúcia Maria Bastos Pereira da Neves, op. cit., p. 276.
} 
agora lhe seja necessária, esta acaba logo que tenha crescido em população, indústria e riqueza”. A potencialidade do Brasil indica que isso não demoraria a acontecer; $3^{\mathrm{a}}$. Qual deve ser a política dos Portugueses da Europa para conservarem todas as suas vastas possessões debaixo do nome de Reino-Unido de Portugal, Brasil e Algarves? A resposta é imediata: "Digo que a de conservarem o estabelecimento de S.M. no Brasil”. O retorno do Rei significa a perda do Brasil para Portugal (“A parte maior não cede a menor”) e ao Brasil não deve interessar um Vice-Rei: “porque é fora de todo o encaixe que o Reino seja sessenta vezes menor que o Vice-Reinado”.

Após expor o problema, apresenta um projeto constando as disposições necessárias à preservação do Reino Unido com vistas ao "engrandecimento do Brasil e do vasto Império Português”. De início, sugere a criação de um "Código geral para todos os Portugueses, e nele se declare que o Rio de Janeiro (ou Bahia) será a Capital do ReinoUnido de Portugal, Brasil e Algarves, e a residência d'El Rei Constitucional na Dinastia de Bragança”. Para deliberação dos assuntos de interesse do Reino indica a necessidade de uma representação na Corte, integrada por portugueses do Brasil e das possessões na Ásia e na África, “e outra na Capital dos Reinos de Portugal e Algarves, composta dos Portugueses residentes nestes Reinos e Ilhas adjacentes, em que se compreenda a Ilha da Madeira, e ainda alguns estabelecimentos d'África, que fiquem mais próximos de Portugal, do que do Brasil”. Ao Rei caberia a nomeação de um Vice-Rei para Portugal com amplos poderes “tudo em nome d'El Rei [...]; mas sem prejuízo dos nomeados, para que não seja necessário aos Portugueses da Europa mendigar favores ao Brasil”. Atento a problemas futuros quanto à sucessão, Antônio d'Oliva indica que o primogênito nunca deveria ocupar o Vice-Reinado e quando acontecer da Coroa pertencer ao Vice-Rei, o mesmo deve ser Rei e ter residência na corte do Reino-Unido. Um possível retorno da família real para Portugal, inclusive do príncipe, deveria ser até mesmo evitado, assim como os portugueses residentes na parte americana do Reino não poderiam ter propriedades em Portugal, "e vice versa; [...]” se excetuando os ministros diplomáticos”. Por fim, recomenda o estabelecimento de leis de comércio entre Portugal e Brasil: "Mostraremos aos Portugueses do Brasil que somos fruto da mesma árvore, que uma vez plantada, só o tempo e a nutrição fará robusta $[\ldots]$ ”. 68

Ana Cristina de Araújo, ao analisar a dinâmica política no Brasil nos anos que antecederam a Independência, refere-se ao debate protagonizado por Antônio d'Oliva de

\footnotetext{
${ }^{68}$ Idem, Ibidem.
} 
Sousa Sequeira e José Joaquim d'Almeida Moura Coutinho, estudante de Leis em Coimbra, envolvendo a manutenção do Reino Unido, ao mesmo tempo em que ressalta a negligência da "historiografia de ambos os países” quanto a esta polêmica. ${ }^{69}$ Sobre José Joaquim Moura Coutinho, a historiadora informa ser um “jovem jurista e periodista da Minerva Constitucional - jornal político-literário publicado no ano de 1823” que refutava a idéia de supremacia do Brasil sobre Portugal, “alegando que, 'na forma do nosso governo atual, considerando o soberano como um executor de leis, é indiferente o seu estabelecimento neste ou naquele reino '”, devendo o rei estabelecer-se em Lisboa quando as circunstâncias de Portugal fossem atendidas. Araújo esclarece que a posição dos liberais portugueses era exatamente a de repelir soluções que visassem, principalmente, o estabelecimento de uma federação ou confederação. É nesse sentido que situa a Adição do projeto para o estabelecimento político do Reino Unido (1821), também de autoria de Antônio d'Oliva, na qual retoma a proposta de natureza confederativa. Nas palavras da autora, “de incidência ibérica, a confederação pressupunha a união interna do Reino Unido e esta só podia alcançar-se, plenamente, ficando 'as duas Cortes na mesma Monarquia'”, ${ }^{70}$

As questões suscitadas nessa discussão adquirem ainda mais vigor quando se examina outro documento atribuído a José Vicente Gomes de Moura ("Publicista dos mais eruditos e fecundos do tempo, inúmeros estudos e observações suas vieram à imprensa sem assinatura)”, editado em Lisboa no ano de $1822 .{ }^{71}$ Reflexões sobre a necessidade de promover a união dos Estados de que consta o Reino-Unido de Portugal, Brazil e Algarves nas quatro partes do mundo é um opúsculo de 107 páginas dividido em duas partes: a primeira consta de trinta reflexões sobre questões relacionadas ao Império português e a necessidade de seu fortalecimento, e a segunda se propõe a responder, antecipadamente, possíveis objeções suscitadas em função dos argumentos anteriores. Sua leitura indica que o autor possuía um conhecimento aprofundado da história pregressa de Portugal, a qual

\footnotetext{
${ }^{69}$ Ana Cristina de Araújo, op. cit., p. 267.

${ }^{70}$ Idem, ibidem, p. 269. Segundo Lúcia Maria Bastos Pereira das Neves, os escritos de Antônio d’Oliva serviram de base para muitas das idéias desenvolvidas por José Bonifácio de Andrada e Silva nas instruções “Lembranças e apontamentos do governo provisório de São Paulo para os seus deputados” às Cortes Gerais de Lisboa. Op. cit., p. 276.

${ }^{71}$ José Vicente Gomes de Moura. Reflexões sobre a necessidade de promover a união dos Estados de que consta o Reino-Unido de Portugal, Brazil e Algarves nas quatro partes do mundo. Lisboa: Tipografia de Antônio Rodrigues Galhardo, 1822, 107 p. (Acervo do IEB). A identificação da autoria do texto foi feita por Sylvio Cravo em um artigo no "Jornal do Comércio” do Rio de Janeiro, em 06 de outubro de 1935, quando esclarece que, de maneira equívoca, o documento foi atribuído a Joaquim José Pedro Lopes, Diretor da Gazeta de Lisboa na qual aparecera publicado. O recorte do jornal com essas informações, para deleite do pesquisador, encontra-se anexado ao opúsculo. Na face interna do original consta: "Escrevi este opúsculo em 1822 e foi impresso pelo atual Redator da gazeta, o honrado Joaquim José Pedro Lopes, a quem remeti o Manuscrito. José Vicente Gomes de Moura”. As citações a seguir foram extraídas desse documento.
} 
recorre em variados momentos para fundamentar a sua análise destinada a fornecer elementos esclarecedores sobre a situação política e econômica do Reino Unido no início da década de 1820. Mais do que isso, serviria para auxiliar a tomada de decisões em curso nas Cortes num momento em que os céleres acontecimentos colocavam o futuro da Monarquia portuguesa em risco.

O publicista considerava a discussão sobre a perpetuação do Reino Unido como superior a qualquer outra e, em razão disso, deveria ser priorizada em detrimento de outros assuntos tidos como secundários. Em decorrência, critica os periódicos pelo tratamento inadequado dado à questão: “semelhantes às toupeiras, que só enxergam os objetos imediatos”. Nessa perspectiva, traça uma perspicaz análise da conjuntura européia com ênfase no papel outrora desempenhado por Portugal, as mudanças políticas decorridas sobretudo após 1807 com a invasão do exército Napoleão e a ousada retirada de D. João VI para o Brasil "entre as mais arriscadas circunstâncias” até os acontecimentos recentes da Revolução de 24 de agosto de 1820, esclarecendo sobre a crise política e a dimensão que poderia assumir caso não fossem tomadas as medidas necessárias para sua neutralização. Conforme observa: “Todos sabem que Portugal é fraco, porque é pequeno, sendo uma quinta parte da Península Espanhola”, em razão disso "tem sofrido perdas gravíssimas” como a sua história já havia demonstrado. A Espanha sempre fora sua inimiga; a Inglaterra, aliada, porém em troca de enormes sacrifícios. Além disso, “como ele não tem forças por si só respeitáveis, e nem sempre tem Ministros tão hábeis como D. Luiz da Cunha, e o Marquês de Pombal, para iludir as ambiciosas pretensões de uma, e a avareza da outra, é forçado a contemporizar com ambas”. ${ }^{72}$

A análise dos documentos de autoria de Antônio d'Oliva de Sousa Sequeira e José Vicente Gomes de Moura permite afirmar que seus autores estavam plenamente convencidos que o Brasil era a única possibilidade de Portugal recuperar seu lugar de destaque junto às demais potências da Europa, ainda que para o primeiro a sua dependência em relação a Portugal teria vigência temporária em virtude de seu potencial de desenvolvimento. Contudo, até essas alterações se efetivarem, a perspectiva de Portugal entre as grandes nações seria dada pela grandeza do Reino Unido. Para Gomes de Moura, o príncipe foi sagaz ao efetuar as alterações na parte americana do Reino considerando que foram no sentido de "dar ao Brasil a grandeza que lhe compete, bem persuadido que é este o único meio de tornar verdadeiramente independente o seu Império”. Ambos estavam

\footnotetext{
${ }^{72}$ Cf. José Vicente Gomes de Moura, op. cit.
} 
imbuídos do ideário liberal e depositavam confiança nas mudanças políticas que as Cortes Gerais poderiam estabelecer para a boa convivência dos portugueses dos dois lados do hemisfério. A constituição a ser elaborada aparece assim como a grande conquista desses povos, mas não prioritária em relação à conservação do Reino. ${ }^{73}$

Esta urgência tinha razão de ser, afinal de contas não se poderia desprezar as diferentes reações manifestadas nas províncias do Brasil cuja "revolução [...] está em parte verificada [...]. Ignoramos porém onde ela irá parar”, nas palavras de Gomes de Moura, exemplificando os casos anteriores de Minas, Pernambuco, o número de escravos em relação aos livres, além do que “o Brasil é capaz de desafiar a cobiça de Potências ambiciosas, como já desafiou a dos holandeses. Convém pois desconfiar mais para errar menos”. A América espanhola também aparece como o grande mal a ser evitado. Ao falar sobre a Monarquia como forma de governo ideal,o autor afirma que ao Brasil não caberia a implantação da República seja em razão dos males que poderia ocasionar seja porque a Monarquia era o único sistema capaz de promover a sua grandeza. Muito provavelmente em função desse receio - que os apelos poderiam desviar os rumos políticos dos portugueses americanos - é que demonstre certo cuidado ao alertar os legisladores para que tratassem das províncias ultramarinas somente quando seus respectivos deputados estivessem presentes, pois assim seriam efetivamente "Gerais e Ecumênicas". ${ }^{74}$

Gomes de Moura não desconhecia os argumentos de Antônio d'Oliva, os quais utiliza para contrapor a sua posição em alguns pontos importantes relacionados às ações estratégicas para a preservação do Reino Unido. É o caso, por exemplo, da proposta de existência de dois congressos que vê como absolutamente desnecessária já que as províncias integravam o mesmo Reino. Da mesma maneira, considera que o lugar a ser escolhido para sediar a Corte era questão das mais importantes que não devia ser decidida para atender vaidade de um ou de outro, mas sim "pelo maior bem possível da maior parte dos cidadãos”. Sobre isso identifica vantagens e desvantagens da mesma permanecer em qualquer parte do Reino e, por isso mesmo, deveria ser questão a ser aprofundada nas Cortes para melhor decisão discordando da proposta de Sequeira de que a mesma deveria permanecer sempre no Brasil. Para ele, a Corte poderia ficar em Portugal durante a

\footnotetext{
73 “Se no vórtice de nossa revolução o Brasil se desunir de Portugal, ou as Províncias ultramarinas umas das outras, ainda que tenhamos internamente a melhor Constituição do mundo, não obstante seremos internamente fracos”. Idem, ibidem.

74 “[...] Ou a Espanha recupera sua América, ou não. Se perde a América será mais fraca que o Reino-Unido, ao menos daqui a alguns anos; se a recupera pode o Brasil atacar a América espanhola e fazer uma diversão útil a Portugal. Portugal separando-se do Brasil arrisca-se a ser Província de Espanha: se tal acontecer, o nome Português ficará extinto na Europa”. Idem, Ibidem.
} 
discussão e implementação das reformas políticas. Após, porém, a aprovação da constituição poderia então retornar ao Brasil estabelecendo-se na Bahia ou Pernambuco lugares mais centrais do Reino Unido - e não no Rio de Janeiro (“não há lugar mais impróprio para a Corte”, seja por causa do clima doentio, seja em função das dificuldades de comunicação com as províncias do Norte e com Lisboa) como desejavam os deputados de São Paulo. No entanto, diante de uma conjuntura tão conturbada, ele próprio evita a fazer afirmações definitivas sobre a permanência ou não da Corte em Portugal:

Contudo, quem pode prever o futuro? quem diria há 50 anos que a Corte passaria para o Brasil? Que dali voltaria para Portugal em 1821? Quem sabe se outra catástrofe a fará sair outra vez de Lisboa para o Brasil? Repito que a utilidade do Reino-Unido reconhecida pela Nação em Cortes Gerais decidirá do lugar da Corte. A esta comum utilidade devem os Portugueses sacrificar suas pretensões, e não querer preferir o aparente ao real, e a vanglória, e vaidade instável à solidez e perpetuidade de sua Monarquia. Falo com os Portugueses de ambos os hemisférios. ${ }^{75}$

Na adição ao opúsculo, José Vicente Gomes de Moura esclarece que redigiu suas reflexões em 1821, mas em março do ano seguinte foi informado dos tumultos ocorridos no Brasil em razão da determinação das Cortes de abolir os tribunais do Rio de Janeiro e exigir a volta da família real, por meio dos decretos de 29 de setembro e $1^{0}$ de outubro de 1821. Essas notícias, todavia, não interferiram em sua defesa sobre a conservação do Reino. Pelo contrário, retoma algumas questões e à luz dos novos acontecimentos avalia a posição dos portugueses de ambos os hemisférios. As Cortes deviam permanecer como o foco de articulação política e das suas decisões é que dependeria o sucesso futuro da Monarquia portuguesa, freqüentemente associado à preservação do Reino Unido. Vale a pena ressaltar que a confiança do autor nessa perspectiva, a despeito das alterações mencionadas, manifesta-se poucos meses antes da declaração de Independência do Brasil pelo príncipe regente em setembro de $1822 .{ }^{76}$ É certo que o cerne dessa discussão - a importância da manutenção do Reino Unido de

\footnotetext{
${ }^{75}$ Idem, ibidem.

${ }^{76}$ A ampla visão conjuntural de José Vicente Gomes de Moura pode ser identificada em suas palavras conclusivas: "Do que fica dito se conclui, que os Reinos de Portugal, Brasil e Algarve com os mais Estados anexos devem empenhar-se e forcejar por se conservar unidos, e identificados o mais estreitamente que for possível. Estes três Reinos unidos podem vir a ser muito, mas desunidos arriscam-se a perder-se de todo. Se a desunião começasse entre eles, quem sabe aonde ela iria parar? Qual a sorte das ilhas adjacentes? Qual a dos Estados de África e Ásia? Qual a das províncias do Brasil? As desgraças resultantes desta espantosa dissolução seriam em verdade incalculáveis, e extremamente funestas. Portugal ficaria inteiro como d'antes: qual seria porém o partido que tomaria os povos do Brasil? Que conflitos se excitarão entre partidos opostos? Que discórdias entre os povos da mesma Província, e entre umas e outras Províncias? Que ocasião mais oportuna para alguma Nação se apoderar das Províncias mais expostas a título de proteção? Então se desenvolveria de maneira terrível a ambição com todos os vícios que a acompanham [...]”. Idem, ibidem.
} 
Portugal, Brasil e Algarves - desdobrou-se em uma série de outros assuntos palpitantes nesse começo de década e que difundiram-se rapidamente entre os residentes dos dois hemisférios. O retorno de d. João VI para a Europa com a permanência de seu filho no Reino americano foi apenas uma das muitas alternativas de direcionamento da crise. Essa situação, no entanto, observa Ana Rosa Cloclet da Silva, aumentava o ambiente de incertezas entre os residentes dos Reinos europeu e americano ao mesmo tempo em que propiciava a potencialização das disputas pela conformação do poder em uma nova “configuração geopolítica do Império”. ${ }^{77}$

É nesse contexto que nos dias $1^{\circ}$. e 2 de fevereiro de 1822, atendendo a determinação das Cortes portuguesas para renovação das Juntas governativas, reconhecidas a partir de então como legítimas, foi eleita uma nova Junta Provisional de Governo na Bahia. Segundo a ata do Senado da Câmara, compareceram no primeiro dia "duzentos e cinqüenta e nove dos eleitores de paróquia”, pouco menos que no dia seguinte. Os eleitos tomaram posse no mesmo dia 2, juntamente com o brigadeiro Manuel Pedro de Freitas Guimarães no comando das armas da Província. Os novos membros do governo provisional incluíam o grande senhor de engenho Francisco Vicente Vianna, o desembargador Francisco Carneiro de Campos, como secretário, o comerciante Francisco Martins da Costa, o capitão-mor Francisco Elesbão Pires de Carvalho e Albuquerque, o cônego José Cardoso Pereira de Melo, o tenente-coronel Manoel Inácio da Cunha Menezes e o desembargador Antônio da Silva Teles, ouvidor da Comarca de Ilhéus. ${ }^{78}$ Vicente Vianna, que assumiu o cargo de presidente, era natural de Salvador e dono de uma das maiores fortunas da Bahia. Filho do rico negociante Frutuoso Vicente Viana, casou-se com Caetana do Sacramento Bandeira, irmã do então deputado às Cortes e negociante Pedro Rodrigues Bandeira, se aliando “a uma poderosa família de comerciantes e senhores de engenho portugueses". ${ }^{79}$

Nessa nova composição, apenas um português europeu fora eleito. Em função disso, foi encaminhado um recurso às Cortes em Lisboa, no qual "mil e cinqüenta e dois constitucionais da notável, e sempre fiel cidade da Bahia, por seu emissário o cidadão Francisco Mendes da Silva Figueiró”, condenavam o processo eleitoral denunciando que a

\footnotetext{
${ }^{77}$ Cf. Ana Rosa Cloclet da Silva, op. cit., p. 307.

${ }^{78}$ Documentos da Municipalidade de Salvador relacionados com a Independência do Brasil, 1821-1823, op. cit., p. 19-23. Antônio da Silva Teles tomou posse em 27 de fevereiro de 1822, loc. Cit., p. 49. Francisco Adolfo de Varnhagen omite o nome de Francisco Vicente Vianna e atribui a presidência da Junta a Francisco Carneiro de Campos. Op. cit., s/d, p. 266. Sobre a eleição da Junta: Ignácio Accioli, op. cit, v. III, p. 293; Braz do Amaral, op. cit., 1957, p. 42.

${ }^{79}$ Cf. Kátia Maria de Queirós Mattoso, op. cit., 1992, p. 260; John Norman Kennedy, op. cit., p. 423.
} 
inclusão de um único português europeu foi resultante da pressão exercida por facciosos partidários do sistema republicano. Afirmavam ainda que alguns indivíduos que haviam contestado o governo anterior, entre eles, “João Primo, principal revolucionário, é elevado a tenente de artilharia de linha, estando, aliás, notado por desertor” e, por outro lado, esclareciam que as posições políticas naquele cenário não se definiam pelo local de nascimento de muitos dos residentes na Bahia: "Devemos confessar, Senhor, que muitos brasileiros merecem o nome de verdadeiros portugueses constitucionais, e não poucos merecem finar seus dias em um patíbulo; e com mágoa também declaramos que um pequeno número de europeus se faz digno do mesmo castigo". ${ }^{80}$ Além disso, o documento evidencia que o quadro político na província era, de fato, conturbado, anunciando um difícil trabalho para os novos dirigentes.

O que não tardou a acontecer. A nomeação do brigadeiro português Luis Inácio Madeira de Melo pelas Cortes como governador das armas em lugar de Manuel Pedro de Freitas Guimarães, chegou a Salvador no dia 15 de fevereiro, dando início a uma série de embates entre os defensores de ambas as partes. ${ }^{81}$ Uma das razões do conflito, de acordo a Junta, seria a existência de "rivalidades de mero brio e pundonor" entre o regimento de artilharia comandado por Guimarães e o batalhão número 12 sob a responsabilidade de Madeira de Melo desde o dia 10 de fevereiro. Isso justificaria as intensas articulações dos militares que, a princípio, recorreram aos mecanismos legais para efetivar seus intentos. De fato, em uma representação encaminhada ao Senado da Câmara de Salvador, que competiria dar posse ao brigadeiro português, 421 pessoas requeriam que a cerimônia não fosse realizada antes de consultar "todas as câmaras da Província, afim de que estas, conformando-se com o parecer e vontade dos povos, dêem os seus acordos, os quais V.S. levará ao conhecimento do soberano congresso para que novamente tomando em sua alta consideração, delibere o que for melhor”. Os signatários argumentavam o papel desempenhado por Manuel Pedro de Freitas Guimarães no dia 10 de fevereiro, “devendose-lhe com justiça atribuir e inteiramente a regeneração desta Província” e, portanto, nada

\footnotetext{
${ }^{80}$ Recurso e adendo ao mesmo que as soberanas Cortes de Portugal dirigem mil e cinqüenta e dois constitucionais da notável, e sempre fiel cidade da Bahia, por seu emissário o cidadão Francisco Mendes da Silva Figueiró. RIGHBa, v. 58, 1932, p. 295-317. De acordo Cipriano Barata, João Primo era um "patriota estimável pelas suas ótimas qualidades, mas odiado pela oposição forte que fazia aos Marotos perniciosos” . Cf. Manifesto, op. cit., p. 13. Para Antônio Pereira Rebouças, ele "era capaz de qualquer empresa arriscada". Op. cit., p. 462.

${ }^{81}$ A carta régia de nomeação dos governadores de armas para as províncias data de 9 de dezembro de 1821.
} 
mais justo que assumisse o posto de comandante das armas. ${ }^{82}$ Importa ressaltar que entre os assinantes do documento constam os nomes de alguns militares que nos anos seguintes desempenhariam papéis de destaque no cenário político da Bahia, a exemplo de: Joaquim Sátiro da Cunha, condenado à morte na forca dois anos depois, em 1824, por seu envolvimento no Levante dos Periquitos; José Antônio da Silva Castro, o principal líder desse levante; Francisco Sabino Álvares da Rocha Vieira, o futuro líder da sabinada em 1837 e o cadete João Primo, ambos participantes ativos nos eventos políticos da Bahia nos anos que se seguiram. ${ }^{83}$

O Senado da Câmara, cujos vereadores haviam tomado posse em 18 de fevereiro, entre eles o advogado Francisco Gomes Brandão, acatou a petição contra a posse de Madeira, além de apontar uma lacuna no diploma régio que autorizava a nomeação. ${ }^{84}$ Nesse mesmo dia, a Junta Provisional havia encaminhado um ofício aos vereadores alertando-os sobre os cuidados que deveriam ser tomados naquelas circunstâncias em virtude de "boatos temerosos de acontecimentos sinistros que podem resultar do choque de partidos que desgraçadamente se anunciam por ocasião da posse no novo Governador das Armas”. Em função disso, determinava que a Câmara, caso tivesse algum problema sobre a nomeação, não deveria deliberar sozinha, mas se apresentar "instantaneamente perante esta Junta para que de comum acordo com ela as Corporações e Cidadãos mais respeitáveis da Cidade se tome a medida que possa Segurar a Salvação da Província”. ${ }^{85}$ No entanto, o encaminhamento da questão mostrou-se muito mais difícil do que o governo presumia. Entre os dias 18 e 21 de fevereiro ocorreram violentos conflitos em Salvador. Muitos fugiram para o Recôncavo e o número de mortos foi estimado em cerca de 200 a 300 pessoas. $^{86}$

Em uma longa carta encaminhada a Lisboa, em 8 de março, os membros da Junta descreveram com minúcia os fatídicos acontecimentos iniciados com o recebimento

\footnotetext{
${ }^{82}$ Representação dos habitantes da Bahia, s/d. Ignácio Accioli, op. cit., v. III, p. 296-299; Braz do Amaral, op.cit., 1957, p. 74-79. Sobre os detalhes dos conflitos: Ignácio Accioli, op. cit., v. III; Luis Henrique Dias Tavares, op. cit., 2005.

${ }^{83}$ Braz do Amaral, op. cit., 1957. Sobre o Levante dos Periquitos, ver: Luis Henrique Dias Tavares, 2003, op. cit., p. 187-252; A sabinada foi tema dos estudos de Paulo Cézar Souza, op. cit.; Douglas Guimarães Leite. Sabinos e diversos: emergências políticas e projetos de poder na revolta baiana de 1837. Salvador: UFBa (Dissertação de Mestrado), 2006. .Acerca da presença de Francisco Sabino e João Primo, entre outros, na dinâmica política da Bahia: Kátia Vinhático Pontes. Mulatos: políticos e rebeldes baianos. Salvador, Universidade Federal da Bahia, 2000 (Dissertação de Mestrado).

${ }^{84}$ Documentos da Municipalidade de Salvador relacionados com a Independência do Brasil, 1821-1823, op. cit., p. 31. Os demais vereadores eram Antônio Ferreira França e Francisco Antônio de Souza Uzel, Joaquim José da Silva Maia como procurador e Joaquim Antônio de A. Seixas como escrivão da Câmara.

${ }^{85}$ Idem, ibidem, p. 33.

${ }^{86}$ Braz do Amaral, op. cit., 1957, p. 153; Luis Henrique Dias Tavares, op. cit., 2005, p. 49.
} 
da nomeação do brigadeiro Madeira de Melo. Além disso, afirmaram que as pequenas rivalidades existentes entre brasileiros e europeus anteriormente "quase nulas e perfeitamente neutralizadas” exacerbaram-se após a instalação das tropas portuguesas na cidade, extrapolando muitas vezes a linha da oficialidade. Importante observar é que nesse detalhamento emerge um quadro de profunda tensão vivenciada na capital que ajuda a entender a fragilidade da estabilidade política na província e a mais completa incerteza sobre os rumos que os acontecimentos tomariam dali pra frente. A Junta, conforme avaliavam, havia tomado todas as providências cabíveis para evitar “os tristes acontecimentos” e restabelecer a ordem, suplicando ao rei e às Cortes medidas eficazes para que não se reproduzisse as mesmas cenas no futuro. Uma das queixas dizia respeito "à inteira independência do poder militar”. Em função disso, a “Junta inerme tem de ser mera espectadora dos atos daquele poder os mais violentos e irregulares; e, achando-se reduzida a uma simples fantasma, torna-se incapaz de sustentar sua autoridade nas ocasiões de maior crise e no meio de castas as mais heterogêneas”. ${ }^{87}$ Significativa ainda é a avaliação feita sobre os segmentos populares da província naquela conjuntura:

o povo da Província que com tanta alacridade tem abraçado a causa da Constituição, pouco apto, principalmente nas classes inferiores, a apreciar convenientemente os sublimes princípios de direito público que a seu favor se tem estabelecido nas bases da Constituição e, na parte desta que se acha concluída, reclama talvez para que se firme e fortifique na adesão, por alguns regulamentos de imediato e sensível conforto; a absoluta franqueza e a isenção dos impostos nas carnes verdes e nas farinhas que constituem o pão ordinário do país, assim como o perdão da décima ao proprietário pobre que só tem uma casa em que mora, produzirão talvez o melhor efeito moral em toda a Província, podendo aliás a fazenda indenizar-se talvez destes valores sobre as aguardentes e outros objetos de luxo.

As consolações são precisas no meio das desgraças públicas: aliás com elas somente se associará a idéia das reformas as mais saudáveis, seguindo-se daí a desesperação, a incerteza e a funesta desobediência às autoridades, por cujo resultado mal poderá a Junta responder, quando aliás o seu voto e desejo é suplicar respeitosamente que, a ser possível, o governo e o soberano congresso haja por bem de a dispensar da árdua comissão de que se acha encarregada e que muito pesa sobre os seus débeis ombros, na qual, visto os perigos da presente época, ela não conta,

\footnotetext{
${ }^{87}$ Carta da Junta Governativa da Bahia, em 8 de março de 1822. Braz do Amaral, op.cit., 1957, p. 135. O batalhão n. 12, comandado por Madeira de Melo, havia lutado na guerra peninsular e, posteriormente enviado de Lisboa para Pernambuco, em 1817, a fim de combater os rebeldes. Com a dizimação daquele movimento, parte da tropa se fixou em Salvador e deixou a cidade somente em 1823 após o fim da guerra civil. Hendrik Kraay. "Identidade racial na política, Bahia, 1790-1840: o caso dos Henriques”. In: István Jancsó (Org.)., op. cit., 2003, p. 521-546.
} 
apesar da pureza de suas intenções, poder corresponder sempre a pública confiança. $^{88}$

Não se pode esquecer de que havia pouco mais de um mês que a Junta havia tomado posse. Tempo suficiente, entretanto, para concluir sobre a dimensão dos problemas políticos da província e, mais do que isso, a sua incapacidade para apresentar uma alternativa possível de solução. A questão dos preços dos gêneros alimentícios deveria mesmo preocupar as autoridades locais numa conjuntura política conturbada como aquela. Poucos dias antes (26 de fevereiro), a gazeta Idade d'Ouro reproduziu as queixas de um leitor sobre os significativos aumentos dos preços do pão e da carne. Era necessário, segundo o autor da carta, que o Senado da Câmara de Salvador controlasse melhor os valores cobrados: "Estou certo que a competente autoridade cuidará em remediar esses males, que olhados de cima parecem bem pequenos, mas que realmente pesam sobre todas as classes, e particularmente sobre as mais oneradas, e que mais contemplação merecem”. ${ }^{89}$ No entanto, a situação na Bahia piorava a cada dia. O brigadeiro Madeira de Melo, vitorioso nos confrontos de fevereiro, enviou vários relatos sobre os conflitos para d. João VI fornecendo a sua versão dos fatos. Numa delas, datada de 17 de março de 1822, acusava o brigadeiro Manoel Pedro de Freitas Guimarães de ter sido o grande responsável pelo agravamento da crise, tendo em vista a atração que exercia sobre os membros do "partido revolucionário ou independente" e as medidas que havia tomado para aumentar esse "partido", a exemplo de promoções, perdão de desertores, recrutamento etc. Além disso, teria impedido a sua posse como governador das armas da Bahia ciente de que isso reduziria "os seus intentos, uma vez que a força armada deixasse de estar debaixo do seu influxo". Todo o arrazoado concluía com um alerta: “Cumpre-me informar a Vossa Magestade que a Cidade da Bahia, pela sua situação geográfica, pelo seu comércio, população e outras particularidades, é um daqueles portos do Brasil que muito convém conservar para assegurar a estabilidade do Reino”. Essa constatação servia para justificar o pedido de envio de mais reforços militares, pois, no ponto de desordem que havia chegado a província “não há outro recurso para se restabelecer a tranquilidade e poderem respirar livremente os cidadãos honrados e pacíficos, senão a força”. ${ }^{90}$

\footnotetext{
${ }^{88}$ Carta da Junta Governativa da Bahia, em 8 de março de 1822. Idem, ibidem, p. 136.

${ }^{89}$ Citado por Maria Beatriz Nizza da Silva, op. cit., 1994, p. 186.

${ }^{90}$ Idem, ibidem, p. 128. Após ser derrotado, Manoel Pedro de Freitas Guimarães foi enviado preso para Portugal. Considerado "insano", em 1824 teria sido recolhido ao "Hospital Militar da Cidade do Salvador e depois colocado sob tutela porque o consideraram louco”. Cf. Luis Henrique Dias Tavares, op. cit., 2005, p. 34.
} 
As divergências políticas ganhavam uma conformação mais virulenta percebidas não somente por meio das falas das autoridades locais, como também pelo envolvimento de uma ampla parcela dos residentes da província que absorvia os elementos propiciadores da instabilidade a partir das suas próprias expectativas. Nesse sentido, um dos aspectos desse alargamento da participação dos citadinos pode ser verificado nas variadas petições encaminhadas ao monarca e aos órgãos de representação sempre acompanhadas por um número significativo de assinaturas. Uma prática que não era desconhecida na América portuguesa, conforme assinalado, mas que, nesse momento, adquiria uma outra dimensão dada as alterações políticas em curso. Madeira de Melo se refere, na carta mencionada acima, às duas representações assinadas por 543 pessoas que pediam o envio de Manoel Pedro para Lisboa; outra, assinada por 848 "negociantes, proprietários, militares e mais cidadãos que se compõem esta populosa Cidade da Bahia” posicionava-se favoravelmente à nomeação de Madeira de Melo como governador das armas da província, criticando um requerimento anterior com 425 assinantes, “a maior parte pessoas desconhecidas, vaidosamente intitulando-se - o povo desta Cidade" que havia contestado a posse do brigadeiro. ${ }^{91}$ Não restam dúvidas que esses mecanismos serviam para reforçar as posições políticas dos contendores, todavia, expressavam também a intensa mobilização de indivíduos de variados segmentos possibilitando o aprofundamento do aprendizado político em situação de crise. Em um cenário de intensa agitação, o periodismo também aparecia como outro aspecto importante desse processo de maturação política.

Com efeito, a abolição da censura prévia (decreto de 2 de Março de 1821) propiciou a circulação de periódicos e panfletos no Reino americano favorecendo o amplo debate sobre assuntos relacionados ao mundo da política, ao mesmo tempo em que fornecia combustível para a exposição de distintas posições. Nessa perspectiva, o papel desempenhado pelos periódicos pode revelar muito da dinâmica do período, não somente pela linguagem e pela utilização de um novo vocabulário político "que exprimiam uma prática constitucional inaugurada a partir de 1820”, como também por meio dos embates expressos em suas páginas. A imprensa impulsionava a rápida difusão das informações entre os variados segmentos da população, tornando público temas e discussões anteriormente restritos ao âmbito privado. Na Bahia, a gazeta Idade d'Ouro do Brazil passou a disputar com outros periódicos e folhetos políticos a atenção da população para os fatos recentes por meio de fortes argumentos nos quais o redator buscava influenciar o

\footnotetext{
${ }^{91}$ Representação de negociantes, proprietários, militares e mais cidadãos da Bahia ao governo de Lisboa, em 22 de fevereiro de 1822. Ignácio Accioli, op. cit., v. III, p. 328.
} 
público leitor, produzindo, desse modo, um efeito pedagógico de grande importância. ${ }^{92}$ Poucos dias depois da adesão da província ao constitucionalismo, em 21 de fevereiro de 1821, o jornal explicava o significado de termos que, a partir de então, seriam incorporados ao universo dos indivíduos. Constituição era o "bom governo, e boas leis, fundadas na natureza dos homens, nas suas precisões, e tendo por alvo final a sua felicidade”; as Cortes, "uma representação nacional, pela qual só se pode regular invariavelmente os destinos do povo e fixar para sempre os destinos da sua felicidade”. O redator chamava a atenção ainda para não confundir “a Liberdade com a licença e a desenvoltura”, evidenciando que para parte daqueles que desejavam mudanças era preciso não perder de vista os seus limites. ${ }^{93}$

Ao lado da gazeta Idade d'Ouro, os residentes da Bahia mantiveram contato ainda com o Semanário Cívico, redigido pelo negociante português Joaquim José da Silva Maia, procurador do Senado da Câmara de Salvador, responsável também pela circulação do Sentinella Bahiense, e com o Diário Constitucional, fundado em 4 agosto de 1821 por Francisco José Corte Real e que tinha entre seus redatores Francisco Gomes Brandão, conhecido pela veemência dos artigos contra as decisões que acreditava prejudicar os portugueses americanos. No dia 10 de abril do ano seguinte, O Diário Constitucional alterou seu nome para $O$ Constitucional sendo suprimido alguns meses depois pelas tropas comandadas pelo brigadeiro Madeira de Melo. Além desses, outros periódicos foram lançados no decorrer dos embates políticos, a maioria de curta duração, refletindo a dinâmica política vivenciada na província naqueles anos. ${ }^{94} \mathrm{Em}$ um dos números de $O$ Espelho, periódico oficioso do Rio de Janeiro, de 17 de setembro de 1822, ao comentar sobre o fechamento do jornal baiano, o redator afirmava que:

O Constitucional era o único periódico que se atrevia a lançar em rosto àqueles tiranos sua arbitrariedade, sua injustiça, sua barbaridade. E que fizeram eles? Assanharam primeiro uma matilha de escritores venais, sem nome, sem luzes, tirados mesmo das filas; surgiram Sentinelas,

\footnotetext{
92 Lúcia Maria Bastos Pereira das Neves, op. cit., p. 169 e da mesma autora "Cultura e política na Independência do Brasil sob a ótica dos folhetos e jornais baianos (1821-1823)”. Anais do Arquivo Público do Estado da Bahia, v. 51, 1994, Salvador-Bahia, p. 191-205; Andréa Slemian; João Paulo Garrido Pimenta, op. cit., 2003, p. 69.

${ }_{93}$ Citado por Lúcia Bastos Pereira das Neves, op. cit., 1994, p. 197.

${ }^{94}$ Um estudo sobre o significado político desses periódicos na Bahia ainda está para ser feito. Dentre os que circularam nesse período, encontram-se: O Analisador Constitucional, O Baluarte Constitucional, O Espreitador Constitucional, A Abelha etc. Cf. Carlos Rizzini. O livro, o jornal e a tipografia no Brasil, 15001822. São Paulo: Imprensa Oficial do Estado, 1988 (Ed. fac-similar). Sobre a trajetória de Francisco Gomes Brandão, que em $1^{\circ}$. de março de 1823, no contexto de lutas políticas na Bahia, adotou o nome de Francisco Gomes Gê Acaiaba de Montezuma, ver Hélio Vianna. "Francisco Gê Acaiaba de Montezuma, visconde de Jequitinhonha”. RIHGB, v. 244, Rio de Janeiro, julho-setembro de 1959, p. 102-134. Consuelo Pondé de Sena afirma que o Sentinella Bahiense teve apenas 15 números publicados e o Semanário Cívico circulou de 1821 a 1823. Op. cit., p. 6.
} 
Analisadores e tantos outros papéis, que fazem a vergonha da literatura, para escoltarem a Idade de Ferro e o Semanário. Mas ainda isto não aterrou o patriotismo dos redatores do Constitucional. ${ }^{95}$

À medida que os acontecimentos políticos desenrolavam-se em Lisboa e no Reino americano, os periódicos posicionavam-se tentando interferir no rumo das decisões a serem tomadas pelo governo local. Desde 9 de janeiro de 1821 que o regente havia decidido permanecer no Brasil contrariando as deliberações da Corte para retornar à Europa. Naquela ocasião, d. Pedro havia recebido muitas demonstrações, oriundas das Câmaras das províncias do Centro-Sul, de que deveria permanecer no Rio de Janeiro. Uma delas, em especial, foi encaminhada por vários indivíduos naturais da Bahia que residiam na corte do Rio de Janeiro. Na opinião dos signatários, era impossível não reconhecer a importância daquela decisão considerando que

salvou a Pátria dos horrores da anarquia, destruindo o gérmen das facções, tornou indissolúveis os laços que unem um ao outro hemisfério português e lançou os fundamentos de um Império que será em pouco tempo o assombro da Europa inteira.

Entretanto, senhor, que o soberano Congresso em cujas luzes e virtudes sobejamente confiam, se ocupa da nossa regeneração política, organizando uma Constituição sábia que realize tão altos destinos da Nação Portuguesa, os abaixo assinados rogam a V.A.R. se digne de aceitar em testemunho da sua gratidão, zelo e fidelidade a oferta que francamente fazem das suas pessoas e bens a favor da causa que V.A.R. tem adotado. ${ }^{96}$

Deixavam explícito, assim, que eram plenamente favoráveis às mudanças constitucionais em curso com a preservação da unidade dos Reinos. Entre os 51 assinantes, os nomes do general Domingos Alves Branco Moniz Barreto e de José da Silva Lisboa. Em Salvador, o Diário Constitucional viu na decisão de d. Pedro um ato heróico, persuadindo o governo da Bahia a enviar uma deputação ao Rio de Janeiro a fim de cumprimentá-lo. Posição distinta daquela defendida pelo Semanário Cívico que criticou duramente os "demagogos e não afeitos ao sistema constitucional”, referindo-se aos autores das representações encaminhadas pelas Câmaras. ${ }^{97}$

\footnotetext{
${ }^{95}$ Citado por Carlos Rizzini, op. cit., p. 413. Alguns desses periódicos também poderiam ser encontrados pelo interior da província como informou o Senado da Câmara de Rio de Contas, em 20 de julho de 1822, sobre a presença de $O$ Constitucional e o Semanário Cívico entre os residentes da vila. Cf. Argemiro Ribeiro de Souza Filho, op. cit., 2003, p. 90.

${ }^{96}$ Manifesto dos baianos residentes no Rio de Janeiro ao príncipe regente, em 15 de janeiro de 1822. Ignácio Accioli, op. cit., v. III, p. 341-342; Braz do Amaral, op. cit., 1957, p. 162-163.

${ }_{97}$ Citado por Lúcia Bastos Pereira das Neves, op. cit., 1994, p. 198. A informação sobre O Espelho consta em Carlos Rizzini, op. cit., p. 387.
} 
Por conta da deliberação do príncipe, em 11 de abril de 1822, a Junta Provisional encaminhou uma correspondência a José Bonifácio de Andrada e Silva, ocupando então o cargo de ministro dos Negócios do Império, na qual congratulava o regente, junto “com todos os cidadãos bons da província”, por ter atendido aos pedidos das províncias do Rio de Janeiro, São Paulo e Minas Gerais e encaminhado a d. João VI e às Cortes as suas reclamações "sobre algumas modificações que pretendem se façam no pacto social que se está organizando no mesmo soberano congresso da nação, a fim de se manter a unidade do reino, já outorgada pela carta de lei de 16 de dezembro de 1815, conservadas as bases da constituição que temos jurado e a união dos portugueses de ambos os hemisférios nelas estatuída”. No entanto, esclarecia que a Bahia estava submetida às decisões do rei e das Cortes conforme decisão tomada anteriormente e, portanto, não poderia cumprir o que lhe ordenava. ${ }^{98}$

A discussão na província sobre a questão de um centro de poder adquiriu maior vitalidade com a solicitação enviada pelos deputados da Bahia à Junta para que as Câmaras fossem consultadas quanto à conveniência de o Brasil possuir uma ou duas delegações do poder executivo em diferentes pontos; ou se o poder deveria residir somente em el-rei delegando uma parte à Junta Governativa e, caso não concordassem com essas proposições, que indicassem o meio mais conveniente para melhor administração. Em sua orientação aos órgãos camarários, em 8 de maio de 1822, o governo provisional determinava que "as pessoas mais iluminadas do seu distrito" deliberassem acerca do assunto. $^{99}$ Tempos depois, a Junta comunicou ao governo de Portugal que 21 vilas haviam respondido as questões e, após observar que quinze indicaram o poder delegado na pessoa do rei e cinco nas juntas provinciais, concluiu: "achando-se em contradição a Vila de Alcobaça, que se conforma a ambos os arbítrios, talvez porque, sendo habitada de índios pouco inteligentes, não souberam exprimir o seu parecer com a devida clareza e precisão". 100

Na resposta do Senado da Câmara da vila de Santo Amaro, localizada no Recôncavo, em 14 de junho de 1822, “em que foram convocadas todas as pessoas zelosas e instruídas da Causa Constitucional”, foi dito que os conselhistas concordaram, por

\footnotetext{
${ }^{98}$ Ofício da Junta Provisória ao ministro José Bonifácio de Andrade e Silva, em 11 de abril de 1822. Mello Moraes, op. cit., t. 2, p. 139. José Bonifácio assumiu o ministério em 16 de janeiro de 1822 permanecendo até 17 de julho de 1823 quando foi substituído por José Joaquim Carneiro de Campos. Idem, ibidem, p. 46.

${ }^{99}$ Ofício da Junta Provisória às Câmaras da Província da Bahia, em 8 de maio 1822. Mello Moraes, op. cit., t. 2, p. 141-142. A correspondência encaminhada pelos deputados é datada de 18 de março de 1822. Loc. cit.

${ }^{100}$ Ofício da Junta Provisória ao Governo de Portugal, em 21 de agosto de 1822. Mello Moraes, op. cit., t. 2, p. 156.
} 
unanimidade, pela existência de um centro de poder executivo no Brasil exercido pelo Príncipe Real de acordo as regras de uma constituição liberal, com a sede estabelecida no lugar mais apropriado para a administração do Reino. Acrescentaram ainda o fato de a assembléia aproveitar para indicar como urgência que

O Brasil tenha um exército próprio para sua defesa e inamovível de Província a Província e de Reino a Reino, salvo no caso de ser mister repelir qualquer agressão feita à dignidade do Reino Unido de Portugal, Brasil e Algarves convindo por conseqüência em que não seja admitido nas Províncias deste Reino destacamento algum de Tropa que não seja de Exército do Brasil. [...] que para promover-se eficazmente a Prosperidade do Brasil se decrete que este Reino ofereça seguro asilo aos Estrangeiros que para ele trouxerem indústria ou capitais e bem assim que se estabeleça a tolerância religiosa [...] que se conserve enfim e sem restrição alguma a franqueza e liberdade de comércio deste Reino e se funde quanto antes uma Universidade em o lugar que mais conveniente for. ${ }^{101}$

O teor do documento evidencia que para esses indivíduos algumas questões já estavam delineadas, dentre elas, a autonomia da segurança nas províncias, certamente em virtude dos últimos acontecimentos, assim como a importância do capital estrangeiro para o desenvolvimento econômico local. Expressava, além disso, o desejo pela permanência de um centro executivo de poder no Brasil Reino. Todavia, enquanto as Cortes lisboetas se mostravam incapazes de dar um direcionamento político que equacionasse as distintas posições no interior do Reino Unido; na Bahia, os distúrbios expunham cada vez mais uma situação de profunda instabilidade resultando na saída de diversas pessoas para o Recôncavo, inclusive membros da Junta Provisional e do Senado da Câmara de Salvador. Ao que tudo indica, o debate envolvendo as questões formuladas pelos deputados da Bahia potencializou a tomada de posição de algumas Câmaras distinta da orientação assumida até então pela Junta Provisional de Governo. Nesse contexto, as articulações promovidas pelo Rio de Janeiro para assegurar o apoio das províncias à regência de d. Pedro começaram a dar os primeiros resultados favoráveis, sobretudo, após a sua decisão, em 3 de junho de 1822, de convocar uma assembléia constituinte para o Brasil Reino.

Já no dia 13 desse mês, o capitão-mor da vila de São Francisco do Conde, Joaquim Inácio de Siqueira Bulcão, um dos autores dos pareceres encaminhados ao Senado da Câmara de Salvador em 1807 sobre a necessidade de melhorias para a lavoura e o

\footnotetext{
${ }^{101}$ Ata do Senado da Câmara de Santo Amaro, em 14 de junho de 1822. Braz do Amaral, op. cit., 1957, p. 199. Esse documento se encontra transcrito também em Deolino Amorim. "A ata de Santo Amaro e a revolução Constitucionalista”. RIGHBa, n. 79, Bahia, 1955, p. 173-185.
} 
comércio locais, lembrado como um dos possíveis envolvidos na tentativa de sedição de 1798 e um dos membros da maçonaria na Bahia, propôs aos residentes da Bahia a aclamação da regência de d. Pedro. Naquelas circunstâncias, essa parecia ser uma saída possível: "Brasilienses, e bons brasileiros, o nosso amado príncipe nos diz: 'E sobre esta pedra edificarei o meu império do Brasil’. E nós, cheios de entusiasmo da maior alegria, em sólida união aclamemos em [altas] vozes: Viva o senhor rei D. João VI, viva sua real alteza, o senhor príncipe D. Pedro de Alcântara, salvador, defensor, protetor, regente do Império do Brasil”. ${ }^{102}$ As condições políticas apontavam pela mobilização das vilas do Recôncavo com o mesmo propósito.

Braz do Amaral observa, com razão, que o regente somente exigiu a retirada das tropas comandadas por Madeira de Melo da Bahia (15 de junho) quando também havia se decidido pela constituinte. Isso, meses após os conflitos ocorridos na província (fevereiro) e a expulsão da divisão enviada por Portugal para conduzi-lo de volta à Europa (março), o que, de alguma maneira, sinaliza uma incerteza quanto às decisões a serem tomadas naquelas circunstâncias. ${ }^{103}$ De qualquer modo, parece admissível que a estratégia de elaboração de uma constituição no Brasil Reino foi fundamental para impulsionar os laços com o Rio de Janeiro, cuja mudança de rumos produziu efeitos imediatos no comportamento de muitas lideranças, a essa altura, aglutinadas nas principais vilas do Recôncavo baiano. Em uma proclamação enviada aos residentes da Bahia, em 17 de junho, d. Pedro conclamava-os a seguirem o exemplo das províncias coligadas e a "entoardes vivas à independência moderada do Brasil, ao nosso bom e amável monarca El Rei o Sr. D. João VI e à nossa assembléia geral constituinte e legislativa do reino do Brasil”. ${ }^{104}$ Não à toa, pouco tempo depois dessas intervenções, diversas câmaras o aclamaram como o defensor perpétuo do Brasil. No entanto, sem deixar de expressar a confiança na manutenção do Reino Unido. As atas das câmaras das vilas de São Francisco de Sergipe do Conde e de Santo Amaro, assinadas por diversos habitantes, em 29 de junho, após registrarem o reconhecimento do príncipe como regente constitucional, finalizaram dando vivas a el-rei, à religião, às Cortes da Nação, “a união dos três Reinos unidos de Portugal, Brasil e Algarves, [e aos] nossos irmãos de Portugal e do Brasil”. Essa aparente ambigüidade evidencia, no entanto, que para esses indivíduos a idéia de Independência não

\footnotetext{
${ }^{102}$ Proclamação de Joaquim Inácio de Siqueira Bulcão aos baianos, em 13 de junho de 1822. Consta na íntegra em Luiz Alberto Moniz Bandeira, op. cit., p. 400. Segundo esse autor, Siqueira Bulcão "era um dos mais ricos senhores de engenho no Recôncavo da Bahia, familiar do Santo Ofício, com brasão de armas, nobreza e fidalguia concedido em 1792 pela rainha D. Maria I. Op. cit., p. 336.

${ }^{103}$ Braz do Amaral, op. cit., p. 151.

${ }^{104}$ Proclamação do príncipe regente aos baianos, em 17 de junho de 1822. Idem, ibidem, p. 163-164.
} 
era ainda uma meta a ser alcançada. Conforme justificavam, a decisão de se unir às vilas coligadas tinha em vista "acalmar a efervescência e confusão que agitava o Recôncavo”, o que não implicava necessariamente, nesse momento, a defesa pela dissolução do Reino Unido. ${ }^{105}$ Com a mesma perspectiva, os residentes de Cachoeira também haviam decidido por reconhecer a autoridade do príncipe, em 25 de junho, mesmo dia em que se registrou fortes ataques das tropas portuguesa à vila. No dia seguinte, decidiram ainda pela formação de uma Junta Interina, Conciliatória e de Defesa, que teria como objetivo "conciliar entre si e defender de qualquer agressão os habitantes desta Vila”. ${ }^{106}$

Em um comunicado ao comandante das armas, em $1^{0}$. de julho, a Junta Provisional condenou a mobilização das vilas do Recôncavo lamentando

a alucinação com que aqueles povos se precipitaram em atos tão arbitrários e ilegais, erigindo-se em juízes de uma questão, sobre que apenas cumpria darem pelas câmaras o seu voto, como lhes fora requerido pelos deputados desta província, e esperar a decisão do soberano congresso, e d'el rei, a quem no dia 10 de fevereiro se jurara obediência, e de cuja imediata dependência ficara a mesma província, ainda depois de estabelecida por el rei a regência do Brasil.

Embora os protagonistas daqueles eventos admitissem que não pretendiam alterar o "regime atual e a administração desta Província”. Dali a algum tempo, após uma ampla articulação entre os principais senhores de engenho residentes no Recôncavo, incluído os das vilas de Santo Amaro e São Francisco do conde, em 21 de agosto de 1822, em que compareceram nos paços do Senado da Câmara da Vila de Cachoeira, “pessoas da nobreza e mais Cidadãos conspícuos, e lavradores, todos proprietários desta vila e seu termo", discutiu-se a necessidade de estabelecer um "Governo Geral, não só para o Recôncavo e comarca da Bahia, mas também para toda a província”. Entre as justificativas para a criação de um "centro comum de autoridade [...], que administre esta província em nome de S. A. R., o sereníssimo príncipe Senhor d. Pedro de Alcântara, regente e defensor do Brasil, segundo as regras do governo representativo", encontrava-se o fato de as comarcas de Jacobina e Valença terem também aclamado a autoridade do príncipe regente. Os signatários acusavam o comportamento da Junta Provisional, "por coação ou por natural fraqueza” de não ter respondido aos apelos das vilas, além de tê-los designado como "rebeldes e facciosos", definindo as condições para a formação do novo governo que

\footnotetext{
${ }^{105}$ Ata da Câmara da Vila de São Francisco, em 29 de junho de 1822. Braz do Amaral, op. cit., 1957, p. 195196.

${ }^{106}$ Citado por Luis Henrique Dias Tavares, op. cit., 2005, p. 101. Fariam parte dessa Junta, o capitão de milícia Antônio Teixeira de Freitas Barbosa (presidente), Antônio Pereira Rebouças (secretário), capitão José Paes Cardoso da Silva, Antônio José Alves Bastos e padre Manuel José de Freitas. Idem, ibidem.
} 
incluía a representação de um deputado por cada vila coligada. Diante das condições para a sua imediata atuação e a dificuldade para reunir todos os indicados, deliberou-se "que o sobredito Conselho Interino de Governo, se repute instalado e entre no exercício de suas funções logo que se reunirem cinco deputados”. ${ }^{107}$

No dia 6 do mês seguinte o órgão foi instalado sob o comando do antigo secretário da Junta Provisional Francisco Elesbão Pires de Carvalho e Albuquerque (Presidente); o vereador Francisco Gomes Gê-Acaiaba Montezuma (Secretário); o corregedor Antônio José Duarte de Araújo Gondim; Manoel da Silva e Souza Coimbra; Manoel Gonçalves Maia Bittencourt e o padre Manoel José de Freitas. As demandas políticas exigiram a organização de um novo centro de articulação e deliberação com uma perspectiva de atuação que não se limitaria às vilas do Recôncavo. Com efeito, a essa altura, os desdobramentos dos conflitos políticos e militares eram sentidos em várias partes da província e não somente na capital e no Recôncavo. ${ }^{108}$ No entanto, interessa-nos, especificamente, realçar o significado da constituição de um novo órgão de poder na Bahia que passou a disputar com a Junta Provisional de Governo, sediada em Salvador, a linha política a ser adotada pela província frente às Cortes reunidas em Lisboa e a regência de d. Pedro no Rio de Janeiro.

Para esses indivíduos, as circunstâncias haviam possibilitado o exercício de um aprendizado político nunca dantes experimentado propiciando uma aceleração nas práticas políticas cotidianas uma vez que os antigos padrões haviam perdido a sua eficácia e as novas regras, por outro lado, ainda eram desconhecidas. ${ }^{109}$ Nesse contexto, a circulação das idéias políticas também se intensificava e, curiosamente, não apenas entre os residentes da província.

Com efeito, a despeito das dificuldades para efetuar a comunicação entre as províncias do Brasil Reino, ela efetivamente se dava. Desde 1821, por exemplo, era divulgado nos periódicos fluminenses a venda de "uma grande porção das três diferentes

\footnotetext{
${ }^{107}$ Termo de Vereação da Câmara de Cachoeira, em 21 de agosto de 1822. Braz do Amaral, op. cit., p. 225230. Sobre a instalação do Conselho, ver também Ignácio Accioli, op. cit.; Luis Henrique Dias Tavares, op. cit., 2001 e 2005. Os membros do governo seriam "eleitos à pluralidade absoluta de votos pelas câmaras e homens bons das vilas coligadas, ou que atualmente têm aclamado a regência constitucional de S. A. R., na razão de um deputado por cada uma das ditas vilas”. Ministério da Justiça. As juntas governativas e a Independência. Rio de Janeiro: Arquivo Nacional/Conselho Federal de Cultura, 1972, v. 2, p. 841-842. Em 14 de outubro de 1822, Francisco Montezuma (Salvador) e Simão Veloso (Inhambupe) foram escolhidos para relatarem a d. Pedro I, aclamado como imperador em 12 desse mês, as atividades do Conselho. Documentos históricos sobre a emancipação política da Bahia. RIGHBa, ano II, v. 2, n. 5, 1895, p 290-291; Hélio Vianna, op. cit., p. 107.

${ }^{108}$ Conforme estudo empreendido por Argemiro Ribeiro de Souza Filho, op. cit., 2003. A análise sobre a participação popular na guerra civil é feita por Sérgio Armando Diniz Guerra, op. cit.

${ }^{109}$ István Jancsó; João Paulo Garrido Pimenta, op. cit.
} 
gazetas que se publicam na cidade da Bahia, e são a Idade d'Ouro, Minerva Bahiense e Semanário Cívico [...]"110 e alguns deles não apenas reproduziam artigos dos jornais baianos, a exemplo de $O$ Espelho, como também estabeleciam debates entre os redatores dos periódicos baianos e fluminenses sobre questões políticas divergentes. Em razão disso, o livreiro Paulo Martin decidiu, em agosto de 1822, “suspender a venda das assinaturas das gazetas baianas, enquanto elas não fizessem causa comum com as províncias coligadas do Reino do Brasil”. 111

Importante observar que, nesse contexto, a situação política da Bahia era também acompanhada pelos habitantes da província Cisplatina que havia sido anexada ao Reino Unido de Portugal, Brasil e Algarves em 1821 na esteira das mudanças conjunturais dos anos pretéritos. ${ }^{112}$ Um dos jornais de Montevidéu, El Patriota, publicava em seus números extratos dos artigos de $O$ Constitucional que expunham a instabilidade política existentes naquela província agravada em meados de 1822, entre outros documentos. Em sua edição de 23 de agosto de 1822, o periódico reproduziu um extrato do jornal da Bahia, pelo visto retirado de jornais do Rio de Janeiro, tecendo duras críticas ao comportamento do comandante das armas Madeira de Melo que meses antes (12 de junho) tinha impedido o Senado da Câmara de Salvador de posicionar-se sobre a regência de d. Pedro. O artigo questionava a posição do general diante das conquistas liberais alcançadas pelos residentes do Reino Unido:

La constitucion ha proclamado la soberania, como residente esencialmente en el pueblo. El rei jurando las bases constitucionales, reconoció este principio de eterna verdad. Nuestros mismos representantes no pueden obrar en contradiccion con él: son nulos todos sus actos, todas sus deliberaciones, siempre que se opongao a la voluntad de los pueblos que es la lei: luego à V.E. incumbe indagar cual sea la voluntad de la provincia para obrar en conformidad à ella [...].

No trepidamos en afirmar que las dos terceras partes de los habitantes de ella quieren que el P.R. sea el Regente de este reino: quieren que esta provincia lo sea sel Brasil, y no de Portugal. Soa tan decidido las pruebas que demuestran esta voluntad, y V.E. esta tan alcabo de ellas, que no es necesario enumerar-las [...].

Las armas son el mas firme apoyo de los gobiernos, cuando obedecen á las leyes, cuando no atacan la libertad pública; mas se si presumen

\footnotetext{
${ }^{110}$ Lúcia Maria Bastos Pereira das Neves, op. cit., 1994, p. 195. Ver também Maria Beatriz Nizza da Silva, op. cit., 1988, p. 16.

${ }^{111}$ Idem, ibidem, p. 195.

112 Os fluxos comerciais entre a América portuguesa e o Vice-Reino do Rio da Prata eram antigas, assim como a troca de informações políticas, sobretudo, após a instalação da família real em 1808, uma medida que interferiu também diretamente nesse território. Cf. João Paulo Garrido Pimenta, op. cit., 2002 e 2003.
} 
árbitras de la suerte de los pueblos, no sabemos que estos sean, sino esclavos de su albedrio, ó de su capricho. ${ }^{113}$

No número seguinte, o periódico de Montevidéu contestou as acusações de possíveis leitores segundo as quais os documentos publicados sobre a Bahia seriam falsos em virtude de terem sido publicados em espanhol e não em português. O redator informou que os originais estariam à disposição dos interessados, divulgando, depois disso, os artigos sem a tradução. Nessa mesma edição, reproduziu notícias do Correio do Rio de Janeiro, de 19 de julho, que traziam parte de uma representação encaminhada pelos residentes da Bahia ao Congresso de Lisboa com os esclarecimentos de que a província só desejava "a bem entendida Liberdade, respeitando os interesses do Reino Irmão, para que este os reconheça iguais no Reino do Brasil, de quem faz nobre e integrante porção”. A continuidade da representação teve que ser interrompida para a divulgação do manifesto de d. Pedro aos governos e às nações amigas, de 6 de agosto de 1822, no qual relatava a situação do Brasil e afirmava sua disposição em defendê-lo dos ataques das Cortes e do “partido dominador”. Certamente para evitar as críticas anteriores, o periódico avisava que apesar das diligências, não havia conseguido os originais de dois documentos importantes: um decreto do regente colocando portos e praças em alerta contra qualquer tentativa de desembarque de tropas e o manifesto em que explicava as razões daquelas ordens. Por isso, requeria "a los señores que reciban impresos de aquel reino se sirvan favorecernos con lo mas notable de ellos, cuando no les sea de incomodidad". ${ }^{114}$ Um desses documentos seria o manifesto de 22 desse mês no qual o príncipe clamava pela união do Brasil Reino a despeito de expressar seu desejo em manter os vínculos com Portugal. De acordo John Armitage, o texto havia sido elaborado por Gonçalves Ledo, então membro do conselho dos representantes, e iniciava com uma frase retirada de uma proclamação que havia sido publicada na França durante a revolução: "O tempo de enganar os homens está passando. Os Governos que ainda pretenderem fundar o seu poder sobre a figurada ignorância dos povos, ou sobre antigos prejuízos ou abusos, terão de ver o colosso da sua grandeza derribado de tão frágil base”. 115

Os fragmentos da representação dos baianos voltariam a ser publicados no El Patriota no decorrer do mês de setembro. Embora tivesse decorrido alguns meses desde a sua elaboração - 15 de abril de 1822 -, o documento, elaborado pelos partidários de d.

\footnotetext{
${ }^{113}$ El Patriota, n. 2, Montevideo-Viernes, 23 de agosto de 1822. Agradeço a João Paulo Garrido Pimenta a cessão de cópia desse documento.

${ }^{114}$ El patriota, n. 4, Montevideo-Viernes, 5 de septiembre de 1822.

${ }^{115}$ Citado por John Armitage, op. cit., p. 62.
} 
Pedro, expressava uma questão importante no contexto das lutas políticas desse período, qual seja, a denúncia sobre a existência de partidos na Bahia que intentavam efetivar seus projetos políticos em meio à conturbada conjuntura política. Para os autores do texto, no entanto, a propagação “em altos brados” sobre a atuação de "partidos de independência democrática”, cisão monárquica, Felisbertinos, e outros”, era apenas um recurso utilizado por uma determinada facção para atingir seus objetivos. ${ }^{116}$

A idéia de que a Bahia abrigava grupos defensores de distintas posições políticas que se manifestaram com vigor após a adesão ao constitucionalismo aparece em alguns documentos da época. Francisco de Sierra y Mariscal, testemunha dos acontecimentos daquela época, fala sobre a manifestação de três partidos na província: o europeu, que pretendia se submeter às decisões de Portugal; o democrata, numeroso, "mas não tinha nem dinheiro, nem cabeça, ele queria os Governos Provinciais independentes” e o aristocrata, que "era fraco e pobre, e ainda não era bem conhecido', desejava instalar um governo independente de Portugal. Da união entre os partidos europeu e democrata é que havia resultado a adesão às Cortes em 10 de fevereiro de 1821 "porque era entre eles que se havia de decidir a sorte do Brasil”.117

Em um de seus relatos às Cortes Gerais, logo após os conflitos de fevereiro do ano seguinte, o brigadeiro Madeira de Melo também identificou a existência de três partidos na Bahia: um, “dos naturais de Portugal o partido quase geral é puramente constitucional, e a este alguns há dos naturais do país que se unem”; aqueles constituídos pelos “mais poderosos já em posses e já em empregos de representação, ligados aos togados do Rio de Janeiro” que desejavam a separação de Portugal e, por último, os que não possuíam as mesmas posses ou empregos dos segundos e defendiam "uma independência republicana em que só figurem os naturais do país”. ${ }^{118} \mathrm{Na}$ avaliação do capitão-mor de Cachoeira, José Antônio Fiúza de Almeida, por essa época, um elemento novo poderia ser notado nessa configuração. Conforme afirma, diversas notícias davam conta “de que nesta vila e seu Distrito, há três partidos revolucionários, a saber, um de Brasileiros, outro de Europeus e o terceiro de Negros”. 119

Ainda que se distinguissem em suas interpretações sobre a natureza desses partidos, o que parece significativo nos documentos é o fato de expressarem a dimensão da

\footnotetext{
${ }^{116}$ El patriota, n. 5, Montevideo-Viernes, 13 de septiembre de 1822.

${ }^{117}$ Francisco de Sierra y Mariscal, op. cit., p. 63. Ver também István Jancsó; João Paulo G. Pimenta, op. cit.

${ }^{118}$ Ofício do governador Madeira de Melo a d. João VI, em 7 de março de 1822. Mello Moraes, op. cit., t. I, p. 334. Ver Luis Henrique Dias Tavares, op. cit., 2005, p. 28.

${ }^{119}$ Ofício do capitão-mor de Cachoeira, José Antônio Fiúza de Almeida, ao capitão de engenheiro às ordens do general da província, em 16 de abril de 1822. Braz do Amaral, op. cit., 1957, p. 189.
} 
atividade política vivenciada pela província cuja manifestação era percebida pela atuação coletiva de indivíduos tentando influir, de algum modo, no novo quadro político que se desenhava. É certo que ênfase dada à atuação de uma facção ou outra não raras vezes servia como argumento para reforçar determinada posição, um recurso bastante utilizado no decorrer dos conflitos políticos na Bahia, no entanto, não deixava de refletir a intensidade do aprendizado político da época e, como corolário, os seus antagonismos. A despeito da prevalência, em boa parte da historiografia do período, de uma imagem das tensões políticas na Bahia centrada na rivalidade entre portugueses e brasileiros, as evidências apontam para uma dinâmica política menos clarividente. Já em 9 de fevereiro de 1822, quando José Clemente Pereira, futuro ministro de Estado, tentava convencer o príncipe a permanecer no Brasil argumentando que o seu regresso à Europa poderia ocasionar indesejáveis, ele questionava: “Será possível que V.A.R. ignore que um partido republicano, mais ou menos forte, existe semeado aqui e ali, em muitas das Províncias do Brasil, por não dizer em todas elas? Acaso os cabeças que intervieram na explosão de 1817 expiraram já? E se existem, e são espíritos fortes e poderosos, como se crê que tenham mudado de opinião?”120

De fato, além da manifestação de algumas posições políticas anteriormente represadas, duas questões são igualmente relevantes nesse complexo quadro político da Bahia do início dos anos de 1820. A primeira delas diz respeito à configuração dessas tendências. Certamente, as condições de intervenção política eram bastante desiguais. ${ }^{121}$ É possível que os republicanos, sem muito espaço para atuação, constituíam uma ala mais à esquerda dos defensores de uma monarquia constitucional independente para o Brasil e da qual tinha em Cipriano Barata a sua maior expressão. ${ }^{122}$ De todo modo, a guerra civil que se instaurou na província e a dualidade de poderes estabelecida com a criação do Conselho Interino de Governo ajuda a entender como o horizonte político esteve bastante nebuloso no decorrer das hostilidades que tiveram como palco central a capital da província e a área de produção açucareira do Recôncavo. Em outras palavras, a despeito dessa separação, os homens (e mulheres) protagonistas dos antagonismos políticos não podem se reduzir a uma contenda entre portugueses e brasileiros, fortemente aferrados a projetos políticos de recolonização e de independência, coerentes com seus interesses identitários. Essa

\footnotetext{
${ }^{120}$ Citado por John Armitage, op. cit., p. 53.

${ }^{121}$ Cf. Antonio d'Oliveira Pinto da França (Org.).Cartas baianas, 1821-1824. Subsídios para o estudo dos problemas da opção na Independência brasileira. São Paulo: Companhia Editora Nacional; Rio de Janeiro: Núcleo Editorial da UERJ, 1980.

${ }^{122}$ Um verdadeiro "Sanscolote [sic]” nas palavras de Francisco de Sierra y Mariscal, op. cit., p. 59.
} 
interpretação simplifica a dinâmica da luta política que se processou no interior da província e não possibilita compreender os momentos de ruptura e de articulação das forças políticas em suas próprias relações e com os centros de poder em Lisboa e no Rio de Janeiro. $^{123}$

A posição política da família do deputado Luis Paulino d'Oliveira Pinto da França serve como um exemplo das fortes ligações estabelecidas entre portugueses europeus e americanos. Nascido em Cachoeira, na Bahia, Luis Paulino era casado com Maria Bárbara Garcez Pinto da França, natural de Portugal. Os dois filhos do casal, Bento, o mais velho, e Luiz, ambos de origem portuguesa, assumiram posições políticas distintas no movimento constitucionalista na Bahia. Enquanto o primeiro defendeu as Cortes portuguesas, comandando as tropas enviadas a Sergipe submetê-la às decisões da Junta Provisional de Governo; o segundo alistou-se no Exército Pacificador organizado para combater as tropas portuguesas e, posteriormente, foi nomeado ajudante-de-campo do general Pedro Labatut, contratado por d. Pedro I para coordenar as operações militares na província. Do mesmo modo, o posicionamento do capitão-mor do arraial da Conquista, no sertão da Bahia, Antônio Dias de Miranda, também é digno de registro. Filho do português João Gonçalves da Costa, conhecido explorador de terras e dizimador de índios naquele território, em outubro de 1822, o capitão-mor informou ao Conselho Interino de Governo que o processo de independência "não só me desviou da ambigüidade em que me achava, manifestando-me o verdadeiro filho da justíssima causa que devo seguir, mas também encheu-me de tão grande júbilo e contentamento". Como demonstração de seu envolvimento, reuniu todos os habitantes do distrito para um ato de aclamação solene do "Protetor e Defensor Perpétuo do Reino do Brasil", além de determinar "fazer descer deste sertão de quinze em quinze dias dois lotes de gado, um para essa vila e outro para a povoação de Nazaré o que continuarei a fazer enquanto nos largos destes sertões houver bois capazes de descerem e por Vossas Excelências me não for determinado o contrário". ${ }^{124}$

Por outro lado, não se pode negar que o antilusitanismo foi um componente importante no aguçamento dos conflitos que em determinados momentos intensificou a violência contra os portugueses europeus residentes na província, inclusive nos territórios sertanejos, sob o risco de não atentar para uma particularidade importante dessa

\footnotetext{
${ }^{123}$ Para uma análise crítica da historiografia sobre o tema, ver Thomas Wisiak, 2001, op. cit.

${ }^{124}$ Ofício do capitão-mor Antonio Dias de Miranda ao Conselho Interino de governo. APEB. Seção de Arquivo Colonial e Provincial. Série Militares/Capitães-Mores. Maço n. 423 (1822). Cf. Maria Aparecida Silva de Sousa, op. cit., 2001.
} 
instabilidade interna da província. ${ }^{125}$ Numa correspondência datada de 27 de maio de 1823, d. Pedro I, que havia sido coroado como Imperador em $1^{\circ}$. de dezembro do ano anterior, alertou ao Conselho sobre as conseqüências das ações contra os europeus que não deveriam, no seu modo de ver, estar relacionadas à causa da Independência:

Não devendo servir de incentivo para perseguição o local de nascimento, por ser mero acidente, uma vez que as idéias e sentimentos dos indivíduos não sejam divergentes do sistema geral, e pronunciado do povo, não pode S. M. o Imperador deixar de estranhar a notícia [...], por ofício do governo provisório da Província de Minas Gerais, de se haver nela refugiado muita gente fugida à perseguição, e depredação contra ela praticada nos sertões da província da Bahia, confinantes com os de Minas, por bandos de homens armados, pelo simples motivo de serem Europeus, seguindo-se terem ficado desertas algumas povoações, tomada de medo de seus habitantes, e porque a iluminada política do Imperador, proclamando a independência do Brasil, só tem em vista ganhar-lhes amigos, e aderentes à causa, e nada tem com a origem destes, muito mais quando em tão remota distância, é possível que os facinorosos, a coberto daquele pretexto, procurem ou cevar ódios, ou cometer roubos; manda [que se] tome as medidas as mais enérgicas [...]. ${ }^{126}$

Poucos dias antes do fim da guerra civil, os negociantes e proprietários portugueses residentes em Salvador enviaram um abaixo-assinado ao Conselho Interino de Governo expressando seus vínculos e interesses com o Brasil, “onde desenvolvendo desde o primeiro período da idade, seu trabalho e indústria, adquiriam bens, contraíram relações, e alianças de família, arraigando-se com mulheres e filhos, preferindo, assim, por escolha o país hospitaleiro, que benigno os acolhera, àquele em que o acaso lhes dera o nascimento”. No entanto, temiam "por suas vidas, e propriedades" caso o governo não tomasse as providências necessárias "fazendo conhecer que Brasileiros e Europeus sem diferença, formam uma mesma família, gozando de iguais direitos, debaixo das mesmas Leis, e Império, e desta sorte unidos, e felizes fazemos sinceros votos pela conservação do nosso augusto Imperador constitucional Brasílico, que a nação tem adotado, contribuindo com todas as nossas forças para o engrandecimento e prosperidade do Império”. ${ }^{127}$ A despeito

\footnotetext{
${ }^{125}$ Argemiro Ribeiro de Souza Filho, op. cit., 2003. ver também Hilton Barros Coelho, op. cit.

${ }^{126}$ Ofício de d. Pedro I ao governo da Bahia, em 27 de maio de 1823. Braz do Amaral, op. cit., 1957, p. 466.

${ }^{127}$ Representação de negociantes e proprietários enviada ao Conselho Interino de Governo, em 30 de junho de 1823. Ignácio Accioli, v. IV, 1933, p. 44. Além dos fortes vínculos econômicos estabelecidos há muito tempo na província, esses indivíduos possuíam intricados laços familiares por meio de casamentos endogâmicos, assim como muitos deles estavam inextricavelmente vinculados à estrutura do Estado. John Armitage argumenta que todos aqueles que, no Rio de Janeiro, tiveram seus cargos retirados por conta do decreto das Cortes portuguesas de 29 de setembro de 1821 viraram patriotas. Op. cit., p. 51. No caso das relações familiares, não raras provocavam sérias fissuras. John Norman Kennedy, op. cit.; F.W.O. Morton, op. cit., 1974; Para o caso da família Gonçalves da Costa, ver Maria Aparecida Silva de Sousa, op. cit., 2001.
} 
disso, o agravamento das tensões no decorrer dos anos de 1820 e começo da década seguinte resultou na expulsão ou no abandono de muitos lusitanos da província ocasionando sérios prejuízos em virtude da carência de capitais para financiar as atividades econômicas, sobretudo, a agricultura. Não à toa, em 1831 os "proprietários e fazendeiros todos unidos” encaminharam uma representação, na qual constavam duas mil e cem assinaturas, ao então presidente da província, João Gonçalves Cezimbra, requerendo providências para o retorno desses negociantes, numa clara demonstração da importância do capital português para a classe proprietária da Bahia. ${ }^{128}$

De qualquer modo, os documentos produzidos pelos organismos de poder na província indicam que a perspectiva para a manutenção da unidade e a defesa da emancipação de maneira vigorosa somente avançaram em direções opostas quando as divergências sobre a natureza da união no interior do Reino se mostraram inconciliáveis, propiciando, assim, novas articulações políticas que assegurassem a estabilidade da província. De fato, os conflitos se exacerbaram na medida em que algumas deliberações das Cortes portuguesas foram vistas como uma tentativa para subtrair ao Brasil a condição política que havia sido afirmada em 1815 e esta perspectiva serviu, de maneira tática, como recurso para o fortalecimento de algumas posições políticas, bem como a exasperação de outras diferenças. ${ }^{129}$

Ainda em 24 de Agosto de 1822, a proprietária do engenho Aramaré no Recôncavo, Maria Bárbara Garcez Pinto da França, ao escrever ao seu marido Luis Paulino, deputado nas Cortes portuguesas, afirmava que:

Eu desespero ao ver que nessa Corte só aparecem fatos mentirosos e a verdade se oculta, para que não seja socorrida a pobre Bahia, nas suas calamidades. Não, não, aqui não querem a Independência. Aqui só desejam gozar dos privilégios de que aí se gozam. Os brasileiros não são enteados, são filhos. Sabes que eu vejo tudo sem prevenção, sem ódios, sabes que eu amo o Rei, a nação, enfim, que sou idólatra pela prosperidade dos portugueses, mas morro de ver que uma dúzia de homens quiseram fazer que o pobre Portugal perdesse a sua melhor possessão. $^{130}$

A incapacidade das Cortes para conciliar as distintas concepções sobre a natureza da nação portuguesa que se pretendia edificar foi percebida desde logo pelos

\footnotetext{
${ }^{128}$ Representação dos habitantes do Recôncavo ao presidente da província, em 18 [!] de 1831. Idem, ibidem, p. 274-276. João José Reis enfatiza essa questão no artigo “A elite baiana face os movimentos sociais, Bahia: 1824-1840”, op. cit. Ver também: Kátia Maria de Queirós Mattoso, op. cit., 1992.

${ }^{129}$ Márcia Regina Berbel. “A retórica da recolonização”. In: István Jancsó (Org.), op. cit., 2005, p. 791-808.

${ }^{130}$ António d’Oliveira Pinto da França (Org.), op. cit., p. 82.
} 
deputados da Bahia que haviam tomado posse em 15 de dezembro de 1821. De início Cipriano Barata protestou contra a continuidade das discussões sem a presença de todos os representantes do Brasil exigindo a rediscussão dos artigos já aprovados. Após muitas discordâncias, alguns deputados abandonaram as Cortes denunciando as dificuldades de conformação do pacto político sustentado numa constituição liberal. ${ }^{131}$ Mas, a rigor, mesmo entre os representantes das províncias do Brasil existiam profundas divergências sobre o assunto e, no caso específico da delegação da Bahia, também não se poderia esperar um consenso entre indivíduos com trajetórias e proposições tão distintas. A avaliação desses representantes feita por Antonio Pereira Rebouças indica um cenário político bastante indefinido:

Assim é que tiveram de partir da Bahia por deputados ao Congresso de Lisboa o comendador Pedro Rodrigues Bandeira, proprietário e capitalista, talvez o mais abastado do Brasil, varão ilustrado e tido por muitos sentimentos patrióticos, porém estranho à política;

O Dr. Domingos Borges de Barros, grande literato e rico proprietário, ilustre amigo íntimo do marechal Felisberto, e que não tivera parte ativa na aclamação da Constituição em 10 de Fevereiro;

Alexandre Gomes Ferrão, brasileiro ilustre e rico proprietário, que também constava que não concorrera para a aclamação da Constituição portuguesa;

O padre Francisco Agostinho Gomes reconhecido por muito versado nas letras e ciências sociais, posto que de caráter inativo;

O vigário colado da freguesia da Vitória, sacerdote muito versado nas sagradas e nas profanas letras;

O Dr. José Lino Coutinho, que, em conseqüência, deixou o exercício de membro da Junta provisória;

O marechal Luis Paulino da França Pinto Gracez [sic], brasileiro de nascimento, mas português de coração;

O bacharel Cipriano José Barata de Almeida, brasileiro patriota ardente e de idéias obstinadamente republicanas. ${ }^{132}$

Após seu retorno ao Brasil, em 23 de maio de 1823, o vigário Marcos Antônio de Souza divulgou um manifesto aos habitantes da Bahia no qual buscava esclarecer acerca das discussões ocorridas nas Cortes portuguesas e, principalmente, justificar a sua posição moderada diante de acontecimentos tão surpreendentes:

\footnotetext{
131 “Em 11 de setembro [1822], Lino Coutinho apresentou indicação assinada por todos os deputados baianos, exceto Luis Paulino, alegando que não poderiam continuar a representar sua província, pois a vontade expressa na Bahia era a da separação, e que, caso a indicação não fosse aprovada, não se julgavam em condições de assinar a Constituição”. Cf. Márcia Regina Berbel, op. cit., 1999, p. 191. Entre os 7 deputados que deixaram as Cortes em outubro de 1822 encontravam-se Cipriano José Barata de Almeida, Francisco Agostinho Gomes e José Lino Coutinho.

${ }^{132}$ Antonio Pereira Rebouças, op. cit., p. 458-459. Ver também Thomas Wisiak, op. cit., 2001, p. 85.
} 
Inimigo de revoluções, quase sempre fatais, porém arrebatado pelo turbilhão revolucionário, e nomeado deputado para as cortes de Lisboa, em 3 de setembro de 1821, muitas vezes [o abaixo assinado] se escusou da perigosa procuração, alegando que muito receava ingerir-se em negócios políticos, segundo a Doutrina do Divino Mestre [...]. Pediu instruções, francamente manifestando que não sabia soldar matérias heterogêneas, nem ligar com união durável, dois países com interesses discordantes e opostos, e cujos habitantes tinham afeições antipáticas. ${ }^{133}$

Embora fizesse críticas ao comportamento da maioria dos deputados de Portugal, o deputado reconheceu que ali também havia "cidadãos distintos, e respeitáveis pelos seus talentos e luzes”, mas estava convencido que as revoluções eram um mal irreparável. ${ }^{134}$ Ao que tudo indica, a disposição da maioria dos deputados não era pelo rompimento com o Reino europeu pelo menos até o aguçamento das divergências nas Cortes e da situação específica da província. Em outro documento, ressalta:

Depois de chegar a Lisboa, em 18 e 22 de Março de 1822 escrevi à junta do governo e senado da cidade da Bahia, solicitando esclarecimentos sobre objeto de tão grande monta [a união de Brasil e Portugal]. Respondem todas as autoridades, depois de consultar as pessoas mais inteligentes e amantes do bem público, que o Brasil devia conservar sua categoria de Reino, ser governado pelo herdeiro da coroa, o mais interessado na conservação da integridade de uma tão vasta monarquia. Isto mesmo propusemos ao congresso, como vontade geral das províncias do Brasil, ou da maioria da nação. Nada é atendido apesar da solene promessa feita em 19 de Dezembro de 1821 em resposta da indicação de um deputado da Bahia, resposta pela qual asseguraram os preponderantes do congresso, que tudo seria dado ao Brasil para seu bom regime e representação política. ${ }^{135}$

Como se nota, as perspectivas políticas eram bem mais incertas do que aparentavam. Ademais, é possível admitir que além do descontentamento com as deliberações das Cortes portuguesas, os proprietários de terras, engenhos e escravos da Bahia, muitos deles alçados à condição de lideranças nesse contexto, tinham outras razões para preocuparem-se com os rumos do movimento constitucionalista na província. Certamente a prevenção não era desprovida de fundamento. Afinal de contas, a questão social na província era um assunto que permanecia entre as preocupações das autoridades

\footnotetext{
${ }^{133}$ Manifesto de Marcos Antônio de Sousa, vigário da Vitória, s/d. Mello Moraes, op. cit, t. 2, p. 249-262. A citação consta na página 250.

134 “[...] depois da fatal experiência da França, não é mais tempo de se alucinarem os homens com otimismo político, e governo perfeito. República universal, felicidade perfeita sobre a terra, é quimera. O homem só deve procurar sua felicidade na moral, nos sentimentos virtuosos, e por conseqüência na obediência às leis, aos imperantes e autoridades legitimamente constituídas”. Op. cit., p. 262.

${ }^{135}$ Carta escrita pelo vigário Marcos Antônio de Sousa, Lisboa, em 29 de Março de 1823. Mello Moraes, op. cit., t. 2, p. 263.
} 
locais. E, ao que parece, ainda mais naqueles dias conturbados em que ganhava novos contornos. Em um comunicado ao comandante das armas, em 19 de fevereiro de 1822, publicado pelo Diário Constitucional, a Junta Provisional de Governo informou sobre as queixas dos moradores de

[...] Cabula, São Bento, Barreiras, Pedrinhas, Pirajá, e Batefolha acerca dos contínuos, e numerosos ajuntamentos, que ali há de diversos negros armados, e mulheres que se lhe agregam cujo fim é sumamente pernicioso [...] que V.Exa. dê a providência, que julgar conveniente, a fim de se dispersarem semelhantes reuniões, que têm lugar principalmente nos Domingos e Dias Santos. ${ }^{136}$

Além disso, o impulso das mudanças políticas havia possibilitado também a maturação política dos segmentos populares que, movidos por seus próprios interesses, despertaram temores daqueles que não pretendiam extrapolar os limites do vintismo português. Em variados momentos percebe-se a apreensão dos dirigentes com a ocupação do espaço público por indivíduos cujas razões para o envolvimento nem sempre poderiam ser coincidentes. Nesse aspecto, é ainda mais significativo notar que a ampliação desse envolvimento espraiou-se por outros lugares distantes dos marcos mais dinâmicos da capital e do Recôncavo. Em 13 de março de 1823, por exemplo, o Conselho Interino comunicou ao ouvidor interino de Jacobina para que os nomes e opiniões públicas dos juízes e vereadores possuidores de má fama fossem apontados criteriosamente advertindo que “as sessões populares não são as próprias para decifrar sobre a conduta de cidadãos sujeitos ao ódio, amizade e a qualquer paixão" ${ }^{137}$ Ao referirem-se à fermentação política ou combaterem os perigos da “anarquia”, dos “partidos” e dos “perturbadores do sossego público”, as autoridades locais, vinculadas ao Conselho Interino de Governo ou à Junta Provisional, deixavam explícito que a dilatação da inserção política possuía um dimensionamento que não deveria ser menosprezada. ${ }^{138}$

Um dos escritos apreendidos no dia 7 de novembro de 1821, por ocasião da tentativa de deposição da primeira Junta de Governo, e atribuído ao cadete João Primo, ensinava:

\footnotetext{
136 Citado por Thomas Wisiak, op. cit., 2001, p. 130. De acordo Ubiratan Castro de Araújo, esses ajuntamentos eram constituídos por escravos e soldados desertores e se concentravam nas densas matas que circundavam a cidade. Op. cit., p. 36.

${ }^{137}$ Correspondência do Conselho Interino de Governo ao ouvidor interino da comarca de Jacobina. APEB. Seção de Arquivo Colonial e Provincial. Registro de Correspondência Expedida. Maço: 1620 (1823).

${ }^{138}$ As constantes denúncias de desassossego público no Sertão da Bahia (Caetité e Rio de Contas), nesse período, são discutidas por Argemiro Ribeiro de Souza Filho, op. cit., 2003.
} 
Todo Cidadão é livre quando nasce, e um dos elementos da liberdade é o direito que cada um tem para manifestar a sua opinião contra a tirania. [...] Dizei-nos se os Povos tiveram poder para obrigar a Sua Magestade Fidelíssima [d. João VI] pela Constituição, por que não terão direito para depor péssimos membros da Junta Provisional, e logo depositar a sua Autoridade em beneméritos Portugueses eleitos pelos Eleitores de Paróquia [...]? Um homem tem direito de matar a quem o quer privar da vida; e os Povos não hão de ter Direito de livrar-se de meia dúzia de perversos, que atacam os Direitos e as relações sociais? Vós assentais que é a raça escolhida para nos governar, e que as outras classes são raças condenadas a vos obedecerem; e com essas lindas idéias quereis que o Povo, que vos aborrece, tome partido para vós, assegurem em vossas trementes e rapinarias mãos a vara de ferro com que o tendes regido! Sim, vós quereis que essa vara abrasada incendeie a Província para mais de uma guerra civil! Sabeis vós, nefandos Proclamadores, até aonde chegará este flagelo da humanidade! ${ }^{139}$

O teor do documento aponta pela existência de uma forma de apreensão das questões políticas do período que ultrapassava a concepção de governo e de participação defendida pela maior parte dos protagonistas do movimento constitucionalista da Bahia. Isso não apenas reafirma a complexidade do quadro político da Bahia, como evidencia que um ideário político, de natureza mais radical, foi absorvido por alguns indivíduos e, certamente, muito antes dos acontecimentos de princípios dos anos 1820. Ao mencionar as diferenças políticas assentadas nas noções de raça e classe, o autor do panfleto trazia para o centro da discussão temas melindrosos em uma província cuja maior parte da mão-deobra era constituída por escravos e homens pobres livres. Pode se considerar que a utilização desse tipo de discurso visava, essencialmente, a mobilização de alguns segmentos da população com o intuito de fortalecer determinados projetos específicos. É uma possibilidade a ser considerada. Da mesma maneira, pode se supor que, naquelas circunstâncias de intensa atividade política, a declaração acima encontrava amparo entre uma grande parcela dos residentes da Bahia. Ademais, não se pode esquecer que 1798 constituiu um marco no processo de elaboração de alternativas políticas na capitania, no qual a própria noção de legitimidade política havia sido também questionada. Nessa direção, é sintomático que os documentos recolhidos naquele dia estivessem em mãos de um escravo, João Crioulo, e do pardo Francisco Antônio de Souza, encaminhados à prisão acusados de portarem e divulgarem “escritos infamatórios e sediciosos”. 140

\footnotetext{
${ }^{139}$ Devassa de escritos inflamatórios e Sediciosos encontrados em mãos de João Crioulo, escravo de Antonio José Pereira Rocha, e Francisco Antonio de Souza. Citado por Argemiro Ribeiro de Souza Filho, op. cit., 2008, (grifos do autor).

${ }^{140}$ Idem, ibidem. Sobre a participação dos segmentos populares no cenário político da Bahia nos anos 1820, tema ainda pouco estudado, ver Hendrik Kraay. "Muralha da Independência e liberdade do Brasil: a
} 
Outra questão importante nesse cenário político era o fato de as lideranças políticas demonstrarem estar atentas à possibilidade desse alargamento do espaço público atingir a ordem societária escravista, agravando ainda mais a situação da província e, em um aspecto que, especialmente, dizia respeito às autoridades como um todo. Isso fica evidenciado em diversos documentos produzidos tanto pelo Conselho Interino de Governo, em Cachoeira, sobretudo em razão das profundas divergências com o general Pedro Labatut, quanto pela Junta Provisional e pelo comandante de armas Madeira de Melo. O primeiro repudiava a iniciativa do general francês em criar tropas de libertos e de escravos para auxiliar no combates às tropas portuguesas ocupantes da capital quando ainda havia homens livres que poderiam ser recrutados. Afinal, era conveniente não conceder armas às classes de cor nas circunstâncias políticas do período não apenas porque possuíam razões suficientes para se rebelarem, "e tanto mais quanto sendo estas classes as que menos têm [a] perder, e menos laços têm sociais, são as mais aptas para sustentarem empresas arrojadas e tresloucadas, mais subversivas”. ${ }^{141}$

A Junta Provincial em Salvador, por sua vez, em $1^{0}$. de julho de 1822, chamava a atenção do brigadeiro Luís Inácio Madeira de Melo sobre a sua decisão de usar a força contra as vilas de Cachoeira e de São Francisco por terem aclamado a regência de d. Pedro, advertindo-lhe o "quanto [era] impolítica e tremenda seria, para a segurança de toda esta província, a tentativa de fazer o Recôncavo, recheado de castas perigosíssimas, teatro de uma guerra exterminadora”. ${ }^{142}$ Para o militar português, o perigo existente no Recôncavo não lhe era desconhecido, entretanto, caberia à classe senhorial solucionar a questão, questionando:

À frente dessa rebelião, não andam esses mesmos que em suas próprias casas têm o instrumento da desgraça, que vossas excelências premeditam? Eles o conhecem, e eu já lho fiz ver: mas se eles o não temem, nós é que o devemos respeitar, esquecendo-nos que da falta de punição dos senhores, em tal caso mais se aumentará a imoralidade dos escravos, seguindo-se a rebelião destes que será a que então reduzirá a província a teatro da mais sanguinolenta e horrorosa cena?”. ${ }^{143}$

A dificuldade de conciliar interesses tão diversos na Bahia era o tema de um panfleto anônimo que circulou na Bahia em 25 de março de 1822. Seu autor expunha os

participação popular nas lutas políticas (Bahia, 1820-1825)”. In: Jurandir Malerba (Org.)., op. cit., p. 303341.

${ }^{141}$ RIGHBa, ano IV, v. 4, n. 14, 1897, p. 563.

${ }^{142}$ Correspondência da Junta Provisional de Governo ao brigadeiro Madeira de Melo, em $1^{\circ}$. de julho de 1823. Ignácio Accioli, op. cit., p. 353.

${ }^{143}$ Idem, Ibidem, p.354. 
empecilhos que se apresentavam contra os interesses daqueles que intentavam levar adiante o projeto da Independência do Brasil:

A maior dificuldade de um Povo, que se quer constituir independente, não é sacudir os inimigos de fora, mas vencer os de casa, destruir ódios, ambições, ciúmes, e paixões intestinas, e enfim fundar um governo, para o que, talvez seja necessário que a Pátria, tão pouco piedosa como Medéia, sacrifique seus próprios filhos. Quanto dizemos, e o mais escusamos repetir, é verdade em geral; são axiomas aplicados ao Brasil, e nunca a qualquer parte dele melhor cabidos que à Bahia, onde a escravatura é desmesurada em proporção dos homens livres, e da que há nas outras Províncias do Brasil, por onde se devem arrecear em proporções os perigos da mal discreta independência.

[...] Que o Brasil tem grandes proporções para ser um grande Império, é verdade incontrastável; mas que presentemente não é nada, e que nada mais apresenta que a figura da debilidade e fraqueza, pela sua solitária e heterogênea população, é verdade também. ${ }^{144}$

Embora o problema da população escrava pudesse servir como recurso para definir alguns encaminhamentos, aprofundando as divergências entre as facções da classe proprietária, não dava para ignorá-lo. Ainda assim, nem todos externavam a mesma insegurança com uma possível reação dos escravos naquela conturbada conjuntura política. Já em abril de 1822 a mesma senhora de engenho, Maria Bárbara, registrou que "a crioulada da Cachoeira”, se aproveitando da convocação de Cortes Gerais, enviara “requerimentos para serem livres". Algo completamente despropositado em sua visão e que aparentemente não lhe causara grande impressão: “Estão tolos, mas a chicote tratamse!”. ${ }^{145}$ Ao que parece, uma parcela importante dos segmentos dominantes da Bahia acreditava que o perigo real contra a ordem, inclusive a escravista, não residia nos cativos, ainda que muitos tivessem nascido no Brasil, mas no amplo contingente de pardos e crioulos livres muitas vezes dispostos a forcejar uma maior inserção político-social. Na avaliação de João José Reis, apesar de não terem ficado imunes à fermentação política do período, os cativos não reuniam condições para uma rebelião em massa mesmo considerando um contexto de divisão no interior da classe proprietária: “Não conseguiram organizar-se para tal, e, ademais, eles também achavam-se divididos em diversas etnias africanas adversárias, além de secular e difundida animosidade entre crioulos e africanos”. 146

\footnotetext{
${ }^{144}$ Citado por Thomas Wisiak, op. cit., 2001, p. 133.

${ }^{145}$ António d’Oliveira Pinto da França (Org.), op. cit., p. 36.

${ }^{146}$ João José Reis, op. cit., 1989. Hendrik Kraay observa que mesmo depois da guerra, um dos problemas que os senhores de engenho tiveram de enfrentar foi o de "restaurar sua autoridade sobre uma população de escravos que havia ouvido e presenciado muitas novidades”. Op. cit., 2006, p. 322.
} 
De qualquer modo, ao corresponderem às proposições oriundas do Rio de Janeiro, parte das classes proprietárias da Bahia reagia a uma possível perda de controle do processo político, já que tudo lhes apresentava indefinido. Luis Henrique Dias Tavares observa, com razão, que a presença das tropas comandadas por Madeira de Melo em Salvador era um problema a exigir solução imediata. Uma tomada de posição das classes dominantes da Bahia, apartada de Portugal, teria de reconhecer a autoridade de d. Pedro I, coroado imperador em $1^{\circ}$. de dezembro de $1822 .{ }^{147}$ Naquelas circunstâncias, a articulação de uma aliança com o herdeiro da dinastia bragantina ampliou, de maneira considerável, a capacidade de resistência do governo de Cachoeira em detrimento dos apoiadores das decisões das Cortes de Lisboa. Mais do que isso, permitiu o refinamento no manejo dos instrumentos políticos que se mostraram eficazes frente o recrudescimento dos conflitos internos naqueles anos. Quando a guerra civil terminou, em 2 de julho de 1823, com a expulsão das tropas portuguesas da capital, uma diversidade de experiências políticas havia deixado seu rastro, cuja significância pode ser ainda mais dimensionada quando se observa outras manifestações desse aprendizado.

\subsection{De capitania a província}

Uma das primeiras proclamações dirigidas pela Junta Provisional de Governo ao exército, ao Senado da Câmara e aos demais residentes da Bahia ainda no dia 10 de fevereiro de 1821, data em que se consagrou a adesão da província às Cortes portuguesas, afirmava que:

Chegou o momento feliz de apresentarem-se vossos heróicos votos. Hoje acabou o Despotismo que sobre nós pesava a mais de três séculos. Nossos Direitos, os mais sagrados, há tanto calcados, surgem hoje do caos tenebroso que os envolvia [...].

Uma sábia Constituição vai proteger-nos. O nosso Adorável Soberano, agora desenganado dos prestígios com que de propósito o fascinaram, vai agora unir-se a nós pelos laços os mais indissolúveis: será o nosso Pai, o nosso apoio, a nossa consolação, e em vez de um espeto de ferro que lhe faziam empunhar, ostentará para nós a Beneficiência, e o verdadeiro Paternal Amor que formam o Seu Coração.

Habitantes da Bahia. O que agora vos cumpre é, a mais fraternal união [...]. e logo se instale o Sábio Provisional Governo, a maior e assinalada obediência às suas disposições, que não poderão ser senão para a nossa felicidade; e isto para que o mundo veja, o que um Povo heróico que só

\footnotetext{
${ }^{147}$ Luis Henrique Dias Tavares, op. cit., 2005, p. 86.
} 
procura regenerar-se, não tem em vista senão a Paz e a Justiça, e para que a grande Obra da Constituição, que esperamos possa prosperar em nossa vantagem. $^{148}$

O discurso dos membros do governo era explícito ao identificar os elementos que caracterizariam uma nova forma de ordem política distinta daquela que até então vigorara nos domínios da Coroa portuguesa. As relações entre a sociedade e o Estado seriam, a partir de então, estabelecidas em uma constituição definida pelas Cortes e a administração local não mais estaria submetida ao amplo poder do antigo governador e capitão-general. Os periódicos trataram de esclarecer ao público sobre as principais diferenças entre um governo monárquico constitucional e os princípios despóticos de um governo absolutista. Em 27 de fevereiro, a gazeta Idade d'Ouro do Brazil escreveu:

E vós, ó porção de compatriotas menos instruídos, que solícitos na melhor escolha do bem avidamente perguntais: que coisa é Constituição? E o que é governo constitucional? Em suma vos respondo, por não caber prolixidade nesta escassa folha: a Constituição, meus compatriotas, o governo constitucional é em resumo um fiel amigo de todo o cidadão, ele sustenta a nossa santa religião, defende a causa da nação, a pessoa do rei, a liberdade civil, o respeito às leis, com a dignidade devida a cada um dos poderes sociais. Tal é a ilustre tarefa, de que se encarregam as nossas Cortes, que se vão celebrar em Portugal, aonde quanto antes mandaremos os nossos deputados, que por nós representem, e sustentem os nossos direitos. As Cortes são uma representação nacional, pela qual só se pode regular invariavelmente os destinos do povo, e fixar para sempre a constância da sua felicidade, porque nas Cortes é onde a vontade nacional é expressada livremente, e escutada com atenção. Nelas se forma a nossa Constituição, onde todo o cidadão deve depositar uma parte da sua liberdade, para garantir ou afiançar os seus direitos individuais [...]. ${ }^{149}$

O Semanário Cívico, ainda mais enfático em suas instruções, produziu, já em seu segundo número, uma forma de diálogo conhecida na época como catecismo político em que se buscava, por meio de perguntas e respostas, elucidar possíveis dúvidas de seus leitores: Que são as Cortes? Que diferença há entre as Cortes antigas, e as que agora se convocam? Que utilidade resulta deste Congresso? Qual é o governo constitucional? Por que dizeis, que esta forma de governo é a melhor? A soberania residirá nas Cortes? foram algumas das questões apresentadas pelo periódico em seus números. Para o redator, esse era um recurso importante para a instrução pública uma vez que considerava não ser suficiente possuir “uma sábia Constituição” sem, no entanto, dispor da educação necessária

\footnotetext{
${ }^{148}$ Proclamação da Junta Provisional de Governo da Bahia, em 10 de fevereiro de 1821. Braz do Amaral, op. cit., 1957, p. 28-29.

${ }^{149}$ Citado por Maria Beatriz Nizza da Silva, op. cit., 1988, p. 29.
} 
para usufruí-la. ${ }^{150} \mathrm{O}$ periódico empenhar-se-ia também na orientação sobre a escolha de um bom deputado para as Cortes, além de observar que apenas em Portugal, na Espanha e na Bahia isso havia sido feito pois não tinha conhecimento que a Gazeta do Rio de Janeiro “se imprimisse alguma coisa a este respeito, e o mesmo [acontecendo] em Pernambuco". 151

Embora esses indivíduos, adeptos de um ideário liberal, estivessem convencidos de que a implantação de uma monarquia constitucional fosse o caminho mais apropriado não apenas para eliminar os males de um Estado absolutista, como também para evitar impulsos radicais de alterações políticas, protagonizaram uma mobilização importante que possibilitou o aprofundamento do aprendizado político de distintas concepções sobre a idéia de inserção política. Curiosa ainda é perceber como a pretensão inicial de defesa da unidade entre os dois Reinos, configurada nas definições das Cortes portuguesa, vai se transmutando para a elaboração de mecanismos que pudessem assegurar a união da província da Bahia associada ao príncipe regente no Rio de Janeiro. Os anos de 1821-1823 constituem, desse modo, um rasgo de experimentação política, sobretudo, para aqueles que nos anos seguintes teriam que lidar com a construção do Império e da nação brasileiros em meio às profundas diferenças existentes entre as províncias e, especialmente, no interior de cada uma. Nesse sentido, é importante destacar como essa dinâmica política interferiu na percepção dos residentes da Bahia dos espaços de representação política com destaque para aqueles que constituíam o canal de ligação entre os residentes e os governos provisórios então constituídos: as câmaras municipais.

Não obstante a idéia de representação política distinta dos princípios de sustentação do Estado absolutista tenha se difundido na Bahia no decorrer do movimento constitucionalista de princípios dos anos 1820, não foi a primeira vez que os residentes de Salvador, particularmente, foram confrontados com a perspectiva de construção desse organismo político. Com efeito, em alguns dos documentos divulgados pelos sediciosos de 1798 aparece, publicamente, a proposição de um sistema representativo corporificado na organização de uma assembléia política então designada por Dieta. Ao discutir sobre o significado dessa proposta nas condições vivenciadas pela capitania em fins do século XVIII, István Jancsó chama a atenção para a novidade dessa expressão considerando a

\footnotetext{
${ }^{150}$ Idem, ibidem, p. 31-32. Para o redator, “[...] não basta possuirmos uma sábia Constituição, que é necessário ter educação adaptada para a receber; que debalde desejaremos que os homens cumpram os seus deveres, se eles ignorarem, quais estes sejam. É pois fundados neste princípio, que nos apressamos em transcrever nesta folha um pequeno Catecismo político, composto nesta cidade por um zeloso cidadão, interessado no bem público que poderá servir para instrução dos meninos nas aulas de primeiras letras”. Loc. cit.

${ }^{151}$ Citado por Lúcia Maria Bastos Pereira das Neves, op. cit., 1994, p. 197.
} 
opção por um termo utilizado para designar diferentes instituições colegiadas na Europa, inclusive, na Polônia que à época servia como referência positiva da idéia de nação, e não de Assembléia ou Assembléia Nacional, como sugeriria a influência da França, ou Parlamento, Câmara ou Congresso, no caso da experiência britânica. O órgão de representação - Dieta -, constituído por "trezentos e noventa e dois Digníssimos Deputados Representantes da Nação”, teria amplos poderes de decisão sobre questões de ordem interna e externa. Ainda que não se tenha indicação sobre o mecanismo a ser utilizado para a constituição da Dieta, além do fato de que provavelmente não tenha se reunido, o que importa destacar, como sugere o autor, é o significado político das proposições do movimento. Conforme afirma, a “idéia de representação política é a primeira inovação de caráter revolucionário que aparece nos Avisos e Prelos”. ${ }^{152}$

Quando a Revolução constitucionalista do Porto eclodiu duas décadas mais tarde, a possibilidade de influir nos destinos políticos da nação portuguesa certamente animou muitos daqueles que acreditavam em outra perspectiva de gestão do Estado a partir das deliberações das Cortes Gerais então convocadas. No plano interno, entretanto, é possível indicar que a perspectiva de influir nos acontecimentos ampliou consideravelmente o empuxo exercido sobre os órgãos deliberativos - Juntas Provisionais de Governo - resultando em um traço indiscutível da dinâmica política do período. Ademais, a intensificação da atividade política propiciou não apenas o alargamento da participação política nesses novos espaços de deliberação política, como também naqueles que já existiam anteriormente, as instituições camarárias. Não se pode esquecer que antes das alterações propiciadas pelo vintismo, os Senados das Câmaras constituíam as únicas unidades administrativas na América portuguesa, o que lhes possibilitava o exercício de amplos poderes. $^{153}$

\footnotetext{
${ }^{152}$ István Jancsó, op. cit., 1996b, p. 176.

${ }^{153}$ Avanete Pereira Sousa, op. cit., 2003, p. 61. Pesquisas recentes têm conferido uma importância fundamental à instituição camarária apontando para um alargamento das suas práticas políticoadministrativas: Alberto Vieira (Org.). O município no mundo português. Seminário Internacional. Funchal: CEHA; Secretaria Regional do Turismo e da Cultura, 1998; Maria Fernanda Baptista Bicalho, op. cit. e da mesma autora "As câmaras municipais no Império português". Revista Brasileira de História, São Paulo, Anpuh; Humanitas Publicações, v. 18, n. 36, 1998, p. 251-280; Maria de Fátima Silva Gouveia. "Redes de poder na América portuguesa. O caso dos homens bons do Rio de Janeiro, 1790-1822”. Revista Brasileira de História, São Paulo, Anpuh; Humanitas Publicações, v. 18, n. 36, 1998, p. 297-330; João Fragoso; Maria de Fátima Gouveia; Maria Fernanda B. Bicalho (Orgs). O antigo regime nos trópicos: a dinâmica imperial portuguesa (séculos XVI-XVIII). Rio de Janeiro: Civilização Brasileira, 2001. Sobre o Senado da Câmara de Salvador. Affonso Ruy. História da Câmara Municipal da Cidade do Salvador. Salvador: Câmara Municipal, 1996; S. Campos. "A Bahia de outros tempos: as posturas do senado da Câmara em 1785”. RIGHBa., 1897, Salvador: Typografia e Encadernações Empresa Editora, v. 7; Avanete Pereira Sousa, op. cit., 1996 e 2003.
} 
O Senado da Câmara de Salvador adquiriu um papel proeminente ao mesmo tempo em que a cidade se dinamizava, realizando uma articulação necessária entre os residentes e o poder metropolitano. Não obstante a ingerência da autoridade régia, os estudos mencionados apontam para uma relativa autonomia da instituição que, não raras vezes, buscava assegurar a prevalência dos interesses locais. Embora os ocupantes dos cargos camarários pudessem ser demitidos quando não exercessem bem a função, a vitaliciedade e a hereditariedade parecem ter sido princípios recorrentes. Não é difícil encontrar indivíduos ocupando sucessivas vezes o cargo de vereador, escrivão ou procurador da Câmara, ou mesmo legar a competência para seus vários descendentes. A rigor, era por meio do órgão camarário que os homens bons poderiam influenciar na gestão local em variados aspectos da vida citadina:

Isto porque as câmaras de faziam presentes em todo o Império, tornandose espaços instituídos para mediar as relações contraditórias entre os diversos interesses em jogo, possuindo, para tanto, certa autonomia que, de fato ou de direito, lhes estava atribuída em todos os ramos da sua competência. Assim, elevavam-se, à condição de um dos organismos político-administrativos mais importantes na estrutura do poder estatal do Antigo Regime português. ${ }^{154}$

John Norman Kennedy observa que os integrantes da elite baiana estavam determinados a utilizar os órgãos do governo para atingir os seus propósitos, resultando daí alguns dos conflitos com os residentes locais como mencionado acima. Segundo ele, os grandes proprietários de terras eram bem representados no Senado da Câmara de Salvador em fins do século XVIII e início do seguinte. Seria o caso, por exemplo, da família Ferrão Castelo Branco, cujos membros ocuparam sucessivamente cargos no órgão camarário, da mesma maneira que os Pires de Carvalho e Albuquerque e os Rocha Pita, essa última representada treze vezes no período entre 1750-1808. O envio dos filhos para a Universidade de Coimbra constituía um recurso importante na preparação para a futura ocupação de cargos burocráticos. Nessa perspectiva, o autor não acredita que o setor mercantil da Bahia tenha suplantado os proprietários de terra na ocupação do poder político em Salvador, uma vez que esses permaneceram atuando ativamente no Senado da Câmara, assim como em postos importantes da administração local. ${ }^{155}$ Para o caso do Rio de Janeiro, Maria de Fátima Silva Gouvêa assinala que a análise das listas nominais dos

\footnotetext{
${ }^{154}$ Avanete Pereira Sousa, op. cit., 2003, p. 102.

155 John Norman Kennedy, op. cit., p. 432-433. Kátia Mattoso informa que Felisberto Caldeira Brant Pontes, futuro Inspetor Geral de Armas da Bahia, ocupou o cargo de vereador nos anos de 1806, 1812 e 1813 . Op. cit., 1992, p. 256.
} 
vereadores entre os anos de 1790-1822 indica uma mudança no perfil dos ocupantes dos cargos camarários. Conforme afirma, em fins do XVIII, os conselhistas aparecem como negociantes, pouco se referindo às suas relações de parentesco, diferentemente de 1822 quando "se apresentavam sob o signo dos títulos honoríficos e das relações familiares que os uniam. A imagem que se queria passar parecia ser aquela de uma sólida família, unida pelos valores da distinção social [...], assim como pelo sentimento promovido pelo pacto estabelecido entre a Coroa - agora já brasileira - e os seus nobres súditos”. ${ }^{156}$ Essa metamorfose social estaria relacionada com o impacto causado no Senado da Câmara da corte pela elevação do Brasil à condição de Reino. O comportamento do órgão frente aos novos acontecimentos, bem como a permanência mais duradoura de determinados homens bons nos cargos da governança, parecem indicar uma estreita articulação entre esses indivíduos e a Coroa portuguesa. Os diversos títulos concedidos ao senado traduzir-se-iam como um reconhecimento dessa representação.

Certamente a instalação da corte na América imprimiu fortes alterações no comportamento dos membros das classes proprietárias motivados pela proximidade do centro do poder e a dilatação das possibilidades na gestão da coisa pública, conforme assinalado. Todavia, como essa mudança repercutiu na composição dos órgãos camarários da Bahia e, em especial, de Salvador, nos primeiros decênios de 1800 é uma questão que demanda estudo mais apurado. Para o que se pretende, interessa realçar como essas instituições absorveram os acontecimentos políticos característicos do movimento vintista considerando que, para a maior parte dos residentes da província, eram os únicos centros de discussão e deliberação política.

Desde a chegada de d. João ea Salvador, em 1808, os membros do Senado da Câmara, esforçaram-se para assegurar que os vínculos entre os residentes da Bahia e o regente fossem mais intensificados. Provavelmente antes mesmo de sua partida para a nova sede da corte, a instituição foi portadora de uma representação, da mesma maneira que havia procedido o corpo de comércio daquela praça, na qual suplicava "para si e por todos os habitantes desta cidade", que o príncipe preferisse Salvador ao Rio de Janeiro para se estabelecer. De acordo o documento, as justificativas para o pedido não se fundamentavam na posição geográfica da cidade, nem mesmo na riqueza de sua economia de exportação e dos seus negócios internos ou ainda na grandeza da sua povoação, antes se sustentavam

\footnotetext{
${ }^{156}$ Maria de Fátima Silva Gouvêa, op. cit., 1998, p. 324. A pesquisadora alerta para algumas lacunas nas listas consultadas que, todavia, não impediram estabelecer parâmetros mais gerais para avaliar o perfil dos "homens de governança".
} 
na consciência, e na notoriedade do caráter sensível e extremamente afetuoso que distingue os seus Habitantes. Não são as fortificações que seguram os Impérios os trabalhos de muitos tipos caem ao ataque de poucos dias o caráter, porém, de um Povo não se muda facilmente: sentimentos afetuosos são os baluartes inexpugnáveis do Trono. A experiência tinha já desenganado a Europa das quiméricas idéias de fazer conquistas nesta longínqua, e vasta Região, antes que V.A.R. lhe pusesse a Planta; e a recente desgraça experimentada em Buenos Aires pelas arenas Inglesas que tinha a sua mercê os mares, acabou de confirmar aquele desengano; se porém houvesse ainda Nação, que se deixasse iludir com tais projetos, e se aproximasse a estas costas, nossa coragem, e nossos esforços se cresceriam com a presença de V.A.R. e quando se pudesse presumir algum infortúnio decerto efêmero, este Senado, Senhor levaria em seus ombros a V.A.R., e sua Augusta Família, ao interior destas terras, e sertões inacessíveis a todo o poder humano. E que Povo, Senhor, será mais digno de presenciar, e de admirar cada dia a Bondade Paternal de V.A.R. e deixar de afirmar, digo Nem os suplicantes podem calar seus justos receios da diminuição da feliz saúde de V.A.R. e deixar de afirmar que a Cidade do Rio de Janeiro é famosa pela sua atmosfera quase sempre anuviada por trovoadas horrorosas, por enfermidades endêmicas.

De mais esta é a Cidade Metropolitana, a que foi a residência do Vice Reinado; e as considerações que exigiram outrora a sua mudança ficam destruídas pela Presença de V.A.R. enfim Senhor a Providência Divina, que guiou V.A.R. atenderá aos justos motivos da nossa súplica, e desde logo esta Cidade concebeu a firme confiança de recobrar a sua primazia incomparavelmente melhorada. ${ }^{157}$

Para além de um discurso enaltecedor do soberano, típico da linguagem da época, ficam evidenciadas no texto as expectativas alimentadas pelos signatários de um futuro promissor ante a presença do príncipe na América. A Bahia, não apenas conservava as condições ideais para a residência do regente, como também poderia recuperar a primazia ocupada anteriormente quando sediava a capital do Vice-Reino. Curioso observar que um dos membros do conselho era o proprietário de terras e engenhos, Francisco Elesbão Pires de Carvalho e Albuquerque que tempos depois seria o secretário da segunda Junta Provisional de Governo da Bahia e, posteriormente, o presidente do Conselho Interino de Governo instalado em Cachoeira.

E o Senado da Câmara não demorou muito para encaminhar uma nova representação ao regente. Em 16 de julho de 1808, os camaristas solicitaram a extensão do decreto real de 11 de junho de 1734 para que a capitania da Bahia gozasse das mesmas prerrogativas da cidade de Lisboa. Segundo os peticionários, o órgão municipal possuía "as

${ }^{157}$ Registro da Súplica que fez o Senado a V.A.R. para si e por todos os habitantes desta cidade rogando-lhe haja de preferir para o seu Real Estabelecimento esta Cidade a do Rio de Janeiro, s/d. APEB. Seção de Arquivo Colonial e Provincial. Cartas do Senado a Sua Magestade. Maço: 132 (1742-1823). 
mesmas pensões e necessidades” do Senado da Câmara daquela cidade no que dizia respeito às despesas com "as obras públicas e seus reparos, Pontes, Fontes, calçadas, e Festas, e Procissões Reais”, além de ter que satisfazer os "soldos dos sargentos mores e Ajudantes dos Corpos Milicianos, e os emolumentos dos Governadores, e Capitães Generais da Capitania, Ouvidores da Comarca, Juizes de Fora, Crime, e Órfãos”, vendo-se impossibilitada de cumprir essas obrigações tendo em vista a "impiedade de seus antigos [...] credores, que penhorando todos os dias as suas rendas, não só não atendem as obrigações do Senado, senão que nem mesmo as terças de V.A.R. que não podem ser tocadas”. 158

As queixas sobre a penúria dos rendimentos do Senado parecem ter sido uma constante nos anos anteriores. Conforme assinala Avanete Pereira Sousa, embora as rendas da Câmara de Salvador excedessem em volume a arrecadação da maioria das instituições similares metropolitanas, "a tendência para o endividamento do erário local soteropolitano, ou seja, o precário equilíbrio entre receitas e despesas, foi realidade incontestável, oriunda das constantes demandas do poder central e da definição de prioridades do próprio poder municipal, face ao desenvolvimento da cidade”. ${ }^{159}$ A capitania da Bahia possuía uma significativa carga tributária, assim como réditos de concessões comerciais. Isso faria da sua capital, um importante centro administrativo-financeiro para o poder metropolitano: "Pela função de cabeça do Estado do Brasil, Salvador atendia a essas e ainda a outras esferas da política do poder central para toda a colônia, tornando-se uma espécie de aparato fiscal da coroa portuguesa em território americano”. ${ }^{160}$ Ao que tudo indica, a precariedade das finanças do Senado somente se agravou nos anos seguintes. Uma correspondência encaminhada pelos vereadores à Junta da Real Fazenda, em 26 de agosto de 1818, confirmava que a tesouraria do órgão possuía uma dívida de 16:709\$811 (dezesseis contos, setecentos e nove mil e oitocentos e onze réis) a despeitos de todo o seu

\footnotetext{
${ }^{158}$ Regimento da Representação que fez o Senado a V.A.R. pedindo-lhe a Extensão do Real Decreto de 11 de Junho de 1734 a favor desta Capitania, em 16 de julho de 1808. APEB. Seção de Arquivo Colonial e Provincial. Cartas do Senado a Sua Magestade. Maço: 132 (1742-1823).

${ }_{159}$ Avanete Pereira Sousa, op. cit., 2003, p. 201. Segundo a autora, no decorrer do século XVIII foram constantes as reclamações dos vereadores que, por diversas vezes, solicitaram do seu procurador em Lisboa intervenção junto ao rei para obter a "isenção do pagamento das terças, sob a alegação de que o valor a elas correspondente seria investido na própria cidade”. Os pedidos não somente seriam negados como tiveram sua cobrança intensificada.

${ }^{160}$ Idem, ibidem, p. 139. Na definição de Ilmar Rohloff de Matos, "a cidade colonial se distingue, antes de tudo, pelas funções de porto e centro administrativo, caracterizando, desta forma, o poder do colonizador e expressando a assimetria do pacto colonial”. O tempo saquarema. A formação do Estado Imperial. 3. ed. Rio de Janeiro: Acess Editora, 1994, p. 28.
} 
empenho para amortizá-la, “mas as suas rendas estão inteiramente esgotadas”. Dentre as justificativas que resultaram na falta de pagamento do débito:

as Públicas demonstrações de Alegria que nos últimos anos tem sido forçoso a cumprir com grande dispêndio, a folha anual a que com alimentos não pode impugnar, o miserável estado das entradas, ruas, ladeiras, fontes, e que assim mesmo se vão lentamente reparando, e com grandes despesas, e ainda as grandes despesas digo as grandes dívidas atrasadas, e grandes somas, e até proveniente de jornais, e salários das mesmas antigas obras, não são aparatosas de mau pagador, são verdadeiras impossibilidades demonstradas, e públicas [...]. Em tais circunstâncias todos os esforços possíveis serão empregados para a amortização da dita soma os quais todavia só poderá conseguir-se com indispensável prejuízo, e detrimento do Público, a cujo Beneficio mais se não poderá acudir, a fim de se poder melhorar digo afim de se poder do melhor modo obedecer a Vossa Magestade. ${ }^{161}$

As manifestações públicas de júbilo a que se referem certamente incluíam as extensas homenagens prestadas ao ex-governador da capitania, d. Marcos de Noronha e Brito, por ocasião da sua nomeação como ministro e secretário de Estado, e os festejos pela aclamação de d. João VI, ocorrida em 6 de fevereiro de 1818. Nesse último caso, a Câmara ainda havia enviado dois representantes para cumprimentar o monarca: Felisberto Caldeira Brant Pontes e Francisco José de Matos Ferreira e Lucena. Não deixa de ser significativo o fato de os vereadores registrarem que a Bahia foi quem primeiro usufruiu da presença do príncipe; também a que havia erigido um monumento público para eternizar a memória daquela época “e que ostenta a sua Lealdade a Vossa Magestade, não só adorando como deve, ao seu Amabilíssimo Soberano, mas até tendo ela so rido[sofrido] bastante a tornar sólidos, e gerais os princípios de sua Fidelidade”. ${ }^{162}$

Além das dificuldades com o erário, os registros evidenciam que o órgão camarário enfrentava problemas de outra natureza que, a rigor, não eram novos. Em uma correspondência enviada à corte, os vereadores queixaram-se das dificuldades para executar algumas atividades em função da desobediência de alguns indivíduos a suas determinações. As reclamações feitas ao Senado - violência, despotismo, infração de direitos -, diziam, soavam como "impropérios que avilta a corporação no conspecto do Povo” resultando em seu “desprezo público”. Para os signatários, um comportamento que

\footnotetext{
${ }^{161}$ Registro da Resposta do Senado à Junta da Real Fazenda em que diz as circunstâncias em que se acham as rendas do concelho. APEB. Seção de Arquivo Colonial e Provincial. Cartas do Senado a Sua Magestade. Maço: 132 (1742-1823).

${ }^{162}$ Registro da carta que o Senado escreveu a Sua Magestade participando ao Mesmo Senhor ter enviado dois deputados para aceitar a Sua Glorioza Aclamação por parte deste Senado e de todo o Povo Bahiense, em [ ] janeiro de 1818. Idem, ibidem.
} 
merecia ser repreendido, afinal, os membros do Senado haviam sido eleitos porque “entraram nos Pelouros, e nestes não entram senão os principais da cidade, os mais distintos e os mais abastados”. ${ }^{163}$ De algum modo, parece claro que havia uma tentativa dos residentes de pressionar o órgão camarário em determinadas ocasiões forcejando uma ampliação de sua esfera de atuação política, conforme assinalado acima. Senão, como entender o pedido dos membros da Câmara de Salvador ao príncipe regente, em uma carta provavelmente escrita entre 1811 e 1812, de que expressamente lhes poupasse das acareações populares e determinasse que "não seja a Câmara mais exposta face a face a Censura do Povo; mais sim ouvido por escrito, como até esta época de intriga se tinha constantemente praticado"? ${ }^{164}$ São questões que necessitam de maior aprofundamento, no entanto, ajudam a entender a intensa mobilização dessas pessoas no momento em que alguma perspectiva de mudança política foi posta com as notícias sobre a Revolução constitucionalista do Porto e, sobretudo, com os seus desdobramentos.

Uma das determinações do decreto de 29 de setembro de 1821 foi a criação das Juntas Provisionais de Governo, independentes entre si e submetidas diretamente às Cortes e ao governo de Lisboa. Essa medida redimensionou os espaços de decisão política até então existentes nas partes americanas do Brasil Reino. Além disso, as instruções para a eleição dos deputados que deveriam integrar as Cortes Gerais reunidas em Lisboa "não reconheceram as antigas unidades administrativas, as Câmaras, como unidades eleitorais, e atribuíram às freguesias, tradicionalmente ligadas à esfera eclesiástica, o grau primário e mais amplo das eleições”. A partir de então, as tradicionais capitanias seriam reconhecidas como unidades provinciais, admitindo que possuiriam também alguma autonomia na eleição dos deputados. ${ }^{165}$

A despeito dessas alterações, os Senados das Câmaras não ficaram alheios à movimentação política. ${ }^{166}$ Pelo contrário, no caso da Bahia, o Conselho Interino de

\footnotetext{
163 Registro da Representação que fez o Senado a Sua.Majestade pedindo a declaração dos seus direitos $e$ jurisdição, s/d. Idem, ibidem.

${ }^{164}$ Registro da carta que o Senado dirigiu a S.A.R., s/d. Idem, ibidem.

${ }^{165}$ Márcia Regina Berbel, op. cit., p. 49.

${ }^{166}$ Iara Lis Carvalho Souza. “A adesão das câmaras e a figura do imperador”. Revista Brasileira de História. São Paulo, Anpuh; Humanitas Publicações, v. 18, n. 36, 1998, p. 367-394. A autora argumenta que ao serem responsáveis pela realização das eleições que escolheriam as juntas, as câmaras gozariam de certa evidência nas províncias, frente às Cortes e ao Rio de Janeiro. Para alguns estudos recentes sobre a participação dessas instituições na conjuntura política dos anos 1820: Renato Leite. "Câmaras das cidades do Rio de Janeiro e de Recife à época da Independência do Brasil 1822-1824”. Alberto Vieira (Org.). O município no mundo português. Seminário Internacional. Funchal: CEHA; Secretaria Regional do Turismo e da Cultura, 1998, op. cit, p. 483-490; Iara Lis Franco S. C. Souza. Pátria coroada: o Brasil como corpo político autônomo 1780-1831. São Paulo: UNESP, 1999; André Nicácio Lima. “As câmaras municipais na crise da Independência: Minas Gerais, Mato Grosso e Goiás (1821-1825). Almanack Braziliense, São Paulo, n. 1,
} 
Governo de Cachoeira funcionava como uma coordenação das decisões das Câmaras do Recôncavo que não ficaram inertes. ${ }^{167}$ Do mesmo modo, nos lugares distanciados das sedes dos governos provisórios, a intensificação da atividade política pode ser dimensionada pela mobilização da população local junto aos órgãos camarários de diversas vilas. Tema ainda pouco explorado pela historiografia. Curioso é que em alguns lugares os residentes não apenas dilataram a sua participação nessas instituições, como também decidiram instalar suas próprias Juntas de Governo apontando para uma forma de organização política mais condizente com as alterações do período. Na vila de Rio de Contas, por exemplo, no Alto Sertão da Bahia, em 14 de agosto de 1822, depois da manifestação de mais de "quinhentos homens armados”, decidiu-se pela aclamação de d. Pedro e a instalação de uma Junta Temporária. Embora os seus membros informassem ao Conselho Interino dois meses depois que reconheciam a sua autoridade e desejavam cooperar para restaurarem a província, a iniciativa não obteve a aprovação do governo de Cachoeira. ${ }^{168}$ Argemiro Ribeiro discute como essa fragmentação do poder, que não ocorreu apenas em Rio de Contas, resultou em fortes divergências com o Conselho Interino que, por diversas vezes, condenou veementemente a "multiplicidade de governos parciais", vista como um empecilho para efetivar a sua centralização de poder. ${ }^{169}$ Importante destacar que a Junta Temporária de Rio de Contas estabeleceu-se algum tempo depois da Junta Interina, Conciliatória e de Defesa criada em Cachoeira (26 de junho), com uma perspectiva ainda restrita de atuação, e antes mesmo da instalação do Conselho Interino de Governo nessa mesma vila (6 de setembro), evidenciando que o quadro de tensão política espraiava-se para além dos marcos da capital e do Recôncavo baianos.

Para tentar coibir a ação das vilas sertanejas, o Conselho recorreu a d. Pedro, por intermédio de seu ministro José Bonifácio de Andrada e Silva, para que chamasse “à ordem as vilas do Rio de Contas e Caetité que fazem economia separada da família provincial e se têm subtraído a autoridade deste Conselho Interino conservando seus governos”, além de reconhecer que outras vilas organizaram governos semelhantes. ${ }^{170}$ Como observa o autor, àquela altura, o governo provisório de Cachoeira não apenas teria que se confrontar com as decisões da Junta Provisional de Salvador, em meio a uma guerra

maio de 2005, p. 114-119. Alguns documentos das câmaras da Bahia encontram-se publicados em: As câmaras municipais e a Independência. Conselho Federal de Cultura/Arquivo Nacional, 1973, v. 1

${ }^{167}$ Wanderlei Pinho, op. cit., p. 258.

${ }^{168}$ Cf. Argemiro Ribeiro de Souza Filho, op. cit., 2003, p. 90 e seq.

${ }^{169}$ Idem, ibidem.

${ }^{170}$ Registro de correspondência expedida pelo Conselho Interino de Governo, em 17 de dezembro de 1822. APEB. Seção de Arquivo Colonial e Provincial. Maço: 637-2. Citado por Argemiro Ribeiro, op. cit., p. 92. 
civil, como também lidar com a autonomia política reivindicada por alguns núcleos interioranos. Em função disso, o Conselho não somente teria rejeitado o nome do deputado eleito por Rio de Contas para integrar o governo provisório, o capitão José Valentim de Souza, alegando que fora "eleito pelos membros da Junta Conciliatória do distrito, e não pela câmara e homens bons da vila e do termo”, como também determinado a prisão dos membros daquele governo. A despeito das medidas reguladoras do Conselho, os conflitos internos nessas vilas, particularmente, revelaram uma complexa situação de instabilidade política de difícil controle por parte das autoridades mesmo após o fim do conflito militar. $^{171}$

Um outro episódio exemplifica a dinâmica política do período. Em 25 de dezembro de 1822, os membros do Conselho Interino foram informados que os moradores da freguesia de Santa Cruz, vinculada à vila de Porto Seguro, no Sul da Bahia, ao aclamarem d. Pedro como imperador decidiram também elevar a localidade à categoria de vila, o que implicava no estabelecimento de uma Câmara. Alguns meses depois, o Conselho cumprimentou-os pela decisão recomendando, entretanto, que deveriam esperar a deliberação do imperante "sem o que não se pode essa freguesia se considerar vila, nem ser válida a nomeação que fizeram de capitão-mor, pois que não é livre aos povos dar-se títulos". 172

Embora na capital da província uma Junta Provisional de Governo fora instalada desde o dia da adesão ao movimento constitucionalista, o Senado da Câmara também esteve no centro de alguns dos importantes acontecimentos registrados naqueles primeiros anos de 1820 em Salvador. Em 15 de junho de 1822, o procurador do Conselho registrou que uma tropa de cavalaria impediu a reunião de vereadores no dia 12 afirmando que "era destinada a prender a Câmara se intentasse a aclamar o Príncipe Regente”. Procedimento que, segundo ele, não teria qualquer fundamento. ${ }^{173} \mathrm{O}$ periódico $O$ Constitucional condenou fortemente aquela atitude em um artigo de 22 de junho reproduzido pelo El Patriota:

No es necesario ser profesor de derecho para censurar tal medida como opresiva y anticonstitucional. No sabiamos si la Càmara pretendia o no

\footnotetext{
${ }^{171}$ Presidência da Província - Registro de correspondência expedida, em 25 de dezembro de 1822. APEB. Seção de Arquivo Colonial e Provincial. Maço: 1618. Citado por Argemiro Ribeiro, op. cit., p. 94. A informação sobre a ordem para aprisionar os membros da Junta de Rio de Contas encontra-se na página 93 e passim.

${ }^{172}$ Registro dos Ofícios Expedidos pelo Conselho Interino de Governo da Província da Bahia. APEB. Seção de Arquivo Colonial e Provincial. Maço: 632-1 (1823).

173 Termo, de 15 de junho de 1822. Documentos da Municipalidade de Salvador relacionados com a Independência do Brasil, 1821-1823, op. cit., p. 61.
} 
mandar tocar la senal de estilo para oir á los ciudadanos sobre aquel asunto; pero supongamos que lo hubiese hecho. ¿Cuál era el objeto de aquella gente armada? ¿Llamar los cuerpos de los cuartelos á la plaza? ¿Para que? ¿Para impedir que la Càmara consultase al pueblo sobre este importantisimo negocio, y aclamase á S.A.R. Regente del Brasil? Y ¿Como lo inpedian? ¿Matando, ó prendiendo la Càmara y ciudadanos? No hablemos de lo primero, pues solamente de fieras antropófagas, y hamas de hombres, se pueden presumir ordenes de tanta iniquidad, y para ser ejecutadas ¿por quienes? Por hombres, y hombres portugueses contra portugueses. ¿Qué ciudadano veria al primer tribunal municipal de la província, vilipendiado y preso, sin que se considerase inmediatamente esclavo de una cohorte pretoriana? La vida entonces era pequeño sacrificio para sostener la libertad proclamada. ${ }^{174}$

As divergências entre o general Madeira de Melo e os membros do Senado da Câmara vieram à tona depois que o órgão recusou-se a efetivar a sua posse como governador das armas da Bahia em fevereiro desse ano. Vale lembrar que um dos vereadores naquela ocasião e um dos maiores críticos à sua nomeação era Francisco Gomes Montezuma, principal redator de O Constitucional.

Poucos dias antes daquela ocorrência, em 10 de junho, o general havia encaminhado uma correspondência à Junta Provisional de Governo queixando-se do comportamento do Senado da Câmara e do periódico. Segundo ele, a instituição descumpria o juramento que havia feito de obediência às Cortes quando agia em comum acordo com o Rio de Janeiro. Essa atitude seria "suficiente para a qualificar de criminosa” e, mais do que isso, aliada com o periódico, pretendia "sublevar o povo”. As condições instáveis em que se encontrava a província recomendavam, em seu entender, maior cautela, sobretudo, naquelas circunstâncias, “em que o povo tem sido levado a um alto grau de efervescência, é perigoso tudo que tende a pô-lo em agitação, e quantas providências se devem para contê-lo nos seus devidos limites não são demasiadas”. O general referia-se, especificamente, à publicação de um artigo no periódico que conclamava os povos para se unirem ao regente, “dirigindo a opinião pública de uma maneira própria para produzir a anarquia e guerra civil”. Era necessária que a Câmara e a Junta Provisional, “as duas principais autoridades da província”, estivessem harmonizadas para o estabelecimento da ordem. Em função disso, solicitava providências do governo provisório. ${ }^{175}$

\footnotetext{
${ }^{174}$ El Patriota, n. 1, Montevideo-Viernes, 17 de agosto de 1822.

${ }^{175}$ Correspondencia do general Madeira de Melo à Junta Provisional de Governo, em 10 de junho de 1822. Mello Moraes, op. cit., t. II, 1982, p. 115-117.
} 
A Junta limitou-se, no dia seguinte, a atenuar as queixas do general. Não poderia, afirmou, cercear o direito de os indivíduos manifestarem os seus pensamentos que era permitido por lei. Também não garantia que o redator de $O$ Constitucional, assim como de todos os outros jornais que circulavam mantinham-se "nos limites da prudência e circunspeção, que exigem as nossas delicadas circunstâncias”, tendo em vista que "em vez de empregarem sua influência em neutralizar os ódios e partidos, desgraçadamente desenvolvidos entre nós, e inculcar o respeito devido às autoridades para se firmar o império da ordem, têm muitas vezes exacerbado os mesmos partidos”. Quanto à Câmara, não lhe parecia que estivesse tramando "alguma revolução nesta cidade” e que pretendia propiciar qualquer distúrbio, considerando o juramento feito às Cortes e ao rei. Além disso, a idéia de uma guerra civil era inconcebível, estando o povo desarmado e o general à frente da tropa armada o que lhe seria "muito fácil conter qualquer pequena porção de turbulentos, que pretenda ainda alterar a paz de que gozamos”. ${ }^{176} \mathrm{O}$ agravamento das tensões na província nos dias seguintes mostraria a percepção dos membros da Junta estava equivocada.

Talvez devido à falta de reação da Junta é que Madeira de Melo tenha decidido cercar o Senado da Câmara naquele 15 de junho. Dez dias depois, em um oficio enviado à instituição voltava a condenar o comportamento do órgão e do periódico O Constitucional que incitava o "Povo sempre disposto a abraçar a novidade, e quase nunca conhecedor dos males, que podem daqui resultar, idéias que talvez possam ser lhe mui funestas”. ${ }^{177}$ Ainda que demonstrava não ter dúvidas quanto às pretensões da Câmara, reclamava o uso da prudência:

O Povo ilude-se muitas vezes a respeito do poder das Câmaras persuadindo-se que elas podem decidir as grandes questões da Nação esta influência é muita perigosa nas revoluções e ela por si mesma deve recomendar-se a Vigilância de V.Exas. Eu rogo a V.Exas. de persuadirem-se de que as minhas palavras São ditadas tão somente pelo amor da Pátria, da Constituição e da boa Ordem, e que eu me julgarei feliz sempre que o povo guardar os limites em que deve conservar-se para não ser conduzido a desgraça. ${ }^{178}$

\footnotetext{
${ }^{176}$ Correspondência da Junta provisional de Governo ao general Madeira de Melo, em 11 de junho de 1822. Idem, ibidem, p. 117-119.

${ }^{177}$ Oficio de Madeira de Melo criticando o Senado da Câmara e o periódico "O Constitucional", em 25 de junho de 1822. Documentos da Municipalidade de Salvador relacionados com a Independência do Brasil, 1821-1823, op. cit., p. 66.

${ }^{178}$ Idem, ibidem, p. 68.
} 
Pouco mais de um ano depois desse registro, o general Madeira de Melo seria expulso da província com as tropas portuguesas. Em meio às deliberações para a retomada do controle político-administrativo da cidade, o Senado da Câmara realizou um ato solene convocado por meio de editais públicos, em 16 de julho de 1823, para o reconhecimento público do governo do imperador d. Pedro I. Em 25 de novembro, Francisco Vicente Viana, o antigo presidente da Junta Provisional de Governo, foi indicado como presidente da província. Conhecido por seu temperamento conciliador, a nomeação de Viana era feita alguns dias após o imperador dissolver a Assembléia Geral Constituinte (decreto de 12 de novembro de 1823), convocada em junho do ano anterior. Essa atitude de d. Pedro I resultou em uma reação curiosa por parte das autoridades locais. Segundo registro feito por Ignácio Accioli, as notícias sobre o fechamento da assembléia chegaram a Salvador um mês depois trazidas pelos deputados Miguel Calmon du Pin e Almeida e Antônio Calmon du Pin e Almeida, que se encarregaram de tranqüilizar os membros da Câmara. No documento encaminhado ao órgão, os irmãos Calmon esclareceram sobre o seu comportamento no período em que atuaram no legislativo, declarando que o imperador "no referido Decreto da dissolução da Assembléia, promete convocar outra representação nacional, para trabalhar sobre um projeto, que lhe há de apresentar, e que será duplicamente mais liberal, que o projeto condenado pela extinta Assembléia”. ${ }^{179}$

A despeito disso, o Senado reuniu um número considerável de pessoas que condenaram a decisão de d. Pedro I, ao mesmo tempo em que exigiram do governo da província a formação “de um conselho composto das principais pessoas” para tomar medidas necessárias à segurança pública, constando as deliberações em uma ata. Ocorre que no dia da reunião do conselho, 17 de dezembro, os presentes decidiram rever a posição anteriormente tomada. Conforme registraram, depois de ponderar sobre "as circunstâncias extraordinárias, e assustadoras, em que se acha esta província, onde infelizmente a segurança individual é a cada passo atacada por continuados motins, e assuadas, e aonde é quase nenhum o respeito devido a todas as autoridades constituídas, em maneira que a cada momento se nos oferece o horrível aspecto da anarquia”, acordaram por unanimidade: a anulação da ata do dia 13, tendo em vista as "expressões pouco refletidas" decorrentes da

\footnotetext{
179 Ofício dirigido ao Senado da Câmara de Salvador, em 13 de dezembro de 1823. Ignácio Accioli, op. cit., v. IV, p. 103. Os deputados que haviam sido eleitos pela Bahia, em 23 de maio de 1823, para a Assembléia Geral Constituinte foram: Cipriano José Barata de Almeida (612 votos), Antônio Ferreira França (595), Francisco Agostinho Gomes (524), Francisco Carneiro de Campos (477), Manuel Antônio Galvão (453), Felisberto Caldeira Brant Pontes (329), Miguel Calmon du Pin e Almeida (322), Manuel Ferreira de Araújo (300), Francisco Ge Acayaba Montezuma (298), José da Costa Carvalho (279), Luis José de Carvalho e Melo (193). Cipriano Barata não assumiu a vaga. As juntas governativas e a Independência, op. cit., p. 826.
} 
efervescência pela notícia da dissolução da assembléia. Em vista disso, o governo da província deveria ordenar a Câmara "que faça riscar, e borrar a mencionada ata, de sorte que não possa ser lida em tempo algum”. ${ }^{180}$

Os conselhistas decidiram ainda comunicar ao imperador a mágoa com que receberam a notícia sobre o fechamento da assembléia, solicitando que apresentasse "com a maior brevidade o prometido projeto de Constituição, duplicamente mais liberal, que o da extinta Assembléia [...] removendo assim a desconfiança dos povos, que ora se acha em extremo açulada”, além de solicitar a restituição dos deputados que haviam sido presos e expulsos do Brasil. Agradeceram a nomeação do ministério e conselho de Estado somente de "súditos nascidos no Brasil", ao mesmo tempo em que requeriam o preenchimento de cargos na província com os mesmos critérios, entre outras deliberações. ${ }^{181}$ Três dias depois foi lançado um manifesto aos habitantes da província com o intuito de atenuar o impacto sobre as últimas notícias vindas do Rio de Janeiro,

Habitantes da Bahia! Passou o assombro do raio, que vos feriu; convém agora examinar seus estragos, ou conseqüências. A dissolução da Assembléia Geral Constituinte e Legislativa parecia à primeira vista arrastar após si a perda da justa liberdade, que tanto desejamos; mas não aconteceu assim. O Decreto de 12 de novembro próximo passado pelo qual Sua Majestade Imperial dissolveu a Representação Nacional, é o mesmo que convoca uma nova Assembléia: mudaram-se os obreiros, porém o Plano do Edifício começado continua. O Governo Imperial ainda se conduz pelos princípios Constitucionais que todos havemos jurado $\left[\ldots . . .{ }^{182}\right.$

O documento clamava pela unidade entre os baianos e a confiança no Imperador e nas autoridades: "Seja a nossa divisa Independência Constitucional, ou Morte”, prometendo divulgar a ata da reunião do Conselho com as medidas que haviam sido aprovadas. ${ }^{183}$

Em 19 de janeiro de 1824, Francisco Vicente Viana tomou posse na presidência da província. No dia 10 do mês seguinte, exatamente três anos após a adesão da Bahia ao constitucionalismo, o Senado da Câmara, juntamente com o presidente empossado, "as Autoridades Eclesiásticas, Civis e Militares e mais cidadãos abaixo assinados”, reunia-se para avaliar o projeto de constituição entregue pelo imperador. Os presentes decidiram

\footnotetext{
${ }^{180}$ Ata do Conselho da província da Bahia, em 17 de dezembro de 1823. Ignácio Accioli, op. cit., v. IV, p. 106.

${ }^{181}$ Idem, ibidem, p. 106-107.

${ }^{182}$ As juntas governativas e a Independência. Rio de Janeiro: Arquivo Nacional/Conselho Federal de Cultura, 1973, p. 856.

${ }^{183}$ Idem, ibidem. Loc. cit.
} 
encaminhar duas observações sobre a carta proposta, esclarecendo, no entanto, que as mesmas não deveriam

de maneira alguma empecer, ou embaraçar o juramento, e observância do Projeto, como Constituição, mas sim que muito respeitosamente se levassem à Presença e Consideração de S.M.I. para o Mesmo Augusto Senhor Dar-lhes a atenção que julgar conveniente, e compatível com o bem do Império, pelo qual S.M.I. se Tem Mostrado tão zeloso, e Interessado. $^{184}$

Depois de indicarem a reflexão sobre o artigo 137 que estabelecia a vitaliciedade dos conselheiros de Estado (“qualidade sem dúvida contrária à natureza de seus cargos, a confiança, e Dignidade de S.M. Imperial, e mesmo ao Bem Geral”) e sobre a natureza da força militar de $2^{\mathrm{a}}$ linha ("não sejam obrigados a sair fora do seu distrito, senão quando perigar a Independência e integridade do Império”), sugeriam a convocação “o quanto antes, e em qualquer tempo [d]o Corpo Legislativo na forma determinada no Projeto, que fica como constituição, Dignando-se de desistir do propósito de reunir uma nova Assembléia Constituinte para o Império”. Entre os argumentos para esse último ponto, o fato de as eleições não terem mais sentido com o juramento da constituição e, além disso, com a sua repetição sentiam "os povos gravíssimos incômodos pelas grandes distâncias da província [...]”. Na ocasião, aproveitaram para agradecer ao imperante a consideração que tivera com a ata do conselho reunido no dia 17 de dezembro, "fazendo completa Justiça ao nosso Patriotismo, [e] adesão que temos à Sua Imperial e Sagrada Pessoa”, requerendo que não deixasse de visitar a província conforme notícia transmitida pelos emissários da Câmara. Por fim, decidiram que a ata dessa reunião seria encaminhada a todas as Câmaras da província para que o conjunto dos habitantes acordasse a "maneira de pensar, e sentir de seus concidadãos sobre o mais importante objeto, como é o de uma Constituição ou Lei Fundamental da que tem depender nossa presente e futura felicidade”. ${ }^{185}$

As experiências individuais e coletivas desses indivíduos haviam possibilitado renovar as suas expectativas de futuro em uma nova conformação de poder. De suas articulações internas e com o poder central resultariam o movimento de construção do

\footnotetext{
184 Termo de vereação extraordinária, em 10 de fevereiro de 1824. Documentos da municipalidade de Salvador relacionados com a Independência do Brasil, 1821-1823, op. cit., p. 146.

${ }^{185}$ Idem, ibidem, p. 146-148. 623 pessoas assinaram a ata, segundo informação constante no final do documento.
} 
Estado nacional, no qual o lugar a ser ocupado pela província seria de fundamental importância. ${ }^{186}$

${ }^{186}$ Em termos de representação provincial, o texto constitucional previa a criação dos Conselhos Gerais compostos de 21 membros nas províncias mais populosas e 13 nas demais (art. 73) com amplas competências sobre a administração regional. Determinava ainda que as funções municipais, assim como as atribuições dos juizes de paz, a serem eleitos localmente, deveriam ser estabelecidas posteriormente por meio de uma lei regulamentar (art. 162; art. 169). A partir dessas alterações, um intenso debate sobre as estruturas de poder do Brasil Imperial foi dimensionado sobretudo a partir da instalação da câmara legislativa dois anos depois da outorga da constituição. Miriam Dolhnikoff defende que as províncias regionais se aliaram à proposta de unidade capitaneada pelo Centro-Sul somente quando se estabeleceu uma articulação que garantiria a autonomia regional para que as respectivas elites pudessem conduzir seus projetos políticos e econômicos sem o controle excessivo do governo central. Argumenta a autora que mesmo grupos que até então havia defendido a autonomia de forma veemente, a exemplo dos pernambucanos em 1817, reconheceram a assembléia constituinte e aderiram ao imperador. Cf. O pacto Imperial. Origens do federalismo no Brasil. São Paulo: Globo, 2005. 


\section{Conclusões}

O processo de independência política do Brasil na Bahia realizou-se de maneira cruenta depois de um ano de guerra civil que resultou em ampla mobilização dos habitantes da província. As implicações daí decorrentes, a violência e uma adesão $a$ posteriori ao projeto de unidade nacional capitaneado pelo Rio de Janeiro, reiteram a complexidade das formas de encaminhamento da crise do Antigo Regime português na América. Embora as contradições desse movimento tenham adquirido maior visibilidade nos primeiros anos de 1820, a sua produção, no entanto, não foi imediata. O estudo buscou compreender como as singularidades dessa situação histórica, aparentemente desconexas de uma idéia de coesão que teria possibilitado a realização de uma independência sem maiores conflitos, adquirem um dimensionamento quando apreendidas no contexto de uma conjuntura mais ampla de grandes alterações nos primeiros decênios dos anos 1820 .

Articular as conjunturas políticas desse período significa contribuir para reabrir interpretações ainda persistentes que realçam os acontecimentos pretéritos apenas para reafirmar a inevitabilidade da emancipação. Esse enquadramento esquemático da história política luso-americana não possibilita a apreensão de elementos importantes em um processo tão fecundo e complexo e, por isso mesmo, prenhe de avanços, recuos, tensões e conflitos. Percorrer um caminho inverso pressupõe tentar identificar as mediações que vinculam o movimento estrutural com a rapidez das mudanças a nível dos acontecimentos. Essa é, talvez, a dificuldade maior, e mais fascinantes, para o historiador. ${ }^{1}$

Os anos finais do século XVIII e o início do seguinte marcaram uma época de importantes ajustamentos das monarquias absolutistas no mundo Ocidental. A maneira como essas alterações foram absorvidas nos Impérios ultramarinos ibéricos, especialmente na América portuguesa, ajudam a esclarecer como as definições políticas da época, ainda que submetidas a demandas particulares, integravam uma mesma e ampla conjuntura de crise. Se, no plano mais geral, os desdobramentos da instabilidade política eram distintos, internamente a recepção do projeto de reordenamento da monarquia bragantina adquiriu diversas feições.

\footnotetext{
${ }^{1}$ Cf. Fernando A. Novais. “As dimensões da Independência”. In: Carlos Guilherme Mota (Org.), op. cit., 1972, p. 23.
} 
Nessa perspectiva, a instalação da família real no Rio de Janeiro foi significativa para a vida política, econômica e social dos residentes no Centro-Sul. Mas não somente para eles. Embora sem a mesma extensão, as mudanças verificadas na Bahia, a partir de 1808, evidenciam novos contornos de uma articulação entre a Coroa e a capitania fundamentais para a preservação do Império que se pretendia assegurar. Com efeito, para muitos contemporâneos, aquela era, de fato, uma época de grandes expectativas e realizações e disso estavam cientes desde o momento em que se apresentaram para dar as boas-vindas ao regente. Favorecidos pelas guerras napoleônicas, os portugueses americanos não apenas podiam desfrutar, pela primeira vez, da presença de um príncipe português na antiga colônia como também ampliar as possibilidades de gestão no interior de um Estado que, por força das circunstâncias, necessitava de expandir-se. E nessa nova projeção a Bahia desempenhava um papel de grande relevância, seja do ponto de vista econômico como um dos principais mercados de exportação e importação de produtos e escravos, seja no aspecto da segurança interna e externa. Não à toa, muitas intervenções realizadas aí buscaram, estrategicamente, corresponder às exigências de determinadas frações da classe proprietária configurando uma relação de troca entre benefícios e fortalecimento dos vínculos com a Coroa. Essa significância fica ainda mais evidenciada quando se avalia que depois do Rio de Janeiro somente a Bahia seria contemplada com alguns recursos importantes a exemplo da primeira escola médico-cirúrgica, da biblioteca pública e do periódico Idade d'Ouro do Brazil, entre outras providências relacionadas à segurança e à economia da capitania. Externamente também era preciso corresponder às exigências impostas pela conjuntura, resultando daí a abertura dos portos (1808) e os tratados firmados com a Inglaterra dois anos depois. O momento de elevação do Brasil à categoria de Reino constitui outro aspecto que não pode ser desconsiderado nesse novo quadro, tanto pelo que representou para uma tomada de posição da Coroa portuguesa diante, sobretudo, do recrudescimento das lutas nas colônias hispânicas, quanto pelo estímulo do sentimento de isonomia política no interior do Império português. Observadas em conjunto, essas intervenções certamente integraram um projeto político mais amplo essencial em um cenário de profunda instabilidade. Mas que também possuía seus revezes.

De fato, as medidas efetuadas pela Coroa produziram um movimento contraditório de aprofundamento da desestruturação do sistema. Isso explica a maneira pela qual os residentes da Bahia aderiram ao constitucionalismo vintista com largo entusiasmo. A disposição de grande parte desses indivíduos, no entanto, não era pela separação imediata do Reino português. Isso fica evidenciado em diversos documentos 
produzidos à época e examinados nesse trabalho, ainda que esse desejo de rompimento não estivesse ausente do horizonte de alguns protagonistas. A idéia de concretização da "nação luso-brasileira” ainda subsistia em meio às alternativas propostas para o equacionamento da crise. A sinuosidade da busca por essa solução, entretanto, acabou por fortalecer o projeto político que acalentava a independência potencializando a sua concretização. Na Bahia, essa perspectiva adquire uma conotação ainda mais visível em função da ocupação da capital pelas tropas portuguesas. Por mais ambíguo que esse posicionamento possa parecer, um exame mais minucioso da complexa situação política ajuda a perceber que muitos ainda alimentavam a crença na possibilidade de os interesses do Brasil Reino serem contemplados numa união com Portugal. Além disso, "romper com a forma monárquica de governo não era tarefa simples, nem, no plano político nem no plano doutrinário, ainda mais no caso brasileiro, que, com a instalação da Corte tornara-se sede de todo o império português”. ${ }^{2}$ Parece claro que muitos dos envolvidos nos conflitos políticos que resultaram na independência desejavam ampliar as mudanças que até então haviam conquistado e isso tanto poderia dizer respeito à adoção de um mecanismo limitador dos poderes do monarca - a constituição - quanto à relação estabelecida entre a corte do Rio de Janeiro com as demais províncias. Na impossibilidade de realização do projeto de união dos dois Reinos, parte das lideranças do movimento direcionou-se para a proposta oriunda do capitaneada por d. Pedro I. Duas questões importantes sobressaem nesse processo e merecem ser retidas.

A primeira diz respeito à dinâmica política no interior da província a partir de sua adesão às Cortes. A mobilização de homens e mulheres permitiu a expressão de diferentes possibilidades de superação da crise numa dimensão antes impensada, inclusive expressando as contradições mais profundas da sociedade local. Se, por um lado, a intensidade da atividade política foi propiciada pela difusão das idéias liberais que a essa altura penetrava em várias partes do mundo Ocidental; por outro, existia um ambiente propício à absorção dessas idéias desde fins do século XVIII, como ficou demonstrado no ensaio de sedição de 1798, um marco no processo de elaboração de alternativas políticas na capitania quando a própria noção de legitimidade política foi posta em questão. A circulação de idéias consideradas perniciosas aos interesses do Estado foi incessantemente combatida mas as evidências indicam que as possibilidades para isso foram variadas, como atestam as proibições a entrada de franceses ou espanhóis e de papéis que pudessem conter

\footnotetext{
${ }^{2}$ Denis Antônio de Mendonça Bernardes, op. cit., p. 498.
} 
indesejadas proposições ou ainda de redes de sociabilidades maçônicas. Em diversos momentos, a Coroa insistiu com o governo local sobre a necessidade dessa vigilância e do controle de homens cativos, libertos ou livres. Em outras palavras, parece plausível considerar a existência de uma pulsação interna pelas autoridades e a violência utilizada por ocasião das manifestações que ocorreram no período, incluindo a Revolução pernambucana, apenas reitera essa proposição. Isso significa dizer que os recursos utilizados pelo Estado, de variados modos, conseguiram manter os habitantes dentro dos marcos pretendidos. Mas a força dos instrumentos perdeu sua eficácia no momento em que a crise ganhou profundidade e, nesse caso, não seria cauteloso tentar refreá-la utilizando os mesmos mecanismos.

O segundo aspecto relaciona-se diretamente a essa movimentação. Os anos de 1821 e 1823 demarcam um período de grandes mudanças na vida política dos contemporâneos. O grau de complexidade das questões que exigiam definição e a novidade do problema de construção de uma ordem política distinta propiciou a organização de novos espaços de discussão e deliberação, assim como a ampliação do debate político, sobretudo, com a intensificação da imprensa. Essas experiências possibilitaram aos indivíduos que se envolveram mais diretamente um aprendizado político que, certamente, foi de grande importância para a construção do Império do Brasil que desejavam. Não se pode esquecer de que a situação crítica da província não se limitava às áreas centrais em que se deu o conflito armado - Salvador e o Recôncavo - mas se estendeu para outros lugares. A dilatação do espaço público propiciou sua ocupação por segmentos que portavam desejos de mudança distintos daqueles pretendidos pelas lideranças. Nesse contexto de imprevisibilidades, era preciso definir uma alternativa para a superação da crise assegurando, contudo, a preservação de seus interesses. Afinal, a radicalidade demonstrada por esses homens pressupunha a adoção de mudanças desde que não interferissem em seu statu quo e embora não soubessem, de antemão, o resultado do empreendimento que se lhes apresentava, certamente não tinham dúvidas sobre o que não deveria ser modificado. ${ }^{3}$

Em períodos de crise, a manifestação das forças políticas em jogo fornece maior complexidade ao movimento, daí porque um dos traços embasadores do processo de formação do Estado e da nação brasileiros foram os conflitos que ocorreram com maior ou menor intensidade não apenas entre as províncias e a corte fluminense, mas também no

\footnotetext{
${ }^{3}$ Conforme a discussão empreendida por Antonio Cândido. "Radicalismos”. Estudos Avançados, v. 4, n. 8, jan/abril 1990, p. 4-18.
} 
interior das classes proprietárias e entre essas e os segmentos de menor condição. No caso específico dos residentes da Bahia que vivenciaram novas experiências de negociação e de acomodação, sobretudo após 1808, mas também possibilidades de maturação política, os anos do constitucionalismo revelaram-se de grande riqueza. Para as classes dirigentes, significou a busca pelo aprimoramento dos mecanismos de dominação mediado pelos instrumentos de uma monarquia constitucional; para as classes subalternas, o acúmulo de experiências no longo processo de construção de um projeto político autônomo.

Resta acrescentar que se a busca pela compreensão do passado é também uma tentativa de apreendermos a realidade presente na perspectiva de construção de projetos de futuro, ${ }^{4}$ as experiências vivenciadas pelos homens naqueles anos certamente têm muito a nos revelar sobre a crise de nossos tempos.

\footnotetext{
${ }^{4}$ Josef Fontana. História: Análise do passado e projeto social. Bauru: Edusc, 1998.
} 


\section{Fontes Documentais e Bibliografia}

\section{Arquivos}

Arquivo Público do Estado da Bahia (APEB)

Biblioteca Nacional do Rio de Janeiro (BNRJ)

Instituto de Estudos Brasileiros (IEB)

Fundação Clemente Mariani (FCM)

Biblioteca Pública do Estado da Bahia (BPEB)

Centro de Estudos Baianos/UFBa (CEB)

\section{Sites}

www.bn.br

www.googlebooks.com.br

www.câmara.gov.br

www.caminhosdoromance.iel.unicamp.br

www.historiacolonial.arquivonacional.org.br

\section{Documentos Manuscritos}

APEB/Seção de Arquivo Colonial e Provincial

Ordens Régias. Maço: 105 (1808-1809)

Ordens Régias. Maço: 106 (1808-1809).

Ordens Régias. Maço: 108 (1807-1810).

Inspetoria Geral das Tropas. Maço: 247 - 9 (1814/1815).

Cartas régias enviadas à capitania da Bahia. Maço: 118 (1816).

Cartas ao Governo. Maço: 235 (1817-1818).

Ordens régias enviadas à capitania da Bahia. Maço: 119 (1818)

Cartas do Senado à sua Majestade. Maço: 132 (1742-1823).

APEB/Setor de Microfilmes

Curiosidades sobre a Bahia, s.l., s.d., s.a..

Requerimento dos vivandeiros, condutores e mais habitantes de diversas classes de Cidadãos da Bahia, dirigido ao Príncipe Regente, contra a falta de economia pública e contra os abusos pelos quais sofrem vexames. Bahia, 31 de julho de 1807 
BNRJ/Divisão de Manuscritos

Representação que fez em 1808, o corpo do comércio da Bahia, pedindo ao Príncipe Regente, que os estrangeiros se não estabeleçam, com casas de negócio nos domínios do Brasil para os não prejudicar, Ms. I - 31,28,26

BPEB/Setor de Periódicos Raros

Diário Oficial do Estado da Bahia. Edição comemorativa do Centenário da Independência. Salvador, 1923

Plano para o estabelecimento de huma bibliotheca pública na Cidade de S. Salvador Bahia de Todos os Santos, offerecido à approvação do Illustrissimo e Excellentissimo Senhor Conde dos Arcos, Governador e Capitão General desta Capitania. Bahia 26 de Abril de 1811

\section{$\mathrm{CEB} / \mathrm{UFBa}$}

Sentinella Bahiense, n. 8, quarta-feira, 21 de agosto de 1822. Bahia: Tipografia da Viúva Serva e Carvalho

IEB

Carta escrita por L.P.A.P. a um seu patrício da cidade da Bahia. Lisboa, na nova Officina de João Rodrigues Neves. Anno MDCCCVIII, com licença da Mesa do Desembargo do Paço, p. 28

Antonio d'Oliva de Sousa Sequeira. Projecto para o estabelecimento político do ReinoUnido de Portugal, Brasil e Algarves oferecido aos ilustres legisladores em Cortes Gerais e Extraordinárias. Coimbra: Real Imprensa da Universidade, 1821

José Vicente Gomes de Moura. Reflexões sobre a necessidade de promover a união dos Estados de que consta o Reino-Unido de Portugal, Brazil e Algarves nas quatro partes do mundo. Lisboa: Tipografia de Antônio Rodrigues Galhardo, 1822, 107 p.

FCM

Cipriano Barata. Manifesto. Rio de Janeiro: na Tipografia de Torres, 1831

\section{Documentos impressos e obras de época}

ABREU E LIMA, J. I. de. Compêndio da História do Brasil. Rio de Janeiro: Eduardo e Henrique Laemmert, t. 1, 1843

ALMEIDA, Miguel Calmon du Pin e. Relatório do Ministério da Fazenda apresentado à Assembléia Geral Legislativa do Império do Brasil. Brasil/Ministério da Fazenda, 1829

Anais da Biblioteca Nacional, Rio de Janeiro, 1916, v. 36

Anais da Biblioteca Nacional. Catálogo de documentos sobre a Bahia existentes na Biblioteca Nacional. Rio de Janeiro, Divisão de Obras Raras e publicações, v. 68 
ARMITAGE, João. História do Brasil: desde o período da chegada da família de Bragança, em 1808, até a abdicação de D. Pedro, em 1831, compilada à vista dos documentos públicos e outras fontes originais formando uma continuação da História do Brasil, de Southey. Belo Horizonte: Itatiaia; São Paulo: Edusp, 1981

As câmaras municipais e a Independência. Conselho Federal de Cultura/Arquivo Nacional, 1973, v. 1

BRITO, João Rodrigues et al. Cartas econômico-políticas sobre agricultura e comércio da Bahia: Lisboa: Imprensa Nacional, 1821

Carta muito interessante do advogado da Bahia, José da Silva Lisboa, para o Dr. Domingos Vandelli, Diretor do Real Jardim Botânico de Lisboa, em que lhe dá notícia desenvolvida sobre a Bahia. RIGHBa, Salvador, n. 76, 1950-1951, p. 99-125.

Cartas de Felisberto Caldeira Brant Pontes, marquês de Barbacena. Economia açucareira da Bahia em 1820. Ministério da Justiça. Arquivo Nacional. Publicação destinada ao III Congresso de História da Bahia, Junho de 1973

CERQUEIRA E SILVA, Ignácio Accioli de. Memórias históricas e políticas da província da Bahia (anotadas por Braz do Amaral). Bahia: Imprensa Oficial do Estado, 1931, v. III e IV

DENIS, Ferdinand. Brasil. Belo Horizonte: Itatiaia; São Paulo: Edusp, 1980

[Luis de Oliveira Mendes] "Discurso preliminar, histórico, introdutivo com natureza de descrição econômica da comarca e cidade da Bahia... (c. 1790)". Anais da Biblioteca Nacional. Rio de Janeiro, 1905, v. XXVII, p. 283-348

Documentos da municipalidade de Salvador relacionados com a Independência do Brasil, 1821-1823. Salvador: Prefeitura Municipal/Departamento de Cultura da SMEC, 1972

Estudo sobre os limites entre os Estados da Bahia e do Espírito Santo”. RIGHBa., 1895, ano II, v. 2, n. 5; p. 267-273 e n. 6, p. 395-401; "Limites entre a Bahia e Pernambuco". RIGHBa., 1896, Ano III, v. 3, n. 8

FERREIRA, Silvestre Pinheiro. "Proposta autographa sobre o regresso da Corte para Portugal e providências convenientes para prevenir a revolução, e tomar a iniciativa da reforma política”. Biblioteca Nacional do Rio de Janeiro. Documentos para a Independência, v. I, Lisboa/Rio de Janeiro, 1923, p. 129-134

FRANÇA, António d'Oliveira Pinto da. Cartas baianas, 1821-1824. São Paulo: Companhia Editora Nacional; Rio de Janeiro: Núcleo Editorial da Universidade do Estado do Rio de Janeiro, 1980

LISBOA, José da Silva. História dos principais sucessos políticos do Império do Brasil dedicada ao Senhor D. Pedro I. Parte 10. Rio de Janeiro: Tipografia Imperial e Nacional, 1827

LISBOA, José da Silva. Memórias dos benefícios políticos do governo de El-Rey Nosso Senhor D. João VI. Rio de Janeiro: na Impressão Régia , 1818

Ministério da Justiça. As juntas governativas e a Independência. Rio de Janeiro: Arquivo Nacional/Conselho Federal de Cultura, 1972, v. 2

Prospecto da Gazeta da Bahia. Bahia, na Tipografia de Manoel Antonio da Silva Serva, ano de 1811. Biblioteca Pública do Estado da Bahia. Setor de Periódicos Raros.

REBOUÇAS, Antônio Pereira. “Recordações Patrióticas. 1821-22”. RIGHBa, n. 48, 1923 
SANTOS, Luiz Gonçalves dos. Memórias para servir à História do Reino do Brasil. Belo Horizonte: Itatiaia; São Paulo: Edusp, 1981

SIERRA Y MARISCAL, Francisco de. "Idéas geraes sobre a Revolução do Brazil e suas conseqüências”. Anais da Biblioteca Nacional do Rio de Janeiro, v. 43-44

SPIX, Johann B. von; MARTIUS, Karl F.P. von. Viagem pelo Brasil. Belo Horizonte: Itatiaia; São Paulo: Edusp, 1989, v. II

TOLLENARE, Louis-François de. Notas dominicais. Recife: Secretaria de Educação e Cultura/Departamento de Cultura, (Coleção Pernambucana, v. XVI), 1978

VASCONCELLOS, Antonio Luiz de Brito Aragão e. "Memórias sobre o estabelecimento do Império do Brazil, ou novo Império Lusitano”. Anais da Biblioteca Nacional do Rio de Janeiro, v. XLIII-XLIV, 1931

VILHENA, Luis dos Santos. A Bahia no século XVIII. Notas e comentários de Braz do Amaral. Salvador: Itapuã, 1969.

WIED-NEWIED, Maximiliano de. Viagem ao Brasil. São Paulo: Companhia Editora Nacional, 1940

\section{Bibliografia}

AGUIAR, Pinto de. "O movimento da Independência na Bahia (aspectos sócioeconômicos)”. Revista de História, v. LIII, n. 105, São Paulo, 1976 1960.

A abertura dos portos. Cairu e os ingleses, Salvador: Livraria Progresso Editora,

ALENCASTRO, Luis Felipe de. O trato dos viventes. Formação do Brasil no Atlântico Sul. São Paulo: Companhia das Letras, 2000

ALEXANDRE, Valentim. Os sentidos do Império. Questão nacional e questão colonial na crise do Antigo Regime português. Porto: Ed. Afrontamento, 1993.

AMARAL, Braz H. do. História da Independência na Bahia. Salvador: Progresso, 1957

“O Brasil no Congresso de Viena”. RIHGB, v. 175, Rio de Janeiro, 1940-1941

AMORIM, Deolino. “A ata de Santo Amaro e a revolução Constitucionalista”. RIGHBa, n. 79, Bahia, 1955, p. 173-185.

ARAS, Lina Maria Brandão de Aras. A Santa Federação Imperial: Bahia, 1831-1833. São Paulo, Universidade de São Paulo, 1995 (Tese de Doutorado)

ARAÚJO, Ana Cristina B. de. "Um Império, um reino e uma monarquia na América: às vésperas da Independência do Brasil”. In: JANCSÓ, István (Org.). Independência: História e Historiografia. São Paulo: Hucitec; Fapesp, 2005.

. “O Reino Unido de Portugal, Brasil e Algarves, 1815-1822”. Revista de História das Idéias. Faculdade de Letras/Instituto de História e Teoria das Idéias, Coimbra, 1992

ARAÚJO, Emanuel. Introdução. In: Luis dos Santos Vilhena. Pensamentos políticos sobre a colônia. Rio de Janeiro: Arquivo Nacional, 1987.

ARAÚJO, Ubiratan Castro de. A guerra da Bahia. Salvador: Centro de Estudos AfroOrientais, 2001 
ARRUDA, José Jobson de Andrade. Uma colônia entre dois impérios. A abertura dos portos brasileiros, 1800-1808. Bauru: EDUSC, 2008

"O sentido da colônia. Revisitando a crise do antigo sistema colonial no Brasil". In: José Tengarrinha (Org.). História de Portugal. Bauru: Edusc; São Paulo: Unesp; Portugal: Instituto Camões, 2000, p. 167-183.

ARTOLA, Miguel. Antiguo Régimen y Revolucion liberal. Madrid, 1979

BANDEIRA, Luiz Alberto Moniz. O feudo. A casa da Torre de Garcia d'Ávila: da conquista dos Sertões à Independência do Brasil. Rio de Janeiro: Civilização Brasileira, 2000

BARICKMAN, Bert J. Um contraponto baiano. Açúcar, fumo, mandioca e escravidão no Recôncavo, 1780-1860. Rio de Janeiro: Civilização Brasileira, 2003

BERBEL, Márcia Regina. A Nação como artefato. Deputados do Brasil nas Cortes portuguesas, 1821-1822. São Paulo: Hucitec/Fapesp, 1999

“A retórica da recolonização”. In: JANCSÓ, István (Org.). Independência: História e Historiografia. São Paulo: Hucitec; Fapesp, 2005, p. 791-808.

BERNARDES, Denis Antônio de Mendonça. O patriotismo constitucional: Pernambuco, 1820-1822. São Paulo: Hucitec/Fapesp; Pernambuco: UFPE, 2006.

BICALHO, Maria Fernanda Baptista. A cidade e o império. O Rio de Janeiro no século XVIII. Rio de Janeiro: Civilização Brasileira, 2003

“As câmaras municipais no Império português”. Revista Brasileira de História, São Paulo, Anpuh; Humanitas Publicações, v. 18, n. 36, 1998, p. 251-280

BLACKBURN, Robin. A queda do escravismo colonial: 1776-1848. Rio de Janeiro; São Paulo, 2002

BOSCHI, Caio César. "Colonialismo, poder e urbanização no Brasil setecentista”. In: Anais do I Colóquio de Estudos Históricos Brasil-Portugal. Belo Horizonte: PUC-MG, 1994

BOXER, Charles R. O império marítimo português, 1415-1825. São Paulo: Companhia das Letras, 2002

BULCÃo SOBRINHO, Antônio de Araújo de Aragão. A Bahia nas Cortes Gerais de Lisboa de 1821. Salvador, 1955

CALMON, Francisco Marques de Góes. "Contribuição para o estudo da vida econômicofinanceira da Bahia no começo do século XIX. Subsídios para a História”. In: João Rodrigues de Brito et al

CALMON, Pedro. História do Brasil. Rio de Janeiro: Livraria José Olympio Editora, 1959, v. IV

CALÓGERAS, João Pandiá. O marquês de Barbacena. São Paulo: Companhia Editora Nacional, 1932

CAMPOS, S. “A Bahia de outros tempos: as posturas do senado da Câmara em 1785”. RIGHBa., 1897, Salvador: Typografia e Encadernações Empresa Editora, v. 7

CÂNDIDO, Antônio. "Radicalismos”, Estudos Avançados, v. 4, n. 8, jan/abril 1990, p. 418. 
CANSANELLO, Oreste Carlos. "De súbditos a ciudadanos. Los pobladores rurales bonaerenses entre el Antiguo Régimen y la modernidad”. Boletin del Instituto de Historia Argentina y americana Dr. Emilio Ravignani. Buenos Aires, Fondo de Cultura Económica, n. 11, 3ª Serie, 1995, p. 113-139

CAVALCANTI, Zélia. O processo de Independência na Bahia. In: MOTA, Carlos Guilherme (Org.). 1822, dimensões. São Paulo: Perspectiva, 1972, p. 231-250

CHAMON, Carla Simon. "O Tejuco faz a festa. Festejo cívico no arraial do Tejuco em 1815”. In: István Jancsó; Íris Kantor (Orgs.). Festa: cultura e sociabilidade na América portuguesa. São Paulo: Imprensa Oficial; Fapesp; Hucitec; Edusp, v. 2, 2001, p. 587-599

CHUST, Manuel. La cuestión nacional americana en las Cortes de Cádiz (1810-1814). Fundación Instituto Historia Social/Universidad Nacional Autónoma de México, 1999

COELHO, Hilton Barros. “Authoridades” e "Anarchistas” no "Império da desordem": conflitos e reconfigurações do poder dominante na Bahia da guerra à consolidação da Independência. Salvador: UFBa, 2003 (Dissertação de Mestrado)

COGGIOLA, Osvaldo (Org.). A Revolução Francesa e seu impacto na América Latina. São Paulo: Nova Stella/Editora da USP; Brasília: CNPq, 1990

COSTA, Marcus de Noronha da. Administração civil, política, militar e econômica do $8^{0}$. Conde dos Arcos na Bahia. RIGHBa, Salvador, n. 93, p. 91-183, dez. 1997

COSTA, Maria Emília Viotti da. "Introdução ao estudo da emancipação política do Brasil”. In: MOTA, Carlos Guilherme (Org.). Brasil em perspectiva. 19. ed. Rio de Janeiro: Bertrand, 1990

COSTA, Wilma Peres. “A Independência na historiografia brasileira”. In: JANCSÓ, István (Org.). Independência: História e Historiografia. São Paulo: Hucitec; Fapesp, 2005

. "Do domínio à Nação: os impasses da fiscalidade no processo da Independência". In: JANCSÓ, István (Org.) Brasil: Formação do Estado e da Nação. São Paulo: Hucitec/Fapesp; Ijuí: ed. Unijuí, 2003, p. 143-193.

CUNHA, Pedro Octávio Carneiro da. “A fundação de um império liberal”. In: HOLANDA, Sérgio Buarque de (Org.). História geral da Civilização Brasileira. O Brasil Monárquico. O processo de Emancipação. São Paulo: Difel, 1985, p. 135-190

DIAS, Maria Odila da Silva. “A interiorização da Metrópole”. In: (Org.). 1822, dimensões. São Paulo: Perspectiva, 1972, p. 160-184

FALCÓN, Francisco J. C. A época pombalina: política econômica e monarquia ilustrada. São Paulo: Ática, 1982

“Pombal e o Brasil”. In: José Tengarinha (Org.). História de Portugal. São Paulo: Unesp; Bauru: Edusc; Portugal: Instituto Camões

FAORO, Raymundo. Os donos do poder. Formação do patronato político brasileiro. 10. ed. São Paulo: Globo, v. 1, 1996.

FERLINI, Vera Lúcia Amaral. Terra, trabalho e poder. São Paulo: Brasiliense, 1988

FLEXOR, Maria Helena Ochi. "Criação da rede urbana na capitania da Bahia no século XVIII”. Actas do Colóquio Internacional Universo Urbanístico Português, 1715-1822. Lisboa: Comissão Nacional para as comemorações dos descobrimentos portugueses, 2001

FONTANA, Josep. La crisis del Antiguo Régimen, 1808-1833. 2.ed. Barcelona: Editorial Crítica, 1982 
História: Análise do passado e projeto social. Bauru: Edusc, 1998

FRAGOSO, João; GOUVÊA, Maria de Fátima; BICALHO, Maria Fernanda B. (Orgs). O antigo regime nos trópicos: a dinâmica imperial portuguesa (séculos XVI-XVIII). Rio de Janeiro: Civilização Brasileira, 2001

; FLORENTINO, Manolo. O arcaísmo como projeto. Mercado atlântico, sociedade agrária e elite mercantil em uma economia colonial tardia. Rio de Janeiro: Civilização Brasileira, 2001

FREIRE, Felisbello. História territorial do Brasil (Bahia, Sergipe e Espírito Santo). Salvador: Secretaria da Cultura e Turismo/Instituto Geográfico e Histórico da Bahia, 1988 (Edição facsimilada)

GARAVAGLIA, Juan Carlos. "Os primórdios do processo de Independência hispanoamericano”. In: István Jancsó (Org.)., op. cit., 2005, p. 207-234

GARCIA, Paulo. Cipriano Barata ou a liberdade acima de tudo. Rio de Janeiro: Topbooks, 1997

GODECHOT, Jaques. Europa e América no tempo de Napoleão (1800-1815). São Paulo: Pioneira; Edusp, 1984.

GOUVÊA, Maria de Fátima. “As bases institucionais da construção da unidade. Dos poderes do Rio de Janeiro joanino: administração e governabilidade no Império lusobrasileiro”. In: JANCSÓ, István (Org.). Independência: História e Historiografia. São Paulo: Hucitec; Fapesp, 2005, p. 707-752.

"Redes de poder na América portuguesa. O caso dos homens bons do Rio de Janeiro, 1790-1822”. Revista Brasileira de História, São Paulo, Anpuh; Humanitas Publicações, v. 18, n. 36, 1998, p. 297-330

GUERRA FILHO, Sérgio Armando Diniz. O povo e a guerra. Participação das camadas populares nas lutas pela Independência da Bahia. Dissertação (Mestrado em História) Universidade Federal da Bahia, Salvador, 2004

GUERRA, François-Xavier. Modernidad y Independências: Ensayos sobre las revoluciones hispânicas. 2. ed. México: Editorial Mapfre; FCE, 1993

HALPERIN DONGHI, T. História da América Latina. 3. ed. Rio de Janeiro: Paz e Terra, 1975

HOBSBAWM, Eric J. A era das revoluções. 9 ed. Rio de Janeiro: Paz e Terra, 1994;

HOLANDA, Sérgio Buarque de. “A herança colonial - sua desagregação”. In: (Dir.). História geral da civilização brasileira. O Brasil Monárquico. São Paulo: Difel, 1985, t. II, v. 1

JANCSÓ, István; PIMENTA, João Paulo G. "Peças de um mosaico (ou apontamentos para o estudo da emergência da identidade nacional brasileira)”. In: MOTA, Carlos Guilherme (Org.). Viagem Incompleta. A experiência brasileira (1500-2000). Formação: histórias. São Paulo: Senac, 2000, p. 127-175.

. “A sedução da liberdade”. In: MELLO e SOUZA, Laura de (Org.). História da vida privada no Brasil. Cotidiano e vida privada na América portuguesa. (Coleção dirigida por Fernando A. Novais). São Paulo: Companhia das Letras, 1997, p. 388-437

. "Bahia 1798: a hipótese de auxílio francês ou a cor dos gatos”. In: FURTADO, Júnia Ferreira (Org.). Diálogos Oceânicos. Minas Gerais e as novas abordagens para uma 
história do Império ultramarino português. Belo Horizonte: Editora UFMG, 2001, p. 361387.

2005.

. (Org.). Independência: História e Historiografia. São Paulo: Hucitec; Fapesp,

(Org.). Brasil: Formação do Estado e da Nação. São Paulo: Hucitec/Fapesp; Ijuí: ed. Unijuí, 2003

"Independência, Independências". In:

(Org.). Independência: história e historiografia. São Paulo: Hucitec/Fapesp, 2005

“A construção dos Estados nacionais na América Latina. Apontamentos para o estudo do Império como projeto”. In: SZMRECSÁNYI, Tamás; LAPA, José Roberto do Amaral (Orgs.). História econômica da Independência e do Império. 2. ed. São Paulo: Hucitec; Edusp; Imprensa Oficial, 2002, 3-26

Na Bahia, contra o Império. História do ensaio de sedição de 1798. São Paulo: Hucitec; Salvador: EDUFBa, 1996

(Orient.). Cronologia de História do Brasil Monárquico, 1808-1889. São Paulo: Humanitas; FFLCH/USP, 2000.

KANTOR, Íris. Esquecidos e Renascidos. Historiografia acadêmica luso-americana (17241759). São Paulo: Hucitec; Salvador: Centro de Estudos Baianos/UFBa, 2004.

KENNEDY, John Norman. “Bahian Elites, 1750-1822”. HAHR, n. 3, v. 53, agosto de 1973

KOSIK, Karel. A dialética do concreto. Rio de Janeiro: Paz e Terra, 1976; Edmilson Carvalho. A produção dialética do conhecimento. São Paulo: Xamã, 2008.

KOSSELECK, Reinhart "Espaço de experiência” e "horizonte de expectativa": duas categorias históricas. In: __ Futuro Passado. Contribuição à semântica dos tempos históricos. Rio de Janeiro: Contraponto; Editora Puc-Rio, 2006, p. 305-327.

KRAAY, Hendrik. Race, State and Armed Forces in Independence-era Brazil. Bahia, 1790s-1840s. Stanford: Stanford University Press, 2001

“Em outra coisa não falavam os pardos, cabras e crioulos: o 'recrutamento' de escravos na guerra de independência no Brasil, 1822-1823”, Revista Brasileira de História, v. 22, 2002, p. 109-126.

. "Muralhas da independência e liberdade do Brasil: a participação popular nas lutas políticas (Bahia, 1820-1825)”. In: MALERBA, Jurandir (Org.). A Independência brasileira: novas dimensões. Rio de Janeiro: Editora FGV, 2006, p. 303-341

LAPA, José Roberto do Amaral. “Um agricultor ilustrado do século XVIII”. In: Economia colonial. São Paulo: Perspectiva, 1973, p. 141-213

LEITE, Douglas Guimarães. Sabinos e diversos: emergências políticas e projetos de poder na revolta baiana de 1837. Salvador, Universidade Federal da Bahia (Dissertação de Mestrado), 2006

LEITE, Renato. "Câmaras das cidades do Rio de Janeiro e de Recife à época da Independência do Brasil 1822-1824”. VIEIRA, Alberto (Org.). O município no mundo português. Seminário Internacional. Funchal: CEHA; Secretaria Regional do Turismo e da Cultura, 1998, op. cit, p. 483-490

LENHARO, Alcir. As tropas da moderação. Rio de Janeiro: Biblioteca Carioca, 2003 
LIMA, André Nicácio. “As câmaras municipais na crise da Independência: Minas Gerais, Mato Grosso e Goiás (1821-1825). Almanack Braziliense, São Paulo, n. 1, maio de 2005, p. 114-119.

LIMA, M. Oliveira. D. João VI no Brasil. 3. ed. Rio de Janeiro: Topbooks, 1996

LINDLEY, Thomas. Narrativa de uma viagem ao Brasil. São Paulo: Companhia Editora Nacional, 1969

LYRA, Maria de Lourdes Viana. A utopia do poderoso Império. Portugal e Brasil: Bastidores da política, 1798-1822. Rio de Janeiro: Sette Letras, 1994

MACHADO, André Roberto de A. A quebra da mola real das sociedades: a crise política do Antigo Regime português na Província do Grão-Pará (1821-1825). São Paulo, Universidade de São Paulo, 2006 (tese de doutorado).

MAGNOLI, Demétrio. O corpo da pátria. Imaginação geográfica e política externa do Brasil (1808-1912). São Paulo: Editora da Unesp-Moderna, 1997.

MALERBA, Jurandir. A Corte no exílio. Civilização e poder no Brasil às vésperas da Independência (1808-1821). São Paulo: Companhia das Letras, 2000 FGV, 2006

(Org.). A Independência brasileira: novas dimensões. Rio de Janeiro: Editora

MANCHESTER, Alan. “A transferência da Corte portuguesa para o Rio de Janeiro”. In: Henry H. Keith; S. F. Edwards (Orgs.). Conflito e continuidade na sociedade brasileira. Rio de Janeiro: Civilização Brasileira, 1970, p. 177-217.

Preeminência inglesa no Brasil. São Paulo: Editora Brasiliense, 1973

MARQUESE, Rafael de Bívar. Administração e escravidão. Idéias sobre a gestão da agricultura escravista brasileira. São Paulo: Hucitec; Fapesp, 1999

MASCARENHAS, Maria José Rapassi Fortunas coloniais. Elite e riqueza em Salvador, 1760-1808. São Paulo, Universidade de São Paulo, 1988 (tese de Doutorado)

MATTOS, Ilmar Rohloff de. O tempo saquarema. A formação do Estado Imperial. 3. ed. Rio de Janeiro: Acess Editora, 1994

MATTOSO, Kátia M. de Queirós. Bahia século XIX: uma província no Império. 2 ed. Rio de Janeiro: Nova Fronteira, 1992

"Os escravos na Bahia no alvorecer do século XIX”. Revista de História, v. XLVIII, n. 97, ano XXV, São Paulo, 1974

Bahia: a cidade do Salvador e seu mercado no século XIX. São Paulo: Hucitec; Salvador: Secretaria Municipal de Educação e Cultura, 1978 1969 Presença francesa no movimento democrático baiano de 1798. Salvador: Itapuã, Ser escravo no Brasil. São Paulo: Brasiliense, 1982

356 “Bahia 1798: os panfletos revolucionários. Proposta de uma nova leitura”, p. 341-

MAURO, Fréderic. “A conjuntura atlântica e a Independência do Brasil”. In: Carlos Guilherme Mota (Org.), op. cit., 1972, p. 38-47. 
MAXWELL, Kenneth. “A geração de 1790 e a idéia do império luso-brasileiro”. In: Chocolate, piratas e outros malandros. Ensaios tropicais. São Paulo: Paz e Terra, 1999, p. 157-207.

MELLO E SILVA, Sylvio C. Bandeira de et al. Urbanização e metropolização no Estado da Bahia. Evolução e dinâmica. Salvador: Centro Editorial e Didático da UFBa, 1989.

MELLO E SOUZA, Laura de. O sol e a sombra. Política e administração na América portuguesa do século XVIII. São Paulo: Companhia das Letras, 2006

MELLO, Evaldo Cabral de. A outra independência. O federalismo pernambucano de 1817 a 1824. São Paulo: Editora 34, 2004

MONTEIRO, Tobias. História do Império. A elaboração da Independência. Rio de Janeiro: F. Briguiet e Cia. Editores, t. 1, 1927

História do Império. O Primeiro Reinado. Belo Horizonte: Itatiaia; São Paulo: Edusp, t. 1 e 2, 1982

MORAES, Alexandre José de Mello. História do Brasil-Reino e do Brasil Império. Belo Horizonte: Itatiaia; São Paulo: Edusp, 1982, t. I e II.

MOREL Marco. “República de 1817” (www.historiacolonial.arquivonacional.org.br).

As transformações dos espaços públicos. Imprensa, atores políticos e sociabilidades na cidade imperial (1820-1840). São Paulo: Hucitec, 2005.

Cipriano Barata na Sentinela da Liberdade. Salvador: Academia de Letras da Bahia: Assembléia Legislativa do Estado da Bahia, 2001

; JANCSÓ, István. "Novas perspectivas sobre a presença francesa na Bahia em torno de 1798”. Topoi, Rio de Janeiro, v. 8, p. 206-232, 2007

MORTON, Frederic W.O. The Conservative Revolution of Independence: Economy, society and politics in Bahia (1790-1840). Oxford, University of Oxford, 1974

. The governorship of the Count of Arcos in Bahia, 1810-1818. Enlightened despotism in an age of revolution, Toronto, outubro de 1986 (texto mimeog.).

MOTA, Carlos Guilherme. Idéia de revolução no Brasil (1789-1801). 4. ed. Estudo das formas de pensamento. São Paulo: Ática, 1996.

Nordeste 1817. Estrutura e argumentos. São Paulo: Perspectiva, 1972a.

(Org.). 1822, dimensões. São Paulo: Perspectiva, 1972

MOTT, Luiz. "Um documento inédito para a história da Independência”. In: MOTA, Carlos Guilherme (Org.). 1822, dimensões. São Paulo: Perspectiva, 1972

NASCIMENTO, Jaime. “O $8^{\circ}$ conde dos Arcos. 200 anos da chegada ao Brasil”. RIGHBa, Salvador, v. 99, 2004, p. 233-34.

NEVES, Erivaldo Fagundes. Estrutura fundiária e dinâmica mercantil. Alto Sertão da Bahia, séculos XVIII e XIX. Salvador: EDUFBA; UEFS, 2005

Uma comunidade sertaneja. Da sesmaria ao minifúndio (um estudo de história regional e local). Salvador: Edufba; Feira de Santana: UEFS, 1998

NEVES, Lúcia Maria Bastos Pereira das. Corcundas e constitucionais. A cultura política da Independência (1820-1822). Rio de Janeiro: Revan; Faperj, 2003. 
"Cultura e política na Independência do Brasil sob a ótica dos folhetos e jornais baianos (1821-1823)”. Anais do Arquivo Público do Estado da Bahia, v. 51, 1994, Salvador-Bahia, p. 191-205

NORTON, Luís A corte de Portugal no Brasil. 2. ed. São Paulo: Companhia Editora Nacional; Brasília: INL, 1979

NOVAIS, Fernando A. "As dimensões da independência”. In: Carlos Guilherme Mota (Org.). 1822, dimensões, op. cit., 1972, p. 15-26

. “Colonização e Sistema Colonial: discussão de conceitos e perspectiva histórica”. In: Aproximações: estudos de História e Historiografia. São Paulo: Cosacnaify, 2005.

; MOTA, Carlos Guilherme. A independência política do Brasil. 2. ed. São Paulo: Hucitec, 1996

Portugal e Brasil na crise do Antigo Sistema Colonial (1777-1808). São Paulo: Hucitec, 1983

"Condições de privacidade na colônia”. In: MELLO e SOUZA, Laura de Org.). História da vida privada no Brasil. Cotidiano e vida privada na América portuguesa. (Coleção dirigida por Fernando A. Novais). São Paulo: Companhia das Letras, 1997

OLIVEIRA VIANNA. Instituições políticas brasileiras. Belo Horizonte: Itatiaia; São Paulo: EDUSP; Niterói: EDUFF, v. 1, 1987

OLIVEIRA, Cecília Helena L. de Salles. A astúcia liberal. Relações de mercado e projetos políticos no Rio de Janeiro (1820-1824). Bragança Paulista: Edusf; Ícone, 1999

PALACÍN, Luis. Goiás - 1722/1822: estrutura e conjuntura numa capitania de Minas. Goiânia, 1972

PARAÍSO, Maria Hilda Baqueiro. O tempo da dor e do trabalho. A conquista dos territórios indígenas nos sertões do Leste. São Paulo, Universidade de São Paulo, 1998 (tese de doutorado).

PASCAL, Anne-Marie. A abolição da escravatura e o teatro português (XVIII- XIX): A polêmica, o exemplo, e a utopia (www.geocities.com/ail_br/aabolicaodaescravatura.htm)

PIMENTA, João Paulo G. Estado e nação no fim dos impérios ibéricos no Prata (18081828). São Paulo: Hucitec; Fapesp, 2002 de Doutorado).

Brasil e América Espanhola. São Paulo. Universidade de São Paulo, 2003 (Tese "a política hispano-americana e o império português (1810-1817): Vocabulário político e conjuntura”. In: JANCSÓ, István (Org.). Brasil: Formação do Estado e da Nação. São Paulo: Hucitec/Fapesp; Ijuí: ed. Unijuí, 2003

PINHO, Wanderley. “Bahia, 1808-1856”. In: Sérgio Buarque de Holanda (Dir.). História geral da civilização brasileira. O Brasil Monárquico. Dispersão e Unidade. São Paulo: Difel, 1985

A abertura dos portos. Cairu. Os Ingleses. A Independência. Salvador: Publicações da Universidade da Bahia, 1961

PONTES, Kátia Vinhático. Mulatos: políticos e rebeldes baianos. Salvador, Universidade Federal da Bahia, 2000 (Dissertação de Mestrado). 
PRADO JÚNIOR, Caio. Formação do Brasil Contemporâneo. 22. ed. São Paulo: Brasiliense, 1992

Evolução política do Brasil e outros estudos. 6. ed. São Paulo, Brasiliense, 1969. História econômica do Brasil. 14. ed. São Paulo: Brasiliense, 1971

QUERINO, Manoel. A Bahia de outrora. Vultos e factos populares. 2. edição revista e aumentada. Bahia: Livraria econômica, 1922

QUINTAS, Amaro. “A agitação republicana no Nordeste”. In: HOLANDA, Sérgio Buarque de (Org.). História geral da Civilização Brasileira. O Brasil Monárquico. O processo de Emancipação. São Paulo: Difel, 1985, p. 206-237

REIS, João José. Rebelião escrava no Brasil. A história do levante dos Malês em 1835. Ed. revista e ampliada. São Paulo: Companhia das Letras, 2003

. “O jogo duro do dois de julho: O ‘Partido Negro’ na Independência da Bahia”. In: ; Eduardo Silva. Negociação e conflito. A resistência negra no Brasil escravista. São Paulo: Companhia das Letras, 1989

A morte é uma festa: ritos fúnebres e revolta popular no Brasil no século XIX. São Paulo: Companhia das Letras, 1991

“A elite baiana face os movimentos sociais, Bahia: 1824-1840”. Revista de História, v. LIV, n. 108, ano: XXVII, São Paulo, Outubro-Dezembro, 1976, p. 347-351

“Escravos e coiteiros no quilombo do Oitizeiro. Bahia, 1806”. In: __; Flávio dos Santos Gomes. Liberdade por um fio. História dos quilombos no Brasil. São Paulo: Companhia das Letras, 1996, p. 332-372

"Nos achamos em campo a tratar da liberdade”. In: MOTA, Carlos Guilherme (Org.). Viagem Incompleta. A experiência brasileira (1500-2000). Formação: histórias. São Paulo: Senac, 2000 p. 241-263.

REISEWITZ, Marianne. Dom Fernando José de Portugal: prática ilustrada na colônia (1788-1801). São Paulo, Universidade de São Paulo, 2003 (Dissertação de Mestrado)

RÉMOND, René. O século XIX (1815-1914). São Paulo: Cultrix, 1976;

RIZZINI, Carlos. O livro, o jornal e a tipografia no Brasil, 1500-1822. São Paulo: Imprensa Oficial do Estado, 1988 (Ed. fac-similar)

ROCHA MARTINS. O último vice-rei do Brasil. Lisboa: Oficina Gráfica do ABC, s/d.

ROCHA, Antônio Penalves. "Economia política e política no período joanino”. In: SZMRECSÁNYI, Tamás; LAPA, José Roberto do Amaral (Orgs.). História econômica da Independência e do Império. 2. ed. São Paulo: Hucitec; Edusp; Imprensa Oficial, 2002, p. 27-43

ROCHA, Antônio Penalves. A economia política na sociedade escravista. São Paulo: Hucitec;USP, 1996

RODRIGUES, Jaime. Infame comércio. Propostas e experiências no final do tráfico de africanos para o Brasil (1800-1850). Campinas: Ed. da Unicamp/Cecult, 2000

RODRIGUES, José Honório. Independência: Revolução e Contra-Revolução. Rio de Janeiro: Francisco Alves, 1975, v. 1

História da História do Brasil (1ª ${ }^{\mathrm{a}}$. parte). Historiografia colonial. 2. ed. São Paulo: Companhia Editora Nacional, 1979 
RUSSEL-WOOD, A. J. R.. "O governo local na América portuguesa: um estudo de divergência cultural”. Revista de História, São Paulo, v. LV, ano XXVIII, 1977, p. 25-79

RUY, Affonso A primeira revolução social brasileira (1798). 2 ed. Companhia Editora Nacional, 1978

. História da Câmara Municipal de Salvador. Salvador: Câmara Municipal, 1953

História do teatro na Bahia.Salvador: Publicações da Universidade da Bahia, 1959

S. A. SISSON. Galeria dos brasileiros ilustres (os contemporâneos). São Paulo: Livraria Martins Editora S.A., v. XVIII

SANTOS, Guilherme de Paula Costa. A Convenção de 1817: debate político e diplomático sobre o tráfico de escravos durante o governo de d. João no Rio de Janeiro. São Paulo, Universidade de São Paulo, 2007 (Dissertação de Mestrado)

SCHULTZ, Kirsten. "A era das revoluções e a transferência da Corte portuguesa para o Rio de Janeiro". In: Jurandir Malerba (Org.). A Independência brasileira: novas dimensões. Rio de Janeiro: Editora FGV, 2006, p. 125-151

SCHWARTZ, Stuart. "Cantos e quilombos numa conspiração de escravos haussás. Bahia, 1814”. In: João José Reis; Flávio dos Santos Gomes. (Orgs.). Liberdade por um fio: história dos quilombos no Brasil. São Paulo: Companhia das Letras, 1996

Burocracia e sociedade no Brasil colonial. São Paulo: Perspectiva, 1979

Segredos internos: engenhos e escravos na sociedade colonial. São Paulo: Companhia das Letras, 1988

SENA, Consuelo Pondé de. A imprensa reacionária na Independência. Sentinella Bahiense. Salvador: Centro de Estudos Baianos/Publicação da UFBa, n. 100, 1983.

SILVA, João Manuel Pereira da. História da fundação do Império brasileiro. Rio de Janeiro: B. L. Garnier Editor, 1865

SILVA, Ana Rosa Cloclet da. Inventando a nação. Intelectuais ilustrados e estadistas lusobrasileiros na Crise do Antigo Regime português (1750-1822). São Paulo: Hucitec; Fapesp, 2006.

SILVA, Daniel Afonso da. Histórias de Bahia. Histórias de Brasil. Apontamentos para o estudo da crise política do Primeiro Reinado na Bahia (1828-1831). São Paulo, 2007 (Dissertação).

SILVA, Luiz Geraldo Santos da. “O avesso da Independência: Pernambuco (1817-1814)”. In: MALERBA, Jurandir (Org.). A Independência brasileira: novas dimensões. Rio de Janeiro: Editora FGV, 2006, p. 343-384

SILVA, Maria Beatriz Nizza da. (Coord.). O Império Luso-Brasileiro (1750-1822). Lisboa: Editorial Estampa, 1986, v. VIII

A primeira gazeta da Bahia: Idade d'Ouro do Brazil. 2. ed. revista e ampliada. Salvador: Edufba, 2005

"Repercussões do movimento constitucional português de 1820 na Bahia e no Rio de Janeiro”. Anais do Arquivo Público do Estado da Bahia, v. 51, 1994, Salvador-Bahia

Movimento constitucional e separatismo no Brasil (1821-1822). Lisboa: Livros Horizonte, 1988 (Coleção Horizonte Histórico) 
SLEMIAN, Andréa. Vida política em tempo de crise: Rio de Janeiro (1808-1824). São Paulo: Hucitec, 2006

; PIMENTA, João Paulo G. O “nascimento político do Brasil”. As origens do Estado e da nação (1808-1825). Rio de Janeiro: DP\&A, 2003.

; PIMENTA, João Paulo G. A corte e o mundo. Uma história do ano em que a família real portuguesa chegou ao Brasil. São Paulo: Alameda, 2008

SOUSA, Avanete Pereira. Poder político local e cotidiano: a Câmara de Salvador no século XVIII. Salvador, Universidade Federal da Bahia, 1996 (Dissertação de Mestrado).

. Poder local, cidade e atividades econômicas (Bahia, século XVIII). São Paulo, 2003 (Tese de doutorado).

SOUSA, Maria Aparecida Silva de. A Conquista do Sertão da Ressaca. Vitória da Conquista: Ed. UESB, 2001.

"Independência e soberania nacional na América luso-espanhola (apontamentos sobre as experiências dos governos provisórios de Santiago do Chile e da Bahia nas lutas pela Independência)”. In: COSTA, Wilma Peres; OLIVEIRA, Cecília Helena de Salles (Orgs.). De um Império a outro. Formação do Brasil, séculos XVIII e XIX. São Paulo: Hucitec; Fapesp, 2007, p. 25-50.

O senado da Câmara de Caetité: apontamentos para o estudo da história política dos sertões baianos. Comunicação apresentada no Seminário Formação do Estado Nacional Brasileiro, Salvador: Cedic; Fundação Clemente Mariani, 2002 (Texto mimeog.).

SOUZA FILHO, Argemiro Ribeiro de. A guerra de Independência na Bahia: manifestações políticas e violência na formação do Estado Nacional (Rio de Contas e Caetité). Salvador, Universidade Federal da Bahia, 2003 (Dissertação de Mestrado);

" "Projetos políticos na revolução constitucionalista na Bahia (1821-1822). Almanack Braziliense, São Paulo, n. 7, maio de 2008, p. 102-118 (www.almanack.usp.br).

SOUZA, Iara Lis Franco S. C. Pátria coroada: o Brasil como corpo político autônomo, 1780-1831. São Paulo: UNESP, 1999

. “A adesão das câmaras e a figura do imperador”. Revista Brasileira de História. São Paulo, Anpuh; Humanitas Publicações, v. 18, n. 36, 1998, p. 367-394

SOUZA, Paulo César. A sabinada. A revolta separatista da Bahia (1837). São Paulo: Brasiliense, 1987.

TAVARES, Constantino do Amaral. Tempos da Independência. Instituto Geográfico e Histórico da Bahia. Salvador, 2000 (Edição fac-similar).

TAVARES, Luis Henrique Dias. Da sedição de 1798 à revolta de 1824 na Bahia. Salvador: Edufba; São Paulo: Unesp, 2003

Independência do Brasil na Bahia. Salvador: EDUFBA, 2005

História da Bahia. 10. ed.. São Paulo: Editora Unesp; Salvador: Edufba, 2001

VARNHAGEN, Francisco Adolfo de. História Geral do Brasil. Antes da sua separação e independência de Portugal. Revisão e Notas de Rodolfo Garcia. 4. ed. São Paulo: Melhoramentos, 1953, v. 5

História da Independência do Brasil até ao reconhecimento pela antiga metrópole, compreendendo, separadamente, a dos sucessos ocorridos em algumas 
províncias até essa data. 4. ed. Revista e anotada por Hélio Vianna. São Paulo: Edições Melhoramentos, s/d

VASCONCELOS, Albertina Lima. Ouro: conquistas, tensões, poder. Mineração e escravidão - Bahia do século XVIII. São Paulo, Universidade Estadual de Campinas, 2003 (Tese de Doutorado).

VERGER, Pierre. Fluxo e refluxo do tráfico de escravos entre o Golfo de Benin e a Bahia de Todos os Santos. Dos séculos XVII a XIX. São Paulo: Corrupio, 1987

VIANNA, Hélio. "Francisco Gê Acaiaba de Montezuma, visconde de Jequitinhonha”. RIHGB, v. 244, Rio de Janeiro, julho-setembro de 1959

Contribuição à história da imprensa brasileira (1812-1869). Rio de Janeiro: Imprensa Nacional, 1945

VIEIRA, Alberto (Org.). O município no mundo português. Seminário Internacional. Funchal: CEHA; Secretaria Regional do Turismo e da Cultura, 1998

VILLALTA, Luis Carlos. "O que se fala, o que se lê: língua, instrução e leitura”. In: MELLO e SOUZA, Laura de Org.). História da vida privada no Brasil. Cotidiano e vida privada na América portuguesa. (Coleção dirigida por Fernando A. Novais). São Paulo: Companhia das Letras, 1997p. 332-385.

WISIAK, Thomas. A 'Nação partida ao meio': tendências políticas na Bahia na crise do Império luso-brasileiro. São Paulo, Universidade de São Paulo, 2001 (Dissertação de Mestrado)

“Itinerário da Bahia na Independência do Brasil, 1821-1823”. In: JANCSÓ, István (Org.). Independência: história e historiografia. São Paulo: Hucitec/Fapesp, 2005, p. 447474.

XIMENES, Cristiana Ferreira Lyrio. Joaquim Pereira Marinho: perfil de um contrabandista de escravos na Bahia, 1818-1887. Salvador, Universidade Federal da Bahia, 1998 (Dissertação de Mestrado).

ZEMELLA, Mafalda,. O abastecimento das Minas Gerais no século XVIII. 2. ed. São Paulo: Hucitec; Edusp, 1990 